Universidad deValladolid

PROGRAMA DE DOCTORADO EN LINGÜÍSTICA,

LITERATURA Y COMUNICACIÓN

TESIS DOCTORAL:

\title{
ESTUDIO Y EDICIÓN CRÍTICA DE LA POESÍA DE FRAY DAMIÁN CORNEJO
}

\author{
Presentada por Zoraida Sánchez Mateos \\ para optar al grado de \\ Doctor/a por la Universidad de Valladolid
}

Dirigida por:

Francisco Javier Blasco Pascual 
"Las emociones que la literatura suscita son quizá eternas, pero los medios deben constantemente variar, siquiera de un modo levísimo, para no perder su virtud. Se gastan a medida que los reconoce el lector" (Borges 151). 


\section{$\underline{\text { ÍNDICE }}$}



1.1. PRESENTACIÓN Y OBJETIVOS …………………............................. 8

1.2. ESTADO DE LA CUESTIÓN ………………………………………... 9

1.3. METODOLOGÍA Y ESTRUCTURA...................................................... 14

2. FRAY DAMIÁN CORNEJO: FRAILE, CRONISTA Y POETA DEL BAJO



2.1. Apuntes biográficos ............................................................................... 18

2.2. Fray Damián Cornejo: poeta del Bajo Barroco …………………………..... 23

3. LA OBRA POÉTICA DE FRAY DAMIÁN CORNEJO........................................ 33

3.1. TRANSMISIÓN MANUSCRITA E IMPRESA ......................................... 33



3.2.1. Poesía dubitada con León Marchante.......................................... 37

3.2.2. Poemas dubitados con otros autores........................................... 45

4. ANÁLISIS CUANTITATIVOS DE LA OBRA DE DAMIÁN CORNEJO......... 47

4.1. INTRODUCCIÓN A LOS ESTUDIOS ESTILOMÉTRICOS .................... 47

4.2. ANÁLISIS DE LA POESÍA PROFANA INDUBITADA DE CORNEJO 49

4.2.1. Metodología aplicada y corpus analizado …………………….... 49

4.2.2. Análisis de frecuencia de palabras............................................. 50

4.2.3. Análisis morfosintáctico …………………………………...... 52

4.2.4. Análisis léxico-semántico.......................................................... 57



4.3. ANÁLISIS DE LA POESÍA PROFANA DUBITADA …………………..... 62

4.3.1. Metodología aplicada y corpus analizado …………………….... 62





4.3.4. Análisis métrico ...................................................................... 70



4.4. ANÁLISIS DE LA POESÍA SACRA INDUBITADA ............................... 73

4.4.1. Metodología aplicada y corpus analizado .................................. 73

4.4.2. Análisis morfosintáctico ........................................................... 74

4.4.3. Análisis léxico-semántico............................................................ 78



4.5. ANÁLISIS DE LA POESÍA SACRA DUBITADA ……………………...... 82

4.5.1. Metodología aplicada y corpus analizado ……………………..... 82












4.6. CONCLUSIONES SOBRE LOS ESTUDIOS CUANTITATIVOS



5. EDICIÓN CRÍTICA DEL MANUSCRITO “2245” DE LA BNE ........................ 99



5.1.1. Presentación de la edición .......................................................... 99

5.1.2. Fuentes manuscritas............................................................. 100

5.1.2.1. Análisis de los manuscritos integri................................ 100

5.2. CRITERIOS DE LA EDICIÓN …….................................................. 112

5.2.1. Ortografía y puntuación ........................................................ 113

5.2.2. Anotación ................................................................................. 113

5.3. EDICIÓN CRÍTICA …..................................................................... 115

5.3.1. Índice de poemas ................................................................. 115

5.3.2. Poemas................................................ 119



5.3.4. Índice de primeros versos .................................................... 355



7. BIBLIOGRAFÍA ................................................................................................ 366



7.1.1. CONTEXTO HISTÓRICO-LITERARIO .............................. 366

7.1.2. TESTIMONIOS SOBRE LA VIDA Y LA OBRA DE FRAY

DAMIÁN CORNEJO ................................................................ 366

7.1.3. CATÁLOGOS DONDE APARECE RECOGIDA LA OBRA DE



7.1.4. ANÁLISIS CUANTITATIVOS .............................................. 377

7.1.5. EDICIÓN …………………….............................................. 379

7.1.6. EDICIÓN EN LENGUAJE MARCADO (XML-TEI) ............. 390





8.1. CATALOGACIÓN DE LOS MANUSCRITOS POÉTICOS DE FRAY

DAMIÁN CORNEJO ............................................................................. 413





8.1.3. Bibliotecas e instituciones extranjeras....................................... 420

8.2. INDEXACIÓN DE LOS MANUSCRITOS QUE CONTIENEN POESÍA ATRIBUIDA A FRAY DAMIÁN CORNEJO .............................................. 422

8.2.1. Bibliotecas españolas............................................................ 422 
8.2.1.1. Biblioteca Nacional de España, ms. 2100 422

8.2.1.2. Biblioteca Nacional de España, ms. 2245 ..................... 423

8.2.1.3. Biblioteca Nacional de España, ms. 3884 ..................... 427

8.2.1.4. Biblioteca Nacional de España, ms. 3921 ...................... 427

8.2.1.5. Biblioteca Nacional de España, ms. 3922 ..................... 428

8.2.1.6. Biblioteca Nacional de España, ms. 3929 ...................... 429

8.2.1.7. Biblioteca Nacional de España, ms. 3930 ..................... 429

8.2.1.8. Biblioteca Nacional de España, ms. 3931 ...................... 429

8.2.1.9. Biblioteca Nacional de España, ms. 4052 .................... 433

8.2.1.10. Biblioteca Nacional de España, ms. 4062 ................... 433

8.2.1.11. Biblioteca Nacional de España, ms. 4135 .................... 435

8.2.1.12. Biblioteca Nacional de España, ms. 4258 .................... 438

8.2.1.13. Biblioteca Nacional de España, ms. 5566 .................... 442

8.2.1.14. Biblioteca Nacional de España, ms. 5862 ................... 447

8.2.1.15. Biblioteca Nacional de España, ms. 12980/1 ............... 447

8.2.1.16. Biblioteca Nacional de España, ms. 12981/35 ............. 447

8.2.1.17. Biblioteca Nacional de España, ms. 17666 .................. 448

8.2.1.18. Biblioteca Nacional de España, ms. 18470 .................. 449

8.2.1.19. Biblioteca Nacional de España, ms. 20813/4 ............... 449

8.2.1.20. Biblioteca Real de la Colegiata de Roncesvalles, ms. 410

8.2.1.21. Biblioteca Real de la Colegiata de Roncesvalles, ms. 28-C-7-6p22 (inédito) ...................................................... 455

8.2.1.22. Biblioteca Fundación Bartolomé March: 406 .............. 456

8.2.1.23. Real Biblioteca del Monasterio del Escorial, ms. Z. IV.18. 459

8.2.1.24. Biblioteca de la Reañ Academia Española, ms. E-39-6654 460

8.2.1.25. Biblioteca Menéndez Pelayo, ms. 156 ......................... 463

8.2.1.26. Biblioteca Pública Dde Toledo, ms. 447 ..................... 467



8.2.2.1. Archivo Histórico Nacional, L 1053 (inédito) ............... 468

8.2.3. Bibliotecas internacionales .................................................... 471

8.2.3.1. British Library, ms. Egerton 1889 ................................. 471

8.2.3.2. Biblioteca Pública Muncipal de Oporto, ms. 647........... 475

8.2.3.3. Hispanic Society of America, ms. Nr. XCV .................. 476

8.2.3.4. Biblioteca Central de Zúrich, ms. D-249....................... 476 
8.2.3.5. Biblioteca Estense-Universitaria de Modena, ms. Est. 199 = Epsilon 32.3.6 (inédito)

8.3. TABLAS SOBRE LA OBRA POÉTICA DE CORNEJO ....................... 480

8.3.1. Tabla de referencias de los manuscritos ................................. 480

8.3.2. Tablas de la lírica indubitada de Cornejo ................................. 481

8.3.2.1. Poesía sacra ............................................................... 481

8.3.2.2. Poesía profana ........................................................... 482

8.3.3. Tablas de la lírica dubitada de Cornejo ................................... 487

8.3.3.1. Poesía dubitada con León Marchante ............................. 487

_8.3.3.1.1. Poesía sacra publicada a nombre de Marchante......487

_ 8.3.3.1.2. Poesía profana publicada a nombre de Marchante...490

_8.3.3.1.3. Clasificación de los poemas publicados en las Obras

poéticas de Marchante........................................497

8.3.3.1.4. Poesía dubitada no publicada en las Obras poéticas de

Marchante....................................................499

8.3.3.2. Lírica dubitada con otros autores.......................500

8.3.3.3. Total de poesías dubitadas e indubitadas.................501

8.3.3.4. Total de poesías sacras y profanas atribuidas a Cornejo..501

8.3.3.5. Métrica de la lírica dubitada e indubitada (sacra y profana) atribuidas a Cornejo...........................................502

8.4. ESTUDIO DE AUTORÍA: GRÁFICOS Y TABLAS............................. 502

8.4.1. Poesía profana indubitada............................................................ 502

8.4.2. Poesía profana dubitada ......................................................... 503



8.4.4. Poesía sacra dubitada.............................................................. 510

8.5. ALGUNAS NOTAS SOBRE EL MANUSCRITO “410” DE LA

BIBLIOTECA REAL DE LA COLEGIATA DE RONCESVALLES ........... 512

8.6. ALGUNAS NOTAS SOBRE LA DIFUSIÓN DE LA POESÍA JOCOSA EN ESPAÑA EN TIEMPOS DE FELIPE IV Y DE CARLOS II ....................... 514

8.7. IMPRESIONES Y LICENCIAS DE IMPRESIÓN DE LAS OBRAS EN PROSA DE FRAY DAMIÁN CORNEJO .................................................. 520





8.8. EJEMPLO DE EDICIÓN CRÍTICA EN LENGUAJE MARCADO (XML-





8.8.2. Edición de algunos poemas de fray Damián Cornejo................ 524 


\section{INTRODUCCIÓN}

\subsection{PRESENTACIÓN Y OBJETIVOS}

Las páginas que se presentan a continuación sintetizan varios años de investigación sobre la vida y la obra poética de fray Damián Cornejo. Esta ha sido realizada mediante un contrato predoctoral en la Universidad de Valladolid (dentro del marco del Proyecto "Ovidio versus Petrarca"1) y se ha completado con dos estancias breves en la Universidad de Córdoba y en el Laboratorio de Humanidades Digitales “LINHD” de la UNED². El objetivo principal de esta tesis era realizar la edición crítica de un manuscrito (“2245” de la Biblioteca Nacional de España) que recopilara gran parte de la lírica que se atribuye al ingenioso obispo palentino.

Se ha pretendido, además, conocer el corpus de poemas que conforma sus creaciones en verso, definir sus características, indagar en su transmisión (manuscrita ${ }^{3}$ e impresa) y catalogar todas las fuentes que las recogen. También se ha querido mostrar los numerosos problemas de autoría que plantean y probar cómo la aplicación de diferentes tipos de análisis estadísticos puede ayudar a resolverlos mediante datos objetivos. Por último, se ha intentado desarrollar una muestra de cómo se podría codificar en lenguaje marcado (XML-TEI) una edición crítica, para poder obtener una visión más detallada de sus variantes y notas y para poder extraer automáticamente información de los datos etiquetados.

Los múltiples y diversos materiales aportados en este trabajo, la metodología interdisciplinar aplicada y los resultados obtenidos pueden no solo contribuir a reivindicar y divulgar los versos de Cornejo (dialogan con la tradición clásica y barroca y buscan hallar nuevos cauces de expresión), sino también ayudar a seguir profundizando en los estudios de

\footnotetext{
${ }^{1}$ El Proyecto de Investigación en el que se enmarca esta tesis "Ovidio vs Petrarca: nuevos textos de la poesía erótica española del Siglo de Oro (plataforma digital y edición” (Ref. FFI2015-68229-P) ha sido dirigido por el catedrático Javier Blasco Pascual y desarrollado en el Departamento de Literatura Española, Teoría de la Literatura y Literatura Comparada de la Universidad de Valladolid.

${ }^{2}$ La estancia realizada en la facultad de filosofía y letras de la UCO (bajo la dirección del catedrático Pedro Ruiz) tenía como finalidad la edición de algunos poemas sacros atribuidos a fray Damián Cornejo, mientras que la llevada a término en Laboratorio de Humanidades Digitales de la UNED (con la supervisión de Salvador Ros) pretendía crear una muestra de cómo codificar en lenguaje XML-TEI una edición crítica de poesía.

${ }^{3}$ En esta investigación, se han dado a conocer tres manuscritos facticios que contienen poemas que se atribuyen a Cornejo: "1053 L” del Archivo Histórico Nacional de España, "28-C-7-6p22” de la Biblioteca Real de la Colegiata de Roncesvalles y "Est. 199 = Epsilon 32.3.6” de la Biblioteca Estense-Universitaria de Módena.
} 
estilometría, en el interés de las ediciones digitales marcadas y en la poco conocida poesía que se cultivó en la península ibérica en la segunda mitad del siglo XVII.

\subsection{ESTADO DE LA CUESTIÓN}

La recurrente imagen de la musa degradada y frívola que en la España del Bajo Barroco (1650-1750) ${ }^{4}$ cantaba poemas prosaicos y festivos esconde un complejo y casi ignorado mundo poético 5 . En él, conviven y se entremezclan elevados versos laudatorios con otros que desbordan humor y crítica $^{6}$ y que explotan con habilidad la convergencia y la divergencia entre lo alto y lo bajo. La progresiva consolidación de la poesía jocosa que se produjo durante el reinado de Felipe IV propició la disolución de las fronteras del decoro estilístico y fomentó la creación de composiciones líricas que buscaban nuevas vías de pensamiento y de expresión ${ }^{7}$. Su desarrollo también se vio fuertemente influenciado por el carácter performativo que adquirió la lírica en la segunda mitad del siglo XVII, como consecuencia del auge de certámenes y eventos públicos donde se exponía o se cultivaba ${ }^{8}$.

León Marchante, José Pérez de Montoro, José Tafalla y Negrete, Francisco de la Torre y Sevil, Damián Cornejo o Vicente Sánchez son algunos de los autores que en este periodo intentaron entretener y sorprender al público mediante versos provocativos y sugerentes. Sus lectores y oyentes debían ser capaces de descifrar ingeniosas agudezas lingüísticas ${ }^{9}$ y de

\footnotetext{
${ }^{4}$ Frente a conceptos como barroquismo, postbarroco o barroco tardío que transmiten juicios de valores o que conforman una historiografía de oposiciones y de exclusiones se ha extendido el uso de Bajo Barroco. Como sucede en la Edad Media y en el Romanticismo, en el Barroco se puede distinguir "una articulación que sigue sus fases de ascenso, cénit y deriva final, con sus elementos respectivos de plenitud y de transición, diferenciados en las etapas alta y baja del proceso histórico" (Ruiz, Para la historia 16).

${ }^{5}$ La concepción negativa de la poesía compuesta en la segunda mitad del siglo XVII se remonta a mediados del periodo decimonónico. Leopoldo Augusto de Cueto, marqués de Valmar, en su Historia crítica de la poesía castellana (1869) consideró que estas eran fruto de "una Musa degradada, que cantaba porque se divertía y no porque sintiese o admirase" (Bègue, Degeneración 21).

6 A partir de 1640, la combinación de lo serio y lo jocoso "burlas y veras" da lugar a la modalidad "jocoseria". Esta emplea lo humorístico con una finalidad edificante o moral, vinculándose así con el género satírico. Las características de esta vertiente de la lírica han sido investigadas por Alain Bègue (Parece que lo jocoserio y Los limites).

${ }^{7}$ En el “Anexo: 8.6.”, se realiza una breve exposición sobre cómo se produjo y difundió la poesía jocosa en la España de Felipe IV y Carlos II.

${ }^{8}$ La habitual exposición pública del arte poética en academias, justas, certámenes y salones literarios promovió en el Bajo Barroco que la lírica adquiriera rasgos de oralidad, se apartara de temas trascendentales y desarrollara un estilo llano y familiar. Tales rasgos ayudaban a captar la atención de los oyentes y hacían que la presencia del poeta fuera sustituida por "una retórica de performance" (Bègue, Hacia la modernidad 64).

${ }^{9}$ Los poemas de este periodo presentan, con frecuencia, un lenguaje polisémico y lleno de yuxtaposiciones de conceptos, que admite numerosas lecturas y que demanda un público que sepa descodificarlas. Para poder extraer todas las dimensiones interpretativas y semánticas que ocultan "entre líneas", este debe desarrollar un tipo de competencia literaria que César Nicolás denomina "anamórfica" por estar regulada por determinadas leyes (tanto lingüística como estéticas) de perspectiva (78).
} 
reconocer en ellas tanto la subversión que se hacía de los elementos presentados de manera idealizada por la tradición neoplatónica ${ }^{10}$ como las múltiples referencias a las producciones de sus geniales predecesores ${ }^{11}$. La inmoralidad, el erotismo y la transgresión del lenguaje y de los códigos petrarquistas que recrean sus versos son herederos de los de Góngora y, sobre todo, de los de Quevedo ${ }^{12}$.

No obstante, las poesías del Bajo Barroco incorporan los fuertes cambios sociales, filosóficos y literarios que se produjeron en España durante el gobierno de los Austrias menores, manifestando con ello una nueva sensibilidad estética y una nueva forma de percibir la realidad ${ }^{13}$. Los temas burlescos ${ }^{14}$, cotidianos o intrascendentes que tratan se recrean a través de un estilo prosaico y descriptivo, donde las estructuras métricas abiertas (décimas, redondillas, romances, quintillas...) adquieren un papel destacado por su flexibilidad ${ }^{15}$. Todos estos elementos, sumados a los ecos de un espléndido pasado, promovieron que sus creaciones desaparecieran de gran parte de las historias de la literatura y que fueran duramente desprestigiadas por la crítica. Juan Manuel Rozas, Miguel Ángel Pérez o Russell Sebold consideraron estas como desafortunadas evidencias "de un movimiento caduco cuando no muerto" (Bègue, Albores 40).

\footnotetext{
${ }^{10}$ En las poesías del Bajo Barroco, el yo poético tiende a ser un mero espectador o descriptor en tercera persona de un objeto o de una situación particular, "con la consecuente inhibición de cualquier sentimiento y cualquier gravedad en la obra considerada. A esta subversión implícita del lenguaje petrarquista cabe añadir otra, explícita - ya presente en la obra de un Quevedo, por ejemplo-, que dio lugar a no pocas composiciones paródicas (en los que tanto los galanes como las damas son antítesis realistas de sus homólogos del período anterior), y burlescas (donde tanto aquéllos como éstas salen rebajados y malparados" (Bègue, Degeneración 23).

${ }^{11}$ Se trata de una escritura de transición que combina fórmulas gongorizantes con otras triviales, sencillas o vulgares, que intentan emular las composiciones jocosas de Quevedo o Lope. Esta, como señala Alain Bègue (Albores 37-69), pone en evidencia la búsqueda individual y colectiva, consciente e inconsciente, de nuevos cauces de expresión y permite conformar un puente entre la lírica del Barroco y la del Neoclasicismo.

${ }^{12}$ Los versos impresos de Quevedo se convirtieron en los más frecuentes en las bibliotecas españolas de la segunda mitad del Siglo XVII y de la primera década del XVIII. A continuación, se hallaban las poesías de Góngora y de Lope de Vega seguidas, con mucha diferencia, de las de Villamediana, de los hermanos Argensola, Esquilache, Ercilla, Bocángel, Ulloa y Pereira, Sor Juana y López de Zárate (Dadson 31).

${ }^{13}$ En las últimas décadas del siglo XVII, se produce una apertura y desarrollo de la ciencia, que conlleva el desplazamiento de la epistemología escolástica a la racionalista, que tuvo su origen en "la duda metódica cartesiana, el sensualismo de Locke y las aplicaciones matemáticas de Newton sobre la naturaleza" (Bègue y Mata 14).

${ }^{14}$ Los poemas burlescos o cómicos se caracterizan por albergar un contenido jocoso, por desmitificar y parodiar los códigos altos (lírica petrarquista, épica, encomiástica) y por emplear un estilo bajo y frecuentemente vulgar. Su finalidad básica es entretener al lector, aunque en sus versos se pueden hallar mensajes propios del modelo satírico: la censura de vicios, el desprestigio de los falsos valores de la sociedad o la ridiculización de los pecadores (Cacho, Poesía burlesca 469).

${ }^{15} \mathrm{El}$ deseo de los poetas del Bajo Barroco de crear una nueva forma de expresión poética hace que desarrollen un estilo llano, familiar, descriptivo y que ahonda en lo cotidiano. Dichas características motivan el cultivo de estructuras métricas abiertas y acercan sus versos al lenguaje de la prosa. Alain Bègue reexamina el llamado problema del "degenerado prosaísmo" que se atribuye a la poesía de este periodo e intenta dar respuestas a su origen (Degeneración 21-38).
} 
Su opinión desfavorable no ha impedido que, desde finales del siglo XX, se hayan realizado estudios y congresos sobre las obras literarias creadas en España entre 1650 y 1750. Su propósito ha sido ofrecer una visión más completa y objetiva de su divulgación y de su evolución temática y estilística. Las primeras visiones de conjunto son de los años noventa ${ }^{16}$, pero es con la llegada del nuevo milenio cuando se producen los avances más relevantes. En 2002, Jesús Pérez Magallón publicó Construyendo la modernidad y, en 2008, la revista Criticón dedicó dos números a la literatura española de este periodo. Tales contribuciones ayudaron a que, poco después, se constituyeran importantes grupos de investigación $\left(\mathrm{PHEBO}^{17}\right.$ y CELES $\left.{ }^{18}\right)$. De este último, surge el reciente monográfico Hacia la modernidad (dirigido por Alain Bègue y Carlos Mata), que pone en evidencia "una forma de ingenio más sensible a las correspondencias triviales y cotidianas y a una poética de lo común, de lo sencillo, de lo familiar, aligerada o desprovista de la dificultad conceptista anterior" (Bègue y Mata 14).

También han jugado un papel significativo en la definición de la lírica hispana del Bajo Barroco y en su difusión las antologías ${ }^{19}$, las ediciones o las reediciones que se han hecho de esta. Con el objetivo de ofrecer una muestra de algunas de las obras poéticas de la segunda mitad del Siglo de Oro que se han editado en las últimas décadas, se ha creado una línea temporal. En ella, se detalla la cronología de los autores, las impresiones antiguas que se hicieron de sus poemas y sus editores modernos ${ }^{20}$ :

\footnotetext{
${ }^{16}$ Las publicaciones y simposios relacionados con la cultura del Bajo Barroco que sirvieron como punto de partida a los estudios sobre la literatura de este periodo han sido recogidos por Alain Bègue y Jean CroizatViallet (5-8).

${ }^{17}$ El equipo de investigación de PHEBO (Poesía Hispánica en el Bajo Barroco), dirigido por Pedro Ruiz, tiene como finalidad el análisis, la edición y la valoración de la poesía escrita en España entre 1650 y 1750. Este se haya vinculado a los proyectos I+D "El canon poético barroco en el siglo XVIII: pervivencia y debates andaluces" y a "Sujeto e institución literaria en la edad moderna".

${ }^{18}$ El Centro de Estudios de la Literatura española de Entre Siglos (siglos XVII-XVIII) "CELES”, encabezado por Alain Bègue, se constituye como grupo de investigación internacional que estudia la producción literaria (poesía, prosa y teatro) y el pensamiento teórico de la literatura española entre el Barroco y el Neoclasicismo. ${ }^{19}$ En 2011, Itziar López editó una antología de varios autores del Bajo Barroco que cultivaron la lírica religiosa cómico-festiva (Juan de Matos Fragoso, Damián Cornejo, León Marchante, Agustín de Moreto, Sebastián Rodríguez...) en la que se analizan las características principales de esta.

${ }^{20}$ También debe mencionarse la edición moderna de Poesías varias (1654) de José Navarro, presentada como tesis en 2014 por Almudena Vidorreta Torres.
} 




Ilustración 1: Ediciones e impresiones de algunos poetas de las segunda mitad del siglo XVII

La poesía del obispo Damián Cornejo es la única de los poetas seleccionados (Francisco de la Torre y Sevil, José Tafalla y Negrete, José Pérez de Montoro, Vicente Sánchez y Manuel de León Marchante) que no se llevó a imprenta ni en vida del autor ${ }^{21}$ ni en la primera mitad del Siglo de las Luces ${ }^{22}$. No obstante, es importante señalar que en esta centuria más de setenta poemas que a él se atribuyen en numerosos manuscritos fueron impresos con el nombre de Marchante en sus Obras poéticas ${ }^{23}$. Exceptuando algunas publicaciones de poesías sueltas ${ }^{24}$, los versos del fraile franciscano circularon a través de múltiples manuscritos facticios (la mayoría póstumos y de dudosa fiabilidad) ${ }^{25}$ hasta finales del siglo pasado.

\footnotetext{
${ }^{21}$ El rechazo de muchos escritores del Bajo Barroco de convertir su obra poética en una mercancía fácilmente reproducible o de adaptarla los medios de divulgación más populares (pliego de cordel o el libro breve) hizo que no llevaran sus versos a imprenta. Tal decisión también pudo verse condicionada por el progresivo auge de las publicaciones de los poetas "amateurs" en dicho periodo (Álvarez Amo 9-24).

${ }^{22}$ Los autores que imprimieron en vida sus obras poéticas (Francisco de la Torre y Sevil, José Pérez de Montoro, José Navarro y Manuel de León Marchante) han sido también más divulgados y estudiados en la actualidad que el resto de poetas seleccionados que no lo hicieron: José Tafalla y Negrete, Vicente Sánchez y Damián Cornejo.

${ }^{23}$ Las setenta y seis poesías disputadas entre Cornejo y el maestro León que fueron impresas en sus Obras poéticas póstumas y las veinte que aparecen en las Obras complutenses han sido recogidas en el "Anexo: 8.3.3.1.".

${ }^{24}$ En el apartado "3.1." y en el "Anexo: 8.3.2. y 8.3.3.", se detallan todas las publicaciones de poemas dubitados e indubitados de Cornejo que se han registrado hasta la fecha.

${ }^{25}$ La mayoría de las producciones líricas del Siglo de Oro presentan problemas de autoría, pues no fueron impresas en vida del autor ni se hallan en manuscritos autógrafos. Estas son fruto de copistas o amigos que recopilaron lo que pudieron. Probablemente, el primer poseedor hizo "una copia fiel, exacta, pura; de ahí se obtienen traslados, más o menos fidedignos, poniendo a veces el nombre del poeta y a veces no. ¡Y a circular! Cada adquirente guarda con celo la hojillas al lado de otras que van formando su pequeña colección poética, y
} 
La edición parcial del manuscrito "410" de la Biblioteca Real de la Colegiata de Roncesvalles que hizo Klaus Pörtl ${ }^{26}$, en $1978^{27}$, permitió la divulgación impresa de un número significativo de sus poesías (cincuenta y nueve) y aportó relevantes materiales para su investigación. A pesar de este importante avance, no fue hasta la década de los noventa cuando la crítica literaria volvió a interesarse por su lírica. En 1993, Miguel Marañón editó una serie de sonetos eróticos que a él se atribuye (Sonetos 25-37) y, tres años después, publicó diversas poesías escatológicas que Cornejo disputa con Juan de Avellaneda (Otro testimonio 71-81).

En el nuevo milenio, Ignacio Díez (La poesía 218-222) e Itziar López (249-266) difundieron varios de sus poemas (sacros y profanos) y analizaron algunas de sus características principales. El artículo de Antonio Carreira (La obra poética 39-54) continuó indagando en estas y sacó a la luz nuevos poemarios que recopilan la lírica del poeta palentino. Tales iniciativas, unidas al esfuerzo de muchos investigadores por rescatar y revalorizar la poesía erótica ${ }^{28}$, han permitido que fray Damián fuese recogido por Alain Bègue (Diccionario 710-713) dentro del corpus de poetas "menores" de la literatura española de la segunda mitad del siglo XVII ${ }^{29}$.

Pero todavía no se han estudiado ni publicado la mayor parte de su poesía ni tampoco resuelto los múltiples problemas de autoría que manifiesta. Todo ello no solo ha dificultado que se ahondara en esta, también ha obstaculizado la completa reconstrucción del largo camino de luces y sombras que recorrieron los escritores del Bajo Barroco hacia una nueva teoría del lenguaje y del discurso poético. Editar la obra lírica del obispo de Orense será otro

cuando hay un volumen suficiente, si es hombre de posibles las hace copiar sobre un grueso cuaderno que rotulará Poesías varias o Rimas de varios ingenios; si no, por poco dinero le encuadernarán en zamarra de pergamino el conjunto de hojas de diferente letra, tamaño y hasta época... Salvo si se trata de alguien muy minucioso, el primer receptor de la breve obra poética aislada no habrá puesto el nombre del autor; ¿para qué, si sabe de quién es, si se trata de un íntimo amigo? Tal vez tampoco lo hayan hecho el segundo o el tercer copiante" (Rodríguez-Moñino, Construcción 39).

${ }^{26}$ Los múltiples problemas que plantea la edición crítica del investigador alemán, por las singulares características que posee el manuscrito que edita, han sido analizados en el "Anexo: 8.5.".

27 Danièle y Michel Maurel, en 1970, editaron las poesías atribuidas a fray Damián que aparecen en el manuscrito "5566" de la Biblioteca Nacional de España, pero los resultados de esta tesis (realizada en la Universidad de Tolouse-Le Mirall) no llegaron a ser publicados.

${ }^{28}$ La publicación de Erótica hispánica (1972) y de Floresta de poesía erótica del Siglo de Oro (1975) marcó el punto de partida de numerosos estudios, congresos, reediciones y proyectos centrados en la presencia del erotismo en la lírica española. En los últimos años, José Antonio Cerezo, Víctor Infantes, Ignacio Díez, José Labrador y Javier Blasco han liderado la mayoría de las investigaciones que se han hecho para reivindicarla y difundirla. Gaspar Garrote (n.p.) recopila algunas de estas en un corpus bibliográfico digital.

${ }^{29}$ En el Parnaso olvidado del Bajo Barroco, ocupan un lugar destacado tanto José Pérez de Montoro como León Marchante, ya que ambos son los escritores que imprimieron más versos en la segunda mitad del siglo XVII. El dramaturgo manchego realizó dieciocho publicaciones de lírica de temática divina y cuatro de profana, mientras que el poeta valenciano llevó a término quince de sacra y diez de humana (Bègue, Relación 399-477). 
paso más para mostrar cómo sus creaciones (al igual que las de sus contemporáneos) no son una "prolongación ni una supervivencia del movimiento del XVII, sino una manifestación viva, arraigada en el gusto de la época" (Bègue, Albores 44).

\subsection{METODOLOGÍA Y ESTRUCTURA}

La presente tesis es una investigación interdisciplinar, donde se combina la crítica textual tradicional con el empleo de herramientas de análisis cuantitativos y de edición digital. La integración de las nuevas tecnologías en la ecdótica permite ofrecer un estudio riguroso y preciso de la poesía de Damián Cornejo y realizar una edición crítica que reproduce la experiencia de lectura de los receptores originales (gracias a la elección de un manuscrito completo) y que aporta información sobre los poemas indubitados ${ }^{30}$, los apócrifos y los dubitados ${ }^{31}$ que la conforman.

Los materiales que acompañan a la edición (catálogos de manuscritos, datos y bibliografía sobre el contexto, la vida y la producción literaria del autor palentino, tablas y gráficos que analizan y recogen la poesía que a él se atribuye...) permiten conocer el corpus poético del obispo de Orense, delimitar las características de los versos que lo integran e indagar en los múltiples testimonios (manuscritos e impresos) que lo difundieron a lo largo de las centurias. Los problemas de autoría que este manifiesta han sido expuestos y se han planteado diversas pruebas estadísticas (algunas de ellas configuradas especialmente para el presente trabajo ${ }^{32}$ ) para intentar resolverlos y para extraer rasgos objetivos sobre el uso que se hace en él del léxico, de la semántica, de la gramática y de la métrica.

Además, se ha incluido una muestra de cómo se podrían codificar en lenguaje marcado (XML-TEI) los poemas editados con el programa Oxygen, para poder obtener una visión más detallada de sus variantes y notas y para poder extraer automáticamente información de los datos etiquetados sobre su contenido, autoría o localización. Todas estas acciones se han organizado en seis grandes bloques. La tabla que se adjunta a continuación especifica los apartados que los conforman y su localización dentro de este trabajo:

\footnotetext{
${ }^{30}$ Se han considerado como poemas indubitados aquellos que se atribuyen exclusivamente a Cornejo y que aparecen en más de cuatro manuscritos integri.

${ }^{31}$ Los poemas de autoría disputada que, según los estudios estadísticos realizados, parecen haber sido escritos por fray Damián han sido marcados en la edición.

${ }^{32}$ La aplicación de biplots (basados en porcentajes extraídos de múltiples categorías morfosintácticas) a corpus de poesía para clasificarlos supone una aportación original a los estudios estilométricos que hasta el momento se habían desarrollado.
} 
Estructura

Cuerpo del trabajo
Material

complementario

\begin{tabular}{|c|c|c|}
\hline $\begin{array}{l}\text { 1. Introducción y } \\
\text { contextualización }\end{array}$ & $\begin{array}{l}\text { 1.1. y 1.3. Presentación de la tesis y de } \\
\text { su metodología. } \\
\text { 1.2. Exposición del estado actual de la } \\
\text { poesía de fray Damián Cornejo. }\end{array}$ & $\begin{array}{l}\text { 8.6. Algunas notas } \\
\text { sobre la difusión de la } \\
\text { poesía jocosa en } \\
\text { España en tiempos de } \\
\text { Felipe IV y de Carlos II. }\end{array}$ \\
\hline $\begin{array}{l}\text { 2. Damián Cornejo: } \\
\text { fraile, cronista y } \\
\text { poeta bajobarroco }\end{array}$ & $\begin{array}{l}\text { 2.1. y 2.2. Estudio sobre la vida y la } \\
\text { obra de fray Damián Cornejo. }\end{array}$ & $\begin{array}{l}\text { 8.7. Impresiones y } \\
\text { licencias de las obras en } \\
\text { prosa de Cornejo. }\end{array}$ \\
\hline $\begin{array}{l}\text { 3. Transmisión de la } \\
\text { poesía de fray } \\
\text { Damián Cornejo }\end{array}$ & $\begin{array}{l}\text { 3.1. Análisis de la transmisión } \\
\text { manuscrita e impresa de la lírica de } \\
\text { Cornejo. } \\
\text { 3.2. Exposición de los problemas de } \\
\text { autoría que plantea su poesía: } \\
\text { - Identificación, localización y } \\
\text { análisis métrico de los poemas } \\
\text { dubitados e indubitados. }\end{array}$ & $\begin{array}{l}\text { 8.1. 8.2. y 8.3.1. } \\
\text { Catalogación } \\
\text { indexación de los } \\
\text { manuscritos. } \\
\text { 8.3.2. y 8.3.3. Tablas de } \\
\text { poemas dubitados e } \\
\text { indubitados de Cornejo. }\end{array}$ \\
\hline $\begin{array}{l}\text { 4. Análisis } \\
\text { cuantitativos de la } \\
\text { obra de Cornejo }\end{array}$ & $\begin{array}{l}\text { 4.1. Presentación del estado actual de } \\
\text { los estudios cuantitativos en el campo } \\
\text { de la poesía. } \\
\text {-Transcripción y normalización de los } \\
\text { corpus de Damián Cornejo, León } \\
\text { Marchante y Sor Juana Inés de la Cruz. } \\
\text { 4.2., 4.3., 4.4. y 4.5. Aplicación de } \\
\text { análisis cuantitativos a los corpus } \\
\text { seleccionados (dubitados } \\
\text { indubitados). } \\
\text { 4.6. Conclusiones globales. }\end{array}$ & $\begin{array}{l}\text { 8.4. Gráficos y tablas } \\
\text { complementarias de los } \\
\text { estudios de autoría. }\end{array}$ \\
\hline 5. Edición crítica & $\begin{array}{l}\text { 5.2. Características de la edición } \\
\text { 5.1.2. Colación y filiación de los } \\
\text { manuscritos integri elegidos. } \\
\text { 5.1.3. Análisis del codex optimus. } \\
\text { 5.3.2. Fijación de los poemas y } \\
\text { anotación filológica. } \\
\text { 5.4. Aparato crítico. }\end{array}$ & $\begin{array}{l}\text { 8.5. Apuntes sobre el } \\
\text { ms. } 410 \text { de la Real } \\
\text { Colegiata } \\
\text { Roncesvalles (editado } \\
\text { parcialmente). } \\
\text { 8.8. Edición crítica de } \\
\text { algunos poemas en } \\
\text { lenguaje XML-TEI. }\end{array}$ \\
\hline $\begin{array}{l}\text { 6. Conclusiones } \\
\text { y bibliografía }\end{array}$ & $\begin{array}{l}\text { 6. Conclusiones sobre la presente } \\
\text { edición y la relevancia de la poesía de } \\
\text { Cornejo y planteamiento de nuevas } \\
\text { vías de investigación. }\end{array}$ & $\begin{array}{l}\text { 7. Bibliografía temática } \\
\text { y completa. }\end{array}$ \\
\hline
\end{tabular}

Tabla 1: Estructura y materiales de la tesis 
Resulta relevante señalar que, debido a la limitación temporal de la tesis, solo se han podido aplicar las pruebas de determinación de autoría (realizadas antes de fijar el texto de la edición $)^{33}$ a los poemas dubitados con León Marchante que aparecen en el manuscrito considerado como optimus. Por el mismo motivo, tampoco se ha podido cotejar en esta las variantes de todos los testimonios integri conservados ${ }^{34}$ ni codificar en lenguaje marcado el conjunto de poemas que la integran. Por último, cabe señalar que la muestra de la edición digital en TEI no se ha podido publicar en la base de datos de "EVI-LINHD" porque la plataforma no funcionaba correctamente.

A pesar de todas las carencias o inconvenientes mencionados y del complejo proceso de aprendizaje y de testeo ${ }^{35}$ de algunas de las pruebas de análisis cuantitativos empleadas (sobre todo las ejecutadas con R y SPSS) y del etiquetado en XML-TEI, los resultados obtenidos y los métodos multidisciplinares aplicados en este trabajo se consideran satisfactorios. Estos pueden suponer un relevante punto de partida para futuros estudios y ediciones sobre la poesía del cronista palentino y de sus contemporáneos y también para investigaciones relacionadas con la estilometría o las ediciones críticas digitales.

\footnotetext{
33 Con el propósito de no introducir en los poemas sometidos al estudio de autoría más cambios que los realizados en la modernización ortotipográfica, se optó por conservar todas las variantes del manuscrito editado, el cual fue copiado por una sola mano.

${ }^{34}$ Se han podido catalogar e indexar todos los manuscritos facticios e integri (descubiertos hasta la fecha) que recogen la obra de fray Damián excepto el llamado de "Manuel Benito", ya que es propiedad de un particular. ${ }^{35}$ Se tuvo que realizar un proceso de formación y de investigación (con R y SPSS) para poder delimitar los diversos códigos "órdenes" que debían introducirse en los programas mencionados y para que estos aportaran datos válidos. Las pruebas iniciales de clasificación de poemas (basadas en rasgos morfosintácticos) se ejecutaron con poesías indubitadas de varios autores con el objetivo de probar su efectividad. Estas se optimizaron a través de diversos testeos hasta alcanzar los resultados expuestos en el apartado “4.”.
} 


\section{FRAY DAMIÁN CORNEJO: FRAILE, CRONISTA Y POETA DEL BAJO BARROCO}

Ingenioso $^{36}$, erudito y controvertido ${ }^{37}$ son tres adjetivos que pueden asociarse a Damián Cornejo, una relevante figura religiosa y literaria de la España de Carlos II. Los importantes cargos que alcanzó en la Orden Seráfica, su éxito como cronista de esta y la dedicación con la que atendía a sus fieles hicieron que se ganara la admiración de sus contemporáneos $^{38}$. El padre Segueyros, discípulo suyo, lo define como “oráculo de ciencias en las cátedras universitarias de Alcalá y como Demóstenes regular ${ }^{39}$ " (Renedo 160). Soares de Silva añade a las cualidades mencionadas la de insigne historiador de la religión franciscana y lo califica como "lucidísimo esplendor de la nación española y glorioso blasón aun casi del presente siglo" (380).

La fama que alcanzó como cronista y la gran difusión manuscrita que tuvieron sus creaciones en verso han promovido que a lo largo de más tres centurias se hayan intentado recopilar y publicar datos sobre su vida y su obra. Joan Muñoz de la Cueva (291-292), Diego Álvarez (Capítulo 3: 475) y Enrique Flórez (195-196), en el Siglo de las Luces, ofrecieron los primeros esbozos de una biografía de Cornejo. Estos son ampliados y corregidos por Benito Fernández (514-521), Agustín Renedo (159-162), Lorenzo Pérez (404-407) y Samuel

\footnotetext{
${ }^{36}$ Pedro Pérez de Sala resalta las habilidades intelectuales de fray Damián diciendo que fue "de agudísimo y fácil ingenio; apto para todo género de estudios; versado en humanidades y todas las literaturas" (Una réplica 430). El padre Segueyros también elogia sus amplios conocimientos en el campo de la religión: "Testigo soy (de la sabiduría de Cornejo) dieciséis años continuados de lector y catedrático en ella (Alcalá), si no es que sea admitido como interesado en lo mucho que dependí de su Reverendísima, en la cátedra presidiendo con sutileza singular toda la Teología escolástica, lo más dificultoso de la Sagrada Escritura y teología moral, llena de noticias de concilios y Padres, que pedían más tiempo que una vida para su comprensión, siendo el más metafísico argumento del concurso, a quienes todos como a oráculo deseábamos percibir el concepto con natural claridad explicado" (Renedo 160).

${ }^{37}$ El hecho de que a un elevado y conocido religioso, como lo fue el cronista palentino, se le atribuyan numerosas poesías jocosas y eróticas ha suscitado diversas confrontaciones en las que se ha puesto en entredicho la autoría de estas. Uno de los debates que alcanzó mayor repercusión fue el que protagonizaron en la prensa decimonónica el obispo Ramón Martínez (39) y Pedro Pérez (Una réplica 429-430). El primero afirmó que los "sucios" poemas que se firmaban con el nombre de fray Damián no podían ser obra de este y, el segundo, contraatacó argumentando que no había ningún indicio para poner en duda su atribución.

${ }^{38}$ El carácter desinteresado y piadoso de Cornejo y el recogimiento ejemplar que mostraba le convirtieron en un codiciado padre espiritual, que atendía "con caridad ardiente a los pobres y enfermos en sus urgentes necesidades, siendo a quien todos ardientemente desean y logran con mucho sosiego confesarse y dirigir su conciencia en la hora de la muerte" (Eiján 302).

${ }^{39}$ La calidad como orador que poseía el poeta palentino es recalcada por su discípulo, fray Francisco de Segueyros, mediante las siguientes afirmaciones: "Eran sus voces urbanamente heroicas, sus periodos ingeniosamente místicos, sus discursos para el entendimiento vivamente especulativos, para la voluntad afectuosamente prácticos, eran todos sus sermones morales para el ejemplo, y metafísicamente sutiles para el discurso" (Renedo 160). Además, tenía la capacidad de sorprender y divertir a sus lectores y oyentes. Eusebio González afirma que "al ilustrísimo Cornejo, cuando menos lo piensa, se le cae el chiste" (3).
} 
Eiján (300-302) a finales del periodo decimonónico y en las primeras décadas del veinte. A mediados de este último, Manuel Pazos (448-461) dio a conocer el testimonio más completo y fidedigno hasta hoy (por recopilar numerosas fuentes originales) sobre la vida del poeta palentino.

No obstante, las posteriores contribuciones que realizaron Klaus Pörtl (Cornejo, Das lyrische 7-49) y Alain Bègue (Diccionario 710-713) resultan bastante significativas, sobre todo, por los datos que ofrecen sobre sus composiciones en verso. A pesar de todas las investigaciones que se han llevado a término, todavía sigue existiendo entre el público y la crítica un gran desconocimiento sobre la figura y las obras de fray Damián Cornejo. ¿Quién fue realmente? ¿Qué aportaciones realizó en el campo literario?

\subsection{Apuntes biográficos}

Damián Francisco García de Labra Cornejo nació en Palencia en $1629^{40}$. Era hijo de Catalina Cornejo ${ }^{41}$, ilustre dama toledana, y de Mateo García de Labra, quien tenía fama de ser un honorable asturiano. La fuerte vinculación de su familia materna a la ciudad imperial hizo que en abril de $1644^{42}$ se trasladase a Ocaña para ingresar en el convento franciscano de Nuestra Señora de la Esperanza. En él y en Ciudad Real cursó durante tres años filosofía. El veintisiete de septiembre de 1653, entró en "el Colegio Mayor de San Pedro y San Pablo de la Universidad de Alcalá $^{43}$, donde probablemente terminó sus estudios de teología ${ }^{44 "}$

\footnotetext{
${ }^{40}$ Los datos sobre partida de bautismo de fray Damián que ofrece Manuel Pazos (454) indican que nació el veintisiete de septiembre de 1629 y que fue bautizado el cuatro de octubre en la Parroquia de San Miguel (Palencia).

${ }^{41}$ Catalina Cornejo pertenecía a uno de los linajes más pudientes de Toledo. Su familia tenía diversas fundaciones y capillas en las iglesias parroquiales de "Santa María Magdalena, San Nicolás y San Bartolomé" (Pazos 48).

${ }^{42}$ El extenso poema "Melancolías del año 1643", atribuido a Cornejo en los manuscritos "4135" de la Biblioteca Nacional de España, "406" de la Bibiloteca Fundación Bartolomé March y "Egerton 1889" de la British Library, podría ser una de las primeras composiciones del poeta palentino. En este, el yo poético se lamenta y denuncia la grave situación política, económica y cultural que atravesaba España en ese año y ataca con ferocidad al valido de Felipe IV.

${ }^{43} \mathrm{La}$ fama como poeta que adquirió Cornejo en la Universidad de Alcalá quedó reflejada en la décima "Apolo en la facultad", que se halla en los manuscritos "406" de la Biblioteca Fundación Bartolomé March (316) y "L 1053" del Archivo Histórico Nacional (228).

${ }^{44}$ No se poseen datos sobre dónde inició fray Damián su formación teológica, aunque sí se conoce que tuvo como lector al padre Antonio Rojo y a uno de sus condiscípulos: el padre Juan Sendín (Pérez, Bibliografía 405).
} 
(Cornejo, Das lyrische 583). En esta célebre institución, durante tres décadas (1655-1685), fue lector de tal materia y catedrático de Prima ${ }^{45}$.

Sus amplios conocimientos sobre temas sacros y su habilidadpara expresar conceptos o ideas hicieron que llegara a ocupar cargos tan importantes en su Orden como el de "guardián del convento de San Diego de Alcalá46 (1673) y el de Custodio Provincial de Castilla (1680, 1681, 1682 y 1692). Fue, además, Comisario Provincial y Examinador Sinodal en el Arzobispado de Toledo" (Bègue, Diccionario 710). Entre 1689 y 1690, el rey Carlos II le otorgó el honor de ser miembro de la Real Junta de la Inmaculada Concepción ${ }^{47}$ y Consejero Real de teología.

Cornejo también fue censor de libros teológicos ${ }^{48}$ y guía espiritual de las Clarisas Descalzas $^{49}$ del convento de San Pascual. Entre sus seguidoras más destacadas se hallan Sor Jerónima de Jesús y Carillo ${ }^{50}$ y Catalina de Jesús y San Francisco ${ }^{51}$. La estrecha relación que mantuvo con esta última hizo que no faltaran "murmuraciones en su asistencia en el prolongado aprieto en tan largo tiempo de la enfermedad de la venerable" (Álvarez, Capítulo 14: 524). El trato familiar que mostraba fray Damián con sus feligresas le otorgó la fama de

\footnotetext{
${ }^{45}$ Fray Damián impartió en la Universidad de Alcalá las materias de escolástica, exégesis, teología moral y mística y, en el claustro de Pastrana, enseñó lógica, las físicas, la metafísica y fue lector de artes (Pérez, Bibliografía 405).

${ }^{46}$ Las obras que hizo fray Damián en el coro y en las paredes, mientras era guardián del convento de San Diego, provocaron gran admiración: "Cada una era tan grande que pedía todas las tareas de una vida varonilmente aplicada" (Renedo 160).

${ }^{47}$ Cornejo recibió el encargo Real de escribir una relación del trabajo que había realizado esta junta. Aunque no se ha descubierto tal manuscrito, "en su poesía religiosa se nota mucho el conocimiento tan profundo de aquel temario tan discutido y candente entre los teólogos de la época" (Pörtl 583).

${ }^{48}$ Las diversas censuras que realizó fray Damián han sido recopiladas por Manuel Pazos: "En 1671 se imprimió en Alcalá el Especial tratado sobre los decretos de non cultu, del P. FR. Pedro de Quintanilla, que ostenta la aprobación del P. Cornejo; el mismo año, y también en Alcalá, se dio a la publicidad el Epítome de las grandezas de san Francisco de Borja, escrito por el P. Francisco García, que también tiene la aprobación de nuestro docto franciscano; en 1674 predicó la oración fúnebre de la sierva de Dios sor María de la Paz, el P. Fr. Juan Gil de Godoy, y que se imprimió en Alcalá con el título de Anual recuerdo de las memorias dulces de la Venerable sor María de la Paz, y a la que asimismo dio su aprobación el P. Cornejo; en 1682 salió de un imprenta complutense las Vespertinas sagradas que explican los Mandamientos de la Ley de nuestro señor, y sermones de los más usuales de la Semana Santa, obra del P. Fr. Juan Pablo García, que fue censurada por el P. Damián. En 1693, y también en Alcalá, dio el P. Fr. Juan Bernique a la estampa la Idea de perfección y virtudes. Vida de la V. M. y sierva de Dios Catalina de Jesús y San Francisco, cuyo espíritu por algún tiempo dirigiera nuestro P. Cornejo, que asimismo aparece dando su aprobación en la obra” (453).

${ }^{49}$ Fray Damián fue el primer confesor de las Clarisas Descalzas del convento de San Pascual, situado entonces en el Prado de San Jerónimo de Madrid" (Pazos 451).

${ }^{50}$ La cercana relación que mantuvo Cornejo con sor Jerónima hizo que pudiera conocer de primera mano sus virtudes: "Veo a toda satisfacción una verdadera humildad, copiada en los desprecios de la Cruz; una desnudez de espíritu, buscando en todo su hacer, y padecer la gloria del Señor; una total negación de la voluntad propia" (Álvarez, Capítulo 8: 497).

${ }^{51}$ Diego Álvarez (Capítulo 14: 524) recoge las palabras que corroboran la estima y la admiración que fray Damián sentía por Catalina de Jesús: "Trátela mucho y siempre con la veneración que merecían sus virtuosas prendas; y finalmente tuve la dicha de asistirla para su dirección en los últimos tiempos de su vida".
} 
ser el mejor "amigo" de las devotas" 52 . Tales rumores no impidieron que en 1682 fuera elegido obispo de Castellamare (Nápoles), un cargo que rechazó. No hizo lo mismo con el nombramiento de obispo de Orense ${ }^{53}$ en julio de $1694^{54}$.

El carácter piadoso y solidario ${ }^{55}$ que poesía Cornejo propició que pronto se ganara el beneplácito de sus diocesanos y que no abandonara oficios más humildes ${ }^{56}$ como el de asistir al Coro y a las funciones de la iglesia. Aunque su frágil salud, las continuas ausencias para sus curaciones ${ }^{57}$, la relajada conducta de ciertos eclesiásticos de Orense y "la imposibilidad de proteger a sus feligreses contra hostilidades de varia índole ${ }^{58}$, le animaron a dirigir diversas peticiones de dimisión ${ }^{59}$ a la Santa Sede que acabó accediendo a su solicitud en 1706” (Flórez 196). La condición que le impuso el Papa Clemencio XI de que siguiera ocupando el puesto hasta que se designara un sucesor provocó que Cornejo ejerciera el cargo de obispo hasta su fallecimiento. Este se produjo el 28 de abril de $1707^{60}$. La noticia de su

\footnotetext{
52 En el periodo decimonónico, los rumores que suscitaron el trato cercano entre Cornejo y sus feligresas hicieron que Diego San José (11) le dedicara un jocoso artículo titulado "Un don Juan con sotana". En él, se dice que el poeta franciscano "solía buscar las deleitosas aventuras del pecado carnal con aquella socarronería y sentado reposo de la gente frailesca, dejando pasar ante sí la fruta femenina y echando la mano a la que está más en sazón...Yo me imagino a su Ilustrísima arrellanado en su cámara episcopal, reposando de la batalla con una opulenta feligresa de aquellos campos galaicos, cari redonda, alta y mullida de pechos, opulenta de flancos como yegua normanda; y medio dormido por la fatiga del envite".

${ }^{53}$ El cronista palentino consultó a sor Jerónima de Jesús si debía admitir el obispado de Orense. Esta, tras encomendarse al Señor en la oración, se dice que recibió la siguiente respuesta: "Mi siervo, fr. Damián, será obispo como mi especial providencia lo tiene determinado. Yo le asistiré como lo pides para que consiga el cumplimiento de sus deseos en mayor obsequio y gloria mía" (Pérez 406).

${ }^{54}$ En las aprobaciones de la cuarta parte de la Crónica Seráfica, fechadas el uno de abril y el dieciséis de julio de 1693, ya se le llama a fray Damián "electo de Orense" (Pazos 454).

${ }^{55}$ Cornejo se volcó en ayudar a los habitantes de la zona cuando estos sufrieron una gran hambruna mediante la reducción de impuestos y la adquisición de alimentos básicos: "La falta de cosechas, puso a la ciudad en una situación por todo extremo calamitosa. Agotado el pan del Pósito, mandó el obispo buscar grano a los conventos de Osera, Monte de Ramo, Celanova, Junquera, Rivas de Sil y otros monasterios ricos, con lo cual, hizo grandísimo servicio a la población y labradores de la circunferente comarca” (Fernández 516).

${ }^{56}$ Enrique Flórez señala que "su instituto de pobreza y desprendimiento de bienes temporales le guardó con tanta exactitud que no conocía las especies de la moneda ni su valor" (195).

${ }^{57}$ El poema que empieza con el verso "Válgame, doña Talía" cuenta la complicada recuperación que habría tenido el cronista franciscano de una fuerte dolencia. Este se halla en los manuscritos "1053" del Archivo Histórico Nacional (233) y “406” de la Biblioteca Fundación Bartolomé March (63).

${ }^{58}$ Damián Cornejo tuvo que mediar y buscar una solución pacífica para el fuerte altercado que se produjo entre sus partidarios y los del concejo en 1703: "El Sr. Cornejo a quien estas colisiones le tenían disgustadísimo, después de haber celebrado una conferencia con los dos capitulares, enviados por el ayuntamiento, excarceló a sus presos de la Torre" (Fernández 517).

${ }^{59} \mathrm{Al}$ renunciar a la mitra de Orense "se le señaló de las rentas de la sede una pensión de mil quinientos ducados para su sustentación” (Pazos 461).

${ }^{60}$ El padre Diego Álvarez quiso saber los detalles de su fallecimiento y recibió el siguiente informe: "hallándose ya el señor Cornejo casi postrado por sus achaques y en ánimo de mudarse de la casa que habían fabricado sus sobrinos canónigos, después que tomase posesión su sucesor, acaeció la casualidad de prenderse fuego el palacio episcopal y con este motivo le pasaron con harta precipitación a la casa de una ilustre señora, llamada doña Isabel de Ciriz, madre de Don Luis Tejada, y de allí le trasladaron al cuarto que sus sobrinos tenían dispuesto para su Ilustrísima en su casa de Fuente del rey, y allí se discurre que falleciera, pues no consta otra cosa (Pazos 461).
} 
muerte y de su sepultura, en la Capilla Mayor de la Catedral de Orense, fue publicada en el periódico francés Gazette ("De Madrid” 271).

Pero Cornejo no solo destacó por los relevantes oficios que desempeñó durante su vida, también alcanzó gran reputación entre sus coetáneos como autor de hagiografías. En 1680, recibió el encargo del Ministro General de su Orden de escribir la vida de san Francisco y de sus primeros discípulos ${ }^{61}$. El primer tomo de la Crónica Seráfica lo publicó dos años más tarde y sus secuelas en 1684, 1686 y $1698^{62}$. El tiempo de escritura que esta extensa obra requirió obligó a su autor a dejar de lado otras obligaciones que para él eran más importantes: “Temía no robar a la debida vigilancia sobre sus ovejas todo aquel desvelo, que forzosamente había de dar a los libros en caso de proseguir la Crónica... quiso pasar antes por el desaire de parecer menos hombre, que por el temor de ser mal obispo" (Pazos 458).

La Crónica seráfica alcanzó un enorme éxito ${ }^{63}$ entre el público del Bajo Barroco, pues fray Damián supo abandonar el estilo sencillo y sobrio de las crónicas anteriores y desarrollar una escritura amena y llena de un "lenguaje conceptuoso y metafórico" (Pörtl $583)^{64}$. La calidad literaria que muestra esta obra la convirtió en una de las veinte narraciones más citadas del Diccionario de Autoridades ${ }^{65}$. No obstante, la fama que logró Cornejo como escritor también se debe a las festivas poesías que a él se atribuyen. Su tono desenfadado y su picante contenido propiciaron que sus versos circularan, principalmente, a través de

\footnotetext{
${ }^{61}$ Fray Damián incluyó en la Crónica Seráfica las vidas de diversos santos, las cuales por su relevancia fueron publicadas de manera autónoma en los siglos XVIII y XIX. La lista de títulos ofrecida por Klaus Pörtl (585586) ha sido completada por Julio-César Santoyo (213-214).

${ }^{62}$ Los cuatro volúmenes que suceden a estos fueron escritos por Eusebio González de Torres en 1719, 1725, 1729 y 1737. José Torrubia puso fin a esta extensa obra con la impresión en Roma de la novena parte en 1756. Entre 1766 y 1789, se reeditaron en Madrid las ocho primeras partes (Pörtl 585).

${ }^{63}$ En el "Anexo: 8.7." se incluye una lista con las licencias y aprobaciones otorgadas para la publicación de los tomos que integran la Crónica Seráfica y las diversas ediciones que se realizaron de estos.

${ }^{64}$ Cornejo, en el prólogo del primer tomo de la Crónica Seráfica, expone la necesidad de renovar la forma de escribir las crónicas: "El estilo de las antiguas era sobradamente sencillo; no está el siglo presente para sencillez tanta, o porque con la malicia se ha estragado el gusto de la devoción y es necesario dar más sazón a sus viandas, o porque (y es lo más cierto) como con la experiencia se han adelantado las artes, se ha mejorado también los gustos, y desdeñan los presentes siglos lo que aplaudieron los pasados".

${ }^{65}$ La obra de fray Damián es considerada por la crítica como un "verdadero modelo de elegancia de estilo, demostrando su vasta erudición en él, bellas letras, elevación y claridad: breve y conciso sin faltar a la claridad de la narración. Profundo, doctrinal y muy versado en la historia y vida de los santos, de tal suerte que no puede leerse un periodo que no cautive dulcemente" (Fernández 516). Tales cualidades hicieron que se incluyeran setecientas setenta referencias de la Crónica seráfica en el Diccionario de Autoridades. El número de citas que presenta esta obra la sitúa por delante de la Crónica General, de La Dorotea de Lope de Vega o de las Novelas ejemplares de Cervantes (Rojo Sánchez 196).
} 
manuscritos facticios y que se le adjudicaran erróneamente algunas piezas dramáticas de este estilo $^{66}$.

En la pluma del obispo de Orense parecen convivir y complementarse, como había ocurrido con Diego Hurtado de Mendoza, Quevedo, Góngora o Lope, las musas más altas y las más mundanas con el propósito sorprender y entretener al público. La elevada reputación que poseía como religioso y cronista lo convirtieron en un buen candidato para "salvar de la anonimia un texto y, sin romper su vinculación a un registro muy concreto, dotarle de un factor de prestigio o distinción. En ningún caso rompía la imagen que de él se conformaba en el imaginario popular. Más bien la confirmaba y la ratificaba" (Ruiz, Góngora 78).

Por ello, resulta significativo el silencio acerca de su faceta de poeta en los estudios biográficos que hicieron sobre él sus contemporáneos y los editores de sus obras en prosa en el Siglo de las Luces. Sobre todo, llama la atención que no se mencione nada sobre sus poemas sacros ${ }^{67}$ ni que estos se imprimieran en vida del autor, como sí ocurrió con los de Pérez de Montoro o León Marchante. Samuel Eiján (302) ha intentado justificar esta relevante omisión aludiendo a dos factores. Por un lado, señala que el escritor palentino cultivó la lírica de forma vocacional y, por otro, defiende que muchas de las poesías que a él se atribuyen "no le pertenecen, sino que están allí malamente incorporadas a las legítimas, quizás por personas enemigas ${ }^{68}$ y con fines nada laudables".

Parece ser cierto que el ilustre franciscano escribió versos de manera ocasional a lo largo de toda su vida ${ }^{69}$, ya que no consta en ningún lugar que se presentara a certámenes literarios ni que decidiera publicarlos. Este último dato, unido al gran número de composiciones que se disputa con el dramaturgo manchego, ha dificultado considerablemente la edición y el estudio de su lírica. Entender el contexto literario en el que se produjo esta y sus características resulta fundamental para poder valorarla correctamente.

\footnotetext{
${ }^{66}$ El diablo predicador y mayor contrario amigo, de Luis de Belmonte, y la obra con el mismo nombre que reelaboró Francisco Malaespina, en 1661, fueron impresas varias veces con la firma de Cornejo (Barrera 101). ${ }^{67}$ Antonio Carreira (La obra 53) señala que sería recomendable poner un signo de interrogación a la lírica indubitada sacra que atribuye a fray Damián, pues puede que esta no haya sido escrita por él.

${ }^{68}$ La justificación que aporta Samuel Eiján no posee ningún fundamento sólido y "parece más bien un intento de salvar la buena fama de un famoso correligionario" (Pörtl 584).

${ }^{69}$ Aunque algunos historiadores, como Juan Pérez de Guzmán (374), han aludido que las poesías atribuidas a Cornejo podrían ser solo fruto de su mocedad, el contenido de composiciones como "Válgame, doña Talía" o "Fernando, a quien por soberbio" permiten defender la hipótesis de que fray Damián cultivó la lírica también en su etapa adulta. Este último poema trata sobre la caída del valido Fernando Valenzuela, que se produjo en enero de 1677. Además, los comentarios que contiene sobre cuál sería su muerte más justa ponen de manifiesto que debió componerse antes de que esta sucediera accidentalmente en 1692.
} 


\subsection{Fray Damián Cornejo: poeta del Bajo Barroco}

Los escritores de la segunda mitad de siglo XVII intentan llevar a término una renovación de la lírica a través de dos tendencias imperantes: la claridad y la naturalidad en el estilo se asociaban a la poesía ligera, mientras que el lenguaje artificioso y oscuro se vinculaba con la elevada o heroica. En esta última, se tendía a "emular a los maestros barrocos ${ }^{70}$, mediante una alusión directa o paráfrasis de las obras magnas (sobre todo del Polifemo) o la adopción de la sintaxis alambicada de un Góngora, o a través de la creación de neologismos dignos de un Quevedo" (Bègue, Hacia la modernidad 65).

La obra poética de fray Damián recurre a las corrientes mencionadas ${ }^{71}$, aunque predomina en ella la voluntad de llegar a todos los públicos ${ }^{72}$. Por ello, tiende a evitar formas muy recargadas, a emplear un estilo familiar (lleno de múltiples expresiones orales y formas populares ${ }^{73}$ o vulgares ${ }^{74}$ ) y a tratar temas cotidianos o intrascendentes ${ }^{75}$. Tales características acercan sus producciones tanto a las premisas principales de los poetas franciscanos ${ }^{76}$ como al ideal poético que sirvió de base para el Neoclasicismo. En su desarrollo, jugaron un papel destacado el uso de una métrica flexible y la inclusión de rasgos narrativos y descriptivos ${ }^{77}$.

\footnotetext{
${ }^{70}$ La herencia de la estética barroca se manifestaba "en la acumulación de un léxico, de unas fórmulas sintácticas y de unos temas característicos, si bien se había llegado a atenuar buena parte de la aspereza conceptual" (Bègue, Hacia la modernidad 64).

${ }^{71}$ En los versos atribuidos a Cornejo, se incorporan alusiones a poesías cultas y populares de Góngora y a composiciones jocosas o eróticas de Quevedo. El poema "En tu alabanza mi musa", dedicado a María Magdalena, es un ejemplo de cómo el cronista palentino integra con ingenio y humor en un tema religioso referencias a las producciones de ambos autores.

${ }^{72}$ Según el propio fray Damián, "para efecto de mover tienen poco fuste, como son el demasiado aliño de las cláusulas, la exquisita sutileza pocas veces bien fundada, de los conceptos; como si todo esto estancado en el oído para el deleite, no dejase seco, y sin jugo el corazón" (Cornejo, Crónica 1:162).

${ }^{73}$ El obispo de Orense suele recurrir a un léxico cotidiano e incluir refranes o frases hechas. No obstante, no renuncia a integrar en su estilo llano cultismos popularizados por Góngora ("campal", "cláusula", "tremendo" o "pluma"), palabras poco recurrentes ("cierzo", "cristalino", "fabuloso" o "inmundo") y neologismos ("canterillo", "jergonazo", "clerizones" o "taimadazo").

${ }^{74}$ La voluntad de los escritores de la segunda mitad del XVII de degradar el lenguaje poético hace que Cornejo emplee en sus lúdicos versos coloquialismos, como "pachorra", "tarascada" o "tapabocas" y vocabulario escatológico ("caca", "cagar" o "palominos").

75 Los poetas del Bajo Barroco intentaban llevar "la casuística hasta su máxima amplitud" (Bègue, Degeneración 22). Esta queda reflejada en títulos como "A una dama que después de haber padecido un gran corrimiento, se sacó una muela y se sangró", de José Pérez de Montoro (58), o "A una doncellita que decía serlo, y procuraba encubrir el preñado con la mantilla o capotillo"75, de Tafalla y Negrete (61).

${ }^{76}$ Los escritores franciscanos son "los que más procuran acercarse al pueblo" y lo que se hallan más "compenetrados del alma popular, ternura, fe sencilla y hasta vulgar lenguaje" (Eiján 249-250).

${ }^{77}$ Cornejo, al igual que el resto de sus contemporáneos, tiende a acumular conceptos e ideas en sus poesías. Esta falta de concisión y el empleo de estructuras métricas abiertas hacen que sus composiciones superen con facilidad el centenar de versos y que adquieran "un carácter prosaico y frívolo que le apartaría, en principio, de la alta finalidad estética" (Bègue, Albores 48).
} 
El extenso e inédito romance "Sueño jocoso", influenciado por la tradición del sueño erótico $^{78}$, cuenta en primera persona las cómicas aventuras amorosas que sufre un hombre mientras duerme y las consecuencias que de estas se derivan tras despertar. La precisión ${ }^{79}$ con la que fray Damián describe el ambiente, las vivencias, las reflexiones del protagonista y el físico de la osada amada ${ }^{80}$ ponen de manifiesto la voluntad del poeta palentino de establecer un diálogo entre el pasado y las nuevas formas de escritura y de pensamiento. Este puente queda retratado desde los primeros versos de la composición:

Cansado anoche de estar

hecho de amor un panarra,

sobre un discurso Babieca

haciendo mil jinetadas.

Después que corrí la posta

al galope de mis ansias,

midiendo de un imposible

la nunca andada distancia.

Después de haber recogido

imaginaciones varias,

que corren en el deseo

y en el desengaño paran.

(vv. 1-12)

\footnotetext{
${ }^{78}$ Antonio Alatorre dedica un monográfico a la presencia del sueño erótico en la poesía castellana de los Siglos Oro. En él, se hace especial hincapié en la evolución que sufrió este desde sus primeras manifestaciones y en la gran influencia de la tradición italiana.

${ }^{79} \mathrm{El}$ auge del empirismo que se vivió en las últimas décadas del siglo XVII quedó reflejado en la literatura de la época e hizo que el yo lírico (solía identificarse con el poeta) mostrase una tendencia a retratar todo con rigor analítico (Bègue, Hacia la modernidad 77).

${ }^{80}$ La protagonista de "Sueño jocoso" actúa con astucia y manifiesta una actitud desafiante ante los juegos eróticos que le plantea su amante. Este la califica de "fullera", por pintar las cartas, y compara su valentía y fuerza con la atribuida a la diosa Palas. Además, en el poema se incluyen diálogos en los que ella defiende su voluntad de estar solo con el hombre que desee: "bien ve que, si yo no quiero, / ni un canillazo me alcanza, / y que llegar no ha podido / a herirme con una cuarta, / y que para no ser fácil, / uñas te he tenido hartas" (vv. 448-454).
} 
El mundo onírico es un espacio en el que el cronista franciscano da rienda suelta a la peligrosa imaginación ${ }^{81}$. En ella, se muestran y ocultan los deseos más profundos y las dificultades que existen para alcanzarlos, aunque se tratan con actitud desenfadada y superficial. Fray Damián se aleja de la sentimentalidad clásica ${ }^{82}$ y juega a revelar y a esconder la realidad ${ }^{83}$, pues para él "los poetas también se llaman Vates, que quiere decir adivino o profeta" (Crónica 3: 131). Sus composiciones entremezclan ingeniosos juegos de apariencias y contrastes (heredados de la tradición barroca) con su afán por retratar una visión desilusionada y lúdica de la penuria y de la inmoralidad que existía en la España de la segunda mitad del siglo XVII ${ }^{84}$. En su poema más popular "Oye, Catuja, dulce hechizo mío", un fraile realiza una detallada e irónica "pintura" 85 a su amada de las múltiples miserias que vive al parar en una fonda rural:

\author{
Lleváronme a acostar, ¡oh cómo siento \\ el haber de pintar el aposento!, \\ porque quisiera, ya que son tan raras, \\ pintarte estas verdades a las claras, \\ y el errar es forzoso la pintura, \\ si no la pinto en sombra muy oscura.
}

\footnotetext{
${ }^{81}$ La imaginación, según fray Luis de Granada (1504-1588), es más peligrosa que el deseo: "Seguramente, por reconocer el dominico que el deseo puede surgir de forma espontánea y acaso por motivos biológicos, en tanto que a la razón, que sí está bajo nuestro control, le corresponde que la imaginación no ayude al deseo a apoderarse de nosotros, dormidos o despiertos" (Ramos 19).

${ }^{82}$ La degeneración poética que atribuyeron los críticos decimonónicos a las composiciones del Bajo Barroco está vinculada, además de con su estilo prosaico, con la falta de sentimentalidad y con el desmesurado valor estético que en ellas se otorgaba a la agudeza incompleja. Esta fue definida por Baltasar Gracián como "el desarrollo de una obra en estrofas unidas únicamente por un hilo temático, que aglomera un indeterminado número de conceptos" (Bègue, Degeneración 30).

${ }^{83}$ Cornejo afirma que "la verdad misma en manos del poeta se pone de susto descolorida; y desfigurada, y pierde los derechos, que tiene legítimos la buena fe y creencia de los prudentes" (Crónica 3: 130).

${ }^{84}$ En los poemas que se atribuyen a fray Damián, circulan lujuriosos miembros del clero, borrachos e inmorales galanes y damas que son retratados satíricamente. Como señala, Alain Bègue, en algunas obras del Bajo Barroco se muestra la voluntad de conferir a la poesía la utilidad social "docere et delectare" que reivindicarían los poetas neoclásicos y los primeros intentos de comunicar (mediante poemas-epístolas) todo tipo de sucesos (Bègue, Hacia la modernidad 81).

${ }^{85}$ El prestigio que en los Siglos de Oro poseía la écfrasis, su fuerza para atrapar la mudable realidad y para conmover al público y su capacidad para de crear ingeniosos efectos de espejo llevó a los escritores de dicho periodo a cultivarla con cierta frecuencia. Esta práctica tiene su origen en la hermandad que desde la época clásica se estableció entre pintores y poetas y que se manifiesta en el famoso motivo del ut pictura poesis de Horacio o en el conocido aforismo de Simónides de Ceos que hacía de la pintura "una poesía muda" y de la poesía "una pintura elocuente" (Civil 419).
} 
Este aposento, pues, en que me hundo

es el culo del mundo,

porque si adonde el sol a nadie ha dado,

es en sentir del vulgo el hojaldrado.

(vv. 135-145)

El tono demoledor con el que el protagonista transmite sus desafortunadas vivencias, los comentarios sobre cómo debe contar todo lo que perciben sus sentidos y la inclusión de frases populares, dilogías, equívocos, paranomasias o estructuras simétricas ${ }^{86}$ son otras de las características que definen los versos de fray Damián ${ }^{87}$ y de sus contemporáneos. Las múltiples autorreferencias que se incorporan en este singular ovillejo entroncan, además, con la tendencia barroca de reivindicar la figura del autor ${ }^{88}$. Estas también aparecen en sus jocosos retratos de damas ${ }^{89}$, los cuales parecen tener como modelo las pinturas que Lope y Quevedo realizaron sobre mujeres feas ${ }^{90}$. Sin embargo, es importante señalar que en la mayoría de los poemas del cronista seráfico no se denigra su imagen ni se regodea en lo obsceno. Tales características acercan sus poesías a las de las escritoras del Siglo de Oro ${ }^{91}$.

\footnotetext{
${ }^{86}$ Los poetas del Bajo Barroco emplean estructuras plurimembres y estructuras fundadas en el paralelismo y la simetría para poder facilitar la comprensión de sus oyentes y lectores. Esto supone "una adaptación de la invención que se traduce por el empleo privilegiado de agudezas compatibles con dichas estructuras: agudezas por correlación — sobre todo la agudeza por improporción y disonancia—, juegos de palabras — derivatio o figura etimológica, equívocos, juegos de palabras por disociación, etc. — y agudezas compuestas" (Bègue, Albores 48).

${ }^{87}$ El cronista palentino defiende la importancia de emplear formas ingeniosas y originales en la escritura poética. Por ello, alaba las obras de fray Francisco Tressato: "son cabalísimas, por la ingeniosidad en las inventivas, propiedad en las metáforas, agudezas, y profundidad en los conceptos" (Crónica 3: 237).

${ }^{88} \mathrm{La}$ progresiva revalorización de la figura del poeta que se produjo en el Siglo Oro ha sido estudiada en profundidad por Pedro Ruiz (La poesía y La rúbrica).

${ }^{89}$ En las poesías del Bajo Barroco, abundan las pinturas jocosas de mujeres, donde se suelen exagerar las anomalías físicas para resaltar su fealdad. Un ejemplo de ello lo podemos hallar en la décima que Francisco de la Torre y Sevil (213) dedica a una vieja: "Clori, pelota te cuento, / cosida con piel de zorra, / en el vestido de borra/ y en la vanidad de viento. / El bote es el de tu ungüento, / las rayas son los extraños / de tus rugas, desengaños; / tus tratos son los reveses, / las faltas serán tus meses y los tantos tus años".

90 Marcella Trambaioli realiza un estudio comparativo sobre los retratos femeninos burlescos de Lope de Vega y Quevedo y recoge algunas de las imágenes más recurrentes que en ellos se emplean para mofarse de las mujeres: "Con respecto al bestiario femenino, si en la correspondiente amplificatio conceptista de Quevedo se acumulan águilas, serpientes, arañas, caballos, ballenas, cornejas, urracas y grifos, entre otros animales verdaderos y fantásticos, en la escritura lopesca desfilan especialmente caballos, jabalíes, gallos, águilas, serpientes, perros, gansos y arpías. En el proceso de cosificación de la figura femenina cada uno recurre a objetos y utensilios disparatados, algunos de los cuales resultan compartidos, como en el caso de la cerbatana" (301).

${ }^{91}$ El verso jocoso escrito por mujeres comparte muchos temas con el de poetas varones: la mofa de ciertos tipos o circunstancias, los retratos burlescos y la parodia del amor cortés y del petrarquismo. Sin embargo, como afirma Adrienne Martín (La poesía, 247-267), se aleja de asuntos escatológicos o sexuales en las que
} 
Además, Cornejo intenta no esbozar las partes erógenas del cuerpo femenino, evitar el lenguaje vulgar e incorporar reflexiones metapoéticas sobre la construcción de tales composiciones y sobre su posible recepción ${ }^{92}$.

Una muestra de cómo el poeta palentino intenta en sus cómicas pinturas de damas ofrecer nuevos cauces expresivos la encontramos en el ovillejo "Sepan todos y todas que yo adoro". Desde el inicio, el protagonista explica con humor sus dudas sobre si en su descriptio puellae ha de seguir o no la costumbre de empezar por el rostro, concluyendo que: "Y si algún mentecato me murmura / que es sin pies ni cabeza esta pintura, / le diré: "Majadero, / yo soy pintor y pinto como quiero" (vv. 21-24). También se burla de los manidos tópicos renacentistas sobre la belleza femenina que inundan los retratos de mujeres. Sobre los ojos de la amada sostiene que: "bien pudiera decir (pero no quiero) / algo de lo de estrellas y lucero, / porque a mí se me hicieron siempre ariscas" (vv. 103-105).

La descripción realista y selectiva del cuerpo femenino que en él se hace (llena de vocabulario coloquial o vulgar) ${ }^{93}$ es interrumpida, continuamente, por las aclaraciones que se introducen sobre el proceso creativo de la pintura ${ }^{94}$. Esto convierte la composición en una ingeniosa reflexión sobre la escritura poética y en una subversión de los tradicionales retratos. La lírica de Cornejo y de sus contemporáneos consolida la ruptura con el ideal de belleza clásico y dota a la mujer de carácter y de autonomía ${ }^{95}$. El soneto de fray Damián "A la brevedad del mayor anhelo" es un ingenioso testimonio de ello. En él, se detalla la

\footnotetext{
estas son denigradas y se adentra en otros como la maternidad, la burla de las ocupaciones y de los roles tradicionales, la moda o la dureza de la vida conventual.

${ }^{92}$ El tipo de retrato femenino que evoca fray Damián, el lenguaje llano que emplea (lleno de expresiones populares) y las reflexiones sobre cómo ha de componer su obra poseen numerosas similitudes con las pinturas jocosas de damas de Sor Juana Inés de la Cruz. Las características de estas últimas han sido analizadas por Juan Matas (91-110).

${ }^{93}$ En el retrato del físico de la dama, se emplean términos populares como: "barba" (v. 143), "cabellos" (v. 35), "cejas" (v. 69), "dientes" (v. 131), "frente" (v. 59), "garganta" (v. 149), "manos" (v. 161), "nariz" (v. 107), "mejillas" (v. 137), “ojos" (v. 81), "orejas" (v. 47), "pechos" (v. 149), "pie" (v. 173), "talle" (v. 167) y "talones" (v. 18).

${ }^{94}$ En la descripción de la parte baja de la cintura, el yo lírico se detiene y dice: "que es el señor poeta vergonzoso / y no quiere pasar más adelante, / por no encontrarse con el guardainfante. / Basta decir que aquesto es un bosquejo / de esta beldad y, con decir, lo dejo; que hay del original a este traslado / lo que va de lo vivo a lo pintado" (vv. 182-187).

${ }^{95}$ La renovación del imaginario femenino que se produce en el Bajo Barroco queda reflejada en el título de composiciones como "Habiendo enviado Celio a Clori un conejo muerto y dentro unos guantes de quintas esencias con un hueso, diciendo era pistola, para que tirase; ella le envió un rosario de avellanas vanas, unos guantes de alcorza y un corazón pintado en un abano de papel con estos versos...", de Pérez de Montoro (224), pues en él se muestra a una dama que interviene activamenente y con ingenio. Algunas de las características que proporcionan un nuevo modelo de mujer en la poesía de este periodo han sido analizadas por Pedro Ruiz (De Solís 486-505) y por Zoraida Sánchez (La mujer 163-176).
} 
realización del acto sexual con una meretriz ${ }^{96}$, que transgrede el físico, la psicología y la conducta de las damas neoplatónicas:

Esta mañana, en Dios y en hora buena,

salí de casa y víneme al mercado.

Vi un ojo negro, al parecer rasgado,

blanca la frente y rubia la melena.

Llegué y le dije: "Gloria de mi pena,

muerto me tiene vivo tu cuidado.

Vuélveme el alma, pues me la has robado

con ese encanto de áspid o sirena".

Pasó, pasé; miró, miré; vio y vila.

Dio muestras de querer. Hice otro tanto.

Guiñó, guiñé; tosió, tosí; seguila.

Fuese a su casa, y sin quitarse el manto,

alzó, llegué, toqué, besé, cubrila,

dejé mi dinero y fuime como un santo.

El espontáneo y breve encuentro carnal con una misteriosa cantonera comienza con un popular refrán de origen religioso "En Dios y en hora buena", que se irá cargando de ironía conforme la acción avance. El veloz esbozo que se hace de la "amada" mezcla características del ideal renacentista de feminidad "blanca la frente y rubia la melena" (v. 4) con rasgos de belleza que se atribuían a las mujeres árabes "un ojo negro, al parecer rasgado $^{97, " ~(v .3) . ~ E s t a ~ a t r a c t i v a ~ y ~ e x t r a v a g a n t e ~ d e s c r i p c i o ́ n ~ n o ~ s o l o ~ l a ~ a l e j a n ~ d e ~ l a ~ L a u r a ~ d e ~}$ Petrarca o de Isabel Freyre, también su comportamiento es distinto. Frente a estas mujeres idealizadas que permanecían impasibles a los ruegos del varón, la protagonista de Cornejo

\footnotetext{
${ }^{96} \mathrm{El}$ oficio de ramera era considerado en el periodo aurisecular un pecado menor, ya que ayudaba a garantizar el bien común: "evitaba faltas tan graves como la sodomía, la pederastia, el adulterio, el incesto o las violaciones" (Vivas y Arias 56).

${ }^{97}$ En el manuscrito " 4135 " de la BNE (155), se halla la variante tapado (v. 3). Este adjetivo hace más explícita la alusión a las tapadas, que eran prostitutas que recurrían a la estrategia de cubrirse la mitad del rostro para hacerse pasar por damas y para incrementar el interés masculino (Deleito y Piñuela, La mujer 64).
} 
posee una personalidad activa y juguetona: “Pasó, pasé; miró, miré; vio y vila / Dio muestras de querer. Hice otro tanto" (vv. 9-10).

El tono solemne y el lenguaje grandilocuente con el que el hombre se dirige a la meretriz, en el segundo cuarteto, recalcan la burla que realiza el autor palentino del "amor cortés"98 en el presente soneto (Díez Fernández, La poesía 222). Esta se acrecienta tras mostrar la rapidez con la que ella accede a los deseos del yo poético: "Guiñó, guiñé; tosió, tosí; seguila" (v. 11). La lacónica ejecución del acto sexual culmina con el pago de los servicios prestados ${ }^{99}$ y con una nueva y subversiva referencia religiosa "fuime como un santo" (v.15).

La mezcla de lo sacro y lo profano en los versos de Cornejo hace que en sus poemas se tantee muchas veces con los límites de lo vedado. Esto exige un público que sea capaz de descodificar tanto las referencias culturales, lingüísticas y literarias que incorpora como las diversas connotaciones de los términos que emplea ${ }^{100}$, las cuales suelen conformar en sus composiciones (sobre todo en las sacras) varios niveles de lectura ${ }^{101}$. Un claro ejemplo son los siguientes versos del romance en eco que dedica a María Magdalena: "Cuando esposa Dios te llama, / ama, y en que seas se empeña / peña que a un fino diamante / amante venza en firmeza" (vv. 13-16). Estos admiten, por un lado, una interpretación religiosa (pondría de manifiesto la enorme fe de la seguidora de Cristo en su Maestro) y, por otro, una lectura profana, que evocaría una relación íntima entre Jesús y la penitente.

Fray Damián se atreve a recrear cómicamente las tentaciones carnales que sufren los santos ${ }^{102} \mathrm{y}$ a dotar a estos de comportamientos o rasgos propios de los bajos fondos sociales

\footnotetext{
${ }^{98}$ Aunque en gran parte de las poesías de temática amorosa que se atribuyen al poeta palentino se realiza una mofa o una subversión del amor idealizado, existen algunas, como "Desde que el sol ardiente" o "Solo el silencio testigo", en las que el fino amor o el amor platónico son tratados con seriedad.

${ }^{99}$ El dinero entregado a una meretriz en los Siglos de Oro tenía una función purgativa. Se creía que, si se cobraban sus servicios, no se cometía delito ni pecado (Cantizano 29).

${ }^{100}$ En el poema "Dulce Jesús, Dios mío", puede verse cómo el poeta palentino intenta llevar al límite varios conceptos relacionados con la vista: "Al raudal del costado / dando de ojos me acerco, / ya ciego no me miro, / aunque he vivido ciego" (vv. 29-33).

${ }^{101}$ Itziar López estudia cómo se construyen y se entrelazan los diversos niveles de significación que conforman la poesía religiosa cómico-festiva. Cuanto mayor es la disparidad entre estos o más ingeniosa su interrelación, mayor es la admiración que el público puede sentir hacia la composición: "el nivel I de significación, el más inmediato, estaba condicionado por el 'asunto' y el carácter religioso de la celebración, siendo consecuencia directa su gran homogeneidad en todas las composiciones, parece adecuado afirmar que lo que determinaba el acierto de la composición y, por tanto, la aprobación y la admiración del público, era la sorpresiva disparidad del nivel II respecto del I y la originalidad con la que establecían los enlaces entre ambos. Estando ya asegurada el carácter sacro del discurso del discurso del nivel I, resulta necesario que en el discurso del nivel II fuera diverso, si no opuesto" (138).

102 Poemas como "De Francisco por menor" o "Hoy mi devoción aclama", atribuidos a Cornejo y a Marchante, son una divertida muestra de cómo san Francisco o santa Clara deben hacer frente a los intentos del diablo de hacerles caer en la lujuria.
} 
(a través de los villancicos-jácaras ${ }^{103}$ ) con el propósito de adoctrinar lúdicamente en la religión católica a sus oyentes y lectores ${ }^{104}$. El humor ${ }^{105}$ que desbordan muchos de los versos sacros de los poetas del Bajo Barroco (la mayoría de ellos fueron compuestos por ilustres miembros del clero ${ }^{106}$ ) y las ingeniosas estrategias retóricas ${ }^{107}$ que incorporan (mediante paranomasias, dilogías, disociaciones o la combinación de varios niveles interpretativos ${ }^{108}$ ) muestran una concepción de la lírica y de la fe cristiana muy distinta a la de siglos posteriores $^{109}$.

El tema más recurrente en la poesía religiosa cómico-festiva que se atribuye a Cornejo es la defensa de la teoría inmaculista. Su amplio conocimiento sobre esta, perteneció a la Real Junta de la Inmaculada Concepción, queda reflejado en sus poemas, que son un fiel testimonio de la fuerte controversia que se vivió en España a mediados del siglo XVII sobre si la Virgen María entró o no en contacto con el pecado original ${ }^{110}$. El poeta palentino, como

${ }^{103}$ Los villancicos-jácaras suponen una interesante manifestación de cómo en el Bajo Barroco se explotaba al máximo la retórica para transmitir con humor hagiografías o eventos destacados en la liturgia católica. Alain Bègue (La jácara 145-156) y María José Alonso (5-35) describen sus principales características y aportan interesantes ejemplos de estos.

${ }^{104}$ El carácter lúdico que adquirieron las ceremonias eclesiásticas y el progresivo auge de la lírica jocosa durante los reinados de Felipe IV y Carlos II promovieron la producción de poesía religiosa cómico-festiva. Esta era requerida con frecuencia para ser recitada o cantada en los múltiples festejos sacros que se celebraban en este periodo por su capacidad para captar la atención del público. Itziar López (15-174) y Alain Bègue (Tres: 99-126) han estudiado las características de este casi desconocido género.

105 En los poemas religiosos burlescos, "la risa cumple dos funciones: es un ingrediente festivo (de ludus) y actúa cual aliado de la doctrina religiosa, en aras del deseado delectare aut prodesse. Es decir, los poetas se valen de una de las modalidades de la risa en el ámbito cristiano: aquella intrascendente y juguetona destinada a aligerar la predicación, frente a la severa que reprehende al pecador” (Sáez 78).

${ }^{106}$ Muchos de los autores que cultivaron la poesía religiosa cómico-festiva (Moreto, León Marchante, Cornejo, Sor Juana...) pertenecían al estado eclesiástico y sus "poesías se leían en celebraciones a las que asistían las autoridades, sin que faltasen representantes de la Inquisición. Emisor y receptor, por tanto, también tienen algo que decir, y algunas comicidades poseen una complicidad profesional” (Sáez 81).

${ }^{107}$ Para evitar la censura, los poetas que escribían poesía sacra jocosa (además de emplear numerosas agudezas lingüísticas y varios niveles de lectura) eludían la confrontación directa con los referentes sagrados a través del personaje del "ciego" o desplazando la burla hacia diablos, judíos o herejes (Osuna, Las oraciones 355-366).

${ }^{108}$ Una interesante muestra de cómo los poetas del Bajo Barroco podían integrar en un villancico jocoso un nivel de lectura sacro y otro profano la ofrece León Marchante en su poema "Vaya el juego del hombre" (Obras poéticas 2: 5): "Nació Dios humilde y pobre / como diestro jugador, / que para arrastrar después / quiso triunfar de menor" (vv. 41-45). En el primer nivel, se haría referencia a la Encarnación de Cristo y, en el segundo, a un popular juego de cartas. La presencia del lenguaje naipesco en la lírica sacra fue una estrategia recurrente en el siglo XVII. Esta ha sido analizada por Jean-Pierre Etienvre (55-104).

109 José Deleito y Piñuela interpreta la poesía religiosa burlesca como el producto de la inmoralidad y la ineptitud de los poetas sacros del Barroco y no como el resultado de un ingenioso juego de ideas o conceptos: "Lo sagrado y lo obsceno o lo pueril eran unidos por los poetas en absurda, irreverente o sucia amalgama. Escribíanse las vidas de Jesucristo, la Virgen y los Santos en tono de burla, y las cuestiones más sagradas se hacían objeto de retruécanos y chistes de pésimo gusto, o daban materia a villancicos, cantados al son de la música en fiestas populares" (La vida 31).

${ }^{110}$ La bula emitida por Alejandro VII, en 1661, puso fin a una intensa y antigua polémica (surgida en el siglo XIV) entre maculistas e inmaculistas. Tras el dictamen papal, se declara que "la Virgen María fue preservada de pecado original en el primer instante de su concepción, que esta preservación constituye el objeto de la creencia, del culto y de la fiesta de este singular privilegio" (López Guil 30). 
otros autores contemporáneos, recrea en tono jocoso los continuos y fallidos intentos del diablo de dañar la virtud de la madre de Cristo ${ }^{111}$. La aportación más interesante que fray Damián hace a esta temática es la elaboración de unas quintillas en las que integra títulos de comedias barrocas a la exposición de la defensa de su pureza. Los primeros versos de estas se ofrecen a continuación:

En títulos, Virgen pura,

de comedias he de ver

que es limpia vuestra hermosura,

pues en Dios esto asegura

amor, honor y poder.

Dios, Virgen, que os eligió

por su madre, como rey,

de toda mancha os libró,

supuesto que os excluyó

de la fuerza de la ley.

(vv. 1-10)

El obispo de Orense intenta captar el beneplácito del público al integrar ingeniosamente conocidas comedias barrocas de Calderón de la Barca, Agustín Moreto, Rojas Zorrilla o Lope de Vega en su discurso inmaculista, que es construido a través de diversos conceptos contrapuestos relacionados con la "limpieza" y la "mancha". Probablemente, el presente poema (como era común en los villancicos o en la oratoria sagrada) fuese cantado y acompañado de música ${ }^{112}$ y de cierta teatralización. El carácter

\footnotetext{
${ }^{111}$ Un ingenioso ejemplo sobre cómo los poetas del Bajo Barroco exponen cómicamente la teoría inmaculista podemos hallarla en las coplas que presentó Juan Ibaso a la justa celebrada en Granada (1650) en defensa de la pureza de la Virgen. Estas han sido editadas y comentadas por Inmaculada Osuna (Juan 91-114).

112 El lugar central que ocupaban las piezas poético-musicales en la liturgia barroca, por su poder de convocatoria y atracción de los creyentes, y sus rasgos principales han sido estudiados por Alain Bègue (Tres 99-126).
} 
lúdico que adquirió este tipo de composiciones permitía no solo atraer más la atención de los lectores y oyentes, sino también indagar en nuevos cauces de expresión.

Fray Damián parece conocer de cerca las tendencias literarias imperantes y las obras de referencia de los Siglos de Oro (populares y cultas) y las incorpora a sus versos con destreza, humor e ironía. Estos, además, ponen de manifiesto un amplio bagaje cultural y lingüístico (entremezcla formas cultas, vulgares, coloquiales y neologismos) y un espíritu crítico con la literatura, la sociedad y la política ${ }^{113}$ de su tiempo. Su amplia formación y su personalidad atrevida, le permiten crear poesías que son testimonio de los profundos cambios que se produjeron en el lenguaje poético y en la España de la segunda mitad del siglo XVII, los cuales conformaron un puente entre la tradición barroca y la sensibilidad estética del Neoclasicismo.

En este largo camino de luces y sombras, se transforma tanto la forma de escribir poemas como su contenido. La lírica bajobarroca, en líneas generales, se acerca a la oralidad, adquiere rasgos prosaicos e intenta despojarse de cualquier atisbo de sentimentalidad o trascendencia. Además, se adentra con humor en lo cotidiano, ahonda en lo marginal (borrachos, estudiantes sin recursos, homosexuales, enfermos de sífilis, prostitutas...) o lo raro $^{114}$, subvierte el imaginario femenino (la Venus Urania se sustituye por la Venus Pandemo) y muestra a las mujeres con ciertas capacidades sociales, intelectuales y literarias ${ }^{115}$. Todo ello hace que los versos que cultivaron fray Damián y sus contemporáneos se conviertan en un interesante testimonio literario, lingüístico y social, que merece seguir siendo estudiado y divulgado.

\footnotetext{
${ }^{113}$ Fray Damián dedica varios poemas a criticar algunas de las políticas de Felipe IV "Los ganados de Fileno" y de Fernando Valenzuela "Fernado a quien por soberbio" y los pactos que se crearon para establecer matrimonios de conveniencia para Carlos II "En la ruda política mía" o "En la firme política nuestra".

114 Poemas atribuidos a Cornejo y a Marchante, como "Un galán corto de talle" o "Oye tarazón de fraile”, o "De las enanas canto", de Juan Gaspar (Peinador 13), retratan en tono burlesco a personas de baja estatura. Todos ellos se enmarcan en la tendencia barroca de intentar mostrar una "visión enriquecedora de la realidad" a través de lo "extravagante o lo anormal" (Maravall 512).

${ }^{115}$ El carácter subversivo que caracteriza a la poesía jocosa promueve en el siglo XVII la progresiva ruptura con la tradición platónica de la Venus Urania y abre paso a un imaginario femenino más realista, diverso y activo (la Venus Pandemo), que es heredero de la lírica erótica clásica. Este cambio hacia un modelo de mujer más igualitario hará que, en la lírica del Bajo Barroco, las damas comiencen a intervenir en prácticas académicas informales y "en juegos de cortes(an)ía como los denominados filis, dengue o chichisbeo" (Ruiz, De Solís 502).
} 


\section{LA OBRA POÉTICA DE FRAY DAMIÁN CORNEJO}

\subsection{TRANSMISIÓN MANUSCRITA E IMPRESA}

Los manuscritos conservados que albergan la obra poética de Cornejo (ninguno autógrafo) son bastante numerosos y pueden datarse entre las décadas finales del siglo $\mathrm{XVII}^{116}$ y la segunda mitad del XVIII ${ }^{117}$. Estos se hallan en múltiples archivos y bibliotecas nacionales e internacionales. En España, se encuentran repartidos entre las siguientes instituciones: Biblioteca Nacional de España (mss. 2245, 3884, 3921, 3922, 3929, 3930, 3931, 4052, 4062, 4135, 4258, 5566, 5862, 12980/1, 12981/35, 17666 у 18470), Biblioteca Real Academia Española (ms. E-39-6654) ${ }^{118}$, Biblioteca de Menéndez Pelayo (ms. 156), Biblioteca Real de la Colegiata de Roncesvalles (mss. 410 y 28-C-7-6p22), Real Biblioteca del Monasterio del Escorial (ms. Z.IV.18), Biblioteca Pública de Toledo (ms. 447), Biblioteca de la Fundación Bartolomé March (ms. 406) y Archivo Histórico Nacional (ms. L-1053). También existen relevantes recopilaciones en instituciones extranjeras como la Biblioteca Pública Municipal de Oporto (ms. 647), la British Library (ms. Egerton 1889), la Hispanic Society of America de Nueva York (ms. Nr. XCV), Biblioteca EstenseUniversitaria de Modena (ms. Est. 199 = Epsilon 32.3.6) y la Biblioteca Central de Zúrich $(\mathrm{ms} . \mathrm{D}-249)^{119}$.

De todos los testimonios mencionados ${ }^{120}$, hay más de una decena ${ }^{121}$ que poseen una cantidad significativa de sus poemas (más de ochenta), un hecho que evidencia el interés que

\footnotetext{
${ }^{116}$ Se han conservado varias recopilaciones breves y algunas copias sueltas de poemas atribuidos a Cornejo que parecen haber sido escritas en las últimas décadas del siglo XVII. Estas se hallan en los manuscritos "3884", "3921", "3922" y "4052" de la Biblioteca Nacional de España, en el "D-249" de la Biblioteca Central de Zúrich y en el "406" de la Biblioteca Fundación Bartolomé March.

${ }^{117}$ La descripción de los manuscritos que recogen la obra poética de fray Damián se halla en el "Anexo: 8.1. y 8.2..".

${ }_{118}$ Antonio Carreira incorporó a la lista de manuscritos que describió Pörtl (Cornejo, Das lyrische 212-226) los siguientes: el "406" de Biblioteca de la Fundación Bartolomé March, el "647" de la Biblioteca Pública Municipal de Oporto, el "E-396654" de la Biblioteca Real Academia Española y el llamado manuscrito de "Manuel Benito", que es propiedad de un particular. Además, descartó el "4121" de la Biblioteca Nacional de España, ya que "ni el estilo ni los temas coinciden con la restante poesía del cronista palentino, y ninguno de los poemas contenidos en este ms. se encuentran en los demás" (La obra 41).

119 Itziar López (401-409) indexa las poesías atribuidas a fray Damián en el códice D-249 de la Biblioteca Central de Zúrich y edita cuatro poemas sacros que a él se atribuyen (249-266).

${ }^{120}$ Los manuscritos "L 1053", "28-C-7-6p22" y "Est. 199 = Epsilon 32.3.6" han sido añadidos al corpus de testimonios poéticos de Cornejo gracias a las investigaciones realizadas en el presente trabajo.

${ }^{121}$ En el apartado "5.1.2.", se analizan las características de los manuscritos integri que recogen la obra poética de fray Damián.
} 
estos suscitaban ${ }^{122}$. La voluntad de darlos a conocer a un público mayor propició que no solo se transmitieran a través de copias manuscritas. Las primeras impresiones de poesías que aparecieron firmadas con el nombre de fray Damián o de algunos de sus poemas indubitados (impresos como anónimos por su contenido controvertido) de las que tenemos constancia son de las últimas décadas del siglo XVIII y se hallan en el Bufón de la corte (Serna 105$109)^{123}$ y en el Correo literario de Murcia (AA. VV., Agosto 91-95) ${ }^{124}$.

En 1845, se publicaron de forma anónima en la Gaceta de las mujeres (AA. VV., Álbum 6-7) dos poesías amorosas que a él se atribuyen ${ }^{125} \mathrm{y}$, diecisiete años después, Bartolomé Gallardo editó con el nombre de Cornejo dos de sus sonetos más polémicos (582$583)^{126}$. Estos reavivaron el interés de conocer las composiciones jocosas del poeta palentino y propiciaron que algunas de ellas fueron incluidas en destacados poemarios de la época: Cancionero de obras de burlas provocantes a risa y Cancionero moderno de obras alegres $^{127}$.

En el periodo decimonónico, las producciones en versos de Cornejo eran tan populares ${ }^{128}$ que se contaban "por docenas, y han sido tan gustadas, celebradas y esparcidas en su tiempo, que no hay biblioteca, pública o privada, que no cuente, por lo menos, con un ejemplar de la colección" (Pérez de la Sala, Una réplica 428). Aunque muchas de estas se consideraban perjudiciales para la moral ${ }^{129}$, la atracción que suscitaban hizo que aparecieron

\footnotetext{
${ }^{122} \mathrm{La}$ atracción que despertaban los versos festivos de Cornejo provocó que surgieran imitadores de estos. En el manuscrito "3922" de la BNE (209) aparecen dos sonetos de un autor contemporáneo "D. J. Y." que simulan dos de sus composiciones más conocidas.

${ }^{123}$ El poema publicado en 1767 por José de la Serna "A Pascuala dijo Bras", considerado actualmente como una composición apócrifa, fue reeditado por Foulché-Delbosc en 1903 (Marañón, Sonetos 25).

${ }^{124}$ La composición "Oye, Fenisa, dulce hechizo mío", atribuida exclusivamente a fray Damián, fue impresa en 1794 como anónima. La clara y extensa denuncia que en ella se hace de la precaria situación de las zonas rurales en España encaja con la línea reformista del Correo literario de Murcia.

${ }^{125}$ Los poemas que se publicaron fueron "Dulce Lisis de mis ojos" y "Amoroso, prudente y cortesano". El primero es una composición dubitada con Marchante, mientras que el segundo puede considerarse una poesía indubitada del cronista palentino. Cabe señalar que el nombre de las protagonistas de ambos textos es distinto al que aparece en los manuscritos que contienen la obra de fray Damián.

${ }^{126} \mathrm{El}$ fuerte contenido erótico que contienen algunos de los sonetos que se atribuyen a Cornejo hizo que se llegara afirmar que, aunque eran admirables, no se podían copiar sin "ir a la cárcel" (Nogales 1).

${ }^{127}$ Las composiciones atribuidas a Cornejo en el Cancionero moderno (1875) fueron editadas como anónimas por Eduardo Lustonó en el Cancionero de obras (1872). Ignacio Díez (La poesía 218) señala que este dramaturgo reprodujo "un romance y un par de sonetos (296-298 y 301-302), que el Cancionero moderno de obras alegres, siguiendo el manuscrito "EG1889 del British, sí atribuye al fraile y añade cuatro sonetos más y dos décimas (61-73)". No obstante, en la antología del humorista español aparecen más poemas vinculados a la obra de fray Damián (294-295 y 299-300).

${ }^{128}$ La gran difusión que alcanzaron los versos de Cornejo en la segunda mitad del siglo XIX quedó reflejada en diarios como Pabellón Nacional: "Y se han achacado inmotivadamente [estas coplas] a otro ingenio más popular; pero sería injusto no dar la preferencia, tratando de poesías desconocidas en el género erótico, a fr. Damián Cornejo, de que también incluyen los colectores alguna muestra, porque si hasta hoy no han podido ver la luz pública, en un voluminoso trabajo bibliográfico campean sin daño de barras" (Ossorio y Bernad 3). ${ }^{129} \mathrm{El}$ fuerte contenido erótico y el carácter transgresor de muchos de los versos que se firman con el nombre de Cornejo pudieron obstaculizar su difusión impresa en el periodo decimonónico: "la licencia de algunas
} 
en relevantes publicaciones periódicas como Madrid Cómico (AA. VV., De todo 2-3), la Revista Contemporánea (Pérez de Guzmán 374) ${ }^{130}$, Hispania (Cotarelo 20) o Flirt (San José, La vieja y Un don Juan). Con el transcurso de las décadas, la poesía de fray Damián también empezó a ocupar un espacio en los estudios y en las antologías de destacados investigadores y editores como Joaquín López Barbadillo (199-200), Camilo José Cela (340 y 362), Marcos Ricardo Barnatán (67), Pierre Alzieu, Robert Jammes e Yvan Lissorgues (36 y 64).

La primera publicación significativa de las creaciones en verso de Cornejo la realizó Klaus Pörtl en 1978 a partir de un extenso fragmento (1-84) del manuscrito de Roncesvalles ${ }^{131}$, cuya continuación (aunque es anunciada en el prólogo) nunca fue impresa. La obra, publicada en Múnich ${ }^{132}$, dio a conocer un número importante de poemas (cincuenta y nueve) y aportó materiales relevantes para indagar en su biografía y en su obra. El investigador alemán describió el contenido de los testimonios que los contienen e indexó los que hasta entonces no habían sido descritos: mss. 4135 y 5566 de la BNE. Además, elaboró una lista con todas las poesías que se asocian al autor palentino (unas doscientas) ${ }^{133}$, indicó su localización y marcó si estas eran de autoría dubitada ${ }^{134}$.

A pesar de este relevante avance, no fue hasta la década de los noventa cuando la crítica literaria volvió a interesarse por su lírica. En 1993, Miguel Marañón (Sonetos 25-37) sacó a la luz algunos sonetos satíricos que se le atribuyen en manuscritos de la BNE y, tres

composiciones es extremada, y aunque la libertad de la época pasaba por tales cosas, sin que las personas fuesen mejores o peores que las de nuestros días, creemos imposible que puedan ver la luz pública" (Pérez de la Sala, Costumbres 45).

${ }^{130}$ Algunos periodistas, como, Juan Pérez de Guzmán (374), reivindican la necesidad de dar a conocer no solo los poemas más controvertidos de Cornejo, pues "los hizo profanos muy bellos, por más que la malicia sólo haya dado a conocer hasta aquí los más livianos y alegres... no todas sus poesías ofenden los oídos y el pudor". ${ }^{131}$ El manuscrito "410" de la Biblioteca Real de la Colegiata de Roncesvalles fue descubierto durante la estancia de Klaus Pörtl en la Universidad de Navarra (1967-1971). Se trata del poemario conservado más extenso de los que intentan recopilar la poesía sacra y profana de Cornejo. Su estructura es bastante compleja, pues recopila materiales de diversas fuentes y entremezcla ocho manos de finales del siglo XVII y del primer tercio del Siglo de las Luces, que dan lugar a once partes. Las principales características de este testimonio y los motivos que llevan a considerarlo poco idóneo para realizar una edición crítica de la lírica de Cornejo se abordan en "Anexo: 8.5.".

${ }^{132}$ La impresión de la edición en territorio alemán dificultó su difusión en España. En la actualidad, se pueden localizar en la península nueve ejemplares de esta repartidos entre las siguientes instituciones: CSIC, BNE, Instituto Cervantes, Biblioteca de Navarra y en las universidades de Alcalá, Navarra, Zaragoza, País Vasco y Valladolid.

${ }^{133}$ Klaus Pörtl (585) señaló que el número de poesías que se atribuyen a Cornejo es de trescientos treinta y tres. Pero tal cifra es errónea, pues cuenta como distintos los estribillos y sus glosas e incluye los diez apócrifos de Roncesvalles y los ochenta y cinco del manuscrito "4121" de la BNE. Tras descontar estos, Carreira (La obra 42) determina que el corpus lírico de fray Damián asciende a unos doscientos poemas.

${ }^{134}$ Los datos aportados al final de la edición de Klaus Pörtl (Cornejo, Das lyrische 212-226) han resultado fundamentales para la creación de las tablas que se incluyen en el "Anexo: 8.3.2. y 8.3.3." sobre el corpus poético dubitado e indubitado de fray Damián. Aunque la lista que elabora el investigador alemán no integra todos los manuscritos integri estudiados en este trabajo, ha ayudado a identificar la mayoría de los poemas que a él se atribuyen. 
años después, divulgó una serie de poesías escatológicas que se relacionan con sus versos (Otro testimonio 71-81). Algunas de las características que estos presentan fueron analizadas por Ignacio Díez (La poesía 218-222) a través de dos célebres composiciones. En ellas, se recrean anécdotas jocosas y atrevidas escenas mediante un lenguaje irónico y cargado de oralidad y de dobles sentidos, que pretende sorprender y entretener al público. Para conseguirlo, Cornejo, al igual que otros poetas del Bajo Barroco, retrata a galanes y a damas que transgreden los códigos petrarquistas, a individuos de los bajos fondos sociales y a lascivos miembros del clero ${ }^{135}$.

La mezcla de lo sacro y de lo profano en los versos de poeta palentino ha sido investigada por Itziar López (249-266) a partir de la edición de varios poemas cómicos, que están protagonizados por vírgenes y santos. Las últimas poesías impresas que pueden vincularse con sus creaciones aparecen en la edición que hizo Manuel Sánchez de las Obras complutenses de León Marchante ${ }^{136}$ y en la antología Aquel coger a la dama a oscuras, editada recientemente por María Martínez, Zoraida Sánchez y Juan Herrero ${ }^{137}$. Los datos que existen sobre la localización y la atribución de todas ellas, al igual que la del resto de poesías dubitadas e indubitadas de fray Damián, se recogen en el "Anexo: 8.3.2. y 8.3.3.". La siguiente tabla sirve como muestra de la información que se puede encontrar en dichos apartados:

\footnotetext{
${ }^{135} \mathrm{La}$ actitud poco recatada y deshonesta que en la cultura del Siglo de Oro se atribuía al clero queda reflejada en algunos poemas jocosos de Cornejo: "Un ciego soy desgraciado" o "Marica, que a decir mal". En ellos, frailes y monjas muestran un comportamiento inmoral y cruel, que es heredero de obras medievales como $\mathrm{El}$ Decamerón o los fabliaux (Díez Fernández, La poesía 176).

${ }^{136}$ En las Obras complutenses de Marchante, se publicaron veinte poemas de temática divina y humana que se atribuyen al maestro León y a Cornejo y que aparecen también en sus Obras poéticas póstumas.

${ }^{137} \mathrm{La}$ antología de poesía erótica de los Siglos de Oro Aquel coger a la dama a oscuras recoge seis poemas indubitados profanos de fray Damián (dos de ellos inéditos).
} 


\begin{tabular}{|c|c|c|c|c|c|}
\hline \multicolumn{6}{|c|}{ Poesía dubitada sacra } \\
\hline $\begin{array}{l}\text { Primer } \\
\text { verso }\end{array}$ & $\begin{array}{l}\text { Atribuida } \\
\text { a LM en } \\
\text { impresos }\end{array}$ & $\begin{array}{l}\text { Atribuida a } \\
\text { LM en } \\
\text { manuscritos }\end{array}$ & $\begin{array}{l}\text { Atribuida a } \\
\text { Cornejo en } \\
\text { manuscritos }\end{array}$ & $\begin{array}{l}\text { Atribuida a } \\
\text { Cornejo en } \\
\text { impresos }\end{array}$ & Métrica \\
\hline $\begin{array}{l}\text { 1. A } \\
\text { conjurar } \\
\text { estas nubes }\end{array}$ & $\begin{array}{l}\text { León } \\
\text { (Obras } \\
\text { poéticas 1: } \\
148) \\
\text { León } \\
\text { (Obras } \\
\text { compluten- } \\
\text { ses 372) }\end{array}$ & T (39) & $\begin{array}{l}\text { A (27), B (60), } \\
\text { H (196v), K } \\
(26), \text { N }(153), \tilde{N} \\
(165 \mathrm{v}), \text { R }(61 \mathrm{v}), \\
\text { S (124v) }\end{array}$ & $\begin{array}{l}\text { Cornejo (Das } \\
\text { lyrische } 161 \text { ) }\end{array}$ & Romance \\
\hline $\begin{array}{l}\text { 2. ¡Ah, } \\
\text { Señor, el de } \\
\text { la hostia! }\end{array}$ & $\begin{array}{l}\text { León } \\
\text { (Obras } \\
\text { poéticas 2: } \\
270 \text { ) } \\
\end{array}$ & & $\begin{array}{l}\mathrm{D}(183 \mathrm{v}), K \\
(68), \mathrm{N}(178), \mathrm{R} \\
(28 \mathrm{v}), \mathrm{S}(138 \mathrm{v})\end{array}$ & $\begin{array}{l}\text { Cornejo (Das } \\
\text { lyrische 111) }\end{array}$ & Copla \\
\hline $\begin{array}{l}\text { 3. Al señor } \\
\text { Bautista, el } \\
\text { jaque }\end{array}$ &  & & $\begin{array}{l}\text { A (12v), B } \\
(66 \mathrm{v}), \mathrm{D}(169 \mathrm{v}), \\
\mathrm{E}(331), \mathrm{M}(19), \\
\mathrm{N}(165), \tilde{\mathrm{N}} \\
(185), \mathrm{R}(75 \mathrm{v}), \\
\mathrm{S}(136 \mathrm{v})\end{array}$ & $\begin{array}{l}\text { Cornejo (Das } \\
\text { lyrische 185) }\end{array}$ & Romance \\
\hline
\end{tabular}

Tabla 2: Muestra de la poesía dubitada sacra de Cornejo

\subsection{PROBLEMAS DE AUTORÍA}

La ausencia de poemarios autógrafos o impresos en vida de Cornejo, la temática festiva de sus poemas y su transmisión manuscrita han propiciado que el corpus poético que a él se atribuye ${ }^{138}$ manifieste numerosos problemas de autoría. Existen noventa y tres poesías que disputa con otros autores. De ellas, ochenta y seis aparecen firmadas también con el nombre del maestro León, cuatro se vinculan a Juan de Avellaneda, una fue publicada a nombre de José Pérez de Montoro, una se asocia a Quevedo y Francisco de Porras y otra se atribuye a Francisco de Valdés o Vallés “Anexo: 8.3.3.2.". En este trabajo, se han identificado y localizado todas estas y se han estudiado las características estilísticas de algunas de las disputadas con Marchante ${ }^{139}$ con el propósito de poder obtener pruebas objetivas que ayuden a determinar cuál es su verdadero creador.

\subsubsection{Poesía dubitada con León Marchante}

\footnotetext{
138 De los cerca de doscientos poemas que se atribuyen a Cornejo, únicamente sesenta y uno pueden considerarse indubitados (cincuenta y dos profanos y nueve sacros).

139 El tiempo que requiere la preparación y el análisis de los poemas para realizar un estudio de autoría ha hecho que solo se sometan a este los dubitados con el maestro León que aparecen en el manuscrito " 2245 " de la Biblioteca Nacional de España..
} 
Varios pudieron ser los motivos que propiciaron que muchos de los poemas que se atribuyen a Cornejo se firmaran también con el nombre de Marchante (1631-1680) ${ }^{140}$. En primer lugar, el gusto de ambos por cultivar temas jocosos. En segundo lugar, el hecho de que sus versos pudieron haberse transmitido en los mismos círculos y de manera simultánea, ambos estudiaron y trabajaron en la Universidad de Alcalá a mediados del siglo XVII ${ }^{141}$. En tercer lugar, el deseo del maestro León de no conservar sus borradores (por el concepto negativo que tenía de estos) ${ }^{142}$ y su decisión de quemar sus creaciones poco antes de morir ${ }^{143}$. En cuarto lugar, la casi total ausencia de manuscritos que le atribuyen poesías al dramaturgo de Pastrana. Por último, la inexistencia de testimonios de poesía autógrafos de fray Damián.

Los poemas dubitados entre el cronista seráfico y León ascienden a ochenta y seis (veintinueve sacros y cincuenta y siete profanos): diez se hallan atribuidos al dramaturgo manchego en manuscritos que recopilan también la obra de Cornejo y setenta y seis ${ }^{144}$ fueron publicados en sus Obras poéticas (1722 y 1733) $)^{145}$. Estas, principalmente de temática divina $^{146}$, se distribuyen de la siguiente manera. En el primer volumen $(1722)^{147}$, se hallan veinticuatro, en el segundo (1733), se encuentran catorce y, en el tercero (1733), treinta y

\footnotetext{
${ }^{140}$ Los principales datos relacionados con la biografía y la producción poética de León han sido recogidos por Manuel Sánchez en su edición sobre las Obras complutenses del dramaturgo manchego.

${ }^{141}$ Marchante ocupó el cargo de prebístero sacristán del colegio de Santiago de los caballeros Manriques en octubre de 1652. Siete meses más tarde, se graduó como maestro de Artes y, un año después, alcanzó el cargo de capellán mayor (Léon, Obras Complutenses 17).

${ }^{142}$ En el amplio epistolario que Marchante mantiene con su prima, el dramaturgo manchego confiesa en varias ocasiones que los partos de su ingenio son desafortunados y que no suele conservarlos: "Ahí te envío los borradores, porque yo nunca los guardo; que si tengo algún acierto, es la desconfianza de los versos que escribo" (León, La picaresca 555).

${ }^{143}$ El editor del primer tomo de las Obras poéticas lamenta en el prólogo que el poeta de Pastrana arrojará sus versos a las llamas y que muriera "sin dejar a lo menos para lo futuro lo más sacro y escogido de aquellos papeles, que pudieron haber servido de utilidad muy grande y mayor mérito con publicarse" (n.p.).

${ }^{144}$ Klaus Pörtl (Cornejo, Das lyrische 212-226) en su edición señaló setenta y un poemas atribuidos a Cornejo que fueron impresos en las Obras poéticas de León Marchante. En este estudio, se han descubierto cinco más. En el primer volumen, se halla "De Diego muy por menor" (182), en el segundo, se encuentra "Ah, Señor, el de la hostia" (270) y, en el tercero, se incluyen "Clodio, del mundo en la plaza" (25), "Diego que con atención" (28) y "Con licencia de Silvia" (58).

${ }^{145}$ En las Obras póstumas de Marchante existen tres poemas dubitados "Hoy sin más ni más me allano", "Un estudiante este curso" y "Un tudesco humana cuba" que fueron publicados previamente en un pliego (1670?), que recoge varios poema profanos atribuidos al dramaturgo manchego (León Relación 15-16).

${ }^{146}$ Las composiciones sacras de los tres tomos suman quinientas quince páginas, casi el triple que la lírica humana. En el primer volumen. los versos sacros ocupan "las primeras 128 páginas, y algunas de las finales. En medio quedan unas 80 de poesía profana, antes de la parte dedicada a comedias y entremeses. En el segundo, la poesía sacra ocupa la totalidad de las 384 páginas. En el tercero, de solo 184, la poesía profana ocupa 97, y el resto es obra dramática" (Carreira, La obra 46).

${ }^{147}$ La grata acogida que tuvo el primer tomo alentó a su editor a recopilar más poemas atribuidos a León. En el prólogo del segundo volumen, este dice que muchos colaboraron para tal fin: "constituyéndose agentes, para solicitarlos de quien los tenía. Todos con ansia a que no queden sepultados en el olvido: señas claras del gusto con que se ha leído el tomo, que ya se dio a la luz" (León, Obras poéticas 2: n.p.).
} 
ocho $^{148}$. Los problemas de autoría que suscitaban las poesías recopiladas en estos, a partir de múltiples fuentes ${ }^{149}$, son planteados en la aprobación del primer tomo ${ }^{150}$ :

He llegado a discurrir en lo principal de ella, que tal vez, aun las que no lo son se le adjudican,

o por autorizarlas antes con su nombre, porque la similitud las equivoca con las suyas: las

notas puestas las distinguen bien para llamar a la duda, dejándola al buen juicio la decisión

competente (León, Obras poéticas 1: n.p.).

La fama de poeta que poseía el maestro León, gracias a la publicación en vida de múltiples poemarios ${ }^{151}$, también pudo haber provocado que los versos que se atribuían a él y a un escritor ocasional (como era el caso de Cornejo) se terminaran imprimiendo con su nombre ${ }^{152}$. Este hecho no sería un caso aislado, pues en el periodo aurisecular se producía una especie de gravitación con los poemas disputados entre dos autores: "el ingenio de mayor renombre en su tiempo es quien las atrae" (Carreira, El manuscrito 45).

Conocer cómo se difundieron los poemas dubitados entre ambos puede aportar datos interesantes acerca de su autoría. Por ello, se ha determinado el número de estos que aparecen en los poemarios integri de fray Damián ${ }^{153}$ y se ha identificado si fueron impresos a nombre

\footnotetext{
${ }^{148}$ En el "Anexo: 8.3.3.1.3.", se especifica qué poemas dubitados con Cornejo se imprimieron en cada uno los de tomos de la poesía de Marchante.

${ }^{149}$ En el prólogo del segundo tomo de la poesía del maestro León puede leerse lo siguiente sobre cómo se recopilaron las composiciones que integran sus Obras poéticas: "Unos, enajenándose de los papeles, que guardaban para su recreo, franqueándolos con liberal mano porque lleguen a la de todos. Otros, constituyéndose Agentes, para solicitarlos de quien los tenía. Todos con ansia a que no queden sepultados en el olvido". A pesar de que los poemas fueron reunidos de este modo, como señala Carreira (La obra 45), los textos editados poseen pocas erratas. En ellos solo se han detectado dos apócrifos; uno en el primer volumen "Canción real a san Jerónimo" y otro en el tercero (atribuido también a Cornejo) que fue impreso a finales del siglo XVI.

${ }^{150}$ En la aprobación del segundo tomo, realizada por Xavier Rodríguez de Arellano, también se plantea el problema de que algunos atribuyen obras que aparecen en este a otro ingenio, pero se apuesta por otorgar su autoría a Marchante: "aunque hay algo en estos libros, que se habrá leído en otros; allí estaban [en] violencia; y aquí como en casa de su dueño" (León, Obras poéticas 2: n.p.).

${ }^{151}$ El maestro León fue el poeta español de la segunda mitad del seiscientos que más publicó en vida. Desde 1658 hasta un par de años antes de su muerte (1680), sus versos sacros fueron llevados a la imprenta en diecinueve ocasiones. Además, el dramaturgo manchego imprimió las composiciones presentadas para la justa de 1657 (realizada en Alcalá de Henares), un poema de temática profana, una carta a un amigo suyo y la relación de un festejo taurino. Todas estas obras se hallan recogidas en el inventario de libros de poesía impresos en el Bajo Barroco (Bègue, Relación 399-477).

${ }^{152}$ La popularidad que poseía el dramaturgo manchego propició que otros autores imprimieran sus poesías con el nombre de Marchante. De estas falsas atribuciones se queja León en sus cartas: "no es mío el villancico que está al talón del impreso; porque siendo fruta de su cosecha, la calumnia cruel ha divulgado que es mío. Así lo depuse ante tres ingenios como antes tres escribanos, para que conste es testimonio el decir que lo hizo el sujeto (La picaresca 583).

${ }^{153}$ Para facilitar su análisis, se ha asignado a los manuscritos integri de Cornejo las siguientes letras: $A$ ("E-39 6654 " de la BRAE), $B$ ("Egerton 1889" de la BL), $D$ ("2245" de la BNE), $H$ ("3931" de la BNE), $M$ ("406"
} 
del maestro León o si se atribuyen también a este último en manuscritos. En la siguiente tabla, se concreta cuántas poesías disputadas entre Cornejo y Marchante incluye cada testimonio y en qué volúmenes de las Obras poéticas del dramaturgo manchego se hallan:

\begin{tabular}{|r|r|r|r|r|}
\hline Manuscritos & \multicolumn{1}{c}{$\begin{array}{l}\text { Vol. I } \\
\text { (1722) }\end{array}$} & \multicolumn{1}{c|}{$\begin{array}{l}\text { Vol. II } \\
\text { (1733) }\end{array}$} & \multicolumn{1}{c|}{$\begin{array}{l}\text { Vol. III } \\
\text { (173) }\end{array}$} & \multicolumn{1}{l}{ Total } \\
\hline A & 9 & 13 & 30 & 51 \\
\hline B & 21 & 13 & 34 & 68 \\
\hline D & 16 & 12 & 32 & 60 \\
\hline H & 20 & 8 & 33 & 61 \\
\hline LL & 9 & 0 & 28 & 37 \\
\hline M & 2 & 12 & 27 & 40 \\
\hline N & 23 & 14 & 33 & 70 \\
\hline$\tilde{N}$ & 16 & 13 & 33 & 62 \\
\hline Q & 2 & 0 & 31 & 33 \\
\hline R & 23 & 14 & 36 & 73 \\
\hline S & 22 & 11 & 32 & 65 \\
\hline
\end{tabular}

Tabla 3: Poesías dubitadas de Cornejo que aparecen en las $O P L M$

Como ya se ha comentado previamente, los dos primeros tomos de la poesía de Marchante (contienen principalmente lírica sacra) albergan menos poemas dubitados que el tercero, el cual posee únicamente profana. Los poemarios más extensos $\left(B, D, N, \tilde{N}, R^{154} \mathrm{y}\right.$ $S$ ) son los que presentan más textos impresos a nombre del maestro León. Cabe señalar también que los manuscritos más breves $(A, L L, M$ y $Q)$ apenas incluyen poemas dubitados del primer volumen y que $L L$ y $Q$ no poseen ninguno del segundo tomo.

Además de las setenta y siete composiciones disputadas con fray Damián que aparecen en las Obras poéticas, existen otras diez (seis de temática sacra y cuatro de lírica profana) ${ }^{155}$ que se firman con el nombre de Marchante en varios manuscritos "Anexo: 8.3.3.1.4.”. Resulta significativo señalar que las atribuciones manuscritas al dramaturgo manchego de poesías dubitadas con Cornejo (tanto de las que fueron impresas como de las que no) resultan bastante reducidas. En el siguiente gráfico, se detalla en qué poemarios se

de la BFBM), $N$ ("5566" de la BNE), $\tilde{N}$ (" 4258 " de la BNE), $Q$ ("4135" de la BNE), $R$ (" $410 "$ de la BRCR) y $S$ ("156" de la BMP). Las referencias completas de estos y del resto de testimonios que contienen poemas atribuidos a fray Damián se pueden consultar en el "Anexo: 8.1.”.

${ }^{154}$ De los setenta y dos poemas dubitados que contiene el manuscrito de Roncesvalles, dos aparecen únicamente atribuidos a Cornejo en este poemario: "Ayer, Angélica, supe (36)" y "Quiero ver a mi tristeza (37)", que se incluyen en el tercer tomo de las Obras poéticas de Marchante.

${ }^{155}$ Se ha añadido el poema "Per signum crucis de la avara" a la lista de atribuciones a Marchante en manuscritos elaborada por Klaus Pörtl (Cornejo, Das lyrisque 212-226). 
encuentran todas estas y se especifica las que fueron publicadas en algunos de los volúmenes póstumos de León:

\begin{tabular}{|c|c|c|c|c|c|}
\hline \multirow[t]{2}{*}{ Ms. } & \multirow[t]{2}{*}{$\begin{array}{l}\text { Poesías } \\
\text { dubitadas (no } \\
\text { publicadas) }\end{array}$} & \multicolumn{3}{|c|}{$\begin{array}{l}\text { Poemas dubitados (atribuidos } \\
\text { en manuscritos a León) } \\
\text { publicados en las OPLM }\end{array}$} & \multirow{2}{*}{$\begin{array}{l}\text { Total de poemas } \\
\text { dubitados } \\
\text { atribuidos a León } \\
\text { en manuscritos }\end{array}$} \\
\hline & & V. I & V. II & V.III & \\
\hline B & 1 & 0 & 0 & 1 & 2 \\
\hline$\tilde{\mathbf{N}}$ & 0 & 7 & 0 & 0 & 7 \\
\hline Q & 8 & 1 & 0 & 1 & 10 \\
\hline$T$ & 0 & 10 & & 6 & 23 \\
\hline$Y$ & 1 & 0 & 0 & 2 & 3 \\
\hline $\mathrm{Z}$ & 1 & 0 & 0 & 2 & 3 \\
\hline
\end{tabular}

Tabla 4: Atribuciones a Marchantes en manuscritos

Llama la atención el elevado número de poemas dubitados (veintitrés) que el manuscrito de $T$ atribuye al poeta de Pastrana. El hecho de que todos ellos se incluyan en sus Obras poéticas podría llevar a pensar que dichas atribuciones pudieron estar condicionadas por los tomos editados. Este dato parece confirmarse al comprobar que en dicho poemario las referencias a Marchante son ulteriores a la transcripción de las poesías (parece ser contemporánea a la publicación del primer volumen ${ }^{156}$ ) y aparecen añadidas en las composiciones que no se indica ninguna autoría o sobrescritas con la palabra "León" en las que sí están firmadas. En algunas de estas últimas, puede distinguirse debajo el nombre de Cornejo.

Las atribuciones al dramaturgo manchego también se incorporaron posteriormente en $\tilde{N}$. La caligrafía de la segunda mano de este (al igual que la de $Q$ ) podría ser de mediados del siglo XVIII. No sucede lo mismo en el manuscrito $Y$. Este se trata de una copia de $Z$, que ha sido datada por Itziar López (391-392) entre 1665 y 1670. Puede concluirse, por tanto, que la mayoría de las referencias a Marchante que aparecen en los manuscritos analizados (mediante correcciones o adiciones) pudieron ser promovidas por la publicación de sus obras, ya que estas son contemporáneas o posteriores a su impresión.

Tras determinar en qué volúmenes de las Obras poéticas de Marchante y en qué manuscritos hay más poemas dubitados con Cornejo, se ha procedido a analizar la métrica de estos para intentar establecer diferencias y semejanzas con la de las poesías indubitadas

\footnotetext{
156 La letra que copia los poemas dubitados del manuscrito de "447" de la Biblioteca Pública de Toledo incorpora las siguientes dataciones: trece de enero de 1721 (32) y 28 de enero de 1721 (94). Estas son anteriores a la fecha de la aprobación del primer tomo de León (1722), que está firmada en mayo de ese mismo año.
} 
del poeta palentino. Para ello, en primer lugar, se ha identificado las estructuras métricas de las composiciones disputadas entre ambos que hay en los tomos publicados del maestro León. La siguiente tabla recoge los porcentajes obtenidos:

\begin{tabular}{|l|r|r|r|r|}
\hline OPLM & \multicolumn{1}{l|}{ Vol. I } & \multicolumn{1}{l|}{ Vol. II } & \multicolumn{1}{l|}{ Vol. III } & \multicolumn{1}{l|}{ Total } \\
\hline Copla & 4,3 & 7 & 2,5 & 3.9 \\
\hline Décima & 0 & 0 & 53,8 & 27,6 \\
\hline Lira & 0 & 0 & 2,5 & 1.3 \\
\hline $\begin{array}{l}\text { Octosílabos } \\
\text { esdrújulos }\end{array}$ & 4,3 & 0 & 0 & 1.3 \\
\hline Quintilla & 26 & 35,7 & 7,6 & 18,4 \\
\hline Redondilla & 13 & 7 & 5.1 & 7,9 \\
\hline Romance & 52,17 & 57,1 & 20,5 & 36.8 \\
\hline Seguidilla & 0 & 0 & 2,5 & 1,3 \\
\hline Soneto & 0 & 0 & 5 & 2,6 \\
\hline
\end{tabular}

Tabla 5: Métrica de los poemas dubitados de Cornejo que aparecen en las OPLM

En el cómputo total de las obras dubitadas que fueron publicadas póstumamente a nombre del dramaturgo manchego, el romance $(36,8 \%)$, las décimas $(27,6 \%)$ y las quintillas $(18,4 \%)$ son las estructuras más empleadas ${ }^{157}$. Sin embargo, se observan diferencias significativas entre los volúmenes, las cuales podrían estar condicionadas por la temática predominante (sacra o profana) en cada uno. En los dos primeros destaca la presencia del romance (supera el $50 \%$ ), mientras que en el tercero sobresalen las décimas con más de la mitad del total. En este último tomo, el número de romances y de quintillas disminuye considerablemente respecto a las publicaciones anteriores y se incluyen sonetos (5\%) y décimas $(53,8 \%)$.

A los resultados previamente comentados, se han añadido los porcentajes de los poemas disputados que aparecen, únicamente, en manuscritos. Estos se han comparado con la métrica de los sesenta y un poemas indubitados de Cornejo (cincuenta y dos profanos y nueve sacros) y de los ciento cincuenta y ocho indubitados de León que aparecen en el primer tomo de las Obras poéticas de Marchante (cincuenta profanos y ciento ocho de temática religiosa) ${ }^{158}$ con el propósito de comprobar las semejanzas y diferencias que se establecen entre ambos autores en el uso de la métrica. Además, se ha realizado el cómputo total de las

\footnotetext{
157 A mediados del siglo XVII, se produce el auge de las composiciones populares (romances, quintillas, décimas, redondillas...), ya que se creían propicias para la desarrollar un lenguaje más natural y acorde con la temática festiva que imperaba en la época (Bègue, Degeneración 22-38).

${ }^{158}$ Se ha elegido para estudiar la métrica de los poemas indubitados de Marchante el primer volumen de sus obras póstumas, pues es el único que contiene poesía sacra y profana y también es el más extenso.
} 
ciento cuarenta y siete poesías (dubitadas con León e indubitadas de fray Damián) que se atribuyen a Cornejo en este trabajo para contrastar los datos. Los porcentajes obtenidos son los siguientes:

\begin{tabular}{|l|r|r|r|r|}
\hline Métrica & $\begin{array}{l}\text { Indubitada } \\
\text { de Cornejo }\end{array}$ & $\begin{array}{l}\text { Dubitada } \\
\text { con León }\end{array}$ & $\begin{array}{l}\text { Atribuida a } \\
\text { Cornejo (total) }\end{array}$ & $\begin{array}{l}\text { Indubitada } \\
\text { de León }\end{array}$ \\
\cline { 2 - 5 } Décima & 1,6 & 4,5 & 3,3 & 23,7 \\
\hline $\begin{array}{l}\text { Endecha } \\
\text { Lira }\end{array}$ & 16,3 & 24,1 & 20,9 & 15,9 \\
Octosílabos \\
en esdrújulos
\end{tabular}

Tabla 6: Porcentajes de metros en la poesía dubitada e indubitada de Cornejo y León

Las diferencias más significativas en el uso de metros entre las poesías indubitadas de Cornejo y las de León se hallan en las coplas y en los sonetos. Las primeras superan en más de un veinte por ciento su presencia en la lírica del dramaturgo manchego y los segundos incrementan en más de veinte puntos en los versos de fray Damián. También resulta relevante la distancia que hay en el empleo de seguidillas y romances. Estos son la estructura más utilizada en los textos del cronista palentino y en los dubitados. Además, hay varios metros que no aparecen en los corpus indubitados de ambos autores, aunque su porcentaje es muy reducido. El obispo de Orense no recurre a seguidillas y pareados y el poeta de Pastrana no incluye septetos ni ovillejos.

Si prestamos atención a las poesías disputadas, cabe señalar que los metros más frecuentes son el romance, la décima, las quintillas y los sonetos. La proporción de estos últimos en ellas se asemeja más a los textos de León, mientras que el reducido porcentaje de coplas (la estructura más recurrente en la lírica de Marchante) las aproxima más a los versos de Cornejo. Por último, llama la atención la elevada presencia de décimas y de quintillas en los dubitados respecto al resto de corpus estudiados. Con el propósito de seguir estableciendo semejanzas y diferencias entre los poemas indubitados de Cornejo, los de autoría segura de León y los que se atribuyen a ambos se ha procedido a analizar el uso de la métrica en las 
composiciones profanas y en las sacras. A continuación, se detallan los porcentajes obtenidos:

\begin{tabular}{|c|c|c|c|c|c|c|}
\hline Métrica & $\begin{array}{c}\text { Sacra } \\
\text { dubitada }\end{array}$ & $\begin{array}{c}\text { Sacra } \\
\text { indubitada } \\
\text { de Cornejo }\end{array}$ & $\begin{array}{c}\text { Sacra } \\
\text { indubitada } \\
\text { de León }\end{array}$ & $\begin{array}{l}\text { Profana } \\
\text { dubitada }\end{array}$ & $\begin{array}{l}\text { Profana } \\
\text { indubitada } \\
\text { de Cornejo }\end{array}$ & $\begin{array}{c}\text { Profana } \\
\text { indubitada } \\
\text { de León }\end{array}$ \\
\hline Copla & 6,8 & 11,1 & 34,2 & 3,4 & 0 & 4 \\
\hline Décima & 0 & 0 & 4,6 & 36,2 & 19,2 & 42 \\
\hline Lira & 0 & 0 & 0 & 1,7 & 0 & 0 \\
\hline Endecha & 0 & 11,1 & 6,4 & 0 & 0 & 0 \\
\hline Novena & 0 & 0 & 0,9 & 0 & 0 & 0 \\
\hline $\begin{array}{l}\text { Octosílabos } \\
\text { esdrújulos }\end{array}$ & 0 & 0 & 0 & 1,7 & 0 & 0 \\
\hline Ovillejo & 0 & 0 & 0 & 0 & 3,8 & 0 \\
\hline Pareados & 0 & 0 & 0 & 1,7 & 0 & 8 \\
\hline Quintilla & 37,9 & 33,3 & 13,8 & 17,8 & 3,8 & 10 \\
\hline Redondilla & 6,8 & 0 & 1,8 & 10,3 & 9,6 & 28 \\
\hline Romance & 41,3 & 44,4 & 25,9 & 27,5 & 30,7 & 16 \\
\hline Seguidilla & 0 & 0 & 11,1 & 3,4 & 0 & 2 \\
\hline Septeto & 0 & 0 & 0 & 0 & 1,9 & 0 \\
\hline Soneto & 6,8 & 0 & 0 & 3,4 & 28,8 & 4 \\
\hline
\end{tabular}

Tabla 7: Métrica de la poesía dubitada e indubitada (sacra y profana) de Cornejo y León

Los resultados extraídos revelan que la temática influye de manera decisiva en la elección de los metros. Los poemas profanos manifiestan una mayor variedad que las composiciones sacras, las cuales carecen de liras, octosílabas en esdrújulos y pareados. Las mayores diferencias que se observan entre los versos humanos indubitados de Cornejo y los de León se hallan en sus estructuras métricas más recurrentes. Por un lado, las décimas ${ }^{159}$ y las redondillas superan en más de un $20 \%$ su presencia en las poesías de Marchante. Por otro, los sonetos y los romances poseen un peso mucho más destacados en las poesías humanas de fray Damián. Por último, los dubitados profanos muestran características similares con los corpus de ambos autores. Como sucede con los indubitados del dramaturgo manchego, presentan un mayor uso de décimas y de quintillas y un menor porcentaje de

\footnotetext{
${ }^{159}$ Las décimas son el metro más usado en las poesías disputadas con Cornejo del tercer volumen de las Obras poéticas de Marchante. Este, según Carreira (La obra 52), sería el tomo menos fiable, ya que es el que contiene más poemas dubitados y el único que se halla incompleto. En los ejemplares conservados, carece de portada y termina en la página ciento ochenta y cuatro, omitiendo con ello información que podría ser relevante para el análisis de su contenido.
} 
sonetos que los del cronista seráfico. Sin embargo, contienen una cantidad de romances y de redondillas similar a la de los versos de este último.

Respecto a los poemas sacros, cabe señalar que, en general, presentan un mayor porcentaje de coplas, romances y quintillas que los de temática no religiosa y que no se utiliza en ellos las décimas ${ }^{160}$. En estos también se observan divergencias importantes entre los indubitados de León y los de Cornejo. El dramaturgo manchego triplica el porcentaje de coplas y reduce considerablemente el de quintillas y romances. Estos son los metros más empleados en las poesías indubitadas del obispo de Orense y en los dubitados de temática religiosa. Exceptuando la proporción de redondilla, se observan más semejanzas en el uso de la métrica con este último que con Marchante. Tal dato podría ser un indicio relevante para ayudar a determinar su verdadera autoría.

\subsubsection{Poemas dubitados con otros autores}

Existen siete poesías (seis profanas y una sacra) que se firman con el nombre del poeta palentino y con el de otros escritores auriseculares: Quevedo, Francisco Valles (o Valdés), Francisco de Porras, Juan de Avellaneda o José Pérez de Montoro “Anexo: 8.3.3.2.”. Las atribuidas a los dos últimos tienen en común que son protagonizadas por inmorales miembros del clero y que las atribuciones al obispo de Orense no son muy abundantes en los poemarios que pretenden recoger su obra poética.

Los problemas de transmisión y de autoría que plantean los cuatro poemas disputados con Juan de Avellaneda ${ }^{161}$ han sido analizados por Miguel Marañón en la edición que realiza de estos (Otro testimonio 71-81). La escasa calidad literaria que poseen (sobre todo los que dan voz a la religiosa) y su estilo rudo hacen que parezca poco probable que pertenezcan a fray Damián, pues como afirma Antonio Carreira: "no hay en la obra conocida de Cornejo nada de lenguaje tan directo, ni tan falto de su característico humor" (La obra 44).

\footnotetext{
${ }^{160}$ Los romances, las quintillas, los villancicos y las seguidillas son las formas métricas más recurrentes en la lírica religiosa cómico-festiva del Bajo Barroco español. Exceptuando las quintillas, el resto de estas están "históricamente ligadas en sus orígenes a la producción lírica popular y tradicional, de difusión básicamente oral y mayoritariamente escrita para ser cantada" (López Guil 77).

${ }^{161}$ La refriega monjil que se atribuye a Cornejo y al fraile jerónimo, autor de Fábula de Dido y Eneas, comienza con "la carta en décimas que las monjas mandan al fraile tras desagradable sucedido; en segundo término la respuesta del fraile en el mismo metro; una contrarrespuesta de las hermanas, esta vez en metro endecasílabo y, por fin, en el cuarto de los poemas, la última de las intervenciones por el clérigo" (Marañón, Otro testimonio $71)$.
} 
Respecto a los otros tres textos dubitados "Casó de un arzobispo el despensero", "El sacristán qué desmán” y "Érase una Virgen pura", aunque se incluyen en más de cuatro manuscritos integri del cronista seráfico, han sido atribuidos a otros autores en publicaciones o estudios. El primero ha sido editado a nombre de Quevedo y de Francisco de Porras (Marañón, Sonetos 31), mientras que el segundo fue impreso en las obras poéticas de José Pérez de Montoro (273). La fuerte ironía, el tono desenfado y el carácter transgresor que ambas creaciones presentan podrían ser indicios que acercarían estas al estilo del poeta palentino. El último, Francesc Civil i Castellví (65) lo adjudica a Francisco Valles (o Valdés) en el comentario que hace sobre esta jácara. La similitud estilística con otras dos composiciones que se vinculan a Cornejo "En títulos, Virgen pura" y "La más hidalga hermosura" y que, al igual que dicho poema, emplean títulos de comedias para evocar acontecimientos sacros pudo propiciar que se firmara también con su nombre.

Aunque el análisis filológico tradicional aporta algunas pistas significativas sobre las características de los poemas de fray Damián, en esta investigación se recurrirá a diversas pruebas cuantitativas para delimitarlas. Gracias a ellas, se podrá, por un lado, determinar de manera objetiva los rasgos morfosintácticos y léxico-semánticas de su escritura en verso y en prosa y, por otro, contrastarlos con los presentes en los textos dubitados que se incluyen en manuscrito $D$ (el elegido para realizar su edición crítica) ${ }^{162}$ con el propósito de intentar resolver su autoría. Para garantizar una atribución más precisa y fiable, se compararán tales datos con los extraídos de las creaciones indubitadas del maestro León y de otros autores contemporáneos.

${ }^{162}$ Los motivos por los que se ha escogido el manuscrito $D$ de la BNE para hacer la publicación de la poesía de fray Damián Cornejo son expuestos en el apartado "5.2.". 


\section{ANÁLISIS CUANTITATIVOS DE LA OBRA DE DAMIÁN CORNEJO}

\subsection{INTRODUCCIÓN A LOS ESTUDIOS ESTILOMÉTRICOS}

El criterio de la semejanza de "tema y estilo", como señala Fernando Plata (293), es producto de una manera de entender la literatura que no tiene en cuenta los códigos de producción literaria de la época y que lleva a menudo a conclusiones erróneas en la atribución de poemas. Si se desea obtener datos objetivos que permitan establecer similitudes o diferencias entre obras en verso, es necesario recurrir a pruebas estadísticas que desvelen con detalle sus características.

Las innovaciones que se están realizando en el procesamiento de lenguaje natural y en el análisis masivo de textos ${ }^{163}$ permiten conocer en profundidad el contenido y la estructura de grandes corpus líricos ${ }^{164}$. La extracción automática de rasgos cuantificables en este campo ha propiciado la aparición de novedosos estudios comparativos, los cuales abarcan desde la evolución de la poesía de un autor hasta el análisis de las obras poéticas creadas en diversas centurias ${ }^{165}$. Investigaciones como las llevadas a término, en el nuevo milenio, por Florentin Smarandache (184-191), Karol Opara (589-598) o Sohrab Rezaei y Nasim Kashanian (5564) han delimitado las características (recurrentes y distintivas) sobre el uso que se hace de la gramática y del léxico en las producciones de varios grupos de poetas, ofreciendo así una visión precisa y completa de estas.

Aunque en la literatura hispana la aplicación de la estilometría en poesía todavía es una práctica poco extendida, en los últimos años se están haciendo importantes avances individuales y colectivos. Por un lado, destacan las recientes iniciativas de Laura Hernández (170-180), Antonio Rojas (111-142) y Marie-Eglantine Lescasse (s.p.) para delimitar los rasgos estilísticos que singularizan las creaciones en verso de autores canónicos de los Siglos de Oro. Por otro, se están desarrollando dos proyectos de investigación relacionados con el

\footnotetext{
${ }^{163}$ El procesamiento masivo de corpus textuales "text mining" abre el camino hacia el análisis distante y el macroanálisis de las obras literarias. Destacan en este campo, los monográficos de Franco Morett y de Matthew Jockers.

${ }^{164}$ Desde 2017, el grupo de investigación Plotting Poetry (forma parte de SIG-DLS y de ADHO) está promoviendo el intercambio de métodos de análisis computacional y estadístico de corpus poéticos a través de la celebración de congresos internacionales.

${ }^{165}$ Entre los diversos estudios que han aplicado la estilometría a corpus poéticos que abarcan amplios periodos cronológicos, pueden señalarse por su actualidad los realizados por Borja Navarro (89-118), Liu Chao-Lin (507-510), Pablo Ruiz, Clara Martínez y Thierry Poibeau (572-576). Estos dos últimos trabajos tienen como eje principal el análisis de sonetos castellanos.
} 
análisis computacional de poemas: ADSO y POSTDATA. El primero, liderado por Borja Navarro, tiene como propósito determinar la semántica y la métrica del soneto áureo castellano; el segundo, dirigido por Elena González-Blanco, intenta promover el análisis semántico de corpus poéticos con el objetivo de establecer vías de comunicación entre diferentes tradiciones literarias y culturales.

El empleo de métodos estadísticos de clasificación en las investigaciones sobre literatura también está ayudando a incorporar nuevas vías de estudio (como es el caso de la minería de opinión ${ }^{166}$ ) y a perfeccionar otras ya existentes como la resolución de problemas de autoría ${ }^{167}$. Este último campo resulta de especial interés para el género poético por los múltiples errores de atribución que se derivan de la transmisión manuscrita e impresa en diferentes siglos. A pesar de que ya han transcurrido varias décadas desde los primeros trabajos que abordaron el tema, estos todavía no son muy frecuentes ${ }^{168}$. La artificiosidad del lenguaje poético, su tendencia a adaptarse a determinadas estructuras métricas y, sobre todo, la escasa extensión que suelen presentar las composiciones líricas dificultan la extracción automática de patrones lingüísticos distintivos.

No obstante, artículos como el de Hugh Craig (George 147-174) y el de Justin Kao y Dan Jurasfsky (1-31) son una muestra de cómo los avances que se están produciendo en el campo de la estilometría aportan pruebas objetivas y cuantificables que permiten distinguir textos en verso, las cuales pueden ayudar a determinar la autoría de poesías que se consideran anónimas o que se atribuyen a varios creadores. Para ello, es imprescindible contar con un corpus de poemas indubitados de los escritores que se pretenden analizar. Cuanto mayor sea el número de palabras que poseen las composiciones que lo integran, mayor fiabilidad tendrán los datos obtenidos. Maciej Elder (Short 21-23) recomienda que estas contengan más de dos mil, aunque advierte que las obras seleccionadas deben manifestar huellas que singularicen con claridad el estilo de su autor. Solo así podrán diferenciarse de las de otros y manifestar características similares con las surgidas de la misma mano.

\footnotetext{
${ }^{166}$ Una compleja muestra del gran interés que supone para los estudios literarios la incorporación de análisis computacional de las opiniones la aportó Julia Silgen. En 2016, esta joven científica presentó en su blog el post "You must allow me to tell you how ardently I admire and love Natural Language Processing", donde expone cómo evolucionan los sentimientos (positivos y negativos) en la novela Orgullo y Prejuicio.

${ }^{167} \mathrm{El}$ empleo de análisis estadísticos en corpus de literatura que plantean dudas relacionadas con la autoría ha sido puesto en práctica por múltiples investigadores. Pueden citarse, a modo de ejemplo, los trabajos realizados por Hugh Craig y Arthur Kinney sobre los problemas que plantea la obra de Shakespeare y el estudio de Javier Blasco (Avellaneda 97-116) sobre el creador de El Quijote apócrifo y el proyecto digital Computational Analysis, Author Attribution, and the Cheap Repository Tracts of the 18th Century.

${ }^{168}$ Entre los trabajos que se consideran pioneros en la aplicación de la estilometría a obras en verso para resolver problemas de autoría se halla el de Michael Smith (23-37). También resulta interesante, por el gran corpus poético que analiza, el llevado a término quince años después por John Burrows y Harold Love (151-175).
} 
El reto de intentar distinguir y caracterizar corpus poéticos breves aplicando análisis cuantitativos intentará ser abordado en los siguientes apartados. Con el propósito de lograr los mejores resultados posibles, las poesías estudiadas de Damián Cornejo y León Marchante serán sometidas a distintos tipos de análisis, los cuales serán contrastados entre sí para verificar o refutar los datos obtenidos. Estos se basarán, por un lado, en clasificaciones realizadas a partir de las frecuencias de las palabras más recurrentes y de las categorías morfosintácticas y, por otro, en el cotejo de los porcentajes de las combinaciones gramaticales "bigramas" más relevantes en ellas, de la medición de su riqueza léxica y de los sentimientos "minería de opinión" que albergan.

Además, se extraerán los términos distintivos de fray Damián y del maestro León que incluyen sus poemas (dubitados e indubitados) y se compararán las formas métricas que emplean. La elección de todos los parámetros mencionados ha estado determinada por los test previamente realizados de cada uno de ellos en las producciones en verso y en prosa de varios autores del Bajo Barroco, los cuales han demostrado que las pruebas aplicadas permiten definir los rasgos estilísticos "huellas" de un autor y diferenciarlos de los de otros escritores.

\subsection{ANÁLISIS DE LA POESÍA PROFANA INDUBITADA DE CORNEJO ${ }^{169}$}

Se ha optado por iniciar el estudio cuantitativo de la lírica de fray Damián por sus poemas humanos, ya que estos son los más recurrentes en su producción poética. Con el propósito de obtener una serie de características objetivas que permitan singularizarlos, se han seleccionado varias poesías profanas que se consideran indubitadas ${ }^{170}$ y extensos fragmentos de la Crónica Seráfica, que han sido contrastados con las creaciones en verso y en prosa de Marchante.

\subsubsection{Metodología aplicada y corpus analizado}

\footnotetext{
${ }^{169}$ Los datos aportados en este apartado han sido publicados en el monográfico de Humanidades digitales: una mirada desde la interdisciplinariedad (Sánchez, Análisis 69-90).

${ }^{170}$ De las cincuenta y dos poesías humanas de autoría indubitada de fray Damián "Anexo: 8.3.2.”, se han seleccionado seis para este estudio. La transcripción de la mayoría de estas se corresponde con el manuscrito $D$, que es el elegido como base para realizar la edición de su lírica. No obstante, el poema "Cansado anoche de estar" ha sido editado a partir del manuscrito $I$, ya que su caligrafía es anterior a $D$ y ofrece una versión de este estructuralmente más coherente.
} 
Se ha transcrito y normalizado la ortografía de un corpus de diez mil palabras de la lírica humana indubitada de Cornejo y del maestro León y de treinta mil de su prosa ${ }^{171}$. Este ha sido conformado según los siguientes criterios. Por un lado, los poemas seleccionados poseen más de trescientas palabras para garantizar que los programas de análisis cuantitativos utilizados (ContaWords, LIWC, R, SPSS, Treetagger y Voyant Tools) puedan extraer datos significativos tanto en su estudio individual como en el de conjunto ${ }^{172}$. Por otro, se han elegido poesías profanas de distinta temática y longitud con el objetivo de obtener rasgos generales y específicos de la lírica de cada autor ${ }^{173}$. Por último, se ha recurrido a diversos fragmentos de las cartas del Marchante y de la Crónica seráfica del obispo de Orense para poder comprobar si existen o no patrones y elementos comunes con sus obras en verso ${ }^{174}$.

Gracias a todo ello, se cuenta con un corpus amplio y variado de textos que ayudará a trazar con exactitud sus características morfosintácticas y léxico-semánticas. Para facilitar la identificación de las obras que lo integran, estas han sido codificadas de la siguiente forma. Se ha utilizada la inicial del apellido de los escritores analizados "L" y "C" para identificar su autoría y los poemas, además, han sido marcados con las "pi” (profana indubitada) y el número asignados a cada uno. Las correspondencias de cada uno se pueden consultar en el “Anexo: 8.4.1.".

\subsubsection{Análisis de frecuencia de palabras}

El análisis de conglomerados (clúster) permite agrupar textos según las palabras más recurrentes y establecer las distancias que existen entre ellos. La fiabilidad y la utilidad de este tipo de clasificación en corpus poéticos hispanos han sido probadas, entre otros

\footnotetext{
${ }^{171}$ El corpus textual de cada autor asciende a veinte mil palabras (cinco mil de poesía humana y quince mil de prosa), una cantidad suficiente para poder trazar con fiabilidad y precisión su perfil lingüístico, ya que se recomienda contar con más de dos mil (Elder, Short 21-23).

${ }^{172}$ Se ha elaborado una tabla "Anexo: 8.4.1." donde se especifican los títulos de los poemas analizados en esta investigación, se concreta su localización, se indica su extensión, el tipo de métrica y la codificación empleada para identificarlos.

${ }^{173}$ Los poemas indubitados seleccionados del maestro León han sido extraídos en su mayoría del primer tomo de sus Obras poéticas, que se considera el más fiable de los que contienen lírica profana. La única poesía de las elegidas de la que se tiene constancia que fue publicada en vida del autor y sobre la que este da testimonio en sus cartas es "Pues el pintar los toros no es excusa". Además, es importante señalar que "Prima mía, estos pollitos" parece tener a la misma destinataria que el epistolario del dramaturgo manchego.

${ }^{174}$ Para conformar los corpus de prosa de cada escritor, se han seleccionado de forma aleatoria algunas de las cartas amorosas que conforman el extenso epistolario que Marchante habría escrito, en un registro informal, a su prima monja (León, La picaresca 532-612) y diversos capítulos, relacionados con la vida de santa Rosa, del tercer tomo de la Crónica seráfica.
} 
investigadores, por Antonio Rojas (111-142). En su estudio sobre las fábulas mitológicas de Góngora, empleó textos que poseen una extensión media superior a las seis mil palabras. Para minimizar los posibles errores ${ }^{175}$ derivados de la brevedad de algunas de las composiciones seleccionadas y de la disparidad que existe en su extensión, en este apartado se ha optado por equiparar su tamaño ${ }^{176}$. A continuación, se muestran y comentan las visualizaciones extraídas a través del paquete "Stylo" de R:



Gráfico 1: Clústeres de palabras más recurrentes (dendogramas y consesus tree)

En el dendograma de la izquierda, se han incluido únicamente las obras en verso de Cornejo (c_pi) y de Marchante (1_pi), las cuales se hallan entremezcladas ${ }^{177}$. La incorporación en el dendograma central de la prosa de ambos autores (1_cartas) y (c_cronica) ayuda a conformar un bloque unitario de algunas de las creaciones del maestro León: 1_pi4. 1_pi5, 1_cartas y 1_pi $2^{178}$. Este se mantiene al aumentar el número de las palabras más

\footnotetext{
${ }^{175}$ En el análisis de frecuencias de palabras, se ha observado una cierta tendencia a agrupar los textos de longitud similar.

${ }^{176}$ Se ha delimitado la extensión de los textos (en verso y en prosa) más largos a un total de entre trescientas y cuatrocientas palabras para que tuvieran una extensión similar con el resto, la oscilación en esta cifra se debe a que se ha intentado evitar la fragmentación de estrofas, oraciones o versos al acotarlos.

${ }^{177}$ Después de observar que el análisis de conglomerados no logra agrupar los poemas de un autor, se ha procedido a comprobar si este consigue aglutinar las partes de una misma composición. Para ello se han dividido las poesías seleccionadas en bloques de cien palabras. Aunque los resultados obtenidos muestran un grado de acierto elevado, en diversos casos se asocian fragmentos de un poema con los de otro de la misma mano y con los de distinto creador.

${ }^{178}$ Las similitudes que se establecen en el análisis de conglomerados y en el árbol de consenso entre los poemas 1_pi2, 1_pi4, 1_pi5 y las cartas de Marchante son reafirmados por los resultados aportados por el programa
} 
utilizadas (de cien a trescientas) en el árbol de consenso ${ }^{179}$. No sucede lo mismo con las poesías de fray Damián, ya que la vinculación que se establecía entre c_cronica, c_pi3 y c_pi $5^{180}$ en el segundo dendograma desaparece en esta última representación. Tales resultados parecen evidenciar que en poemas de poca extensión (de un mismo autor) la frecuencia de las palabras más empleadas, en general, difiere tanto en estos que dificulta su agrupación.

\subsubsection{Análisis morfosintáctico}

Tras verificar que los análisis clústeres basados en las frecuencias de palabras recurrentes (dendogramas y árboles de consenso) no resultan los más pertinentes para distinguir la lírica profana indubitada de Cornejo de la de Marchante, se ha procedido a estudiar la morfosintaxis de esta y de sus narraciones. La utilidad de este tipo de investigaciones para determinar la autoría de obras dubitadas ha sido probada por Florentin Smarandache (184-191). No obstante, en el presente trabajo se va más allá, pues se representan los porcentajes de las categorías gramaticales "variables" a través de gráficos de dispersión de multivariantes "biplots", los cuales permiten ofrecer resultados más precisos en la clasificación de los poemas estudiados.

Para la extracción de los porcentajes de algunas de las principales categorías gramaticales ${ }^{181}$ se ha recurrido a la herramienta Treetagger, que posee un grado de fiabilidad superior al $90 \%{ }^{182}$. A partir de estos, se ha conformado, a través del programa $\mathrm{R}$, dos análisis de multivariantes "biplots". En el primero, se ha representado los corpus de poesía (sin

CopyCath Gold. Estos obtienen los porcentajes más elevados del corpus de poesías del maestro León (42\%, $33 \%$ y $46 \%$ ) al compararse con dicho epistolario.

${ }^{179} \mathrm{El}$ árbol de consenso se diferencia del dendrograma en que no representa un solo resultado. Este combina la información derivada de múltiples dendrogramas en uno solo, obteniendo con ello datos más precisos (Rojas 120).

${ }^{180}$ La asociación que se conforma en el análisis de frecuencia de palabras entre los poemas c_pi3 y c_pi5 es corroborada por los datos obtenidos a través de CopyCath Gold. El porcentaje que vincula a ambos es el más elevado (46\%) de los extraídos del corpus de Cornejo. Además, su semejanza con la Crónica seráfica (a pesar de que difieren en la temática y en el género) también es la más alta: $40 \%$.

${ }^{181}$ En esta investigación, se han elegido las siguientes variables de análisis: adjetivos (ADJ), adverbios (ADV), artículos (ART), nombres comunes (NC), preposiciones (PREP), cuantificadores (QU), demostrativos (DM), interrogativos (INT), posesivos (PPO), pronombres personales (PPX), clíticos (PPC), marcas de negación (NEG), conjunciones copulativas (CC), conjunciones adversativas (CCAD), conjunciones subordinantes (CSUBX) y conjunción "que" (CQUE).

${ }^{182}$ Se han revisado (parcialmente) los resultados de los análisis morfosintácticos obtenidos por el programa Treetagger y el margen de error en ninguno de los textos seleccionados supera el diez por ciento del total. 
fragmentar) ${ }^{183} \mathrm{y}$, en el segundo, se ha incorporado los textos en prosa (completos) con el objetivo de contrastar sus características morfológicas y sintácticas:

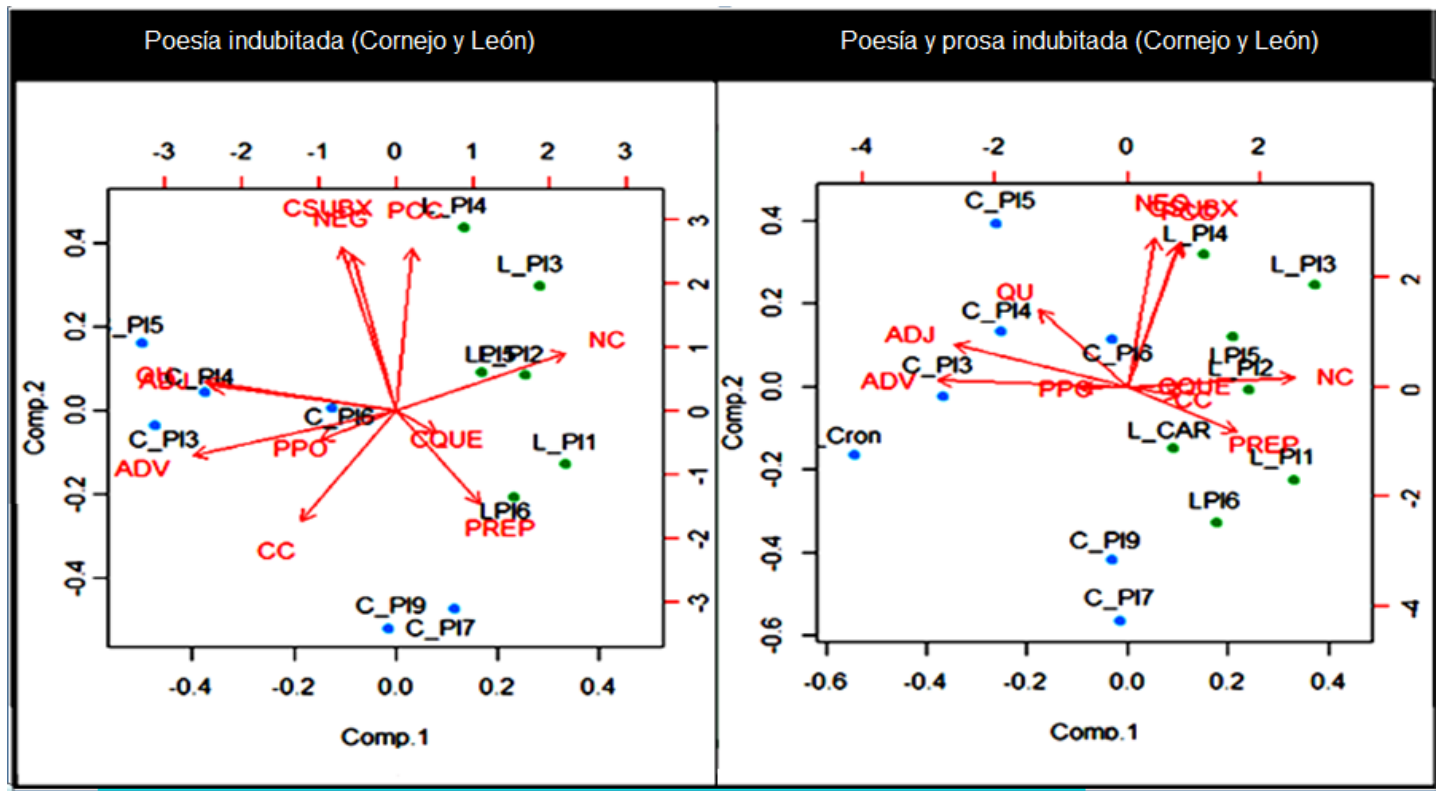

Gráfico 2: Biplot de la morfosintaxis (Cornejo y Marchante)

En el primer biplot, se puede observar que la lírica de fray Damián ocupa los cuadrantes de la parte izquierda y la del maestro León los de la derecha, creando con ello dos bloques bien diferenciados. En el constituido por el poeta palentino, se distinguen dos grupos. Los poemas más breves ${ }^{184}$ (c_pi7 y c_pi9) se sitúan en el extremo inferior y los más extensos (c_pi3, c_pi4 y c_pi5) en el lateral del eje central. La poesía c_pi6 (extensión media) se halla más próxima a estos últimos. En la obra en verso del dramaturgo manchego, se distinguen tres agrupaciones. En la parte superior derecha, aparecen 1_pi3 y 1_pi4, que son composiciones de mediana extensión. Un poco más abajo, se encuentran las poesías más largas de Marchante: 1_pi2 y 1_pi5. A escasa distancia de estas, en el cuadrante inferior, se localizan 1_pi1 y 1_pi6, dos textos de longitud media.

La inclusión, en el segundo gráfico, de la Crónica Seráfica y de las cartas del maestro León altera levemente los resultados. El poema c_pi5 se distancia más del grupo de Cornejo, mientras que 1_pi4 sufre el proceso inverso y se aproxima más al bloque de Marchante ${ }^{185}$.

\footnotetext{
183 Tras realizar diversas pruebas para comprobar si la fragmentación de los textos altera (de manera significativa) los resultados de los porcentajes de las variables morfosintácticas, se ha concluido que no y se ha optado por mantener su extensión original.

${ }^{184}$ Se han establecido tres niveles para clasificar la extensión de los poemas seleccionados: Extensos (superan las mil palabras), medios (entre trescientas cincuenta y mil) y breves (menos de trescientas cincuenta).

${ }^{185}$ La mayor distancia que se observa entre la morfosintaxis de la prosa de Cornejo y su poesía y el epistolario de Marchante y su lírica es verificada en el análisis realizado con el programa CopyCatch Gold. Este establece
} 
Las poesías que parecen poseer una mayor similitud con la prosa de su autor son: c_pi3, 1_pi1, 1_pi2 y 1_pi6 ${ }^{186}$. Para poder comprobar si los datos morfosintácticos obtenidos son fiables, se ha incluido una selección de poesías profanas indubitada de Sor Juana Inés de la Cruz $^{187}$ “Anexo: 8.4.1.”. Además, se ha realizado un análisis de frecuencias de palabras con el propósito de contrastar los resultados:



Gráfico 3: Biplot y dendograma (Cornejo, Marchante y Sor Juana)

En el biplot se conforman tres bloques independientes, los cuales corresponden con los autores analizados. La incorporación de las creaciones de la poeta mexicana ha permitido añadir más variables a este (DM, PPC y PPX $\left.^{188}\right)$. Tales modificaciones contribuyen a aglutinar más los poemas que integran los grupos conformados por la lírica de fray Damián y la del maestro León. En ellos, las poesías más breves del cronista seráfico (c_pi6 y c_pi7) y del dramaturgo Manchego (1_pi3 y 1_pi6) son las que más se alejan del resto de sus creaciones. Sucede lo mismo, con excepción de SJ_pi2, con las composiciones de Sor Juana. La inclusión de su obra en el análisis de conglomerados no solo no ha contribuido a separar

una relación de semejanza del 59\% en la producción del cronista palentino y del $63 \%$ en las obras del dramaturgo manchego.

${ }^{186}$ Las similitudes morfosintácticas que se manifiestan entre los poemas c_pi3 y 1_pi2 respecto a la prosa de Cornejo y de Marchante son corroboradas en los análisis de conglomerados "clúster" y de discriminantes y en el árbol de consenso realizados en el apartado previo.

${ }^{187}$ Se ha elegido la lírica de la escritora novohispana porque es contemporánea a la de Cornejo y Marchante y porque en sus versos se puede apreciar la influencia de este último (Tenorio, Sor Juana y León Marchante 543561).

${ }^{188}$ El programa Treetagger etiqueta como PPC los clíticos (la, las, los, le y les) y el resto de pronombres átonos (me, nos, te...) y los personales se señalan con PPX. 
los corpus poéticos de los escritores estudiados, también ha dispersado más los poemas de Marchante que se relacionaban en el dendograma y en el árbol de consenso del apartado anterior.

Gracias a la prueba realizada con la lírica de la poeta novohispana, se ha podido verificar que el análisis de la morfosintaxis aporta resultados fiables a la hora de establecer diferencias entre poesías de distinta autoría y de diversa longitud. Para poder delimitar con mayor exactitud los datos y para que estos puedan ser cotejados en futuras investigaciones con los de otros poemas (dubitados e indubitados) de ambos, se han sometido a otros análisis de multivariantes ${ }^{189}$ a través del programa SPSS. Por un lado, se ha realizado un análisis clúster para comprobar si las poesías de autoría segura de Cornejo y Marchante conformaban grupos diferenciados a partir de los porcentajes gramaticales extraídos Por otro, se han sometido a un análisis de discriminantes los bloques resultantes para determinar cuáles son las categorías gramaticales que mejor permiten diferenciar los versos humanos de Cornejo y de León:

Análisis clúster

\begin{tabular}{|l|r|r|}
\hline \multirow{2}{*}{} & \multicolumn{2}{|c|}{ Clúster } \\
\cline { 2 - 3 } & \multicolumn{1}{|c|}{1} & \multicolumn{1}{c|}{2} \\
\hline ADJ * & 4,60 & 6,35 \\
ADV * & 3,60 & 14,78 \\
NC * & 19,66 & 5,03 \\
PREP & 12,35 & 11,90 \\
QU & 3,84 & 3,73 \\
PPO & 2,39 & 2,62 \\
PPX & 2,10 & 2,65 \\
PPC & 1,85 & 1,32 \\
NEG & 1,98 & 1,77 \\
CC & 3,41 & 4,22 \\
CSUBX & 2,50 & 2,17 \\
CQUE & 4,46 & 4,73 \\
ART * & 10,21 & 6,58 \\
\hline
\end{tabular}

Análisis de discriminantes

\begin{tabular}{|rr|r|r|}
\hline \multicolumn{1}{|r|}{ Número de caso de clúster } & \multicolumn{1}{c|}{ Media } & \multicolumn{1}{c|}{$\begin{array}{c}\text { Desviación } \\
\text { estándar }\end{array}$} \\
\hline 1 & ADJ & 4.6000 & .73095 \\
& ADV & 3.6000 & 1.37113 \\
& NC & 19,6625 & 2.84150 \\
& ART & 10,2125 & 2,00531 \\
\hline 2 & ADJ & 6,3500 & 2.05791 \\
& ADV & 14.7833 & 4.95436 \\
& NC & 5.0333 & 2.43858 \\
& ART & 6.5833 & 2.26134 \\
\hline
\end{tabular}

Tabla 8: Análisis clúster y de discriminantes

El análisis de clasificación "clúster" ha separado correctamente los corpus analizados. El dramaturgo manchego (clúster 1) destaca en el uso de sustantivos y de

\footnotetext{
${ }^{189}$ Se ha recurrido al empleo de análisis clúster y de análisis discriminante. El primero permite agrupar entidades que comparten similitudes en las variables introducidas, mientras que el segundo (a partir de los conjuntos creados en el clúster) determina cuáles son las variables que mejor diferencian los grupos previamente establecidos.
} 
artículos, mientras que el cronista franciscano (clúster 2) utiliza más adjetivos y adverbios. Aunque las frecuencias de uso del resto de elementos morfológicos son similares en ambos autores, se pueden extraer de estas algunas conclusiones relevantes. El maestro León realiza un mayor empleo de preposiciones (PREP), cuantificadores (QU), marcas de negación (NEG) y de los clíticos (PPC). No ocurre lo mismo con los posesivos (PPO) y los pronombres personales (PPX), pues el escritor palentino recurre más a estos ${ }^{190}$. Respecto a la utilización de las oraciones compuestas, cabe señalar que Marchante supera al obispo de Orense en el cómputo total de subordinadas (CSUBX).

Todos estos datos han sido contrastados con los aportados por la Crónica seráfica y el epistolario del poeta manchego y se ha concluido que en tales obras se mantienen las principales diferencias que registran las tablas comentadas y también el menor uso que hace Cornejo de las negaciones y los nexos subordinantes. Con el propósito de seguir estableciendo diferencias en la utilización que hacen ambos de la gramática, se han analizado (a través de ContaWords) las combinaciones más recurrentes de nombres, verbos y adjetivos mediante nueve bigramas:



Gráfico 4: Frecuencia de bigramas (poesía profana indubitada)

El bigrama más recurrente en las poesías indubitadas humanas de fray Damián y del maestro León es la combinación de un adjetivo más un nombre $(\mathrm{A}+\mathrm{N})$ y el menos utilizado por ambos es el de dos adjetivos seguidos $(\mathrm{A}+\mathrm{A})$. El cronista seráfico emplea con mucha más frecuencia la estructura de un sustantivo más un nombre o un adjetivo y Marchante explota más la de verbos con adjetivos y nombres. Estos resultados apenas coinciden con los

\footnotetext{
${ }^{190}$ La poesía profana de Cornejo manifiesta un uso mucho más elevado que la de Marchante de los posesivos y de los pronombres personales, sobre todo, de primera persona. Los poemas del cronista seráfico quintuplican el empleo de "mi" y de "me" y duplican la presencia de "yo". Estos datos muestran que sus versos dan un mayor protagonismo a la caracterización y a las intervenciones del sujeto poético.
} 
extraídos en sus prosas, pues la única combinación que en ellas ofrece datos similares a los recientemente comentados es el de $\mathrm{N}+\mathrm{A}$.

\subsubsection{Análisis léxico-semántico}

Se ha realizado un análisis del léxico de los poemas estudiados para ver si mediante este se pueden o no confirmar las relaciones establecidas en el estudio de la morfosintaxis y para determinar si existen diferencias significativas en el vocabulario empleado por Cornejo y Marchante. Este se ha sometido a un doble filtro. Los términos que se han seleccionado son distintivos entre ambos ${ }^{191}$ y su uso no es muy frecuente (no presentan más de veinticinco casos en la lírica recogida en el $\mathrm{CORDE}^{192}$ ) entre 1660 y $1680^{193}$. A continuación, se comentarán los resultados obtenidos en el corpus de cada autor:

\begin{tabular}{|c|c|c|c|c|c|}
\hline C_pi3 & C_pi4 & C_pi5 & C_pi6 & C_pi7 & C_pi9 \\
\hline \multicolumn{6}{|c|}{ Palabras compartidas con c_cron } \\
\hline Abrasada & Anchura & Andrajo & Astucia & Entera & Arrimar \\
\hline Almohada & Conciencia & Cabestro & Confusión & Reverencia & Extremo \\
\hline Formada & Compostura & Ceniciento & Estruendo & Servido & Francesa \\
\hline Campaña & Jardín & Piadosa & Servicio & & Pesado \\
\hline Cierzo & Ojeriza & Prolija & Vulgar & & \\
\hline \multicolumn{6}{|c|}{ Palabras compartidas con otros poemas de Cornejo (c_pi) y con c_cron } \\
\hline Carmín & Barba & Barba & & Cuerdo & Extraño \\
\hline Concepto & Carmín & Cuerdo & & Flaca & Flaqueza \\
\hline Flaca & Concepto & Extraño & & Maña & \\
\hline Flaqueza & Forzoso & Flaqueza & & & \\
\hline Maña & Mejilla & Forzoso & & & \\
\hline Mejilla & & Paño & & & \\
\hline Paño & & & & & \\
\hline
\end{tabular}

Tabla 9: Términos distintivos en la prosa y la poesía de Cornejo

\footnotetext{
${ }^{191}$ Las flexiones de género y número de los términos seleccionados también son palabras distintivas entre ambos autores.

${ }^{192}$ El Corpus diacrónico del español reúne más de dos millones y medio de palabras de los Siglos de Oro. No obstante, no está actualizado y no incluye toda la poesía que se escribió en este periodo.

${ }^{193}$ Las fechas que aparecen en varias de las poesías de Cornejo y León y el contenido de algunas de ellas permitirían situar entre 1660 y 1680 el periodo en el que desarrollaron su mayor producción lírica.
} 
Todos los poemas de fray Damián analizados contienen varias muestras de vocabulario "infrecuente" en la lírica del periodo seleccionado, que se hallan en la transcripción parcial realizada de la Crónica Seráfica y que no aparecen en los textos de Marchante: anchura, cabestro, compostura, estruendo, prolija, vulgar... Las poesías humanas atribuidas al obispo de Orense que establecen menos relaciones léxicas con los versos y con la prosa del escritor palentino son las más breves (c_pi6, c_pi7 y c_pi9), las cuales también se encuentran más distanciadas morfosintácticamente de su bloque. Tales composiciones, exceptuando c_pi6, poseen términos que están presentes en las creaciones más extensas: c_pi3 y c_pi5. Estas últimas son las que comparten más palabras con el resto de Cornejo: maña o flaqueza o paño. El poema c_pi4 se relaciona lexicalmente con ambas ${ }^{194}$, aunque posee más en común con c_pi3.

A partir del vocabulario extraído, se pueden establecer una serie de relaciones semánticas. Estas aluden a habilidades o rasgos psicológicos "astucia”, "cuerdo" "maña", "ojeriza", "piadosa" y a descripciones físicas (flaca, flaqueza y mejilla) y anímicas “confusión”. Además, la lírica profana atribuida a fray Damián parece poseer un especial interés por los detalles. En ella, se intenta retratar con exactitud los colores "carmín" y "ceniciento" o los elementos del entorno: almohada, andrajo, cierzo o paño. Tras estudiar las relaciones léxicas que se conforman en las creaciones del obispo de Orense, se ha procedido a analizar las que se establecen en las obras en prosa y en verso de Marchante:

\begin{tabular}{|l|l|l|l|l|l|l|}
\hline \multicolumn{1}{|c|}{ L_pi1 } & L_pi2 & \multicolumn{1}{c|}{ L_pi3 } & \multicolumn{1}{c|}{ L_pi4 } & \multicolumn{1}{c|}{ L_pi5 } & L_pi6 \\
\hline \multicolumn{7}{|c|}{ Palabras compartidas con I_car } \\
\hline Comisario & Canela & Bizca & Bobería & Aguinaldo & Condición \\
\hline Hocico & Clamor & Fantasma & Carretero & Alcalde & Entierro \\
\hline Metal & Lampiño & Palacio & Chispa & Búcaro & Maldita \\
\hline Preso & Majuelo & & Chulo & General & \\
\hline & Mesonero & & Pícaro & Locutorio & \\
\hline \multicolumn{1}{|c|}{ Palabras compartidas con otros poemas de Marchante (I_pi) y con I_car } \\
\hline Corrido & Caña & Parto & Prima & Corrido & Caña \\
\hline Luna & Cuadrilla & & Sabio & Difunto & Cuadrilla \\
\hline
\end{tabular}

\footnotetext{
${ }^{194}$ Además de los términos señalados, existen muchos otros que no se hallan en la prosa transcrita de Cornejo ni en la obra seleccionada del poeta de Pastrana y que relacionarían de manera significativa c_pi3, c_pi4 y c_pi5, tal como sucedía en el análisis morfosintáctico. La composición c_pi3 comparte con c_pi4 vocabulario de escaso uso como "guardainfante", "menudencia" o "virotazo" y con c_pi5 "fullera", "lanuda" y "mostacho". En los poemas c_pi4 y c_pi5, aparecen "guedeja", "pulla” y "sábana”.
} 


\begin{tabular}{|l|l|l|l|l|l|}
\hline Madera & Difunto & & & Egipto & \\
\hline Parto & Egipto & & & Galeno & \\
\hline & Galeno & & & Luna & \\
\hline & Madera & & & Prima & \\
\hline & Sabio & & & & \\
\hline
\end{tabular}

Tabla 10: Términos distintivos en la prosa y la poesía de León

Todos los poemas seleccionados del maestro León albergan diversas palabras que se hallan en la transcripción realizada de sus cartas amorosas ${ }^{195}$, que no aparecen en el corpus de fray Damián y que poseen una frecuencia de aparición baja en la lírica seleccionada del CORDE. Es el caso de "bizca", “canela", “chispa", "clamor", “fantasma", "hocico", "lampiño" o "majuelo". Las composiciones del escritor manchego que establecen menos conexiones de léxico con el resto son las más breves: 1_pi6 y 1_pi3. Esta última es la segunda que aparece más distanciada morfosintácticamente de su prosa.

Por el contrario, las que más palabras "infrecuentes" comparten con el epistolario y con el resto de poesías son las más extensas: 1_pi2 y 1_pi5. En ellas encontramos "caña", "cuadrilla", "madera" y "luna". También estos poemas son los que poseen más vocabulario en común, corroborando así los resultados obtenidos en el análisis gramatical: "difunto", "Egipto" y "prima". Respecto a la semántica de las palabras extraídas, cabe señalar que algunas se pueden agrupar por profesiones (carretero, comisario, galeno y mesonero) y por atributos o estados de individuos: chulo o sabio ${ }^{196}$.

Para poder extraer datos estadísticos relacionados con el léxico y la semántica de los poemas humanos y de la prosa de Cornejo y Marchante, se ha recurrido al programa LIWC. Este ha permitido calcular el porcentaje de los términos que transmiten emociones (positivas y negativas) y de las palabras de contenido autorreferencial y social que en ellos aparecen. Además, a través de Voyant Tools, se ha concretado la riqueza de vocabulario que presentan sus corpus con el propósito de comprobar si esta varía o no de manera significativa entre los autores estudiados y entre las creaciones de distinto género escritas por la misma mano. En la siguiente tabla, se ofrecen los resultados obtenidos:

\footnotetext{
${ }^{195}$ El epistolario del maestro León, a pesar de su tono festivo y su registro informal, posee menos semejanzas léxicas con la lírica profana de este que las observadas en el corpus poético y en la prosa culta y sacra del cronista palentino.

${ }^{196}$ Existen muchos otros términos poco utilizados que no se encuentran en la prosa transcrita de fray Damián ni en la del poeta de Pastrana y que vinculan de manera significativa varios poemas atribuidos a León: 1_pi2 y 1_pi5 contienen "carabina" y "bastón”. En estas dos últimas composiciones, aparecen "asado" y "angular". La afición de Marchante a las fiestas de toros queda reflejado en el léxico taurino que se incluye en 1_pi1 y 1_pi5: bramido, lanzada y coso.
} 


\begin{tabular}{|l|r|r|r|r|r|}
\hline & $\begin{array}{c}\text { Self- } \\
\text { Reference }\end{array}$ & $\begin{array}{l}\text { Social } \\
\text { Words }\end{array}$ & $\begin{array}{l}\text { Positive } \\
\text { emotions }\end{array}$ & $\begin{array}{l}\text { Negative } \\
\text { emotions }\end{array}$ & $\begin{array}{l}\text { Type / token } \\
\text { ratio 197 }\end{array}$ \\
\hline \multicolumn{7}{|c|}{ Damián Cornejo } \\
\hline $\begin{array}{l}\text { Poesía } \\
\text { profana }\end{array}$ & 1.21 & 0.93 & 0.21 & 0.56 & 36.1 \\
\hline $\begin{array}{l}\text { Prosa } \\
\text { religiosa }\end{array}$ & 0.13 & 0.44 & 0.46 & 0.70 & 33.6 \\
\hline \multicolumn{7}{|c|}{ León Marchante } \\
\hline $\begin{array}{l}\text { Poesía } \\
\text { profana }\end{array}$ & 0.54 & 0.99 & 0.24 & 0.66 & 35.2 \\
\hline $\begin{array}{l}\text { Prosa } \\
\text { profana }\end{array}$ & 1.57 & 0.94 & 0.28 & 0.33 & 30.5 \\
\hline
\end{tabular}

La lírica profana de Cornejo da más relevancia al uso de la primera persona que la de Marchante. No sucede lo mismo con la prosa, ya que la correspondencia íntima del maestro de León posee una presencia elevada del yo. Cabe destacar también que las composiciones del dramaturgo manchego manifiestan una mayor voluntad de conectar emocional y socialmente con el receptor. Respecto al tipo emociones que transmiten las poesías de ambos, es importante mencionar que adquieren un papel más destacado las emociones negativas. Estas, al igual que las positivas, son más abundantes en los poemas de Marchante que en los de fray Damián. Sucede lo contrario con sus narraciones.

Por último, si se observa el ratio léxico ${ }^{198}$, las obras del obispo de Orense (principalmente su poesía humana) albergan una mayor diversidad de vocabulario. No obstante, los porcentajes no se distancian demasiado de los de los versos de maestro León, pues recibieron una formación muy parecida y sus creaciones no buscan la erudición. Tales resultados se han comparado con la prosa de sus respectivos autores y se ha podido concluir que existe una diferencia relevante entre la riqueza de palabras que utiliza el dramaturgo manchego en sus cartas y en sus versos. En ellos, el porcentaje obtenido es cinco puntos más elevado que en su epistolario íntimo.

\subsubsection{Conclusiones}

\footnotetext{
${ }^{197}$ Como la extensión de los corpus analizados influye en la obtención del porcentaje de riqueza léxica, se han equiparado cada uno de ellos a 4.746 palabras. Esta es la cantidad que posee el corpus más breve: poesía profana de Marchante.

${ }^{198}$ La riqueza léxica (variedad de palabras) de un texto depende de su extensión. Por lo común, las obras breves son las más ricas en términos, pues en ellas se suele repetir menos vocabulario (Rojas 118).
} 
Los diversos estudios estadísticos realizados aplicados a la morfosintaxis, a la semántica y al léxico han permitido singularizar y clasificar con claridad (al contrario que sucedía con las frecuencias de palabras más recurrentes) la producción literaria de cada autor y establecer rasgos o elementos comunes entre los textos en prosa y en verso que la integran.

La lírica seleccionada del cronista palentino retrata con detalle la psicología y el físico de los personajes y el ambiente en el que se desenvuelven, dando un papel destacado al sujeto poético. Por ello, presenta un mayor número de adjetivos y adverbios. Por el contrario, los versos del dramaturgo manchego son menos precisos en sus descripciones y suelen centrarse en divulgar sucesos acontecidos a terceras personas. En estos, se da más valor a los sustantivos, especialmente a aquellos que identifican individuos o profesiones, y a los artículos. Tales datos, además del menor uso que hace Cornejo de las negaciones y de los nexos subordinantes, coinciden con los resultados obtenidos en sus prosas.

En el uso de bigramas también se han apreciado diferencias relevantes entre ambos autores. El cronista seráfico emplea con mucha más frecuencia la estructura de un sustantivo más un nombre o un adjetivo y Marchante explota más la de verbos con adjetivos y nombres. Estos resultados apenas coinciden con los extraídos en sus prosas, pues la única combinación que en ellas ofrece datos similares a los recientemente comentados es el de $\mathrm{N}+\mathrm{A}$.

La lírica profana de Cornejo da más relevancia al uso de la primera persona que la de Marchante. No sucede lo mismo con la prosa, ya que la correspondencia íntima del maestro de León posee una presencia elevada del yo. Cabe destacar también que las composiciones del dramaturgo manchego manifiestan una mayor voluntad de conectar emocional y socialmente con el receptor. Respecto al tipo emociones que transmiten las poesías de ambos, es importante mencionar que adquieren un papel más destacado las emociones negativas. Estas, al igual que las positivas, son más abundantes en los poemas de Marchante que en los de fray Damián. Sucede lo contrario con sus narraciones.

El análisis cuantitativo léxico-semántico ha ofrecido más datos relevantes sobre los versos profanos indubitados de Cornejo y Marchante. Ha permitido demostrar que las poesías de este último poseen una mayor voluntad de conectar emocional y socialmente con el receptor y, por ello, intentan retratar más sentimientos, tanto positivos como negativos. Por último, ha puesto de manifiesto que las creaciones (prosa y verso) del obispo de Orense albergan una mayor diversidad de vocabulario que los corpus analizados del dramaturgo manchego. 


\subsection{ANÁLISIS DE LA POESÍA PROFANA DUBITADA}

Tras delimitar los datos morfosintácticos y léxico-semánticos que caracterizan la poesía profana indubitada y la prosa de los autores analizados (Cornejo y León) e identificar sus diferencias, la mayoría de sus poemas humanos dubitados se ha sometido a las mismas pruebas que estos (ver “4.2.”). Tan solo se ha exceptuado el estudio de la frecuencia de las palabras más recurrentes, ya que (como se ha demostrado en el apartado anterior) no aportaba datos fiables ni relevantes para discernir entre sus creaciones en verso. Los resultados obtenidos han sido contrastados con los previamente comentados con el propósito de poder resolver los problemas de autoría que plantean.

\subsubsection{Metodología aplicada y corpus analizado}

En esta investigación, se ha transcrito y normalizado un corpus de doce poemas humanos indubitados de fray Damián y del maestro León (seis de cada poeta) y cuarenta y dos que se disputan entre ambos ${ }^{199}$. Aunque su extensión es bastante diversa, los datos porcentuales extraídos mediante los programas utilizados (ContaWords, LIWC, R, Treetagger, SPSS y Voyant Tools) pueden aportar resultados relevantes, tanto individuales como de conjunto, sobre su morfosintaxis, su vocabulario y su métrica.

En la codificación de las poesías seleccionadas, se ha utilizado la inicial del apellido de Cornejo y de León (“C” y "L") y la marca "pi” para identificar su autoría indubitada y señalar su temática humana. Las composiciones que se atribuyen a ambos "dubitadas" se han identificado con "d_p”. Además, en algunas pruebas del estudio morfosintáctico se han incluido seis poesías profanas de Sor Juana Inés de la Cruz "SJ_pi” para probar la fiabilidad de los datos obtenidos Las correspondencias de todos los poemas analizados se pueden consultar en el "Anexo: 8.4.2. Tablas 39 y 40".

\subsubsection{Análisis morfosintáctico}

\footnotetext{
199 De los cincuenta y siete poemas profanos dubitados con León, se han seleccionado los cuarenta y dos que aparecen en el manuscrito $D$. Su transcripción se corresponde con la de dicho poemario.
} 
Gracias a la herramienta Treetagger ${ }^{200}$, se ha podido obtener los porcentajes de algunas de las principales categorías gramaticales ${ }^{201}$ que aparecen en la poesía sacra (dubitada e indubitada) de fray Damián y del maestro León. A partir de estos, con el programa $\mathrm{R}$, se han generado varios análisis de multivariantes, los cuales representan gráficamente las diferencias y las similitudes morfosintácticas que existen entre las diversas poesías analizadas. Como la extensión de las obras influye en los resultados, se han conformado dos biplots; el primero cuenta con todos los poemas indubitados de Cornejo y Marchante y los dubitados y, el segundo, con todos estos y con los de autoría segura de menor longitud



Gráfico 5: Biplots de poemas dubitados e indubitados de Cornejo y Marchante

En el primer biplot puede observarse que la mayoría de textos dubitados tienden a concentrarse en los cuadrantes inferiores al presentar un porcentaje superior de sustantivos comunes y conjunciones subordinadas. Tales características los aproximan más a las composiciones de León (cuadrante superior izquierdo) que a las de Cornejo (cuadrante superior derecho). Las poesías más extensas del cronista palentino se distancian bastante del resto por poseer una cantidad más elevada de cuantificadores y adverbios.

\footnotetext{
${ }^{200}$ Se han revisado (parcialmente) los resultados de los análisis aportados por el programa Treetagger y el margen de error en ninguno de los textos seleccionados supera el diez por ciento del total.

${ }^{201}$ En esta investigación, se han elegido las siguientes variables de análisis: adjetivos (ADJ), adverbios (ADV), artículos (ART), nombres comunes (NC), preposiciones (PREP), cuantificadores (QU), demostrativos (DM), interrogativos (INT), posesivos (PPO), pronombres personales (PPX), clíticos (PPC), marcas de negación (NEG), conjunciones copulativas (CC), conjunciones subordinantes (CSUBX) y conjunción «que» (CQUE).
} 
Después de suprimir los textos indubitados de mayor longitud (C_pi3, C_pi4, C_pi5, L_pi1, L_pi2 y L_pi5) y dejar los que poseen una extensión más similar a la de los dubitados, estos últimos se dispersan por todo el biplot. Como sucedía en el anterior gráfico, la mayoría de poemas disputados continúan estando un poco más próximos a las creaciones de Marchante (cuadrante inferior derecho) que a las de fray Damián (cuadrante inferior izquierdo). Con el propósito de comprobar si la inclusión de otro poeta altera o no los resultados, se ha añadido a las visualizaciones comentadas las poesías profanas indubitadas de Sor Juana Inés de la Cruz “Anexo: 8.4.2. Gráficos 17 y 18”. Su incorporación provoca que las composiciones dubitadas e indubitadas del maestro León y de Cornejo se compacten, aunque siguen sin mostrar una tendencia clara que permita asociar con fiabilidad cada uno de los textos disputados a un autor.

Para intentar precisar estos datos, se ha recurrido a otras pruebas de multivariantes que permiten discernir de manera individual los casos seleccionados. Por un lado, se ha realizado (a través del programa SPSS) un análisis clúster con el objetivo de comprobar si su morfosintaxis está más próxima a la de fray Damián o a la de León o si poseen características gramaticales distintas a las de tales autores. Por otro, se ha aplicado un análisis de discriminantes a los datos obtenidos para determinar las categorías gramaticales que más influyen en su agrupación. En estas pruebas solo se han contemplado los poemas indubitados breves de Cornejo y de Marchante (C_pi6, C_pi7, C_pi9, L_pi3, L_pi4 y L_pi6) y los dubitados, pues presentan menos diferencias estilísticas con estos últimos. A continuación, se muestran dos tablas con los resultados:



Tabla 12: Análisis clúster y de discriminantes 
Las cincuenta y cuatros poesías analizadas constituyen dos grupos en el análisis clúster “Anexo: 8.4.2. Tabla 41”. El primero, como se muestra en el análisis de discriminantes, destaca por el uso elevado de adverbios y pronombres personales y está conformado por los poemas indubitados de Cornejo y los doce dubitados que el análisis de clasificación le atribuye, mientras que el segundo realiza un mayor uso de nombres comunes y artículos y lo constituyen las poesías de Marchante y las treinta dubitadas restantes ${ }^{202}$. Tras seleccionar las categorías gramaticales que diferencian con claridad los bloques mencionados (ADV, ART, NC y PPX), se ha efectuado una nueva prueba de clasificación, la cual asigna tres composiciones dubitadas más a León ${ }^{203}$. No obstante, es importante señalar que la supresión de variables en este puede afectar a la precisión de los resultados, ya que se eliminan categorías que pueden ayudar a diferencias los corpus de ambos autores.

Con el propósito de probar si existen más semejanzas estilísticas entre las poesías profanas indubitadas de fray Damián y de Marchante y las dubitadas que se han asociado a cada uno en el análisis clúster, se han analizado con el programa ContaWords las combinaciones "bigramas" más recurrentes de nombres, verbos y adjetivos que aparecen en los corpus analizados ${ }^{204}$ :

\begin{tabular}{|lll|l|l|l|l|l|l|l|l|l|}
\hline Bigramas & $\mathbf{N}+\mathbf{N}$ & $\mathbf{N}+\mathbf{V}$ & \multicolumn{1}{|c|}{$\mathbf{N}+\mathbf{A}$} & $\mathbf{V + N}$ & $\mathbf{V + V}$ & $\mathbf{V}+\mathbf{A}$ & $\mathbf{A}+\mathbf{N}$ & $\mathbf{A}+\mathbf{V}$ & $\mathbf{A}+\mathbf{A}$ \\
\hline $\begin{array}{l}\text { Indubitados } \\
\text { de Cornejo }\end{array}$ & 16,29 & 58,96 & 25,8 & 37,23 & 45,85 & 16,92 & 72,73 & 28,57 & 0 \\
\hline $\begin{array}{l}\text { Dubitados } \\
\text { atribuidos } \\
\text { a Cornejo (9) }\end{array}$ & 16,00 & 62,00 & 20,00 & 39,78 & 46,24 & 13,98 & 70,00 & 30,00 & 0 \\
\hline $\begin{array}{l}\text { Indubitados } \\
\text { de León }\end{array}$ & 12,3 & 66,31 & 21,39 & 40,08 & 36,29 & 22,78 & 68,25 & 26,45 & 0,83 \\
\hline $\begin{array}{l}\text { Dubitados } \\
\text { atribuidos } \\
\text { a León (30) }\end{array}$ & 13,27 & 64,37 & 22,60 & 35,29 & 50,49 & 16,67 & 63,23 & 34,19 & 2,58 \\
\hline
\end{tabular}

Como puede verse en la tabla, existen algunas semejanzas entre los poemas indubitados de un autor y los Tabla 13: Frecuencia de bigramas disputados que al mismo se

\footnotetext{
${ }^{202}$ Es importante señalar que D_p21, D_p35 y D_p38 fueron impresos en un pliego suelto (1670?) junto a varios poemas indubitados de Marchante (León, Relación 15-16).

${ }^{203}$ Los poemas dubitados atribuidos a fray Damián son los siguientes: D_p3, D_p7, D_p9, D_p18, D_-p19, D_p29, D_p34, D_p37, D_p40, D_p32, D_p36 y D_p38 Estos tres últimos en el análisis de discriminantes se asignan a Marchante. Es importante señalar que, excepto D_p37 y D_p38, todos se hallan impresos en el tercer volumen de las Obras poéticas del dramaturgo manchego, el cual (como se ha dicho previamente) es el menos fiable.

${ }^{204}$ Se han analizado por separado los bigramas de los tres poemas dubitados (D_p32, D_p36 y D_p38) que en el clúster se asocian con Cornejo y que en el análisis de discriminante se asignan a Marchante para comprobar con qué autor guardan más semejanza. Los resultados obtenidos muestran que las combinaciones gramaticales de estas composiciones poseen más similitudes con las del poeta palentino.
} 
asocian. Los bigramas en los que se aprecian más similitudes en ambos poetas son: $\mathrm{N}+\mathrm{N}$ y $\mathrm{N}+\mathrm{V}$. Es importante señalar que, exceptuando la combinación $\mathrm{N}+\mathrm{A}$, los porcentajes de las producciones que se vinculan a fray Damián (dubitadas e indubitadas) se hallan más próximos que los del maestro León. Las diferencias que se aprecian en la mayoría de bigramas de las composiciones asociadas a este (dubitadas e indubitadas) podrían poner de manifiesto lo siguientes factores. Por un lado, estas podrían deberse a la diversa extensión de los poemas analizados. Por otro, podrían evidenciar que alguno de los textos disputados que se atribuyen a León en los análisis de clasificación no son de él. Por último, tales alteraciones podrían señalar que estos no presentan una huella de autor clara.

\subsubsection{Análisis léxico-semántico}

Se ha realizado el análisis del léxico y de la semántica de la lírica profana indubitada y dubitada de Cornejo y Marchante para completar los datos estilísticos aportados en el estudio morfosintáctico y para comprobar si existen diferencias significativas en el vocabulario que se emplean en tales corpus. A partir del programa LIWC, se ha indagado en el tipo de emociones (positivas y negativas) que predomina en estos, en su subjetividad y en su contenido social. Su riqueza léxica ha sido extraída con la herramienta Voyant Tools. Los resultados obtenidos se muestran en la siguiente tabla:

\begin{tabular}{|c|c|c|c|c|c|}
\hline & $\begin{array}{c}\text { Self- } \\
\text { Reference }\end{array}$ & $\begin{array}{l}\text { Social } \\
\text { Words }\end{array}$ & $\begin{array}{l}\text { Positive } \\
\text { emotions }\end{array}$ & $\begin{array}{l}\text { Negative } \\
\text { emotions }\end{array}$ & $\begin{array}{l}\text { Type/ token } \\
\text { ratio }^{205}\end{array}$ \\
\hline \multicolumn{6}{|c|}{ Damián Cornejo } \\
\hline Poesía indubitada & 1.21 & 0.93 & 0.21 & 0.56 & 47.2 \\
\hline $\begin{array}{l}\text { Dubitados atribuidos } \\
\text { a Cornejo (9) }\end{array}$ & 0.83 & 0.88 & 0.26 & 0.26 & 46.8 \\
\hline \multicolumn{6}{|c|}{ León Marchante } \\
\hline Poesía indubitada & 0.54 & 0.99 & 0.24 & 0.66 & 46.5 \\
\hline $\begin{array}{l}\text { Dubitados atribuidos a } \\
\text { León (30) }\end{array}$ & 0.73 & 0.89 & 0.34 & 0.62 & 45.6. \\
\hline
\end{tabular}

Tabla 12: Análisis léxico-semántico

205. Como la extensión de los corpus analizados influye en la obtención del porcentaje de riqueza léxica, se han equiparado la longitud de cada uno estos a 1033 palabras, que es la cantidad que posee el corpus más breve: dubitados atribuidos a Cornejo. 
Puede señalarse que tanto la lírica profana indubitada de Cornejo como los poemas dubitados que a este se atribuyen ${ }^{206}$ dan más relevancia a las autorreferencias que los vinculados a Marchante. Sucede lo contrario con las emociones negativas, ya que se observa un mayor uso en estos últimos. Respecto al empleo de palabras sociales, cabe señalar que tanto los poemas indubitados como los dubitados que se atribuyen al dramaturgo manchego presentan un porcentaje un poco más elevado que los corpus asociados con fray Damián. Si se analiza la riqueza léxica, las poesías del obispo de Orense y las composiciones dubitadas que a él se atribuyen albergan una mayor diversidad de vocabulario que las atribuidas a León.

Por último, se ha intentado comprobar las relaciones léxicas que existen tanto entre los poemas analizados como entre estos y las producciones indubitadas en prosa y verso (profano y sacro ${ }^{207}$ ) de ambos autores. A continuación, se ofrece la tabla donde se recopilan las palabras distintivas ${ }^{208}$ de Marchante y de Cornejo que se encuentran en ellos con el objetivo de determinar la presencia que estas tienen en las doce poesías dubitadas ${ }^{209}$ que en el estudio de la morfosintaxis se vinculan al cronista palentino:

\footnotetext{
${ }^{206}$ Se han analizado por separado el léxico y la semántica de los tres poemas dubitados (D_p32, D_p36 y D_p38) que en el clúster se asocian con Cornejo y que en el análisis de discriminante se asignan a Marchante para comprobar con qué autor guardan más semejanza. Los resultados obtenidos muestran que en uso de autorreferencias, palabras sociales y sentimientos negativos poseen más similitudes con las del dramaturgo manchego.

${ }^{207}$ Se ha transcrito un corpus de poesías sacra indubitada de ambos autores que consta de seis mil palabras: tres mil para cada poeta. Los datos sobre estas pueden consultarse en el "Anexo: 8.4.3. Tabla 39".

208 Para garantizar una extracción equitativa de las palabras distintivas, estas se han limitado a diez.

209 Se han incluido los tres poemas (D_p32, D_p36 y D_p38) que en el análisis de clasificación se atribuyen al cronista palentino y que en el análisis de discriminantes se asignan a Marchante para comprobar cuántas palabras distintivas de cada uno poseen. Estas composiciones se han marcado en la tabla con cursiva para facilitar su identificación.
} 


\begin{tabular}{|l|l|l|l|l|l|}
\hline D_p3 & D_p7 & D_p9 & D_pl8 & D_pl9 & D_p29 \\
\hline \multicolumn{5}{|c|}{ Palabras distintivas de Cornejo } \\
\hline Camestolendas & Agasajo & Cirio & Agravio & Araña & Artífice \\
\hline Desperdicio & Ganancia & Delirio & Ponderación & Baqueta & Desfigurado \\
\hline Goteras & Jugar & Franca & Público & Caza & Dibujo \\
\hline Fábrica & Juez & Imagen & Explicación & Conciencia & Mudanza \\
\hline Frívolas & Requebrar & Industria & & Confitadas & Pintor \\
\hline Grana & - & Pobreza & & Espigón & \\
\hline Mejillas & & & & Mosca & \\
\hline Muñeca & & & & Moscatel & \\
\hline Muñeca & & & & Plaga & \\
\hline & & & & Rincón & \\
\hline & & & Palabras distintivas de Marchante & \\
\hline Moneda & Barato & Remitir & Alivio & Cola & \\
\hline & Tercia & & Cordura & Entrambos & \\
\hline & & & Entablar & Rabo & \\
\hline & & & Sabio & Sobrecarga & \\
\hline
\end{tabular}

\begin{tabular}{|c|c|c|c|c|c|}
\hline$D \_p 32$ & D_p34 & 1936 & D_p37 & D_p38 & p40 \\
\hline \multicolumn{6}{|c|}{ Palabras distintivas de Cornejo } \\
\hline Ánima & Aplaudida & \begin{tabular}{|l|l} 
Fragua &
\end{tabular} & & Barrabás & Dulce \\
\hline \multirow[t]{7}{*}{ Arrepentido } & Casco & Guisa & & Emboque & Juego \\
\hline & Celebrada & Melindre & & Maza & Pelota \\
\hline & Particular & Morder & & Mostaza & Ufano \\
\hline & Privada & & & Pesadumbre & Vuelo \\
\hline & & & & Sarmiento & \\
\hline & & & & Uva & \\
\hline & & & & & \\
\hline \multicolumn{6}{|c|}{ Palabras distintivas de León } \\
\hline \multirow[t]{3}{*}{ Entrambos } & Barbado & Estudiante & Dilatado & Vasallo & \\
\hline & Manojos & Gorrón & Cargado & & \\
\hline & & Tripas & & & \\
\hline
\end{tabular}

Tabla 15: Palabras distintivas de Cornejo y Marchante

Como puede verse todas las poesías, excepto D_p18 y D_p37, comparten más palabras distintivas con Cornejo que con Marchante. Tal hecho podría ayudar a corroborar los datos del estudio morfosintáctico que las atribuyen a fray Damián. Las dos composiciones que poseen más léxico en común con este autor son D_p3 y D_p19 (las más extensas) y las únicas que no contienen ningún vocablo distintivo del maestro León son D_p29 y D_p40. 
Respecto a la semántica de las voces extraídas, cabe señalar que pueden observarse en ellas algunas relaciones. El dramaturgo manchego parece mostrar una tendencia a incluir atributos o estados de individuos (barbado, estudiante, gorrón, sabio o vasallo), mientras que el cronista palentino tiende a utilizar términos vinculados con el mundo del arte (desfigurado, dibujo, imagen y pintor) y del juego (emboque, juego, jugar o pelota) e intenta identificar objetos: baqueta, casco, cirio, espigón y maza.

Tras comprobar que la mayoría de los poemas analizados contienen más términos distintivos de fray Damián que de Marchante, se ha procedido a determinar si entre ellos también se establecen conexiones léxicas relevantes que puedan probar que fueron escritos por la misma mano. Para ello, se ha procedido a extraer las palabras no funcionales que estos comparten $^{210}$. Los resultados obtenidos se muestran en la siguiente tabla:



Tabla 16: Palabras compartidas entre los poemas atribuidos a Cornejo

\footnotetext{
${ }^{210}$ Para garantizar una extracción equitativa de las palabras que comparten los poemas seleccionados, estas se
} han limitado a diez. 
Aunque todos los poemas analizados presentan múltiples términos en común, existen importantes diferencias entre ellos relacionadas con su extensión. Los textos más breves (D_p29 y D_p34) son los que menos contienen, mientras que los de mayor longitud son los que más albergan: D_p3, D_p7, D_p9, D_p18 y D_p19 211. Las poesías que más léxico comparten entre ellas son D_p9 y D_p18, que presentan cuatro vocablos en común. D_p9 también posee tres voces que se hallan en D_p3.

El vocabulario que más se reitera en las composiciones analizadas (alma, amor, amante, blanca, cosa y niña) era bastante recurrente en el barroco. No obstante, en estas pueden observarse algunos casos significativos. Llama la atención que en D_p37 y D_p38 aparece la voz "pescuezo", pues esta posee una frecuencia de uso casi nula (según el CORDE) en la lírica del siglo XVII. La escasez en el empleo de esta palabra podría ser un claro indicio de que pudieron ser compuestos por el mismo autor. Lo mismo sucede con “bodegón”, que se incluye en D_p19 y D_p36. Respecto a la semántica del léxico extraído, cabe destacar que abunda el vocabulario relacionado con el físico (boca, cara, corazón, cuerpo, espaldas, mano, manos, ojo, pies y pescuezo), el cual, como se ha señalado en el apartado “4.2.4.”, parece interesar especialmente a Cornejo.

\subsubsection{Análisis métrico}

Con el propósito de completar la caracterización de los poemas profanos que se han analizado en los apartados anteriores, se ha procedido a delimitar las formas métricas que se utilizan en ellos. A pesar de que el número de poesías dubitadas que se atribuyen a Cornejo en el estudio de clasificación es reducido (nueve), conocer los porcentajes de estas y compararlos con los que se asocian en él a Marchante (treinta) puede aportar datos relevantes sobre si existen diferencias significativas entre estas en el uso de los metros. Además, puede ayudar a establecer relaciones con el empleo que se hace de la métrica en los poemas indubitados humanos del cronista palentino. Los resultados obtenidos se han representado a través de dos gráficos:

\footnotetext{
${ }^{211}$ El poema D_p19 parece guardar una estrecha relación con D_p26, ya que cuentan el desarrollo de una broma pesada y comparten, además, términos de escaso uso en la lírica barroca como "zurriaga" y "moscas". Tales datos podrían indicar que fueron escritos por la misma mano.
} 




Gráfico 6: Análisis métrico de los poemas dubitados

La décima es el metro más recurrente en los poemas dubitados analizados, aunque su proporción es más elevada en los atribuidos a Marchante en el clúster. Tal dato coincide con el mayor uso que hace el dramaturgo manchego de esta estructura en sus poesías profanas indubitadas (ver “3.2.1.”). Lo mismo sucede con las quintillas, que en este caso no se incluyen en el gráfico de textos que se atribuyen a Cornejo. La presencia del soneto ${ }^{212}$ en este último también podría ser un indicio más para corroborar su autoría, pues es el segundo metro más empleado en las poesías humanas que solo se firman con su nombre y su presencia es casi inexistente en las indubitadas del poeta de Pastrana. Aunque la redondilla y la copla tienen un mayor peso en estas últimas, su uso en los poemas atribuidos a fray Damián en los clústeres es más reducido. Por último, resulta relevante señalar que ni la lira ni los octosílabos en esdrújulos se incluyen en los corpus de indubitados analizados.

\subsubsection{Conclusiones}

El estudio cuantitativo de la morfosintaxis, del léxico y de la métrica ha ofrecido más datos relevantes sobre las características de las poesías analizadas y sobre la autoría de los poemas humanos disputados entre ambos autores. A través de los diversos estudios de multivariantes, a pesar de la diversa extensión de los textos, se han conformado dos grupos de poemas dubitados, que se han asociado con los corpus de composiciones de autoría segura analizados. Los doce vinculados a la lírica indubitada de Cornejo en los análisis de clasificación presentan un uso elevado de adverbios y pronombres personales, mientras que

\footnotetext{
${ }^{212}$ El soneto y las redondillas son las estructuras usadas en los tres textos dubitados (D_p32, D_p36 y D_p38) que en los clústeres se atribuían a fray Damián y en el análisis de discriminantes a León.
} 
los restantes comparten con la poesía de Marchante una mayor predilección por utilizar nombres comunes y artículos.

El análisis de bigramas ha aportado nuevas divergencias entre los dos conjuntos mencionados respecto a la utilización de combinaciones gramaticales. Los poemas dubitados vinculados a fray Damián y sus indubitados emplean más $\mathrm{N}+\mathrm{N}, \mathrm{N}+\mathrm{V}$ y $\mathrm{A}+\mathrm{N}$, mientras que los atribuidos a León y sus poesías de autoría segura hacen un mayor uso de A+A y N+V. En el análisis semántico, también se han hallado rasgos que permiten distinguirlos. Los primeros muestran una presencia más destacada de autorreferencias, una menor proporción de emociones negativas y una riqueza léxica más elevada que los atribuidos a Marchante y sus indubitados.

Respecto al léxico distintivo, cabe señalar que en casi todos los casos parece verificar la autoría de los poemas atribuidos en el estudio morfosintáctico al obispo de Orense y que en estos compartían múltiples términos, varios de ellos de escaso uso en la época. Por último, el análisis métrico ha puesto en evidencia que los dubitados que se asocian a Marchante poseen una mayor diversidad en el uso de los metros y que en los que se vinculan a Cornejo en los clústeres de clasificación manifiestan un porcentaje más elevado de sonetos y redondillas.

Tras valorar todos los datos gramaticales, semánticos, léxicos y métricos obtenidos, se puede concluir que las doce poesías dubitadas profanas que se asocian en al cronista palentino comparten más características estilísticas con este que con los versos de León. Excepto D_p37 y D_p38, todas estas se hallan en el tercer volumen de las Obras poéticas del dramaturgo manchego, que (como se ha comentado previamente) parece ser el menos fiable.

Sin embargo, los resultados no pueden considerarse concluyentes, pues también se han observado algunos rasgos similares entre los poemas dubitados vinculados a Cornejo y las producciones indubitadas de Marchante y los poemas que en el análisis de clasificación se asocian a él. Además, no se puede descartar tampoco que entre estos últimos no haya ninguno que no sea suyo y que tal hecho alterara algunos datos aportados. Tampoco se puede obviar la posibilidad de que las composiciones estudiadas no posean una "huella" de autor clara que pueda ser detectada mediante datos cuantificables. 


\subsection{ANÁLISIS DE LA POESÍA SACRA INDUBITADA ${ }^{213}$}

El escaso cultivo que hizo fray Damián de la lírica religiosa ha provocado que se llegara a poner en duda incluso la autoría de las nueve poesías de temática divina que únicamente se firman con su nombre (Carreira, La obra 53) ${ }^{214}$. Con el propósito de intentar aportar datos objetivos y cuantificables que permitan singularizarlas, estas y algunos poemas indubitados de temática religiosa del maestro León ${ }^{215}$ han sido sometidos a diversos análisis de clasificación. Además, se han extraído sus características morfosintácticas y léxicosemánticas y se han cotejado los resultados para intentar establecer diferencias entre ambos corpus.

\subsubsection{Metodología aplicada y corpus analizado}

Se ha transcrito y normalizado un corpus de dieciséis mil palabras de lírica indubitada (seis mil de sacra y diez mil de profana) y treinta mil de la prosa de ambos autores ${ }^{216}$. Los textos seleccionados ${ }^{217}$ poseen más de cien palabras para garantizar que los programas de análisis cuantitativos utilizados (ContaWords, LIWC, R, SPSS, Treetagger y Voyant Tools) sean capaces de extraer datos relevantes tanto en su estudio individual como en el de conjunto $^{218}$. En su codificación, se ha utilizado la inicial del apellido de Cornejo y de León ("c" y "l"), las marcas "si" y "pi" para indicar si se trata de poesías divinas o humanas indubitadas y el número asignados a cada una. Sus respectivas referencias se hallan en la tabla del “Anexo: 8.4.3.". Las obras en prosa incluyen el mismo sistema de marcación e integran también las primeras letras de su título: C_cron y L_car.

\footnotetext{
${ }^{213}$ Los datos aportados en este apartado han sido publicados en el duodécimo volumen de Studea Aurea (Sánchez, Análisis 287-306).

214 Aunque el número de poemas que se atribuyen a fray Damián es abundante (unos doscientos), solo treinta y ocho son de temática religiosa. De estos, solamente nueve se pueden considerar indubitados "Anexo: 8.3.2.1.”.

215 Los poemas sacros indubitados de León presentan menos ingenio verbal, más música y variedad métrica, más personajes risibles y una tendencia mayor al entremés que los de Cornejo (Carreira, La obra 48).

${ }^{216}$ El corpus textual de cada autor asciende a veintidós mil palabras: quince mil de prosa, cinco mil de poesía humana y dos mil de sacra. El número de términos de esta última (aunque su análisis es el eje central de este apartado) es menor que el de lírica profana, ya que la cantidad de poemas indubitados religiosos de fray Damián es más reducida que la de sus versos humanos.

${ }^{217}$ Las poesías indubitadas sacras del maestro León que se han seleccionado para este estudio pertenecen al primer volumen de sus Obras poéticas y a unos villancicos que publicó en pliegos sueltos en 1662 (León, Letras).

${ }^{218}$ El número mínimo de palabras que posee cada poema en este estudio es más reducido que en el de poesías profanas indubitadas (ver “4.3.1."), pues los textos divinos de Cornejo y de Marchante (en general) poseen una extensión mucho menor que los de temática no religiosa.
} 


\subsubsection{Análisis morfosintáctico}

Gracias a la herramienta Treetagger, se ha podido obtener los porcentajes de algunas de las principales categorías gramaticales que aparecen en la lírica indubitada y en las narraciones de fray Damián y del maestro León ${ }^{219}$. Estos han permitido generar varios análisis de multivariantes que han sido representados a través de biplots, los cuales pretenden mostrar las relaciones morfosintácticas que se manifiestan entre las producciones en verso y en prosa de un mismo autor y entre las poesías sacras de ambos. A continuación, se ofrecen dos gráficos (uno para cada poeta) con los resultados obtenidos al analizar la gramática de sus diversas creaciones:



Gráfico 7: Biplots de los corpus en prosa y en verso de Cornejo y Marchante

Se observan patrones comunes en las producciones de Cornejo y de Marchante. La temática de sus poemas parece influir de manera decisiva en el uso de la gramática; las composiciones humanas y las religiosas constituyen bloques independientes, aunque estas últimas se muestran más dispersas. Además, los versos que poseen más semejanzas con las narraciones (L_car y C_cron) son los de contenido profano ${ }^{220}$, posiblemente, por su estilo más prosaico y su mayor extensión.

\footnotetext{
${ }^{219}$ Se han revisado (parcialmente) los resultados de los análisis morfosintácticos obtenidos por el programa Treetagger y el margen de error en ninguno de los textos seleccionados supera el diez por ciento del total.

${ }^{220}$ Los resultados obtenidos en el estudio de multivariantes han sido corroborados con los obtenidos en el programa CopyCatch Gold. Las obras en prosa de Cornejo y de Marchante poseen en este un porcentaje de similitud más elevado con los poemas profanos (59\% y $63 \%$ respectivamente) que con los sacros: $45 \%$ y $46 \%$. Además, la semejanza entre los versos humanos y los divinos de fray Damián es algo más alta que en los del maestro León: $48 \%$ y $46 \%$.
} 
En el biplot que recoge las obras de maestro León, puede verse cómo sus poesías humanas se aglutinan en los cuadrantes de la derecha, que presentan un mayor número de artículos, preposiciones y pronombres. Respecto a su lírica divina, cabe señalar que conforma dos grupos. Las poesías situadas en la mitad superior (L_si1, L_si7, L_si8 y L_si9) tienen una longitud parecida y se caracterizan por incluir un número más elevado de marcas de negación, mientras que los que se hallan en la parte inferior (L_si2, L_si3, L_si4, L_si5 y L_si6) albergan más cuantificadores, adverbios y adjetivos.

En el análisis de multivariantes que recopila las creaciones de fray Damián, se observa que gran parte de sus composiciones (divinas y humanas) se sitúan en la parte derecha del gráfico. Tal dato pone de manifiesto que existe una mayor similitud entre estas que entre las del dramaturgo manchego. Los poemas profanos de Cornejo contienen más adverbios y adjetivos y los sacros (exceptuando el bloque constituido por C_si2, C_si3 y C_si7) utilizan más nombres comunes, artículos y cuantificadores.

Para poder comprobar si se aprecian diferencias importantes entre los corpus de lírica sacra indubitada del cronista seráfico y del maestro León, se han sometido a dos pruebas. En la primera, se han confrontado en un análisis de multivariantes y, en la segunda, se ha añadido al biplot resultante la poesía religiosa de Sor Juana Inés de la Cruz ${ }^{221}$ con el objetivo de poder determinar si su distancia aumenta o disminuye al incluir esta. Los resultados de ambos estudios son los siguientes:



Gráfico 8: Biplots de los corpus en verso de Cornejo, Marchante y Sor Juana

${ }^{221}$ Los datos sobre los poemas de Sor Juana pueden consultarse en la tercera tabla del “Anexo: 8.4.”. 
En el gráfico de la izquierda, se conforman tres bloques independientes. Por un lado, se hallan los poemas divinos del dramaturgo manchego, menos L_si9, los cuales destacan por utilizar con más frecuencia artículos, adverbios, adjetivos, cuantificadores, interrogativos y clíticos. Por otro, se encuentran la mayoría de las poesías sacras del obispo de Orense (exceptuando C_si2, C_si3 y C_si7), que presentan un mayor uso de demostrativos, preposiciones, posesivos y pronombres personales. Por último, en los cuadrantes de la derecha, aparecen cuatro composiciones: una de marchante (L_si9) y las tres últimas citadas de fray Damián.

La incorporación del corpus de la escritora novohispana, en el biplot de la derecha, mantiene separados todos los textos del maestro León y los del cronista seráfico. No obstante, C_si2, C_si3 y C_si7 continúan alejados del resto de los atribuidos al poeta palentino $^{222}$. Cabe señalar, además, que la morfosintaxis de las poesías sacras de Sor Juana se asemeja bastante a la del Cornejo e, incluso, algunos de sus poemas (SJ_si2, SJ_si4 y SJ_si5) llegan a entremezclarse, pues poseen una frecuencia parecida de preposiciones, artículos, pronombres y clíticos. A pesar de las similitudes que comparten sus producciones divinas, estas pueden distinguirse con claridad si no se añaden en el análisis de multivariantes las poesías de Marchante "Anexo: 8.4.3”.

Tras comprobar que existen diferencias relevantes entre los versos religiosos del cronista seráfico y los del maestro León, se ha procedido a identificar qué elementos gramaticales son los más recurrentes en estos. Con el propósito de poder delimitar con mayor exactitud los datos y para que estos puedan ser cotejados en futuras investigaciones con los de otros poemas de ambos, se han sometido a otros análisis de multivariantes a través del programa SPSS. Por un lado, se ha realizado un análisis clúster para comprobar si las poesías de autoría segura de Cornejo y Marchante conformaban grupos diferenciados a partir de los porcentajes gramaticales extraídos. Por otro, se han sometido a un análisis de discriminantes los bloques resultantes para determinar cuáles son las categorías gramaticales que permiten diferenciar los versos humanos de Cornejo y de León:

\footnotetext{
${ }^{222}$ La división de la lírica religiosa indubitada de Cornejo en dos grupos podría estar relacionada con las siguientes causas. Por un lado, los versos de C_si3 están constituidos por títulos de comedias y, por tanto, el uso que se hace en estos de la morfosintaxis no manifiesta el estilo personal de su autor. Por otro, su mayor extensión (como también sucede con C_si2 y C_si7) propiciaría que aparecieran diferencias en el empleo de la categorías gramaticales entre este y las poesías sacras de menor longitud de fray Damián.
} 


\begin{tabular}{|c|c|c|c|c|c|c|}
\hline \multicolumn{3}{|c|}{ Clúster } & \multicolumn{4}{|c|}{ Análisis de discriminantes } \\
\hline & \multicolumn{2}{|c|}{ Cluster } & \multirow{2}{*}{\multicolumn{2}{|c|}{ Cluster Number of Case }} & \multirow[b]{2}{*}{ Mean } & \multirow[b]{2}{*}{ Std. Deviation } \\
\hline & 1 Cornejo & 2 León & & & & \\
\hline $\mathrm{NC} *$ & 25,60 & 17,30 & 1 Cornejo & $\mathrm{PPC}$ & 2,1011 & 1,33121 \\
\hline PREP * & 13,40 & 1,30 & & NC & 20,0400 & 3,44819 \\
\hline $\mathrm{PPC} *$ & 2,92 & 14,20 & & PREP & 11,3333 & 2,17966 \\
\hline PPO & 6,70 & 1,80 & & ART & 7,4922 & 2,83914 \\
\hline ADV & 1,20 & 2,20 & 2 León & PPC & 10,6556 & 2,66651 \\
\hline ADJ & 4,80 & 4,90 & & $\mathrm{NC}$ & 18,3667 & 3,39779 \\
\hline QU & 6,70 & 2,70 & & PREP & 1,3556 & 1,12373 \\
\hline $\mathrm{CC}$ & 4,80 & 4,40 & & ART & 9,4111 & 2,72096 \\
\hline ART * & 4,20 & 11,10 & & & & \\
\hline PPX & 2,40 &, 90 & & & & \\
\hline CQUE & 4,20 &, 00 & & & & \\
\hline DM & 1,20 & 1,30 & & & & \\
\hline NEG & 2,00 & 2,70 & & & & \\
\hline csuBX & 1,20 & 4,40 & & & & \\
\hline
\end{tabular}

Tabla 17: Análisis clúster y discriminante

El análisis de clasificación "clúster" ha separado correctamente los corpus analizados. El dramaturgo manchego (clúster 2) destaca en el uso de artículos y clíticos, mientras que el cronista franciscano (clúster 1) utiliza más sustantivos, preposiciones y posesivos. Estos datos coinciden con los aportados en sus poesías humanas indubitadas y en sus prosas ${ }^{223}$. Con el propósito de seguir estableciendo diferencias en el uso que hacen ambos de la gramática, se han analizado las combinaciones más recurrentes de nombres, verbos y adjetivos mediante nueve bigramas: $\mathrm{N}+\mathrm{N}, \mathrm{N}+\mathrm{V}, \mathrm{N}+\mathrm{A}, \mathrm{V}+\mathrm{N}, \mathrm{V}+\mathrm{V}, \mathrm{V}+\mathrm{A}, \mathrm{A}+\mathrm{N}, \mathrm{A}+\mathrm{V}$ y $\mathrm{A}+\mathrm{A}$. Los resultados obtenidos se ofrecen a continuación:



Gráfico 9: Frecuencia de bigramas

\footnotetext{
${ }^{223}$ En la prosa y en los poemas profanos de Marchante, se observa un mayor empleo de artículos y clíticos y un menor uso de posesivos que en los mismos corpus de Cornejo. Además, el poeta palentino en sus narraciones y en sus versos humanos también recurre menos que el dramaturgo manchego a las negaciones y a los nexos subordinantes.
} 
El bigrama más recurrente en sus poesías indubitadas sacras es la combinación de un adjetivo más un nombre $(\mathrm{A}+\mathrm{N})$ y el menos utilizado es el de dos adjetivos seguidos $(\mathrm{A}+\mathrm{A})$. Cornejo emplea con mucha más frecuencia la estructura de un sustantivo más otra categoría (nombre, verbo o adjetivo) y Marchante explota más la de verbos con adjetivos y nombres. Tales resultados coinciden en su mayoría ${ }^{224}$ con los obtenidos en sus versos humanos. No sucede lo mismo con las narraciones de ambos. El único bigrama que ofrece datos similares a los recientemente comentados es el de " $\mathrm{N}+\mathrm{A}$ ", pues este aparece con mayor frecuencia en la Crónica Seráfica que en el epistolario del maestro León.

\subsubsection{Análisis léxico-semántico}

Se ha realizado el análisis del léxico y de la semántica de la lírica sacra indubitada de fray Damián y Marchante para completar los datos estilísticos aportados en el estudio morfosintáctico y comprobar si existen diferencias significativas en el vocabulario empleado por ambos. A partir del programa LIWC se ha indagado en el tipo de emociones (positivas y negativas) que predominan en sus poemas, en su subjetividad, en el contenido social de estos y en su riqueza léxica. Los resultados se han contrastado con su poesía profana indubitada y su prosa con el objetivo de establecer relaciones entre las producciones de cada autor. En la siguiente tabla se ofrecen los porcentajes obtenidos:

\begin{tabular}{|c|c|c|c|c|c|}
\hline & $\begin{array}{l}\text { Self- } \\
\text { References }\end{array}$ & $\begin{array}{l}\text { Social } \\
\text { Words }\end{array}$ & $\begin{array}{l}\text { Positive } \\
\text { emotions }\end{array}$ & $\begin{array}{l}\text { Negative } \\
\text { emotions }\end{array}$ & $\begin{array}{l}\text { Type / token } \\
\text { ratio }^{225}\end{array}$ \\
\hline \multicolumn{6}{|c|}{ Damián Cornejo } \\
\hline $\begin{array}{l}\text { Poesía } \\
\text { sacra }\end{array}$ & 0.39 & 0.41 & 0.17 & 0.58 & 41.1 \\
\hline $\begin{array}{l}\text { Poesía } \\
\text { profana }\end{array}$ & 1.21 & 0.93 & 0.21 & 0.56 & 44.6 \\
\hline $\begin{array}{l}\text { Prosa } \\
\text { religiosa }\end{array}$ & 0.13 & 0.44 & 0.46 & 0.70 & 41.7 \\
\hline
\end{tabular}

${ }^{224}$ Cornejo en sus poemas indubitados profanos hace un mayor uso que Marchante de los bigramas " $\mathrm{A}+\mathrm{N}$ ", "V+V", "N+A" y "N+N", mientras que el dramaturgo manchego emplea más las combinaciones de "V+A". "V+N", "N+V", "A+A" y "A+V".

${ }^{225}$ Como la extensión de los corpus analizados influye en la obtención del porcentaje de riqueza léxica, se han equiparado la longitud ( 2150 palabras) de todos los textos seleccionados. Esta se corresponde con la cantidad que posee el corpus más breve: poesía sacra de Cornejo. 


\begin{tabular}{|c|r|r|r|r|r|}
\hline \multicolumn{7}{|c|}{ León Marchante } \\
\hline $\begin{array}{c}\text { Poesía } \\
\text { sacra }\end{array}$ & 0.31 & 0.74 & 0.48 & 0.83 & 39.6 \\
\hline $\begin{array}{c}\text { Poesía } \\
\text { profana }\end{array}$ & 0.54 & 0.99 & 0.24 & 0.66 & 34.4 \\
\hline $\begin{array}{c}\text { Prosa } \\
\text { profana }\end{array}$ & 1.57 & 0.94 & 0.28 & 0.33 & 37.0 \\
\hline
\end{tabular}

En primer lugar, puede señalarse que la lírica de Cornejo, especialmente la profana, da más relevancia al uso de la primera persona que la de Marchante. No sucede lo mismo con la prosa, ya que la correspondencia íntima del maestro de León posee una presencia elevada del yo. En segundo lugar, cabe destacar que las composiciones del dramaturgo manchego manifiestan una mayor voluntad de conectar emocional y socialmente con el receptor, sobre todo, en sus versos sacros ${ }^{226}$. En tercer lugar, respecto a las emociones es importante mencionar que en las creaciones de ambos autores, exceptuando la crónica de fray Damián, predominan los sentimientos positivos. Estos, al igual que los negativos, son más abundantes en las poesías de Marchante.

Por último, si se observa la riqueza léxica, las obras del obispo de Orense, principalmente su poesía humana, albergan una mayor diversidad de vocabulario. No obstante, cabe señalar que en los poemas divinos la distancia entre los porcentajes de ambos es más reducida que en el resto de corpus. Esto podría deberse a un afán por parte de León de dotar a sus textos religiosos de un lenguaje más culto o elevado.

Tras determinar la existencia de diferencias significativas en el léxico y en la semántica de la lírica sacra de Cornejo y Marchante y concretar algunas de las semejanzas que esta presenta con sus poemas profanos y su prosa, se ha procedido a recopilar las palabras distintivas que se reiteran en sus obras ${ }^{227}$. Con el objetivo de aportar una muestra equitativa de estas, se ha restringido el número de ejemplos que aparecen en la siguiente tabla a diez:

\footnotetext{
${ }^{226}$ La capacidad de León Marchante para ganarse el beneplácito del público hizo que compusiera versos sacros para las Capillas Reales (1661-1679) y que se imprimieran múltiples pliegos sueltos de sus poesías religiosas. Pueden consultarse los datos de publicación de estos últimos en el estudio de Alain Bègue (Relación 399-347). ${ }^{227}$ Las flexiones de género y número de los términos seleccionados también son palabras distintivas entre ambos autores.
} 


\begin{tabular}{|c|c|c|c|c|c|}
\hline Léxico & $\begin{array}{l}\text { Poesías } \\
\text { sacras }\end{array}$ & $\begin{array}{l}\text { Poesía } \\
\text { sacra y } \\
\text { profana }\end{array}$ & $\begin{array}{l}\text { Poesía } \\
\text { sacra y } \\
\text { prosa }\end{array}$ & $\begin{array}{l}\text { Poesía } \\
\text { profana y } \\
\text { prosa }\end{array}$ & $\begin{array}{l}\text { Poesía y } \\
\text { prosa }\end{array}$ \\
\hline \multirow{10}{*}{$\begin{array}{c}\text { Manuel } \\
\text { de } \\
\text { León }\end{array}$} & & Cuadrilla & Deidad & Bajeza & Casta \\
\hline & & Oscuro & Gallego & Cadena & \\
\hline & & Polvo & Madera & Canela & \\
\hline & & Retablos & Parto & Carretero & \\
\hline & & Trueno & Plomo & Chulo & \\
\hline & & & Preñada & Comisario & \\
\hline & & & & Egipto & \\
\hline & & & & Galeno & \\
\hline & & & & Mesonero & \\
\hline & & & & Sabio & \\
\hline \multirow{10}{*}{$\begin{array}{l}\text { Damián } \\
\text { Cornejo }\end{array}$} & Llaga & Borrar & Abrojos & Abismo & Conforme \\
\hline & & Calma & Bondad & Andrajo & Estruendo \\
\hline & & Madeja & Desdicha & Almohada & Mesa \\
\hline & & Manteles & Llagas & Carmín & \\
\hline & & Medra & Martirio & Ceniciento & \\
\hline & & & $\begin{array}{l}\text { Omnipo- } \\
\text { tencia }\end{array}$ & Cierzo & \\
\hline & & & Propósito & Codicia & \\
\hline & & & Pureza & Empedernido & \\
\hline & & & Universal & Flaca & \\
\hline & & & Zozobra & Mejilla & \\
\hline
\end{tabular}

Tabla 19: Palabras distintivas entre Cornejo y León

Las creaciones de fray Damián poseen un mayor número de vocabulario distintivo que las de Marchante y, en varios casos, llega a duplicar o triplicar este. En ambos autores, destaca la cantidad de términos que se hallan en sus poemas profanos y en su prosa y también los que aparecen en esta y en sus versos divinos. En estos últimos y en sus corpus completos (prosa y lírica), Cornejo y León muestran una menor cantidad de léxico no compartido. 
A partir del vocabulario extraído de los textos analizados se ha podido establecer una serie de relaciones semánticas. Las obras del escritor palentino parecen mostrar una tendencia por describir detalles del físico (flaca, madeja, mejilla o llagas) y de la personalidad de los personajes (codicia, empedernido, pureza y omnipotencia) y de su ambiente o entorno: almohada, andrajos, ceniciento, carmín, cierzo, estruendo, manteles o mesa. Además, en sus producciones religiosas se pretende captar los infortunios que estos sufren: martirio, desdicha y zozobra. Respecto a las producciones del dramaturgo manchego, es importante señalar su especial interés hacia la descripción de materiales (plomo, madera, cadena y polvo) y su afán por identificar profesiones (carretero, comisario, galeno y mesonero) y atributos o estados de individuos: casta, preñada, chulo, deidad, gallego y sabio.

\subsubsection{Conclusiones}

Los análisis cuantitativos aplicados a la morfosintaxis, al léxico y a la semántica de las producciones literarias de fray Damián y del maestro León han permitido singularizar sus poemas sacros indubitados y establecer elementos comunes entre estos y los versos profanos y las narraciones de cada autor, demostrando con ello que el cronista seráfico sí que cultivó la lírica divina.

Gracias al uso de biplots, se han podido visualizar las diferencias morfosintácticas que existen entre las poesías religiosas de Cornejo y las de Marchante. Tales rasgos han sido corroborados a través de la obtención de las medias de las principales categorías gramaticales que aparecen en el conjunto de estas, las cuales coinciden en los siguientes casos con las de las poesías profanas. El poeta palentino emplea una mayor cantidad de posesivos y recurre menos a los clíticos, los artículos y las negaciones que el maestro León. Estas dos últimas categorías coinciden con los datos obtenidos en la Crónica seráfica y en el epistolario del dramaturgo manchego.

En el uso de los bigramas, también se han observado similitudes importantes entre los versos religiosos y los humanos de un mismo escritor. El cronista seráfico utiliza con mucha más frecuencia la estructura de un sustantivo más otra categoría (nombre, verbo o adjetivo) y el dramaturgo manchego explota más la combinación de verbos con adjetivos y nombres. El único bigrama que reitera los resultados comentados en la prosa de los autores estudiados es $\mathrm{N}+\mathrm{A}$.

El estudio cuantitativo del léxico ha ofrecido más datos relevantes sobre sus obras. Por un lado, ha puesto en evidencia que los poemas de fray Damián, en especial los profanos, 
contienen más referencias a la primera persona que los de Marchante. Por otro, ha permitido mostrar que las poesías de este último, sobre todo las de temática sacra, poseen una mayor voluntad de conectar emocional y socialmente con el receptor y, por ello, intentan retratar más sentimientos, tanto positivos como negativos. Por último, ha puesto de manifiesto que las creaciones del obispo de Orense, principalmente su poesía humana, albergan una mayor diversidad de vocabulario.

La extracción de las palabras distintivas que aparecen en los poemas divinos estudiados ha ayudado, además, a confirmar los vínculos que existen entre las composiciones en prosa y en verso de cada autor, siendo mucho más elevado el número de estas en los de Cornejo. La semántica de los términos recopilados parece mostrar que las poesías sacras del poeta palentino, al igual que sucede en las profanas, tienden a describir con detalles la fisionomía de los personajes y el entorno y las del dramaturgo manchego manifiestan un interés por identificar materiales, entidades o profesiones.

\subsection{ANÁLISIS DE LA POESÍA SACRA DUBITADA ${ }^{228}$}

Tras delimitar los datos morfosintácticos y léxico-semánticos que caracterizan la poesía sacra indubitada y la prosa de Cornejo y de Marchante e identificar los que los diferencian, se han sometido los poemas divinos dubitados entre ambos a las mismas pruebas que estos. De los veinte nueve existentes, se han seleccionado los que únicamente aparecen en el manuscrito $D$, ya que este es el elegido para hacer la edición de la lírica de fray Damián. Los resultados obtenidos han sido contrastados con los comentados en los apartados previos con el objetivo de poder resolver los problemas de autoría que plantean.

\subsubsection{Metodología aplicada y corpus analizado}

En esta investigación, se ha transcrito y normalizado un corpus de dieciocho poemas religiosos indubitados de fray Damián y del maestro León (nueve de cada poeta) y veinte dubitados $^{229}$. Todos ellos han sido analizados por diversos programas (ContaWords, LIWC, R, SPSS, Treetagger y Voyant Tools) para poder extraer datos relevantes, tanto individuales

\footnotetext{
${ }^{228}$ Gran parte de los datos obtenidos en este apartado han sido publicados en el XLII Anuario de Estudios filológicos (Sánchez, Análisis 247-263).

${ }^{229}$ Trece de las poesías sacras dubitadas que han sido analizadas en esta investigación fueron publicadas en las Obras poéticas de Marchante y tres aparecen atribuidas en manuscritos a él y Cornejo. El número de atribuciones manuscritas a este último es bastante superior "Anexo: 8.3.3.1.".
} 
como de conjunto, sobre su morfosintaxis y su vocabulario. En la codificación de las poesías seleccionadas, se ha utilizado la inicial del apellido de Cornejo y de León ("L" y "C") y las marcas "si" y "d_s" con el propósito de indicar si se trata de composiciones indubitadas o dubitada. Además, en algunas pruebas del estudio morfosintáctico se han incluido seis poesías sacras de Sor Juana Inés de la Cruz "SJ_si”" para probar la fiabilidad de los datos obtenidos. Las referencias de todos los textos analizados se pueden consultar en las tablas del “Anexo: 8.4.3. y 8.4.4.”.

\subsubsection{Análisis morfosintáctico}

El estudio cuantitativo del uso de la morfosintaxis permite distinguir y clasificar con un alto grado de fiabilidad textos, breves y extensos, de diferentes autores. Gracias a la herramienta Treetagger, se ha podido obtener los porcentajes de algunas de las principales categorías gramaticales que aparecen en la poesía sacra (dubitada e indubitada) de fray Damián y del maestro León ${ }^{230}$. A partir de estos, con el programa $\mathrm{R}$, se han generado un análisis de multivariantes que representa las diferencias y las similitudes morfosintácticas que existen entre las diversas poesías analizadas:



Gráfico 10: Biplots de poesía sacra indubitada y dubitada

\footnotetext{
${ }^{230}$ En esta investigación, se han elegido las siguientes variables de análisis: adjetivos (ADJ), adverbios (ADV), artículos (ART), nombres comunes (NC), preposiciones (PREP), cuantificadores (QU), demostrativos (DM), posesivos (PPO), pronombres personales (PPX), clíticos (PPC), marcas de negación (NEG), conjunciones copulativas (CC), conjunciones subordinantes (CSUBX) y conjunción “que” (CQUE).
} 
Aunque ninguno de los tres corpus analizados (L_s, C_s y D_s) constituye un grupo de poesías cohesionado, los datos reflejados en el biplot manifiestan características que los singularizan. Los poemas situados en los cuadrantes izquierdos del gráfico pertenecen a Marchante y presentan un empleo elevado de clíticos "PPC” y artículos “ART”, mientras que los que se hallan en los de la derecha son los dubitados y los indubitados del cronista seráfico y tienden a utilizar más los posesivos y las preposiciones. Resulta significativo señalar que el grueso de las composiciones que integran estos dos últimos grupos se halla en la parte central del gráfico y que los textos que ocupan los extremos (superior e inferior) parecen distanciarse del resto de su conjunto por sus diferencias de extensión ${ }^{231}$. A pesar de ello, todas las poesías disputadas entre ambos autores se hallan más próximas a las creaciones de fray Damián y, por tanto, poseen una mayor similitud morfosintáctica con estas que con las de León.

Para corroborar tales datos, se ha recurrido a otras pruebas de clasificación de individuos o entidades que también se basan en el estudio de multivariantes. Por un lado, se ha realizado (a través del programa SPSS) un análisis de conglomerados “clúster” con el objetivo de determinar el número de grupos que conforman los poemas seleccionados y para comprobar en cuáles de estos se integran cada uno de ellos. Por otro, se ha aplicado un análisis de discriminantes para determinar las categorías gramaticales que más influyen en su agrupación. A continuación, se muestran dos tablas con los porcentajes obtenidos:

Análisis Clúster

\begin{tabular}{|l|r|r|}
\hline \multirow{2}{*}{} & \multicolumn{2}{|c|}{ Clúster } \\
\cline { 2 - 3 } NC & 1 & \multicolumn{1}{|c|}{2} \\
PREP & 18,37 & 18,37 \\
PPC & 1,36 & 11,72 \\
PPO & 10,66 & 2,15 \\
ADV & 1,32 & 2,98 \\
ADJ & 3,69 & 4,57 \\
QU & 7,30 & 6,57 \\
CC & 5,37 & 4,81 \\
CSUBX & 3,12 & 3,21 \\
ART & 2,22 & 2,12 \\
PPX & 9,41 & 6,79 \\
CQUE &, 91 & 2,16 \\
DM & 1,56 & 3,56 \\
NEG &, 54 &, 71 \\
\hline
\end{tabular}

Análisis de discriminatntes

\begin{tabular}{|cl|r|r|}
\hline \multirow{2}{*}{ Cluster Number of Case } & Mean & Std. Deviation \\
\hline \multirow{2}{*}{ 1 León } & PPC & 10,6556 & 2,66651 \\
& PPO & 1,3222 & 1,05211 \\
& PREP & 1,3556 & 1,12373 \\
& ART & 9,4111 & 2,72096 \\
& CQUE & 1,5556 & 2,37913 \\
\hline \multirow{2}{*}{ 2 Cornejo } & PPC & 2,1510 & 1,14977 \\
y & PPO & 2,9845 & 2,05850 \\
& PREP & 11,7241 & 2,02752 \\
& ART & 6,7923 & 2,36483 \\
& CQUE & 3,5567 & 1,42151 \\
\hline
\end{tabular}

Gráfico 20: Análisis clúster y de discriminantes

\footnotetext{
${ }^{231}$ Los poemas que ocupan el cuadrante izquierdo superior presentan (en su mayoría) una extensión más elevada que los situados en la parte inferior. Este dato volvería a poner de manifiesto que los rasgos morfosintácticos pueden verse influenciados por la longitud de los textos.
} 
Las treinta y ocho poesías estudiadas han constituido dos grupos en el análisis de conglomerados. El primero destaca por el uso elevado de clíticos y artículos y está constituido por los poemas indubitados de Marchante. El resto de las composiciones (indubitadas del cronista seráfico y dubitadas) conforman el segundo grupo, donde se aprecia un abundante empleo de preposiciones, posesivos y de subordinadas introducidas por la conjunción "que"232. El análisis de discriminantes muestra que las variables que permiten diferenciar mejor los dos bloques son "PREP", "PPO", "PPC" y "ART". Tras aplicar este sobre los corpus analizados, se ha podido corroborar los datos aportados en el clúster y en el biplot "Anexo: 8.4.".

Con el propósito de continuar probando las semejanzas estilísticas que existen entre las poesías sacras indubitadas de fray Damián y las disputadas con Marchante, se han analizado con el programa ContaWords las combinaciones "bigramas" más recurrentes de nombres, verbos y adjetivos que aparecen en los corpus analizados:



Gráfico 11: Frecuencia de bigramas

El bigrama más frecuente en las poesías indubitadas sacras de Cornejo y de Marchante es la combinación de un adjetivo más un nombre $(\mathrm{A}+\mathrm{N})$ y el menos utilizado es el de dos adjetivos seguidos $(\mathrm{A}+\mathrm{A})$. En estas, el cronista seráfico emplea con mucha más frecuencia la estructura de un sustantivo más un nombre o un verbo y el dramaturgo manchego explota más la de verbos con adjetivos y nombres ${ }^{233}$. Con excepción de la combinación $\mathrm{N}+\mathrm{N}$, los porcentajes de los bigramas que se utilizan en los poemas religiosos dubitados entre ambos se asemejan más a los obtenidos en las poesías de fray Damián.

\footnotetext{
${ }^{232}$ Todos estos datos han sido contrastados con los aportados en el análisis de la poesía profana indubitada de Cornejo y de Marchante (ver "7.4.") y se ha podido concluir que la temática influye en el uso que estos autores hacen de la gramática. En las composiciones humanas, el maestro León emplea abundantemente los sustantivos comunes y los artículos y fray Damián utiliza muchos más adjetivos, adverbios y cuantificadores.

${ }^{233}$ Tales resultados coinciden en su mayoría con los obtenidos en los versos indubitados humanos de ambos autores, pues estos únicamente presentan diferencias en el uso de los bigramas N+V y A+N (ver “4.2.”).
} 


\subsubsection{Análisis léxico-semántico}

Se ha realizado el análisis del léxico y de la semántica de la lírica sacra indubitada y dubitada de Cornejo y Marchante para completar los datos estilísticos aportados en el estudio morfosintáctico y comprobar si existen diferencias significativas en el vocabulario que se emplean en tales corpus. A partir del programa LIWC, se ha indagado en el tipo de emociones (positivas y negativas) que predomina en estos, en su subjetividad, en su contenido social y en su riqueza léxica. Los resultados obtenidos se muestran en la siguiente tabla:

\begin{tabular}{|r|r|r|r|r|r|}
\hline \multicolumn{2}{|c|}{ Self-references } & $\begin{array}{c}\text { Social } \\
\text { Words }\end{array}$ & \multicolumn{1}{c|}{$\begin{array}{c}\text { Positive } \\
\text { emotions }\end{array}$} & \multicolumn{1}{c|}{$\begin{array}{c}\text { Negative } \\
\text { emotions }\end{array}$} & $\begin{array}{l}\text { Type / token } \\
\text { ratio 234 }\end{array}$ \\
\hline C_si & 0.39 & 0.41 & 0.17 & 0.58 & 41.1 \\
\hline L_si & 0,31 & 0,74 & 0.48 & 0.83 & 39.6 \\
\hline & & & & & \\
\hline
\end{tabular}

Tabla 21: Análisis léxico-semántico

Tanto la lírica sacra indubitada de Cornejo como los poemas dubitados dan más relevancia a las autorreferencias que los de Marchante y que en las poesías disputadas estas poseen un porcentaje mayor. Sucede al contrario con las palabras sociales, ya que las composiciones del dramaturgo manchego manifiestan una mayor voluntad de conectar con el receptor que el resto de corpus. Respecto a las emociones es importante mencionar que en ellos predominan los sentimientos negativos, los cuales también son más abundantes en las poesías religiosas de León. El porcentaje de emociones positivas que trasmiten estas últimas es muy parecido al de los textos de autoría disputada ${ }^{235}$. Si se observa la riqueza léxica, las

\footnotetext{
${ }^{234}$ Como la extensión de los corpus analizados influye en la obtención del porcentaje de riqueza léxica, se han equiparado su longitud (2150 palabras). Esta se corresponde la cantidad que posee el corpus más breve: poesía sacra indubitada de Cornejo.

235 Todas las diferencias observadas sobre el léxico y la semántica en las poesías sacras de fray Damián y de Marchante coinciden con las obtenidas en la lírica profana indubitada de ambos (ver “4.2.”).
} 
obras del obispo de Orense y las del Marchante poseen una diversidad de vocabulario similar a la de las dubitadas.

Se ha procedido también a recopilar las palabras distintivas que aparecen en los corpus de lírica indubitada (sacra y profana) y de prosa de ambos escritores para comprobar la presencia que estas tienen en cada uno de los poemas dubitados ${ }^{236}$. Los resultados se han recogido en tres tablas ${ }^{237}$. En las dos primeras, aparecen los textos que se publicaron en las Obras poéticas de León y, en la última, los que se atribuyen a ambos en manuscritos:

\begin{tabular}{|c|c|c|c|c|c|c|c|}
\hline D_s2 & D_s3 & D_s5 & D_s6 & D_s8 & D_s10 & D_s13 & D_s16 \\
\hline \multicolumn{8}{|c|}{ Palabras distintivas de Marchante } \\
\hline Encomiendas & Amarillo & Risa & Lado & Médico & Egipto & Arca & Arca \\
\hline \multirow[t]{5}{*}{ Montañés } & Cadena & Zarza & & & Gitano & Cascarón & Caña \\
\hline & Desierto & & & & Inclusa & Casta & Gritos \\
\hline & Danzar & & & & Labrador & Portátil & Lado \\
\hline & Jaque & & & & Tostado & & Sabio \\
\hline & Recoleto & & & & & & \\
\hline \multicolumn{8}{|c|}{ Palabras distintivas de Cornejo } \\
\hline Desnudez & Entero & Luzbel & Costado & Bulto & Bondad & Contenta & Ejecutar \\
\hline Oblea & Momento & Profundo & Penitente & Postrada & Equidad & Copete & Guardián \\
\hline Puño & Regalo & Torpeza & Quebrado & Quebrado & Marzo & Flaca & Guardado \\
\hline Querellas & Reverencia & & & & Pañal & Grana & Huraño \\
\hline Túnica & Tragedia & & & & Saludador & Milagros & Mañas \\
\hline \multirow[t]{5}{*}{ Yermo } & Travieso & & & & Soledad & Pobrete & Mil \\
\hline & Quizá & & & & & Profundo & Testigos \\
\hline & Vellón & & & & & Recogida & \\
\hline & & & & & & Vedar & \\
\hline & & & & & & Vale & \\
\hline
\end{tabular}

Tabla 22: Palabras distintivas (I)

En todas las poesías se aprecia una mayor presencia de término distintivos de Cornejo. No obstante, en algunas como D_s8 o D_s5 el número de palabras que solo

${ }^{236}$ Las flexiones de género y número de los términos seleccionados se han considerado palabras distintivas.

${ }^{237}$ Los vocablos que se hallan en más de un poema dubitado se han marcado en cursiva. 
aparecen en los corpus de Marchante es bastante similar. Sucede lo contrario con D_s2 y D_s13. En esta última composición, dedicada a santa Clara, resulta relevante la cantidad de léxico distintivo del cronista seráfico que posee, pues tal hecho (junto a los datos aportados en el análisis gramatical) ayudaría a refutar la teoría de Antonio Carreira (La obra 47) que defiende que el maestro León podría ser el autor de esta ${ }^{238}$.

Respecto a la semántica de las palabras extraídas, cabe señalar que pueden observarse en ellas algunos patrones. Marchante parece mostrar una tendencia a incluir profesiones (médico, labrador o recoleto) y atributos o estados de individuos (sabio y montañés), mientras que Cornejo tiende a describir rasgos relacionados con la psicología (travieso, huraño, pobrete o contenta) o con la apariencia externa (yermo, entero, profundo o desnudez). Tales características y la preeminencia de vocabulario distintivo de fray Damián se mantienen en el resto de textos analizados:

\begin{tabular}{|l|c|c|c|l|l|l|l|}
\hline D_s7 & D_s9 & D_s12 & D_sl4 & D_sl7 D_s18 & D_s22 & D_s23 \\
\hline \multicolumn{7}{|c|}{ Palabras distintivas de Marchante } & Alivio \\
\hline & Limpieza & Cuemo & Festejar & Borrones & & & Lucimiento \\
\hline & Vicario & Luna & Iracundo & Golosina & & & Omisión \\
\hline & & & & Guerra & & & Trofeos \\
\hline & & & & Veneno & & & \\
\hline & & & & & & & Apetito \\
\hline Cerrado & Bola & Gloriosa & Animo & Admiración & Arrojar & Garra & \\
\hline Oscurecer & Cordel & Manzana & Codicia & Culebra & Cordel & Grano & Conocimiento \\
\hline Pensil & Extraordinario & Original & Dragón & Dragón & Codicia & Ponderación & Desfigurado \\
\hline Sello & Particular & Querella & Fiereza & Luzbel & & Postrada & Inútil \\
\hline Serpiente & Pureza & Sano & Sierpe & Sierpe & & Reverencia & Misericordia \\
\hline & Virginal & Trueca & Torpeza & Serpiente & & Ruin & Mísero \\
\hline & & & & Quebradero & & Siquiera & Obstinado \\
\hline & & & & & & Tajada & \\
\hline & & & & & & Ufano & \\
\hline
\end{tabular}

Tabla 23: Palabras distintivas (II)

\footnotetext{
238 Antonio Carreira (La obra 47-48) sostiene que en las Obras poéticas de Marchante hay varios poemas indubitados dedicados a santa Clara en los que se pone en entredicho su castidad con juegos de palabras similares a los empleados en D_s13.
} 
En las poesías dedicadas a la Inmaculada Concepción (D_s7, D_s9, D_s12, D_s14 y D_s17) y en D_s18 y D_s22, la presencia de palabras distintivas de fray Damián es elevada y las del dramaturgo manchego casi nula. No ocurre lo mismo con D_s23, aunque en este poema sigue siendo superior el número de términos que Cornejo no comparte con Marchante. Es importante señalar que las composiciones que defienden la pureza de la Virgen se reitera léxico distintivo del cronista seráfico: codicia, cordel, dragón, serpiente y sierpe. Algunos de estos vocablos aparecen también en los poemas este sobre mismo tema que no fueron publicados en las Obras poéticas de León:

\begin{tabular}{|c|c|c|c|}
\hline D_s24 & D_s25 & D_s26 & D_s27 \\
\hline \multicolumn{4}{|c|}{ Palabras distintivas de Marchante } \\
\hline Vasallo & & & Cresta \\
\hline \multirow[t]{2}{*}{ Ventana } & & & \\
\hline & \multicolumn{3}{|c|}{ Palabras distintivas de Cornejo } \\
\hline Abrigo & Confianza & Cristalino & Abrasada \\
\hline \multirow[t]{9}{*}{ Desposar } & Temeridad & Dragón & Aclamaciones \\
\hline & Puriedad & Escollo & Atocha \\
\hline & & Edificio & Fervorosa \\
\hline & & Esplendor & Mil \\
\hline & & Gigante & \\
\hline & & Montero & \\
\hline & & Pureza & \\
\hline & & Sierpe & \\
\hline & & Soberbio & \\
\hline
\end{tabular}

Tabla 24: Palabras distintas de Cornejo y Marchante

Para reforzar los datos que indican que los textos analizados fueron escritos por la misma mano, se ha extraído el vocabulario que estos comparten entre sí. Con el objetivo de representar los resultados de forma clara y concisa, se han creado dos visualizaciones: la primera alberga los poemas que defiende la ausencia de pecado en la madre de Dios y la 
segunda contiene los relacionados con santos. En las creaciones vinculadas a la Purísima Concepción, se ha incluido (mediante esferas) los términos que aparecen en la poesía indubitada de fray Damián que trata esta temática (C_si7) ${ }^{239}$ para ver cuántos y cuáles comparten con esta y también para comprobar las relaciones léxicas que se establecen entre ellas $^{240}$ :



Ilustración 3: Poemas dubitados sobre la Purísima Concepción

Todos los poemas analizados comparten diversas palabras (no funcionales) con C_si7 y entre ellos ${ }^{241}$, aunque sobresalen D_s9, D_s14 y D_s17. Estos, además, son los que presentan más vocabulario en común con el resto, sobre todo, con D_s7, D_s24 y D_s26. Resulta significativo señalar que existen varios términos distintivos que se reiteran en más de la mitad de las composiciones estudiadas (D_s12, D_s14, D_s17 y D_s $24^{242}$ y D_s26) y

239 Las palabras no funcionales que comparten C_si7 con los poemas dubitados que tratan el tema de la Purísima Concepción son las siguientes: devotos, gracia, fuerza, justicia, nunca, pureza, siempre, soberano y tierra.

${ }^{240}$ Se han cotejado también el vocabulario del soneto de temática mariana (D_s27) y se ha concluido que comparte varios términos distintivos de Cornejo (marcados con asterisco) tanto con el resto de textos sacros dubitados que hablan sobre la Inmaculada como con los que tratan de vidas de santos.

${ }^{241}$ El léxico que más se reiteran en las poesías seleccionadas es el siguiente: gracia, hermosura, pura y hombre. ${ }^{242}$ Resulta significativo que en la composición D_s24 comparta tanto léxico con el resto de dubitados, ya que (como se ha dicho en el apartado "3.2.2.") esta también se atribuye a Francisco de Valdés (o Vallés). La 
que estos pertenecen a Cornejo: dragón, gigante, pureza, puriedad y sierpe. Sucede lo mismo con las poesías que tratan sobre hagiografías, pero estas contienen una menor cantidad tanto vocabulario distintivo como de léxico no funcional que se repite:



Ilustración 4: Poemas dubitados sobre santos

Los poemas que comparten más vocablos (a pesar de no hacer alusión a la misma divinidad) son D_s3 y D_s16. Esta última composición y D_s6 también presentan múltiples palabras en común. Llama la atención la relevancia que se le da en estas poesías al físico, pues en todas ellas hallamos una referencia a este: dedo, cuerpo, garganta, mano, manos, pie, piel y pies. En relación con los términos distintivos que contienen (profundo y quebrado) cabe señalar que alguno de ellos está presente en la mitad de las obras seleccionadas (D_s5, D_s6, D_s8 y D_s13). Resulta llamativo, además, que D_s3 y D_s16 presenten los adverbios "nunca" y "siempre", los cuales se encuentran en diversos poemas sobre la Purísima Concepción ${ }^{243}$

\subsubsection{Análisis métrico}

presencia de vocabulario compartido y distintivo y las semejanzas morfosintácticas que manifiesta con el resto de poesías analizadas serías indicios para descartar la posibilidad de que este último fuera su autor.

${ }^{243}$ Otros vocablos que también comparten los poemas dubitados de tema mariano con los hagiográficos son los relacionados con el físico (cabeza, manos y pies) y verbos como "cantar" o "comer". 
Con el propósito de seguir estableciendo diferencias y semejanzas entre los tres corpus de poesía sacra analizada, se ha procedido a delimitar las formas métricas que se utilizan en ellos. Para garantizar una mayor precisión en los datos de la lírica de León, se ha recurrido a los porcentajes extraídos de los poemas divinos indubitados del primer volumen de las Obras poéticas de León. Los resultados obtenidos se han representado a través del siguiente gráfico:



Gráfico 12: Análisis métrico

En los tres tipos de metros analizados, se observa una mayor similitud entre los veinte poemas dubitados y los indubitados de fray Damián. La proporción de romances y de coplas es casi idéntica en ambos y la de quintillas solo difiere un $10 \%$. Tales datos ayudarían a corroborar las pruebas presentadas anteriormente que atribuían al poeta palentino todas las poesías sacras disputadas con Marchante que se hallan en el manuscrito $D$.

\subsubsection{Conclusiones}

Gracias a los análisis de multivariantes, se ha podido visualizar las semejanzas en el uso de la gramática que existen entre las poesías divinas atribuidas exclusivamente a fray Damián y las dubitadas con el dramaturgo manchego. Además, estos han permitido obtener las medias de las principales categorías morfosintácticas que en ellas aparecen e identificar las que permiten diferenciarlas de las composiciones del maestro León: artículos, preposiciones, clíticos y posesivos. En el empleo de los bigramas gramaticales, también se han observado similitudes importantes entre los versos religiosos indubitados de Cornejo y los dubitados con Marchante, pues en ellos se aprecia un mayor interés por utilizar las combinaciones de un nombre, un adjetivo o un verbo con otro verbo. 
El análisis cuantitativo del léxico y de la semántica ha ofrecido más datos relevantes sobre las características de los textos estudiados. Por un lado, ha puesto en evidencia que tanto los poemas divinos (dubitados e indubitados) de fray Damián contienen una mayor riqueza léxica y más referencias a la primera persona que los del dramaturgo manchego. Por otro, ha permitido mostrar que las poesías sacras indubitadas de este último poseen una mayor voluntad de conectar con el receptor y que retratan más sentimientos negativos que el resto de corpus analizados. Además, la extracción de las palabras distintivas ha puesto de manifiesto que comparten un mayor número de estas los poemas sacros disputados entre ambos con las obras en prosa y en verso (profano y divino) del cronista seráfico. Por último, el estudio de la métrica de las composiciones dubitadas también ha corroborado que existe entre estas y los versos de temática religiosa que únicamente se firman con el nombre de fray Damián grandes semejanzas.

Tras valorar todos los datos gramaticales, léxicos y métricos obtenidos, se puede concluir que las poesías dubitadas que se han analizado poseen más semejanzas estilísticas con las obras escritas por Cornejo. No obstante, la similitud temática con las producciones divinas de Marchante y el hecho de que pudieron difundirse entre los mismos círculos propiciaron que se acabaran publicando poco después de sus muertes con el nombre de este último, que era un poeta consagrado. Tal suceso no sería un caso aislado, ya que como afirma Antonio Carreira en el periodo aurisecular se producía una especie de gravitación con las composiciones líricas disputadas entre dos autores "el ingenio de mayor renombre en su tiempo es quien las atrae. Por ello, la norma filológica ha llegado a la conclusión de que cuando un poema se atribuye a dos ingenios, uno famoso y otro desconocido, este será el autor más probable (La obra 45).

\subsection{CONCLUSIONES SOBRE LOS ESTUDIOS CUANTITATIVOS REALIZADOS}

Los avances que se están llevando a término en el procesamiento de lenguaje natural (PNL) y en el análisis masivo de textos permiten desarrollar estudios de corpus poéticos más complejos y fiables. Estos ayudan a distinguir, mediante datos objetivos, incluso las creaciones de escritores con un estilo, una formación y un contenido similar. Para ello, es imprescindible contar con un conjunto de obras indubitadas de los autores que se pretenden estudiar. Cuanto mayor sea el número de palabras que poseen las composiciones que lo integran, mayor fiabilidad tendrán los resultados obtenidos. Maciej Eder (Short 341-342) 
recomienda que estas contengan más de dos mil, aunque advierte que las producciones seleccionadas deben manifestar huellas que singularicen con claridad el estilo de su creador. Solo así podrán diferenciarse de las de otros y manifestar características similares con las surgidas de la misma mano.

La brevedad que suele caracterizar a la poesía condiciona las pruebas que se pueden aplicar para su correcta atribución. Si se trabaja con poemas muy breves o de distinta longitud y si se mezclan obras de diverso género o temática (sacra o profana) para contrastar los datos, no es recomendable emplear procedimientos basados en las frecuencias de las palabras más recurrentes. Estas suelen verse muy limitadas por la extensión y, por tanto, es aconsejable analizar y contrastar otros parámetros que dependan menos de ella ${ }^{244}$ : análisis de multivariantes basados en porcentajes morfosintácticos, estudios de combinaciones de gramaticales "bigramas" y la extracción automática de rasgos léxico-semánticos y métricos.

Después de haber sometido los corpus de poesía y de prosa indubitada de dos autores hispanos del Bajo Barroco (fray Damián Cornejo y Manuel de León Marchante) a los análisis mencionados, se ha podido demostrar que existen diferencias estilísticas cuantificables entre ambos. Estas caracterizan objetivamente sus obras y ayudan a resolver los problemas de autoría que plantean. Las mayores semejanzas gramaticales, semánticas y léxicas en las producciones de cada escritor se han dado en las poesías profanas más extensas, aunque también se han podido delimitar rasgos comunes en el resto de sus creaciones en verso y entre estas y su prosa.

En la siguiente tabla, se recogen los rasgos distintivos de las obras analizadas de fray Damián (morfosintácticos, semánticos, léxicos y métricos) respecto a las del dramaturgo manchego, los cuales han sido clasificados según su género y su temática (divina o humana). Para ofrecer una visión más precisa de los resultados, se han incorporado los signos de comparación “<” y ">”. Estos especifican si el cronista palentino emplea los parámetros analizados con más frecuencia o menos que Marchante:

\footnotetext{
${ }^{244}$ Las diversas pruebas de frecuencias de las palabras más recurrentes y de análisis de multivariantes morfosintácticas a las que se han sometido los corpus indubitados seleccionados (Cornejo, León y Sor Juana) han puesto de manifiesto que la longitud de los textos (en prosa y en verso) influye significativamente en las relaciones de semejanza y divergencia que se establecen entre ellos. No obstante, se han obtenido datos más fiables y precisos en su clasificación automática al aplicar los segundos, pues en todos los casos se han atribuido correctamente a su respectivo autor.
} 


\begin{tabular}{|c|c|c|c|}
\hline \multirow{2}{*}{$\begin{array}{l}\text { Damián } \\
\text { Cornejo }\end{array}$} & \multicolumn{3}{|c|}{ Características distintivas con Marchante } \\
\hline & Poemas sacros & Poemas profanos & Prosa \\
\hline \multirow{3}{*}{ Morfología } & $<\mathrm{NC}$ y PREP & \multicolumn{2}{|c|}{$<\mathrm{ADJ}$ y ADV } \\
\hline & \multicolumn{2}{|l|}{$\begin{array}{l}>\mathrm{PPC} \\
<\mathrm{PPO}\end{array}$} & \\
\hline & \multicolumn{2}{|l|}{$\begin{array}{l}>\text { ART } \\
>\text { NEG }\end{array}$} & \\
\hline \multirow[b]{2}{*}{ Sintaxis } & \multicolumn{2}{|l|}{$<\mathrm{CC}$} & $>\mathrm{CC}$ \\
\hline & \multicolumn{2}{|l|}{$\begin{array}{l}<\text { CQUE } \\
>\text { CSUBX }\end{array}$} & \\
\hline Bigramas & \multicolumn{2}{|l|}{$\begin{array}{l}<\mathrm{N}+\mathrm{A}, \mathrm{N}+\mathrm{N} \text { y } \mathrm{V}+\mathrm{V} \\
>\mathrm{A}+\mathrm{A}, \mathrm{V}+\mathrm{A} \text { y } \mathrm{V}+\mathrm{N}\end{array}$} & $<\mathrm{N}+\mathrm{A}$ \\
\hline \multirow{3}{*}{$\begin{array}{l}\text { Semántica } \\
\text { Riqueza } \\
\text { Léxica }^{245}\end{array}$} & \multicolumn{2}{|c|}{$\begin{array}{l}\text { Autorreferencias } \\
>\text { Emociones negativas y positivas }\end{array}$} & $\begin{array}{l}>\text { Autorreferencias } \\
<\text { Emociones negativas } \\
\text { y positivas }\end{array}$ \\
\hline & \multicolumn{3}{|c|}{ > Palabras sociales } \\
\hline & \multicolumn{3}{|c|}{$\begin{array}{l}\text { La proporción de type-token ratio en todos los corpus analizados es superior a } \\
\text { la de Marchante: prosa (3.1), poemas profanos }(0.9) \text {, poesías sacras }(0.5) \text {. }\end{array}$} \\
\hline $\begin{array}{l}\text { Léxico } \\
\text { distintivo }\end{array}$ & \multicolumn{3}{|c|}{$\begin{array}{l}\text { Interés por detallar la psicología y el físico de los personajes y el entorno, } \\
\text { mientras que León opta por la descripción de materiales identificar profesiones } \\
\text { y atributos o estados de individuos. }\end{array}$} \\
\hline Métrica & $\begin{array}{l}<\text { Quintilla y romance } \\
>\text { Copla y endecha }\end{array}$ & $\begin{array}{l}<\text { Romance y sonet } \\
>\text { Décima y redondi }\end{array}$ & \\
\hline
\end{tabular}

Tabla 25: Características distintivas de las obras de Cornejo respecto a las de León

Las obras indubitadas que se han analizado de fray Damián poseen un porcentaje mayor de posesivos y de conjunciones subordinadas introducidas por "que" y una menor proporción del resto de nexos subordinantes, de artículos, clíticos y negaciones que las de Marchante. No obstante, en el uso de la morfosintaxis se observan algunas divergencias relevantes entre la lírica profana y la sacra que se atribuye exclusivamente al poeta palentino y entre estas y su narración. Sus poemas de temática religiosa emplean más sustantivos y preposiciones que los del maestro León, mientras que los de contenido humano (como sucede con los fragmentos analizados de la Crónica Seráfica) recurren más a adjetivos y adverbios. Resulta relevante mencionar que la frecuencia de conjunciones coordinadas en Cornejo es más alta en sus composiciones en verso que en su prosa.

Si prestamos atención a los bigramas, él único que muestra porcentajes superiores en

\footnotetext{
${ }^{245}$ Los porcentajes de riqueza léxica provienen del apartado "4.4.3.”.
} 
todas las obras analizadas del obispo de Orense (respecto a los obtenidos en los corpus del dramaturgo manchego) es la combinación de un nombre y un adjetivo. Las poesías profanas y sacras de fray Damián comparten, además, un mayor uso de $\mathrm{N}+\mathrm{N}$ y $\mathrm{V}+\mathrm{V}$ y un menor empleo de $\mathrm{A}+\mathrm{A}, \mathrm{V}+\mathrm{A}$ y $\mathrm{V}+\mathrm{N}$ que los poemas de León.

También se manifiestan características comunes y diferentes en el análisis semántico entre su prosa y su obra poética. La alta proporción de autorreferencias que presentan los poemas (sacros y profanos) de Cornejo disminuye bastante en la narración que hace de la vida de santa Rosa, pero en ambos corpus se utilizan menos palabras sociales que en las creaciones de Marchante. Este último no solo manifiesta en sus versos un mayor interés en hacer partícipe al público que los poemas analizados del obispo de Orense, sino que recurre con más frecuencia a emociones positivas y negativas para intentar conmoverlo con más fuerza. Tal estrategia es utilizada en los fragmentos extraídos de la Crónica Seráfica.

En cuanto al léxico, es importante destacar la mayor riqueza de vocabulario que manifiestan todas las obras analizadas de fray Damián (sobre todo su prosa) respecto a las de León. Tal dato podría ser consecuencia de los amplios conocimientos que poseía el cronista seráfico por su alta formación y por los destacados cargos que desempeñó. Además, llama la atención las diferencias en el tipo de palabras distintivas que poseen las producciones de ambos autores. El poeta palentino muestra un especial interés por retratar la psicología y el físico de los personajes y el entorno y el dramaturgo manchego pone más su foco en identificar materiales, profesiones y atributos o estados de individuos.

Por último, se observan diferencias significativas en la elección que hacen de los metros los escritores estudiados. Cornejo en sus poemas sacros opta más por la quintilla y el romance y Marchante por la copla y la endecha. En las poesías humanas del cronista seráfico, se mantiene su tendencia de recurrir más al romance e incorpora un alto porcentaje de sonetos, mientras que León tiende a elegir décimas y redondillas.

Gran parte de los datos comentados previamente sobre las producciones indubitadas de fray Damián coinciden con los de las poesías dubitadas que se atribuyen a él en los análisis de clasificación, manifestando así una huella de autor común entre ellas. Pero también existen algunas divergencias, sobre todo en los versos humanos disputados, que deben ser mencionadas. Por ello, se ha configurado una tabla donde se sintetizan los resultados obtenidos en los poemas (sacros y profanos) que se atribuyen en los estudios cuantitativos al cronista seráfico y se contrastan con los que se asocian en estos al dramaturgo manchego. 
Cabe señalar que, al no haberse vinculado ninguna poesía sacra dubitada a este último, las características mostradas en dicho apartado son las de las composiciones de temática religiosa que únicamente se firman con su nombre. Los rasgos que se reiteran entre los poemas sacros y profanos que se atribuyen a un mismo escritor se han marcado en cursiva y los que coinciden con los indubitados de cada uno en negrita:

\begin{tabular}{|c|c|c|c|c|}
\hline \multirow[b]{2}{*}{$\begin{array}{l}\text { Análisis de } \\
\text { clasificación }\end{array}$} & \multicolumn{3}{|c|}{ Características de los poemas dubitados } & \multirow[b]{2}{*}{$\begin{array}{c}\text { Profanos } \\
\text { atribuidos a } \\
\text { Marchante }\end{array}$} \\
\hline & $\begin{array}{c}\text { Sacros } \\
\text { atribuidos a } \\
\text { Cornejo }\end{array}$ & $\begin{array}{l}\text { Sacros } \\
\text { indubitados de } \\
\text { Marchante }\end{array}$ & $\begin{array}{l}\text { Profanos } \\
\text { atribuidos a } \\
\text { Cornejo }\end{array}$ & \\
\hline Morfología & < PPO y PREP & $<A R T$ y $\mathrm{PPC}$ & $<$ ADV y PPX ${ }^{246}$ & $<A R T$ y $\mathrm{NC}$ \\
\hline Sintaxis & $<C Q U E$ & $<$ CSUBX & $\begin{array}{l}<\text { CSUBX } \\
<\text { CQUE }\end{array}$ & $<\mathrm{CC}$ \\
\hline Bigramas & $\begin{array}{l}<\mathrm{N}+\mathrm{A}, N+N \\
\mathrm{~N}+\mathrm{V}, \mathrm{V}+\mathrm{V}\end{array}$ & $\begin{array}{l}<A+A, V+A \\
\mathrm{~V}+\mathrm{N}\end{array}$ & $<N+N$ & $<A+A, V+A$ \\
\hline Semántica & $\begin{array}{l}\text { <Autorreferen- } \\
\text { cias } \\
<\text { Emociones } \\
\text { positivas }\end{array}$ & $\begin{array}{l}<\text { Palabras } \\
\text { sociales } \\
<\text { Emociones } \\
\text { negativas }\end{array}$ & $\begin{array}{l}<\text { Autorreferen- } \\
\text { cias } \\
>\text { Emociones } \\
\text { negativas y } \\
\text { positivas }\end{array}$ & $\begin{array}{l}<\text { Palabras } \\
\text { sociales } \\
<\text { Emociones } \\
\text { negativas } \mathbf{y} \\
\text { positivas }\end{array}$ \\
\hline $\begin{array}{l}\text { Riqueza } \\
\text { Léxica }^{247}\end{array}$ & \multicolumn{2}{|c|}{$\begin{array}{l}\text { Los atribuidos a Cornejo superan en } \\
0.7 \text { a los atribuidos a León }\end{array}$} & \multicolumn{2}{|c|}{$\begin{array}{l}\text { Los atribuidos a Cornejo superan } \\
\text { en } 1.2 \text { a los atribuidos a León }\end{array}$} \\
\hline $\begin{array}{l}\text { Léxico } \\
\text { distintivo }\end{array}$ & $\begin{array}{l}\text { Hace hincapié en } \\
\text { el físico y la } \\
\text { psicología de las } \\
\text { entidades sacras }\end{array}$ & $\begin{array}{l}\text { Incide en la } \\
\text { identificación de } \\
\text { materiales, } \\
\text { profesiones, } \\
\text { atributos o } \\
\text { estados de } \\
\text { individuos. }\end{array}$ & $\begin{array}{l}\text { Muestra interés } \\
\text { en el mundo del } \\
\text { arte y del juego. }\end{array}$ & $\begin{array}{l}\text { Insiste en la } \\
\text { descripción de } \\
\text { atributos o de } \\
\text { estados de } \\
\text { individuos }\end{array}$ \\
\hline Métrica & $\begin{array}{l}<\text { Quintilla y } \\
\text { romance }\end{array}$ & $\begin{array}{l}<\text { Copla y } \\
\text { endecha }\end{array}$ & $\begin{array}{l}<\text { Soneto, copla } \\
\text { y redondilla }\end{array}$ & $\begin{array}{l}<\text { Décima y } \\
\text { quintilla }\end{array}$ \\
\hline
\end{tabular}

Tabla 26: Características distintivas de los poemas dubitados

Los resultados obtenidos en las poesías dubitadas profanas atribuidas a Cornejo en los análisis de clasificación muestran menos rasgos similares con la lírica indubitada del cronista palentino que los poemas sacros que se vinculan a él en estos. Las mayores

246 También se aprecia un mayor uso de posesivos en los poemas profanos dubitados que se asocian a Cornejo en los estudios de clasificación que en los que se atribuyen en estos a León. Tal característica es compartida con las poesías sacras analizadas que se disputan entre ambos.

${ }^{247}$ Los porcentajes de poemas sacros provienen del apartado "4.5.3.” y los de las poesías profanas del "4.3.3.”. 
divergencias que presentan respecto al resto de versos que se firman exclusivamente con su nombre y a los que se vinculan a él en las pruebas realizadas se hallan en el uso de bigramas y en la métrica ${ }^{248}$. Ocurre lo contrario con las poesías disputadas de temática sacra atribuidas a fray Damián, pues estas emplean casi las mismas combinaciones gramaticales y frecuencias de quintillas y romances que los indubitados religiosos del poeta palentino. Pero todos ellos comparten las siguientes características al contrastarlos con la lírica asociada a León: un mayor uso del nexo subordinante "que" y de la combinación de dos sustantivos seguidos, utilizan más autorreferencias y menos palabras sociales y poseen una mayor diversidad de vocabulario.

Si comparamos tales datos con los de las poesías indubitadas (sacras y humanas) del dramaturgo manchego y las dubitadas profanas que los estudios cuantitativos realizados asignan a él, puede concluirse que existen más semejanzas entre estas que entre los corpus comentados en el párrafo anterior. En todas, la proporción de artículos y de los bigramas $\mathrm{A}+\mathrm{A}$ y $\mathrm{V}+\mathrm{A}$ es superior que en los poemas indubitados de Cornejo y en los atribuidos a él en los análisis de clasificación, así como también el porcentaje de emociones negativas y de palabras sociales. Tal como se ha comentado previamente, parece haber una tendencia en los versos de Marchante de intentar hacer partícipe al público en ellos y de conmoverlo. Además, es importante señalar que se establecen grandes semejanzas en el tipo de léxico distintivo que contienen los poemas sacros y profanos asociados a León. Como sucedía en sus indubitados, los vocablos extraídos describen atributos o estados de individuos.

Los parámetros extraídos en los diversos análisis cuantitativos de la lírica y la prosa de los escritores seleccionados manifiestan rasgos objetivos que permiten no solo establecer semejanzas morfosintácticas, gramaticales, semánticas y léxicas entre los textos de autoría segura y los que se les atribuyen en las pruebas de clasificación, sino también delimitar las huellas estilísticas que diferencian sus creaciones. No obstante, es necesario que los programas que permiten realizar este tipo de pruebas se perfeccionen y que sean más accesibles para los filólogos. Solo así se podrá fomentar y mejorar el desarrollo de investigaciones de corpus poéticos relacionadas con la estilometría.

\footnotetext{
${ }^{248}$ La única combinación gramatical que aporta resultados similares en los poemas profanos dubitados que se atribuyen en los estudios de clasificación a Cornejo y en sus indubitados al contrastarlos con los resultados de Marchante es la de N+N. Lo mismo sucede con el uso de la métrica. Solamente los sonetos poseen una frecuencia más elevada en tales corpus que en las poesías asociadas al maestro León.
} 


\section{EDICIÓN CRÍTICA DEL MANUSCRITO “2245” DE LA BNE}

\subsection{INTRODUCCIÓN}

\subsubsection{Presentación de la edición}

El deseo de reivindicar cómo se intentó plasmar en el Bajo Barroco una nueva concepción de la lírica nos ha llevado a rescatar del casi total olvido los ingeniosos versos de fray Damián Cornejo. La exhaustiva labor de investigación que inició Klaus Pörtl, en 1978, con el propósito de realizar una edición crítica de estos ha sido el punto de partida para continuar con su recopilación, análisis y difusión. Las creaciones del cronista palentino no solo son un fiel testigo del diálogo que intentaron establecer los poetas de este periodo entre tradición e innovación, también muestran (por los múltiples problemas de autoría que plantean) la compleja realidad histórica de la transmisión de la poesía aurisecular.

En la presente edición crítica, se ha intentado ofrecer una visión más completa y fidedigna de su producción lírica que la aportada por el investigador alemán ${ }^{249}$. Se ha incrementado considerablemente el número de textos publicados (más del doble) y editado múltiples indubitados que permanecían inéditos ${ }^{250}$. Además, se han consultado otras fuentes primarias para el cotejo he indicado los poemas que se consideran dubitados ${ }^{251} \mathrm{o}$ apócrifos. Por último, se ha procurado enmendar los errores del manuscrito base mediante las variantes de otros testimonios (enmmedatio ope codicum y enmeditio ope ingenii) ${ }^{252}$ e incorporado versos de estos cuando el contenido de una poesía lo requería. Los textos resultantes, en nuestra humilde opinión, ofrecen "la que parece mejor entre todas las soluciones posibles" (Carreira, Introducción 30).

\footnotetext{
${ }^{249}$ Los problemas que plantea la edición que realizó Klaus Pörtl de la poesía del cronista palentino pueden consultarse en el "Anexo: 8.5.".

${ }^{250}$ Se han editado diecinueve poemas profanos indubitados y dos dubitados (uno de temática sacra y otro de humana) que no habían sido publicados hasta la fecha.

${ }^{251}$ Se han marcado los textos dubitados con una almohadilla “\#” y con dos “\#\#” los disputados con León que, según los estudios de autoría realizados, podrían haber sido compuestos por fray Damián.

${ }^{252}$ Para realizar las enmiendas, siempre se ha tenido en cuenta "el estilo del autor (usus scribendi), la métrica (res metrica), la estructura y contexto (conformatio textus) y la lectio facilior" (Blecua, Estudios 28).
} 


\subsubsection{Fuentes manuscritas}

\subsubsection{Análisis de los manuscritos integri}

La ausencia de autógrafos y de testimonios que fueran revisados por fray Damián, el hecho de que no publicara en vida sus versos y los múltiples problemas de autoría que presentan plantean importantes dificultades a la hora de enfrentarse al estudio de sus múltiples manuscritos integri conservados. La mayoría de ellos fueron creados en un marco temporal próximo (entre finales del siglo XVII y el primer tercio del siguiente) y poseen relevantes diferencias en su contenido. Además, los poemas que las integran manifiestan una gran contaminación textual en las variantes y enmiendas. Todo ello, unido a la probable existencia de testimonios anteriores e intermedios que no nos han llegado, hace que cualquier intento de fijar un stemma parezca "condenado al fracaso" (Carreira, Introducción 24).

Ante este panorama, nos limitaremos a establecer familias, a señalar una cronología aproximada y a determinar objetivamente cuál puede ser el poemario conservado más completo y fiable para realizar una edición crítica de la poesía de este ingenioso obispo ${ }^{253}$. Con tal propósito, se ha analizado el contenido y la caligrafía de los manuscritos integri que la recogen. En el siguiente gráfico, se ofrece la cantidad de poesías atribuidas a fray Damián que alberga cada uno de ellos ${ }^{254}$ :



Gráfico 13: Número de poemas atribuidos a Cornejo

\footnotetext{
${ }^{253}$ El llamado manuscrito de "Manuel Benito" no ha podido ser cotejado con el resto de testimonios, ya que es propiedad de un particular. Este es descrito brevemente por Antonio Carreira (La obra 43).

${ }^{254}$ Las referencias asignadas a cada manuscrito son las siguientes: $A$ ("E-39 6654" de la BRAE), $B$ ("Egerton 1889 " de la BL), $D$ ("2245" de la BNE), $H$ ("3931" de la BNE), $M$ ("406" de la BFBM), $N$ ("5566" de la BNE), $\tilde{N}$ ("4258" de la BNE), $Q$ ("4135" de la BNE), $R$ ("410" de la BRCR) y $S$ ("156" de la BMP). En el "Anexo: 8.3.1.", se puede consultar la tabla que recoge todos los manuscritos que recopilan la poesía de Cornejo. Su catalogación se halla en el "Anexo: 8.1.” y su indexación en el "Anexo: 8.2.”.
} 
El testimonio que incluye más composiciones es $R$. Sus ciento noventa y siete poesías hacen que se establezca una distancia significativa (casi un $25 \%$ ) con los otros dos manuscritos más largos $N$ y $S$. Tal diferencia se debe a la cantidad de poemas repetidos, apócrifos y de dudosa atribución que alberga ${ }^{255}$. Tras estos, se hallan $B, D$ y $\tilde{N}$ con cerca de ciento treinta y $A$ y $H$ con algo más de un centenar. Los manuscritos que no llegan a las tres cifras son $L L, M y Q$. Para comprobar si su brevedad está condicionada por el escaso número o la ausencia total de composiciones sacras, se ha delimitado el porcentaje de lírica divina y humana (considerada como dubitada o indubitada de Cornejo) que poseen ${ }^{256}$ :



Gráfico 14: Porcentaje de poesía sacra y profana

La proporción de poesía divina es mucho más reducida que la centrada en temas humanos en todos los manuscritos ${ }^{257}$, ya que esta no supera en ningún caso el $26 \%$. Su presencia, por tanto, no sería un factor determinante en la extensión de los poemarios. De los testimonios que poseen un porcentaje más elevado de poemas sacros, solo $N$ y $S$ pertenecen al grupo de los más largos. Entre los de mediana longitud, destacan en esta temática $A$ y $D$. Como ya se ha comentado, en los más breves (con excepción de $M$ ) la presencia de estos es nula " $L L$ " o casi inexistente " $Q$ ". Tal hecho contribuye a que en ellos la proporción de textos profanos sea más elevado que en el resto.

\footnotetext{
${ }^{255}$ En el “Anexo: 8.5." se especifican los poemas apócrifos, repetidos y los que únicamente se atribuyen a Cornejo en $R$ para poder justificar por qué este testimonio es el más extenso y también uno de los menos fiables. ${ }^{256}$ En este estudio se han excluido las poesías apócrifas que se incluyen en los poemarios de Cornejo y las que se atribuyen a él y no se encuentran en más de cuatro manuscritos integri. Las referencias sobre todas estas composiciones aparecen en las páginas finales de la edición de Klaus Pörtl (Cornejo, Das lyrische 212-226). ${ }^{257}$ El número de poesías sacras y profanas que hay en cada manuscrito se halla recogido en el "Anexo: 8.3.3.4.".
} 
Llama la atención el bajo porcentaje en $R$ de lírica humana (51\%). Esto es debido a que muchos de los textos que lo conforman (30 \%) son apócrifos, no se atribuyen a Cornejo en más de cuatro manuscritos integri (indubitados) o no se consideran dubitados. Con el propósito de poder precisar más en los resultados, se ha extraído la proporción de poesías divina y humana (dubitada e indubitada) que alberga cada testimonio:



Gráfico 15: Porcentaje de poesía sacra y profana (dubitada e indubitada)

La lírica sacra indubitada es la menos frecuente en los poemarios que recopilan los versos de fray Damián, ya que no supera en ningún caso el $7 \%$ del total. Esta, exceptuando $B$, se encuentra únicamente en los más extensos. No sucede lo mismo con la poesía divina de autoría disputada, pues aparece en casi todos los testimonios analizados y su porcentaje duplica o triplica a la anterior. Aunque llega a alcanzar en $A, M$ y $\tilde{N}$ el $20 \%$, ocupa en estos un espacio bastante reducido respecto a los profanos.

El porcentaje de poesías dubitadas e indubitadas de temática humana en los manuscritos integri oscila (excluyendo $R$ ) entre el $32 \%$ y el $45 \%$ y su proporción es muy similar en el cómputo de cada uno. La diferencia entre ambas no supera nunca el $7 \%$. Tales datos pondrían de manifiesto que circularon entremezcladas. Para comprobar si tienen más peso en los poemarios analizados las composiciones indubitadas del cronista seráfico o las disputadas con otros autores y para intentar delimitar cuál podría ser el más fiable para ser editado, se ha extraído el porcentaje total de estas y se ha conformado el siguiente gráfico: 




Gráfico 16: Porcentaje de indubitados y dubitados

La proporción de poesías dubitadas es superior en todos los testimonios a la de indubitadas ${ }^{258}$, aunque esta difiere de manera significativa en algunos de estos. Mientras que en $A, B$ y $\tilde{N}$ las diferencias entre ambas superan el $20 \%$, en otros como $D, H, L L$ y $Q$ este porcentaje se reduce a más de la mitad. Entre estos últimos, se hallan los dos testimonios que poseen una mayor proporción de textos de atribución segura (superior al $43 \%$ ): $D$ y $Q$. Les sigue de cerca $\mathrm{S}$ y, tras este, $N$ y $H$ con alrededor del $40 \%$.

Los manuscritos que presentan un menor porcentaje de poesías indubitadas, exceptuando a $R^{259}$, son también los que poseen una cantidad proporcionalmente superior de dubitados. Destacan sobre el resto $A, B$ y $\tilde{N}$, que contienen entre un $10 \%$ y un $15 \%$ más que $D, H, L L$ y $S$. Por último, cabe señalar que los poemarios que manifiestan una frecuencia más alta de composiciones que no se consideran en este estudio ni dubitadas ni indubitadas son $L L, H, M$ y $R$.

Si se tienen en cuenta todos los datos aportados, los testimonios que "a priori" parecerían ser más fiables (por tener un porcentaje alto de indubitados y una baja proporción de dubitados y de "otros") serían $D$ y $Q$. No obstante, este último al no contener casi lírica sacra ofrecería una visión incompleta de la producción en verso de fray Damián.

\footnotetext{
${ }^{258}$ La mayor presencia de poesías dubitadas en los manuscritos se debe, principalmente, a que el número de estas (noventa y dos) es superior a la de los poemas indubitados: sesenta y uno. En el "Anexo: 8.3.3.3." se pueden consultar el número exacto de ambas en cada testimonio.

${ }^{259}$ Aunque $R$ es el poemario que contiene más poemas dubitados de Cornejo (ochenta y dos), el elevado porcentaje de "otros" que posee hace que la proporción de poesías disputadas con otros autores sea inferior a la del resto de poemarios.
} 
Los manuscritos integri conservados que han intentado recopilar la poesía de Cornejo podrían datarse entre la última década del siglo XVII y la segunda mitad del Siglo de las Luces $^{260}$. A continuación, se ofrece una cronología aproximada de estos. En la parte superior de la línea temporal, se han situado los testimonios que se inician con poesía sacra y, en la inferior, los que lo hacen con lírica profana con el objetivo de mostrar que esta última es la tendencia estructural predominante. Además, se han marcado con asterisco los poemarios que poseen manos de diversas épocas:



Ilustración 4: Cronología aproximada de los manuscritos integri analizados

Los manuscritos, escritos a una sola mano, que tienen una caligrafía más antigua $\left(M^{261}\right.$ y $\left.D^{262}\right)$ presentan diferencias significativas en su estructura, contenido y variantes ${ }^{263}$,

\footnotetext{
${ }^{260} \mathrm{El}$ interés de difundir los versos de fray Damián en la primera mitad del siglo XVIII coincidió con las diversas impresiones que se hicieron en este periodo de las obras de poetas del Bajo Barroco como Antonio de Solís, José Pérez de Montoro o León Marchante (ver “1.2.”).

${ }^{261}$ La referencia que hay en el título de $M$ al cargo de obispo de Cornejo (asignado en 1693) y su caligrafía permiten datar este en una fecha algo posterior a su nombramiento en la diócesis de Orense.

${ }^{262}$ El poemario $D$ contiene una marca de agua ("DPZ-060" del catálogo de "fil.dpz.es") que está datada en Daroca (Zaragoza) en 1680, pero la caligrafía y algunos poemas de Gerardo de Lobo que integra hace que su datación sea un poco más tardía (ver "5.1.2.1.”).

${ }^{263}$ Se ha realizado el cotejo de las variantes de diversos poemas profanos y sacros que comparten todos los manuscritos integri estudiados. A partir de tal observación, se ha podido concluir que, a pesar de los errores
} 
las cuales comparten con otros posteriores y dan lugar a dos familias. La primera estaría constituida por $A, L L, M$ y $Q$, mientras que la segunda por $D, H, N, \tilde{N}$ y $S$. El poemario $B$ parece estar influenciado por ambas pero, como se señalará más adelante, posee más rasgos en común con los integrantes del primer conjunto. Por último, cabe señalar que $R$ guarda bastantes semejanzas con los testimonios del segundo grupo $^{264}$, aunque su estructura fragmentaria (constituida por múltiples manos de diversas épocas) y las peculiaridades que manifiesta su contenido y su distribución hacen que se aleje un poco de ellos (ver "Anexo: 8.6.”).

Los poemarios que conforman el bloque uno $(A, L L, M$ y $Q)$ se caracterizan por ser en general más breves que los del dos, por no presentar poesía sacra indubitada y por iniciarse con poemas de temática divina, exceptuando $L L$ que no los posee. Además, sus composiciones profanas se ordenan de manera similar ${ }^{265}$ e incluyen el soneto "Casó de un arzobispo el despensero", que no se halla en los del segundo grupo. Existen otras poesías que son exclusivas del primer conjunto, pero que no aparecen en todos sus integrantes. $M$ y $Q$ presentan "Yo soy un ermitaño pobre", un texto que expondría las reflexiones que habría hecho fray Damián sobre la crisis que atravesaba España en 1643. $L L$ y $M$ albergan dos poemas que también tratarían temas vinculados con su vida: "Válgame, doña Talía" y "Apolo en la facultad"266. Ambos testimonios y A contienen los pareados "Per signum crucis de a vara"267, que se atribuyen en $B$ a León ${ }^{268}$.

El manuscrito más extenso de este grupo es $A$ (supera la centena de poesías) y el más breve $L L^{269}$ con ochenta y cinco. Este último es el más moderno de los testimonios integri conservados y tiene la peculiaridad de formar parte del fondo del Archivo Histórico Nacional

disyuntivos, de las innovaciones y de la contaminación que presentan cada uno de los testimonios analizados, existen una serie de errores conjuntivos y de lecciones equipolentes que permiten agruparlos en las dos familias mencionadas (ver "5.1.2. Tabla 27").

${ }^{264}$ La gran extensión de $R$, la inclusión de poemas sacros indubitados, la mayor presencia de poesías dubitadas, el hecho de que se inicie con lírica profana y la ausencia de composiciones que solo aparecen en poemarios del grupo uno lo acercan al segundo conjunto. De los manuscritos que integran este último, el que muestra más semejanzas en sus variantes con $R$ es $S$. Además, resulta relevante señalar que se conformaron en la misma fecha "1737" y que sus títulos, al contrario que los del resto de testimonios, intentan mostrar la variedad temática de los textos que los integran.

265 Aunque existen variaciones en la disposición de los poemas que integran, en líneas generales siguen una misma tendencia. Cabe señalar que los sonetos profanos en el conjunto uno se disponen casi al inicio de las poesías de dicha temática, mientras que en el grupo dos se colocan en la mitad o en la parte final de estas.

${ }^{266}$ El poema sirve como cierre de $M(316)$, mientras que en $L L$ se halla en la parte central (328v).

${ }^{267}$ Dicha poesía en $M$ se encuentra en la parte inicial de los poemas profanos (147) y en $A(106), B(69)$ y $L L$ (260) se sitúa en la parte final de estos.

${ }^{268}$ Existen otras composiciones que manifiestan discrepancias en la atribución en los integrantes del grupo uno. $Q$ atribuye al maestro León los poemas "De Oriente vienen tres reyes" y "Virgen, nadie culpada os ha creído". El primero, se incluye bajo el nombre de fray Damián en $A$ y $M$ y, el segundo, en los dos citados y en $B$.

${ }^{269}$ En el título de $L L$, se señala que Cornejo fue obispo de "Mondoñedo". Este error no se comete en el resto de manuscritos integri, aunque sí aparece en el poemario I (280). 
por estar rodeado de noticias diversas de la comunidad de Galicia, lugar donde residió durante sus últimos años Cornejo y donde falleció. Otro de los poemarios del conjunto uno que posee una característica singular es $Q$. Su título señala que reúne composiciones de Manuel de León y de fray Damián y, en las páginas iniciales, advierte que las primeras poesías son de Marchante y el resto del obispo de Orense ${ }^{270}$. Tales indicaciones no aparecen en ningún otro testimonio. Resulta relevante señalar que su caligrafía parece posterior a la publicación de las Obras póstumas del dramaturgo manchego (1722 y 1733) y que los textos dubitados con Cornejo que se atribuyen a él no aparecen impresos en estas.

El poemario $B$, escrito a dos $\operatorname{manos}^{271}$, posee un título ${ }^{272}$ casi idéntico al de $M$ y la flor que aparece en la cubierta de ambos se asemeja bastante. Comparte también con este las poesías "Casó de un arzobispo el despensero", "Per signum crucis de a vara" y "Yo soy un ermitaño pobre" ${ }^{273}$ que, como ya se ha señalado, solo están presentes en el bloque uno. Como sus integrantes, no contiene lírica sacra indubitada y la disposición de los poemas profanos iniciales es parecida (ver nota 265). Además, manifiesta más errores conjuntivos y lecturas equipolentes con ellos que con los del segundo conjunto "5.3.3". No obstante, su amplia extensión, su número elevado de poesías dubitadas y el hecho de que comience con versos humanos podrían manifestar que en su creación también pudo tener de referencia a algún integrante (conservado o perdido) de esta última familia.

Los manuscritos analizados del grupo dos $(D, H, N, \tilde{N}$ y $S)$ incluyen poemas indubitados de temática religiosa, más composiciones dubitadas con el dramaturgo manchego ${ }^{274}$ y la disposición de su contenido (sobre todo de las poesías iniciales) es casi idéntica. A pesar de ello, su extensión varía bastante. El más largo es $N$ (posee ciento cuarenta y siete poemas), mientras que el más breve “ $H$ ” tiene ciento cinco. Este último es el testimonio del segundo bloque que presenta menos poesías sacras de autoría segura y el único de él que no incluye el poema "El sacristán qué desmán”, el cual no se halla en el

\footnotetext{
270 Se trata de seis poemas sacros y dos profanos "Anexo: 8.2.1.11.”.

${ }^{271}$ La primera mano (principios del XVIII) ocupa casi todo el poemario, mientras que la segunda (finales del siglo XVII) se incorpora después del índice y conforma las páginas finales (95-115).

${ }^{272}$ Los títulos de $M$ y de $B$ solo se diferencian en la forma en la que se refieren a la figura del obispo de Orense. El poemario de la Fundación de Bartolomé March alude a él como "ilustrísimo señor don", mientras que el de la British Library emplea "padre". Esta última forma es como se presenta a Cornejo en la mayoría de manuscritos integri.

${ }^{273}$ Esta extensa composición aparece integrada en la parte inicial de los poemas profanos de $M(83)$ y en $B(95)$ y $Q$ (156) fue posteriormente añadida al final de los poemarios.

${ }^{274}$ El número de poesías dubitadas entre fray Damián y León que se incluyen en el primer tomo de las Obras líricas póstumas (1722) del dramaturgo manchego es mucho más reducido en el primer grupo "Anexo: 8.3.3.1.3". En $Q$ y en $M$, la presencia de estas es casi nula. Tal dato, unido a la mayor brevedad de los integrantes de este bloque, hace que el número total de dubitados sea menor que los poemarios que constituyen el dos.
} 
conjunto anterior. El caso de $\tilde{N}$ también resulta llamativo, pues fue escrito por dos manos de distinta época. Sus primeros folios (1-19v) poseen una caligrafía que parece ser del primer tercio del XVIII y el resto presenta una letra de mediados de este. Dicho poemario guarda una gran similitud con $D$ y $S^{275}$.

En el siguiente gráfico, se sintetizan los principales datos comentados sobre el contenido, la estructura y la cronología de los poemarios analizados. Los que poseen alguna característica que los distancia de su bloque (como se ha señalado previamente) han sido marcados con un asterisco. La gradación de colores usada refleja las similitudes que existen entre ellos:



Ilustración 5: Clasificación de los manuscritos integri

\footnotetext{
${ }^{275}$ Los manuscritos $D$ y $S$ poseen una disposición de los poemas similar (exceptuando la parte final) y comparten múltiples errores conjuntivos. Además, son los únicos que albergan la composición "Guardar la mujer es ley".
} 
La cantidad de manuscritos integri conservados que pretenden reunir la poesía de Cornejo y su proximidad temporal (menos de un siglo de diferencia) ha propiciado que se haya hecho una selección para llevar a término el cotejo de sus variantes y enmiendas. Esta ha sido realizada teniendo en cuenta los siguientes criterios. En primer lugar, se han elegido poemarios que contienen lírica sacra y profana y que albergan un porcentaje bajo de poemas dubitados. En segundo lugar, se ha procurado que todos no procedieran de la misma familia con el propósito de recoger el máximo número de variantes. En tercer lugar, se ha optado por escoger fuentes de distinta cronología para observar si esta influye o no en las variaciones que presentan. Los testimonios que mejor cumplen tales características son: $A, B, D, M$ y $S^{276}$. A continuación, se ofrece una pequeña muestra de los errores conjuntivos y disyuntivos que manifiestan ${ }^{277}$ :

\begin{tabular}{|c|c|c|}
\hline Ms. & Errores conjuntivos & Errores disyuntivos \\
\hline $\mathbf{A}$ & \multirow{3}{*}{$\begin{array}{l}\text { Poema: "Érase una virgen pura" (47- } \\
\text { 48vv.). } \\
- \text { en un portal sin franca / } \\
\text { halló casa con dos puertas }[\mathrm{A}, \mathrm{B}, \mathrm{M}] . \\
-\quad \text { en un portal sin cubierta } \\
\text { halló casa con dos puertas }[\mathrm{D}, \mathrm{S}] . \\
\text { *La rima exige (e-a). } \\
\text { Poema: "Quisimí quisimona" (v. 45). } \\
\text { - pues pone apala el cabe }[\mathrm{A}, \mathrm{B}, \mathrm{M}] . \\
\text { - pues pone de cabe a pala }[\mathrm{D}, \mathrm{S}] .\end{array}$} & \multirow{3}{*}{$\begin{array}{l}\text { Poema: "María, viéndote hermosa" } \\
\text { (v.38). } \\
\text { - las que acabo de reñir }[\mathrm{A}] \text {. } \\
\text { - las que acabo de plañir }[\mathrm{B}, \mathrm{D}, \mathrm{M}, \mathrm{S}] \text {. } \\
\text { *El contexto exige "plañir". } \\
\text { Poema: "Clori, que para ser linda" (v. } \\
\text { 32). } \\
\text { - hace con ellas su hecho / y con ellas la } \\
\text { deshecha [B]. } \\
\text { - hace con ellas su hecho / y contigo la } \\
\text { deshecha estampa }[\mathrm{A}, \mathrm{D}, \mathrm{M}, \mathrm{S}] \text {. } \\
\text { Poema: "Cansado anoche de estar" } \\
\text { (84v.). } \\
\text { - debida a su margen gracia }[\mathrm{M}] . \\
\text { - debida a su gracia estampa [A, B, D, S]. } \\
\text { *La rima exige (a-a). }\end{array}$} \\
\hline B & & \\
\hline $\mathbf{M}$ & & \\
\hline D & $\begin{array}{l}\text { Poema: "Cansado anoche de estar" } \\
\text { (85v.). } \\
\text { - la luz, ardiente lechuza, / que de mi } \\
\text { velón chupaba }[\mathrm{A}, \mathrm{B}, \mathrm{M}] \text {. }\end{array}$ & $\begin{array}{l}\text { Poema: “Oye, Catuja, dulce hechizo } \\
\text { mío" (220v.). } \\
\text { - no le sentó a la sal empedernida [A, B, M, } \\
\text { S]. }\end{array}$ \\
\hline S & $\begin{array}{l}\text { - la luz le hacía / que de mi velón } \\
\text { chupaba [D, S]. } \\
\text { Poema: "Hoy a la Concepción } \\
\text { aclamaciones" (v. 7). } \\
\text { - hoy limpia su opinión, aunque le cuesta } \\
\text { [A, B, M]. } \\
\text { - se limpia su opinión, aunque le cuesta } \\
\text { [D, S]. }\end{array}$ & $\begin{array}{l}\text { - no le sentó a la mano empedernida }[\mathrm{D}] \text {. } \\
\text { Poema: Marica, que a decir mal (v. 62). } \\
\text { - a medrada de valida }[\mathrm{S}] . \\
\text { - a privada de valida }[\mathrm{A}, \mathrm{B}, \mathrm{D}, \mathrm{M}]\end{array}$ \\
\hline
\end{tabular}

${ }^{276}$ En el "Anexo "8.1. y 8.2.", se ofrece una descripción de estos y la indexación de los poemas atribuidos al cronista seráfico que contienen.

${ }^{277}$ En el aparato crítico de la edición "5.3.3.”, pueden consultarse todas las variantes que presentan los poemas de los manuscritos cotejados. 
El manuscrito $M$ (el más breve) comparte múltiples errores conjuntivos con $A$ y $B$, mientras que $D$ lo hace con más frecuencia con $S$ (el más extenso), corroborando así las filiaciones mencionadas previamente ${ }^{278}$. No obstante, todos los testimonios presentan también errores disyuntivos que los alejan de los grupos mencionados. Tal dato, la contaminación textual que se observa en los poemarios (sobre todo en $S)^{279}$ y las diferencias que se aprecian en su contenido y en la disposición de los poemas, especialmente del primer grupo, parecen indicar que existieron más copias (primarias e intermedias) que las que nos han llegado y que pudieron coexistir dos arquetipos ${ }^{280}$.

$D$ y $M$ podrían ser los representantes conservados más primitivos de cada uno de los arquetipos teorizados. De estos dos, $M$ es el que contiene más lecciones correctas. A pesar de ello, tanto el manuscrito de la Fundación Bartolomé March como $A$ y $B$ son más breves que $D$ y $S$, no poseen lírica sacra indubitada de Cornejo y manifiestan un porcentaje más elevado de poemas dubitados. Resulta relevante mencionar también que los poemarios más modernos $(A$ y $S)$ son los que contienen más errores de copia y más lecciones singulares. Además, $S$ manifiesta una menor proporción de textos indubitados que $D$.

Tras valorar todos los datos aportados sobre el contenido, la filiación y la cronología de los manuscritos integri analizados, se ha concluido que el poemario $D$ es el que parece ofrecer una visión más completa y fidedigna de la poesía de Damián Cornejo. Los motivos que permitirían sostener tal afirmación son los siguientes. Por un lado, es el que parece más fiable por tener un porcentaje alto de indubitados y una baja proporción de dubitados y de “otros". Por otro, pertenece al grupo dos y, por tanto, posee una mayor cantidad y variedad de poemas. Por último, es el integrante de este bloque que posee una caligrafía más antigua y unitaria. Por todo ello, se ha optado por elegirlo como manuscrito base para la edición crítica de su lírica.

\subsubsection{El codex optimus}

\footnotetext{
${ }^{278}$ Existen algunos casos aislados en los que se producen errores conjuntivos entre $B$ y $D$, como en "Sueño jocoso" (v. 274). Además, es importante señalar que hay múltiples composiciones que estos comparten y que no están presentes en $A$ y en $M$.

${ }^{279}$ El manuscrito $S$, en múltiples ocasiones, opta por las variantes que contienen $B$ o $M$ o incorpora versos que no se incluyen en los testimonios seleccionados. Uno de los casos más significativos sucede en el poema "Oye, Catuja, dulce hechizo mío". En él, aparecen diez versos que permiten darle a la composición un cierre más coherente.

${ }^{280}$ Los "arquetipos" pueden contener lecciones "no auténticas, pero aparentemente correctas, que pasan a sus descendientes. Y no es ocioso recordar que, asimismo, una lección auténtica puede ser errónea (...) pues los autores también cometen errores inevitablemente en el acto de escribir" (Blecua, Manual 48).
} 
El manuscrito $D(215$ x 154$)$ se halla encuadernado en pergamino del siglo XVIII y su estado de conservación es bueno. En la parte superior del lomo, puede leerse, aunque con cierta dificultad, "Obras poéticas del padre Cornejo" ${ }^{281}$. En la parte inferior de este, aparece su signatura actual de la BNE “2245” y, en la esquina superior izquierda del interior de la cubierta, su olim "G-408”. Incluye dos hojas de guarda. En el revés de la segunda, hay una anotación, realizada por un tal "Méndez", que indica que si la obra se extravía se devuelva a su poseedor "don Miguel de Arratiguibel y Gorospe"282.

El poemario contiene doscientas veinticinco hojas de papel (de la V a la VII están en blanco) con foliación antigua. Esta solo manifiesta alteraciones en la página ciento ochenta y nueve, que se halla repetida. Tras las dos hojas de guarda, se encuentra la portada, que posee el mismo título del exterior. Cabe señalar que no posee ningún tipo de ornamentación y que en la parte inferior de la página aparece un gran tachón, cuyo contenido no ha podido ser descifrado.

Las ciento treinta y dos poesías que alberga (ciento veintinueve de Cornejo y tres de Gerardo Lobo ${ }^{283}$ ) se hallan recogidas en la tabla de contenidos (II, III y IV), ninguna de ellas está repetida. Los poemas fueron copiados a una columna por una mano, cuya caligrafía parece ser de principios del siglo XVIII. Además, existen otros indicios significativos que permiten situar con precisión su cronología. Por un lado, la filigrana que contiene "DPZ0060 ״284 está fechada en 1680 en la localidad de Daroca (Zaragoza) ${ }^{285}$ :

\footnotetext{
${ }^{281}$ El título es muy similar al del manuscrito $A$ : "Obras del padre Cornejo".

${ }^{282}$ La única información que se ha hallado que podría hacer referencia a su poseedor es una nota de defunción de 1777 de alguien con el mismo nombre y el primer apellido "Arratiguibel", que vivía en Ataun (Guipúzcua). Esta ha sido extraída del ensayo de Juan Carlos de Guerra (89).

${ }^{283}$ Los poemas que se incluyen de Gerardo Lobo son los siguientes "Después, amigo, del día" (201v-210), "Será estudio principal" (210-215) y "Reo convicto" (215-215). Este último fue publicado como pliego suelto en 1710 .

${ }^{284}$ La información detallada sobre esta marca de agua puede hallarse en la base digital de filigranas de la Escuela Taller de Restauración de la Diputación Provincial de Zaragoza.

${ }^{285}$ Resulta significativo mencionar que varios de los manuscritos integri de fray Damián podrían vincularse a provincias próximas a Zaragoza. El poemario $M$ procede de la Biblioteca de Medinaceli y $R$ se halla en la Biblioteca Real de la Colegiata de Roncesvalles. Además, cabe señalar que $A$ perteneció a un cura del municipio de Barbolla (este de Segovia) y que su filigrana es muy similar a la DPZ-0550 del catálogo de "fil.dpz.es", la cual procede de Villalengua (Zaragoza).
} 




Ilustración 7: Filigrana 126. Extraída de: fil.dpz.es

Por otro, las poesías que incluye de Eugenio Gerardo Lobo (201-223) nos ofrecen una datación post quem y otra ante quem del manuscrito. El poema "Después, amigo, del día" fue escrito por el soldado manchego durante las maniobras militares que inició a finales de noviembre de 1710 en los Montes de Toledo. Además, el hecho de que se incluya en primer lugar es una señal de que se copió antes de 1738, ya que a partir de ese año las obras del poeta toledano comienzan "invariablemente con «Reo convicto en el tribunal de su conciencia», «Triunfo de la Castidad»y otros romances de asunto religioso y alambicado estilo, de los que sabemos, sin duda, que son de fecha temprana, cuanto menos anterior a 1713” (Álvarez Amo 630). Por último, la anotación que hay al margen (201v) ${ }^{286}$ señala que las composiciones que se presentan a continuación son del "capitán de caballería corazas en el Regimiento Viejo de Granada", cargo que desempeñó Lobo ${ }^{287}$ desde 1704 hasta el fin de la Guerra de Sucesión Española (1713). Por tanto, el poemario parece haber sido creado en una fecha muy próxima a la resolución de dicho conflicto.

La copia de los poemas es monocromática (negra) y se ejecutó con bastante meticulosidad, pues apenas se aprecian correcciones sobre los textos. La caligrafía de la mano que las realiza parece contemporánea y no introduce cambios significativos. Los títulos aparecen centrados y no presentan ninguna ornamentación destacada. En el margen izquierdo de estos, suele incluirse el tipo de métrica. La recopilación de las poesías atribuidas a fray Damián se abre con lírica profana (1-147v), continua con sacra $(147 \mathrm{v}-200)$ y se cierra con un poema de temática humana $(201)^{288}$. La distribución los dos grandes bloques

\footnotetext{
${ }^{286}$ En el folio doscientos uno dice "hasta aquí del padre Cornejo"; en el reverso de este, se añade: "Desde aquí adelante poesías de don Eugenio Gerardo Lobo, capitán de caballería corazas en el Regimiento Viejo de Granada".

${ }^{287}$ En 1726, Gerardo Lobo ocupó el cargo de ayudante mayor de las Guardias Españolas de Infantería.

${ }^{288} \mathrm{La}$ indexación de las composiciones se halla en "Anexo: 8.2.1.2.".
} 
mencionados (lírica profana y divina) no es aleatoria. Estos se agrupan, generalmente, por el tipo de métrica o los temas tratados, estableciendo con ello numerosas semejanzas con otros manuscritos integri de Cornejo: $H, N, \tilde{N}$ y $S$.

El códex analizado se cierra con una nota situada debajo del último poema profano atribuido a Gerardo Lobo (225), donde se advierte sobre la liviandad de algunos de las obras que incluye: "Humildemente, sujetando su dictamen, por testa el autor de este papel que si hubiese voz impropia, siniestra inteligencia o bastarda interpretación que oponga en algún modo a nuestros católicos dogmas que, desde luego, se desdice".

\subsection{CRITERIOS DE LA EDICIÓN}

El objetivo de esta edición es constituir un texto lo más próximo posible al original, o al modelo ideal de este, a través de la corrección de erratas del manuscrito elegido como base y del cotejo de variantes que existen entre los testimonios seleccionados: $A ; B, D, M$ y $S$. Se ha incluido entre corchetes cualquier adición al texto de $D$. Si esta forma parte de una variante se ha añadido además un asterisco “[... $]^{*}$ ”. Tal símbolo ha sido también utilizado para señalar la supresión de un "error por adición”. Todos aquellos términos o elementos que precisan una aclaración han sido anotados a pie de página.

El aparato crítico negativo se ha incluido en el apartado "5.3.3." con el propósito de entorpecer lo menos posible la lectura de los poemas. Para ahorrar espacio y para facilitar la identificación de lecciones (iguales y divergentes) de los manuscritos cotejados, se ha señalado únicamente la variante del texto base en los casos en los que se ha optado por fijar la de otros testimonios. Se ha marcado con “^” cuando los manuscritos $(A, B, M$ y $S)$ añaden palabras y versos de la transcripción de $D$ y con “ ” cuando no los incluyen ${ }^{289}$.

Los problemas de atribución que presentan muchas de las poesías editadas han sido reflejados mediante la incorporación en su título de los siguientes símbolos: indubitadas “ $\&$ ”, dubitadas “\#” (los poemas disputados con Marchante que, según los estudios de autoría realizados, podrían haber sido escritos por Cornejo contienen dos almohadillas) ${ }^{290}$ y apócrifas “+”.

\footnotetext{
${ }^{289}$ Los versos que no aparecen en los manuscritos cotejados con el códice optimus no se trascriben. Se identifican con “ ” y con su numeración correlativa correspondiente.

${ }^{290}$ Las poesías dubitadas con otros escritores que no han podido someterse al estudio de autoría se han marcado también con almohadilla.
} 


\subsubsection{Ortografía y puntuación}

En la presente edición se ha modernizado la ortografía, la acentuación, la puntuación y los signos de interrogación y admiración de acuerdo con la norma académica actual, aunque con algunas excepciones con el propósito de conservar rasgos significativos de la lengua de la época y singularidades estilísticas de los textos. Los cambios introducidos y los elementos conservados se detallan a continuación.

Por lo que respecta a las consonantes, se han codificado y sistematizado aquellas grafías sin un claro valor fonológico $(b / v ; c / q ; c / z / c ; j / x / g ; i / j ; u / v)$, se ha regularizado el uso de $h$ y los grupos consonánticos de origen similar ( $p h, t h$ y $c h$ ) y se han eliminado las geminadas ( $c c, p p$ y $s s$ ). Cuando las consonantes $n v$ aparecen como $m b$, se recuperan las primeras. Se ha tratado de conservar ciertas peculiaridades de la lengua del momento como los arcaísmos (agora) o alteraciones significativas en su uso (celebro). En relación con las vocales, se han suprimido las dobles (fee), actualizado el uso de $y / i$ y de $v / u$ con valores vocálicos y mantenido todas las formas en las que hay diferencias fonéticas (mormura).

Se han eliminado las asimilaciones con pronombre pospuesto y las contracciones morfológicas de preposición más artículo o demostrativo (deste, desa o daquesto y sus variantes) y de expresiones como enhoramala. Se han mantenido las asimilaciones de líquidas en casos de infinitivo + pronombre enclítico (contemplarla / contemplalla) y las formas arcaicas de futuros contractos, del tipo verná o tenrá; así como las formas diptongadas hoy perdidas (entriego).

Además, se han preservado fenómenos como el laísmo y el leísmo. En lo que se refiere a las mayúsculas, se han suprimido todas las palabras que hoy se escriben con minúscula, exceptuando algunas entidades (Dios, Niño, Virgen...), las celebraciones religiosas (Pascuas, Corpus, Adviento...) y las referencias a instituciones y edificios con nombres de santos (convento de San Francisco).

\subsubsection{Anotación}

En las notas a pie de página, se explican todas las voces, comunes y propias que el lector contemporáneo podría desconocer o que se emplean en un sentido distinto al actual, las referencias a personajes, obras, entidades y lugares (reales o ficticios) y eventos que permitan entender mejor el contexto, el contenido o la interpretación de la composición. Además, se han comentado las palabras con diversas acepciones y recogido el significado de las frases hechas, las expresiones y los refranes que se incluyen. También se han utilizado 
las notas para aclarar las diversas lecturas que plantean los textos o el trasfondo ideológico de algunas de las afirmaciones que contienen.

La anotación tiende a ser breve, ya que no se pretende competir con enciclopedias o glosarios especializados. Todas las citas que se han incluido de otras fuentes han sido modernizadas. En varias entradas, se ha considerado pertinente ofrecer, además de la explicación académica, pasajes de otros autores en los que el término o la idea se utiliza con un sentido similar o diverso al empleado por fray Damián o alguna indicación de que existe más información al respecto. Por último, se ha remitido de unas entradas a otras si la aclaración era la misma.

Las abreviaturas empleadas en la anotación filológica, citadas en la bibliografía “7.15. y 7.2.”, son las siguientes: “Aut.” (Diccionario de Autoridades), “Corr.”(Vocabulario de refranes y frases proverbiales, de Correas), "Cov." (Tesoro de la Lengua Castellana, de Covarrubias), "CVC" (Refranero multilingüe, Centro Virtual Cervantes) y "DLE" (Diccionario de la lengua española, RAE et. alt.). 


\subsection{EDICIÓN CRÍTICA}

\subsection{1. Índice de poemas}

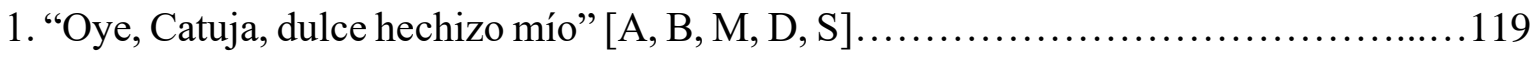

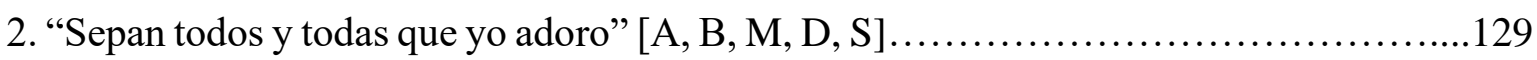

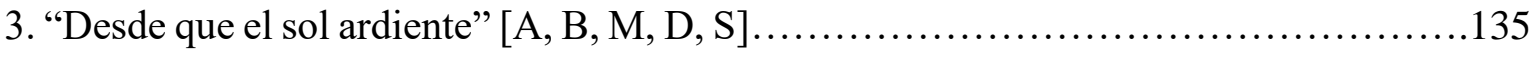

4. "Dulce Lisis de mis ojos" [A, B, M, D, S ] ................................... 139



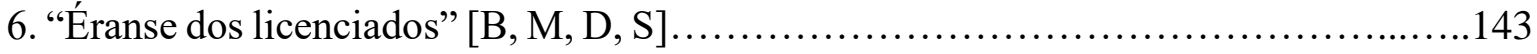







10. "Un estudiante de hogaño" [A, B, M, D, S ] ................................. 151























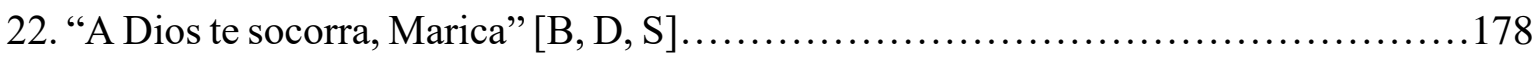



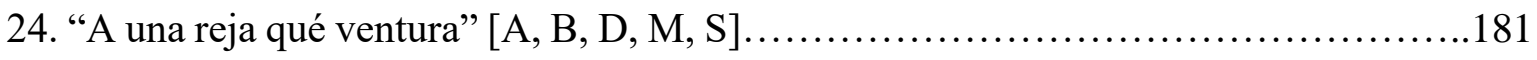

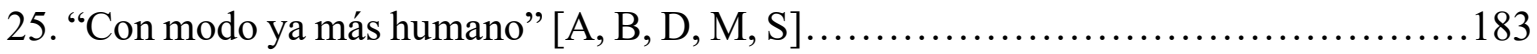

26. "Solo el silencio testigo" [A, B, D, M, S] ................................... 184



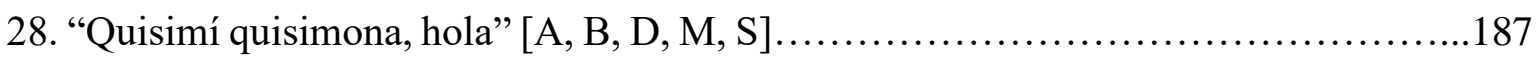

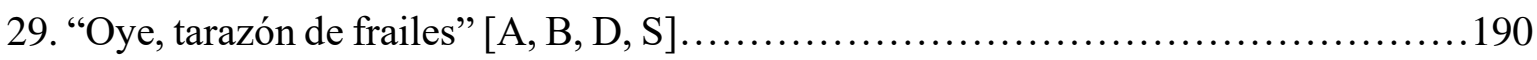




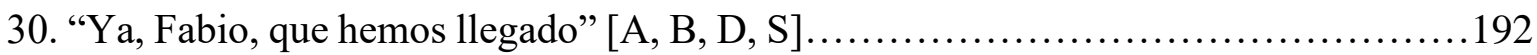

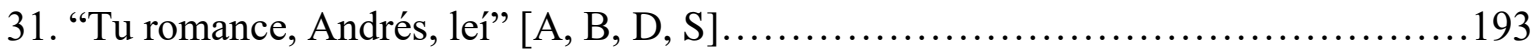

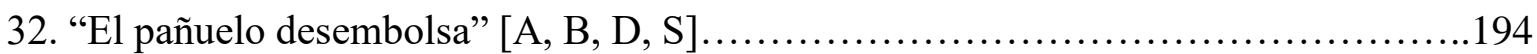

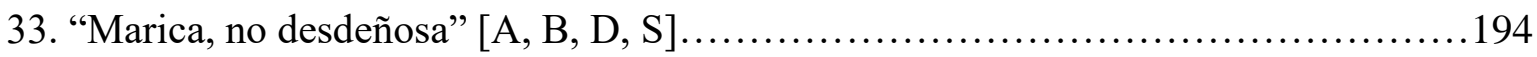

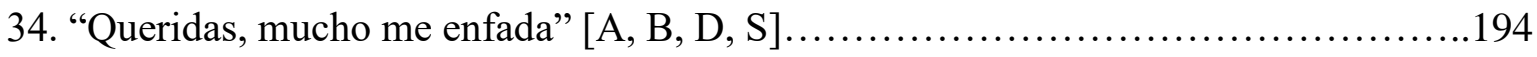

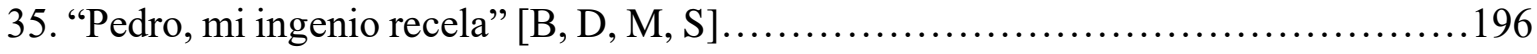

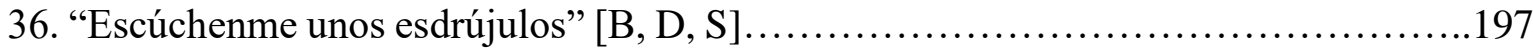

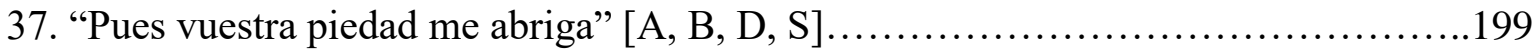

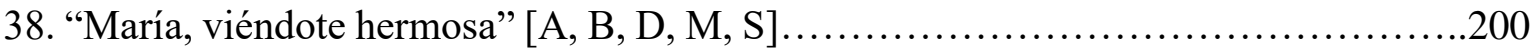

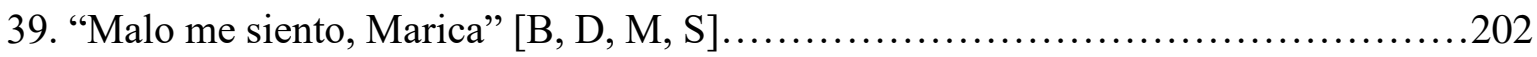

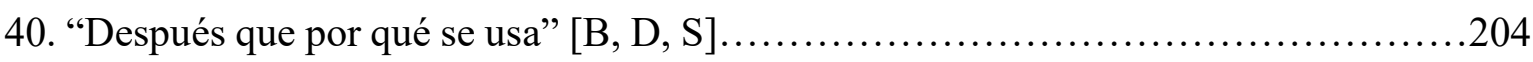

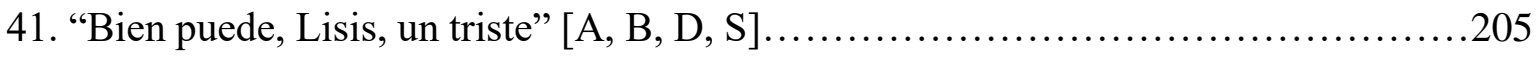



















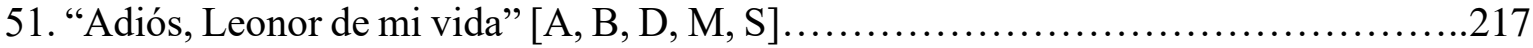











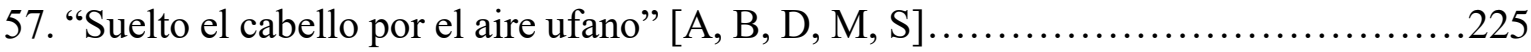





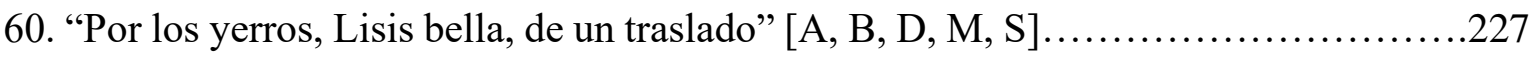



62. "Breve pie reducido a cárcel breve" [A, B, D, M, S] ...........................229

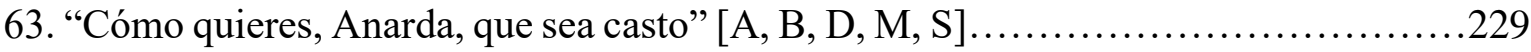




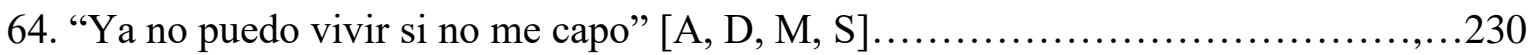

65. "Disparates, Antón, muy mal zurcidos" [A, B, D, M, S] .........................231

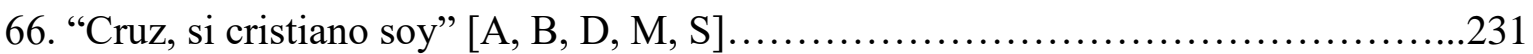

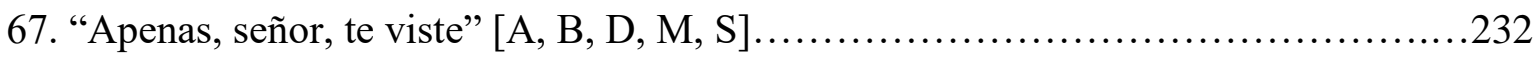

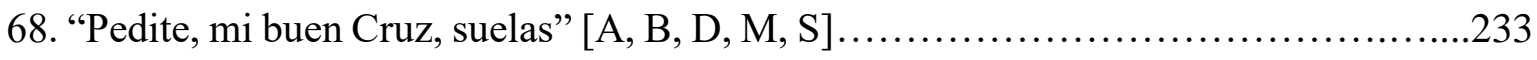

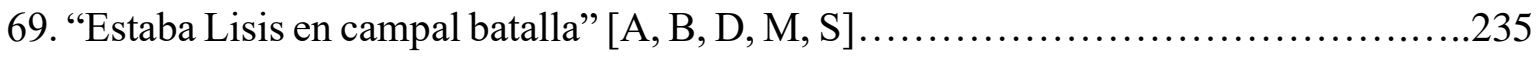

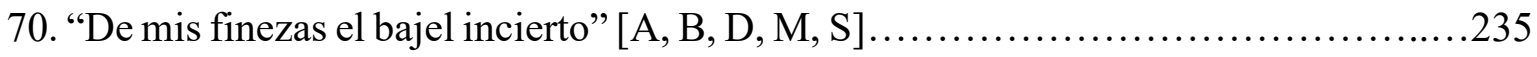

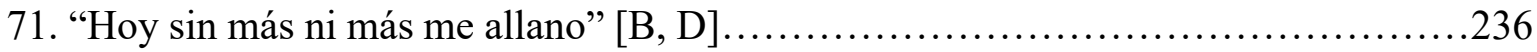

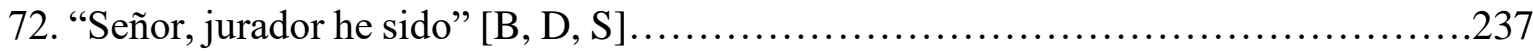

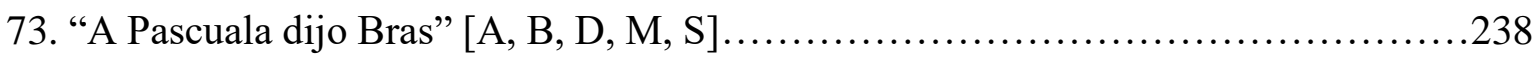

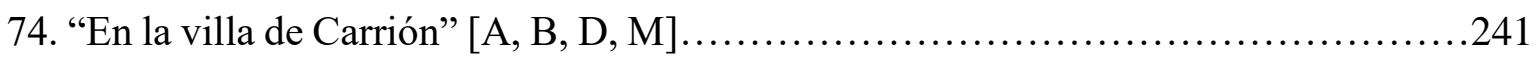

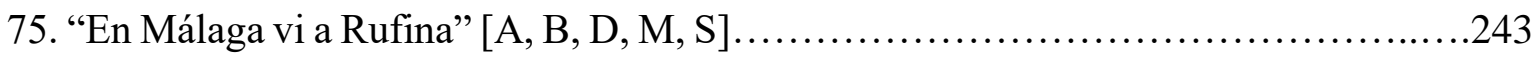

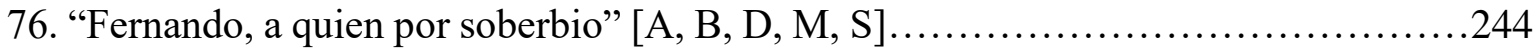



78. "En la firme política nuestra" [A, B, D, S ] .................................. 247

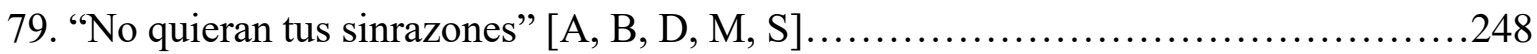

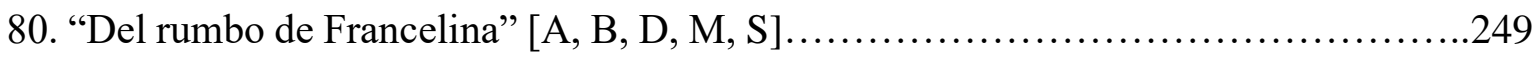

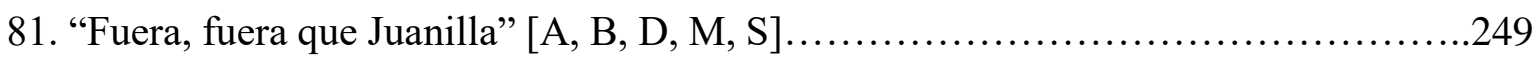

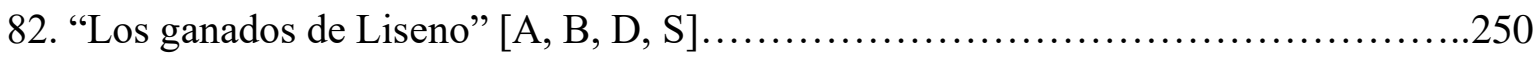

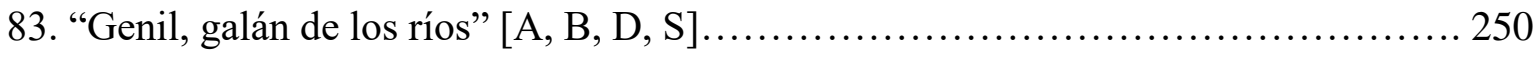

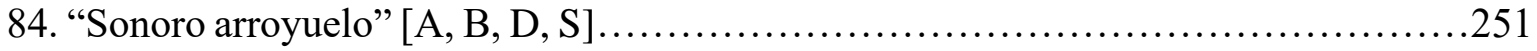

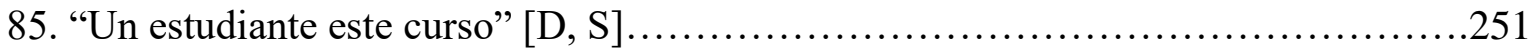

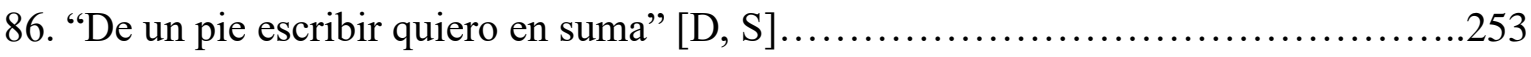

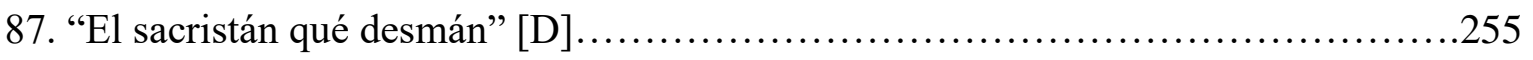

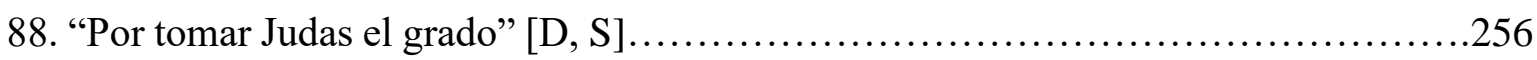

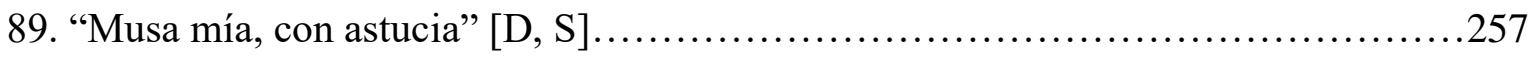

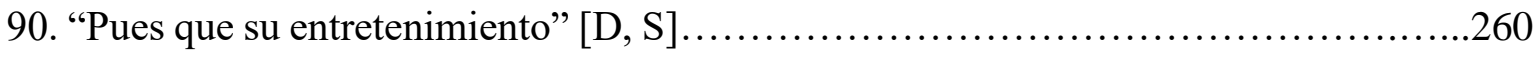

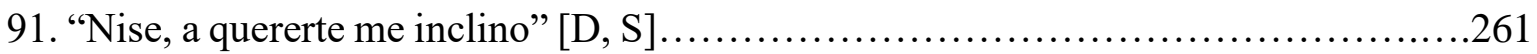

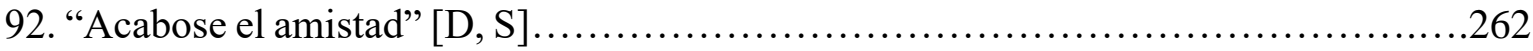

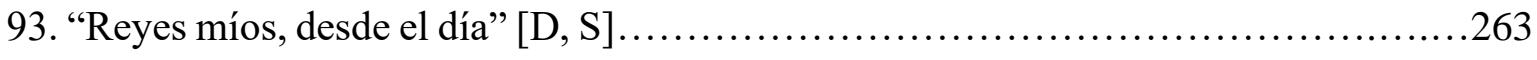

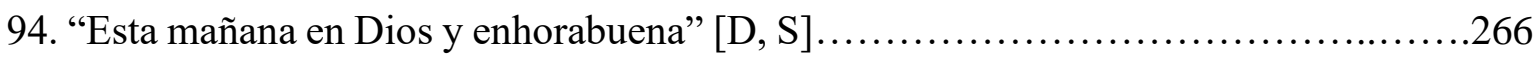



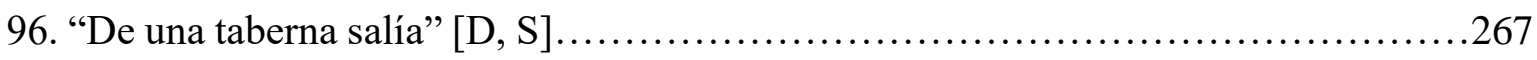

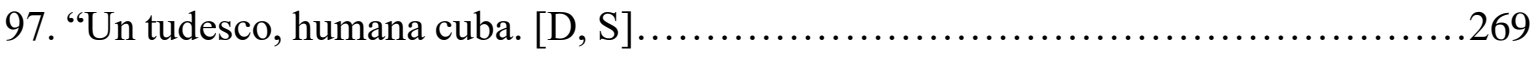




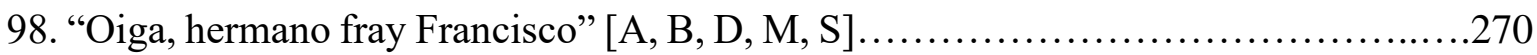

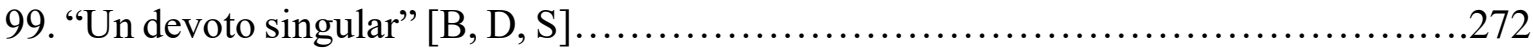

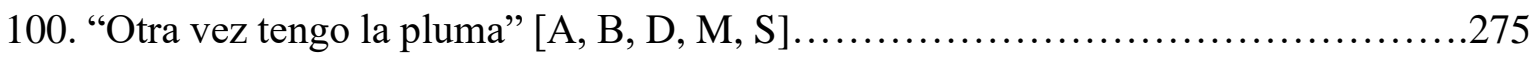

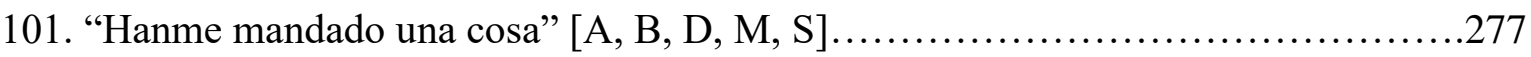

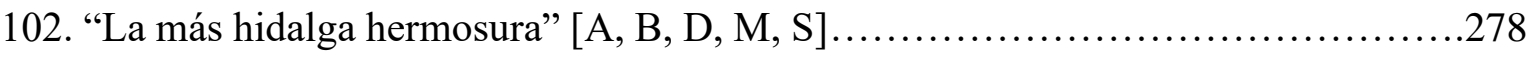

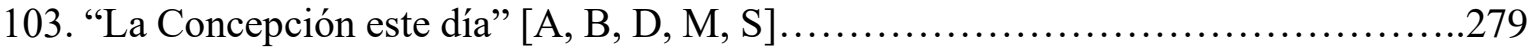

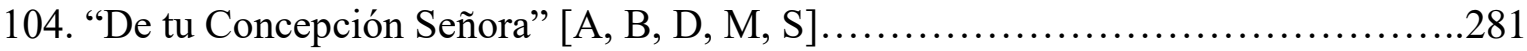

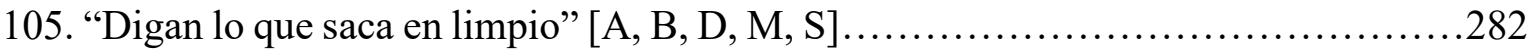

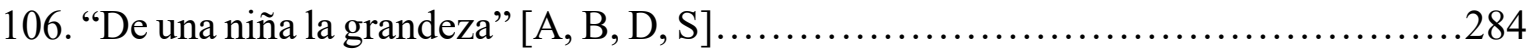

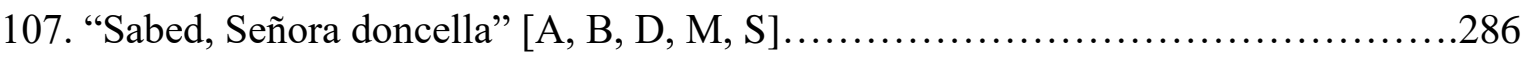

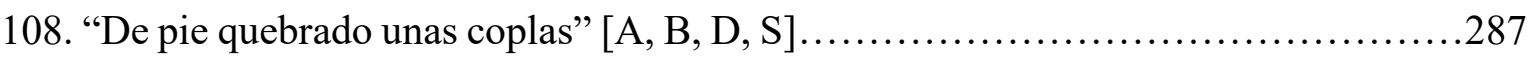

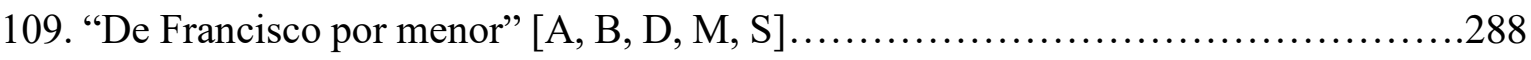

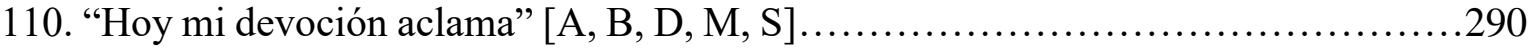

111. “Al señor Bautista, el jaque” [A, B, D, M, S] .................................293

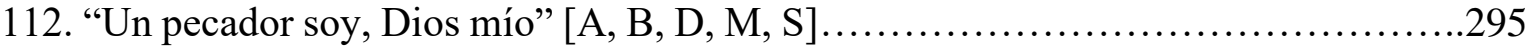

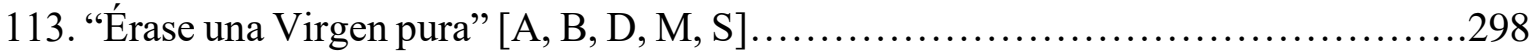

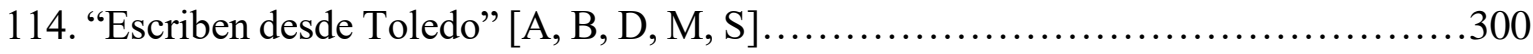

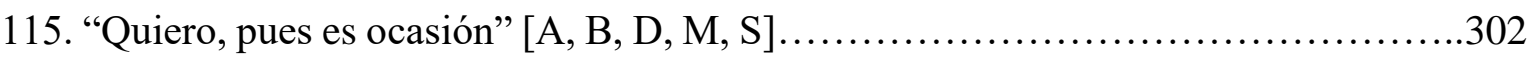



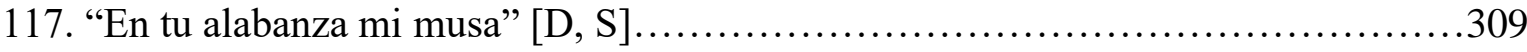

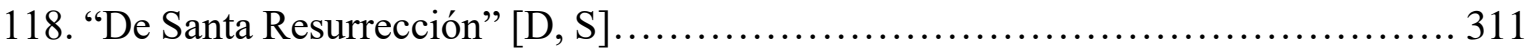

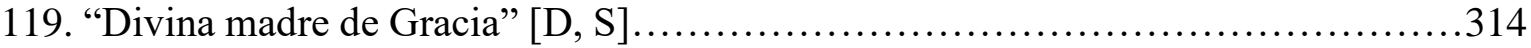

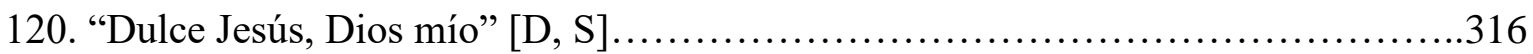

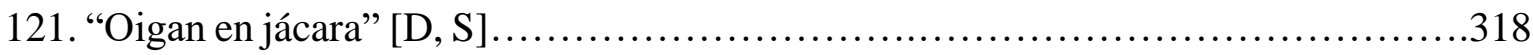

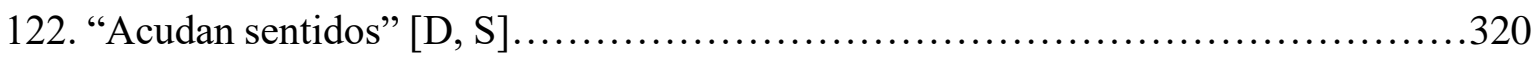

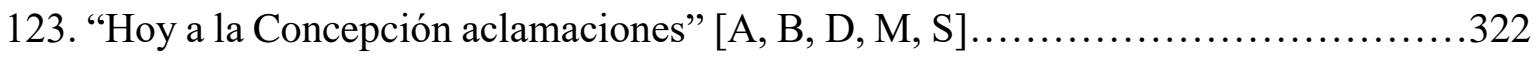

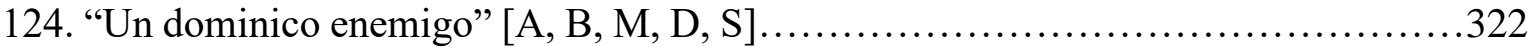

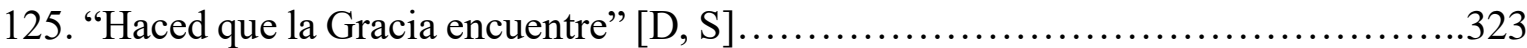

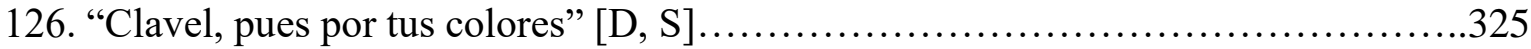

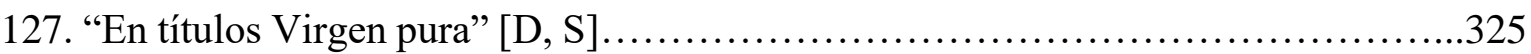

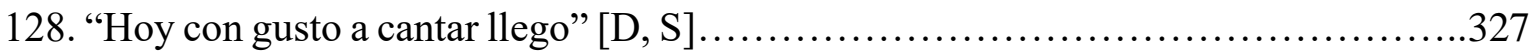

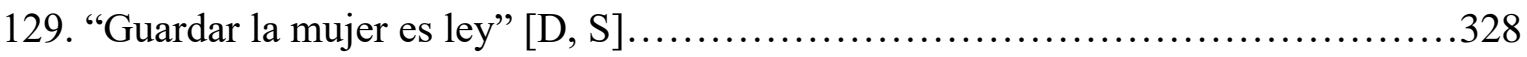




\subsubsection{Poemas}

\section{El agosto del fraile en Madrigales ${ }^{1}$ (1) \&}

\section{Ovillejo}

Oye, Catuja ${ }^{2}$, dulce hechizo mío, dueño del alma, ley del albedrío3.

Oye, piadosa de mis muchos males, en unos mal*escritos madrigales ${ }^{4}$

5 la relación que puede ser de ciego ${ }^{5}$, después que tan fullera ${ }^{6}$, en dulce juego, me llevaste los ojos y con ellos el alma por despojos. Primeramente, mi salud (no es nada)

10 está cosa perdida, y muy quebrada, y remedio no espero ${ }^{7}$, si del cielo no cae algún braguero, puesto que voy de aquel* achaque viejo ${ }^{8}$,

\footnotetext{
${ }^{1}$ El término "Madrigales" podría hacer referencia tanto al género del poema como a la localización donde, supuestamente, ocurrieron los hechos que se cuentan. El título del manuscrito $R$ ayudaría a sostener esta última hipótesis "Pintura de un pueblo donde cierto religioso fue a pedir el agosto (que es en el lugar de Madrigales). Escribiola a una monja su devota" (8). Este podría tratarse de Madrigal de la Vera (Cáceres). ${ }^{2}$ El nombre de la amada, Catuja, parece ser una alusión jocosa a las catujas o cartujas, que son las integrantes de la orden religiosa fundada por san Bruno en el siglo XIII en Francia. Además, la procedencia de este sustantivo (diminutivo de Catalina) podría ser considerado como una referencia oculta a Catalina García Fernández (1639-1677), discípula de fray Damián. Según Álvarez (Capítulo 14: 524), ambos habrían mantenido una estrecha y controvertida relación durante los últimos años de vida de la fundadora del Colegio de Doncellas Pobres de Santa Clara.

${ }^{3}$ Según la creencia cristiana, Dios ha otorgado al hombre la "ley del albedrio" y, por tanto, este posee la capacidad de tomar sus propias decisiones. Dicha ley en la concepción del "fino amor" queda limitada a la voluntad de la amada, pues ella se convierte en la "dueña" (v. 2) del alma del enamorado por la relación de vasallaje que entre ambos se establece.

${ }^{4}$ La considerables extensión del poema y su temática rural lo alejarían, en principio, del madrigal que se popularizó en España en los Siglos de lo Oro. No obstante, hay que tener en cuenta que en su origen el término madrigal "mandrial" se empleaba para los cantares rústicos o toscos de los pastores y que en Italia se cultivaba una forma larga de este género "madrigalone” o "madrigalessa” (Ruiz, La boscarecha s.p.). ${ }^{5} \mathrm{La}$ detallada pintura que realiza Cornejo de las desafortunadas vivencias de un fraile (parece ser su álter ego) en un paraje rural hacen que pueda vincularse a las llamadas "relaciones de sucesos", que eran creaciones históricas o literarias que en el periodo aurisecular solían ser recitadas y vendidas (en pliegos de cordel) por ciegos. Este tipo de composiciones ha sido estudiado por Nieves Pena Sueiro (43-63).

${ }^{6}$ El lenguaje naipesco era empleado en la poesía amorosa para cantar los deseos y para manifestar los rencores "porque en el amor, como en el juego, los tahúres son casi siempre víctimas de los fulleros. O, mejor dicho, de las fulleras" (Etienvre 19). El término "fullera" también se utiliza en el poema indubitado de Cornejo "Sueño jocoso".

${ }^{7}$ Fray Damián combina rasgos de la llamada silva-métrica (estilo llano y espontáneo, presencia de un narrador expreso y referencias a la práctica de la écfrasis) con elementos de la silva-soledad (amplia extensión de la composición, carácter descriptivo y temática relacionada con la naturaleza). Las características de los diversos géneros que presenta la silva en la lírica hispana en los Siglos de Oro han sido investigadas por Juan Montero Delgado y Pedro Ruiz Pérez (19-56).

${ }^{8}$ Podría tratarse de una referencia jocosa a los numerosos problemas de salud que fray Damián padeció en su vejez, los cuales le llevaron a renunciar a su cargo de obispo. En el poema inédito "Válgame, doña Talía", Cornejo cuenta con humor uno de sus achaques. Este se halla en los manuscritos "406" de la Biblioteca Fundación Bartolomé March (63) y “1053” del Archivo Histórico Nacional (233).
} 
perdiendo por el piezgo mi pellejo.

Llegué a un lugar que tiene, bien mirado, de término el estar sólo acabado;

y al ver cosa tan mala, me confundo, cómo se hizo lugar en este mundo.

No tiene un árbol, y es forzoso infiera

20 que no ha llegado aquí la primavera9, que ofendida de ver miserias tantas, se extrañó de poner en él sus plantas; dan de* una peña dos breves resquicios del líquido cristal, dos desperdicios ${ }^{10}$.

25 Y dije "desperdicios" con cuidado, por ser cristal para desperdiciado, que son sus aguas tan sin ruido sordas*, que no pueden correr de puro gordas. Un día que las vi, la sed tentome,

30 caí en la tentación ${ }^{11}$, pero amargome, y dije: ¡Oh fuente!, a mal contenta hueles, pues de estar aquí, estás hecha de hieles ${ }^{12}$ y a papar* de tus aguas me convidas, que están saladas, porque están sentidas ${ }^{13}$.

35 Las casas, sin tener nada que importe, es cada cual una lucida corte, (que así suelen llamar los cortesanos al rancho donde duermen los marranos), donde ven de mis ojos las porfías coche aquí, coche allí ${ }^{14}$ todos los días. "Ténganme que me caigo", están clamando

\footnotetext{
${ }^{9}$ Cornejo parece recoger el esbozo de la última parte de las Soledades de Góngora, donde el longevo peregrino enamorado pasaría por un paisaje estéril y abandonado, y contraponerse a la imagen de la naturaleza viva y cambiante que estructura la "Selva al verano, en canción informe” de Matías Ginovés. La ruptura de los ciclos naturales (ausencia de la llegada de la primavera) en el poema del cronista palentino habría desencadenado la falta de vegetación y de un río que contagiara de vida el lugar. Se establece, por tanto, una ruptura con el "locus amoenus" y el "beatus ille" de la tradición clásica y un intento de continuar con la evolución de la llamada "silva / selva". Esta ha sido analizada por Montero y Ruiz (29).

${ }^{10}$ La descripción que se hace del río (vv. 24-34) parodia las idílicas características que la tradición clásica ha atribuido a este y las hermosas descripciones que del "líquido cristal" realizan Góngora en su Soledad Primera y Matías Ginovés en su "Selva al verano, en canción informe”, las cuales han sido analizadas por Pérez Lasheras (123).

${ }^{11}$ Parece ser una alusión al pasaje bíblico en el que Jesús vaga por el desierto y, tras un ayuno de cuarenta días y cuarenta noches, supera la tentación del diablo de hacerle beber y comer (Lucas 4, 1-6).

12 Estar hecho de hieles: "Frase con que se pondera la desazón con que alguno espera una cosa que le da cuidado o la displicencia que tiene de oír alguna conversación o en alguna parte contra su gusto" (Aut.). Cabe señalar que la amargura "hiel" que le provoca a la fuente estar en un paraje tan desolado y seco "aguas tan sin ruido" (v. 27) hacen que las lágrimas que vierte salen sus aguas (v. 34).

${ }^{13}$ La contraposición que se establece entre las aguas "sordas" (v. 27) y las "sentidas" (v. 34) al asociarse con la metáfora del cristal líquido (v. 24) podrían aludir a la descripción que hace el autor de la Fábula del Polifemo (Góngora s.p.) de la fuente que encarna a Acis y de la piel de Galatea: "al sonoro cristal, al cristal mudo" (v. 192). Además, el exceso de salinidad (v. 34) que estas poseen y la imagen de la peña (v. 23) podrían recrear también la muerte del joven siciliano y las lágrimas que vierte la nereida al presenciarla: "Con lágrimas la ninfa solicita / las deidades del mar, que Acis invoca; / concurren todas y el peñasco duro / a sangre que exprimió, cristal fue puro" (vv. 493-496).

${ }^{14}$ Coche allá o coche aquí: "Frase que se usa cuando se procura que los puercos, llamados también cochinos, entre en la pocilga o se junten con los demás" (Aut.).
} 
una por una todas* $\mathrm{y}^{*}$ engañando

la vista, que sospecha

que se tienen, y es que hacen la deshecha ${ }^{15}$

con que cuando del sol en los ardores

me asuran los calores,

y como el temor de que se caen me asombra,

yo no puedo parar a sol ni a sombra ${ }^{16}$.

Las calles son tan malas, que entendido

50 tengo que cuantas faltas hay, y ha habido

en ciudades y villas,

el tiempo las echó* por descubrillas

en estas calles solas,

donde al bajar los hombres como bolas

55

suelen venir rodando en su aspereza

y romperse a porrazos la cabeza,

pues al subirlas el que no desbarra

ha de menester andar una hora a garra ${ }^{17}$.

El templo, cuya puerta está en la plaza,

60 no es nada bueno, mas ni tiene traza,

y a pensar he llegado,

viéndole todo tan desbaratado,

que Jesucristo en él está aburrido

y por estar cerrado no se ha ido.

65 Los santos que allí están de devociones

yo no los puedo ver por figurones ${ }^{18}$,

porque al buscarlos graves y modestos

los hallo que están siempre descompuestos.

Hay de bulto una imagen y no creo

70 que Virgen sea, porque yo la veo

toda muy mal parada

y a poder de desuellos descarada.

Porque* son de los años y los días

tantas las groserías

$75 \mathrm{y}$ las fuerzas tan raras,

que se introducen a desuellacaras ${ }^{19}$.

En fin, Virgen de bulto fue en su origen,

${ }^{15}$ Hacer la deshecha; "Disimular" $(D L E)$. Esta expresión es usada también en los poemas atribuidos a Cornejo y Marchante "Oigan lo que saca en limpio" y "Clori, que para ser linda".

${ }^{16}$ Se trata de una combinación de dos frases populares "No parar" (pondera la eficacia viveza o instancia con que se ejecuta alguna cosa o se solicita) y "No dejar a sol ni a sombra" (perseguir a alguien a todas horas y en todo sitio). La expresión completa que aparece en el poema "No parar a sol ni sombra" se halla también en El Entremetido y la Dueña y el Soplón de Quevedo (Marañón, El Entremetido 62).

${ }_{17}$ Andar a garra: Es una acción que se relacionaría con estar en actitud vigilante o defensiva. Aparece también en los poemas atribuidos a Cornejo "Sueño jocoso" y "Un devoto singular".

${ }^{18}$ Se juega con el doble significado de la palabra figurón en la época. Esta, por un lado, podría hacer referencia a una figura de gran tamaño y, por otro, aludir al protagonista de las comedias de dicho nombre, que se caracterizaba por ser feo, de mala traza, "ridículo o pintoresco" (DLE).

${ }^{19}$ Se trata de una dilogía que puede hacer alusión tanto a un "barbero que afeita mal" como a una "persona desvergonzada o de malas costumbres" $(D L E)$. Esta última definición puede extrapolarse a los conceptos "mal parada" (v. 71) y “descarada" (v. 72), los cuales se asocian en el poema a la desfigurada estatua de la Virgen. 
mas ya no es más que el bulto de la Virgen ${ }^{20}$.

Y no la rezo, porque fuera insulto

80 que un hombre tan de bien rezara a bultos.

La torre es tan enana

que no sale del suelo, y la campana,

que dormir no me deja,

muy cascada está ya de puro vieja.

85 Y ten más otra mengua,

que tiene sobre vieja mala lengua ${ }^{21}$,

y parece al tocarla cada día

un cencerro de mayor cuantía.

Pues de una manga que en las procesiones

90 sacan, ¿qué diré yo ${ }^{22}$, que los calzones

imita* de la guarda de tudescos ${ }^{23}$,

que parece que todos los greguescos

y zaragüelles se han hecho de manga ${ }^{24}$,

para hacer una buena mojiganga ${ }^{25}$.

95 Pues la cruz es tan mala e indevota

que había de estar puesta en la picota.

Ya que tengo la iglesia bien pintada,

voy, Catuja, a pintarte mi posada.

Por huéspedes hallé (qué buen despacho ${ }^{26}$ )

100 desposada una mula con un macho,

que me hospedaron (de ellos no me quejo)

de voluntad con todo su aparejo ${ }^{27}$.

Un niño de pintarte se me queda,

solo por no decirte algo que yeda,

105 porque a mi obligación mucho desdice

que diga yo la caca que él no dice;

en fin, el tal muchacho tiene bríos,

para hacer sus mandados, no los míos.

La cena cuidadosos previnieron,

110 pan de para buen hambre ${ }^{28}$ me pusieron,

\footnotetext{
${ }^{20}$ Se recalca el deterioro del lugar a través de la evolución de la figura de la Virgen. Esta pasa de ser una estatua de piedra o de madera de la Madre de Dios (v. 76) a ser una escultura sin formas delimitadas y apenas reconocibles (v. 77).

${ }^{21}$ Mala lengua: "Persona murmuradora o maldiciente" $(D L E)$.

${ }^{22}$ Podría tratarse de una alusión al laude "¿Qué diré yo, miserable?”.

${ }^{23}$ Se compara el adorno que cae de la cruz "manga" con el holgado uniforme de la guardia imperial alemana, que constaba de librea, calzas, medias, sombrero y capotillo.

${ }^{24}$ Hacer de manga: Se trata de una expresión que se utiliza en sentido peyorativo para indicar que algo se ha hecho "para el mismo fin" (DLE).

${ }^{25}$ El carácter lúdico de la mojiganga hacía que sus protagonistas fueran vestidos con todo tipo de ropajes y disfraces estrafalarios. El personaje carnavalesco que, al parecer, dio origen a este género era el bojiganga o mojarrilla. Este es descrito en el capítulo once de la segunda parte de El Quijote (Cervantes s.p.) como un "demonio bailador de vejigas", por su aspecto de bufón enloquecido y por llevar un palo con vejigas de vaca.

${ }^{26}$ Se trata de la reformulación de la frase adverbial "Gentil despacho" con la que "se significa la queja y sentimiento que causa una respuesta áspera, o frívola resolución, en caso que merecía lo contrario" (Aut.). ${ }^{27}$ Se juega con el doble significado de "aparejo", para señalar tanto el arreo que llevan las mulas (v. 100) como para aludir a la disposición de los huéspedes "de voluntad" (v. 102).

${ }^{28}$ Remite el dicho popular "Para buen hambre, no hay pan duro", que señala que cualquier alimento es bueno para el que se halla hambriento.
} 
y aunque de buena gana ${ }^{29}$ me lo daban, dije que para qué me lo enduraban.

La huéspeda me dijo: "¿Somos santos?

Si eso, padre ${ }^{30}$, no come, muerda cantos ${ }^{31}$ ".

115 Para mis dientes (dije) gentil medra, qué más tiene morder de un pan de piedra.

"Tráigame, por su vida, un pan casero, que este es pan de monte, y no le quiero". Pusiéronme después, viéndome mozo,

120 de mansísima oveja un bravo trozo, y de haber dicho bravo no me mudo, porque aunque era de oveja, era muy crudo; y que lo asaron pienso demoniazos, según estaba negro a tizonazos.

125 ¡Pues el vino!, por Dios, que al más modesto le hiciera hacer un gesto, y aunque era la sed mucha que tenía, beberlo temeroso no quería, porque a la sed y a mí no nos matara;

130 y volviendo la cara de un crucifijo dije a una pintura:

"Pase de mí este cáliz de amargura", que pues mi dura suerte así lo fragua, yo haré buen pecho y echáreme al agua".

135 Lleváronme a acostar, ¡oh cómo siento el haber de pintar el aposento!, porque quisiera, ya que son tan raras, pintarte estas verdades a las claras ${ }^{33}$, y el errar es forzoso la pintura,

140 si no la pinto en sombra muy oscura. Este aposento, pues, en que me hundo es el culo del mundo ${ }^{34}$, porque si adonde el sol a nadie ha dado, es en sentir del vulgo el hojaldrado;

145 este sitio a la luz es tan extraño que nunca le da el sol en todo el año. Está, para que [en]* todo malo sea, al amor de la lumbre y chimenea,

${ }^{29}$ Hacer una cosa de buena gana: "Hacerla con gusto y voluntad" (Aut.). La expresión se asocia también con "buen hambre" (v. 110).

${ }^{30}$ Parece ser una nueva autorreferencia (v. 13). Cabe señalar que la mayoría de manuscritos que recogen la obra del obispo palentino, aparecen atribuidos al "padre Cornejo".

${ }^{31} \mathrm{La}$ acción de morder trozos de piedras "cantos" y la negación de la huéspeda de servir un pan blando al protagonista se pueden relacionar con la expresión "Duro como un canto", que "da a entender y compara la dureza de alguna cosa o la porfía y terquedad de alguna persona en deponer su juicio y también en dar nada de lo que se le pide" (Aut.).

${ }^{32}$ Se trata de una alusión al evangelio de Marcos (10, 35-45), donde Jesucristo advierte a los apóstoles que quien desee estar a su lado cuando alcance la Gloria deberá beber también "del cáliz de amargura". Es decir, tendrá que pasar por todos los padecimientos que él sufrió.

${ }^{33}$ A las claras: Expresa algo que se puede diferenciar "con toda distinción y claridad" (Aut.). Además, esta formas es utilizada para servir de contrapunto cromático de "sombra muy oscura" (v. 140).

${ }^{34}$ El culo del mundo: Frase popular empleada para "indicar un lugar muy lejano" (DLE). 
y cada instante se me sube el humo, con tener yo pachorra ${ }^{35}$, y me consumo de verme tal y en tan notable exceso, que he de salir de aquí morcón profeso ${ }^{36}$. Hácese en él también junta prolija de toda sucia y mala sabandija:

155 hay ratones alanos, que a las orejas tiran inhumanos, mas ya, como me faltan las guedejas, en unas fundas meto las orejas, porque son tan glotones,

160 que, aunque las mías fueran orejones, para una tarascada fuera una de ellas la menor tajada. Vense también aquí descomunales chinches frisones, pulgas garrafales ${ }^{37}$, 165 que, cuando en la quietud del sueño asaltan, unas asustan, otras sobresaltan; la ocasión de hacer mal jamás la pierden, estas pellizcan y las otras muerden.

Este es el aposento y sus alhajas,

170 mira si es malo; pues la cama, pajas. era la tal un jergonazo* en cerro $\mathrm{y}$ en viéndola me puse como un perro ${ }^{38}$, solo por ajustarme cuerdo en algo, pues la cama es como para un galgo.

175 Eran calvas las mantas, no peludas $\mathrm{y}$, después que dejaron ser lanudas, descubrieron, atrechos carcomidas, una hilaza muy mala de raídas. Las sábanas, que pueden ser eternas, 180 tenían, aunque gordas, malas* piernas, porque buenas y gordas no lo he visto en sábanas jamás, ¡por Jesucristo! $!^{39}$, que las tales no pierden por delgadas, sino* por gordas y por mal hiladas.

185 Tengo, pared en* medio, por vecino un prójimo o pollino,

\footnotetext{
${ }^{35}$ Se trata de una enfermedad que afecta al "flema", que es uno de los cuatro humores en que la medicina antigua dividía los "licores" del cuerpo humano. Este humor era de "naturaleza fría y húmeda. Criase principalmente en el estómago, y aumentase en el invierno, y con los manjares fríos y húmedos, difíciles de cocer y pegajosos" (Aut.).

${ }^{36}$ La continua exposición del protagonista (un profeso) al humo de la chimenea le permite establecer una comparación entre él y los morcones, los cuales se someten al proceso de ahumado.

${ }^{37}$ Se conforman una serie de hipérboles para mostrar el gran tamaño de los animales e insectos que campan por la habitación. Los ratones se equiparan a perros alanos (v. 155), los chinches son corpulentos como los caballos frisones (v. 164) y las pulgas alcanzan las dimensiones de las cerezas (v. 164).

${ }^{38}$ Ponerse como un perro: "Frase vulgar con que se significa que alguno se enoja, irrita y enfurece con facilidad" (Aut.).

${ }^{39}$ Sirve como alusión al sudario que cubrió a Cristo tras su muerte. La construcción en Turín de la capilla de la Sábana Santa (1668-1694) es coetánea a la etapa de madurez de fray Damián y, por tanto, también podría ser una referencia a esta.
} 
que a patadas el sueño me atropella; y lo que más me aflige y me degüella es que entona un rebuzno tan inmenso

190 que no puedo aplacarle ni por pienso. Acompaña[a]* sus voces de ordinario un puerco gruñidor, ¡qué buen canario!, aunque me lisonjea en algún modo, porque al fin, como yo, lo gruñe todo.

195 Por esto que aquí tengo referido, con el gustoso sueño tan reñido ando, y llegan a tanto mis enojos que no puedo mirarle de mis ojos; buscarle suelo, y es para notado

200 que esté con él reñido y no encontrado; y no me he visto como estoy (es cierto), menos vivo jamás ni más despierto. Esto de noche paso, que de día aún lo paso peor, por vida mía.

205 Del comer, a la hora señalada, hallo una mesa muy desmantelada, puesto que lo que sirve de manteles unos andrajos son con arambeles; mas con estar bien falta de comida,

210 es (si la vieras) mesa proveída: el aderezo todo monta un clavo, hay un cuchillo malo por el cabo. Para el vino una jarra degollada, que en un tiempo fue blanca y vidriada,

215 mas ya de sarro está tan asquerosa que con costras parece una sarnosa. Un vaso de alto borde maltratado, donde bebo, y no es vicio, muy penado; de alcornoque un salero,

220 donde porque la mano un majadero no le sentó a la sal*empedernida, esta vez, se escapó de ser molida. Un pan, que aún el cuchillo empedernido resiste fuerte y no se da a partido,

225 y si a morderle hay alguien que se aliente, ha de ser muy valiente por el diente, que son sus canterillos susto de muelas, ruina de colmillos. A esta mesa sentado, mal cocida

230 una olla podrida me ponen siempre, porque me consuele, y llamela podrida, porque suele traer la tal (no es risa) unos olores no de buena guisa.

235 En tazas, que pudieran por groseras tener todos los votos para horteras, 
el caldo me administran, no lo abono, pero peca de flaco, y le perdono todas sus faltas, que es en fin nobleza

240 saber disimular una flaqueza.

De la ración el plato no es pequeño, antes tiene resabios de barreño, donde viene de ajaros grande suma con otras suciedades como espuma.

245 Tanto troncho de berza, que imagino, cuando a comer la olla no me inclino, que es causa y muy bastante el hacerse de pencas ${ }^{40}$ la bergante. Buscaba entre las berzas el tocino

250 y no le hallando púseme mohíno; conociolo la huéspeda y me dijo: "Qué busca, señor, con tanto agraman", dijo, "Pues si busca el tocino, no en mis días, que no echamos acá esas porquerías".

255 Si alguna vez la pido un guisadillo (asco me da el decillo), salen de aquellas manos, siempre avaras, el ajo espeso y las tajadas claras.

Esto en casa se pasa (pero espera),

260 contaré lo que pasa por de fuera. El día de san Roque ${ }^{41}$ hubo novillos, y de bravo choque, pusiéronme en la plaza en muy buen puesto, mas con mala traza

265 El cura y yo, con otros clerizones, veíamos los novillos faetones.

La barrera la hicieron con gran treta, pues era una viejísima carreta.

Sacaron un novillo ceniciento ${ }^{42}$

270 (puedes creerme, Catuja, que no miento) arremetiole al carro con fiereza que clérigos y cura de cabeza dieron en aquel suelo, y quedáronse fríos como un hielo.

275 Solo yo, como fuerte y animoso, en las ruedas me puse con reposo; oliome, como suele a los cabestros,

${ }^{40}$ Hacerse de pencas: "No consentir fácilmente en lo que se le pide, rehusar lo mismo que desea" (Aut.).

${ }^{41}$ San Roque se celebra el dieciséis de agosto, mes que da título al poema. En esta festividad, en la comarca de la Vera (donde se sitúa el pueblo de Madrigal de la Vera), es tradición realizar festejos taurinos y desfiles de personajes grotescos.

${ }^{42}$ La asociación de los bravos novillos con la figura de Faetón (v. 265) y la aparición de un novillo de color ceniciento (v. 268) podrían ser una nueva alusión a la poesía de Góngora. El poeta cordobés en la décima "Cristales el Po desata" (Góngora s.p.), basada en el final del mito de Ovidio, equipara dicha divinidad con un toro "sañudo" (v. 6), el cual termina convertido en "fulminada ceniza" (v. 9). 
y me dijo entre dientes: "De los nuestros"43.

Pues pudiendo matarme,

280 lo que hizo el novillo fue usarme.

Te lo cuento por si acaso

capricornio me hacías del Parnaso ${ }^{44}$,

porque tal cortesía

no la he visto jamás, por vida mía.

285 Los hombres con quien trato son chanflones,

faltos de prosa, cortos de razones,

y de aquestas pienso se quedarán en blanco ${ }^{45}$,

si para hacerlas les faltara un banco

que sus pies les prestara;

290 traen zapato ramplón* con antipara

gallaruza y capa con*capilla

a lo de Sancho Panza y mojarrilla ${ }^{46}$.

De a jeme las orejas,

el pecho descubierto, y con guedejas

295 en dos haces las cerdas divididas,

los mostachos grasientos y caídos,

toscos y enmarañados los cabellos,

pues ¿las mujeres?, como para ellos.

Guardadas mucho, mejor obrarán

300 si de ellas se guardaran,

que son, aunque caseras,

con mandil y con tocas unas fieras,

sin que la edad las valga a las más niñas

porque son unos $\operatorname{cocos}^{47}$ con basquiñas.

305 Cuando salen de casa a lo modesto, la menos mala va muy puesta a gesto, y no falta quien salga a requebrarlas, aunque mucho mejor fuera a cascarlas*48. Traen con paños las caras abrigadas

310 y han menester echarlas en coladas ${ }^{49}$, si quieren las porconas

\footnotetext{
${ }^{43}$ El protagonista (parece ser el álter ego de fray Damián) no es herido por Faetón (hijo del dios del sol) por tratarse de un poeta. Cabe señalar que la identificación de Helios con Apolo "líder de las musas" se consolida en la época helenística.

${ }^{44}$ La constelación de Capricornio se vincula en la mitología griega con el dios Pan, que representa la naturaleza salvaje y el pánico que puede derivarse de los efectos de esta. El yo lírico le dice a su amada que no lo identifique con tal figura del Parnaso, pues esta también era conocida por su fuerte apetito sexual.

${ }^{45}$ Quedarse en blanco: "Frase que significa lo mismo que quedarse sin lo que se deseaba, no conseguir lo que se pretendía" (Aut.)

${ }^{46} \mathrm{El}$ vestuario rústico y estrafalario que presentan los aldeanos se asemeja al característico del mojarrilla (ver nota 25) y a la indumentaria de Sancho Panza. El escudero del ingenioso hidalgo lleva "abarcas que cerraban pies, algunas veces envueltos en peales, sayo jironado, caperuza peor que la del bobo, cuello basto y camisa de estopa, zurrón, tosco pellico y zamarro adobado con miera" (Astrana 120).

${ }^{47}$ Es un coco: "Frase vulgar con que se pondera y exagera que alguna persona es morena, fea u horrible en sumo grado" (Aut.).

${ }^{48}$ Se emplea como metáfora del coito.

${ }^{49}$ Se conforma un calambur entre la acción de blanquear "en coladas" y la de pegar algo "encoladas". Este último término se contrapone a "resquebrarlas" (v. 307) y "cascarlas" (v. 308).
} 
que salgan (si es posible) de tizonas ${ }^{50}$. El cabello, ni largo ni tendido, en sogas o maromas dividido,

315 y otras, aunque rabonas sus coletas, de par en par sus abultadas tetas.

El talle, a sus anchuras, que no quieren meterlo en apreturas, no sea que de justo u oprimido

320 reviente acaso o dé algún* estallido. Traen las basquiñas a lo de garzonas y las pezuñas se les ven frisonas $y$ aun a medio mogate ${ }^{51}$ unas calzas que traen de cordellate,

325 con las cuales, no es bulla, cada pierna parece una gran pulla ${ }^{52}$, mas, con ser estas calzas tan groseras, más de cuatro las tienen con goteras, pero son fuego malo en sus aliños, 330 goteras de canal $^{53}$, maestra de niños. En fin, niña* (ya escampa), todas las tales son gente sin trampa, cosa que me ha excusado más de un choque, porque donde no hay aros, no hay emboque ${ }^{54}$.

335 [Aquí al agosto vine y he quedado sin hacer agosto y agostado ${ }^{55}$ por lo que he referido, mas espero volverme en primavera, si no muero. Ruego, Catuja mía, más que a tus ojos, 340 vaya a volver en hora los enojos, que aquí me cansa todo cuanto veo. Y a Dios hasta que logre este deseo, que es solo el que templar hace mis males, y sírvete con estos madrigales]*.

\footnotetext{
${ }^{50}$ El consejo de echar "en colada" a una mujer para sacarla de "tizona" también aparece en el poema atribuido a Cornejo y a Marchante "María, a tu sucia cara".

${ }^{51}$ A medio mogate: Expresión que señala algo que se realiza "con descuido o poca advertencia en lo que ejecuta o sin la perfección debida" (Aut.).

${ }^{52} \mathrm{El}$ empleo de referencias a animales en las descripciones de mujeres, "porconas" (v. 310), "garzonas" (v. 320) o "pulla" (v. 325), fue una práctica recurrente en los retratos femeninos burlescos del Barroco. Marcella Trambaioli realiza un estudio contrastivo sobre su uso en las pinturas jocosas de Quevedo y de Lope (301).

${ }^{53}$ La comparación de una mala mujer con una gotera tiene origen bíblico. En los Proverbios (27, 15-16) se dice: "Gotera constante en día de lluvia y mujer rencillosa son semejantes. El que trata de contenerla es como refrenar al viento y recoger aceite con su mano derecha".

${ }^{54} \mathrm{La}$ ausencia de emboque "engaño" vuelve a recalcar la simplicidad de los habitantes de la aldea "gente sin trampa" (v. 331) y que evita conflictos y mentiras "choque" (v. 332). También podría ser otra referencia a cómo se celebraba el día de san Roque en la comarca de la Vera (Cáceres). En esta es tradición jugar a los "palillos", que es un juego similar a los bolos "emboque".

${ }^{55}$ Hacer su agosto: Frase que, además del sentido literal, indica "lograr alguna ocasión de utilidad considerable" (Aut.). Esta también es empleada en el poema atribuido a Cornejo y a Marchante "Un devoto singular".
} 


\section{Pintura a una dama (11) \&}

\section{Ovillejo}

Sepan, todos y todas ${ }^{56}$, que yo adoro

una niña bonita como un oro ${ }^{57}$,

que aunque pícaro, chulo y taimadazo, me sacudió Cupido un virotazo,

5 porque el dicho rapaz siempre se alaba de que al más pintado ${ }^{58}$ se la clava.

Aquesta, pues que ya me llenó el ojo ${ }^{59}$, si, ucedes ${ }^{60}$, por enojo no lo tienen, pintarla determino

10 (miren, ¡qué temerario desatino!), como si para ello sean bastantes ni Apeles ni Timantes ${ }^{61}$. Pero si fácil fuera, en quererla pintar que mucho hiciera.

15 Solo en el no saber ${ }^{62}$ está ahora el toque ${ }^{63}$,

\footnotetext{
${ }^{56}$ Cornejo confecciona un ingenioso monólogo (en el que hace partícipes y críticos a los lectores u oyentes) sobre el proceso creativo de una pintura de una dama. En ella, se expone con humor la relación entre arte, poesía y realidad y se parodia los desgastados modelos petrarquistas. Fray Damián toma como referente la Fábula de Apolo y Dafne de Polo de Medina y el retrato de una mulata del escritor murciano "Hoy hace justo un año, y cinco meses" (El buen s.p.). Estas y la presente composición poseen gran semejanza con el ovillejo "El pintar de Lisarda la belleza" de Sor Juana (Obras s.p.), quien también parece haber tenido como referencia para realizar su pintura las obra del creador de Ocios de la soledad. Resulta relevante señalar que a través de la Condesa Paredes la poeta mexicana pudo haber entrado en contacto con las poesías de Polo de Medina (Matas 91-110), de José Pérez de Montoro (Tenorio, Sor Juana y Pérez 665-675), de León Marchante (Tenorio, Sor Juana y León 543-561) y con las del cronista seráfico.

57 Ser bonito como un oro: Frase popular que tiene su origen en la representación del oro como un símbolo de riqueza, esplendor y perfección.

${ }^{58}$ Al más pintado: "Modo de hablar que significa lo mismo que al más sabio, al más hábil, prudente o experimentado" (Aut.). Esta expresión también es usada en los primeros versos de Fábula de Apolo y Dafne de Polo de Medina.

${ }^{59}$ Llenar el ojo: "Frase con que se da a entender que una cosa ha contentado mucho por parecer perfecto y aventajado en su especie" (Aut.). La imagen del ojo lleno asociada al amor se podría relacionar con las teorías del médico renacentista Marsilio Ficino (Serés 75). El filósofo italiano creía que los ojos eran canales por los que se introducían las "emanaciones" del ser amado y se unían a las del receptor para producir la transformación de uno en otro y viceversa. Esta solo se daba si se establecía una reciprocidad amorosa.

${ }^{60}$ La presente composición, la Fábula de Apolo y Dafne de Polo de Medina y "El pintar de Lisarda la belleza" de Sor Juana intentan involucrar al público en la creación de su jocosa pintura mediante el apóstrofe a la segunda persona del plural. No obstante, la escritora mexicana y Cornejo optan por la forma "ucedes", mientras que el poeta murciano elige "ustedes".

${ }^{61}$ La referencia a Apeles y a Timantes, dos pintores destacados de la Antigua Grecia, parecer ser un guiño a la silva "Y el famoso español, que no hablaba" (Cacho, Quevedo s.p.), donde Quevedo realiza un extenso elogio de las pinturas de algunos autores españoles. En ella, se dice que las creaciones de Pablo de Villafañe "no igualaran Apeles ni Timantes" (v. 43). Cabe señalar, además, que Polo de Medina (El buen s.p.) hace referencia a este último en el retrato que dedica a la mulata: "viéndote retratada de la mano / de tu galán Apeles" (vv.91-92).

62 Otra similitud con la poesía citada de Sor Juana se halla en la falta de experiencia en el arte de la pintura que el yo lírico manifiesta al inicio del poema: "sin haber en mi vida dibujado" (v. 7).

${ }^{63}$ Se trata de una dilogía. Por un lado, puede hacer aludir a una "prueba, examen o experiencia" y, por otro, indicar la recepción del "auxilio o la inspiración de Dios" (Aut.).
} 
mas yo la he de pintar choque o no choque ${ }^{64}$; aunque me afligen muchas confusiones, si echaré por el rostro o los talones.

Mas, ¿por qué dificulto? ${ }^{65}$

20 ¿Es más, señores, que pintar a bulto ${ }^{66}$ ?

Y si algún mentecato me murmura*67 que es sin pies ni cabeza ${ }^{68}$ esta pintura, le diré: "Majadero, yo soy pintor y pinto como quiero"69.

25 Fuera de que sería buena historia hacer yo de mi dama pepitoria.

Mas por seguir el [más]* común torrente, y dar un tapaboca al maldiciente, por la cabeza mi pintura empieza

30 (iqué lindo quebradero de cabeza! ${ }^{70}$ ), Y al empezar así me da desvelo, pues es forzoso aquí el andar a pelo ${ }^{71}$; mucho este yerro siento, mas, ¿de qué me arrepiento?,

35 si aunque más los cabellos la pintara, en pelillos ninguno ya repara ${ }^{72}$, y si lo sé de algunos bobarrones, calvos los he de hacer a repelones ${ }^{73}$, porque nadie se atreva en este suelo a ofender mi pintura ni en un pelo ${ }^{74}$. Mas dejo riñas, y a mi pelo vuelvo,

${ }^{64}$ Se interpreta en el sentido metafórico del "golpe que causa la admiración o el eco que hace al entendimiento una buena razón, oída o leída, sin antecedente premeditación" (Aut.).

${ }^{65}$ Polo de Medina en su citada fábula de Apolo y Dafne también cuestiona las confusiones que le plantea empezar el cómico retrato de la ninfa: "pero ¿cómo los versos dificulto?, / ¿cómo la vena mía se resiste?” (vv. 5-6).

${ }^{66}$ El gusto por los "borrones" se atribuye a Tiziano y pone de manifiesto la creencia de que solo estos dan la auténtica versión de lo vivo. Las "pinceladas gruesas” para los artistas barrocos son las más adecuadas para captar lo inacabado, lo variable, lo inestable del hombre y de la vida (Maravall 513).

${ }^{67}$ El yo lírico considera que quien juzgue negativamente su retrato será un "mentecato", igual sucede en la pintura citada con anterioridad de Sor Juana: "Que siempre el que censura y contradice / es quien menos entiende lo que dice" (vv. 97-98).

${ }^{68}$ Sin pies ni cabeza: "Sin sentido" (DLE).

${ }^{69}$ La libertad creadora que manifiesta el sujeto poético a la hora de retratar a la dama también está presente en el ovillejo de la poeta novohispana: "Yo tengo de pintar, dé donde diere, / salga como saliere" (vv. 20 21). Fray Damián y Sor Juana se rebelan contra la imitatio clásica y defienden su capacidad de invención, otorgando a la mujer características distintas a las del desgastado imaginario de la tradición petrarquista. Juan Mata (91-110) analiza en profundidad los atributos que la religiosa atribuye a Lisarda y los compara con las descripciones femeninas que hace Polo de Medina en los poemas citados previamente.

${ }^{70}$ Quebradero de cabeza: Se trata de una dilogía que juega, por un lado, con el significado literal de la expresión "lo que la molesta, fatiga, cansa e inquieta" y, por otro, con el metafórico "el objeto del cuidado amoroso" (Aut.). Esta expresión es empleada en otros poemas atribuidos a fray Damián y Marchante: "Pues vuestra piedad me abriga" y "Oigan lo que saca en limpio".

${ }^{71}$ A pelo: "Vale también a tiempo, a propósito de una ocasión" (Aut.).

${ }^{72}$ La imagen de la dama sin pelo también se halla en el retrato que Sor Juana hace de Lisarda: "y calva está de haberla repelado / y así en su calva lisa / su cabellera irá también postiza” (vv. 172-174).

${ }^{73}$ A repelón: "Modo adverbial con que se explica que una cosa se está tomando o disipando poco a poco" (Aut.).

${ }^{74}$ Ni un pelo: "Absolutamente nada" (DLE). 
y a decir me resuelvo

que es mi ninfa ${ }^{75} \tan$ linda $[\mathrm{y}]^{*} \tan$ briosa

que de pelo le nace el ser hermosa;

bravo concepto dije con ser rudo ${ }^{76}$

y que no pecara por peliagudo ${ }^{77}$.

En sus bellas orejas,

fuera de que las cubren las guedejas,

no pretendo gastar mis pinceladas

50 por no hacer de mis musas $\operatorname{arracadas}^{78}$;

y no piensen* que ignoro la manera

de pintar su beldad, que yo dijera,

viendo su compostura misteriosa,

que son de la belleza cosicosa ${ }^{79}$;

55 bien pudiera alabarlas de otro modo,

pero no me acomodo,

porque no quiero sepan, he advertido,

lo que puedo decilla yo al oído.

Ya a la frente he llegado presuroso

60 y supongo lo terso y espacioso,

y en ella quiero, pues está a mi cargo,

darme tantas en ancho como en largo;

digo, pues, de ella en un concepto llano ${ }^{80}$,

como buen castellano,

65 que la prueba mayor de su belleza

es dejarse ver siempre con llaneza.

Mire, quien censurare mis razones,

si hallara en mis conceptos tropezones.

Ya en las cejas estoy, pero no quiero

echar por el camino carretero ${ }^{81}$,

que me será forzoso

decir que cejé atrás su presuroso

75 Se trata de un equívoco que puede adquirir tanto el significado de "joven hermosa" como el de "prostituta". En poemas atribuidos a Cornejo, como "Del rumbo de Francelina" y "Yo soy, ilustre Academia", también se juega con tal ambigüedad. Félix Cantizano (154-175) dedica un artículo a analizar la resemantización del término "ninfa" en la poesía de los Siglos de Oro.

${ }^{76}$ El concepto "rudo" que es suprimido en los manuscritos cotejados y que aparece en $R$ es "gozar de sus madejas", que podía tener connotaciones eróticas y evocar también la picante Novela de las madejas de Melchor de la Serna. A continuación, se incluyen los cuatro versos del testimonio $R$ en los que este se integra: "y no le pinto que, aunque está a mi cargo, / es quererlo tomar muy a lo largo. / Basta decir, mirando sus guedejas, / que bien puede gozar de sus madejas".

${ }^{77}$ Se trata de una dilogía que juega con el significado de "tener el pelo largo" y con la habilidad de alguien de ser "sutil o mañoso" (DLE).

${ }^{78}$ Se emplea el término "arracadas", relacionado con los pendientes de las orejas, en el sentido de "hijos pequeños que le quedan a las viudas" $(D L E)$, para resaltar que el yo lírico no quiere que sus musas queden "huérfanas" y no puedan seguir indagando en nuevos cauces expresivos.

${ }^{79} \mathrm{La}$ "cosicosa" hace referencia a un enigma difícil de resolver (Cov.). La asociación de la belleza femenina a este tipo de incógnita también es recreada por Sor Juana en las coplas "Qué cosa y cosa, Pascual" (Obras 245): "vi una mujer tan hermosa / que parece cosi-cosa" (vv. 19-20).

${ }^{80}$ Se establece una conexión entre la "llaneza" de la frente de la dama y el estilo sencillo con el que se desarrolla el poema. Sor Juana sigue la misma estrategia que Cornejo al proclamar "y bájese a la frente mi reparo; / gracias a Dios que salgo a lo claro, /que me pude perder en su espesura, / si no saliera por la comisura" (vv. 185-188).

${ }^{81}$ Representa para los poetas el camino que recorre Apolo (líder de las musas) con sus caballos. 
curso de mi venilla caminante ${ }^{82}$, y yo quiero pasar más adelante.

75 Vaya, pues, si mi musa no se aleja, un conceptillo de entre ceja y ceja ${ }^{83}$; estas dos, por opuestas, se hacen puntas ${ }^{84}$, y así no las verán entrambas juntas, y está la división muy acertada,

80 porque la hubieran hecho ya cerrada.

Ya el llegar a los ojos me da enojo, pues me obliga el dibujo a abrir el ojo ${ }^{85}$ yo tengo con los ojos ojeriza ${ }^{86}$, porque si se desliza

85 una pluma, y escribe un desacierto, hará a la ninfa, o ninfo, tuerta o tuerto; y dirá quien no sabe hacer endechas: "Este nunca pintó cosa a derechas". Pero [por]* qué me aflige

90 lo que el otro dirá de lo que dije, que si mis versos muerde el tontiloco, si le doy qué roer, no hago muy poco. Mas dejemos enojos, y algo bueno digamos de los ojos;

95 son sus niñas (¡qué brava bobería hacer reparo en una niñería!, mas no importa que ahora las alabe, que en niño asunto gran concepto cabe), son sus niñas traviesas ${ }^{87}$, en efecto,

100 y aborrecen también cualquier aprieto, y así, para lograr sus travesuras, andan toda la vida a sus anchuras; bien pudiera decir (pero no quiero) algo de lo de estrellas y lucero ${ }^{88}$,

105 porque a mí se me hicieron siempre ariscas,

\footnotetext{
${ }^{82}$ Fray Damián defiende con humor el ingenio poético (frente a la imitación clásica) a través de diversas alusiones a sus musas (v. 50 y v.75), a Febo (v. 70) y a su vena creativa (v. 74 y v. 170). Lo mismo hará Sor Juana en su retrato a Lisarda. Como señala Juan Mata (94), "basta con observar en estos versos la invocación a la 'musa' (v.12), o las alusiones a 'la vena' (v. 35), la 'locura' o la propia 'tentación' (v.14) del 'diablo' (v.11), para confirmar su inclinación a favor de la tradición del ingenium poético”.

${ }^{83}$ Tener algo entre ceja y ceja: "Tenerlo como pensamiento o propósito fijos" (DLE).

${ }^{84}$ Hacer punta: "Contradecir con tesón la opinión de otros" (Aut.).

${ }^{85}$ Abrir el ojo: "Estar advertido para que no le engañen" (DLE).

${ }^{86} \mathrm{La}$ estrecha vinculación que se establece entre los ojos y los enojos (por manifestarse en ellos la ira) se halla en el retrato de Lisarda que hace Sor Juana (vv. 219-220) y en el de Polo de Medina (El buen s.p.) de una mulata (vv. 157-158).

${ }^{87}$ El poeta murciano, en la pintura de un galán a su dama mulata, también utiliza la imagen de las niñas traviesas "pupilas" con el propósito de romper con la visión idílica de la amada: "dos enlutados ojos con dos niñas, / de quien son cuatro párpados basquiñas, / que con travieso estilo / al sesgo miran siempre y nunca al hilo" (vv. 179-182).

${ }^{88}$ Cornejo, al igual que hace Polo de Medina en su Fábula de Apolo y Dafne (vv. 117-123), se mofa de la tradición idealista de comparar los ojos con elementos celestes. La metáfora de estos como estrellas también es tratada con humor por Sor Juana en su pintura de Lisarda: "pues ya no os puede usar la musa mía / sin que diga, severo, algún letrado / que Garcilaso está muy maltratado" (vv. 56-58).
} 
tan agudas que van echando chispas.

La nariz con bellísimos matices ${ }^{89}$

(aunque yo entiendo poco de narices)

es blanca y afilada;

110 allá va este concepto que no es nada.

$\mathrm{Y}$, por mi fe, que dudo

que ninguno le diga más agudo,

afilado lo han dicho hasta hoy muy pocos,

no sé si el conceptillo tiene mocos

$115 \mathrm{y}$, si los tiene, no me da cuidado, pues vendrá a ser con eso más sonado ${ }^{90}$.

A la boca he llegado con la prisa

(Jesús, señor, iqué tentación de risa! ${ }^{91}$ ),

es su boca, o boquita,

120 donosita, bonita y tamañita;

que yo no tengo a manos

otros dichos que sean más enanos;

sus colores corales merecían,

pues a pedir de boca ${ }^{92}$ le venían.

125 También pide claveles ${ }^{93}$ a montones, mas para que abreviemos de razones, digo de ella (y no piensen que soy loco) que digo mucho, con decir muy poco; de su aliento* sé, por cierta ciencia,

130 que no faltan halos en mi conciencia. Los dientes no los pinto, y dejo tan confuso laberinto, que no es pintura de chacota aquesta que enseñando los dientes está puesta,

135 fuera de que no tengo por decencia detenerme a pintar tal menudencia. Olvidadas*[dejaba]* las mejillas, que a las mil maravillas por sus vivos colores

140 jardín parecen de vistosas flores ${ }^{94}$, y así el jazmín y rosas encarnadas más nacidas le vienen que pintadas. Para la barba, aquí saber quisiera

${ }^{89}$ Fray Damián toma esta frase de la Fábula de Apolo y Dafne del poeta murciano (v. 100), pero se aleja de su modelo para plantear el uso de un concepto inusual asociado a las narices largas.

${ }^{90}$ Se establece una dilogía que alude tanto al hecho de algo que se "menciona o se cita" como a la acción de "limpiarse los mocos" (DLE).

${ }^{91}$ Se trata de una reescritura de la frase que Polo de Medina (Fábula s.p.) utiliza para retratar las mejillas de Dafne: "Jesús, señor, iqué tentación de rosas!" (v. 77).

${ }^{92}$ A pedir de boca: "Frase para expresar que una cosa viene ajustada, cabal, muy a tiempo y a medida del deseo" (Aut.). En la descripción que el poeta murciano realiza de la boca de la ninfa, donde también se remite a los claveles, se emplea esta misma estructura (v. 66).

${ }^{93} \mathrm{La}$ relevancia que adquirió el clavel en la poesía barroca, a partir del uso que de él hizo Góngora, es analizada por Javier de la Peña (93-110).

${ }^{94}$ Fray Damián hace referencia a la multitud de coloridas plantas y flores que simbolizaban en la lírica de corte idealista a las mejillas de la mujer y que son recogidas por Polo de Medina (Fábula s.p.) en la pintura de un galán a una mulata (vv. 210-239): grana, jazmín, rosas, ébano, clavel y mosquetas. 
si alguna de las musas es barbera,

145 y si no, aquí me quedo,

que lo que no sé hacer, hacer no puedo,

aunque a mí solamente me compete,

por si me hace después ella el copete.

La garganta, señores, y los pechos

150 denlos por bien pintados y bien hechos

que, pasando a las manos de este tranco,

me los pienso dejar todos en blanco ${ }^{95}$;

$\mathrm{y}$ aunque decir pudiera

que son de nieve, es una friolera ${ }^{96}$,

155 fuera de que es tan linda la pintada

que no puede ofenderla el sol en nada,

y si de nieve fuera construida,

viéramos la muchacha derretida;

cosa que su belleza no permite,

160 pues si el sol se la mira, se derrite.

De sus hermosas manos, en* el campo

etíope bozal parece el ampo

y, así, por lo de sol y torneadas,

me parece que son tornasoladas

$165 \mathrm{y}$, aunque aquestos son dichos triviales,

no lo pierden aquí por manuales ${ }^{97}$.

El talle no le pinto, que es desaire

echar sin para qué versos al aire ${ }^{98}$;

$\mathrm{y}$, así, en el ancho mar de esta hermosura

170 se engolfa en buscar pie* mi vena dura;

ya di con él, y fue ventura rara,

que temí que por poco no le hallara;

él es un pie meñique*

de alcorza o de alfiñique,

175 y está tan encogido el tal menino

que parece novicio capuchino ${ }^{99}$,

y si la vista piensa que le siente ${ }^{100}$,

\footnotetext{
95 Dejar en blanco: "Es dejar sin escribir alguna parte o cosa que debía estar escrita" (Aut.).

${ }^{96}$ Este concepto se halla también en la descripción que hace Sor Juana de las manos de Lisarda: "que es la una mano como la otra mano. / Y si alguno dijere que es friolera / el querer comparar de esta manera" (vv. 346-348).

97 Se juega con la dilogía de la palabra "manual" al señalar tanto al retrato de las manos que se está realizando como a los tópicos clásicos que se utilizaban para describirlas. Se incluye como ejemplo la metáfora del "ampo" (v. 162), la cual se hiperboliza y se parodia al decir que la blancura de sus manos es tal que este a su lado es del color de un esclavo de Etiopía (v. 162).

${ }^{98}$ Echar al aire: "Vale descubrir o desnudar alguna cosa" (Aut.).

${ }^{99}$ Los integrantes de los Hermanos Menores de la Vida Eremítica procuran tener una vida austera y contemplativa. Su deseo de llevar el recogimiento del alma al extremo podría asociar su imagen a una posición encogida del cuerpo y, por tanto, de poca estatura.

${ }^{100}$ Polo de Medina en su retrato de Dafne (Fábula s.p.) también realiza una hipérbole del pie pequeño de la dama (ideal de belleza renacentista), recalcando que ni siquiera es perceptible al oído y a la vista: "nunca ha sido este / pie visto ni oído" (v. 41). Sor Juana trata el tema en su pintura de Lirsarda, pero solo involucra al sentido de la visión: "el pie yo no lo he visto, y fuera engaño retratar el tamaño" (vv. 361-362).
} 
miente la vista, y el sentido miente ${ }^{101}$, y cuando en dudas o en verdades lucho, sin poderle yo ver, le quiero mucho ${ }^{102}$

Que aquesto aquí se quede es ya forzoso, que es el señor poeta vergonzoso y no quiere pasar más adelante, por no encontrarse con el guardainfante.

185 Basta decir que aquesto es un bosquejo ${ }^{103}$ de esta beldad, y con decir lo dejo, que hay del original a este traslado lo que va de lo vivo a lo pintado ${ }^{104}$.

\section{Otra pintura a una ausencia de una dama (17) \#}

\section{Sexta lira}

Desde que el sol ardiente su luz desata y su dorado coche conduce al Occidente, donde en lúgubres sombras de la noche

5 oscurece su fúlgida madeja ${ }^{105}$, [ni dejo el llanto ni el dolor me deja]*.

De mí, ausente querida ${ }^{106}$, la privación y ausencia siento tanto que el alma enternecida,

10 en lágrimas deshecha y vivo llanto, para buscarla, en líquidos despojos, se asoma a las ventanas de mis ojos ${ }^{107}$.

\footnotetext{
${ }^{101}$ Podría tratarse de un alusión a la teoría del saber sensible que proclamaba Descartes y que se basaba en desconfiar de la percepción sensorial. Esta sería un foco de engaños y, según la "duda metódica", tendría que ser rechazada para poder alcanzar la verdad.

${ }^{102} \mathrm{El}$ amor ciego que manifiesta el yo lírico hacia el pie de la dama puede compararse con el sentimiento que san Agustín, en el capítulo cuarto de Amor de Dios (s.p.), decía que se debía tener hacia Dios. La belleza suprema del creador debía ser admirada y querida, aunque no fuera visible, pues él ha otorgado la vida y los sentidos al ser humano y también su afecto: "Él no ha querido aún descubrirse ante ti; pero te ha enviado sus dones, te ha dado las arras, como prenda de amor y señal de su predilección. Si pudieras conocerlo, si vieras su hermosura, no dudarías jamás".

${ }^{103}$ Sor Juana califica su retrato de Lisarda como un "borrador" (v. 160).

${ }^{104}$ La pintura para los escritores barrocos era un medio para reformar y rehacer lo dado por la naturaleza. La intervención del artista en este proceso de captar la realidad introducía "un elemento nuevo, haciendo del modelo otro de lo que ante su personal observación se ofrece" (Maravall 515). Polo de Medina (El buen s.p.), en los versos finales de su pintura de una mulata, también intenta justificar las diferencias que puede haber entre esta y la dama que sirve de referente para el retrato: "Las faltas me perdona, / que por ellas remito / al vivo original todo lo escrito" (vv. 317-319).

105 La presencia del carro del Dios-sol permite establecer dos campos semánticos contrapuestos. Por un lado, el asociado al astro rey (ardiente, luz, dorado y fúlgida madeja) y, por otro, los vinculados a la oscuridad (lúgubres, sombras, noche y oscurece).

${ }^{106}$ El tópico petrarquista de la ausencia del amado tuvo una larga tradición en la lírica española gracias, primero, a los versos de Garcilaso de la Vega y, más tarde, a los de Herrera, Góngora, Cetina, Figueroa o Barahona de Soto. Jesús Ponce Cárdenas (39-44) realiza una rigurosa revisión de la canción de ausencia en esta.
}

107 Ver nota 59. 
En pensar solamente

que de mi vida vivo separado ${ }^{108}$,

el corazón, en lágrimas deshecho ${ }^{109}$, arrancarse pretende de mi pecho.

¡Ay, infeliz estrella,

20 siempre conmigo fuisteis rigurosa!

Pues a mí, Anarda bella ${ }^{110}$, ¡de mi vista quistaste cariñosa!

Siempre fuiste a mi mal* firme y constante,

[siempre a mi bien mudable, siempre errante]*.

¡Oh fiera suerte mía!

$¡$ Oh destino infeliz del hado injusto!

¡Oh dura tiranía ${ }^{111}$ !

¡Oh privación amarga de mi gusto!

Si he de vivir muriendo de esta suerte ${ }^{12}$,

menos rigor, sin duda, es darme muerte.

Yo sin mí Anarda ¡cielos!

Perder el juicio ${ }^{113}$ de dolor es poco,

pues hallan mis desvelos

que en perder [solo]* el juicio no estoy loco;

antes por ser amante, siendo cuerdo,

pierdo la vida y el sentido pierdo.

108 Platón concebía el amor como un "restaurador" de la antigua naturaleza humana que intenta hacer uno solo de dos. Esta teoría la expone en un par de diálogos. En El banquete, sostiene que los amantes "salen de sí mismos" para formar una unidad indiferenciada con el objeto de su amor, mientras que en El Fedro desarrolla el mito de los caballos alados y el auriga (simbolizan las tres almas del hombre) con el propósito de explicar el proceso del enamoramiento (Serés 15-18).

${ }^{109}$ Él corazón se considera desde la antigüedad clásica la fuente de la que emanan las pasiones. La idea de que de él brota el amor en forma de lágrimas, presente en la Odisea, se convirtió en un tópico en el periodo aurisecular, que servía para mostrar el sufrimiento que causa el amor y la incapacidad del lenguaje para captar este.

${ }^{110}$ El apóstrofe "Anarda bella" es una referencia al sexteto en liras "Quien quiere nueva arte" de Quevedo (Las tres 45), donde se trata el dolor que sufre el galán por la ausencia de la amada. Tal situación le lleva a reflexionar, como sucede al protagonista del presente poema, atribuido a Cornejo y a Marchante, sobre el vínculo que le une a su otra mitad: "En dos lugares puede / sin dividirse nunca ni apartarse / un cuerpo solo hallarse, / cuya experiencia a mí se me concede / en la divina ingrata / que yo adoro (vv. 18-24).

${ }^{111}$ El rechazo de la amada y el deber del enamorado de acatar su voluntad (por ser su vasallo) hacen que en ocasiones él defina su relación como una "tiranía" (v. 27 y v. 40). La identificación del amor como "tirano" o de la dama como una "tirana" aparece en varios poemas atribuidos a Cornejo, "Sueño jocoso" o "Amoroso, prudente y cortesano", pues tales imágenes eran populares en las composiciones que abordaban el "fino amor". Este es el caso del soneto de Lope de Vega "Qué estrella saturnal, tirana hermosa" (Sonetos s.p.).

${ }^{112}$ El amor comporta la no pertenencia a sí mismos de los amantes y su "muerte simbólica", que se puede manifestar como "huida del corazón, intercambio de corazones, vivencia en el amado y, por supuesto y principalmente la transformación del amante en el amado" (Serés 90). Quevedo reflexiona sobre el tópico del "morir por amar" en su poema a Anarda (Las tres 45): "No es verdad que partida / del cuerpo vil el alma, el hombre muera, pues ya la mía está fuera, y a Anarda busca, que es su misma vida, / mostrando amor en mí con bravo altivo, / que sin el alma en él muriendo vivo" (vv. 24-30).

113 Cuando el caballo del instinto puede más que el racional, el alma es incapaz de volar hacía la belleza y ocasiona una suerte de enfermedad o locura. Guillermo Serés (19-23) ahonda en esta teoría, desarrollada en El Fedro, y explica cómo evoluciona hasta convertirse en un tópico en la poesía amorosa de corte idealista. 
Si morir determino

por no padecer más, es cobardía,

y si mortal me animo

40 a no sentir, parece tiranía;

$\mathrm{y}$, pues, no sé qué hacerme en tal desvelo.

¡Cielos, dadme favor, valedme cielo!

Si piensa que dichoso

fui en algún tiempo mi tenaz memoria ${ }^{114}$,

45 en tristeza aquel gozo

es insufrible, infierno aquella gloria.

Que es el pasado bien, según mi cuenta,

más que dicha, verdugo que atormenta,

¿Qué importa que lozano

50 el almendro, vestido de pimpollos,

cuando asoma el verano

tanta copia introduzca de cogollos

si al asalto menor de un fiero viento,

lo que fue lozanía, es escarmiento?

55 ¿Qué importa que amanezca,

desperdiciando luz el sol hermoso,

si es fuerza que anochezca,

para tener sepulcro tenebroso,

donde caduco entre mustios desmayos

60 noche tendrá por luz ${ }^{115}$, sombra por rayos?

¿Qué importa que una fuente,

cuando en líquidas sombras se desata

su traviesa corriente,

juegue* cristales, desperdicie plata ${ }^{116}$,

65 y que corra veloz, libre y ufana

si en mares pierde lo que en tierra gana?

Luego, no tuvo dicha

quien glorias tuvo y alcanzó favores

si quedó por desdicha

70 de tal suerte sujeto a los rigores,

pues lo que gloria fue, dicha y contento,

es infierno después, pena y tormento.

iAy fortuna, fortuna,

que acosta del pesar la dicha ofreces,

75 cobras ciento por una ${ }^{117}$

y, aun, a censo las pones las más veces,

${ }^{114} \mathrm{El}$ alma al contemplar la belleza del ser amado recuerda "anamnesis" la belleza ideal y eterna del mundo de las ideas del que proviene y anhela volver a él (Serés 17-18).

${ }^{115}$ La imagen de la noche como manifestación simbólica de la ausencia de la amada "luz" se podría relacionar con la célebre composición de san Juan de la Cruz, que representa las dificultades que ha de afrontar el alma "Esposa" hasta su unión con la divinidad "Esposo" (Serés 263-284).

${ }^{116}$ Se podría considerar una referencia a la descripción que se realiza del líquido cristal en la Soledad primera de Góngora (Lambea 123), donde se dice que "hacen sus aguas con lascivo juego; / engarzando edificios en su plata" (vv. 208-209).

${ }^{117}$ Se trata de una reformulación de una expresión de origen bíblico "Dar ciento por una", que intenta mostrar la generosidad infinita de Cristo (Mateo, 19, 29). Esta también se halla en el poema atribuido a Cornejo y Marchante "Cien reales por mí perdiste". 
pues $\mathrm{si}^{*}$ algunas me distes por un tanto, ya te pago los réditos en llanto.

Pero cuando mis males

80 al sol comparo, al árbol y a la fuente, que en todo son iguales, siente el amor y mi discurso siente, que piadoso conmigo quiere el cielo que dónde halle mi mal, halle el consuelo.

85 Porque de la manera que al almendro sustenta la esperanza de verse en la primera*

forma, [que]*de los tiempos la mudanza le privó criminal, así concibo

90 que es la esperanza quien me tiene vivo.

También, como la fuente del mar, rompiendo el vínculo espumoso, recobra su corriente y a su centro se vuelve caudaloso,

95 así pretende la fortuna mía a su centro volver en algún día ${ }^{118}$.

También, del modo mismo, según del sol mi pensamiento infiere, que en tal lóbrego abismo,

100 por volver a nacer contento, muere; así, yo en tal abismo y mal tan fiero, por volver a vivir, contento muero.

Pero, piadosos cielos, mientras que tanta dicha se concierta

105 a tantos desconsuelos, el curso suspended, cerrad la puerta, porque presumo en tal confusa calma que, suspirando, he de exhalar el alma.

Suspiros amorosos,

110 prueba que califica mis amores, pues voláis presurosos, a mi dueño, decidle mis temores; contad lo que aquí estoy padeciendo, cómo vivo ¿si es vida estar muriendo ${ }^{119}$

115 Decidle que constante me cumpla lo que tiene prometido, mientras que yo, su amante cuidadoso, cortés, reconocido,

\footnotetext{
${ }^{118}$ El alma desea volver a su centro, es decir, alcanzar la continuidad del propio ser en el otro "la unidad" mediante el amor. Este constituye el puente entre el mundo de las ideas y el terrenal y permite al hombre desarrollar sus mejores facultades y sanar su espíritu y su cuerpo tras producirse la transformación (Serés 15-16).

119 Quevedo da respuesta a esta pregunta en el soneto "Mejor vida es morir que vivir muerto" (Quevedo, Poesías 175), donde dice que prefiere la muerte antes que vivir sufriendo por la falta de amor de la amada: "El cuerpo, que del alma está desierto / (ansí lo quiso Amor de alta belleza), /de dolor se despueble y de tristeza: / descanse, pues, de mármoles cubierto" (vv. 4-8).
} 
contra las ondas de mi suerte loca, soy escollo constante, firme roca ${ }^{120}$.

\title{
4. Pintura a una dama (20v) \#
}

\section{Romance}

\author{
Dulce Lisis de mis ojos ${ }^{121}$,
} hoy quisiera en metro grave $\mathrm{e}^{122}$ lo que humana tú desmientes decirte en divinidades.

5 Cobarde a pintarte llego, mas en empeño tan grande si a retratarte no acierto, cumpliré con retratarme ${ }^{123}$. De* competir con tu pelo

10 el oro ${ }^{124}$ pálido yace más que mucho, si aún al sol a la melena ${ }^{125}$ le traes. Sin hacer raya ${ }^{126}$, tu frente vence en blancura a los Alpes,

15 cuya nieve, copo a copo*, de envidiosa se deshace. Son de un círculo tus cejas dos bien parecidas mitades, que dan a tus bellos ojos

20 sendas hijas de azabache ${ }^{127}$. De tus dos ojos, las niñas ${ }^{128}$

\footnotetext{
${ }^{120}$ La imagen de la dama ausente como un escollo constante y una dura roca se halla también en El Milagro por los celos de Lope de Vega. Don Álvaro al hablar sobre la ausencia de su amada (inicio de la jornada tercera) establece dicha comparación: "su constancia es menester, / mas no tiene el mar poder / contra un escollo constante / y si al pecho de diamante / bate el mar, ten, que es razón" (s.p.).

${ }^{121}$ El apóstrofe a Lisis en el primer verso de la composición es una práctica recurrente en los poemas de Quevedo que a esta dedica, ya que es una manera de darle presencia y de individualizarla (Roig 102).

${ }^{122}$ Calderón popularizó el uso del romance para desarrollar "monólogos de carácter grave, solemne o lírico, en esto culto, como alocución encomiástica o recriminatoria, salutación galante y consejos morales, a menudo en forma paralelística como dúo amoroso" (Marín 1141).

${ }^{123}$ Se trata de un equívoco. En su primera aparición (v. 7), se utiliza en el sentido de describir la fisonomía de alguien y, en la segunda (v.8), hace referencia al acto de "desdecirse de lo que se había dicho" (Aut.).

${ }^{124}$ Se trata de una reescritura de los primeros versos del poema de Góngora "Mientras por competir con tu cabello" (Góngora s.p.). Conforme avanza la composición, el imaginario idealista que en este se recrea se irá subvirtiendo con humor.

${ }^{125}$ Una singularidad en la descripción del cabello de la dama (respecto a la tradición idealizante) que está presente en los retratos que hace Quevedo de Lisis y de Floralba es la "melena". Esta aportaba una visión más erótica y sensual de la amada que las habituales trenzas (Roig 103).

${ }^{126}$ Hacer raya: "Aventajarse, esmerarse o sobresalir en algo" $(D L E)$. Esta expresión aparece también el poema indubitado de Cornejo "Cansado anoche de estar".

${ }^{127}$ En la poesía idealista de los Siglos de Oro las cejas se solían vincular a arcos de color oscuro. Dicha metáfora tiene su origen en un soneto de Petrarca y representa a estas como armas que usa el hijo de Venus para herir a los hombres. Bienvenido Morros (129) pone de ejemplo unos versos de Bartolomé Argensola: "Silvia, dos arcos te ha dado / para tus cejas Cupido, de ébano / son (no bruñido, dices tú, sino aserrado)". ${ }^{128}$ Ver nota 87.
} 
tan guapas son y matantes

que a cintarazos de luces

ver las estrellas ${ }^{129}$ me hacen.

25 Cuanto a beldades tus ojos

guerras hicieron campales,

buen golpe ${ }^{130}$ sacó de hermosa

tu nariz, por meter paces.

$\mathrm{Si}$ a tu boca se atrevieron

30 atrevidos los corales,

con un color que es vergüenza,

corridos ${ }^{131}$ los tristes yacen.

De tu cuello, una azucena

aprender a blanquearse

35 quiso, pero su desvelo

paró todo en deshojarse ${ }^{132}$.

Son de cristal tu dos pechos,

dos pomos en todo iguales,

aunque a borbotones hierve

40 a lento calor la sangre ${ }^{133}$.

La nieve y marfil tuvieron

blancas competencias antes,

pero ya en tus manos son

nieve y marfil, uña y carne ${ }^{134}$.

45 Talle de acabar con todos

tienes, y es cosa notable

que de ajustado ${ }^{135}$ presuma

quien es de vidas ultraje.

El que a tu garbo atendiere,

50 sin descredito de fácil,

puede rendirte desvelos

y enamorarse del aire.

Lo que me ocultó el recato

\footnotetext{
${ }^{129}$ Ver alguien las estrellas: "Sentir un dolor muy fuerte y vivo" (DLE). Esta locución sirve como parodia a la representación de los ojos de la dama como estrellas, impulsada por la tradición idealista, y muy explotada por Quevedo en los poemas amorosos que dedica a Lisis (Roig 98).

${ }^{130}$ Se trata de una dilogía que hace referencia tanto al acto de provocar admiración o sorpresa como al de confrontar con violencia un cuerpo contra otro. Esta última acepción se relaciona con el vocablo "cintarazos" (v. 23).

${ }^{131}$ Se utiliza en el sentido de "avergonzados" y se vincula al color de los corales (v. 30) y al de sonrojarse (v. 31). El cromatismo del rojo se complementa más adelante con la aparición de la sangre (v. 40) y se contrastará (como era frecuente en la lírica de corte idealista) con el del blanco, representado principalmente por la azucena (v. 33), el marfil y la nieve (v. 41).

${ }^{132}$ La imagen de una azucena marchita asociada con la blancura de una dama podría evocar el célebre soneto de Garcilaso "En tanto que de rosa y azucena" (Garcilaso s.p.).

${ }^{133}$ Se produce una asociación entre la presencia de la sangre y el deseo carnal, la cual era recurrente en la poesía erótica de los Siglos de Oro. Además, al estar unida a la metáfora de los pechos (como dos cristales bien tallados, donde la sangre hierve) podría ser una nueva alusión a la lírica amorosa del autor de $E l$ Buscón, ya que en ella suelen combinarse las joyas, el fuego y la sangre para evocar la pasión (Gallego 71). ${ }^{134}$ Ser uña y carne: "Frase que exagera la unión de amistad que hay entre algunos" (Aut.).

${ }^{135}$ Se trata de una dilogía que, por un lado, hace referencia a una silueta apretada y, por otro, a mostrar un talante justo y recto.
} 
no puedo $\operatorname{pintar}^{136}$, mas saque

el discreto de este todo

si serán buenas las partes.

\section{Habiendo pedido asunto en una Academia para escribir, no se lo dieron por estar todos repartidos y le dijeron que tomase por pie el no habérsele dado y vistiese a una dama, que otro dejaba desnuda a orillas de un río (22v) \#}

\section{Romance}

Yo soy, ilustre Academia, un poeta desgraciado, que aun para darme de pie ${ }^{137}$ no habéis querido hacer caso.

5 Si pensáis que para ello no soy, estáis engañados, pues tengo un mucho de pobre y no muy poco de casco $^{138}$. Bien puedo entrar en docena ${ }^{139}$

10 que, aunque veis de mal hato, he metido cucharada ${ }^{140}$ de las musas en el plato. De que me neguéis el pie traigo la queja en la mano,

15 pues verificad a bulto es* errar para acertarlo. Solo siento que el asunto [es tullido]* y no da un paso ${ }^{141}$ ni hay concepto que le venga,

20 si no le traigo arrastrando. Pero, pues, es ya forzoso que haya de salir a rancho mi musa, en la escaramuza de pies ajenos me valgo.

25 De una ninfa ${ }^{142}$, que desnuda dejó un amigo en el baño, me quiero arrimar al pie

\footnotetext{
${ }^{136} \mathrm{Al}$ igual que en otros retratos atribuidos a fray Damián "Sepan, todos y todas, que yo adoro" o "Yo soy, ilustre Academia", la descripción se detiene antes de llegar a las partes íntimas de la dama.

${ }^{137}$ Dar el pie: "Frase con que se pide a alguno le sirva de apoyo para subir a algún lugar, tomándole un pie para ayudarle" (Aut.).

${ }^{138}$ Se emplea este término, relacionado con los pies de las bestias caballares, en el sentido de juicio o capacidad de reflexión de una persona. Un uso similar aparece en el poema atribuido a Cornejo y Marchante "En el mar de tu hermosura".

${ }^{139}$ Meterse en docena: "Frase que se usa cuando uno, siendo desigual, se entremete en la conversación o número de personas de más categoría" (Aut.).

${ }^{140}$ Meter cucharada: "Frase que se dice del que en todo cuanto se habla o discurre quiere dar dictamen, interrumpiendo a los otros en materias que no profesa ni entiende" (Aut.). Esta expresión también aparece en los poemas indubitados de Cornejo "Cansado anoche de estar" y "Tu arroz, Marica, me enfada".

${ }^{141}$ Dar un paso: "Realizar un progreso perceptible en lo que se hace o se intenta" (DLE).

142 Ver nota 75.
} 
por roerle su zancajo ${ }^{143}$. Sacarla del agua quiero,

que es no dama bacallao

aquesta, que se ha de estar

en remojo todo el año.

Lástima tengo de verla

en carnes y tiritando,

35 y quiero para vestirla

hacer de mi musa un sayo.

Cubrirla quiero, y aún pienso

que si el pintor no ha errado,

tomarán de mis oyentes

40 el cubrirla ${ }^{144}$ más de cuatro.

Salió pues de las aguas

la hermosa Clori ${ }^{145}$, mostrando

solo su rostro divino

y lo demás muy humano.

45 Al salir, como su cielo,

perlas vino derramando ${ }^{146}$;

imaginé que llovía

con estar el tiempo claro.

Para enjugarse, en un lienzo

50 arrebozó su alabastro,

mas tan cortés que dejaba

la viesen de claro en claro ${ }^{147}$.

Corrió después la cortina ${ }^{148}$

primera de su recato

$55 \mathrm{y}$, quedándose ella in*albis,

nos dejó a todos en blanco ${ }^{149}$.

Echose su guardapiés

y los demás aparatos

lo más aprisa que pudo,

143 Roer los zancajos: "Frase que vale murmurar o decir mal de alguno, censurando sus más leves y pequeñas faltas en ausencia suya" (Aut.).

${ }^{144}$ Se trata de un equívoco. En su primera aparición (v. 37), se utiliza para hacer referencia a la acción de "tapar u ocultar algo", mientras que en la segunda (v. 40) adquiere connotaciones sexuales, pues alude al acto de "la generación de los animales" (Aut.).

${ }^{145}$ Es la diosa griega de los jardines y las flores y a ella se le atribuía la cualidad de mantenerse eternamente joven. Su imagen fue recurrente en la poesía hispana de los Siglos de Oro.

${ }^{146} \mathrm{La}$ imagen de las perlas que se derraman se halla en varios textos religiosos del Siglo de Oro relacionados con la figura de Cristo, como las Meditaciones para la Sagrada Comunión de Baltasar Gracián (83), las coplas al nacimiento del hijo de Dios de Vicente Sánchez (285) o las coplas sobre el Niño Dios de José Pérez de Montoro (2: 311). Esta metáfora también aparece en el poema indubitado que fray Damián dedica a María Magdalena "En tu alabanza mi musa".

147 De claro en claro: "Modo adverbial, que vale lo mismo que abierta y manifiestamente y con toda claridad" (Aut.).

${ }^{148}$ Correr la cortina: "Metafóricamente vale descifrar, descubrir y manifestar lo que está oculto, dudoso, oscuro y sumamente difícil de percibirse y entenderse" (Aut.).

${ }^{149}$ Se establece un paralelismo entre las expresiones "quedarse in albis" (v. 55) y "dejar en blanco" (v. 56), cuyo significado es "sin saber qué decir" o "sin lograr lo que se espera" $(D P D)$. Además, el autor recurre al término latino para recalcar la blancura y la luz que desprende el cuerpo desnudo de la dama y para hacer referencia al "alba", una túnica blanca. Esta permite consolidar el campo semántico de tejidos que ha conformado: hato (v. 10), sayo (v. 36) y lienzo (v. 49). 
por evitar un catarro.

Sentose, al fin, y calzose,

como todos nos calzamos:

en cada pierna su media

y en cada pie su zapato.

65 Ajustó su ponleví

sin fuerza, porque es tamaño

su pie que, con ser estrecho,

aún le venía muy ancho.

Atase* también las ligas

70 con tan afinados lazos

que cayeron, por su gusto,

en ellos algunos guapos.

No hay que pintar lo demás,

porque excederá* el retrato

75 al origen lo que va

de lo vivo a lo pintado ${ }^{150}$.

Sin ponerla más aliño

pondré su fin deseado

a mi remendón* romance*,

80 hilvanado de retazos.

En los pies paro, y me quedo

de hacerlo muy consolado,

pues ya que entré con mal pie ${ }^{151}$

con dos pies buenos acabo.

85

\section{Sátira a unos colegiales que dieron a unas damas moscas confitadas (25) \#\#}

\section{Romance}

Éranse dos licenciados galanes a lo de Arcadia ${ }^{152}$, discurso de poco aprieta, voluntad de mucho abarca.

5 De estos que a las caperuzas poniendo los cuernos andan y a la polaina, sin Dios y sin conciencia, echan calza ${ }^{153}$. Hombres que si se pregona

10 moscatel pera en la plaza, el uno al otro se mira

\footnotetext{
150 Ver nota 104.

${ }^{151}$ Entrar con mal pie: Expresión contraria a "entrar con el pie derecho o con buen pie" y que significa empezar alguna cosa con mala suerte o desdicha (Aut.).

${ }^{152}$ Los galanes que viven en la Arcadia (un lugar utópico del imaginario clásico y renacentista) eran pastores bucólicos que tenían una visión del amor idealizada y que desarrollan largos parlamentos en los que se expresan las inquietudes y el sufrimiento que este les plantea.

${ }^{153}$ Echar a uno la calza: "Es notarle por perjudicial o molesto para huir de él no creerle ni fiarle de sus operaciones" (Aut.).
} 
y a entrambos tiembla la barba ${ }^{154}$.

Esta de aquestos dos brutos

es definición zurriaga,

15 que alcanza de rabo a oreja;

oigan, pues, lo que solapa.

Podencos de bodegón

salen una tarde a caza

de moscas ${ }^{155}$, llevando cola

20 entrambos para pegarlas.

Para cogerlas a[1] vuelo ${ }^{156}$

mil indulgencias y gracias

toman, porque de las moscas

era cada cual un Papa.

25 A tiros de sus alientos

iban cayendo que es plaga,

no como miel ${ }^{157}$, porque aquesta

de asno en boca no hay posada ${ }^{158}$.

Como de las mataduras

30 son las moscas camaradas,

ellas picaban en ellos

y ellos con ellas pegaban.

Brutos, mirad que no es

lo que os pica lo que os mata,

35 que lo que os pica es la mosca

y lo que os mata la albarda ${ }^{159}$.

De la caza los despojos

presentaron a unas damas

y de mosca muerta ${ }^{160}$ hicieron

40 necedades confitadas.

No les culpo lo galante,

que en ellos es cosa llana,

que se quitaron las moscas

de la boca para darlas.

45 Pero que necios presuman

que pudiese pasar plaza ${ }^{161}$

de cortesana agudeza,

tan sucia moscatelada,

no lo he podido sufrir,

${ }^{154}$ Temblar la barba: "Expresión jocosa con que se explica lo mismo que tener miedo o recelar de alguno o alguna cosa" (Aut.).

155 Cazar moscas: "Ocuparse en cosas inútiles o vanas" (Aut.).

${ }^{156}$ Coger al vuelo: "Lograrlo de paso o casualmente" (DLE).

${ }^{157}$ Remite a la popular frase "Acudir como moscas a la miel", que significa "acudir a donde se ha sacar algún provecho" (Cov.).

158 Podría aludir al refrán "No se hizo la miel para la boca del asno", que sirve para recriminar a quienes no saben apreciar el valor de algo $(C V C)$.

${ }^{159}$ Podría tratarse de una referencia al refrán "La culpa del asno echan a la albarda", que enseña "que por no confesar algunas personas sus defectos, o su corta habilidad o inteligencia, atribuyen a otros sus propias culpas o los males que han causado sus acciones" (Aut.).

${ }^{160}$ Mosca muerta: "Apodo que se aplica al que es al parecer de ánimo o genio apagado, pero no pierde la ocasión de su provecho o no deja de explicarse en lo que siente" (Aut.).

${ }^{161}$ Pasar plaza: Se toma "por fama u opinión" (Aut.). 
pues aun en Sierra Nevada

no hiciera más un diciembre

que presentar moscas blancas ${ }^{162}$.

Quien hizo tal disparate

debiera traer clavada

55 la mosca de Arjona ${ }^{163}$, siempre,

a la gurupa en la ancas.

Si fuera alcalde de corte,

les pusiera en las espaldas

por la burla de Moscovia ${ }^{164}$

60 de vaqueta la toalla.

A unas damas les dan moscas

dos galanes, no reparan

que una mosca hay para moras

y otras para las cristianas ${ }^{165}$.

65 Si a damas mantener tela

quieren para regalarlas,

no han de dar caza de moscas ${ }^{166}$,

mas den a la mosca caza.

Mas estos dos solo pueden,

70 en mi conciencia jurada,

en un rincón de basura

mantener tela a una araña ${ }^{167}$.

Chanflona salió la burla,

pues no pudieron pasarla,

75 que los engaños en mosca ${ }^{168}$

siempre son moneda falsa.

En esto paró la burla,

y yo para celebrarla

de mosquetero les tiro

80 en cada silbo una bala.

Carguen otra vez su mosca ${ }^{169}$

y con espigón se vayan,

\footnotetext{
${ }^{162}$ Moscas blancas: "Llaman por alusión a los copos de nieve que vienen cayendo por el aire" (Aut.).

${ }^{163}$ La mosca de Arjona, que corta dos veces: "Del que se hace mosca muerta y al taimado bellaco se le envía tal castigo. Hubo un tiro en la fortaleza de Arjona que llamaban la mosca, con que mosqueaban los moros" (Corr.).

${ }^{164}$ Se juega con la semejanza entre el término mosca y Moscovia (antigua provincia de Rusia). Tal asociación se hace también en el poema atribuido a Cornejo y a Marchante "Óiganme, damas, que empuño". ${ }^{165}$ Podría ser una alusión a la canción popular "La mosca y la mora" (Ruíz, Repertorio 81): "Estando la mora en su lugar / vino la mosca para hacerle mal. / La mosca a la mora, / la mora en su moralito y sola" (vv. 1-4).

166 Ver nota 155.

${ }^{167}$ Podría ser un referencia a la expresión "tela de araña", que señala un "discurso sutil y de ninguna sustancia" (Aut.). Además, también sería una nueva alusión a la canción popular "La mosca y la mora" (Ruíz, Repertorio 81): "Estando la mosca en su lugar / vino la araña para hacerle mal /. La araña a la mosca, / la mosca a la mora, / la mora en su moralito y sola" (vv. 5-9).

${ }^{168}$ Se utiliza en el sentido "de dinero" (DLE).

${ }^{169}$ Se emplea en la acepción de "carabina corta que usaron algunos cuerpos militares $(D L E)$.
} 
y lleven de este romance

la soga $a^{170}$ por sobrecarga ${ }^{171}$.

\section{Sátira a estas damas que, por hartarse de las sobredichas moscas, quedaron ahítas (28) \#}

\section{Romance}

Óiganme, damas, que empuño

del buen gusto la zurriaga

en favor de los galanes,

5 que supieron mosquearlas ${ }^{172}$.

Saliendo de pedigüeñas

de golosinas a garra ${ }^{173}$,

buscando la flor del berro,

en la mosqueta se clavan.

10 Muy ayunas del recato

pidieron colación larga

y hallaron quien se la diese

moscovita y no romana ${ }^{174}$.

Del conservare dineris

15 alabo en ellos la maña

si en confitar mosca negra,

conservaron la dorada ${ }^{175}$.

Para beber sin peligro,

suelen comer otras damas

20 azúcar bolado, y estas

azúcar con alas.

Bien se conoce por esto

que no tienen buenas almas,

pues en colación comían

25 las aves aderezadas.

Si de entendidas presumen,

es la presunción ya vana

\footnotetext{
${ }^{170}$ Llevar o traer la soga arrastrando: "Frase con que se explica que alguno ha cometido delito grave, por el cual va siempre expuesto al castigo" (Aut.).

${ }^{171}$ Se usa en su sentido metafórica para indicar "la cosa molesta que sobreviene y se añade al sentimiento, pena o pasión del ánimo" (Aut.).

${ }^{172}$ Se juega con el término "mosquear" para señalar tanto la acción de importunar a alguien como al suceso acontecido en el anterior poema "Éranse dos licenciados", donde unos galanes dan de comer moscas confitadas a unas damas.

173 Ver nota 17.

${ }^{174}$ Las damas, en lugar de pedir la parva materia que los días de Vigilia permitía la Iglesia romana para evitar que cayera mal la bebida, eligen comer la confitura (llenas de moscas "moscovita") que les ofrecen sus pretendientes. Tal acción hace, además, que se salten involuntariamente el ayuno de comer carne los días de penitencia. La alusión a Moscovia en dicho contexto no parece únicamente fruto de su semejanza con la palabra "mosca", pues durante el siglo XVII la Iglesia ortodoxa rusa realizó una serie de reformas relevantes que la distanciaron de la Iglesia de Roma.
}

175 Ver nota 75. 
en gente* a quien moscas muertas ${ }^{176}$

hacen burlas y las tragan.

30 Que las huelan mal las bocas

la vil materia lo causa,

del interés y con moscas

fue cada mosca una llaga.

A dos carrillos comían ${ }^{177}$

35 y de sus blancas gargantas

supieron, las muy golosas,

hacer las nueces moscadas.

Qué ricas habrán quedado

si, en esta ginobesada ${ }^{178}$,

40 tienen asientos de moscas

del estómago en la caja.

No para el arca guardaron

moneda, que es para arcadas

antes el engaño visto;

45 se inclinaron a trocarlas ${ }^{179}$.

Si se desbautizan, porque

como a unas moras las tratan,

y están de la mosca heridas,

pónganse una telaraña ${ }^{180}$.

\section{A un borracho (29v) \#}

\section{Quintillas}

A uno que se hace una uva ${ }^{181}$

celebrar vi en cierto corro;

$\mathrm{y}$, así, es fuerza que me suba

5 a sacudir esa cuba ${ }^{182}$

con las colas de ese zorro ${ }^{183}$.

Aqueste insigne varón

es, en todas ocasiones,

\footnotetext{
${ }^{176}$ Mosca muerta: "Apodo que se aplica al que es al parecer de ánimo o genio apagado, pero no pierde la ocasión de su provecho" (Aut.).

177 Comer a dos carrillos: "Comer con rapidez y voracidad" $(D L E)$.

${ }^{178}$ Se trata de una referencia jocosa sobre la actitud poco honesta que se asociaba a los genoveses. Según Correas, estos "son moros blancos. Dicen que metieron la conciencia en la faltriquera, y las mujeres la vergüenza, y estaba rota y perdiose".

${ }^{179}$ Se emplea como metáfora del coito.

${ }^{180}$ Podría remitir a la frase "Eso se cura con una telaraña", que da "a entender la facilidad del remedio o compostura de una cosa" (Aut.). También podría ser una referencia a la canción popular de "La mora y la mosca" (Ruíz, Repertorio 81): "Estando la mosca en su lugar / vino la araña para hacerle mal /. La araña a la mosca, / la mosca a la mora, / la mora en su moralito y sola" (vv. 5-9).

${ }^{181}$ Hecho una uva: "Muy borracho" (DLE).

${ }^{182}$ Se trata de una dilogía que hace referencia tanto a la "persona que bebe mucho vino" como al recipiente que sirve para contener "agua, vino, aceite u otros líquidos" $(D L E)$.

${ }^{183}$ Las colas de zorro se usaban para limpiar el polvo. Tal imagen podría remitir también a la expresión "Resollar la zorra", que significa "vomitar el vino" (Aut.).
} 
un viviente cangilón*184

en cuya respiración

se curan los orejones.

Vino bebe que es espanto

y esto, aunque muy bien lo trae,

como* le hace humillar tanto,

15 todos le tienen por santo

porque saben cuándo cae.

Y si no se templa un poco

en este dulce reclamo,

según las materias toco,

20 presto le veremos loco

o por lo menos con ramo ${ }^{185}$.

Los vestidos más ligeros

en cuero trae aforados ${ }^{186}$

y, así, gasta muchos cueros,

25 porque los deja apurados*

solo por los bebederos.

De muy callado, en efecto, cuando bebe se acredita, pero el que fuere discreto

30 no le fie su secreto,

porque luego le vomita ${ }^{187}$.

Sabiendo sus mañas viejas,

le toman algunos rufos;

y aunque no tiene guedejas,

35 en estando hasta las cejas, ${ }^{188}$

es hombre de muchos tufos ${ }^{189}$.

Un día con buena fe

dijo alzando el entrecejo:

"Tremendo martirio fue

40 el de san Bartolomé,

pues se quedó sin pellejo ${ }^{190 "}$ ".

\footnotetext{
${ }^{184}$ Dilogía que hace una nueva alusión a un recipiente (v. 5) que, según Covarrubias, era utilizado para el vino y que también asocia los efectos de la embriaguez con el movimiento de una noria. Cabe señalar, además, que podría ser una referencia al pueblo de Canjáyar, conocido por su larga tradición de cultivar viñas.

${ }^{185}$ El término "ramos" engloba las llamadas enfermedades "imperfectas" (Aut.). Una de las que pueden contraer con facilidad los borrachos son las paperas, ya que se transmiten al inhalar gotas de saliva de una persona contagiada o por compartir con esta tazas o utensilios. Resulta relevante recordar que con ramos se marcaba la entrada de las tabernas.

${ }^{186}$ Se trata de una forma de pago de los derechos Reales que hacían los cosecheros a través de la tasación del vino que producían. El protagonista realiza tal cobro a través de "cueros", que son recipientes en los que se transporta el vino. Dicho término en el habla coloquial también significa borracho.

${ }^{187}$ Dilogía que señala tanto el acto de "descubrir lo que estaba secreto" (Aut.) como el de "arrojar por la boca violentamente lo que estaba en el estómago" (Aut.).

${ }^{188}$ Hasta las cejas: "Frase adverbial que se dice del que posee alguna cosa con abundancia o está poseído de ella" (Aut.).

${ }^{189}$ El término tufos se emplea en el sentido de "soberbia, vanidad o entonamiento" (Aut.).

${ }^{190}$ San Bartolomé fue desollado vivo por haberse negado a adorar a los ídolos de Astiages, rey de Armenia. El hecho de que se trate del patrón de los curtidores y el hincapié que se hace en la pérdida de "pellejo" permiten relacionar el cierre del poema con su temática central.
} 


\section{Dando chasco a un borracho (30v) \#}

\section{Décima}

Clodio $^{191}$, del mundo en la plaza ${ }^{192}$, mirándote mona ${ }^{193}$ y sola, ya que te falta la cola,

5 he querido ser tu maza ${ }^{194}$. Suéltala si te embaraza y de ella te desazonas, $\mathrm{y}$ advierte que en tan burlonas chanza llevo lo* peor,

10 pues, por ser hoy tu pintor, me he metido a pintar monas.

Muy bien lo sé que no acierto cuando tu pintura escribo ${ }^{195}$, porque mona tal al vivo

15 quiere pincel menos muerto.

Mas, por mi disculpa, advierto al lector de este traslado que repare, con cuidado, que de él a su original

20 habrá tal distancia cual de lo vivo a lo pintado ${ }^{196}$.

De Baco a honor y cultura tanto se da tu ejercicio que de beber, que es un vicio, 25 tú repara que es locura. A puro trago se apura tu discurso y, cuando empieza a rendirte la pureza del dicho Dios contra ti, 30 harás mil locuras si se te pone en la cabeza ${ }^{197}$.

En tan vinosos desvelos tan humilde y manso estás que te vemos que te vas

\footnotetext{
${ }^{191}$ Podría ser una sátira del personaje histórico Publio Claudio Pulcro (general de la República de Roma, perteneciente a la gens Claudia, que luchó en las Guerras Púnicas), quien habría llevado una vida inmoral y llena de vicios (Pino 131-150).

${ }^{192}$ El hipérbato es una referencia a Roma, que en los Siglos de Oro era conocida como la "plaza del mundo". Esta se halla también en el poema atribuido a Cornejo "Disparates, Antón, muy mal zurcidos". ${ }^{193}$ En estilo jocoso y familiar se llama la embriaguez o borrachera (Aut.).

${ }^{194}$ El término maza se emplea en el sentido de "tronco u otra cosa pesada con que se prende y asegura a los monos o micos para que no se huyan" (Aut.).

195 Ver nota 104.

${ }^{196}$ Ver nota 150.

${ }^{197}$ Por el contexto, podría relacionarse con la expresión "Subirse a la cabeza", que significa "ocasionar aturdimiento" $(D L E)$.
} 
echando por esos suelos ${ }^{198}$.

Mas lo que corta los vuelos ${ }^{199}$

de mi discurso y le embota ${ }^{200}$,

en tan bacanal* derrota,

es que rezar no te escucho,

40 y debiera rezar mucho

persona que es tan de bota ${ }^{201}$.

También de las aguas eres

tan contrario en cuanto fraguas

que, después que andan en aguas,

aborreces las mujeres ${ }^{202}$.

No aguas nunca los placeres

ni tienes fe con agüeros

$\mathrm{y}$, así, de la verdad los fueros

quebrarás si, en puridad,

50 no te dicen la verdad

pura, desnuda y en cueros ${ }^{203}$.

No te corras, y perdona,

y si te corres $^{204}$, no dudo

despiertes, porque no pudo

55 salir corrida una mona ${ }^{205}$.

Mas mira que tu persona

es bien que corriente sea,

porque un hombre que se emplea

en ser así badulaque

60 será acertado que saque

de su cuero la correa ${ }^{206}$.

\footnotetext{
${ }^{198}$ Echarse por los suelos: "Frase que, además del sentido recto, vale humillarse o rendirse con exceso" (Aut.). Resulta relevante señalar que el vocablo "suelo" también hace referencia a los restos del vino que quedan en las tinajas.

${ }^{199}$ Cortar los vuelos: "Frase que, fuera del sentido recto, vale detener o suspender a uno en el modo de proceder o en sus acciones" (Aut.).

${ }^{200}$ Se emplea en el sentido metafórico de "privar del conocimiento y del sentido a uno" (Aut.). Podría relacionarse con "poner en la cabeza" (v. 30).

${ }^{201}$ Se establece un calambur entre una persona "devota" y otra a la que le gusta mucho el vino "de bota".

${ }^{202}$ Podría remitir al polémico suceso que habría protagonizado Publio Claudio Pulcro "Clodio" durante la ceremonia del Bona Dea, un ritual sagrado en el que participaba las mujeres nobles de Roma y al que les estaba vetada la entrada a todos los hombres. La concupiscencia de este general y las consecuencias legales de haber intervenido en tal acto (del que salió impune) han sido estudiadas por Francisco Pina Polo (131-152).

${ }^{203}$ En cueros: "Modo adverbial que significa tener descubiertas las carnes, sin vestidura alguna" (Aut.). Esta expresión también es una referencia al recipiente donde se guarda el vino.

${ }^{204}$ Se utiliza en el sentido de "burlar, avergonzar y confundir" (Aut.).

${ }^{205}$ Corrido como una mona: "Dicho de una persona que ha quedado burlada y avergonzada" (DLE).

${ }^{206}$ Del cuero salen las correas: "Frase con que se significa y da a entender que alguno que hace galanterías con otro de quien tiene caudales o intereses las ejecuta a costa del que las recibe" (Aut.).
} 


\section{Sátira a un estudiante que comió menudo (32v) \#}

\section{Redondillas}

Un estudiante de hogaño

comiendo en un bodegón

un menudo, con perdón,

sacó el vientre de mal año ${ }^{207}$.

Aunque melindre no fragua,

de las morcillas* infiero

que eran tripas de cochero,

porque nunca han visto el agua.

Empezose a santiguar;

10 y el menudo, en mi sentir, para más que bendecir, estaba para alabar ${ }^{208}$.

En fin, el pobre gorrón que las morcillas olía,

15 para comerlas, hacía

de las tripas corazón ${ }^{209}$

Echáronle en su cazuela dos manos de mala guisa ${ }^{210}$ que, por ir el mozo aprisa,

20 corre, mas no se las pela.

Los pies no es bien que se alaben, pues aunque con las morcillas, saben a las maravillas; pero a lavapiés no saben.

Según tiraba, no dudo, que a lo que comer le dieron muy apunto lo trajeron, pero vino a tiempo crudo ${ }^{211}$.

De las morcillas que muerde

30 mucho pimiento sacaba, y él muy contento se estaba entre lo rojo y lo verde ${ }^{212}$.

En fin, se fue sin pagar, porque el domine al partir

35 dejó mucho que decir,

207 Sacar el vientre de mal año: "Modo de hablar con que se a entender que se ha comido mucho o que se ha comido algo más y de más sustancia que lo que de ordinario se come" (Aut.).

${ }^{208}$ Se crea un calambur entre "alabar" y "a lavar" con el propósito de recalcar con comicidad la suciedad del menudo.

${ }^{209}$ Hacer alguien de tripas corazón: "Esforzarse para disimular el miedo, dominarse, sobreponerse en las adversidades" (DLE).

${ }^{210}$ De mala guisa: "En mal estado o disposición” (Domínguez 904).

${ }^{211}$ Tiempo crudo: "Modo de hablar con que se da a entender que se llegó a alguna parte o se solicitó alguna cosa tarde y sin oportunidad, en mala ocasión y coyuntura, fuera de sazón” (Aut.).

${ }^{212}$ Se trata de un verso que aparece en la tercera jornada de Los bandos de Vernona de Rojas Zorrilla, que a la vez es una cita paródica de uno de los versos iniciales del romance de Góngora "Entre los caballos sueltos" (Rojas Zorrilla 293). 
pero nada que contar ${ }^{213}$.

\section{Sueño jocoso (33v) \&}

\section{Romance}

Cansado anoche de estar ${ }^{214}$

hecho de amor un panarra, sobre un discurso Babieca ${ }^{215}$

haciendo mil jinetadas ${ }^{216}$.

5 Después que corrí la posta ${ }^{217}$

al galope de mis ansias, midiendo de un imposible

la nunca andada distancia.

Después de haber recogido

10 imaginaciones varias,

que corren en el deseo

y en el desengaño paran.

Alterado el apetito,

las potencias zabucadas,

15 los deseos consentidos

y sin sentidos el alma ${ }^{218}$.

Me apeé de mi discurso,

y a que se dé una panzada ${ }^{219}$

libre en el prado le suelto

de una engañosa esperanza ${ }^{220}$.

${ }^{213}$ Se trata de una dilogía que hace alusión tanto al acto de computar dinero como al de relatar algún acontecimiento.

214 El ambiente en el que se desarrolla el sueño (confuso y caótico), su estructura (exordio, sueño propiamente dicho y epílogo), su perspectiva cómica y el "yo narrador-autor" lo enmarcan dentro de la tradición del sueño literario hispano del Siglo de Oro, que ha sido estudiado por Teresa Gómez Trueba. No obstante, incorpora rasgos propios del estilo personal de Cornejo (ironía, humor demoledor y referencias intertextuales) y características de la lírica del Bajo Barroco (lenguaje llano y cargado de oralidad y subversión de los tópicos petrarquistas).

${ }^{215}$ En los sueños literarios era habitual incluir personajes alegóricos, históricos o ficticios para aumentar la sensación de irrealidad y confusión. La presencia de Babieca también permite desplegar una gran cantidad de léxico ecuestre en los primeros versos del romance: "jinetadas" (v. 4), "corrí la posta" (v. 5), "galope" (v. 6) y "apeé" (v. 16).

216 Hacer jinetadas: La frase hacer jinetadas corresponde a "hacer caballerías, hacer gambetas, hacer cabriolas, hacer piruetas" (Corr.).

217 Correr la posta: "Es caminar con celeridad en caballos, a propósito para este ministerio, que están prevenidos en los lugares a ciertas distancias, y el que la corre los va remudando, y toma su postillón donde le dan los caballos, así para volverlos, como para enseñarle el camino que lleva" (Aut.).

${ }^{218}$ Los sueños, según Torres Villarroel, embargaban los cinco sentidos y las facultades de las potencias del alma (entendimiento, memoria y voluntad) perdían "su capacidad de discernimiento en beneficio de la fantasía. La memoria hace de servidor de la fantasía, suministrando a esta los materiales que necesita pare el espectáculo que va a representar y la fantasía que ahora acaba de despertarse, empieza a exhibir semejanzas de figuras y acciones ante el entendimiento, que no es ya sino espectador pasivo" (Gómez Trueba 202).

${ }^{219}$ Darse una panzada: "El hartazgo de comida o bebida, y por extensión se dice de otras cosas" (Aut.).

${ }^{220}$ Los sueños de contenido paródico solían situarse en "un plano intermedio y ambiguo entre la realidad y la ficción, entre el sueño y la vigilia” (Gómez Trueba 303). 
En el pesebre del gusto $^{221}$,

le previne entre la paja

de mal formada idea

una voluntad cebada,

25 donde a las leyes del diestro ${ }^{222}$

lozanas vivezas ata

la razón, a quien le sirve

un imposible de aldaba.

Púseme a mirar atento

30 del desengaño la cara ${ }^{223}$,

que fue de todo mi gusto

formidable marimanta.

Viendo que con ilusiones

la fantasía me cansa,

35 cuidadoso al sentimiento,

hizo el desvelo la cama ${ }^{224}$.

Trato de entrar prevenido

en consulta con mi almohada,

que puede por lo lanuda

40 hacer un papel de barba ${ }^{225}$.

Desnúdeme, y al aliño

la atención tengo negada,

tan ilusa que no cae

en los lazos que desata.

45 Sin ti me vi, y en pelota, $y$ al ver que al bote me faltas, qué saltaba no te digo, mas juro a Dios que botaba.

Todo un volcán fue de fuego

50 mi boca que, en la abrasada

pólvora de mis deseos,

fulminó en despechos balas.

Diole la pasión los tacos,

sirviéndole en esta carga

el sentimiento de impulso

y de baqueta la rabia.

Andaba de ronda el Frío,

yo que del gusto las armas

que en solo un estoque traigo

\footnotetext{
${ }^{221}$ El presente poema se enmarca también en la tradición aurisecular del sueño erótico, que ha sido estudiada por Antonio Alatorre en el monográfico de El sueño erótico en la poesía española de los Siglos de Oro. ${ }^{222}$ Podría tratarse de las leyes que rigen el embuste, el disimulo y la mentira.

${ }^{223}$ Parece ser una referencia al sueño de Quevedo "El mundo por de dentro" (Quevedo, Sueños 70-86), donde el narrador "el Desengaño" intenta hacerle ver al protagonista la verdadera moral que hay detrás de lo visible.

${ }^{224}$ Hacerle la cama a alguno o a alguna cosa: "Vale lo mismo que preparar y disponer de antemano lo conducente al fin que se pretende, antes de ponerlo en ejecución" (Aut.).

${ }^{225}$ Se trata de una dilogía que señala tanto el papel que en las comedias representa un viejo o anciano "porque se pone una cabellera cana y barbas postizas" (Aut.) como un tipo de papel con bordes rugosos e inacabados, los cuales se asemejan a la lana "lanuda" (v. 39).
} 
60 todas las noches sin vaina ${ }^{226}$.

Sabiendo que a todos hace su rigor temblar la barba, para que no me cogiese, me escondí entre mis frazadas.

65 A tus cartas del despecho*, que tirana ${ }^{227}$ me maltrata, a pelo $^{228}$ y a letra vista 229 me voy echando en baraja ${ }^{230}$. Diestro tahúr brujuleo

70 mas, como pintas las cartas, fullera ${ }^{231}$ me ganas siempre con naipes hechos al alma. Finezas repaso tuyas, qué bien haces si me pagas,

75 que yo generoso juego siempre sobre tu palabra. Picado ${ }^{232}$ el juego repito con obstinación bizarra, porque me pierdo gustoso

80 en saber que tú me ganas. De tu papel me despido sendas, dejando hocicadas estampadas en su margen, debida a su gracia estampa.

85 La luz, ardiente lechuza* que de mi velón chupaba en* lentos de fuego sorbos*, la pringué de olivos nata ${ }^{233}$, porque le daba en los ojos

90 la vida le quite ingrata con un suspiro, que fue sornavirón de su llama. El Dios cegara* que (a tiento) logra tiros de su alfaba, dorado virote ${ }^{234}$, flecha

226 Se conforma un campo semántico relacionado con el ámbito bélico, que simboliza la pasión y el erotismo: pólvora (v. 51), fulminar (v. 52), balas (v. 52), carga (v. 54), baqueta (v. 56), armas (v. 58), estoque (v. 59) y vaina (v. 60).

227 Ver nota 111.

${ }^{228}$ La locución adverbial "A pelo" se utiliza para recalcar que el protagonista se halla sin protección y desnudo ante el deseo. Tal idea se había señalado previamente con "en pelota” (v. 45) y "sin vaina" (v. 60). ${ }^{229}$ A letra vista: "Vale puntual o inmediatamente" (Aut.).

${ }^{230}$ Entrarse o echarse en la baraja: "En los juegos de envite es no querer lo que se envida, y en otros juegos no querer jugar la mano, por no tener cartas ò puntos bastantes para contrarrestar ù disputar el juego.

${ }^{231}$ Ver nota 6.

${ }^{232}$ El léxico de los naipes brinda un campo amplio para representar juegos eróticos. Algunos de los términos más recurrentes que aparecen en la lírica aurisecular son: "bastos", "flux", "tenderete", "atravesar" o "picar" (Etienvre 23).

${ }^{233}$ Se trata de una metáfora del semen.

${ }^{234}$ Las flechas de oro que lanzaba Cupido provocaban el enamoramiento de la persona que las recibía y las de plomo el rechazo. 
con que el corazón me pasa.

Busco a la herida el remedio $\mathrm{y}$, en las congojosas bascas, desangrándome en deseos

100 no hallé el trapo que buscaba.

Dónde estás, ingrata mía,

que del tropel de mis ansias

no te dueles. Para qué

me tientas, si no me palpas,

105 dije. Y al echar la mano ${ }^{235}$, intrépidamente osada,

hallé mi cama vacía

y mi diligencia vana.

Encogido entonces de hombros ${ }^{236}$,

110 la pierna tendín ${ }^{237}$ a la larga

y viviendo de memoria,

que así vive quien bien ama ${ }^{238}$.

Viendo que ya, poco a poco,

mi desvelo boqueaba

115 al sueño llamé por señas,

que le di dos cabezadas ${ }^{239}$.

Dormido de ojos, que yo

nunca me duermo de espaldas,

a rienda suelta ${ }^{240}$ corría

120 de la esfera imaginaria

el espacioso distrito.

Cuando la señora sastra

de los embustes, aquella

zurcidora de mohatra

125 por cuyo capricho suelen

las mujeres lardeadas

dispararse de cohetes

voladores a la playa

del campo de Barahona ${ }^{241}$,

130 (donde del cabrón ${ }^{242}$ la sarta, contando del espinazo

${ }^{235}$ Echar la mano: "Asirlo, cogerlo, prenderlo" (DLE).

${ }^{236}$ Encogerse de hombros: "Expresión con que se da a entender que se niega alguna cosa o que se ignora" (Aut.).

${ }^{237}$ Tender la pierna: Locución verbal que equivale a "Dormir a pierna tendida" (Cov.). Es decir, "sin preocupación, tranquilamente" (DLE).

${ }^{238}$ Según Aristóteles (Serés 56), el amor arranca de la visión de la belleza y se renueva a través del recuerdo, pues "la visión es una pasión que el color imprime en el aire, y de este pasa al ojo, en cuyo elemento acuoso se refleja como en un espejo; el movimiento o pasión producido por la sensación es conducido después a la fantasía, que puede producir el fantasma incluso en ausencia del objeto percibido, merced a la memoria".

${ }^{239}$ Dar cabezadas: "Es dormitar o empezar a dormirse, bajando y levantando la cabeza" (Aut.).

${ }^{240}$ A rienda suelta: "Metafóricamente vale sin sujeción, y con toda libertad" (Aut.).

${ }^{241}$ El campo de Barahona (una explanada de la provincia de Soria) es un lugar donde se cree que las brujas acudían con sus escobas "cohetes voladores" (vv. 127-128) para realizar aquelarres. Existe una real cédula del rey Enrique VI de Castilla (fechada 4 de agosto de 1496) que indica que en ese emplazamiento "hay hombres y mujeres que se llaman brujos, se dan al diablo y se reúnen de noche".

${ }^{242}$ El macho cabrío simboliza al demonio. 
con sumisiones extrañas)

rezan en ella y, al cabo,

besan todas la medalla.

135 Dígolo*, la Fantasía ${ }^{243}$

sobre sus hombros me carga;

$\mathrm{y}$, como el hombre de bofe

tiene* no sé qué migaja,

sin mucho trabajo pudo

140 a las puertas de tu casa

[ponerme, y que yo salida

buscase, pues me dio entrada]*.

Tieso, y derecho a tu alcoba,

llegué, y supe que quien ama

145 cualquier* embarazo burla

y jamás tropieza en nada.

Revestime de podenco

$\mathrm{y}$, dando vuelta a la sala,

un rincón vi sin aliños

150 los despojos de la caza*.

Al lecho asesté la mira

$\mathrm{y}$, viendo la liebre echada,

dije para mí: "Yo apuesto

que si me viera, saltaba.

155 Si se me escapa esta vez,

plegue a Dios que horrible maza

de caracolado hueso

(mulato marfil que gasta,

a diligencias del ocio,

160 tanto marido en guirnaldas

martes de carnestolendas ${ }^{244}$ )

me vaya dando en las ancas".

Pero metáforas dejo.

Y porque quizás pintada,

165 ni parada, te habrás visto, mírate pintiparada.

Negro atezado el cabello, serenamente, inundaba*

en avenidas de sombras

$170 \quad$ los armiños de la *almohada.

El azabache una higa

no vale ${ }^{245}$ si a él se compara,

el ébano es blanco y rubio

\footnotetext{
${ }^{243}$ La personificación alegórica de la Fantasía permite ahondar tanto en la experiencia onírica como en la amorosa. La Fantasía representaba para Aristóteles la parte hacedora de imágenes del alma, ya que es la que "realiza el trabajo de los procesos más elevados del pensamiento y la que canaliza la pasión amorosa. De ahí que el alma nunca ama ni piensa sin una imagen" (Serés 64).

${ }^{244}$ El martes de carnestolendas "carnaval" es la víspera del Miércoles de Ceniza y, por tanto, el último día para realizar burlas, comer carne y divertirse antes de la Cuaresma.

${ }^{245}$ No vale una higa: Equivale a "No valer nada" $(D L E)$. Resulta relevante señalar que la higa suele estar hecha de azabache (v. 171).
} 
y la mora es doña Blanca ${ }^{246}$.

La frente a su sombra yace

hermosa, sin hacer raya ${ }^{247}$,

ipoder de Dios qué señora

tan esparcida y tan llana!

Por lo serena ${ }^{248}$, parece

180 una noche toledana ${ }^{249}$,

quien no supiere el misterio

luego, al instante, se parta

de Madrid para Toledo.

$\mathrm{Y}$ en los coches una carta

185 me llevará a don Catarro

de Tos, persona sonada,

en toda aquella ciudad,

que en la Puerta de Bisagra ${ }^{250}$

está de guardia y con flema;

190 porte, cuatro moquetadas

le dará y a letra vista

tendrá de contado un asma

con que podrá a todo hombre

echar roncas ${ }^{251} \mathrm{y}$ echar claras

195 y, a gargajazos y mocos,

acabar con toda Holanda ${ }^{252}$.

De negros átomos era

cada ceja, bien poblada,

República de Etiopia

200 con quien la pez pasó plaza ${ }^{253}$,

porque competirla quiso

meramente de mulata.

Y, aun, la vi con tanta jeta

que de corrida se calza

205 unas botas para irse

\footnotetext{
${ }^{246}$ Se hiperboliza y parodia el color del pelo de la amada, pues es tan oscuro que cualquier cosa que se compare con él (azabache, ébano o la tez de una mora) parece clara.

247 Ver nota 126.

${ }^{248}$ La calificación de la noche como "serena" podría ser una referencia a la oda "Noche serena" de fray Luis de León (Bedford s.p.), donde se expresa el deseo de que el alma "despierte” y abandone el engañoso y efímero mundo terrenal para alcanzar la verdad y la belleza celestial: "El hombre está entregado al sueño, / de su suerte no cuidando; / y con paso callado / el cielo, vueltas dando, / las horas del vivir le va hurtando" (vv. 21-25).

${ }^{249}$ La "noche toledana" es aquella que "se pasa sin dormir" (Aut.). Esta expresión también se emplea en el poema atribuido a Cornejo "De santa Resurrección".

${ }^{250}$ Se trata de la puerta monumental, conocida con el nombre de "Nueva", que está situada en las murallas de Toledo.

${ }^{251}$ Echar roncas: "Además del sentido recto, que es amenazar con ellas, vale estar ronco" (Aut.). Esta expresión aparece también en el poema atribuido a Cornejo y a León "Es de Fausto la fiereza".

${ }^{252}$ Se trata de una alusión a la Guerra de Holanda (1672-1678), que enfrentó a Francia, Münster, Colonia e Inglaterra, primero, contra las Provincias Unidas y, después, contra la Cuádruple Alianza. España se adhirió a esta última en 1673. El resultado del conflicto fue desfavorable para el Imperio español, pues en los Tratados de Nimega (1678) Francia obtuvo el Franco-Condado de España y se cedieron también territorios de los Países Bajos.

${ }^{253}$ Etiopía fue el único país africano que en la Edad Moderna no fue colonizado "plaza" y el primero en adoptar el cristianismo "pez".
} 
de camino en hora mala.

Si de estos arcos amor ${ }^{254}$

se vale para su aljaba,

que mucho que a virotazos

210 consiga victorias tantas

y en sus espeteras tenga

sobrada siempre la caza.

Los parpados de sus ojos,

hermoso claustro de nácar ${ }^{255}$,

215 son adonde amor encierra

por traviesas dos muchachas ${ }^{256}$,

que (con extraña viveza)

con dulce desgarro matan

a cuantos incautos ponen

220 los ojos en sus ventanas ${ }^{257}$,

que halagüeñas se introducen,

que traidoras con la azada

de una mal formada risa,

secretamente, el alcázar

225 minan de los albedríos,

adonde en barriles guarda

la pólvora del deseo,

la voluntad recatada,

y en donde tiranas siempre

230 vivas centellas disparan;

con que tienen, por su gusto,

tanta voluntad volada,

tanto arruinado albedrío,

tantas prisioneras almas,

235 que nos les falta a tus ojos

para purgatorio nada.

La nariz es artificiosa,

por acertar a pintarla

un disparate la ofrezco

240 a la musa de mi guarda

todo de cera, que pese

dos arrobas ${ }^{258} \sin$ la tara.

La nariz artificiosa

pirámide se levanta

245 que, haciendo punta ${ }^{259}$ a lo bello,

a cuantas narices campan

(o chatas o borroneas

de la hermosura) en la playa*

${ }^{254}$ Metáfora de las cejas de la amada (ver nota 127).

${ }^{255}$ En los Siglos de Oro, las mujeres empleaban nácar molido para colorear sus párpados.

${ }^{256}$ Ver nota 87.

257 Ver nota 59.

258 Se puede relacionar con la frase "Pesar por arrobas", que denota "la abundancia de las cosas, pues ella misma hace que no se detengan a menudencias, sino que se den en cantidad grande para salir de ellas" (Aut.).

${ }^{259}$ Ver nota 84. 
las reta y las desafía.

250 Y, aun, dice dándolas vaya ${ }^{260}$

a la grande que se meta

y a la pequeña que salga,

[porque ella, ni más ni menos,]*

tiene de linda ventajas

255 tan ciertas que ha de ganar, en cualquier apuesta que haga,

a la corta y a la larga.

Es la boca tamañita,

un melindrico de grana,

260 un átomo de carmín,

como quien no dice nada.

Niña, si fuere mayor,

no la despliegues y calla,

que yo no m[i]ento, pues ella

265 es siempre tan apocada.

Y si mi musa supiera

que tengo tan malas mañas,

me degollara la vena ${ }^{261}$

para que, descabezada,

270 escribiera disparates.

Y, sin soplarme palabra,

siendo así que yo no como

si no me sopla esta dama

de aquella helicona fuente ${ }^{262}$,

275 que, porque guardo a vara

en los cofres de unos riscos

barras de líquida plata,

aquel caballo avechucho

(a quien chismes dieron alas ${ }^{263}$ )

280 con una pisa de coces

le* hizo correr la campaña ${ }^{264}$.

Digo, en fin, que, de esta suerte,

aunque me viera sin habla,

seco de sed y rabiando,

285 no me diera una sed de agua.

Por* eso, digo y me vuelvo

${ }^{260}$ Dar una vaya: "Burla o mofa que se hace de uno o chasco que se le da" (Aut.).

${ }^{261}$ Dilogía que remite a las cavidades por las que circula la sangre y al "numen poético o facilidad para componer versos" (Aut.).

${ }^{262}$ Se trata de la fuente Hipocrene, que se halla en el monte Helicón (consagrado a Apolo y a las Musas). Según la mitología griega, esta tuvo su origen en el golpe que dio Pegaso a la montaña para intentar reducir el tamaño del dios Helicón, engrandecido por el canto de las Musas.

${ }^{263}$ Dar alas: "Modo de hablar metafórico que vale tanto como dar aliento, osadía, ánimo o favor a otro, para que se atreva a ejecutar algo, que sin esta confianza por sí solo no lo ejecutaría" (Aut.). Esta expresión se relaciona con Pegaso "caballo avechucho" (v. 278) y con la "Helicona fuente" (v. 174). El origen del célebre corcel alado parece ser la sangre derramada por Medusa, después de que la Gorgona fuera asesinada por Perseo. Este había conseguido conocer la ubicación de su víctima gracias a la revelación de las Grayas, quienes también lo ayudaron para obtener las sandalias aladas de Hermes.

${ }^{264}$ Batir o correr la campaña: "Es recorrerla, para saber el estado de los enemigos, y observar sus intentos, y operaciones" (Aut.). 
a tu boca a retocarla.

Vila y quédeme elevado

a Dios con la colorada.

290 Nadie el color la compita,

porque le*hará la mostaza ${ }^{265}$

al clavel ${ }^{266}$ que más se precia

de ser en mayo botargas.

Si de la sierra el madroño

295 (villano orgulloso) baja,

váyase con un erizo

a rascar, que tiene sarna.

Tome la guinda el acero

y sepa que está opilada,

300 y váyase paseando

de puro miedo a hacer aguas ${ }^{267}$.

Que este color es tan vivo

que, aun, las pullas más tacañas

están en presencia suya

305 callando como unas santas.

Pues los dientes ya los temo,

que es su menudencia rara,

pero escucha el disparate,

mejor que se ha visto, ensarta.

310 ¿Qué es cosicosa esta boca? ${ }^{268}$

Está muy buena y perlática;

esdrújulo, qué mal suena,

vuelvo este verso a la estampa.

Qué es cosicosa esta boca,

315 sin tener nada de flaca,

de vieja, ni impertinente,

tiene mucho de perlada.

Harto lindo era el concepto

si no calzara polaina.

320 Pues el aliento a su puerta, mendigo de oler el ámbar, pidiendo humilde limosna, bebiendo los aires anda.

Y ella le da para guantes ${ }^{269}$

325 todo el aliento que exhala.

Es la barba sin pera,

sana como una manzana ${ }^{270}$,

para un encaje de gusto,

${ }^{265}$ Hacer la mostaza: "Frase que usan los muchachos, y vale hacer salir sangre de las narices uno a otro, cuando andan a puñadas" (Aut.).

266 Ver nota 93.

${ }^{267}$ Hacer agua: "Dicho especialmente de un proyecto: Presentar debilidad o síntomas de ir a fracasar" (DLE).

${ }^{268}$ Ver nota 79.

${ }^{269}$ Dar para guantes: Hacer un regalo (Domínguez 897). Resulta relevante señalar que dicha expresión se relaciona con el "ámbar" (v. 321), ya que este se empleaba para perfumar los guantes de los caballeros.

${ }^{270}$ Sana como una manzana: Locución con la que se pondera "la buena salud de una persona" $(D L E)$. 
¿qué punta tan extremada?

El niño de la rollona ${ }^{271}$

de Chipre (aquel que se sangra

de la vista y la cisura)

tiene de mirar vendada,

para pagar del deseo

335 golosinas confitadas.

Entre todas las del mundo,

te echó sin duda la barba ${ }^{272}$.

Mira, niña, no la vea

doña Venus, que anda a garra ${ }^{273}$

340 de hermosura y, si la ve,

apuesto que te la rapa.

Nunca ha tenido que ver

con tus mejillas el nácar,

que es un pobretón que ayer

345 era de perlas mortaja.

Y un conchudo cómo puede, mezcla tan rica no gasta.

Las rosas y los jazmines ${ }^{274}$

quieren hacer caravanas,

350 mas de su beldad caduca

está todas las mañanas,

a carcajadas de risa,

hecha toda una babosa el alba.

Y, aún, de verlas envidiosas

355 (que se deshacen de rabia)

de saludador el cierzo,

soplo a soplo, las despacha.

Es la garganta que anima,

sin ser de nieve, frescaza,

360 derechamente de linda

gana a la más estirada.

No es blanca, que en su color

(trigueño subalternado)

vive al ampo, y al armiño

365 le paga la media a nata ${ }^{275}$.

De su nuez, pudiera hacerse,

doy caso que se cáscara,

para abadejo de Venus,

sabrosísima nogada.

370 Airosa la mano tiene,

${ }^{271}$ El niño de la Rollona que tenía siete años y mamaba: Frase popular que señala que "hay algunos muchachos tan regalones que con ser grandes no saben desasirse del regazo de sus madres; salen estos grandes tontos o grandes bellacos viciosos" (Cov.).

${ }^{272}$ Echar a la buena barba: "Señalar a alguien para que pague lo que él y sus compañeros han comido o gastado" (DLE).

${ }^{273}$ Ver nota 17.

274 Ver nota 94.

${ }^{275}$ La media nata era un derecho que se pagaba "al ingreso de cualquier beneficio eclesiástico, pensión o empleo secular, correspondiente a la mitad de lo que producía en un año $(D L E)$. 
por lo mueble y bien formada, si marfil como en la uña, algodón como en la palma. Qué armoniosos los dedos,

375 retóricamente parlan, por las coyunturas dicen bellezas amontonadas. Pues la muñeca, en mi vida vi cosa tan aseada,

380 no tiene en sus bujerías Cupido mejor alhaja.

Pues el brazo, yo he pensado que el amor echó de mangas ${ }^{276}$, está con él y, por eso,

385 todo cuanto quiere alcanza. Esto vi y esto admiré, que lo demás, recatada, guardaba como oro en paño ${ }^{277}$ la ropa escusabarajas.

390 Aquí entro yo, que mirando a la ocasión tan rodada, como pelota después de haber hecho muchas faltas. Dije entre mí: "De esta vez,

395 la dejo del todo calva que, aunque sé que es tan esquiva que no vuelve a quien la llama, si yo el mostacho la pesco, la he de gozar o pelalla".

400 Y ella, porque no la pele, si es mujer, no será ingrata.

En fin, yo que soy aquel de quien la jácara canta: "Érase un hombre a quien dieron

405 atrevimiento las armas".

Como un Bernardo te embisto ${ }^{278}$ con mi hoja toledana ${ }^{279}$, mas tú reparando diestra uñas arriba ${ }^{280}$ me aguardas.

$410 \quad$ Y vive Dios que tenías

\footnotetext{
${ }^{276}$ Echar de manga a alguien: "Valerse de él con destreza y disimulo para conseguir lo que se desea, sin darlo a entender" (DLE).

277 Como oro en paño: Se utiliza "para explicar el aprecio que se hace de algo por el cuidado que se tiene con ello" (DLE).

${ }^{278}$ La fuerza y la osadía que caracteriza al semilegendario personaje del Bernardo del Carpio es traslada en este poema al campo de plumas.

${ }^{279}$ El acero de la ciudad de Toledo se hizo popular en el Imperio español por su calidad para fabricar material bélico, principalmente, espadas.

${ }^{280}$ Uñas arriba: "En la esgrima es la estocada que se tira volviendo los gavilanes y la mano hacia arriba. Usase también metafóricamente por el que se dispone a defenderse o a no convenirse en alguna especie que le proponen" (Aut.).
} 
las uñas de más de marca, gran parte de tus desuellos

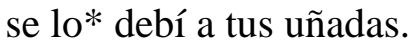

Y te preciarás de honesta,

415 siendo una desuellacaras ${ }^{281}$.

De ambos allí las acciones

tan equívocas andaban

que, siendo yo el que subía,

eras tú quien gateaba;

420 porque [hacer]* la zambullida

quise, heridilla vedada,

lección* que me dio un maestro

de niños (cuando en la Francia

corrí de la picardía

425 los países y las tablas);

de puño me diste en rostro

no sé cuántas estocadas ${ }^{282}$,

que, hasta en los reveses, llevas

a la fortuna ventaja.

430 Tú, en fin, sin mostrar flaqueza

y yo sin ejecutalla.

Tieso estuve como un palo,

tú valiente como Palas ${ }^{283}$

hasta que, ya de la fuerza

435 y de la carne obligada,

a rastrear empezaste

de mis suspiros la causa.

Que en lances tan apretados,

esto es moral para hurañas,

440 la más entera se mella,

y la más de fuerte se casca.

Dígolo porque a partido,

y aun a partida ${ }^{284}$, te dabas,

diciendo menos esquiva:

445 "Envaine uced, señor Carranza'285, ya hemos probado las fuerzas

pero, aunque me siento flaca,

bien ve que, si yo no quiero,

ni un canillazo me alcanza.

${ }^{281}$ Se trata de una dilogía que hace referencia tanto a la acción de desollar un rostro como a una persona "desvergonzada, descarada, de mala vida y costumbres" $(D L E)$.

${ }^{282}$ Se establece un enfrentamiento de armas, con estocadas y zambullidas (v. 420), que sirve como metáfora de la batalla que la mujer debía afrontar en el campo de plumas. Según los códigos de cortejo de la lírica erótica aurisecular, ella tenía que "resistirse" y "forcejear" para aumentar el placer masculino antes del coito. Dicho ritual de seducción queda reflejado en el soneto apócrifo de Francisco de Quevedo " Primero es el besalla y abrazalla" (Quevedo, Sonetos s.p.).

${ }^{283}$ Podría referirse a Palas Atenea (diosa de la guerra, la sabiduría, las ciencias y justicia) o a Palas (hija del dios Tritón y compañera de juegos de Minerva), que fue derrotada por Atenea en una pelea.

${ }^{284}$ La moza del partido o "partida" es aquella que se dedica a la prostitución.

285 Jerónimo Sánchez de Carranza (¿1539-1608?) fue un militar y escritor español, que es denominado el padre de la esgrima española. 
Y que llegar no ha podido

a herirme con una cuarta, y que, para no ser fácil, uñas te he tenido hartas; de comer a dos carrillos ${ }^{286}$,

455 acuérdese por su cara, mucha carne y, aún, se tienen enteras muchas tajadas. Y le hizo saber por fuerza cuántas son cinco y la garra ${ }^{287}$ ".

460 Yo que la merced conozco, qué me has hecho, señalada de tu verdad, escocido, trataba de echarte calza ${ }^{288}$.

Al tiempo que ya del sueño

465 que de liviano pecaba, me embargó todo los gustos algún demonio matraca, que melindroso me dijo: "Mira, niño, que son largas

470 historias de Calaínos ${ }^{289}$ aquello de ya cabalga".

Desperté en mi cama, solo, y halleme cual* digan damas, que no han de meter conmigo

475 las dueñas su cucharada ${ }^{290}$. Iban de mí de coraje tacos como de una vaca, no me llegaba al tobillo el salto de siete tapias.

480 Un crecimiento tan fuerte tenía que me llevaba el gran diablo. Pero ya estoy mejor, a Dios gracias, porque el padre confesor,

485 con dos en cruz manotadas, me santiguó santamente las secas ${ }^{291}$ y las mojadas ${ }^{292}$.

${ }^{286}$ Comer, o masticar, a dos carrillos: "Comer con rapidez y voracidad” (DLE).

${ }^{287}$ Cinco y la garra: "Expresión con que se da a entender que lo que se tiene solo ha costado tomarlo o que se tiene por hurto" (Aut.).

${ }^{288}$ Echarle a uno calza: "Es notarle por perjudicial, o molesto para huir de él y no creerle, ni fiarse de sus operaciones" (Aut.).

${ }^{289}$ Alusión a la estrafalaria aventura que protagonizó el ficticio caballero andante del poema anónimo "Romance del moro Calaínos" (AA. VV. Romancero s.p.). Esta dio origen a la expresión "Coplas de Calaínos", que se utilizaba para indicar "noticias remotas e inoportunas" (Corr.).

290 Ver nota 140.

291 Santiguar las secas: "Castigar o maltratar a uno de obra y de palabra" $(D L E)$.

292 Hace referencia a dos tipos de males: las secas (una inflación en las glándulas que, por el contexto del poema, parece afectar a las partes bajas "almorranas") y las mojadas (herida hecha con algo punzante). Sobre estas dolencias insistirá, más adelante, el protagonista al decir que tiene adrede "las ancoras desolladas" (v. 511). "Las secas y las mojadas" se podrían relacionar, además, con el dicho "A gran seca 
Díjome: "Tenga sosiego y no se altere de nada,

490 que la carne es testimonio que esa niña le levanta.

Tenga muy buenos aceros ${ }^{293}$, y esto se entiende sin vainas, y degüelle sus pasiones,

495 y esa carne gallegaza castíguela, que lo hará peor si la trae en palmas ${ }^{294}$. Y se saldrá con ser puerca siempre si no la batana,

500 que está gorda y la pureza nunca sufrió tantas ancas. Póngala la paja al ojo 295 $y$, si engreída y lozana quiere guardainfante, sea

505 un verdugado su gala". Eso, padre, es que me azote, dije, y me holgara en el alma, que no estuviera el remedio tan atrás mano en* mi casa.

510 Esto de tener adrede las ancoras desolladas, para el puto que se pega por detrás, es buena traza. El que almorranas tuviere

515 que tenga siempre de espaldas y, en Roma*, con cardenales ${ }^{296}$ esté en hora buena el Papa.

Que yo, que todas mis culpas paran en dos muchachadas,

520 harto* habrá para envolverlas con una Sábana Santa.

Cata es del sueño, y soltura la pintura si no es mala; quien soñaba lo que quiso, 525 quería como pintaba ${ }^{297}$.

\footnotetext{
gran mojada”, que se dice “del que ejecuta alguna acción con exceso, que dejó de hacer por mucho tiempo, o le sobreviene algún bien inesperado de que había carecido" (Aut.).

293 Tener buenos aceros: "Fuerza y brío para todo" (Corr.).

${ }^{294}$ Traer en palmas: "Frase con que se da a entender que a alguno se le complace y da gusto en todo cuanto desea y apetece" (Aut.).

295 Se podría relacionar con la expresión "Poner a alguien delante de los ojos algo", que es convencerlo "con la razón o con la experiencia para que deponga el dictamen errado en que está" $(D L E)$. Además, por el contenido escatológico de la escena, también remitiría a la acción de "limpiar el trasero".

${ }^{296}$ Dilogía que hace referencia tanto a un miembro del colegio consultivo del Papa como a un moratón. La mención al Santo Pontífice y a los cardenales le permite introducir el tema de la "Sábanas Santa" (Ver nota 39).

297 Pintar como querer: "Presentar las cosas no como son o han de ser, sino conforme al capricho o la conveniencia de quien las presenta" (Aut.).
} 


\section{Quintillas jocosas (48v) \#}

\section{Quintillas}

Vengar quiero mis rencillas, pues en* ser fiera te ensayas, Lisis $^{298}$, en estas quintillas que son, por sangre, morcillas, aunque te parezcan bayas ${ }^{299}$.

Y quiero, pues tu desdén con mi voluntad se encuentra, enseñarte a querer bien, ítem que sepas también

10 que la letra con sangre entra ${ }^{300}$.

$\mathrm{Y}$ advierte que mi intención no es dejarte enojada, pues bien sabe mi razón que es lástima dar picor 15 a quien está ya picada ${ }^{301}$.

Un incendio vengativo causó en mi amor tu despego, en que me abrasaba vivo, pero ya contra ti, altivo, me vengaré a sangre y fuego ${ }^{302}$.

Sangrote una mano fiera, y a mí me espanta (no es chanza) no saber de qué manera una lanceta te hiera, 25 siendo tú tan buena lanza ${ }^{303}$.

Al fin, te fui a ver un día, $\mathrm{y}$ al ir a entrar por tu puerta se te soltó la sangría ${ }^{304}$

\footnotetext{
${ }^{298}$ Ver nota 121.

${ }^{299}$ Se dice del vejamen "compuesto de palabras picantes y dichas con intención y a fin de que otro se corra y avergüence" (Aut.).

${ }^{300}$ La letra con sangre entra: "Denota que es necesario el trabajo y el estudio para aprender algo o para avanzar en algo. A veces, se asocia únicamente al castigo corporal como estímulo para aprender" $(C V C)$.

${ }^{301}$ Se trata de una dilogía que señala tanto el estado de "sufrir o provocar enojo" como el de sentirse "excitado o estimulado".

302 A sangre y fuego. "Significa alguna cosa en que se ponen extraños y violentos medios para lograrla y cuesta mucha oposición el conseguirla" (Aut.). Esta expresión también aparece en el poema "Mi bien, juro por mi amor".

${ }^{303}$ Buena lanza o linda lanza: "Se llama el sujeto que la maneja con gran destreza, y por ironía se dice del que no está en opinión de hombre bizarro y de valor" (Aut.).

${ }^{304}$ Dilogía que puede remitir tanto a la apertura de una herida como a la pérdida de la virginidad. Esta última acepción se vincularía con "entrar por tu puerta" (v. 27). Cabe señalar que la sangría de una mujer es un tópico erótico de herencia petrarquista, el cual se basa en el deseo y la compasión que genera en el enamorado ver la piel de su amada teñida de rojo y rasgada. La descripción del cuerpo ensangrentado (trazado mediante contrastes cromáticos entre el bermejo y el blanco) se suele completar con la mención a joyas u objetos valiosos, como lo es la sangre de la dama.
} 
con que (no con pena mía)

te quedaste medio muerta.

Cuantos miraron bañar en púrpura tu alabastro ${ }^{305}$, al tiempo de ir yo a entrar, muy bien pudieron sacar

35 tu sinrazón por el rastro.

Con que yo advertido quedo, que atenta a tus sinrazones tú siempre (decirlo puedo) en sintiéndome, de miedo,

40 se te bajó a los talones ${ }^{306}$.

Y como allá en el tobillo estaba la vena rota brotó, y aún me maravillo que, siendo tal el sustillo,

45 te quedase ni una gota.

Viendo al líquido coral ${ }^{307}$, que contigo no se aviene, dije con ansia fatal:

"¿Cómo a un triste trata mal

50 quien tan buena sangre tiene?".

Mas que a ti, que agradecer tengo a tu sangre en mis males, pues tú no me puedes ver, y aquí a tu sangre vi ser

55 fina como los corales.

De que saco en conclusión que arrepentida del mal [que me hiciste sin razón]*, sin ser mal de corazón,

60 tuviste gota coral ${ }^{308}$.

Dejarte quiero, porque ya me has pagado el pesar, y muy bien pagado a fe, pues te he picado ${ }^{309}$ hasta que te he hecho la sangre saltar.

Ya he vengado con primor el desprecio y la afrenta que hiciste a mi firme amor, pues he tomado en rigor

\footnotetext{
305 Parece ser una recreación de los últimos versos del célebre soneto de Góngora "Prisión del nácar era articulado" (Góngora s.p.), donde el poeta cordobés retrata la sangría que sufre una dama en su mano al pincharse con una sortija: "sacrílego divina sangre bebe: / púrpura ilustró menos indiano / marfil; invidiosa, sobre nieve / claveles deshojó la Aurora en vano".

${ }^{306}$ Bajarse la sangre a los talones: "Frase que vale asustarse" (Aut.).

${ }^{307}$ La metáfora de la sangre como un líquido coral (v. 46) se halla en los primeros versos de la Soledad primera de Góngora, donde se retrata a esta como un "espumoso coral” (Góngora s.p.).

${ }^{308}$ Nombre con el que se conoce la epilepsia, que hasta principios del siglo XX se intentaba curar mediante sangrías.

${ }^{309}$ Se emplea como metáfora del coito.
} 
de ti venganza sangrienta ${ }^{310}$.

No temo que tus efectos

condenen aquestos modos, poniéndole mil defectos, que por nuevos mis conceptos

75 van vertiendo sangre todos ${ }^{311}$.

Todos van ensangrentados.

Recíbelos, niña, en bulla

sin que te cueste cuidado, pues, siendo tan colorado[s],

80 quién no dirá que son* pullas*.

Ya con aquesta paulina ${ }^{312}$

quedarás escarmentada

y así, sin darte mohína,

sírvate de disciplina

85 y ¡adiós con la colorada! ${ }^{313}$

\section{El mismo autor a sus quintillas (51) \&}

\section{Décima}

A la desatada llaga ${ }^{314}$

para mostrar mi talento,

en estilo bien sangriento,

[he]* dicho* versos que es plaga ${ }^{315}$.

5 Sin duda, que ya se estraga

con tan sanguínea influencia

mi vena ${ }^{316}$, si con prudencia

miro, en caso tan forzoso,

que es un mal muy peligroso

10 si es de sangre la correncia.

\section{Epigrama a ojos azules (51v) \#}

\section{Redondillas}

\footnotetext{
${ }^{310}$ Se trata del llamado "blutrache", un principio de Derecho de los pueblos germánicos. La "venganza de sangre" se aplicaba cuando un miembro de una familia era asesinado o herido y esta deseaba saldar dicha deuda con el agresor. En los Siglos de Oro, se conoce también con el nombre de "venganza del honor".

311 Verter sangre: "Acabar de suceder o estar muy reciente" y "Estar muy colorado o encendido el rostro de alguien" $(D L E)$.

${ }^{312}$ Se emplea en el sentido de "reprensión áspera y fuerte" $(D L E)$.

${ }^{313}$ Adiós con la colorada: Expresión familiar usada "para despedirse" (DLE).

${ }^{314}$ Dilogía que alude tanto a una "úlcera" como a cualquier "daño o infortunio, que causa pena, dolor y pesadumbre" (DLE).

${ }^{315}$ Se trata de una dilogía que hace referencia a una "llaga" (v. 1) y al "daño grave o corporal enfermedad que sobreviene a alguna persona" (Aut.).

316 Ver nota 261.
} 
Desde que tus niñas bellas ${ }^{317}$

vio el Amor, dejó el arpón

y tomó por su blasón

en campo azul dos estrellas ${ }^{318}$.

5 Y cuando la vista pules,

viendo tus ojos, cualquiera

darse dichoso quisiera

un verde ${ }^{319}$ con dos azules.

\section{A una dama fácil $(51 v) \&$}

\section{Décimas}

Tu $\operatorname{arroz}^{320}$, Marica $^{321}$, me enfada, porque en él (por varios modos)

llegan libremente todos

a meter su cucharada ${ }^{322}$.

5 Y es cosa para admirada, que aquel que a gustarle llega

salga mal de la refriega ${ }^{323}$;

porque tu arroz (bien mirado)

debiera, por bien meneado,

no saber tanto a la pega ${ }^{324}$.

\section{Habiendo perdido una dama por causa del autor cien reales, él la envió dos y, al no quererlos recibir, escribió esta décima (52) \#}

\section{Décima}

Cien reales por mí perdiste

y yo te remito dos.

No los quisiste y, por* Dios,

que neciamente anduviste.

5 Es posible que no viste

con* tu raro entendimiento

\footnotetext{
${ }^{317}$ La metáfora de las "niñas bellas" para representar los ojos de la amada era un recurso común en los Siglos de Oro. Un ejemplo de ello lo encontramos al final del primer acto del El perro del hortelano, cuando Teodoro habla sobre Diana: "vuseñoría: Esos ojos, / le dije, esas niñas bellas, / son luz con que ven los míos" (Lope de Vega, El perro s.p.).

318 Ver nota 88.

${ }^{319}$ Darse un verde: "Frase que vale holgarse o divertirse por algún tiempo" (Aut.).

${ }^{320}$ Se trata de una metáfora para representar el órgano sexual femenino.

${ }^{321}$ El nombre de "Marica", referido a una mujer, se empleaba en los Siglos de Oro como un diminutivo de los compuestos de "María". Además, este estaba cargado de connotaciones negativas, pues con él se solían nombrar a mujeres de los bajos fondos y a prostitutas.

322 Ver nota 140.

${ }^{323}$ Metáfora del coito. Se relaciona por su significado con "meneado" (v. 10) y "pega" (v. 10).

${ }^{324}$ Saber a la pega: "Frase metafórica con que se da a entender que alguno imita y sigue las malas costumbres y vicios de sus padres o que corresponde a la mala sangre que heredó de ellos" (Aut.).
} 
que te estaba muy a cuento ${ }^{325}$, pues diste* ciento por uno ${ }^{326}$; ya que no cobras ninguno,

\section{Contra monjas (52v) \&}

\section{Quintillas}

Un ciego soy desgraciado, monjas, que de vuestro fuego he salido acuchillado.

Y quiero, pues he cegado,

5 pegaros palo de ciego ${ }^{328}$.

Mostrar quiero un desengaño

al mundo, por cosa rara, de vuestro vivir extraño, que le compré por mi daño

10 por los ojos de la cara.

Y, así, todo el mundo advierta

que este linaje garduño ${ }^{329}$, aun* al* que está más alerta, le dan una mano abierta

15 y se la pegan de puño.

Y hasta que yo, por mi mal, experimenté su trato, no alcancé con mi caudal que aquesta gente infernal

20 es carne de garabato ${ }^{330}$.

Muchas del amor heridas viven con pasión postrada, pero será bien que midas

\footnotetext{
${ }^{325}$ A cuento: "Modo adverbial. Lo mismo que al caso, al propósito" (Aut.).

${ }^{326}$ Ver nota 117.

${ }^{327}$ La deuda económica que contrae el yo poético con la dama podría poner de manifiesto el pago de unos servicios sexuales prestados. Como señala Alejandro Reidy (60), "Eros y oros se cruzan metafóricamente o explícitamente en una serie de poemas donde el dinero y otros bienes de consumo participan en la celebración del sexo".

${ }^{328}$ Palo de ciego: Expresión que designa "cualquier daño o injuria que se hace sin reflexión o medida" (Aut.) y que sirve también como referencia a la popular figura del ciego que transmite relatos o poemas.

${ }^{329}$ Se podría interpretar como ratero o como una alusión a un tipo de felino "gato garduño". En los Siglos de Oro, se estableció una estrecha relación entre las mujeres y las gatas tanto en la lengua como en la literatura. Adrianne Martín (Erotismo 406) señala que en La Gatomaquia de Lope de Vega las felinas sirven como metáfora del género femenino, pues tal representación forma parte del imaginario colectivo desde la Edad Media. Además, como afirma esta misma autora en la lengua gallega gata puede ser eufemismo para prostituta, y jato o gato para el sexo femenino. Igual sucede con gato en portugués, chat y chatte en francés ('gatita' y 'coño') y con pussy en inglés.

${ }^{330} \mathrm{La}$ carne de garabato es aquella que se cuelga en un instrumento en forma de garfio. El refrán "Estase la carne en el garabato, por falta de gato" se utiliza para señalar a las mujeres que son recogidas y castas, porque no se les ofrecen ocasiones y por el natural recato y vergüenza de no dar a entender su incontinencia. Resulta relevantes señalar también que el término "garabato" se emplea para definir a la dama que corrompe a sabiendas el garbo o que arrastra con su hermosura a los galanes (Cov.).
} 
que no importa hallar salida, si no es posible la entrada.

La que muestra más amor suele ser la más huraña, porque esta gente en rigor cuando nos hace un favor es cuando más nos araña.

Afán parece pesado el que de amarlas se encarga, y es lo peor, que el cuitado, aunque se sienta cansado, no ha de echarse con la carga ${ }^{331}$

Hay monja* que gustar suele* de ver al que se desvela penar y de él no se duele, pero, si doblas, le huele;

40 le quiere que se las pela.

Triunfando de oros ${ }^{332}$, cualquiera gana. Y no fuera tan malo si ya que un hombre perdiera, salir de bastos ${ }^{333}$ pudiera y las baldara de un palo.

Y si las suelen querer a muchas de estas garduñas, porque en su buen parecer soles son; bien pueden ser, 50 pero lo serán con uñas.

Fuera de aquesto, aunque iguale la monja más singular al sol; el sol nada vale si aún en invierno no sale donde le puedan tomar

Nadie con ellas se enrede y estén todos avisados , que el que aquí ganar más puede, y sin que blanca ${ }^{334}$ le quede, saldrá con muchos cornados ${ }^{335}$.

\footnotetext{
${ }^{331}$ Echarse con la carga: "Es abandonarlo todo, deponiendo todo reparo o inconveniente para decir o hacer alguna cosa, o para no ejecutarla, aunque sea útil y provechosa, por enfado o despecho" (Aut.).

${ }^{332}$ Triunfar de oros: Se dice, por alusión al juego de naipes en que se vence con este palo, de "la acción de dar mucho dinero por alguna cosa consiguiéndola por este medio" (Terreros y Pando 712). Ver nota 6.

${ }^{333}$ Se trata de una nueva referencia a uno de los palos de la baraja española, cuya imagen se representa con "uno o varios leños en forma de porras toscas" $(D L E)$. Esta iconografía se complementa en el poema con la alusión a "un palo" (v. 46).

${ }^{334}$ Sin blanca: "Modo exagerativo para ponderar que alguna persona no tiene dinero alguno" (Aut.). El término "blanca" también designa una moneda de vellón, que en tiempo del rey Alfonso XI equivalía a la tercera parte de un maravedí.

${ }^{335} \mathrm{El}$ cornado es una moneda de baja ley que mandó hacer el rey Alfonso XI (para remediar la falta de dinero) y que valía el tercio de una blanca. La similitud del vocablo "cornado" con "cornada" permitiría en el contexto del poema asociarlo con el carácter agresivo que en él se atribuye a las monjas.
} 


\section{Al haber visto el pie a una dama (54) \#}

\section{Décimas}

En el mar de tu hermosura

por buscar pie me engolfé 336 ;

y pues que no me anegué

(no tuve poca ventura),

5 rindiose tu compostura

a mis peticiones tiernas,

después de penas eternas,

con razón, pues no conviene

que quien tan hechas las tiene

10

estuviese haciendo piernas ${ }^{337}$.

Dispensando en tu recato,

porque mi amor se despique ${ }^{338}$, me enseñaste un pie $^{339}$

en un dedal por zapato ${ }^{340}$.

15 No me costó muy barato

registrar allí su ser,

pues nunca llego a entender,

cuando con mis dudas lucho,

cómo quiero a tu pie mucho

20 si nunca le puedo ver $^{341}$.

Viendo del pie la belleza

y de tu rostro la rosa,

conocí que eras hermosa

toda, de pies a cabeza ${ }^{342}$.

25 Bien que de tu gentileza,

puesta de amor en la playa,

dar a toda beldad vaya ${ }^{343}$

$\mathrm{y}$, aun, darle alcance también,

que te aseguro, mi bien,

que por pies no se te* vaya $^{344}$.

Mirele por un resquicio,

y tan encogido estaba

que mi discurso dudaba

\footnotetext{
${ }^{336}$ Se trata de una dilogía que alude tanto a "dejarse llevar por imaginación, pensamiento y afectos" como a "entrar un nave muy adentro del mar" como a (Aut.). Resulta relevante señalar que la imagen del enamorado como una nave que se encalla en el mar entronca con la tradición clásica (a través del mito de Hero y Leandro) y con el petrarquismo.

${ }^{337}$ Hacer piernas: "Estar firme y constante en un propósito" (Aut.).

${ }^{338}$ Ver nota 232.

${ }^{339}$ Los pies en los Siglos de Oro se consideraban una de las partes más erógenas del cuerpo femenino. Por ello, debían permanecer ocultos y tapados. Si una mujer decidía enseñárselos a un hombre, su recato y su honestidad quedaban en grave entredicho.

340 Ver nota 100

${ }^{341}$ Se hiperboliza el reducido tamaño del pie de la amada, un rasgo muy valorado dentro del canon de belleza femenino del Renacimiento y del Barroco.

${ }^{342}$ De pies a cabeza: "Enteramente" (DLE).

${ }^{343}$ Se utiliza en el sentido de hacer burla o mofa (Aut.)

${ }^{344}$ Irse por pies: "Frase que vale huir o escapar, por la ventaja en la carrera, del que sigue" (Aut.).
} 
si sería pie novicio

$35 \mathrm{y}$, viendo que tu edificio

se funda en este cimiento,

dije: "Acá, en mi pensamiento,

ser bella bien puede ser,

mas no negará tener

40 poco o ningún fundamento".

De tu mudanza los $\operatorname{cascos}^{345}$

temerlos ya no conviene,

pues quien tan buenos pies tiene

no andará en malos pasos ${ }^{346}$.

45 Favores tan poco escasos

avivan aquí mi fe

a empresas nuevas, porque

ha de ser caso forzoso

ser en favores dichoso

50 quien entró con tan buen pie ${ }^{347}$.

\section{A una dama que, estando ausente y sangrada, pedía celos a su galán (55v) \#}

\section{Décimas}

Mi bien, juro por mi amor

que en tu prolijo accidente

sentí, con estar ausente,

de tus males el rigor;

5 sangrástete y el dolor

me turbó ¡ay triste la vida!

Pero, como dividida

un alma vive en los dos,

no fue maravilla ( ay Dios!)

10 que yo sintiese la herida ${ }^{348}$.

Con bulliciosas señales

mi sangre, que el mal advierte,

por estorbarte la muerte,

quiere salir a raudales ${ }^{349}$.

$15 \mathrm{Y}$, porque en tan duros males

de tu corazón el brío

no desfalleciese frío,

sin mirar en el bien suyo,

para socorrer al tuyo*,

20 desamparar quiso al mío.

\footnotetext{
${ }^{345}$ Dilogía que señala tanto "la uña del pie y de la mano que se corta y alisa para sentar la herradura" como el "hueso cóncavo que cubre la cabeza" (Aut.).

${ }^{346}$ Andar en malos pasos: "Frecuentar malas compañías o comportarse de modo que pueden seguirse malas consecuencias" (DLE).

${ }^{347}$ Entrar con buen pie: "Empezar a dar acertadamente los primeros pasos en un asunto" $(D L E)$.

${ }^{348}$ Ver nota 112.

${ }^{349}$ A raudales: "Abundantemente" (DLE).
} 
No fue fineza muy rara

esta de mi sangre, pues, ni lo podrá ser, ni es

la que en propio interés para.

25 Y, como sí se repara,

si tu sangre se vertiera,

tu vida riesgo corriera

y en mí es bien que concluya,

que iba a socorrer la tuya,

30 por asegurar la mía ${ }^{350}$.

Salir quiso luego, luego,

$\mathrm{y}$ al ir con ansia a estorballa

en mi pecho una batalla

se levantó a sangre y fuego ${ }^{351}$,

35 siguiose al punto el sosiego

a encuentro tan fiero y duro ${ }^{352}$.

Cuando diligente apuro,

con amor y con cordura,

que está tu vida segura,

40 cuando yo vivo seguro.

De aquí, mi discurso alcanza

que hay bastante fundamento,

para que tu pensamiento

pierda la desconfianza.

45 Vive sin tener mudanza

de* quien ofreció desvelos

a tus dos hermosos cielos*353,

sin recelar de mi fe,

porque te aseguro

50 que es muerte vida con celos ${ }^{354}$.

Dime cómo he de poder

olvidarte, dulce dueño ${ }^{355}$,

siendo en tan dichoso empeño*

mi ser tuyo y tú mi ser.

55 No te llegues a perder

en aqueste puro abismo,

porque es de amor barbarismo

que presuma tu cuidado

\footnotetext{
${ }^{350}$ La transformación del amante en el amado, según la teoría platónica, permite vivir en él y, por tanto, el bienestar de uno garantiza la supervivencia de ambos (ver nota 112).

${ }^{351}$ Ver nota 302.

352 El enamorado afronta una batalla eterna contra el deseo "fuego amoroso", pues los códigos que marcan el amor cortés impiden que este triunfe. El enorme sufrimiento que provoca el rechazo de la dama alimenta la "llama" de sus sentimientos y puede provocar en él la desesperación o la locura (ver nota 113).

353 Metáfora de los ojos.

${ }^{354}$ La concepción barroca de los celos como algo inseparable del amor podía justificar que aquellos que habían caído presa de la pasión amorosa fueran conducidos por estos al fatal destino. En la comedia $L a$ escolástica celosa de Lope de Vega, podemos encontrar un ejemplo de ello. Cardenio, aparece al principio como "enfermo de amor", confiesa "que «muere de celoso pesar» (v. 1874)" (Argente del Castillo 15).

355 El apelativo "dueño" forma parte del léxico del fino amor, que concibe el sentimiento amoroso como una relación de vasallaje.
} 
que, de mí mismo* olvidado,

\section{A uno muy preciado de valiente siendo gallina (57v) \#}

\section{Décimas}

Es de Fausto ${ }^{357}$ la fiereza*

y la condición tan bronca

que, en cada aliento, una ronca

echa ${ }^{358}$ siempre que bosteza.

5 Como es tanta su crudeza*,

no hay quien le pueda sufrir;

de que yo vengo a inferir

que, aqueste crudo $^{359}$ señor,

de un avestruz el calor

10 no le podrá digerir ${ }^{360}$.

Hallase en las cuchilladas

y el tirar puntas le implica,

porque siempre una marica ${ }^{361}$

entiende más de puntadas ${ }^{362}$.

15 A este danzante de espadas ${ }^{363}$

persuadirle yo quisiera

a que otro oficio eligiera,

que es fuerza que me admire

de mirar que puntas tire

20 el que mejor las hiciera $^{364}$.

\footnotetext{
${ }^{356}$ Se establece un juego de palabras entre "el olvido" y "el recuerdo" de uno mismo que se enmarca dentro de la teoría platónica del amor y de la reminiscencia. Ver nota 114.

${ }^{357}$ Se trata de una referencia a la leyenda germánica de Fausto. Esta tenía como fuente histórica a Johann Georg Faust, quien se ganó la fama de insolente y ególatra.

${ }^{358}$ Ver nota 251.

359 Dilogía que señala tanto “al que hace profesión de ser guapo y valentón” como al “cruel, áspero, sangriento y despiadado" (Aut.).

${ }^{360}$ No poder digerir a alguno o a alguna cosa: "Vale no poderle sufrir, no ser de su genio o serle repugnante y enfadoso" (Aut.). La arrogancia "crudeza" (v. 5) que se atribuye al protagonista haría que no se echara atrás ante la furia "calor" (v. 9) de un avestruz.

${ }^{361}$ Se emplea en el sentido de "hombre afeminado y de pocos bríos, que se deja supeditar y manejar, aun de los que son inferiores" (Aut.).

362 Dilogía que alude a un buen manejo en el ámbito de la costura (trabajo destinado principalmente a las mujeres) y al de cometer prácticas eróticas homosexuales.

${ }^{363}$ La danza de espadas puede aludir tanto a una pendencia o riña como a un baile que se hacía golpeando las armas al ritmo de la música. Ambas interpretaciones continuarían con la mofa que se hace de Fausto. Resulta relevante señalar que el término "danzante" también descalificaría a este al considerarlo una "persona ligera de juicio, petulante y entremetida" $(D L E)$.

${ }^{364}$ Hacer punta: Esta expresión en el Diccionario de Autoridades posee tres entradas que pueden encajar con el presente poema. Por un lado, "contradecir con tesón la opinión o resolución de otros". Por otro, "sobresalir entre otros de su especie". Por último, señalar a seres o animales "cuando intentan huir o apartarse".
} 
Pendencias ${ }^{365}$ andan* cuajando, y a mí me tiene aturdido que se quiera hacer temido quien sale de ellas temblando ${ }^{366}$,

25 que anda galleando*.

Pero yo no sé si crea

que el dicho Fausto gallea, pues antes mi fe imagina que será, siendo gallina ${ }^{367}$,

30 mas cierto, pues cacarea.

Todas las noches, enteras, de mil pendencias que empolla si saca libre la cholla, es porque le salen güeras ${ }^{368}$.

35 Señores, vaya de veras quién es* el que no repara en una cosa tan rara, que es fuerza que los aturda, como que pendencias urda

40 el que mejor las hilara.

Por lo cual, en penitencia a este escarramán ${ }^{369}$ intruso, le condeno a rueca y huso ${ }^{370}$. Con el de mucha clemencia,

45 no se halle nunca en pendencia, pues que no le obliga* el fuero por marica, y le requiero que en el nocturno tropel, en vez de espada y broquel,

50 me salga con serenero ${ }^{371}$.

\footnotetext{
${ }^{365} \mathrm{El}$ término pendencias recalca las riña y disputas que provoca el carácter del protagonista, las cuales ya habían sido señaladas mediante "echar roncas" (vv. 3-4), "cuchilladas" (v. 11), "danzante de espadas" (v. 15) y "hacer punta" (v. 20).

366 Johann Georg Faust fue acusado de abusar de los alumnos de la escuela de Kreuznach, donde se dice que ocupó el cargo de director. Tras la revelación de este supuesto suceso, habría huido para no ser condenado.

${ }^{367}$ Ser un gallina: "Se llama al que es cobarde, pusilánime y tímido" (Aut.).

${ }^{368}$ Salir huera una cosa: "Desvanecerse lo que se esperaba y creía por cierto conseguir" (Aut.). Con esta expresión se completa el campo semántico relacionado con el ave galliforme: "galleando" (v. 25), "gallea" (v. 27), "cacarea" (v. 30), "empolla" (v. 32), y "güeras" (v. 34).

${ }^{369}$ Escarramán es un rufián que tiene su origen en las jácaras de Quevedo y que, más tarde, conformaría el arquetipo del jaque, un personaje osado e inmoral. Puede citarse, a modo de ejemplo, el entremés El rufián viudo llamado Trampagos, de Cervantes, y El gallardo Escarramán, de Salas Barbadillo.

${ }^{370}$ El tormento que muchas mujeres sentían al dedicarse al oficio de la costura queda recogido en la siguiente frase popular: "Rueca y huso: ¡mal fuego te arda!, que no hay madera tan poca que tanto mal me haga" (Núñez 553).

${ }^{371}$ El término "serenero" designa tanto la cubierta que usa en la cabeza el sereno como la toca que utilizan las mujeres para protegerse de la humedad de la noche. Esta última acepción complementaria el léxico que se ha empleado en el poema para retratar al protagonista como afeminado: "marica" (v. 13) y "gallina" (v. 29).
} 


\section{A unos mozos que salieron a torear (59) \#}

\section{Romance}

De Pinto ${ }^{372}$, para un festejo, corren un novillo bravo cuatro mozos, que mejores no podían ser pintados.

5 Como toreros noveles salen en potros bizarros al caso, pero salieron solo ellos acosados. Parece que olió el novillo

10 ser modernos en el trato, pues dándoles sendas vueltas cual nuevo los ha parado. Con rejones cortos entran, a lo de toreros guapos,

15 pero lo que es hacer suertes ${ }^{373}$ lo llevan muy a lo largo ${ }^{374}$. Todos en ala ${ }^{375}$ le cercan al toro que, como* un rayo, [les hizo que levantasen

20 el cerco más que de paso ${ }^{376}$. Aguizgarle llegan todos, mas el monstruo, que es huraño,] con uno y otro respingo los iba echando tan altos.

25 Hecho señor del cortijo, el toro tan a su mando los tuvo que los hacía que le sirviesen rodando.

A los potros y jinetes

30 trocó, pues a los caballos volvió lo de dentro afuera y a es[os] otros de arriba abajo. Todos de capa caída ${ }^{377}$, ya cayendo y levantando,

35 dejan el toro después de muchos lances rodados.

Al fin de aquesta contienda, fue el toro el más bien librado, ${ }^{378}$ pues, aunque quedó corrido,

${ }^{372}$ Se trata de un pueblo de la Comunidad de Madrid.

${ }^{373}$ Hacer suertes: Equivale a "capear al toro o novillo" (DLE).

${ }^{374}$ A lo largo: "Modo adverbial que significa a lo lejos y a distancia" (Aut.).

${ }^{375}$ En ala: "En fila" (DLE).

${ }^{376}$ De paso: "Ligeramente, sin detención" (DLE).

${ }^{377}$ Andar de capa caída: "Padecer gran decadencia en bienes, fortuna o salud" (DLE).

${ }^{378}$ Podría relacionarse con la expresión "Librar bien", que significa "salir con felicidad y ventura de alguna dependencia o negociado" (Aut.). 
40 ellos se fueron picados ${ }^{379}$.

De donde podrá inferirse

que en otra de escarmentados

no se verán, pues en esta

cayeron ya de sus asnos ${ }^{380}$.

\section{A una dama que, siendo galanteada de muchos, se casó con un sacristán (62v) \&}

\section{Romance}

Dios te socorra, Marica ${ }^{381}$, en esa angustia fatal, pues quiere sepulcro quien

se casa con sacristán.

5 Dote para es[e] otro mundo

este tu novio te trae

de responsos, que es moneda

que no vale por acá.

Objeto de tus bellezas

10 le hiciste, pero él es tal

que, aunque ahora no lo sientes,

temo que te ha de enterrar.

A mil poderosos dejas,

y es tanta tu vanidad

15 que a un sacristán te has rendido,

porque a par de Dios está.

Mullidor* de sepulcros,

gracias a Dios puedes dar,

que te deparo ${ }^{382}$ entre tantos

20 a quien te las mullirá.

Es tan raro este delito

que, siendo él en si venial,

solo por ser con quien es

te ha de hacer culpa mortal ${ }^{383}$.

25 A todos los delincuentes

les salva la inmunidad

de la Iglesia, pero a ti

te ha de condenar.

\footnotetext{
379 Dilogía que hace referencia tanto al hecho de sufrir una herida como al acto de ser "pinchado". Este último significado en el contexto del poema es una burla hacia los picadores que no fueron capaces de "herir al toro en el morrillo con la garrocha, procurando detenerlo cuando acomete al caballo" (DLE).

${ }^{380}$ Caer, o caerse, alguien del burro: "Reconocer que ha errado en algo" (DLE).

381 Ver nota 321.

382 Podría guardar relación con la frase "A Dios te la depare buena", que señala que "algún negocio se arriesga o expone a la contingencia de que salga bien o mal, porque no hay otro modo de manejarle" (Aut.). ${ }^{383}$ La diferencia entre un pecado venial y uno mortal, según el catolicismo, se halla en la conciencia y en el consentimiento que se tiene al realizarlo. Los pecados menores serían producto de una acto inconsciente o ejecutado sin plena intención, mientras que los mayores serían fruto de un acto deliberado y plenamente aceptado. La elección de la protagonista de yacer "casar" (v. 4) con un sacristán sería considerado un pecado mayor, pues su cargo como religioso le obligaría a guardar celibato.
} 
Averigüemos, Marica,

30 en qué te pudo obligar

un hombre que vive solo

de que mueran los demás.

$\mathrm{Si}$ a su clamor compasiva

fuiste, debieras mirar

35 que pagar indica muerte

clamores $^{384}$ a un sacristán.

Si por rico, no hayas miedo

que tenga en su vida un real,

que su dinero cantando

40 como se viene se va ${ }^{385}$.

Si por lo bien entendido, ninguno te negara

que, si canta en la tribuna,

le entiende todo el lugar.

45 Si por cantar ${ }^{386}$, a mi ver,

no te puede cantar más

que los kiries y la Gloria ${ }^{387}$,

pero tú los llorarás ${ }^{388}$.

Si te guizgaron las tortas,

50 que por todos santos hay,

plegue a los cielos que no

te cueste la torta un pan $^{389}$.

Si por galán, poco importa,

si es tan corto su caudal

55 que, para que tú lo comas,

lo ha de quitar del altar.

Si porque tus faltas cubra,

bien lo pensaste en verdad,

pues lo que es echar la tierra ${ }^{390}$

60 ninguno como él lo hará.

Si por afable, lo erraste,

que un hombre tan infernal

que, aun a los santos sacude,

\footnotetext{
${ }^{384}$ Se trata de un equívoco. En su primera aparición (v. 33), remite a una voz "lastimera y afligida". y, en la segunda (v. 36), alude al "toque triste de las campanas que se da por los difuntos" (Aut.).

${ }^{385}$ El dinero del sacristán cantando se viene, y cantando se va: "Refrán que advierte que lo que cuesta poco trabajo en adquirirlo se desprende con facilidad" (Aut.). Góngora recurre a este dicho para conformar el estribillo de "Tres hormas, si no fuel un par" (Góngora s.p.).

${ }^{386}$ Dilogía que hace referencia tanto a la acción de producir sonidos melódicos como al acto sexual. La vinculación del verbo cantar en la poesía jocosa de los Siglos de Oro con este último significado, sobre todo en la relacionada con miembros del clero, es recurrente. Un claro ejemplo de ello lo encontramos en las décimas "Jacinta, ayer te escuché" (León, Obras 3: 24) y en el romance "Señoras, ya que es Cuaresma" (Pérez de Montoro, 2: 280).

${ }^{387}$ Entre los ritos iniciales de la misa se halla el "Kirie eleison" y el "Himno de Gloria".

${ }^{388}$ Llorar los kiries: "Llorar mucho" (Aut.).

${ }^{389}$ Costar algo la torta un pan: Según el Diccionario de Autoridades puede significar tanto "costar mucho más de lo que vale" como "exponerse por conseguir algo a un daño o riesgo que no se había previsto".

${ }^{390}$ Echar tierra a un negocio: "Encubrirle" (Cov.). Esta expresión se relaciona con la acción de sepultar a los muertos "enterrar" (v. 12) y con el oficio principal que se atribuye en el poema al sacristán "mullidor de sepulcros" (v. 17).
} 
mejor te sacudirá.

65 Cera busca $^{391}$ y aborrece

tanto la sinceridad

que, si tú fueres sin cera $^{392}$,

nunca tendrás con él paz.

En fin, de tan buen marido

70 solo puede esperar

que serás bien sacudida,

mas acudida muy mal.

No quiero doblar tus penas,

porque, si a doblar las vas,

75 nadie como tu marido

las sabrá también doblar ${ }^{393}$.

\section{Amorosa soledad (62v) \&}

\section{Décimas}

Para qué es tu atrevimiento

corazón enamorado,

si, al fin, no has de ver logrado

tan altivo pensamiento.

5 Deja ya tan loco intento,

mas no, sigue tu pasión,

no dejes tu inclinación

que, aunque no lo has de lograr, amar solo por amar

10 es el mejor galardón ${ }^{394}$.

Amor que al favor aspira

no se debe así llamar,

pues, más que al enamorar,

a su propio interés tira;

$15 \mathrm{y}$, así, el que puesta la mira ${ }^{395}$

tiene al favor vigilante;

digo en mí rigor* constante,

cuando sus designios copio,

que este tal tiene amor propio,

20 pero que no es propio amante.

Bien, pues, me puedo arriesgar,

\footnotetext{
${ }^{391}$ Buscar cera: "Buscar conflictos". También podría relacionarse con buscar relaciones sexuales.

${ }^{392}$ Se establece un calambur entre "ser sincera" y "estar sin cera".

${ }^{393}$ Se trata de un equívoco. En su primera aparición (v.73), señala la voluntad de evitar el aumento del sufrimiento; en la segunda (v.74) alude al intento de reducir o encoger las penas: en la última (v. 76), hace referencia al acto de tocar las campanas para los muertos.

${ }^{394}$ Una de las bases sobre la que se sostiene el amor cortés es la de no esperar ninguna recompensa del amado, ya que el sentimiento que provoca es desinteresado y permanente.

395 Poner la mira en algo: "Hacer la elección de ello, poniendo los medios necesarios para conseguirlo" (DLE).
} 
Anarda bella ${ }^{396}$, a querer, pues no tengo que perder y mucho puedo ganar.

25 No quiero no malograr esta ocasión que me ofrece amor, que a tu desdén crece. Ya lo dije, si he errado, muérase de declarado

30 quien de callado perece*.

Que un imposible procura mi amor no lo dudo, no. Mas si amarte* puedo yo, no quiero mayor ventura

35 que, aunque parece locura, amar al que desconfía.

Se engaña la fantasía ${ }^{397}$, pues halla un triste su daño de su ser el desengaño

40 con que en sí nunca se fía.

\section{A una dama que, estando destocada, se asomó a una reja y su galán la asió una mata de cabellos $(63 \mathrm{v})$ \#}

\section{Décimas}

A una reja qué ventura, sin adorno y sin aliño, te miré, y el desaliño pudo aumentar tu hermosura.

$5 \mathrm{Al}$ verte sin compostura, te rendí mi voluntad, conociendo, por verdad, no hay resistencia en los ojos cuando brinda sus antojos

10 sin aliño una beldad.

Sin prisiones el cabello, ni bien negro ni bien rubio, inundó en dulce diluvio la candidez de tu cuello.

15 Yo, que tan sereno y bello le vi, quise con presteza

\footnotetext{
${ }^{396}$ La situación amorosa que plantea el yo poético parece aludir a la comedia pastoril La Arcadia de Lope de Vega (Porteiro 211). A final del segundo acto, Anfriso intenta olvidarse de su amor imposible, Belisarda, mediante la conquista de Anarda (quien ha urdido una serie de engaños para separar a los protagonistas) y le dice a esta última: "Para mí no hay Belisarda / que solo hay Anarda bella" (vv. 1799-1800). ${ }^{397}$ Ver nota 243.
} 
engolfarme ${ }^{398}$ en su grandeza

si, al fin, no me reportara,

temiendo que me anegara

en el mar de tu belleza.

Viendo que libre y exento, cuando el aire se desata, entre una y otra mata, permite halagos el viento

25 y que con lascivo aliento te retoca el airecillo, dije que me maravillo ya de su rara hermosura, si por las hebras se apura

30 la hermosura del ovillo ${ }^{399}$.

La brújula ${ }^{400}$ de una reja me permitió (qué favor) que tocase, sin temor, tu hermosísima madeja ${ }^{401}$.

35 Pero ya un pesar me deja no pequeño, aunque es vano, de que a fuer de cortesano deje la ocasión perder, pudiendo siempre tener toda la dicha en mi mano.

Si con industria mañosa sujetarme así has querido, cuando yo estoy tan rendido, es tu* diligencia ociosa.

45 Sabes lo que maliciosa mi razón discurre en ello, que ha sido solo en hacello dar a entender que podías llevarme donde querías

50 con solamente un cabello.

Siendo la ocasión ${ }^{402}$, querida, de que mi amor hizo empeño, te tuve, querido dueño, de los cabellos asida ${ }^{403}$.

\footnotetext{
${ }^{398}$ Dilogía que señala tanto la acción de adentrarse en la profundidad del mar como la de "meterse mucho en un negocio, dejarse llevar o arrebatar de un pensamiento o afecto" (DLE). La primera acepción se relaciona en el poema con el "mar de tu belleza" (v. 20).

${ }^{399}$ La imagen de la madeja para representar el cabello de la dama era un tópico dentro del imaginario neoplatónico.

${ }^{400}$ Se emplea en el sentido de apertura.

${ }^{401}$ Ver nota 76.

${ }^{402}$ Se podría relacionar con la expresión "La ocasión, la pintan calva". Esta tiene su origen en la representación de la diosa grecorromana Ocasión sin pelo, excepto por encima de la frente, y simboliza "la dificultad de no perder la oportunidad de algo cuando se presenta de frente y cómo resulta prácticamente imposible detener su curso" $(\mathrm{CVC})$.

${ }^{403}$ Asirse de un cabello: "Es valerse de cualquier pretexto, aunque sea muy leve, para ejecutar alguna cosa o para solicitarla, desearla y apetecerla" (Aut.).
} 
Esta dicha conseguida

cesará a mi desvelo,

a favor ninguno anhelo,

pues no tengo que esperar

que alguno me puedas dar,

60

que me* vengan tan a pelo ${ }^{404}$.

\section{A una dama que se casaba con un capón (65v) \#}

\section{Décimas}

Con modo ya más humano

se da a tratar tu belleza,

pues recibes con llaneza,

Lisis ${ }^{405}$, cualquier besamano.

5 A Fabio le das la mano, cuando a mí me das pesares, y aun otros más singulares favores pienso que espera, porque el buscar la manera

10 huele a manos y cuajares ${ }^{406 *}$

Lo que en esta vejación mi discurso más atolla es que me lleve la polla ${ }^{407}$ jugando al hombre un capón ${ }^{408}$.

15 De ti ningún galardón ya, Lisis, mi fe no espera, con tu Fabio en caponera puedes holgarte del* todo ${ }^{409}$ y no hay que dudar del modo, que buscará la manera.

\footnotetext{
${ }^{404}$ Venir a pelo: "Se dice para significar venir a cuento, venir con oportunidad" (CVC). 405 Ver nota 121.

406 A manos y cuajares: La recurrente práctica de vender en las carnicerías juntos los cuajares y las extremidades de la reses dio origen a dicha expresión.

${ }^{407}$ Se trata de una dilogía que alude tanto a una "muchacha o moza de poca edad y buen parecer" como a "aquella porción, que se pone y apuesta entre los que juegan" al "Juego del hombre" y a otros (Aut.).

${ }^{408}$ Los capones son los hombres que no pueden tener relaciones sexuales con mujeres, ya sea por tener un impedimento físico en sus genitales o por llevar la sotana. Estos eran considerados en los Siglos de Oro semejantes a los sodomitas, porque tampoco podían engendrar. Intimar con ellos, por tanto, se creía que era un pecado tan grave como la homosexualidad (Díez Fernández 230).

409 Sirve como metáfora de los favores de Lisis que recibirá Fabio, pues en las caponeras los capones únicamente se dedican a engullir alimentos.
} 


\section{Amante callado y sospechoso (66) \#\#}

\section{Estribillo}

Solo el silencio testigo

ha de ser de mi tormento,

pues no cabe lo que siento

en todo lo que no digo ${ }^{410}$.

\section{Glosa.}

\section{Décimas}

En sospechoso amor toca

quien calla, que es*, si se apura,

maliciosa calentura

la que no sale a la boca.

5 Otros con cordura poca

callar (de necios abrigo)

sigan, que yo el callar sigo.

No peligre mi opinión,

siendo de mi inclinación

10 solo el silencio testigo ${ }^{411}$.

Hacer al amor agravio

bella Isabela solicita,

quien al corazón le quita

los desahogos del labio.

15 Con acuerdo poco sabio, oculten otros su intento, que yo en el ardor que siento, que tanto el alma me apura, hallo que el hablar locura

20 ha de ser de mi tormento.

Pasión se llama infelice

la que callando imprudente, sintiendo lo que no dice, de fino se solemnice

25 mi público sentimiento

y si por grave el tormento no cupiere en mi razón ni en humana explicación, quepa la ponderación,

\footnotetext{
${ }^{410}$ Se trata de una famosa redondilla que fue glosada por diferentes poetas (Bocángel, José Pérez de Montoro o Miguel de Barrios), utilizada para ilustrar la definición de paradoja por Gracián y empleada en varias obras de teatro por Calderón (quien la popularizó) y por sus contemporáneos: "Matos Fragoso, Moreto, Salazar y Torres, Antonio Hurtado de Mendoza, Solís, Diamante, Pérez de Montalbán y Suárez de Deza" (Suárez 439).

${ }^{411}$ Según las doctrinas pitagóricas, el amor humano se define como comunicación de almas, cuyo idioma "no podía ser otro que el silencio. Mediante este idioma se accedía a la eternidad y Calderón lo ratificó de forma categórica en su verso: «el idioma de Dios es el silencio»” (Suárez 441).
} 
pues no cabe lo que siento ${ }^{412}$.

No es amante con acierto

el que callando se entabla,

que tiene un amor sin habla

mucho andado para muerto.

35 Llegué del favor al puerto,

quien la derrota que sigo

sigue de mi amor testigo.

Sea el alivio, que es error,

hacer agravio a mi amor

40 en todo lo que no digo.

27. A una dama que gastó lo mejor de su mocedad con frailes y a la vejez decía mal de ellos y se había empeñado con un sacristán. Sátira (67) \&

\section{Romance}

Marica $^{413}$, que a decir mal

de frailes te precipitas,

estando, por condenado,

tu amor siempre en la capilla.

5 Ellos de ti no hacen caso

sin nota de grosería,

que no son las reverencias

para tan descortés niña ${ }^{414}$.

Resabio de privilegio

10 tienes y lo saco, amiga,

en que de tu trato todas

las órdenes participan.

Pila de los frailes, todos,

fuiste siempre conocida,

15 sino es que tu sacristán

te ha sacado ya de pila ${ }^{415}$.

Del mercenario te pagas,

del agustino te obligas

y el teatino de tus partes

20 tiene muy larga noticia.

Si piensas que no te entienden,

412 En el Amigo, amante y leal (1631), Calderón incluye al principio de la jornada primera un discurso donde se pone de manifiesto el plano en el que se mueven los sentimientos humanos: "Solamente el alma sabe / comprender afecto igual, / porque es esencia inmortal, / que mi amor inmenso, /y grave en menos caja no cabe, / (...) con que siento lo que digo, / y no digo lo que siento" (Suárez 441).

${ }^{413}$ Ver nota 321.

${ }^{414}$ En germanía, el término "niña” significa prostituta (Alonso Hernández 255).

${ }^{415}$ La expresión "Sacar de pila" (ser padrino de alguna criatura en el Bautismo) se utiliza en el sentido de dejar de ser la amante de los religiosos. 
poco, amiga, gongorizas,

porque más que a soledades ${ }^{416}$

te inclinas a compañías.

25 Deja de decir mal de ellos

y que es indecente; mira

que, por vana, te deseche

quien te averiguó partida ${ }^{417}$.

Cuando despreciarte miro

30 los frailes, pienso, Marica,

que tus flaquezas con ellos

te tienen desvanecida.

Perdida por ellos fuiste

más que mucho, niña mía,

35 que si tantos te jugaron

estés por ellos perdida ${ }^{418}$.

Espantadiza te has hecho,

de los frailes te retiras,

te estás en los "Padres Nuestros"

40 y dices: "Ave María" ${ }^{419}$.

¿Después de las otras muchas

das en esta niñería?

Dinos que te sobresaltan,

mas no que te asustan digas.

45 Trata de ser bien mirada

de quien fuiste tan bien vista

y mira con quién te tomas,

antes, muchacha, que riñas.

De un fraile son los consejos

50 que con buena intención tira,

porque más no los escupas

ha hacerte tragar saliva ${ }^{420}$.

De que tus desatenciones

\footnotetext{
${ }^{416}$ Se alude en tono jocoso a las Soledades de Góngora (Góngora s.p.). Tal asociación se realiza gracias a la referencia en el verso anterior del término "gongorizar", que recalca la actitud poco reflexiva de la protagonista.

417 Ver nota 284.

${ }^{418}$ Se trata de un equívoco. En su primera aparición (v. 33), se emplea en el sentido de "menospreciada" o "dañada" y, en la segunda (v. 35), podría señalar tanto a una mujer "descuidada en sus obligaciones o incorregible en sus vicios y costumbres" como a una "ramera, viciosa, prostituta y de mal vivir" (Aut.). Esta última acepción se vincularía con "partida" (v. 28).

${ }^{419}$ Remite al popular chiste de "La embarazada por el Ave María". Este cuenta la historia de una solterona que acude a la iglesia con la intención de quedarse embarazada, tras haber escuchado que una mujer lo había conseguido después de que el cura le diera el "Ave María". El párroco le dice que está equivocada, pues tal suceso lo había provocado un "padre nuestro" y este ya había sido despedido.

${ }^{420}$ Tragar saliva: "Frase que explica el no poder desahogarse ni oponerse a alguna determinación, palabra, o acción que ofende, por la autoridad de la persona que la hace, o dice, o por otras razones de conveniencia, o política" (Aut.).
} 


\section{llegasen a su noticia}

no te admires, porque tú

siempre los tienes encima ${ }^{421}$.

Ya su buen trato te cansa,

sus donaires te fastidian,

pero yo me acuerdo cuando

60 te hacían mear de risa.

Mucho medras, pues te pasan

a privada de valida ${ }^{422}$,

con que vienes a ser dama

de su cámara y orina.

65 No hacías ascos cuando estabas

de ellos tan antojadiza,

que una vez gustaste de uno

$\mathrm{y}$ te hizo buena barriga ${ }^{423}$.

Este corte de vestido

70 quien te conoce te envía;

él es de picote, arroja

el que traes de picardía.

\section{Sátira a otro asunto (69) \&}

\section{Romance}

Quisimi ${ }^{424}$ quisimona*, ;hola!

Con su pan se lo coma ${ }^{425}$, ;hola!

Vaya, vaya de bureo.

Oigan, y nadie se corra.

5 Tengan todos su correa

y guárdense de mi soga.

Quisimi quisimona, ihola! (...).

Quien goloso de conservas

vende su amor a una monja

${ }^{421}$ Podría relacionarse con la expresión "Estar encima de algo o de alguien", que significa "vigilarlo con atención, atenderlo con sumo cuidado" (DLE). Además, por el contexto del poema, las acciones de "tienes encima" y "te sobresaltan" (v. 43) parecen aludir a actos sexuales.

${ }^{422}$ Se realiza una burla del ascenso social que ha experimentado la protagonista al convertirse en la privada "retrete" de un hombre de poder "valido".

${ }^{423}$ Figuradamente se toma por "preñez" (Aut.).

424 "Quisimi” y "quisimona" son dos palabras inventadas, que se utilizan para construir el estribillo del romance. Este tipo de neologismos eran habituales en las composiciones jocosas de los Siglos de Oros. Un ejemplo de ello lo encontramos en el poema erótico "Mozas si os queréis holgar", donde se emplea el término "dungandux" tanto en el estribillo como en el cuerpo del texto (Labrador 53).

${ }^{425}$ Con su pan se lo coma: "Frase con que se da a entender que alguno posee o tiene alguna cosa con mala fe o dice y obra algo que no es justo ni razonable y que por consecuencia no se le aprueba ni envidia, porque no puede tener buen paradero" (Aut.). 
10 y anda todo el año a garra ${ }^{426}$,

por hacerle andar a orza ${ }^{427}$.

Quisimi quisimona, ;hola! (...).

El que a la red de un convento

mira la pesca gustosa

15 y nunca coge la trucha,

aunque las bragas remoja ${ }^{428}$.

Quisimi quisimona, jhola! (...).

La que se paga $^{429}$ de frailes

y antepone, cariñosa,

20 alegas cortesanía,

reverencias de corona.

Quisimi quisimona, ;hola! (...).

El que a doncella festeja

tan guardada y oficiosa,

25 que no ha lugar de rascarse ${ }^{430}$,

por mucho que amor la coma.

Quisimi quisimona, ;hola! (...).

La mal acondicionada

que con la honrada persona

30 de su marido es entera

y partida ${ }^{431}$ con las otras.

Quisimi quisimona, ;hola! (...)

La fruncidica beata

que, con maña artificiosa,

35 por parecer santa y cuerda,

se tañe, mas no se toca ${ }^{432}$.

Quisimi quisimona, ;hola! (...).

[El mancebo, poco cuerdo,

que elige por mujer propia

40 una viuda, que es el plato

que ha servido en otra boda.]*

Quisimi quisimona, ;hola! (...).

No se queje el descuidado

que a su mujer deja sola,

\footnotetext{
${ }^{426}$ Ver nota 17.

${ }^{427}$ A orza: "Término náutico que se dice cuando va el bajel torcido a un lado o echado sobre uno de los costados: y por semejanza se dice de las cosas que están torcidas o ladeadas" (Aut.).

${ }^{428}$ Parece remitir al refrán "No se toman truchas a bragas enjutas", que señala que "lo que es valioso o estimado requiere esfuerzo y diligencia, incluso molestias, del mismo modo que cuando se quiere pescar uno se moja, como sucede con la pesca de la trucha" $(C V C)$.

${ }^{429}$ Se trata de una dilogía que puede interpretarse como "satisfacer por el delito, culpa o yerro, por medio de la pena correspondiente" y como responder "al afecto, cariño u otro beneficio" (Aut.). Además, puede relacionarse con el acto de la prostitución y con la estrecha relación que había en los Siglos del Oro entre eros y oros (ver nota 327).

${ }^{430}$ Se emplea en el sentido de "masturbarse".

431 Ver nota 284

432 Se emplean los verbos "tañer" y "tocar", vinculados al uso de instrumentos, como metáforas de la masturbación femenina. No obstante, se establece una diferencia entre ambos. El primero, parece usarse en su acepción de "interesarse por algo" y, el segundo, en la de "estimular".
} 
pues pone de cabe a pala ${ }^{433}$

que le pegue golpe en bola ${ }^{434}$.

Quisimi quisimona, ;hola! (...).

El que con la dama ausente

gasta de día las horas

en pensarla, habiendo otros

que la ensillen y la corran ${ }^{435}$.

Quisimi quisimona, ;hola! (...).

La doncella que traviesa

con su amante gustos logra

$55 \mathrm{y}$, comiendo arroz con leche ${ }^{436}$, quiere sacar tripa horra ${ }^{437}$.

Quisimi quisimona, ;hola! (...).

El que con gana de holgarse

va en casa de alguna buscona

60 y con espigón se vuelve ${ }^{438}$,

porque no vino con mosca ${ }^{439}$.

Quisimi quisimona, ;hola! (...).

El que se casa con flaca

$\mathrm{y}$ amante de peleona

65 entra tendiendo la raspa $a^{440}$

la noche que se desposa.

Quisimi quisimona, ;hola! (...).

El que tiene tan mal gusto

que se enamora de gorda,

70 y obligado de la carne,

un rastro escoge por novia.

Quisimi quisimona, ;hola! (...).

El preciado de entendido,

que sin dinero y con coplas,

75 quiere dama no sabiendo

que adonde las dan las toman ${ }^{441}$.

Quisimi quisimona, ;hola! (...).

El letrado interesado

que tiene siempre que aboga

\footnotetext{
${ }^{433}$ Poner cabe a pala: "Poner la ocasión de alguna cosa en las manos" (Terreros 293). También se podría relacionar con "Cabe de paleta", que se llama en "el juego de la argolla, cuando casualmente quedan las dos bolas en tal proporción y espacio, que solo cabe entre las dos la pala con que se juega, que es la distancia que ha de haber por lo menos para tirar el cabe. Translaticiamente es la ocasión que impensadamente se vino a las manos" (Aut.).

${ }^{434}$ Golpe en bola: "El cabe que se da a la bola opuesta, en el juego de la argolla o de trucos, por el aire y sin rodar la bola, elevándola rectamente con la pala o con el taco" (Aut.).

${ }^{435} \mathrm{La}$ acción de "montar a caballo" sirve como metáfora del coito.

${ }^{436}$ Ver nota 320.

${ }^{437}$ Sacar horra: "Sacar libre a alguien y sin pagar su parte o la de otros en un negocio" (DLE).

${ }^{438}$ Se emplea como metáfora de erección.

${ }^{439}$ Ver nota 168.

${ }^{440}$ Tender alguien la raspa: "Echarse a dormir o descansar" (DLE).

${ }^{441}$ Donde las dan, las toman: "Quien hace daño a alguien o habla mal de él, suele recibir el mismo pago. Se emplea para advertir a quien ha hecho alguna faena que seguramente recibirá la réplica correspondiente" $(\mathrm{CVC})$.
} 
si leyes como en la uña ${ }^{442}$, infierno como en la bolsa.

Quisimi quisimona, ;hola! (...).

El doctor que barbipleno, con pocas letras y gordas,

85 nos quiere vender la pera moscatel por bergamota ${ }^{443}$. Quisimi quisimona, ihola! Con su pan se lo coma, ;hola

\section{A un hombre en abreviatura fraile meñique que, hipócrita de estatura, se engrandece a costa del alcornoque (71) \#}

\section{Romance}

Oye, tarazón de frailes, sabandija que en el charco de este mundo te introduces a ser hombre, siendo trasgo.

5 Tú que no te parecías $\mathrm{y}$, hoy, para parecer algo, te has añadido, aunque siempre te sales con ser menguado ${ }^{444}$. Oye, verás de mi genio

10 discursos muy bien fundados, que hoy no puedo hablar a bulto ${ }^{445}$, supuesto que a ti te hablo. En unos corchos te has puesto, para ser mayor, y es llano

15 que debes al corcho mucho, pues ya te ha puesto en estado ${ }^{446}$.

A tener grande estatura anhelas, y no es muy vano* tu discurso, pues sabemos

20 todos que te las calzado. Resabios de mujer tienes, si con atención reparo, que quieres lo que pretendes conseguirlo a chapinazos.

25 La cortedad de tus zancas suples mañoso con zancos y los talones ocupan

\footnotetext{
${ }^{442}$ Se utiliza en el sentido "de destreza o suma inclinación para defraudar o hurtar" (Aut.).

${ }^{443}$ Hace referencia a una estafa, pues la pera moscatel se considera de mucha menos calidad que la bergamota.

${ }^{444}$ Se trata de una dilogía que recalca su escasa de estatura y su carácter miserable o mezquino. Tales rasgos se habían señalado ya con el término "sabandija" (v. 2).

${ }^{445}$ A bulto: "Aproximadamente, sin cálculo" (DLE).

${ }^{446}$ Se emplea en el sentido de poseer "cierta medida de la estatura regular que tiene un hombre" (Aut.).
} 
el lugar del espinazo.

Por cuartos, del talle arriba,

30 tienes solo dos ochavos ${ }^{447}$

$\mathrm{y}$, del talle abajo, has hecho,

contra la ley, cuartos falsos.

Más bien, puedes apearte

del corcho, y vuelvan los cuartos

35 a ser octavos, pues ya

la moneda se ha bajado ${ }^{448}$.

Para que jugando al hombre ${ }^{449}$

no te ganase un enano,

que apostó a chico contigo,

40 te* pusiste más dos tantos.

Cuando te acuestas, tan otro

estás que no podrá el diablo

conocerte, pues se muda

todo tu ser de alto a bajo.

45 Grande falta de corcheras

ha de haber ya los veranos,

solo porque con el corcho

tan sin Dios te has levantado.

Para el tiempo que haya falta

50 de chapines, yo te mando

venturas, pues las mujeres

morirán por tus pedazos ${ }^{450}$.

De santo este ardid te apoya,

pues cada día miramos

55 que tenéis los pies del suelo

levantados más de un palmo.

Aunque cuando en zancos miro

que te mueves tan despacio,

no lo creo, mas no puedes

60 morir en carrera, hermano.

Enmiéndate, pues el mundo

todo te murmura* tanto

que aun pienso que los ratones

te han de roer los zancajos ${ }^{451}$.

\footnotetext{
${ }^{447}$ El ochavo era una moneda castellana que equivalía a la mitad de un cuarto.

${ }^{448}$ Las diversas alteraciones que sufrió la moneda en Castilla y los graves problemas de circulación que esta tuvo durante el reinado de los últimos Austrias en España ha sido estudiada por Javier de Santiago Fernández (353-398).

${ }^{449}$ Se trata de un juego de naipes "entre varias personas, con elección de palo, que sea triunfo, y el que le elige se llama hombre. Hay varias especies de él, jugándose unas veces entre más personas que otras, y con más o menos cartas, con descarte o sin él, y se le dan varios nombres: como la zanga, la cascarela, el cinquillo y otros" (Aut.).

${ }^{450}$ Morirse por sus pedazos: "Frase familiar con que se explica que alguno tiene especial cariño a otra persona" (Aut.).

${ }^{451}$ Roer los zancajos a alguien: "Murmurar o decir mal de él en su ausencia" (DLE). El uso del vocablo "zancajos" también reitera los rasgos de "persona de mala figura o demasiado pequeña" (DLE).
} 


\section{Convidando una dama a su galán a finezas amorosas, en metáfora de un juego de hombre (73) \#}

\section{Décimas}

Ya, Fabio, que hemos llegado

al garito de Cupido ${ }^{452}$

que ajustemos un partido

me ha parecido ajustado.

5 Jugar un hombre ${ }^{453}$ envidado $^{454}$

puedes conmigo de veras,

y no juzgues* lisonjeras

mis* finezas, pues tan presto*

pongo en amor todo el resto ${ }^{455}$,

10 con gana de que me quieras.

Si llegas a resolverte, verás que con obligarte procuro amante ganarte, sin que puedas perderte,

15 en esta dulzosa suerte.

Funda, amor, tu triunfo y palma*, y yo, en tan dichosa calma, llevaré el riesgo, atrevida jugada, el alma y la vida,

20 solo por ganarte el alma.

De mano saldré jugando ${ }^{456}$, para que tú, previniendo, la suerte ganes sirviendo ${ }^{457}$, cuando yo salgo triunfando ${ }^{458}$;

25 con que los dos arrestando, con mañosas fullería ${ }^{459}$, las dos almas a porfía nadie saldrá con la suya ${ }^{460}$, pues yo saldré con la tuya

30 y tú saldrás con la mía.

De amor el juego arriesgada, ya que me animó el cuidado,

\footnotetext{
${ }^{452}$ El "garito del amor" es un espacio donde se da el amor tahúr o el amor fullero, que suele presentar contenido erótico. Un ejemplo de ello lo encontramos en la sátira de Luis Antonio "En el garito del amor" (Etienvre 22).

${ }^{453}$ Ver nota 449.

${ }^{454}$ En algunos juegos de naipes, señala "la apuesta que se hace parando, además de los tantos ordinarios, cierta cantidad a un lance o suerte" (Aut.).

${ }^{455}$ Se podría relacionar con la expresión "Echar, o envidar, el resto", que se emplea en el juego para "parar $\mathrm{y}$ hacer envite de todo el caudal que alguien tiene en la mesa Hacer todo el esfuerzo posible" (DLE).

${ }^{456}$ Salir de mano: Empezar el juego.

${ }^{457}$ En el juego de naipes es "jugar la carta del palo, que se pide, especialmente cuando es inferior" (Aut.).

${ }^{458}$ Dilogía que indica tanto la acción de ganar como el empleo de una "carta del palo de más valor" $(D L E)$.

${ }^{459}$ Ver nota 6.

${ }^{460}$ Salir con la suya: "Frase que vale conseguir uno su intento, cuando tiene contradicción para lograrlo" (Aut.).
} 
pondré en dejarte picado ${ }^{461}$

y en quedarme yo picada.

35 Si este partido te agrada,

juntaremos dos extremos

picados, y en paz saldremos,

cuando a jugar nos pongamos,

solo con que nos perdamos

40 entrambos, y no ganemos.

\section{Habiendo un poeta hecho un romance sátiro contra otro pobrete, se le respondió cagándose en él y con estas (74v) \#}

\section{Décimas}

Tu romance, Andrés, leí.

Y si no me engaña* el casco ${ }^{462}$, lo que, ayer, para mi chasco, hoy, es como para ti.

5 Volvértele quise así, con particular cuidado, no sea que algún barbado lo quiera vender por suyo, pues todos saben que es tuyo

10 en viéndole mojonado.

Tus coplas de celebradas tienen dicha y de aplaudidas, ayer, fueron muy válidas ${ }^{463}$, hoy, las miras muy privadas ${ }^{464}$.

15 Si tus fatigas logradas miras con tales despojos, haz romances a manojos ${ }^{465}$. A todos no temas, no, y verás que, como yo

$20 \operatorname{los}^{*}$ ponen sobre sus ojos ${ }^{466}$.

461 Ver nota 232.

${ }^{462}$ Se emplea en el sentido de cabeza.

${ }^{463}$ El término "válidas" no solo recalca que los poemas mencionados por el yo poético antes eran aclamados por el público, también conforma una paranomasia con la palabra "valido". Esta permite señalar que ya no tienen la aceptación de un cargo destacado y relacionarla con "privadas" (v.14), pues "privado" era otro sustantivo empleado para de designar un puesto privilegiado.

${ }^{464}$ Dilogía que hace referencia tanto a algo que se reserva a unos pocos particulares como a la letrina o "plasta grande de suciedad o excremento, echada en el suelo o en la calle" (Aut.). Las dos últimas acepciones se vincularían con "mojonado" (v. 10).

${ }^{465}$ A manojos: "En abundancia" (DLE).

${ }^{466}$ Hace referencia al ano. Además, se podría relacionar con la expresión "Poner a alguien delante de los ojos algo" (ver nota 295). 


\section{Epigrama gracioso a una dama (75) \&}

\section{Redondillas}

El pañuelo desembolsa ${ }^{467}$

mi mano si solo un beso

me das, Inés, aunque de eso

no he de echar nada en la bolsa ${ }^{468}$.

Pues es bueno el cambio, trueca;

porque dar sin más ni más

es mal hecho, y ya sabrás

que quien da y besa, no peca ${ }^{469}$.

33. Otro a otra dama que no correspondía a las finezas amorosas con que su galán la pretendía $(75 v) \&$

\section{Redondillas}

Marica $^{470}$, no desdeñosa

te resistas que, aunque yo

estuve malo, ya no

tengo maldita la cosa ${ }^{471}$.

5 Cuando por ti amante peno,

ingrata y terrible estás

conmigo; no haya ya más,

que ya está bueno lo bueno ${ }^{472}$.

\section{A unas doncellas que querían bien a unos portugueses y estuvieron por ellos encerradas en una cuadra $(75 \mathrm{v}) \#$}

\section{Décimas}

Queridas, mucho me enfada

que, aunque sean descorteses, tengáis con dos portugueses la voluntad revelada.

$5 \quad$ No sé yo que ganéis nada

\footnotetext{
467 Ver nota 327.

${ }^{468}$ No echárselo en la bolsa: "Frase que denota no interesarse o no tener utilidad en alguna cosa" (Aut.).

${ }^{469}$ Quien da y besa, no peca: Se trata al parecer de un refrán conventual, que no aparece ni en los refraneros viejos ni en la recopilación de Correas. Este es recogido por Sor Juana en los últimos versos de "Acuérdome Filis mía": "Doyle por ella a tus / mil besos en recompensa / sin que parezca delito, / pues quien da y besa, no peca" (Pérez Martínez 64).

470 Ver nota 321.

${ }^{471}$ Metáfora de la disfunción eréctil.

${ }^{472}$ Metáfora del órgano genital masculino.
} 
en seguir tan sin razones

del portugués los pendones,

sino es que, al haber derretido

tanto sebo, habéis querido

10

hartaros de chicharrones ${ }^{473}$.

Aunque vuestro amor no apruebo,

no me maravillo, amigas,

que con ellos buenas migas ${ }^{474}$

hagáis, porque tienen sebo ${ }^{475}$.

15 Antes, cuando a buscar pruebo

disculpa a vuestro cuidado,

hallo que algún resfriado

tenéis, y tomáis* por medio

poner, para su remedio,

en el pecho un encerado ${ }^{476}$.

Si los estáis adorando,

niñas mías, hacéis mal,

porque amor de Portugal

en Castilla es contrabando ${ }^{477}$.

25 Ved que os están engañando

con finezas, que son vanas,

que como, con buenas ganas,

os ven* doncellas y hermosas

quieren* ajaros las rosas ${ }^{478}$,

30 solo por ser castellanas.

Que sois bien galanteadas

imagináis $\mathrm{y}$, a mi ver,

mas cierto debe de ser

que estáis por ellos sitiadas.

35 Resistidles alentadas,

con valerosa firmeza,

porque si vuestra belleza

así no fortalecéis,

sois doncellas, y daréis

40

por hambre la fortaleza ${ }^{479}$.

${ }^{473}$ Dilogía que señala tanto el sebo del cerdo frito (v. 9) como algo que ha sido quemado al fuego. Cabe señalar que el acto de "hartarse de comer chicharrones" podría ser una metáfora erótica.

${ }^{474}$ Hacer buenas migas: "Frase que significa avenirse bien, y tener amistad con alguno" (Aut.).

475 Se trata de un equívoco. En su primera aparición (v. 9), señala la "grasa dura y sólida" y, en su segunda (v. 14), indica "caudal o hacienda en abundancia" (Aut.). Esta última acepción podría hacer referencia al crecimiento económico del Imperio portugués en la segunda mitad del siglo XVII, gracias a sus dominios coloniales y a su independencia de España (1668).

${ }^{476}$ El sebo se usaba en los Siglos de Oro en la preparación de untos y de emplastos medicinales, ya que tales sustancias les daban la consistencia necesaria.

${ }^{477}$ Durante la Guerra de la Restauración portuguesa (1640 -1668), España y Portugal decretaron bloqueos comerciales con el enemigo. No obstante, la falta de recursos y las frecuentes campañas basadas en "correrías" propiciaron la especulación y el contrabando fronterizo.

${ }^{478}$ Se emplea como metáfora de la pérdida de la virginidad. La acción de "ajar las rosas" también parece evocar la expresión "Ajar la belleza", que se utiliza cuando "los años, el tiempo, o alguna enfermedad acaban con lo florido y terso del rostro, especialmente en las mujeres hermosas" (Aut.).

${ }^{479}$ El empleo de léxico bélico, "sitiadas" (v. 34), "resistidles" (v. 35), "fortaleza" (v. 40), "salidas" (v. 44)

y "cámara" (v. 50), sirve como metáfora de la relación amorosa. Además, el hecho de que los "bandos" 
Mirad, pues, que vais erradas, y acordaros advertidas que otra vez, siendo salidas ${ }^{480}$, estuvisteis encerradas.

45 De necedades pasadas, podéis bien tomar asilla de deshacer la gavilla, porque aquel encierro, que entonces cámara fue,

50 será otra vez camarilla ${ }^{481}$.

\section{A un catedrático secular, siendo en la condición muchacho, no quería leer algunas veces, enfadándose de muy pocas cosas (77) \#}

\section{Décimas}

Pedro, mi ingenio recela, mirándote tan lampiño que vienes, por ser muy niño, de mala gana a la escuela.

5 Todo el curso se desvela por verte con la cartilla; ven, pues, porque es maravilla que un niño, simple y sincero, que puede comer papero,

10 de a tantos hombres papilla ${ }^{482}$.

Por levísima ocasión, furias derramas perennes. Llamaste "Pichón", y tienes mucha hiel para pichón.

15 Ven, y darás la lección a quien oírte desea $y$, si en no venir se emplea, tu tema te ha de pesar y has de venir a besar la* (que no tienes) correa ${ }^{483}$.

Si cesan* tus boberías, no lo llevaremos mal,

enfrentados sean de Portugal y Castilla podría ser una nueva alusión a la Guerra de Restauración portuguesa (v. 24).

${ }^{480}$ Dilogía que hace referencia tanto al "acometimiento y pelea que hace algún número de tropas de la Plaza sitiada, para fines de su defensa" como a las "hembras de algunos animales cuando tienen propensión al coito" (Aut.).

${ }^{481}$ El granero "cámara" (v. 49), donde previamente los portugueses habían encerrado a las doncellas, es sustituido ahora por la "camarilla", un lugar "más privado que suelen tener un aposentillo pequeño donde azotan a los muchachos" (Aut.).

${ }^{482}$ Dar papilla: "Metafóricamente vale cautela o astucia halagüeña para engañar a otro" (Aut.).

${ }^{483}$ Besar la correa: "Frase con que se da a entender que el que antes no quería reconocer superioridad en otro, o tener necesidad de él, después se vio precisado a hacerlo con humilde reconocimiento o arrepentimiento" (Aut.). 
porque gente de caudal

no repara en niñerías.

25 No hagas más supercherías,

cese ya tu sin razón.

Mira que es fuerte ocasión,

para cascarte la bola ${ }^{484}$,

que nos* hagas* la mamola ${ }^{485}$,

30 siendo tu siempre mamón ${ }^{486}$.

Con lo que más enfureces

a mí, como a los demás,

es mirándote que estás

siempre; tan en tus niñeces

35 vemoste que, muchas veces,

fieros nos haces, no pocos.

$\mathrm{Y}$ es, para volvernos locos,

cosa bastante que tú*,

que te espantas* con el $\mathrm{Bu}$,

40 nos andes haciendo $\operatorname{cocos}^{487}$.

\section{A una dama que por interés se daba a todos (78v) \#}

\section{Octosílabos esdrújulos}

Escúchenme unos esdrújulos,

sin círculos ni preámbulos,

de una niña ${ }^{488}$ que, por pícara ${ }^{489}$,

una alma tiene de cántaro ${ }^{490}$.

5 Esta con galanes pródigos

muestra su semblante plácido,

mas con los de bolsa estíticos

tiene su punta de rábano ${ }^{491}$.

${ }^{484}$ Podría interpretarse como masturbación masculina.

485 Hacer la mamola: "Frase que, además del sentido recto, vale engañar a uno con halagos y caricias fingidas, tratándole de bobo" (Aut.).

${ }^{486}$ Dilogía que puede hacer referencia tanto a la persona que tiene comportamientos infantiles "niñerías" (v. 24) como a la práctica de felaciones. Cabe señalar que el comportamiento sodomita que parece tener el protagonista era considerado en los Siglos un pecado "contra natura", el cual era penado con la muerte "agravada, normalmente con fuego en la hoguera y en diversas penas accesorias (la pérdida de bienes, etc.)" (Díez Fernández, La poesía 232).

${ }^{487}$ Hacer cocos: Expresión que se emplea para halagar a alguien con fiestas o ademanes (con el propósito de "persuadirle a hacer algo" y para indicar "ciertas señas o expresiones" que denotan cariño (Aut.). Resulta relevante señalar que tanto "Coco" como "Bu" (v. 40) se utilizan para designar a una figura espantosa y fea, que sirve para atemorizar o contener a los niños.

${ }^{488}$ Ver nota 414.

${ }^{489}$ La estrecha relación que se estableció en la literatura aurisecular entre prostitución y picaresca femenina ha sido estudiada en profundidad por Enriqueta Zafra.

${ }^{490}$ La astucia y la inmoralidad que se atribuía a una "pícara" (v. 3) y el hecho de que esta se dedicara a la prostitución "niña" (v. 3) habrían convertido su alma en algo duro y vacío "cántaro" Dicha caracterización se contrapone con las cualidades que se relacionan con la expresión "Alma de cántaro", que señala a una "persona sumamente ingenua o pasmada" $(D L E)$.

${ }^{491} \mathrm{La}$ ingesta de rábano favorece el estreñimiento "estíticos" (v. 8). La respuesta de la dama ante los hombres tacaños o mezquinos "estíticos" es darles de su propia medicina. 
Aborrece la política

10 de sutil estilo, sátiro, que es requebrar en equívocos quererla hablar en arábigo ${ }^{492}$.

Si alguno endura las dádivas y está del amor hecho un páparo*,

15 hace que se vuelva frívolo, viniendo el pobre muy cálido. Con pisaverdes es rígida, si* jugaron de galápagos ${ }^{493}$, porque a su pañal mirífico*

20 no ha de llegar ningún zángano. Quiere a los de oficio ínfimos, porque, en su sentir lunático, tiene por arte de príncipes, si es liberal, el mecánico.

25 Al carnicero más pícaro le da lugar en su tálamo, porque no le falte el* hígado ${ }^{494}$, que es su común, su tentáculo. El letrado más científico,

30 si es pobre, arrime los bártulos ${ }^{495}$ que, si no vende los códigos, no tiene ley con los párrafos. Tiene por un zote al médico que no la receta práctica

35 algunas doradas píldoras ${ }^{496}$ o un poco de ungüento pálido ${ }^{497}$. Al notario de más crédito le da en la bolsa mil tártagos, porque sepa que ella es águila

40 si él es de rapiña pájaro. Nunca se pagó de lágrimas, que es su natural tan áspero que hace el papel de Demócrito con los galanes heráclitos ${ }^{498}$.

45 Con ser hábito antiquísimo el no dar entre monásticos, Belisa, sin ser pontífice,

\footnotetext{
${ }^{492}$ Hablar en arábigo: Expresarse de manera incomprensible o difícil de entender.

493 Jugar con picardía y cautela.

${ }^{494}$ Se trata de una dilogía que hace referencia tanto a la víscera como al "ánimo, valor, brío y bizarría para ejecutar cualquiera acción arriesgada" (Aut.).

495 Arrimar los bártulos: "Dejar el estudio" (Corr.).

${ }^{496}$ Los boticarios, según Correas, solían dorar las píldoras para ocultar el sabor amargo del acíbar que contenían. De ahí, surgió la expresión "Dorar la píldora”, que significa "adular para conseguir algo" (DLE). ${ }^{497}$ Parece hacer referencia al semen.

${ }^{498}$ Se contrapone la tópica imagen de Demócrito, el filósofo que ríe y es optimista, con la de Heráclito, que se ganó la fama de ser una persona triste y con una visión negativa de la vida.
} 
les quita a todos el hábito ${ }^{499}$.

Si no la dan los canónigos,

50 se ríe de lo fantástico,

porque nunca fue solícita

de tener sin uvas pámpanos ${ }^{500}$.

Con los dadivosos clérigos

hace siempre el beneplácito

$55 \mathrm{y}$, aunque es lega*, sin escrúpulo

tira sueldos eclesiásticos.

Cuantos la festejan míseros

tienen todos su fin trágico,

porque los deja esta sátrapa

60 in puribus naturalibus ${ }^{501}$.

Y así, por Dios, todos déjenla

solita como un espárrago 502

y si la dieren del límite*

ha de ser con un látigo.

\section{Pidiendo a una señora un poco de arrope para dar a una dama (80) \#}

\section{Décima}

Pues vuestra piedad me abriga ${ }^{503}$, vuestra largueza me arrope, arrope pido que un tope ${ }^{504}$ a andar a orza ${ }^{505}$ me obliga.

5 No con doblez, enemiga, hagáis de mi verdad ascos $\mathrm{y}$, si pensáis que son chascos, sabréis que mi quebradero de cabeza ${ }^{506}$, a lo que infiero,

10 quiere que arrope ${ }^{507}$ los cascos.

\footnotetext{
${ }^{499}$ Quitar el hábito a un clérigo puede interpretarse como sacarlo de su Orden o como desnudarlo.

${ }^{500}$ Metáfora de la virilidad masculina.

${ }^{501}$ Se puede traducir como "desnudo".

502 Solo como el espárrago: "Locución que se dice del que no tiene parientes, o del que vive y anda solo, sin hacer compañía con otros” (Aut.).

${ }^{503}$ Dilogía que hace referencia tanto al acto de arropar (vv. 2, 3 y 10) como a la acción de favorecer o amparar.

${ }^{504}$ Se trata de una dilogía que señala un golpe sufrido y la parte sobresaliente de alguna cosa. Esta última acepción, podría remitir a los genitales masculinos, cuyo extremo estaría vinculado con "quebradero de cabeza" (v. 9-10) y "cascos" (v. 10).

${ }^{505}$ A orza: "De manera torcida o de lado" (DLE).

506 Ver nota 70.

507 Se trata de un equívoco. En su primera aparición (v. 2), se emplea en el sentido de "dar calor". Tal acción, como se relaciona con un comportamiento liberal "largueza" (v. 2), parece adquirir connotaciones eróticas. En su segunda aparición (v. 3), alude al mosto cocido, que se empleaba como remedio medicinal. El uso de este ayudaría a aliviar el "tope" (v. 3). En su tercera aparición (v. 10), señala la acción de "hacer entrar en calor" o "provocar sudor" en los "cascos", que podrían ser una metáfora de ejercitar el miembro viril.
} 


\section{Sátira a cierta dama por quien su galán padecía las penas del purgatorio (80v) \&}

\section{Redondillas}

María, viéndote hermosa, dos mil despegos temí, mas en tratándote vi que pecas de pegajosa ${ }^{508}$.

Nadie en ser fiera te iguala, pues por ti, cruel sirena, mi vergüenza (que era buena) está que es vergüenza mala ${ }^{509}$.

Engañaste si imaginas

10 que cuando, por mi dinero, busco a las Maricas ${ }^{510}$, quiero también a las Catalinas ${ }^{511}$.

De buena conciencia y arte ser niña ${ }^{512}$ en esto señalas,

15 pues unas cosas tan malas echas a la mejor parte ${ }^{513}$.

Lo que a ofenderme más llega es que pienses, importuna, que puedo querer yo a alguna solo por lo que se pega.

Pero que te has engañado, ya lo puedes conocer en que no te puedo ver por lo que se me ha pegado.

Bien quisiera reprimirme en no reñírtelo todo, pero si tú de este modo me tratas, ¿no he de podrirme?

Cielo te llamé, mas hoy, te pregunta mi desvelo

\footnotetext{
${ }^{508}$ Dilogía que señala tanto a "lo que con facilidad se pega a otra cosa" como a "aquellas cosas a que con facilidad se aficiona la voluntad, y halla dificultad en desprenderse de ellas" (Aut.). La primera acepción pondría en evidencia el comportamiento "libertino" de la dama, mientras que la segunda evidenciaría la gran atracción que provoca esta entre los hombres.

${ }^{509}$ Ser una mala vergüenza: "Frase con que se pondera la inutilidad o grave defecto de alguna cosa" (Aut.). ${ }^{510}$ Diminutivo que se utilizaba usualmente en los Siglos de Oro para referirse a "Las Marías". Resulta relevante señalar, además, que la alusión al nombre de "Marica" no es casual. Este se relacionaba en la época con la prostitución y con la sífilis, que es el tema central del poema. Quevedo ofrece un ejemplo de ello en el romance "A Marica la Chupona", protagonizado por una meretriz que sufre "el mal francés" (Quevedo, Obras 4: 497).

${ }^{511}$ Se trata de una referencia jocosa a la sífilis. La presencia de esta enfermedad venérea en la poesía erótica de los Siglos de Oro ha sido estudiada por Ignacio Díez Fernández (La poesía 257-286). Su alta posibilidad de contagio se podría relacionar en el poema con los términos "pegajosa" (v. 4) y "pega" (v. 20).

512 Podría hacer referencia a las santas que poseen dicho nombre. Además, cabe recordar que fray Damián fue confesor e íntimo amigo de la religiosa Catalina de Jesús y San Francisco (Álvarez Capítulo 14: 524). recoge las palabras que corroboran la estima y la admiración que fray Damián sentía por Catalina de Jesús: ${ }^{513}$ El mal francés suele presentar bubas en los genitales.
} 
¿cómo si ya subí al cielo, en el purgatorio estoy?

Mas gloria a mí, Dios bendito, que por su amor (sin segundo) quiere que en aqueste mundo purgue y pene mi delito.

No juzgues burlas del ocio las que acabo de plañir, que está ya para reír

40 muy enconado el negocio.

Y son sus fuerzas tan pocas que para decir sus menguas, ya que no pueden ser lenguas, se hace el pobrecillo bocas ${ }^{514}$.

45 Cosa es que me pone miedo ver que (con mi ración poca) sustentar puedo una boca, mas tantas bocas no puedo.

Medicinas, como borra ${ }^{515}$,

50 le aplican, y en tal pesar temo no ha de levantar cabeza $^{516}$, porque hizo porra ${ }^{517}$.

Tiéneme muy afligido ver que esté de tan mal porte, que si en él no se da un corte ${ }^{518}$, va mi negocio perdido.

Y el mísero con mancilla ${ }^{519}$, como si llegara a vello, cuando tocan a degüello ${ }^{520}$, 60 se ha metido en la capilla ${ }^{521}$.

Adiós, y no te dé enfado, pesar que es en mí tan justo, que mal puede hablar con gusto

\footnotetext{
${ }^{514}$ Entre los síntomas del mal francés se halla la presencia de llagas "bocas" (vv. 44 y 48), la fatiga "fuerzas tan pocas" (v. 41) y la inflamación y el empeoramiento de las heridas "enconado" (v. 40).

${ }^{515}$ Se trata del bórax, una sustancia blanca (constituida por sal de ácido bórico y sodio) que se usa en la piel como antiséptico.

${ }^{516}$ Levantar cabeza: "Recobrarse o restablecerse de una enfermedad” (DLE). Esta expresión también podría relacionarse con la disfunción eréctil que provoca la sífilis.

${ }^{517}$ Hacer porra: "Pararse sin poder o querer pasar adelante en algo" (DLE).

${ }^{518}$ Dar un corte: "Responderle de forma rápida, ingeniosa y ofensiva" $(D L E)$.

${ }^{519}$ Dilogía que señala tanto una deshonra como una llaga o herida que mueve a compasión. Esta última acepción se vincularía con "bocas" (vv. 44 y 48).

${ }^{520}$ Tocar a degüello: "En el arma de caballería, dar la señal de ataque" $(D L E)$.

${ }^{521}$ En la capilla: "Fuera del sentido recto de estar el reo previniéndose en ella para recibir la muerte: metafóricamente significa estar uno aguardando un pesar, o una cosa de gusto, que porque ha de suceder la espera con esta ambigüedad, de que se origina su cuidado" (Aut.). La palabra "capilla", además, se podría interpretar en varios sentidos. Por un lado, podría señalar el "edificio contiguo a una iglesia o parte integrante de ella, con altar y advocación particular" ( $D L E)$. Por otro, podría hacer referencia al recado que se lleva en los cuerpos de la milicia "para poner el altar en cualquiera parte que se haga alto, y los ornamentos y vasos sagrados para decir misa" (Aut.). Esta acepción se relaciona con la expresión "Tocar a degüello" (v. 59). Por último, podría aludir a la "parte del hábito que visten los religiosos de varias Órdenes para cubrir la cabeza" (Aut.).
} 
quien está tan malhumorado ${ }^{522}$.

\section{Otra al mismo intento (82v) \&}

\section{Romance}

Malo me siento, Marica ${ }^{523}$, desde el verano pasado, que estando a solas contigo

5 tuve ciertos sobresaltos.

Mas, pues, son de mi flaqueza

efectos el mal que paso ${ }^{524}$, confieso estar en los huesos, mi dolor, de puro flaco ${ }^{525}$.

10 Ando de muy mala guisa ${ }^{526}$, y es bien para ponderarlo; que no andando yo contigo, ando yo en tan malos pasos ${ }^{527}$. No puedo andar sin arrimo,

15 mas, como galanes tantos te sobran, no extraño mucho que me hayas así arrimado ${ }^{528}$. Infeliz suerte es la mía, pues, por mis pasos contados ${ }^{529}$,

20 por culpa tuya he venido hoy a parar en un palo ${ }^{530}$. Cuando yo más amoroso buscaba en ti mi regalo, con tres pies a la francesa ${ }^{531}$, 25 me hiciste salir andando. Si así los tratas a todos, poco debes de estimarlos, pues das por esas paredes ${ }^{532}$

\footnotetext{
${ }^{522}$ Dilogía que señala, por un lado, a alguien que está desabrido o desdeñoso y, por otro, a una persona enferma $(D L E)$. Esta última acepción deriva de la creencia clásica de que la alteración de los humores provocaba patologías.

${ }_{523}$ Ver nota 510.

${ }^{524}$ Ver nota 514

${ }^{525}$ La sífilis provoca la pérdida de peso y el dolor muscular.

526 Ver nota 210.

${ }^{527}$ Andar en malos pasos: "Frecuentar malas compañías o comportarse de modo que pueden seguirse malas consecuencias" $(D L E)$

${ }^{528}$ Se trata de un equívoco. En su primera aparición (v. 12), hace referencia al acto de amancebarse y, en la segunda (v. 16), alude a la acción de dejar o abandonar.

${ }_{529}$ Por sus pasos contados: "Por su orden o curso regular" $(D L E)$.

${ }^{530}$ Se podría relacionar con la expresión "Poner a alguien en un palo", que significa "ahorcar o castigar con otra pena de muerte" (Aut.). Cabe señalar también que uno de los tratamientos más recurrentes que se empleaban en los Siglos de Oro para curar el mal francés era el agua de palo de santo (Díez Fernández, La poesía 260$)$.

${ }_{531}$ Tres pies, o un pie, a la francesa: "Inmediatamente, con rigor" $(D L E)$.

${ }^{532}$ Darse alguien contra, o por, las paredes: "Apurarse y fatigarse sin acertar con lo que desea" (DLE).
} 
con ellos a cada paso.

30 Bien se te luce, Marica, ser dama a lo cortesano, pues, porque nunca te falten, traes los galanes rodando ${ }^{533}$. Siendo ligero en extremo,

35 hoy me siento tan pesado que (de haber saltado ${ }^{534}$ mucho) ya no puedo dar un paso ${ }^{535}$. Mis miembros ya no son míos, pues se muestran tan extraños

40 que antes los mandaba mucho, mas ya no están a mi mando ${ }^{536}$. A una quínola o primera ${ }^{537}$ echar quisiera mis brazos, mas es imposible cosa,

45 porque no puedo jugarlos. $\mathrm{Y}$ es que tus cosas, Marica, las tomé tan a mi cargo que tengo por imposible poder alzar de ellas mano.

50 Solo a reñir me acomodo, pues, aunque me embista el diablo, no hayas miedo que yo saque en la cabeza las manos. Fuera de que el mal mayor, 55 que hacerme puede el contrario, será menearme el bulto ${ }^{538}$ y será hacerme agasajo. Mas con ser mi mal tan grande, estoy con él tan hallado

60 que, primero que le deje, me han de haber muy bien untado ${ }^{539}$. Buen humor gasto contigo, mas, aunque le tengo malo,

\footnotetext{
${ }^{533}$ Se podría relacionar con la expresión "Traer a alguien arrastrando", que significa. "Fatigarlo mucho" (DLE).

${ }_{534}$ Metáfora del coito.

${ }^{535}$ Dar un paso: "Realizar un progreso perceptible en lo que se hace o se intenta" $(D L E)$.

${ }^{536}$ Cuando la sífilis se haya en una fase muy avanzada, dificulta la coordinación de los movimientos del cuerpo y entumece la musculatura.

${ }^{537}$ Son dos juegos de naipes.

${ }^{538}$ Menear el bulto: "Dar de golpes o palos a alguno" $(D L E)$. Esta expresión, por el contenido del poema, podría considerarse también una metáfora de la masturbación masculina: "en la cabeza las manos" (v. 52). ${ }^{539}$ Se trata de una dilogía que, por la temática del poema, puede señalar el acto de recibir el Sacramento de la Extremaunción (el mal francés es una enfermedad mortal) y el de aplicar una sustancia viscosa sobre la piel con el propósito de intentar remediar sus síntomas. Resulta relevante señalar que las fricciones y emplastos con mercurio eran uno de los tratamientos más empleados en los Siglo de Oro para ello. De ahí surgió la frase "Una noche con Venus y una vida con Mercurio".
} 
mi trabajo mayor es

que le tengo y no le paso ${ }^{540}$.

\section{A san Diego de Alcalá (84v) \#\#}

\section{Cuarteta}

Después que porque se usa, tantas chanzas engastado, anda ya mi pobre musa de pie quebrado ${ }^{541}$.

$5 \quad \mathrm{Y}$ aunque en buenas piernas viene, disimulará conmigo san Diego, que no las tiene todas consigo ${ }^{542}$.

Fue un santo, que tal destrozo

10 hizo en su cuerpo cuitado, que murió, siendo muy mozo ${ }^{543}$, de muy zurrado.

Si la carne le tentaba, de sus fueros se reía

15 y unos chascos la pegaba que la abría ${ }^{544}$.

Muchos enfermos escucho que sanó, y así me espanto que, andando con malos mucho,

20 fuese tan santo.

A un corcovado sanó, que de médico el indulto no le tuviera, si no curara a bulto.

25 Quien anda buscando medios para calenturas, yerra, que en su sepulcro remedios

\footnotetext{
${ }^{540}$ Dilogía que sirve para señalar tanto la ausencia de mejoría de una enfermedad como su imposibilidad de transmitirla. En el periodo aurisecular, se creía que la sífilis era producto de la lujuria y, por tanto, su contagio y su imposibilidad de cura eran un castigo divino (Díez Fernández, La poesía 257).

${ }^{541}$ Dilogía que señala tanto una forma métrica que se emplea en el poema como la "lesión" que padece la musa del poeta por haberla "engastado" (v. 2) mucho.

${ }^{542}$ La enorme devoción que suscitó san Diego de Alcalá (1400-1463) tras su muerte hizo que muchos devotos (buscaban cura para sus dolencias) robasen algunas de sus reliquias. De tal hecho, da testimonio Eusebio González de Torres (Crónica 6: 109-113).

${ }^{543}$ Se usa en el sentido de "servir al público" (Aut.), pues fray Diego es conocido por mostrar gran generosidad hacia los más necesitados.

${ }^{544}$ San Diego desde su juventud decidió someterse a duras penitencias, las cuales conllevaban extremas abstinencias de ingesta y sueño y duras flagelaciones. González de Torres (Crónica 6: 20-23) detalla con rigor todas ellas. Resulta relevante señalar la gran similitud de la imagen de su tortura (vv. 15-16) con los castigos a los que se somete santa Clara en el poema "Hoy mi devoción aclama", atribuido a Cornejo y Marchante.
} 
hay como tierra ${ }^{545}$.

Un prodigio no se alaba

30 de su capilla ${ }^{546}$, y es grande,

y es, cuando el mundo se acaba,

que no se acabe.

En fin, para hacerle fiestas,

la Real Capilla postrada

35 viene ${ }^{547}$, con ser gente aquesta

muy entonada.

\section{Un amante a su amada (85v) \#}

\section{Romance}

Bien puede, Lisis $^{548}$, un triste

declararse, que es rigor

que el corazón lo padezca

y que lo encubra la voz.

5 La vida me ha de costar

tan ciega ${ }^{549}$ resolución,

mas, si de cobarde muero,

muera atrevido yo $^{550}$.

Nada en declararme medro,

10 mas me dicta la razón

que, si el achaque no sana,

es la dolencia mayor.

Yo te adoro, ya lo dije.

Si el amarte ha sido error,

15 merezca por amoroso

este delito perdón,

No me vale resistencia

\footnotetext{
${ }^{545}$ Se trata de una alusión jocosa a los restos de san Diego, quien fue desenterrado (pocos días después de su fallecimiento) y expuesto al público en una urna. Eusebio González de Torres (Crónica 6: 394-399) describe tal suceso y los diversos milagros que a este se asocian.

${ }^{546}$ El deseo de la Congregación Franciscana de crear en la Capilla de San Diego uno de los más hermosos conjuntos artísticos de Alcalá hizo que no escatimaran en gastos en su decoración y, sobre todo, en el altar mayor. Mercedes Agulló y Cobo detalla con precisión las costosas obras que se llevaron a término en ella a mediados del siglo XVII (3-76).

${ }^{547}$ El cuerpo de san Diego fue trasladado al Palacio Real de Madrid en octubre de 1661 con el propósito de sanar al príncipe Felipe Próspero. Tras el fallecimiento de este y el nacimiento de Carlos II, se realizaron en su honor diversos homenajes, los cuales reunieron a toda la corte. Tales sucesos fueron rememorados por González de Torres (Crónica 6: 448-454).

548 Ver nota 121.

${ }^{549}$ Dilogía que hace referencia tanto al acto de obrar "sin la debida reflexión" como al sentimiento amoroso, que "ofusca la razón" (Aut.).

${ }^{550}$ La situación desesperada que atraviesa el yo poético hace que verbalice el secreto amoroso, infringiendo con ello la ley codificada del amor: "que el corazón lo padezca / y que lo encubra la voz" (vv. 3-4). Esta ley es un motivo recogido en la tradición cancioneril española y que se propaga con el petrarquismo. Boscán y Garcilaso, mediante el elocuente llanto, marcaron los primeros pasos para no violar la regla del silencio y manifestar el dolor que producía dicho sentimiento (Vidorreta 257).
} 
que, como es rayo el amor ${ }^{551}$, adonde halla fortaleza

hace el estrago mayor ${ }^{552}$.

Que me rendí te confieso,

ya* que permite el dolor

de esta penetrante herida

que muera con confesión.

25 El postrarme, a mí, habrá sido,

para ti, corto blasón

$\mathrm{y}$, para mí, el rendimiento

más fuerza que inclinación.

Pues tu beldad tan del todo

30 la libertad me robó

que, aun para amarte, no quiso

dejar libre mi elección ${ }^{553}$.

No admires tales efectos

de fuerza tan superior,

35 que a rayos de una beldad

¿qué resistencia bastó?

Ya que me miras postrado

no malogres, Lisis, no,

en un rendido albedrío

40 tanta flecha y tanto arpón ${ }^{554}$.

[A tus rayos ${ }^{555}$ triste muero,

mas en tan gallarda acción

que mucho que a rayos muera

quien al cielo se atrevió.

45 Si a tus luces atrevido

soy soberbio Faetón,

ya en horribles precipicios

se castiga mi ambición ${ }^{556}$.

Porque registro a tus luces

50 quise hacerme, ciego estoy,

mas siempre cegó quien quiso

registrar la luz del sol ${ }^{557}$.

\footnotetext{
${ }^{551}$ Se trata de un tópico platónico que está presente en autores auriseculares como Góngora, Herrera o soto, quienes conciben el amor como un "rayo de luces" (Vidorreta 250).

${ }^{552}$ Cuanta más "resistencia" (vv. 17 y 36) o "fortaleza" (v.19) manifiesta el enamorado contra su imposible deseo, mayor es su sufrimiento.

${ }^{553}$ La pérdida de la voluntad "albedrío" (v. 39) es consecuencia de la condición de vasallo de la amada. El enamorado que anhele cumplir con las leyes del "fino amor" ha de satisfacer cualquier deseo de ella. Esta ausencia de libertad (v. 30) desemboca en el tópico de la "cárcel de amor".

${ }^{554}$ Ver nota...

${ }^{555} \mathrm{La}$ amada encarna la belleza y esta es representada, según la tradición platónica, mediante la luz solar, que llega al amante a través del rayo divino y que penetra en él por su mirada (Serés 59-60).

${ }^{556} \mathrm{La}$ imagen de la amada como un astro de fuego "luces" (v. 45) y como desencadenante de la "muerte" del enamorado (v. 41), por acercarse con bizarría a este, se equipara al trágico destino de Faetón. Cabe señalar que en los Siglos de Oro también se recurrió al mito de Ícaro para expresar la misma idea, pues este "murió como víctima del sol en su ascenso, tratando de escapar de un laberinto con el que se compara, así, al amor" (Vidorreta 252).

${ }^{557}$ Hace referencia a la creencia cristiana de que el ser humano no puede acceder a un conocimiento superior o divino sin sufrir terribles consecuencias. Los ojos de los mortales están acostumbrados a vivir entre las
} 
Si triunfar solo pretendes de un altivo corazón,

55 pues ya la victoria gozas, suspende la ejecución]*. Merezcante mis finezas, en premio de esta afición, de tu poderosa mano

60 un desechado favor. Porque si lograda veo aquesta mi pretensión, de nuevo empezaré a ser ya que al presente no soy ${ }^{558}$.

65 Dale crédito, piadosa

Lisis, a mi triste* voz, que se ultraja lo bizarro si atiendes mucho al rigor.

\section{A una dama que dio licencia a su galán para que la quisiera (87) \&}

\section{Décimas}

Licencia solo me has dado, Lisis $^{559}$, para que (rendido en la aras de Cupido) te sacrifique un cuidado ${ }^{560}$

5 de este bien, lo limitado a ingratitud grande imputo, pues, cuando fino ejecuto servicios en tu agasajo, me condenas al trabajo,

10 sin la esperanza del fruto $^{561}$.

La mayor dificultad que hay del amor en la lid es descubrir con ardid quien ama su voluntad ${ }^{562}$;

15 luego, si tu* libertad atenta a mis cortesanos pensamientos, nunca vanos, la batalla me presenta,

sombras "ignorancia". Si se acercan demasiado a la "luz" que este produce, acaban cegados (v.51). Sor Juana Inés de la Cruz, en Primer sueño, recurrirá al mito de Faetón y al de Ícaro, entre otros, para expresar "el pecado de soberbia intelectual y la posibilidad siempre inminente de su castigo" (Vivalda 103).

${ }^{558}$ Ver nota 112.

559 Ver nota 121.

${ }^{560}$ Se trata de una dilogía que señala tanto "el recelo y temor de lo que puede sobrevenir" como "la persona a quien se tiene amor" (Aut.). La imagen de esta ofrecida en sacrificio en el altar de Cupido evocaría el tópico de "morir de amor" (ver nota 112).

${ }^{561}$ Metáfora del coito.

562 Ver nota 3. 
sin duda ninguna intenta

que lleguemos a las manos ${ }^{563}$.

Es amor un dulce fuego

que del favor se alimenta

$\mathrm{y}$, aunque la vida atormenta,

a la posesión su ruego

25 camina*. Luego, pensar

puedo que quien para amar*

me dio licencia en rigor,

pues quiere que viva amor,

el incendio ha de cesar ${ }^{564}$.

30 Esa pasión* declarada ${ }^{565}$

a discurrir me* convida

que ha de ser agradecida,

quien permitió ser amada.

Pues a mi vida postrada

35 miras, a tanto desvelo

permite (en* tal desconsuelo)

que un alma de angustias llenas,

que por tu amor anda en pena,

llegue a gozar de tu cielo ${ }^{566}$.

\section{Fraterna exhortatoria a un galán que gastaba con su dama poco dinero y mucha prosa $(88 \mathrm{v})$ \#}

\section{Décimas}

Anfriso, con atención

quieres de Clori el empleo,

pues tendrás a tu deseo

imagen de devoción;

5 ofrécela el corazón

fino, constante y rendido ${ }^{567}$,

mas has de estar advertido

que malogras tu cuidado,

si eres largo en lo rezado,

$10 \mathrm{y}$ tan corto en lo ofrecido.

${ }^{563}$ Llegar a las manos: "Reñir, pelear" (DLE). Esta expresión se relaciona con la "batalla" (v. 18) o la "lid" (v. 12) que en la poesía erótica de los Siglos de Oro han de mantener los amantes antes del acto sexual (Ver nota 282).

${ }^{564}$ Aunque el yo poético considera el sentimiento amoroso como un "dulce fuego" (v. 21), se aleja del tópico platónico de concebir este como algo puro y eterno: "Dulce fuego, limpio ardor, / luz que ardiendo no se acaba" (Lope de Vega, Comedia 538). El amor que proclama el protagonista del presente poema se alimenta de la satisfacción sexual "amor humano". Sin esta, su llama no puede mantenerse viva (vv. 2129).

565 El yo lírico rompe con la llamada "ley del silencio" (ver nota 550).

${ }^{566}$ La acción de "gozar de tu cielo" puede admitir una interpretación profana y otra sacra. Por un lado, se relacionaría con el deleite sexual de la amada "amor humano" y, por otro, con el alcance de la gloria celestial a través del "amor divino". Esta última lectura se vincularía con la expresión "Gozar de Dios", que significa "lo mismo que haber muerto y logrado la Bienaventuranza" (Aut.).

${ }^{567}$ Ver nota 3. 
Amor en sus juegos vanos, por lo que a niño ${ }^{568}$ le toca, mucho más que a los de boca, se inclina a juegos de $\operatorname{manos}^{569}$;

15 luego, serán chabacanos pensamientos, en igual lance, presumir* bozal*, que en los garitos del amor ${ }^{570}$ no has de ser buen jugador,

20 si no fueres liberal.

Querer salir con el cargo, (no te me quedes absorto) es, si tratas de andar corto ${ }^{571}$, tomarlo muy a lo largo ${ }^{572}$.

25 Y así, querido, te encargo que si pretendes favor, no seas tan hablador en las finezas que ensartas, pues, aunque juega amor cartas,

30 juega a los dados mejor ${ }^{573}$.

Bien al parecer se inclina tu fe a su ser, mas quimera es pensar que, siendo güera*, te la ha de pasar por fina*.

35 Cosas tu ingenio imagina que a disparates se asoman, hijo mío, no se doman con chistes ya* las mujeres; sabe, si vencerlas quieres ${ }^{574}$, 40 que a donde las dan, las toman ${ }^{575}$.

${ }^{568}$ Referencia al dios Cupido.

569 Juegos de manos: "Acciones festivas y de burla, con que uno juega con otro" (Aut.).

${ }^{570}$ Ver nota 452.

${ }^{571}$ Hace alusión a la expresión "Andar corto de dinero", que significa que se tiene poco dinero o el justo (DLE).

572 A lo largo: "Significa a lo lejos y a distancia" (Aut.).

${ }^{573}$ Mientras que en los juegos de cartas interviene el azar y el ingenio, los dados solo dependen de la "fortuna, y por eso altera e incita mucho el ánimo" (Aut.).

574 Ver nota 282.

575 Donde las dan, las toman: "Quien hace daño a alguien o habla mal de él, suele recibir el mismo pago. Se emplea para advertir a quien ha hecho alguna faena que seguramente recibirá la réplica correspondiente" (Aut.). 


\section{Enamorando a una dama cuyo nombre era Palma (89v) \&}

\section{Décimas}

Palma $^{576}$, en viendo tu beldad, amorosamente ciego ${ }^{577}$, hallé mi desasosiego y perdí mi libertad ${ }^{578}$.

5 Idólatra a tu beldad sacrificios hace el alma, siendo en tan dichosa calma yo (porque a todos asombre con verdad) el primer hombre

10 que tiene el alma en su palma ${ }^{579}$.

Si por su palma mi amor puede alcanzarte atrevido, haré alardes de vencido con señas de vencedor ${ }^{580}$.

15 De esta victoria mayor para ti blasón arguyo, pues advertido concluyo que no importa en tal porfía que sea la palma ${ }^{581}$ mía,

20 si ha de ser el triunfo tuyo.

Para ablandarte ese pecho saber quisiera un ensalmo, porque una palma sin palmo no da fruto de provecho ${ }^{582}$;

25 y si no bien satisfecho está de mí tu apetito, porque mi cuerpo es poquito, tal error no se te encaje, que no hará mal maridaje, 30 de un palmo a falta un palmito ${ }^{583}$.

Bien sé que no te merezco, Palma, por virginidad, pero muévate a piedad el martirio que padezco;

\footnotetext{
${ }^{576}$ Se trata de un equívoco que servirá de eje argumental en el poema. Por un lado, señala un nombre de mujer (vv. 1 y 32), por otro, un sinónimo de palmera (v. 23). Por último, hace referencia a la parte interna de la mano (vv. 10, 11 y 40). Por último, indica el símbolo de la victoria (v. 19).

577 Ver nota 113.

578 Ver nota 3.

${ }^{579}$ Su alma en su palma: "Vale tanto como decir que haga otro lo que quisiere y gustare con toda libertad, y sin respecto a la conciencia".(Aut.).

580 Ver nota 282.

${ }^{581}$ Se establece una dilogía entre la parte interna de la mano y el símbolo romano de la victoria y del martirio para los cristianos (v. 34).

${ }^{582}$ Hay palmas macho y hembra. Estas últimas "no producen jamás su fruto, sino tienen cerca de sí el macho" (Aut.).

${ }^{583} \mathrm{El}$ palmito se asemeja en la forma de las hojas a la palma, pero crece debajo de la tierra y posee un cogollo dulce y comestible. Este sirve como metáfora del órgano sexual masculino.
} 
de tu desdén adolezco

teniendo la vida en calma,

pero en dolor tan del alma,

si me pagas liberal,

se me quitará mi mal,

40 luego, como por la palma ${ }^{584}$.

45. Pidiendo celos una dama a su galán de un fraile italiano, de quien el dicho galán confesaba era muy querido. Y, siendo muy lindo, se alababa de ello (91) \&

\section{Décimas}

Don Juan, no tengo por bueno

que te quiera un fraile tanto,

que eres muy lindo, y no santo,

y te dará algún barreno ${ }^{585}$.

5 Mucho mi suerte condeno, pues quiere que en celos pene de un italiano, que tiene a tu beldad por despojo; que, al fin, le llenaste el ojo ${ }^{586}$

10 y temo que él te le llene.

46. A una dama que lloraba mucho de dolor de un divieso que le salió en la mano (91v) \#\#

\section{Redondillas}

Hoy, Clori, pretendo, amante, decirte, muy en mi seso, algo sobre tu divieso ${ }^{587}$, pues da materia bastante.

5 A fuer de buen cortesano tomará tu enfermedad, aunque fuera necedad, estando en tan buena mano ${ }^{588}$.

Ánimo tienes de un tordo,

10 pues lloras amargamente solo por un accidente, que es un grano todo en gordo.

Tanto llorar por un grano

${ }^{584}$ Como por la palma de la mano: "Modo de hablar, con que se significa la facilidad de ejecutar o conseguir alguna cosa" (Aut.). Por el contenido del poema, podría vincularse esta expresión con la masturbación o el coito.

${ }^{585}$ Metáfora con la que se representa la penetración homosexual (ver nota 486).

${ }^{586}$ Llenar el ojo: "Contentarle mucho, por parecer perfecto y aventajado en su especie” (DLE). Está acción en el poema se relaciona con la práctica de la sodomía.

${ }^{587}$ Se emplea como metáfora del falo.

${ }^{588}$ En buenas manos: “Al cuidado de alguien capaz de manejar o hacer bien aquello de que se trata” $(D L E)$. 
bien pudieras excusar,

pues sanar o no sanar

estaba, Clori, en tu mano ${ }^{589}$.

Pena te costó importuna

el no poder menearla,

como, si por no jugarla,

20 se perdiera mano ${ }^{590}$ alguna.

Terrible desasosiego

te dio su extraña dureza, mas, viendo que tu belleza

lloraba, ablandose luego.

25 En lo que te hizo llorar

a los principios, señala

que un divieso es fruta mala, estando por madurar.

Sin duda, en tu mano estaba

30 desvanecido el divieso, pues tan hinchado en exceso le vi yo que reventaba ${ }^{591}$.

$\mathrm{Y}$ es bien que le solemnices, pues dio señal (bien mirado)

35 de estar en ti bien hallado, echando muchas raíces.

Y, aún, tú estabas bien hallada, pues fue fuerza sobornarte para sanar con untarte

40 la mano, muy bien untada ${ }^{592}$.

Lo que de admirar no dejo

es que, viniendo a caer

en mano de una mujer, saliese con el pellejo ${ }^{593}$.

45 Por esto, al divieso puedes

darle gracias, y no en vano,

pues hizo, Clori, a tu mano

muy señaladas mercedes ${ }^{594}$.

\section{A una dama que dio a su galán unas pelotas (93) \#\#}

\section{Décimas}

Ya que tan galante has sido

que dos pelotas me has dado,

${ }^{589}$ Estar algo en mano de alguien: "Depender de su elección o decisión” (DLE).

${ }^{590}$ Perder la mano: En los juegos de naipes se dice "cuando el jugador que lleva la mano es forzado a perder su turno, debido a que sus fallos no se lo permiten" (DLE).

${ }^{591}$ Representa el proceso de erección y de eyaculación.

${ }^{592}$ La aplicación de un ungüento para curar el divieso puede asociarse también con la eyaculación (v. 32).

${ }^{593}$ Se puede relacionar con la expresión "Quedar con pellejo", que significa "salir con vida" (Corr.).

${ }^{594}$ Hacer a uno la merced: "Frase irónica con que se expresa que a alguno le han maltratado o hecho daño" (Aut.). Por la temática erótica del poema, se puede interpretar también en el sentido de recibir placer. 
no será poco acertado

que ajustemos un partido ${ }^{595}$.

5 Juguemos, niña, te pido.

Y si en empresa tan alta

el temor te sobresalta

de perder, mi amor te ofrece

que he de salir de mis trece ${ }^{596}$,

10 por darte a ti quince ${ }^{597} \mathrm{y}$ falta.

Quince y falta, cortesano,

te ofrecí*, y más también,

de ventaja; será bien

que me des a mí la mano ${ }^{598}$,

15 para que con ella, ufano,

no me rinda algún desvelo,

aunque me queda un consuelo

de que* si echares muy alta

las pelotas, no haré* faltas ${ }^{599}$,

20 pues las sé coger al vuelo ${ }^{600}$.

Gran ventaja en rechazar ${ }^{601}$

me llevas, pues, sin cansarte,

solamente con echarte

me puedes, niña, ganar.

25 Pero yo que he de saltar, a empeño mayor me obligo;

$\mathrm{y}$, aunque le conozco, digo

que juguemos, desde luego,

pues no puede ser mal juego

30 si es de saltos ${ }^{602}$ y contigo.

Pero, pues, que tú al sacar

no te amañas, a mi ver,

al bote te has de poner

y yo te las he de echar;

35 vuélvelas a rechazar,

con un ademán ligero.

Y, si así lo hicieres, quiero

que en esta dulce derrota,

si tú perdieres pelota,

\footnotetext{
${ }^{595} \mathrm{El}$ juego de pelota se practica "ajustando el partido tres, a tres, cuatro, a cuatro. En cada partido hay uno que saca, otro que vuelve, otro que contrarresta. Juégase con unas palas de madera enherbadas, aforradas en pergamino, con que se arrojan las pelotas" (Aut.). En el poema, se utiliza este deporte como metáfora del ritual de seducción que se establece entre los protagonistas.

${ }^{596}$ Significa lo contrario que "Estarse en sus trece", que "vale mantenerse, o persistir con pertinacia en una cosa, que se ha aprehendido o empezado a ejecutar" (Aut.).

${ }^{597}$ En el juego de la pelota es "cada uno de los dos primeros lances y tantos que se ganan" (Aut.).

${ }^{598}$ Dar la mano a alguien: "Ampararlo, ayudarlo, favorecerlo" (DLE). También se puede interpretar en el sentido de compromiso serio "matrimonio".

${ }^{599}$ Hacer falta: "No estar uno pronto al tiempo que debía estarlo" (DLE).

${ }^{600}$ Coger al vuelo: "Frase, que fuera del sentido recto, vale lograr alguna cosa de paso o casualmente" (Aut.).

${ }^{601}$ Rechazar o volver la pelota: "Vale resistir a lo que se propone con otra razón de igual o mayor eficacia, que la que se da para obligar a ello" (Aut.).

${ }^{602}$ Metáfora del acto sexual.
} 


\section{Enviando a una dama una vela blanca al tiempo que estaba para ausentarse de ella (94) \#\#}

\section{Décimas}

De pedir (nunca yo fuera)

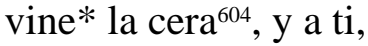

de tres partes que cogí,

te remito la tercera.

5 Recibe, niña, esa cera

que te doy, para obligarte,

y aquí puedes enterarte

de mi galante largueza,

pues de una triste pobreza

10 te ferio la tercia parte ${ }^{605}$.

Que a todo amante prefiero

en esto, niña, verás,

pues doy ceras ${ }^{606}$, y los demás

dieran cero veces cero.

15 Yo vengo a ser el primero

que el alma no se le arranca

de ofrecer con mano franca ${ }^{607}$

a su querida, pues, hoy,

si cera blanca ${ }^{608}$ te doy,

otros ni cera ni blanca ${ }^{609}$.

Mas, pues, por ti se desvela

mi cariñoso delirio,

quisiera que fuera cirio ${ }^{610}$

aquesa pequeña vela.

${ }^{603}$ Rechazar alguien la pelota: "Rebatir lo que dice otra persona, con sus mismas razones o fundamentos" $(D L E)$. Esta expresión, por el contenido del poema, haría referencia a la "costumbre" en la poesía erótica aurisecular de que la dama ponga algo de "resistencia" a los deseos del varón. Tras esta oposición inicial "vuélvelas a rechazar / con ademán ligero" (vv. 35-36), se produciría la "dulce derrota" (v. 38) y la contienda final "pelotero" (v. 40).

${ }^{604}$ La costumbre de "pedir cera" se vincula a la Pascua y al público juvenil. Esta puede acompañarse de cancioncillas y, en los Siglos de Oro, tenía como finalidad recaudar fondos para las procesiones o para la iglesia. Es importante señalar también que la cera se utilizaba en la época como forma de pago, pues era un producto básico y cotizado (v. 20).

${ }^{605}$ El pago o cobro de la cera dada (v. 41) parece poner en evidencia la estrecha vinculación que en el periodo aurisecular se estableció entre Eros y los oros (ver nota 327), pues tal sustancia se emplearía como metáfora de favores sexuales.

${ }^{606}$ Dilogía que señala tanto la sustancia que producen las abejas como la realización de prácticas eróticas.

607 Dilogía que indica un comportamiento "sincero y leal en el trato" y el pago "libre de impuestos y contribuciones" (Aut.). Esta última acepción se vincula con "ferio" (v. 10) y "pago" (v. 41).

${ }^{608}$ La cera blanca es aquella que está "ya labrada y curada, habiéndosele quitado el color amarillo que saca del panal, lavándola, y ejecutando otras diligencias, por cuyo medio queda proporcionada, para servir en los usos a que se quisiere aplicar: como velas, o bugías, hachas y otras cosas" (Aut.). Se usaría como metáfora del semen.

609 Ver nota 334.

${ }^{610}$ El cirio (v. 23) y la vela (v. 24) son una metáfora del falo. 
Esta voluntad nivela

y verás, si te parece,

que en ella más* mi amor crece,

pues serás, en conclusión,

imagen de devoción

30 de quien su cirio te ofrece.

Dar vela ${ }^{611}$, por despedida,

un amante que se ausenta

no es bueno, según mi cuenta,

si está cerca la partida;

35 pues, si la mujer olvida

al ausente, caso es llano,

que el darte cera no es vano,

pues, así, mi industria quiere

que esté, cuando tu amor muere,

40 con la candela en la mano ${ }^{612}$.

En pago de esa candela, no quiero favor alguno, mas que de mí con ninguno no te hagas a la vela ${ }^{613}$,

45 porque, si mi amor recela tal vileza de tu estilo, cortaré a mi amor el hilo ${ }^{614}$; y si lo contrario hicieres, y a mí solo me quisieres,

50 de mi harás cera y pabilo ${ }^{615}$.

\section{A una dama (95v) \#}

\section{Décima}

María, a tu sucia cara

pretendo dar un jabón ${ }^{616}$,

diciéndote, con perdón,

que es por lo espesa bien rara.

5 No en fregarla seas avara, cuando tu mano, fregona ${ }^{617}$,

${ }^{611}$ Dar vela: "Salir del puerto para navegar" $(D L E)$. Se emplea como metáfora de prácticas sexuales.

${ }^{612}$ Estar con la candela en la mano: Frase que se dice "del moribundo, que está prevenido con la vela para espirar" y que se usa en sentido metafórico para indicar que se acaba "alguna cosa o estar próxima a su fin" (Aut.).

${ }^{613}$ A la vela: "Prevención o disposición necesaria para algún fin" (Aut.). Se usa como metáfora del coito.

${ }^{614}$ Se podría relacionar con la expresión "Cortar el hilo de la vida", que significa "matar, quitar la vida" $(D L E)$. Esta se asocia por su significado con "Estar con la candela en la mano" (v. 40).

${ }^{615}$ Hacer de él cera y pabilo: "Cuando uno hace de otro lo que quiere" (Corr.). Cabe señalar que la unión de los términos "pabilo", se vincula a "hilo" (v. 47), y cera mediante la conjunción copulativa volverían a recrear la imagen de la vela (v. 41).

${ }^{616}$ Dar a alguien un jabón: "Castigarlo o reprenderlo ásperamente” (DLE).

${ }^{617}$ La baja condición social de las fregonas en los Siglos de Oro hacía que estas se vincularan con el mundo de la prostitución. 
a ningún plato ${ }^{618}$ perdona;

$\mathrm{y}$, si fueres a lavar,

en colada la has de echar,

porque salga de tizona ${ }^{619}$.

\section{A un corcovado que galanteaba a una dama y la daba músicas y ella le aborrecía y desde su casa le cantaron esta sátira (95) \#\#}

\section{Romance}

Un galán corto de talle y dilatado de zancas, muy metido de pescuezo y muy salido de espaldas.

5 Encaramado de giba, muy agachado de cara, muy redoblado de cuerpo y de espaldas una vara. Hombre tal que, aunque le digan

10 sus delitos en las barbas, no le ofenden, porque todos murmuran a sus espaldas ${ }^{620}$. Con sus once ${ }^{621}$ de corcova, festejando a cierta dama,

15 cargado de dos bacías ha dado en decir dos vanas. Ella ha dado en no quererle; y hace muy bien, si repara que su galán no se enmienda,

20 siendo tan de atrás la falta.

Con música la festeja, no ha sido boba la traza, que es de quien tiene mal pleito meter a voces su causa.

25 Como la corcova es mucha, con encogimiento anda, mal hace, que no negocia quien anda encogido y ama. $\mathrm{Si}$ enderezarse no puede,

30 perdida va su esperanza, que no se gana con hembras si no se endereza nada ${ }^{622}$.

${ }^{618}$ Metáfora que representa a los clientes de las prostitutas.

${ }^{619}$ El consejo de echar "en colada" a una mujer para sacarla de "tizona" también aparece en el poema atribuido a Cornejo "Oye, Catuja, dulce hechizo mío".

${ }^{620}$ A espaldas de alguien: "Aprovechando su ausencia, sin que se entere, a escondidas de él” (DLE).

${ }^{621}$ Se establece un símil entre la forma del número once y las dos protuberancias que conforman la giba del protagonista. Esta da lugar a la expresión "Estar algo a las once", que significa estar "ladeado y sin la rectitud que debe" ( $D L E)$.

${ }^{622}$ Hacer referencia a la erección. 
No hay que tratar que la obligue, que tuviera muy mala alma

esta niña si pudiera*

un tan mal hecho agradarla.

Aunque inclinado le mira, nunca de su amor se paga ${ }^{623}$, que no le agradan los hombres

40 de inclinaciones tan malas.

Como es de espaldas cargado, le aborrece la muchacha, que es hombre que, sin razones, se le ha de echar con la carga ${ }^{624}$.

45 Todo su amor fabuloso le ha juzgado, y no se engaña, pues, siendo tan contrahecho, de ser muy fino se alaba.

Mas, con todo, le promete

50 que le querrá como haga que se allane la corcova, pues todo el amor lo allana ${ }^{625}$.

\section{Despedida de una dama (98) \#\#}

\section{Coplas de pie quebrado}

Adiós, Leonor de mi vida, y no sientas que no viertan llanto mis ojos, que son sus niñas puercas.

5 Llora tú, si te parece que esto puede ser fineza, que yo apostaré que el llanto te está de perlas ${ }^{626}$.

No temas su desperdicio,

10 pues sabes*, por cosa cierta, que tengo bastantes conchas ${ }^{627}$ para cogerlas ${ }^{628}$.

Humedece las mejillas, verás que tienes en ellas

15 cama de marfil y grana ${ }^{629}$

${ }^{623}$ Se emplea en el sentido de corresponder el afecto.

624 Ver nota 331.

${ }^{625}$ Se trata de una alusión jocosa al tópico latino "Omnia amor vincit".

${ }^{626}$ De perlas: "Demuestra la propiedad con que se dice o hace alguna cosa, o se acomoda a otra" (Aut.). El uso de esta locución vinculada al llanto (v. 7) sirve, además, para aludir a la recurrente metáfora renacentista que lo representa como perlas.

${ }^{627}$ Tener muchas conchas: "Frase vulgar con que se da a entender que uno es muy reservado y difícil de engañar o atraer a lo que se intenta o pide" (Aut.).

${ }^{628}$ El término "conchas" asociados a la acción de "coger" sirve como metáfora del coito.

${ }^{629}$ Ver nota 94. 
con sus goteras.

Mas hay que, aunque el llanto suelen

carnes hacerme ${ }^{630}$ mil necias*, por* ausencias tú te haces

carnestolendas ${ }^{631}$.

Muy encargada a un amigo

te deja mi diligencia,

para tener guardamano

de mi muñeca ${ }^{632}$.

25 Ya, querida de mis ojos, toca a marchar la obediencia, aunque el amor que te tengo tañe a la queda*.

Se en corresponderme firme,

30 porque todo el mundo sepa que a Leonor estimé mucho y la hice* buena $^{633}$.

Si en riñas de amor te hallares, que puede ser que se ofrezca,

35 te pido que con ninguno

la mano metas ${ }^{634}$.

Que será frívola cosa, no hallándome en la pendencia, haber de sacar las manos

40 en la cabeza ${ }^{635}$.

Aunque eres tan manual ${ }^{636}$, no permitas que te lean, que yo sé que no te ojeen si los ojeas.

45 Si en tu amor alguien cayere, de tu mano no le tengas ${ }^{637}$, no sea que se levante mi* bien con ella.

Pero dale a quien quisieres

50 las manos ${ }^{638}$, aunque yo pierda,

${ }^{630}$ Hacerse carne: "Vale consumirse y deshacerse con alguna pena y sentimiento" (Aut.).

${ }^{631}$ Hacer carnestolendas: Consiste en hacer festejos e inmoralidades para burlarse y divertirse antes de que empiece el periodo de recogimiento de la Cuaresma. Cabe señalar que el término "carnestolendas" es voz compuesta de las latinas "Caro y Tollo, que significa las carnes que se han de quitar" (Aut.).

${ }^{632}$ Se emplea en el sentido de "joven frívola y presumida", que debe de ser protegida "guardamano" (v. 23) para evitar la deshonra.

${ }^{633}$ Hacerla buena: "Probarla" (Aut.). Se utiliza en sentido erótico.

${ }^{634}$ Meter la mano: Se puede interpretar tanto en el sentido de "reprender o castigar con severidad" como en el de "tocar o manosear a alguien con intención erótica" $(D L E)$.

${ }^{635}$ Se podría relacionar con la expresión "Venir con las manos en la cabeza", que indica "herido y sin lo que deseaba" (Corr.).

${ }^{636}$ El término "manual" ayuda en el contexto del poema a seguir retratando la personalidad de la dama. Por un lado, sirve para señalar su genio dócil y complaciente. Por otro, recalca la "facilidad" con la que los hombres pueden acceder a ella.

${ }^{637}$ Tener alguien a otra persona en su mano: "Tenerla en su poder o sometida a su arbitrio" (DLE).

${ }^{638}$.Ver nota 598. 
pues son dos blancas ${ }^{639}$ nomás

poca moneda.

No quiero ponerte tasa,

pues no eres manca ni lerda;

55 huélgate con quien quisieres,

si hay a quien quieras.

Y si has de fundar alguna

fábrica en esta mollera,

no hay sino empezar la obra

$60 \operatorname{manos}^{640}$ y a ella.

Adiós (¡ay, cómo lo siento!),

mas que mucho que lo sienta

si está muy para morirse,

quien la piel deja ${ }^{641}$.

\section{A una fea presumida (100) \#}

\section{Romance}

Clori, que para ser linda, cuando ciegamente anhelas y tu vanidad te engaña,

5 tu parecer te condena.

Juez árbitro de tu causa

te constituyó a ti mesma;

y lo acertarás, que tienes

cara de decir sentencias.

10 No te espantes, que te salgan

de tu galán las finezas

guieras; si al averiguarte

partida $^{642}$, vana te encuentra ${ }^{643}$.

Por una tronera $\mathrm{el}^{*}$ cielo

15 suele verse, mas tú piensas

que eres cielo, y él no puede

verse por una tronera ${ }^{644}$.

Dos damas a tu galán

le has buscado (cosa fea),

20 pues con ensayos de dama vistes traje de tercera ${ }^{645}$.

\footnotetext{
${ }^{639}$ Ver nota 334.

${ }^{640}$ Manos a la obra: Se usa "para alentarse alguien a sí mismo, o animar a los demás, a emprender o reanudar un trabajo" (DLE).

${ }^{641}$ Dejar alguien la piel: "Esforzarse al máximo en algo" (DLE).

${ }^{642}$ Ver nota 284.

${ }^{643}$ Dilogía que muestra tanto la actitud arrogante y presuntuosa de la dama como su incapacidad para aceptar su fealdad.

${ }^{644}$ Se trata de un equívoco. En su primera aparición (v. 13), señala una "ventana pequeña y angosta" y, en su segunda (v. 17.), indica "la persona desbaratada en sus acciones o palabras y que no lleva método ni orden en ellas" (Aut.).

${ }^{645}$ Hace referencia a la figura de la alcahueta.
} 
Para valerte* en* su* empeño, metes gente* $\mathrm{y}^{*}$ andas cuerda, pues estas dos del empeño

te sabrán sacar por fuerza ${ }^{646}$.

Bien das a entender que es poco

tu caudal, pues una prenda

que tienes tan de tu gusto

en tantas partes la empeñas ${ }^{647}$.

30 Mas bien tu galán te paga

esta acción, pues con llaneza

hace con ellas su hecho

y contigo la deshecha ${ }^{648}$.

Gran cosecha de mentiras

te venderá por finezas,

pues unas cosas por otras

dice cuando te requiebra ${ }^{649}$.

No pienses que te agasaja,

que juega mucho con ellas

$40 \mathrm{y}$ anda de ganancia, y suele dar de barato quien juega ${ }^{650}$.

Con que tendrás, pues, a dos, no puedes sacar la prenda ${ }^{651}$; galán a medias que es

peor que parir a medias ${ }^{652}$.

\section{A una ausencia (101) \&}

\section{Estribillo}

En aquesta soledad

ausente muero ${ }^{653}$, bien mío,

que, si estoy amando ausente, no puedo decir que vivo ${ }^{654}$.

${ }^{646}$ Por fuerza: "Precisamente, necesariamente, sin excusa" (Aut.).

${ }^{647}$ El término “empeño" es un equívoco que se vincula a la caracterización celestinesca de la protagonista. En su primera aparición (v. 21), muestra la voluntad o deseo de satisfacer la lujuria; en su segunda (v. 24), promociona la prostitución; en la última (v. 28), indica el acto de prostituirse.

648 Ver nota 15.

${ }^{649}$ Se usa en el sentido metafórico de "galantear, cortejar una dama" (Aut.).

${ }^{650}$ Se trata de una equívoco. En su primera aparición (v. 38), remite al acto de retozar y, en su segunda, al de $\operatorname{apostar}($ v. 40).

651 Sacar prendas: "Embargar" $(D L E)$. Esta expresión, basada en un mandamiento judicial, se relaciona con los primeros versos de la composición (vv. 5-8). En ellos, se dice sobre la protagonista: "Juez árbitro de tu causa / te constituyó a ti mesma; / y lo acertarás, que tienes / cara de decir sentencias”.

${ }^{652}$ Parir a medias: "Frase con que se pondera la dificultad de concurrir a algún trabajo o cuidado con otro, como ayudando a parecerle" (Aut.).

${ }^{653}$ Ver nota 106.

${ }^{654}$ El amor o la caritas conlleva la no pertenencia a sí mismo de los amantes. Cuando este no es correspondido "amor simple”, provoca su "anulación unidireccional” (Serés 100-111). 


\section{Glosa.}

\section{Décimas}

Como de tus ojos bellos

ausente estoy, Nise mía,

si de mirarlos vivía,

fuerza es morir de no vellos

5 y más me muero por ellos ${ }^{655}$.

Aunque veo* tu crueldad,

ten Nise de mi piedad ${ }^{656}$

$\mathrm{y}$ no tu rigor aumente

mis penas, pues muero ausente

10 en aquesta soledad.

Si el mirarte solamente

daba vida a mi esperanza,

ya murió mi confianza,

pues que de ti estoy ausente;

15 y no sé, Nise, si miente

en presumir mi albedrío ${ }^{657}$,

que me trates con desvío,

pues pudieras, si en ti hay fe,

creer que te adoro y que

20 ausente muero, bien mío.

Dices, Nise, que la ausencia

es madrastra del amor ${ }^{658}$,

mas bien se ve que es error,

pues te adora mi obediencia,

25 que, aunque no esté en tu presencia,

te adoraré eternamente;

$\mathrm{y}$, pues, sabes claramente

lo bien que siempre te quise,

también conoce*, mi Nise,

30 que te estoy amando ausente.

Si del cuerpo se ha apartado

el alma que le asistió,

el cuerpo que antes vivía

es cierto que ya murió.

35 Luego, si el cuerpo soy yo

y tú el alma que recibo ${ }^{659}$,

con evidencia concibo

que he muerto forzosamente,

\footnotetext{
655 Ver nota 112.

${ }^{656}$ Cuando el amante es incapaz de contemplar a la amada "se sube un escalón más: el concurso de la fe, o sea, la explicación en términos religiosos o místicos (...) los propios de la caritas, esto es, del amor piedad (...) de la expresión de la necesidad de sublimar el amor platónicamente (o paulinamente): el amor humano le permite, merced a la transformación, elevarse al amor ideal, ascender por la scala perfectionis" (Serés 189).

657 Ver nota 553.

${ }^{658}$ Evoca el refrán "La ausencia es madrastra del amor, y bien querencia” (Corr).

${ }^{659}$ Ver nota 112.
} 
que estando yo ausente no puedo decir que vivo.

\section{Glosa.}

\section{Décimas}

¡Ay, Felisa*, quien pudiera, a tan penoso tormento decir todo lo que siento ${ }^{660}$, para descansar siquiera!

45 Mas, pues, mi fortuna fiera no me deja estar contigo; y no cabe lo que digo para que mi amor se crea, pues mi voz no basta, sea solo el silencio testigo ${ }^{661}$.

Para quien ama constante, una ausencia (qué rigor) es el tormento mayor que tener puede un amante;

55 y no hay remedio bastante para mi mal, porque siento que, cuando aplicar intento remedio a mi desventura, callar mi dolor, locura ${ }^{662}$,

60 ha de ser mi tormento.

Ya me he resuelto a callar esta pena tan atroz, que no es bastante mi voz para poderla explicar;

65 y mal pueden aliviar ni quitar mi sentimiento, pues no puedo mi tormento, por más que hacerle me obligo, caber todo lo que digo,

70 pues no cabe lo que siento ${ }^{663}$.

Que es tibio habrás sospechado el incendio de mi amor, pues de este fuego ${ }^{664} \mathrm{el}$ ardor a la boca no ha arrojado;

75 mas jay!, que si retirado en mi pecho este enemigo ha estado es por si consigo

\footnotetext{
${ }^{660}$ Ver nota 550.

661 Ver nota 411.

662 Ver nota 113.

${ }^{663}$ Platón afirmaba que el alma del hombre debe tender a integrarse en el alma del mundo a través del amor. Este es el camino para elevarse de lo sensible a lo insensible y, por tanto, el sentimiento que produce la amada no puede "caber" dentro de un cuerpo, pues forma parte de lo absoluto y de lo universal (Serés 23). 664 Ver nota 352.
} 
que sepas, si puede ser, que solo puede caber en todo lo que no digo ${ }^{665}$.

\section{Manifiesta un amante a la dama su pasión (103v) \&}

\section{Romance}

Pues que me han dado licencia, Lucinda $^{666}$, tus ojos bellos ${ }^{667}$ para decir mi pasión: va de penas, va de celos.

5 Luego que te vi, te amé, porque amarte y ver tu cielo bien pudieron ser dos cosas, mas ninguna fue primero. Ya muero de amor ${ }^{668}$, Lucinda,

10 mas tan dulcemente muero, que de morir a tus rayos ${ }^{669}$ blasona mi entendimiento. Callando mi amor te digo, y callando lo encarezco,

15 que para decir mi amor no hay lengua como el silencio ${ }^{670}$. Mas miento, que ya te he dicho, con lágrimas de mi pecho $\mathrm{y}$ con suspiros que formo,

20 los tormentos que padezco. Que suspirando, amando y padeciendo lo que calla la voz dice el afecto.

No pretendo yo, mi bien, que pongas por mí respeto

25 ni tu crédito a peligro ni tu pundonor a riesgo. Solo pretendo que sepas que no fue jamás mi intento profanar con mis palabras

30 el decoro de tu cielo.

Verdad es que, a los principios, nació de burlas mi empleo.

Mas ya son las burlas veras, que no hay burlas con deseo.

665 Ver nota 550.

${ }^{666}$ Se trata de una referencia a la amada y musa de muchos de los poemas amorosos de Lope de Vega: Micaela de Luján, conocida en los versos del Fénix como "Camila Lucinda" o "Lucinda".

${ }^{667}$ La mención a los "ojos bellos" de Lucinda al inicio de un poema la encontramos en el soneto "Con una risa entre los ojos bellos" del célebre dramaturgo (Lope de Vega, Sonetos s.p.).

${ }^{668}$ Ver nota 112.

669 Ver nota 556.

${ }^{670}$ Ver nota 411. 
35 Es el amor en las almas

como en los hombre el juego,

que comenzando de burlas,

vienen a perder luego.

Comencé por divertirme,

40 eres bella, no soy necio;

empecé a jugar contigo,

entré libre y salí preso ${ }^{671}$,

que quien llega a burlarse con el fuego ${ }^{672}$,

o se quiere abrasar o no es discreto.

\section{A una pobre que salió muy estropeada de un mal francés habido en buena guerra (105) \&}

\section{Soneto}

Un mal francés ${ }^{673}$ Marica ${ }^{674}$ tan grosero

contigo anduvo y te paro tan flaca

que a tu boca, sin dientes ${ }^{675}$, dejo vaca

5 y a tu cuerpo, sin carne, hizo carnero ${ }^{676}$.

Era el humor sutil, y tan ligero,

que en dos carreras solas las sonsaca.

De tus muelas obró y, por más matraca,

los huesos te dejó en el cutis mero.

10 Por tu flaqueza ${ }^{677}$ y mucha travesura

a tal estado la fortuna loca

te ha traído, y es tal tu desventura

que. en los líquidos huesos, suerte poca

de tu cuerpo ha quedado la figura

15 y en carnes vivas ${ }^{678}$ tu desierta boca.

\footnotetext{
671 Ver nota 553

${ }^{672}$ Se podría relacionar con la expresión "Jugar con fuego", que indica "hacer con imprudencia algo que puede traer consecuencias negativas" (DLE).

673 Ver nota 511.

${ }^{674}$ Ver nota 321.

${ }^{675}$ El empleo del gas del mercurio en los Siglos de Oro para tratar la sífilis provocaba en los pacientes la pérdida de los dientes.

${ }^{676}$ Se usa en el sentido de osario, pues el cuerpo de la protagonista se halla "sin carne" (v. 4). Se puede relacionar el término carnero con la palabra vaca (v. 3), tanto por pertenecer ambos animales a la misma familia "bovidae" como por indicar esta algo vacío o incompleto.

${ }^{677}$ Dilogía que hace referencia tanto a la pérdida de peso y a la debilidad que provocaba el mal francés como a la fragilidad y facilidad para caer en el algún vicio. La protagonista del poema habría caído en la lujuria, que se consideraba la principal causa de contagio de dicha enfermedad (ver nota 540).

${ }^{678}$ Carne viva: "En la herida o llaga, carne sana, a distinción de la que está con pus o en putrefacción" $(D L E)$. Esta expresión se podría vincular con una de las acepciones de "carnero" (v. 4), que señala el lugar donde se arrojan los cadáveres.
} 


\section{A una monja hermosa, desdeñosa (105v) \&}

\section{Soneto [coronado con dos redondillas]}

[Lisis ${ }^{679}$, tu favor invoco cuando con tu desdén lucho, porque, ya que rezas mucho, reces también por mí un poco.

Y no tira mi intención a estorbar tu santa vida, antes mi amor te convida a que tengas devoción]*.

A todos tu beldad rigores flecha, Lisis, con duro y obstinado pecho, y el que te quiere más, a su despecho, solo en desdenes hace su cosecha.

Nunca tu beldad al amor pecha, teniendo en la hermosura su derecho, y cada muerte que, aunque santa, has hecho a tus ojos amor pone por flecha ${ }^{680}$.

Mas, aunque eres capacha ${ }^{681}$ y sin empacho, como a todos a mí me pongas tacha, solo por adorarte, me encapacho.

Y si tu voluntad bien me despacha, aunque francisco soy ${ }^{682}$ desde muchacho, fraile tengo de ser de la capacha.

\section{A una dama que, estando destocada, se asomó a una reja y su galán la asió una mata de cabello (106) \&}

\section{Soneto con cola}

Suelto el cabello ${ }^{683}$ por el aire ufano, sin adorno ni aliño, bien vestida, lograste dos arpones ${ }^{684}$ en mi vida, ambos a dos con poderosa mano.

\footnotetext{
${ }^{679}$ Equívoco que, en su primera aparición (v. 1) señala algo que causa “desabrimiento y pena” (Aut.) y, en su segunda (v.8), alude a las flechas de amor que lanza Cupido.

680 Ver nota 234.

${ }^{681}$ Capacho es el nombre popular con el que se conoce a los miembros de la Orden de San Juan de Dios, los cuales adoptaron dicho apodo por usar con frecuencia (para cargar frutas y cosas menudas) una esportilla de palma "capacha".

682 Podría tratarse de una autorreferencia, ya que Cornejo ingresó con catorce años en la Orden de San Francisco.

${ }^{683}$ Ver nota 125.

${ }^{684}$ Ver nota 234.
} 
Del garbo el uno fue, porque lozano tiene el garbo ${ }^{685}$ también su propia herida, otro de tu beldad que, engrandecida, flechas dispara con rigor tirano ${ }^{686}$.

Como en confusos lazos se desata

10 tu poblado cabello, a gran ventura tuve feliz asirme de una mata ${ }^{687}$.

Por lo cual, mi discurso conjetura que, si audaz el ingenio se retrata, en bosquejo ${ }^{688}$ se queda la pintura.

Porque tu hermoso pelo

15 anda con el del sol al* redopelo $^{689}$; y no le pinto que, aunque está a mi cargo, es quererlo tomar* muy a lo largo ${ }^{690}$. Basta decir, mirando tus guedejas, que bien puedes gozar de tus madejas.

\section{Habiendo pedido una mano un galán y no habiéndola conseguido, le pide un dedo (107) \&}

\section{Soneto}

Amoroso, prudente y cortesano la mano te pedí691, que es mi desvelo tal que, sabiendo que tu mano es cielo, quise tomar el cielo con la mano ${ }^{692}$.

Mas, viendo que mi fe trabaja en vano, a tocar de tu mano un dedo apelo ${ }^{693}$

\footnotetext{
${ }^{685}$ Se trata de un equívoco. En su primera aparición (v. 5), manifiesta un aire de perfección y, en su segunda (v. 6), señala gentileza.

686 Ver nota 111.

${ }^{687} \mathrm{La}$ acción de asir una mata puede tener una doble lectura. Por un lado, la de agarrar con la mano un trozo de cabello (para intentar que no escape) y, por otro, la de arraigar una pequeña planta. Ambas interpretaciones pueden evocar actos eróticos. Igual sucede, en el último verso de la composición, con el "gozar de tus madejas" (ver nota 76).

${ }^{688}$ El hecho de que no se decida a terminar de "pintar" el retrato y el deseo de que lo que se intenta plasmar en él quede a merced del "audaz ingenio" (v. 13) ayudan a reforzar la sensualidad del poema. El recurso del "bosquejo" de la amada también es empleado por fray Damián en "Sepan todos y todas que yo adoro". ${ }^{689}$ Al redopelo: "Contra el curso o modo natural, violentamente" (Aut.).

${ }^{690}$ A lo largo: "Difusamente y con extensión” (Aut.).

${ }^{691}$ Pedir la mano de una mujer: "Solicitarla de su familia en matrimonio" (DLE).

${ }^{692}$ Tomar el cielo con las manos: "Denota la cólera o ira grande, que se ha recibido por alguna pesadumbre" (Aut.).

${ }^{693}$ Se podría relacionar con la expresión "Dar un dedo de la mano", que "pondera el deseo grande que se tiene de conseguir alguna cosa" (Aut.).
} 
para que a mi valor, en dulce duelo ${ }^{694}$, con un dedo, le rinda amor tirano ${ }^{695}$.

Muévate de amorosa a compasiva,

10 Lisis, este cuidado afectuoso.

Muera el desdén y la fineza viva.

Llegue yo a tocar tu dedo venturoso, y que me falta, no de mí se escriba, un solo dedo ${ }^{696}$ para ser dichoso.

\section{Desmiente las desconfianzas de una dama un galán con un retrato suyo algo desparecido (107v) \&}

\section{Soneto}

Rudo pincel de mano inadvertida

mentiroso, de mí copió un traslado ${ }^{697}$, pero mal puede estar bien retratado quien te eligió por alma de su vida.

Error del arte fue, mal dirigida, en el cual puede, Lisis bella ${ }^{698}$, tu cuidado advertir que no soy cual me han pintado, como me pintan sin mi fe rendida.

No culpes del pincel el desacierto,

10 que estar otro y estar desparecido en el dibujo, puede ser acierto ${ }^{699}$.

Porque, cuando de amor estoy perdido, no pareciera bien, es caso cierto, estar perdido yo y el parecido.

\section{Al mismo asunto (108) \&}

\section{Soneto}

\footnotetext{
${ }^{694}$ Se trata de una paradoja que representa el tópico del sentimiento amoroso como una fuente de felicidad y de dolor contra la que el enamorado ha de lidiar. El enfrentamiento físico que supone el "duelo" sirve, además, como metáfora del acto sexual (ver nota 282).

${ }^{695} \mathrm{La}$ incapacidad del amante petrarquista de lograr los favores de su amada y su condición de vasallo de esta hacen que considere el amor como tirano. Góngora, en "Déjame en paz amor tirano" (Góngora s.p.), desarrolla dicho tema y presenta a los enamorados como seguidores de una milicia. Esta en el poema de Cornejo puede relacionarse con la imagen del "dulce duelo" (v. 5).

${ }^{696}$ Podría tratarse de un metáfora de la masturbación.

${ }^{697}$ La belleza particular que vislumbra el amado es un "traslado" o "copia" de la belleza ideal y eterna del mundo de las ideas del que proviene. Cabe señalar que el amor que ello origina es producto de la contemplación de "su propia naturaleza vista en el otro": el amado actúa como un espejo para el amante y viceversa" (Serès 17).

698 Ver nota 121

${ }^{699}$ Cornejo trata con humor la imposibilidad de retratar fielmente al amado, pues en su alma está grabada la imagen de la amada (Serès 142-143). El resultado de intentar pintar este hecho, como dice el protagonista del poema, es un "error del arte" (v. 5).
} 
Por los yerros, Lisis bella*700, de un traslado

no me calumnies de desconocido,

que el pintor me pintó como ha querido ${ }^{701}$,

pero no como quiero me ha pintado.

Si tan otro el dibujo me ha parado, al artífice culpa inadvertido.

El mismo soy, mudanza en mí no ha habido, aunque me tiene amor desfigurado ${ }^{702}$.

Que soy otro, después que soy tu amante,

10 esa honrada pintura lo asegura:

hombre y libre antes fui, mas ya inconstante.

Tan trocado me tiene tu hermosura que, aun de mí, no soy ya mi semejante, porque ya no soy yo ni mi figura ${ }^{703}$.

\section{Al ponerse una dama en la guedeja unos jazmines que aún no habían salido del botón y a pocas horas se abrieron en el mismo pelo (108v)}

\section{Soneto}

De emboscada entre matas de tu pelo ${ }^{704}$, rompiendo de esmeralda la clausura, ofendido un jazmín ${ }^{705}$ de tu blancura, de punta en blanco*706, salió al duelo.

Sus blancas hojas sin algún recelo esgrimió. Pero al ver en tu hermosura tantos reparos hechos de luz pura, en deshojarse ${ }^{707}$ puso su desvelo.

Mas blanco ya, de más descolorido, miedo que tu belleza le dio en pena de su cándido orgullo inadvertido,

escarmientos le intima $a^{*}$ una azucena ${ }^{708}$. "No te atrevas", le dice, "pues rendido ${ }^{709}$ ves* que Clori me trae a la melena".

\footnotetext{
700 Ver nota 121.

${ }^{701}$ Ver nota 297.

702 Ver nota 108.

703 Ver nota 112.

${ }^{704}$ El poema posee algunas semejanzas con la canción "De la florida falda" de Góngora (Góngora s.p.). En ambos, el amante pide a Clori (cuyo cabello está adornado con jazmines) que acceda a sus deseos: "Más, Clori, que he tejido / jazmines al cabello desatado, / y más besos te pido / que abejas tuvo el escuadrón armado" (vv. 13-17).

705 Ver nota 94.

${ }^{706}$ De punta en blanco: Se puede interpretar como "con todas las piezas de la armadura antigua puestas" "con puntería directa al disparar a corta distancia" (DLE).

${ }^{707}$ Dilogía que señala el acto de perder las hojas y el de "esparcir, derramar la elocuencia" (Aut.). También podría interpretarse por el contenido bélico del poema como "desarmarse".

${ }^{708}$ La azucena sirve como símbolo de blancura

709 El término "rendir" completa el léxico militar sobre el que se construye el poema: "emboscada" (v. 1), "de punta en blanco" (v. 4), "duelo" (v. 4), "esgrimió" (v. 6) y "deshojarse" (v. 8). Este representa en el poema el intento de seducción que lleva a término el jazmín.
} 


\section{Soneto panegírico que aún no le viene a la media pierna al dueño del asunto (109) \&}

\section{Soneto}

Breve pie ${ }^{710}$ reducido a cárcel breve, hermosa de mi vista fue fatiga, pues, cuanto más curiosa la averigua, si cae en él, al lazo se lo debe ${ }^{711}$.

Hermosa basa ${ }^{712}$, por quien veloz se mueve columna hermosa ${ }^{713}$ que a rendir me obliga, que para cautivar sobre la liga, que en dorada prisión guarda su nieve $\mathrm{e}^{714}$.

No de tu rueda ya, fortuna ingrata,

10 temeré a los vaivenes cauteloso, que si en rápido curso se desata

de tu pie al movimiento caudaloso, pues mi Arnarda querida así me trata; con su pie, a tu pesar, me hace dichoso ${ }^{715}$.

\section{Al mismo asunto (109v) \&}

\section{Soneto}

Cómo quieres, Anarda, que sea casto quien miró de tus piernas el hechizo, y que no se dé un verde ${ }^{716}$ a lo castizo quien, hasta las rodillas, tiene el pasto.

Si la memoria al gusto le hace el gasto, ya el apetito tiene pasadizo;

\footnotetext{
${ }^{710}$ Ver nota 100.

${ }^{711}$ La visión de un pie femenino descubierto, coronado por un lazo, parece tener como referente el primer cuarteto del soneto de Lope "Yo vi sobre dos piernas plateadas" (Lara 25), donde se equiparan las piernas de una mujer con las columnas de un templo. Esta composición y las variantes que dicha metáfora posee han sido analizadas por Lara Garrido (23-68).

${ }^{712}$ El inicio del segundo cuarteto es similar al del soneto de Francisco Terraza “ Ay basas de marfil, vivo edificio" (Lara 38), que representa a la amada como un templo de amor. Fray Damián recurre también a dicha imagen y potencia su erotismo al incluir intensos movimientos (vv. 11-12).

${ }^{713}$ La metáfora de la pierna como una columna ayuda a configurar la descripción de la amada como un templo (v. 5).

${ }^{714}$ La imagen de las piernas de la amada como una prisión dorada en la que se guarda la nieve podría vincularse al romance de Quevedo "Las columnas de cristal" (Lara 46-48). En él se representan las piernas de la mujer como montañas cubiertas con las hebras del vellón de Colcos y con un valle nevado (vv. 1520).

${ }^{715}$ Mientras que el cierre de los sonetos mencionados previamente de Lope y de Francisco Terraza resulta poco alentador para el protagonista, el poema de Cornejo (como el romance anteriormente citado de Quevedo) parece dejar una puerta abierta para el goce del amado.

${ }^{716}$ Darse un verde: "Vale holgarse o divertirse por algún tiempo, con alusión a las caballerías, que le toman en la primavera" (Aut.).
} 
permíteme deleite no postizo,

puesto que no hago incesto ni embanasto ${ }^{717}$.

Con tu pierna de Venus la pantorra,

puesto* que tiene todo su caudal en piernas,

es de borra, muy floja y muy magruja.

La de la diosa Palas ${ }^{718}$ hizo porra ${ }^{719}$,

mas, pues me picas ${ }^{720}$ con la que gobiernas,

no es pierna la tu pierna, sino aguja ${ }^{721}$.

\section{Otro soneto (110) \&}

\section{Soneto}

Ya no puedo vivir si no me capo, porque si tengo bolas, y no emboco ${ }^{722}$, $\mathrm{y}$, aunque te diga cabe ${ }^{723}$, no te toco, todo en gordo será vaina de trapo.

Si de ser inocente así me escapo, a lo menos de amante doy en loco; pues nevando camisas, poco a poco, si las mojo muchísimo, no empapo ${ }^{724}$.

Quién te viera no grave y espetada, cuando el amor se goza sin sospecha a mi manera atenta, y no a mi modo.

Yo quedaré contento y tú pagada, pues supieras cuál es* mi pij ${ }^{725}$ derecha y me quisieras bien, con vaina y todo ${ }^{726}$.

\footnotetext{
717 Se establece un juego de palabras entre "incesto" y "embanasto" basado en la acción de meter algo en una canasta. Esta sirve como metáfora del coito.

718 Ver nota 283.

${ }^{719}$ Hacer porra: "Pararse sin poder o querer pasar adelante en algo" (DLE).

${ }^{720}$ Dilogía que se utiliza en el sentido de excitar sexualmente y en el de herir.

${ }^{721}$ Se establece un vínculo semántico entre los términos "Palas" (v. 12), "porra" (v. 12) y "aguja" (v. 14), Este último se puede relacionar, además, con la planta llamada "aguja de Venus", que en el presente poema halla su símil en las piernas de la protagonista "piernas de Venus" (v. 9).

${ }^{722}$ Dilogía que hace referencia al juego del emboque o de la argolla (donde se pasa una bola por una tronera o por el aro) y a la acción de introducir algo por una parte estrecha. Ambas acepciones aluden al coito.

${ }^{723}$ En el juego de la argolla, el cabe es el "golpe de lleno", que "da una bola a otra, impelida de la pala con que se juega, de forma que llegue al remate del juego, con que se gana raya" (Aut.).

${ }^{724}$ Se trata de un calambur que se construye sobre el verbo "empapar" (empleado como metáfora de la eyaculación masculina) y sobre "en papo", que indica la parte externa de los genitales femeninos.

725 Abreviatura de "pija".

${ }^{726}$ Se podría relacionar con la expresión "dar con vaina y todo", que significa "pegar con la espada envainada, como castigo afrentoso" (Aut.). Esta, por el contenido del poema, adquiría un sentido erótico.
} 


\section{Al desaliño de los versos de un poeta de polainas y greguescos (110v) \&}

\section{Soneto}

Disparates, Antón, muy mal zurcidos

escribes y conceptos mal pensados;

estos son cortos, mas como nevados, aquellos grandes, mas como llovidos.

Veranse tus romances muy corridos ${ }^{727}$ en la plaza del mundo ${ }^{728}$ por silbados y tus conceptos muy avergonzados, causando risa por lo mal vestidos.

Si salir de poeta con la empresa

quieres, será forzoso que te* enmiendes;

pule el estilo y el ingenio* aguza,

que no hay musa* ninguna a sayaguesa*729

y te darán, cuando laurel pretendes,

todas las nueve musas ${ }^{730}$ caperuza $^{731}$.

\section{A uno que se llamaba Cruz y perseguía al autor por haberle pedido unas suelas} (111) \&

Cruz, si cristiano soy, ¿qué me persigues?

Cruz, si diablo no soy, di ¿qué me quieres?

Si yo soy bautizado y tú cruz eres,

cuando de ti me escondo, ¿qué me sigues? ${ }^{732}$

Cruz, a que yo te diga no me obligues

mi parecer y aun treinta pareceres;

no tan mal uses, Cruz, de tus poderes,

que haré que de mí, Cruz, * te santigües.

Tienes de cruz $^{733}$ el nombre solamente

$10 \mathrm{y}$, sin razón, a todos nos molestas,

y así que ha de llevarte es evidente

\footnotetext{
${ }^{727}$ La escasa calidad de los romances hace que sean rechazados por el público "silbados" (v. 6) y que, por ello, salgan corridos "avergonzados" (v. 7). Cabe mencionar que los "corridos" también son un tipo de romance (con rasgos etílicos de jácara), que se acompaña con la guitarra y que alcanzó gran popularidad en el siglo XVIII en Latinoamérica.

728 Ver nota 192.

${ }^{729}$ Se emplea en el sentido de persona tosca y grosera. Resulta relevante señalar que el "sayagués" es un habla rústica, que toma elementos del "dialecto leonés de la comarca de Sayago, utilizada por personajes villanescos en el teatro español de los siglos XV al XVII" (DLE).

${ }^{730}$ Las nueve musas que acompañan a Apolo y que sirven, según la tradición griega, como fuente de inspiración a pensadores y artistas son: Calíope, Clío, Erato, Euterpe, Melpómene, Polimnia, Talía, Terpsícore y Urania.

${ }^{731}$ Dar en caperuza: "Darle a alguno un golpe en la cabeza haciéndole mal y, translaticiamente, darle alguna pesadumbre o hacerle alguna molestia, por vengarse o satisfacerse de él" (Aut.).

${ }^{732} \mathrm{El}$ constante acoso que sufre el protagonista por parte de Cruz pondría de manifiesto el comportamiento sodomita de este último (ver nota 486). Resulta relevante señalar que el presente poema comparte temática y personajes con otras poesías indubitadas de fray Damián "Apenas, señor, te viste" y "Pedite, mi buen Cruz, suelas".

${ }^{733}$ Se emplea en el sentido metafórico de "peso o carga intolerable, pensión, pena y trabajo" (Aut.).
} 
el demonio, por otras y por estas.

¡Oh quién le viera al diablo penitente

ir al infierno con su cruz acuestas

\section{Al mismo asunto (111v) \&}

\section{Décimas}

Apenas, señor, te viste

y el cuchillazo empuñaste ${ }^{734}$,

mi Cruz, cuando ejecutaste

tu furia en aqueste triste.

5 Yo no sé qué conseguiste

con tu intención depravada.

Si piensas que acreditada

tu ciencia está, ya* es en balde,

porque ya cualquier alcalde

10 ejecuta su alcaldada.

Porque pedí ${ }^{735}$, criminal, me atropella tu desdén.

Si tú despides tan bien, no lleves el pedir mal

15 castigo bien desigual.

Tu sin razón este día

ofrece a la culpa mía,

pues dice tu falsa lengua

que esto que en ti ha sido mengua

20 ha sido en mí demasía.

Si porque pedí, no más, fulminas tales castigos, mi buen cruz, seamos amigos y no pediré jamás.

25 Suelas te pedí, y me das

fieros azotes, tirano ${ }^{736}$;

y aún le queda el brazo sano

a tu fuerza inexorable*, porque siempre un miserable

30 [al dar aprieta la mano]*737.

Ya es en ti razón de estado, aunque no puesta en razón,

\footnotetext{
${ }^{734}$ Se trata de una metáfora de la erección del miembro viril.

${ }^{735}$ Hace referencia a "pedir suelas" (v. 25), que por el contexto parece indicar que se trata de favores sexuales. Este deseo también se pone de manifiesto en la composición indubitada de Cornejo "Pedite, mi buen Cruz, suelas". Resulta relevante señalar la estrecha relación que se establecía en los Siglos de Oro entre los zapatos y el erotismo y también las múltiples composiciones jocosas que tienen estos como eje central.

${ }^{736}$ El vocativo "tirano" suele aludir en los poemas que tratan sobre relaciones afectivas a la amada (ver nota 111). En la presente composición, también se relaciona con "alcalde" (v. 9) y "alcaldada" (v. 10).

${ }^{737}$ Apretar la mano: "Añadir fuerza y rigor: y esta frase se suele usar cuando castigan a un hombre, o muchacho, y quieren que escarmiente, se dice, o se manda al que le castiga, que apriete la mano" (Aut.).
} 
que el que mete petición

ha de quedar condenado.

35 De esta vez, escarmentado yo me vengo a resumir, si contigo he de vivir, a no pedirte jamás; $\mathrm{y}$, así, tan bueno serás

40 que no haya más que pedir.

\section{Al mismo asunto (113) \&}

\section{Décimas}

Pedite, mi buen Cruz, suelas ${ }^{738}$, pero tu miseria es tal que por ello*, criminal, sin darme suelas ${ }^{739}$, me asuelas*.

5 Por esto, te desconsuelas, por esto, furores brotas $\mathrm{y}$, por esto, te alborotas. No vi cosa semejante, el diablo de aquí adelante

10 te puede pedir, que azotas ${ }^{740}$.

Quién vio necedad jamás, más patente a todas luces ${ }^{741}$, como que Cruz se haga cruces ${ }^{742}$, porque le piden, no más,

15 pues válgate, satanás, miserablón, insolente, que se te da impertinente que todo el mundo te pida, cuando no vi hombre en mi vida

20 de tan lindo despidiente.

Para qué son aspavientos ${ }^{733}$ por cosa tan leve, di, ¿por qué suelas te pedí haces tales sacramentos?

25 Este nombre a tus intentos, por ser poca tu prudencia, les cuadra por excelencia, pues pedirte, en conclusión,

\footnotetext{
738 Ver nota 737.

${ }^{739}$ Dar suelas: Dar caricias amatorias.

${ }^{740}$ Parece hacer referencia a prácticas de sadomasoquismo.

${ }^{741}$ A todas luces: "Por todas partes, de todos modos" (DLE).

${ }^{742}$ Hacerse cruces: "Demostrar la admiración o extrañeza que causa algo" (DLE).

${ }^{743}$ Dilogía que expresa tanto el "horror, admiración, o extrañeza de alguna cosa, manifestada en voces o acciones descompasadas" como "los tajos y reveses que hacen en el aire los que riñen sin alcanzarse los unos a los otros, cruzando y atravesando las espadas" (Aut.).
} 
fue, para ti, extremaunción

$30 \mathrm{y}$, para mí, penitencia ${ }^{744}$.

No niegues, que no es razón,

que allí con pasión obraste,

pues en mi espalda dejaste

señales de tu pasión ${ }^{745}$.

35 De aquesta bárbara acción, llega a entender mi cuidado que no quedó en mal estado, de esta vez, para contigo, pues, aunque no eres mi amigo,

40 me estás muy apasionado.

De ti te olvidaste, triste, cuando fiero me azotaste, pues dieras conmigo al traste ${ }^{746}$ si advirtieras en qué diste;

45 pero no cuerdo anduviste en ello, si se repara, pues, viendo que cara a cara ${ }^{747}$ pidiéndote te injurié, si me diste zurra, fue

50 porque yo te la pagara ${ }^{748}$.

Que son graves culpas estas de pedirte, es cosa clara, que (a no serlo) no llevara tan pesada cruz a cuesta ${ }^{749}$.

55 Mi Cruz, mucho me molestas, pero yo también te acudo, pues que me pagas ${ }^{750}$, no dudo, en esto que hacer me obligas, porque, si tú me santiguas ${ }^{751}$, 60 mira cómo te saludo ${ }^{752}$.

\footnotetext{
${ }^{744}$ Se hace referencia a dos sacramentos cristianos que tienen como finalidad la purificación del alma: el de la unción de los enfermos "extremaunción" (v. 29) y el de la confesión de los pecados "penitencia" (v. 30).

${ }^{745}$ Equívoco que, en su primera acepción (v. 32), se utiliza en el sentido de deseo y, en su segunda (v. 34), se emplea como muestra de perturbación o de sufrimiento. Además, sirve como alusión a los azotes que recibió Cristo antes de ser crucificado.

${ }^{746}$ Dar al traste: "Metafóricamente vale destruir alguna cosa, abandonarla o perderla" (Aut.).

${ }^{747}$ Cara a cara: "En presencia de alguien y descubiertamente" (DLE).

${ }^{748}$ Dilogía que hace referencia tanto al acto de "corresponder al afecto, cariño u otro beneficio" como al de satisfacer por el delito, culpa o yerro, por medio de la pena correspondiente" (Aut.). Además, por el contenido sodomita del poema, podría relacionarse con la prostitución.

749 Ver nota 735.

${ }^{750}$ Se usa en el sentido de "complacer, agradar, satisfacer o dar gusto" (Aut.).

${ }^{751}$ Dilogía que señala el acto de castigar o maltratar a alguien y el de hacer la señal de la cruz sobre algún enfermo. Esta último uso se vincularía con el sacramento de la extremaunción (v. 29).

${ }^{752}$ Se toma "por castigar, dando golpes" (Aut.). Esta acción completaría el campo semántico de la violencia física que se ha ido conformando en el poema: "asolar" (v. 4), "azotar" (v. 10), "aspavientos" (v. 21), “azotaste” (v. 42), “zurra” (v. 49) y "santiguar" (v. 59).
} 


\section{Soneto jocoso $(114 v) \&$}

\section{Soneto}

Estaba Lisis ${ }^{753}$ en campal batalla ${ }^{754}$

resistiendo de Filis el asalto,

que encendido de amor, de juicio falto,

solicitaba descortés gozalla.

Derribola y no pudo sujetalla

porque, al ir con ansia a dar el salto,

de un respingo le echó Lisis tan alto

$\mathrm{y}$, a pie juntillas ${ }^{755}$, defendió su valla ${ }^{756}$.

Ya verán que es forzoso que se emperre,

10 Filis amante con tan ruin suceso.

No hay que espantar que con amor se yerre.

Si con amor a darme, no hay seso*.

En fin, ella se estuvo erre que erre ${ }^{757}$

y el pobre se quedó tieso que tieso ${ }^{758}$.

\section{A una monja pidiendo celos a un hombre que tenía por sobrenombre Puerto} (115) \&

\section{Soneto}

De mis finezas el bajel incierto

el mar de amor ${ }^{759}$ surcaba con bonanza,

mas halló (grave pena) mi esperanza

más seguros los riesgos en el puerto ${ }^{760}$.

5 Viendo este mal que, a mi pesar, es cierto

quien podrá, con segura confianza,

poner de la fortuna, en la balanza

de sus felicidades, el concierto ${ }^{761}$.

Pero el consuelo que a mi mal aplico,

10 cuando mis dichas, Lisis, desconciertas, es que si piensas que en el puerto rico

\footnotetext{
${ }^{753}$ Ver nota 121.

${ }^{754}$ Ver nota 282.

${ }^{755}$ A pies juntillas: "Con los pies juntos" (DLE).

${ }^{756}$ Se trata de una metáfora que expresa la voluntad de la protagonista de proteger sus partes íntimas y, con ello, evitar la realización del acto sexual.

${ }^{757}$ Erre que erre: "Vale lo mismo que terca y porfiadamente" (Aut.).

${ }^{758}$ Tieso que tieso: "Erre que erre" $(D L E)$. Esta expresión en el poema adquiere también el significado de "excitado".

${ }^{759}$ El vínculo que se establece en el soneto entre el mar y el amor no correspondido del protagonista se podría relacionar con la tradición de la "piscatoria". Esta se popularizó en España gracias a Góngora y fue cultivada y adaptada por otros autores relevantes como Lope de Vega o Luis Carrillo y Sotomayor. Madoka Tanabe (25-28) comenta algunos sonetos del poeta cordobés que tratan dicha temática.

${ }^{760}$ Se trata de una dilogía que hace referencia tanto al lugar donde se guardan y se refugian los barcos como a la "boca madre de las mujeres" (Aut.).

${ }^{761}$ Dilogía que señala un pacto y la acción de los monteros de reconocer el terreno para saber dónde se ha de cazar. Esta actividad se utiliza en el lenguaje erótico como una metáfora de "seducir" o "conquistar".
} 
desembarcaste, son tus penas ciertas, porque todo su ajuar lleva en el pico ${ }^{762}$, y quedaraste por tu puerto a puertas ${ }^{763}$.

\section{A los escribanos (115v) \#}

\section{Quintillas}

Hoy sin más ni más me allano, musa mía, aunque lo gruñas, a dar tras un escribano que, como es asunto de uñas, se me ha venido a la mano ${ }^{764}$.

En quintillas ha de ser la sátira que hacer trato, porque haya más que ver, aunque conozco ha de ser

10 buscar cinco pies al gato ${ }^{765}$.

Hombre es de tal calidad que, cuando un pleito procura, miente con seguridad y nunca dice verdad,

15 aunque hable de la escritura ${ }^{766}$.

Por negocios, se desalma ${ }^{767}$, para divertir el ocio, $\mathrm{y}$, por no quedarse en calma, deja el negocio del alma

20 y va al alma ${ }^{768}$ del negocio.

Tiene sutileza extraña, si algún dinero se emboca, para sacarle con caña, porque, desde luego, al punto araña, en conociendo que hay mosca ${ }^{769}$.

En todas las ocasiones, por apartados retiros,

\footnotetext{
${ }^{762}$ Llevarse en el pico: "Frase que significa hacer gran ventaja a alguno en la ejecución o comprehensión de alguna cosa" (Aut.).

763 A puertas: "Significa con tanta necesidad y pobreza que es necesario pedir limosna" (Aut.). Esta expresión se contrapone a "puerto rico" (v. 11), que sirve como metáfora del goce sexual.

${ }^{764}$ Venir a las manos: "Reñir, batallar" (DLE).

${ }^{765}$ Buscar cinco pies al gato: Buscar "ocasión de pesadumbre y su daño" (Corr.).

${ }^{766}$ Se trata de una dilogía que hace referencia tanto al "instrumento público jurídico, firmado por la persona que le otorga, delante de testigos, y autorizado de escribano" como a la Escritura Sagrada "Biblia" (Aut.).

${ }^{767}$ Dilogía que indica "hablar con tales expresiones de ingenuidad y candor, que en cada una de ellas parece vierte o exhala el alma el que las profiere" y que alude a la acción de "quitar a alguno la vida violentamente" (Aut.).

${ }^{768}$ Equívoco que, en su primera aparición (v. 19), señala al espíritu y, en su segunda (v. 20), al "objeto verdadero de él, su móvil verdadero, secreto o principal" (Aut.).

${ }^{769}$ Ver nota 168.
} 
anda a caza ${ }^{770}$ de doblones ${ }^{771}$

y tiene lindos cañones,

30 para no errar los tiros.

Muy como en cosa precisa

anda en tales ejercicios,

mas no lo hace deprisa,

que, aunque se quede sin misa,

35 nunca falta a los oficios ${ }^{772}$.

Pero esto es ya sin razón

y, así, con más advertencia,

volviendo por su opinión,

no le he de llamar ladrón,

40 aunque es cargo de conciencia ${ }^{773}$.

\section{A un jurador (117) \#}

\section{Quintillas}

Señor, jurador he sido, mas hoy, que me he confesado y vuestro pan he comido ${ }^{774}$, estoy muy arrepentido,

5 por Jesucristo adorado.

Pero yo no comprehendo* lo que es aquesta* comida que, si a su sabor* atiendo, hallo que me da, en comiendo,

10 mayor hambre, por mi vida.

Si en el altar* soberano tan solo un bocado he visto, ¿qué ha de comer un cristiano, donde con tan corta mano

15 se da el pan, cuerpo de Cristo?

No es el regalo muy malo si a comerle me prevengo, mas yo sé de este regalo que le vi puesto en un palo ${ }^{775}$

20 por el ánima que tengo.

Vida y muerte se concibe con estos misterios dos,

\footnotetext{
${ }^{770}$ Andar a caza: "Buscarlo afanosamente" (DLE).

${ }^{771}$ Moneda de oro de España, "que ha tenido diferentes precios según los tiempos, siendo lo más regular equivaler a cuatro pesos escudos" (Aut.).

772 Dilogía que señala al "rezo que tienen obligación a decir todos los días los eclesiásticos" y a "la oficina de los escribanos, donde trabajan, y hacen los instrumentos públicos, y despachan lo que es de su ejercicio" (Aut.).

773 Cargo de conciencia: "Lo que la grava" $(D L E)$. Se emplea, además, para recalcar la relevancia y complejidad del oficio de escribano (v. 3).

${ }^{774}$ Se trata de la hostia sagrada.

${ }^{775}$ Referencia a la crucifixión de Cristo (v. 30).
} 
$y$ de entrambos se percibe

que Cristo en la cruz no vive

y en el pan sí vive Dios.

Pero, aunque inmortal le advierto

en su verdad infinita,

bien puedo afirmar de cierto

que le vi de amores muerto ${ }^{776}$,

30 por aquesta cruz bendita.

Juan, pues la luz habéis sido ${ }^{777}$

de este dios oculto, vos,

no le mostréis escondido,

que ya le hemos conocido,

por aquesta cruz de Dios ${ }^{778}$.

\title{
73. Letra burlesca (118) +
}

\section{Coplas}

\author{
A Pascuala dijo Bras ${ }^{779}$ \\ que por cierta niñería \\ alma y vida le daría \\ y trescientas cosas más ${ }^{780}$.
}

5 Prometiole el arrebol

del rostro de la fortuna,

los dos cuernos de la luna

y los cabellos del sol,

un caracol

10 de escalera,

la mollera

del cura de Talavera ${ }^{781}$,

con dos sillas

de costillas,

\footnotetext{
${ }^{776}$ Se expresa en tono jocoso el sacrificio de amor que hizo Jesucristo para redimir a la humanidad de sus pecados. Resulta relevante señalar que la imagen de ver a alguien de "amores muerto" pone también de manifiesto el tópico de "morir de amor" (ver nota 112).

${ }^{777}$ Según el evangelio de Lucas $(1,76)$, Dios otorgó a san Juan la tarea de ser el precursor de Jesús y de prepararle el camino.

778 Se podría relacionar con la expresión "estar por esta cruz de Dios" (DLE.), que posee dos acepciones que encajarían con el contenido del poema. Por un lado, una que indica que "no se ha comido" y se vincularía a los versos en los que se trata la escasa ingesta de alimento que supone la hostia consagrada (vv. 9-14). Por otro, una que señala que "no se ha podido entender algo", que se asociaría al misterio de la Eucaristía (v. 25).

${ }^{779}$ Esta composición apócrifa se halla en todos los manuscritos integri de fray Damián y fue publicada con su nombre en 1767 (Serna 105) y en 1903 (Foulché-Delbosc, Varia: 234-235).

${ }^{780}$ Es una frase vulgar que se utiliza para ponderar una necedad o desacierto. Foulché-Delbosc (Coplas 261-268) señala que se halla en múltiples composiciones de contenido absurdo y extravagante y edita las coplas anónimas "Parió Mariana en Orgaz", que al parecer la hicieron popular. Estas se asemejan formalmente y en su contenido al poema atribuido a Cornejo.

${ }^{781}$ Se trata del dramaturgo extremeño Diego Sánchez, que solía incluir en sus obras elementos cómicos absurdos e inconexos con la trama principal.
} 
un plato y dos escudillas

y el aire de contrapás ${ }^{782}$,

y trescientas cosas más.

Prometiole la montera

con que Adonis iba a caza ${ }^{783}$,

20 de Ganimedes la taza ${ }^{784}$, y de Saturno la esfera ${ }^{785}$, una cuera

de Golías ${ }^{786}$

con sus chías,

25 y un costal de alcamonías, un escarpín

de Caín,

la toma de san Quintín ${ }^{787}$,

y las botas de Caifás ${ }^{788}$

30 y trescientas cosas más.

Unas martas que se aforren

de los pellejos de Ursón ${ }^{789 *}$,

la pretina de Sansón

35

y el juicio de Vinorre ${ }^{790}$,

con la torre

de Lodones ${ }^{791}$

dos frisones,

un pastel de camarones,

un* mazapán

40 del preste Juan ${ }^{792}$,

un bigote de Roldán ${ }^{793}$

\footnotetext{
782 El contrapás es una danza popular catalana de tono solemne.

783 Adonis, dios que representaba la belleza masculina, murió mientras cazaba un jabalí, enviado por Artemisa.

${ }^{784}$ La extraordinaria hermosura de Ganimedes, príncipe troyano, hizo que Zeus los raptara y lo convirtiese en su amante y en el copero de los dioses.

${ }^{785}$ Saturno, según Ptolomeo, constituía la esfera planetaria más alta del cosmos.

${ }^{786}$ Según la tradición bíblica, Goliat fue un gran soldado filisteo, que fue derrotado por el rey David (Samuel 17, 49-50).

${ }^{787}$ La Batalla de San Quintín se produjo el diez de agosto de 1557, dentro de la contienda de las Guerras italianas (1551-1559), y enfrentó al Imperio español y a Francia. La resolución de esta fue a favor de las tropas españolas.

788 José ben Caifás (sumo sacerdote judío de la secta de los saduceos) fue uno de los implicados en la conspiración que se preparó para condenar a muerte a Jesucristo.

${ }^{789}$ Ursón (llamado también Orsón) es un personaje legendario del medievo francés que fue criado por una osa. Lope de Vega en la comedia El nacimiento de Ursón y Valentín (1588-1595) versiona la historia de los hermanos de gemelos del rey Pinoso.

${ }^{790}$ Vinorre (o Vinorro) fue un popular loco en la España de los Siglos de Oro. Góngora lo utiliza en el soneto “¡Aquí del Conde Claros, dijo, y luego” para criticar a Lope de Vega (Góngora s.p.).

${ }^{791}$ Se trata de la también llamada Atalaya de Torrelodones, construida entre el siglo IX y XI, que se encuentra en el municipio madrileño de Torrelodones.

${ }^{792}$ El preste Juan (o pastor Juan), según las leyendas medievales, fue un virtuoso gobernante cristiano del Lejano Oriente que descendía de los tres Reyes Magos y que poesía un rico territorio, lleno de extraordinarios tesoros.

${ }^{793}$ Roldán (conocido como Roland u Orlando) fue un legendario comandante franco, cuya misión principal fue la defensa_del territorio francés frente a los bretones. Su muerte en la batalla de Roncesvalles fue recogida en el Cantar de Roldán.
} 
y un guante de Fierabrás ${ }^{794}$,

y trescientas cosas más.

Una desgracia de un martes

45 y una ventura de un viernes,

la cabeza de Holofernes ${ }^{795}$

con un bachiller en artes,

las dos partes

de Amadís 796

50 con ámbar gris*797,

con orégano y anís,

los intestinos de Calaínos 798

y el caballo de Longinos ${ }^{799}$

relinchando por detrás,

55

y trescientas cosas más.

Una alcorza de un guijarro

y de un tiro la respuesta,

$\mathrm{y}$ tres nueces de ballesta

con unas ruedas de un carro,

60 un zamarro,

una alcuza,

al moro Muza ${ }^{800}$

los dientes de una lechuza

y un jamón

65 del matracón

del puerto de san Antón ${ }^{801}$

y la oración de san Blas ${ }^{802}$,

y trescientas cosas más.

Los dientes de un arador

70 y de un mosquito los sesos,

y de dos quebrantahuesos

el arco y flechas de amor,

un ruiseñor,

dos hidalgos

75 con dos galgas,

de la pandorga las nalgas

en cecina

\footnotetext{
${ }^{794}$ Fierabrás de Alejandría es un personaje de ficción de varios cantares de gesta franceses, conocido por su extraordinaria fuerza y por ser enemigo de Roldán (v. 41) y de los doce pares.

${ }^{795}$ Holofernes, general asirio de las tropas de Nabucodonosor II, fue decapitado mientras dormía por Judith, una hermosa judía.

${ }^{796}$ El Amadís de Grecia (1530) es un libro de caballerías español (se enmarca en la serie iniciada por el Amadís de Gaula) escrito por Feliciano de Silva. Está constituido por dos partes de extensión desigual, que se hallan separadas por el sueño del autor.

${ }^{797}$ Se trata de una sustancia que se encuentra "en las vísceras del cachalote, sólida, opaca, de color gris con vetas amarillas y negras, de olor almizcleño, usada en perfumería" (DLE).

798 Ver nota 289.

${ }^{799}$ Longino, según las leyendas medievales, habría sido el soldado romano (posteriormente convertido en santo cristiano) que lanceó el costado de Jesucristo.

${ }^{800}$ El moro Muza puede hacer alusión a algún dirigente andalusí, a un estereotipo escatológico del moro o a una figura similar a la del "hombre del saco".

${ }^{801}$ Es un puerto de Gipuzkoa.

${ }^{802}$ Se trata de un rezo que se realiza a Blas de Sebaste para pedirle favores o milagros.
} 
y Celestina

echando una melecina

a Lupercio por detrás,

y trescientas cosas más.

Unas botillas azules,

resplandor y solimán,

y una gorra de Milán ${ }^{803}$,

85 del conde don Peranzules ${ }^{804}$

dos baúles

y un pimiento

del convento,

la mula del Nacimiento

90 de retorno

para Osorno ${ }^{805}$

y el Deo gracias $^{806}$ al torno,

con el por siempre jamás

y trescientas cosas más.

74. Desengaño del deleite sensual. Jácara (121) \&

\section{Romance}

En la villa de Carrión ${ }^{807}$

del partido de Toledo,

a nueve días de agosto,

vísperas de san Lorenzo ${ }^{808}$,

5 probamos esta ensalada ${ }^{809}$

yo y un peón extremeño.

Oíd, mozos de Carrión,

todos los que vais saliendo

desde la Europa del mundo.

10 Mirad, que os habla un manchego ${ }^{810}$,

que por ser acuchillado ${ }^{811}$

es de todos el más bueno.

Propiedades de las putas ${ }^{812}$

${ }^{803}$ Las gorras que procedían de Milán eran de alta calidad y se caracterizaban por sustentarse "con un cerquillo de hierro" (Cov.).

${ }^{804}$ Pedro de Ansúrez (1037-1118), llamado también el Conde Peranzules, fue siervo de Alfonso VI, quien le concedió el señorío de Valladolid.

805 Osorno la Mayor es un municipio de Palencia.

${ }^{806}$ El Deo gratias “Gracia a Dios” se utilizaba para entrar en un casa o para ganar la estimación y confianza de alguien $(D L E)$.

${ }^{807}$ Carrión de Calatrava es un pequeño municipio de Ciudad Real.

${ }^{808}$ San Lorenzo se celebra el día diez de agosto, día en el que se produjo su martirio en la hoguera.

${ }^{809}$ Se trata de un género misceláneo de canciones que poseen diversos metros.

${ }^{810}$ Fray Damián, aunque nació en Palencia, se consideraba manchego. Su familia materna procedía de la ciudad de Toledo y él se trasladó en su adolescencia a esta para iniciar su formación.

${ }^{811}$ Se emplea en el sentido metafórico de "experimentado, práctico y capaz de las cosas que ha visto y tratado" (Aut.).

${ }^{812}$ Parece evocar el poema anónimo "Putas son luego en naciendo" recogido en el Cancionero de Sebastián Horozco (274-275). 
os diré, si bien me acuerdo.

15 Por putas se perdió Troya ${ }^{813}$

y los troyanos guineos ${ }^{814}$ :

si no fue su fin por putas,

fue por esas, que es lo mesmo.

Por una puta Sansón,

20 rayó de los filisteos,

moliera en una tahona

ciega no el alma, sí el cuerpo ${ }^{815}$,

y el santo mozo José

por otra puta fue preso

25 y, por ella, padeció

en la cárcel mil tormentos ${ }^{816}$.

Por putas dejan los hijos

a sus padres, cuando viejos,

los casados sus mujeres,

30 los frailes sus monasterios.

Putas les dan de comer

a escribas y fariseos,

porque, si no hubiera putas,

nunca hubiera tantos pleitos.

35 A todos los que me oyen,

hago testigos de aquesto:

putas nos quitan los cuartos,

putas nos ponen los cuernos,

putas nos hinchen de bubas ${ }^{817}$

40 hasta barbas y cabellos;

y por ellas infernamos,

y por ellas padecemos

purgatorio, en esta vida,

$y$, en el otro mundo, infierno.

$45 \mathrm{Y}$, pues tantos males causan,

alto a las putas, mancebos.

* Al arma ${ }^{818}$ contra estas tales, yo seré capitán vuestro.

Si por putas empezamos,

50 por putas acabaremos, que en todo tiempo las putas

\footnotetext{
${ }^{813}$ Hace referencia a la traición amorosa que protagonizó Helena, esposa del rey Menelao, al huir junto al príncipe Paris.

${ }^{814}$ El envío de esclavos de Guinea (territorio ocupado por los portugueses desde el siglo XV) hacia América desató, en 1576, en la Nueva España una fuerte epidemia de sífilis.

${ }^{815}$ Sansón, uno de los últimos jueces israelitas antiguos, fue hecho prisionero de los filisteos tras confesarle a Dalila, una prostituta de la cual se enamoró, cómo podía ser vencido. Después perder su cabellera, fuente de su fuerza, sus enemigos le arrancaron los ojos y lo tuvieron moliendo grano hasta que pudo llevar a término (gracias a su fe en Dios) su trágica venganza (Libro de los Jueces, 13-16).

816 José, uno de los doce hijos de Jacob, fue acusado de abusar de la esposa de su señor (Potifar). Esta, tras el rechazo del joven hebreo a sus encantos, decidió vengarse levantando un falso testimonio en su contra (Génesis 37).

${ }^{817}$ Se trata de uno de los síntomas de la sífilis (ver nota 514).

${ }^{818}$ Al arma: Se usa "para prevenir a los soldados que tomen prontamente las armas" (DLE).
} 
no quieren sino dinero.

Lo que habéis de echar en putas

echadlo en polla o carnero,

en buen conejo o perdiz,

que os hará mejor provecho.

Rogad a Dios por quien da

tan saludables consejos,

que me libre Dios de putas,

60 que me tienen casi muerto.

\section{Sátira (123) \&}

\section{Romance}

En Málaga vi a Rufina, y está tan pobre de data que, si no es ella, no hay quien en Málaga mal haga ${ }^{819}$.

5 Cantaba y bebía mucho, y sin vino no cantaba, por apostar quién la diera una cántara cantara ${ }^{820}$. La pícara ${ }^{821}$ nunca quiso

10 picar que, según yo estaba, confieso que me rindiera si la pícara picara ${ }^{822}$. Como hombre en las acciones se subía ya en las barbas,

15 de suerte que fuera un tigre, si la bárbara barbara.

Mas ella con los afeites ${ }^{823}$ parecía ya estofada $\mathrm{y}$, en su lugar, la tenían

20 por la máscara más cara Desde niña, tuvo quien jamás la dejó ser mala $\mathrm{y}$, antes de salirse, tuvo quien la cáscara cascara ${ }^{824}$.

\footnotetext{
819 Paronomasia que se construye sobre la locución "Hacer mal", cuyo significado de "domar un caballo" $(D L E)$ adquiere en el poema un sentido erótico, pues la protagonista es una prostituta.

${ }^{820}$ Dilogía que remite a la acción de producir con la voz sonidos melódicos y al acto sexual.

${ }^{821}$ Ver nota 489.

822 Ver nota 232

${ }^{823}$ El uso de ungüentos en meretrices, para aumentar el apetito sexual del varón. era considerado una acción que impedía salvar sus almas. También era pecado el empleo de vestidos o recurrir a la conversación (Vivas y Arias 56).

${ }^{824}$ Hace referencia al acto sexual.
} 


\section{Sátira a don Fernando Valenzuela (123v) \&}

\section{Romance}

Fernando $^{825}$, a quien por soberbio ${ }^{826}$

llama con razón Luzbel, contra el mérito y la honra, las provincias hizo arder ${ }^{827}$.

5 Arde el premio en vivas llamas $\mathrm{y}$ arde su ambiciosa sed, lo que va del muerto al vivo y del cayado al laurel. Desconoce el sol las Indias,

10 cuando en* Villasierra ${ }^{828}$ ve del Potosi ${ }^{829}$ todo el cerro arrancado de su ser.

Sentose en el trono y, luego, los hipócritas, después,

15 al malicioso ante Cristo tuvieron por justo juez. Ingrato a tan gran prodigio, entre uno y otro vaivén, como son sus obras falsas,

20 solo se ensayó* en caer. Contra su ciega codicia, Juan transformado en Miguel ${ }^{830}$, dijo con lucida escuadra: "Villano ${ }^{831}$, quien como el rey

\footnotetext{
${ }^{825}$ Fernando de Valenzuela y Enciso (1636-1692) fue un destacado y controvertido noble y político (nacido en Nápoles), que alcanzó el cargo de valido (1674-1677) durante parte de la regencia de doña Mariana de Austria (vv. 13-14). Los delitos judiciales que cometió mientras ocupaba tal puesto hicieron que fuera condenado al exilio.

${ }^{826}$ Existen algunas parodias y composiciones derivadas del romance aquí editado, que se inician con los versos "Fernando, a quien los leales" y "Fernando, a quien los crueles". Rita Goldberg comenta estos y relaciona el presente poema con el inicio del romance histórico "Don Pedro, a quien los crueles" (182187).

${ }^{827}$ Parece ser una referencia a la Guerra de Holanda (ver nota 252). Además, Juan José de Austria tuvo que afrontar durante esos años la Guerra de Messina. Todo ello terminó de dañar su imagen y evidenció las escasas dotes militares del hermanastro de Carlos II.

${ }^{828}$ Carlos II le otorgó a Fernando de Valenzuela, en 1675, el título de primer marqués de la Villa de San Bartolomé de Pinares (Ávila), que se conocería a partir entonces con el sobrenombre de "Marquesado de Villasierra". Este privilegió aumentó aún más el poder que ostentaba el valido, pues poseía ya la distinción de Caballerizo Mayor y Conservador del Consejo de Italia.

${ }^{829}$ Se trata de una ciudad del sur de Bolivia (conocida también como "Villa Imperial de Potosí"), que está situada en las faldas de una legendaria montaña llamada "Cerro Rico". Se encontraba en ella la mina de plata más grande del mundo durante los Siglos de Oro.

${ }^{830}$ Se establece una comparación entre don Juan de Austria y el arcángel Miguel, protector de la Iglesia y enemigo de Luzbel. Este último es representado en el poema como Fernando de Valenzuela (v. 2), quien es también llamado "el malicioso ante Cristo" (v. 15).

${ }^{831}$ Dilogía que señala a un personaje "ruin, indigno o indecoroso" y a un "habitador del estado llano de alguna villa o aldea". Resulta relevante señalar que Fernando de Valenzuela provenía de una familia modesta. Su padre, Gaspar de Valenzuela, fue un capitán español que gobernaba la plaza de Santa Ágata de Nápoles (Fernández Giménez s.p.).
} 
cae despeñado al abismo, y sus parciales con él, $\mathrm{y}$, entre turbulentas nubes, las puertas se van tras él" "832. Los clarines y lamentos

30 dan pésame, y para bien, a su alteza en sus fatigas ${ }^{833}$, y de su corona al rey. Sin borrar su real decoro, se trasplantó este clavel,

35 dejando mustia la rosa, con ingenioso desdén. Por inspiración divina, un día al amanecer, viéndose el niño perdido

40 quiso que le hallasen rey ${ }^{834}$. Divinas disposiciones nos hicieron noche al rey, pero con medina el cielo tal ara le dio a escoger.

45 Esta admirable mudanza firme el cetro ha de tener $\mathrm{y}$, a costa de una entereza, dichoso el retiro es ${ }^{835}$.

Otros más fieles ministros ${ }^{836}$

50 dieron consigo al través y no es lo peor que él diga: "De paje, vine a marqués ${ }^{837 "}$ ".

\footnotetext{
${ }^{832}$ Don Juan de Austria criticó con dureza las múltiples argucias y pactos "puertas" (v. 28) que el Duende de Palacio "Villano" (v. 24) realizó para subir con rapidez en la escala social y para alzarse con el poder de la corona.

${ }^{833}$ El enfrentamiento entre Fernando de Valenzuela y don Juan de Austria por el poder tuvo grandes repercusiones para Mariana de Austria "la rosa" (v. 35), quien era fiel defensora y patrocinadora del Duende de Palacio y enemiga acérrima del bastardo de su marido. Tras la caída del valido, la reina madre tuvo que permanecer recluida en Toledo hasta la muerte en 1679 del ilegítimo heredero.

${ }^{834}$ Aunque Carlos II fue proclamado rey con apenas tres años (1665), su precaria salud hizo que muchos lo dieran por un monarca "perdido" (v. 39), pues auguraban su muerte prematura y sin descendencia. El candidato alternativo, don Juan de Austria, intentó por todos los medios hacerle "noche al rey" (v. 42) para poder ocupar su lugar.

${ }^{835}$ Poco antes de la proclamación de la mayoría de edad del rey (catorce años), los Consejos de Estado y de Castilla incitaron a la Regente a alejar a Fernando de Valenzuela de la Corte. A pesar de que se le asignó el cargo de embajador de Venecia, consiguió quedarse en España y ser nombrado alcalde de la Rambla y Capitán General de Granada. En esta ciudad, permaneció hasta que la situación política mejoró. Cabe señalar que la referencia al "retiro" (v. 48) también podría ser una alusión al suceso que, por esas mismas fechas, aconteció en el Buen Retiro. Don Juan de Austria recibió en el célebre parque madrileño una Real Orden para que se marchara inmediatamente a Italia.

${ }^{836}$ Tanto Fernando Valenzuela como don Juan de Austria poseían importantes apoyos en la Corte meses antes de que Carlos II cumpliera la edad, fijada por Felipe IV, para ejercer personalmente el gobierno. En el bando de la regente y del valido, estaban el Almirante de Castilla, los condes de Aguilar, Oropesa y Melgar y, en el del candidato ilegítimo, se hallaban el Duque de Alba, el Conde de Monterrey y los cardenales de Aragón y Portocarrero.

${ }^{837}$ Fernando Valenzuela, aunque tenía un origen plebeyo (v. 24), alcanzó el título de Marqués de Villa Sierra (v. 10).
} 
Mejor es que le eches en tierra ${ }^{838}$

los frailes, en mi entender,

pues le cubre san Lorenzo ${ }^{839}$,

que le descubra no es bien.

Lo que le faltó en la cuna,

lo ha ostentado al fallecer;

$\mathrm{y}$, por su pie, al mauseolo

60 sin la lanilla se fue.

Y, pues el panteón le cubre, muera honrado antes que dé

o la cabeza al cuchillo

o la garganta al cordel ${ }^{840}$.

\title{
77. Pregón (125v) \&
}

\section{Romance}

\author{
En la ruda* política mía ${ }^{841}$
}

dos leyes observo, y tan unas las dos

como que muera, si no veo a Antandra* ${ }^{* 42}$,

como que viva, si miro a su sol ${ }^{843}$.

5 Tan rendido y constante la adoro

que no hay piedra fina de tanto valor,

pues es mi fineza un fino diamante,

que solo se engasta en mi adoración.

Solo en la ausencia de infinitos tiempos,

${ }^{838}$ Echarse alguien en tierra: "Humillarse, rendirse" (DLE).

${ }^{839}$ Valenzuela se refugió, en enero de 1677, en el monasterio de San Lorenzo del Escorial (buscando la protección del suelo sagrado) del ataque que realizó Juan José de Austria contra el valido de la regente. Este acabó con su detención y la rendición del gobierno de la reina Mariana de Austria (Fernández Giménez s.p.).

${ }^{840}$ Tras la detención del Duende de Palacio, se inició un juicio para probar las acusaciones de prevaricación, venta de cargos públicos y robo de las arcas reales "lanilla" (v. 60) que había contra él. El veredicto de culpabilidad conllevó la confiscación de sus bienes y el exilio (durante diez años) a Filipinas. Cumplido este, se trasladó a México, donde murió en 1692 por un accidente con un caballo (Fernández Giménez s.p.). ${ }^{841}$ Los cuatro primeros versos de la composición son una reelaboración de los cuatro con los que se abre el cántico que hace la Discordia en la tercera jornada de La estatua de Prometeo: "En la ruda política vuestra, / dos leyes tenéis, y tan justas las dos / como que muera el que fuere homicida, como que pene el que fuere ladrón" (Calderón, La estatua 340). La comedia mitológica de Calderón, publicada en 1677, parece evocar la compleja situación política que atravesaba España durante la regencia de doña Mariana de Austria. Fray Damián, consejero de teología de Carlos II, podría haber recurrido a dicha composición como una forma de mostrar también las vicisitudes que existían alrededor del heredero de Felipe IV.

${ }^{842}$ Podría ser una referencia a una de las protagonistas de la égloga de Albanio de Lope de Vega, donde supuestamente se recrean los intrincados acontecimientos que rodearon el enlace de don Antonio Álvarez de Toledo, quinto Duque de Alba. Las referencias en el poema de Cornejo a la naturaleza, un recurso poco habitual en su obra, reforzarían la teoría de vincular este con el ambiente bucólico de la composición del célebre dramaturgo: "En las selvas, los montes y prados / los ecos se escuchan que aborta mi voz y las plantas, los ríos, las fuentes” (vv. 17-19). Además, el posible trasfondo político de la égloga sería otro guiño al lector avispado sobre el contenido crítico del presente pregón, pues el octavo Duque de Alba (junto al Conde de Peñaranda, el Conde de Ayala y don Pedro de Aragón) aconsejaron la conveniencia de casar a Carlos II (tras cumplir en 1676 su mayoría de edad) con "una Princesa que estuviera ya en edad casadera" (Francisco 638).

${ }^{843}$ Ver nota 556. 
10 que así han parecido a mi injusto* dolor, pues seis días de no ver el cielo son dos mil siglos de condenación. Y, así, en ansias, suspiros, congojas se abrasa el deseo en mi inclinación,

15 pues mi destino es fragua que $\operatorname{arde}^{844}$ a soplos de incendio, que es más superior. En las selvas, los montes y prados, los ecos se escuchan que aborta mi voz; y las plantas, los ríos, las fuentes,

20 si no me consuelan, me dan la razón. En lo oculto de mis pensamientos, tengo un suave apacible fervor, que es muy bueno para imaginado y poseído es mucho mejor.

\section{Otro pregón (126v) \&}

\section{Romance}

En la firme política nuestra ${ }^{845}$, dos leyes guardamos, tan justas las dos como admitir a quien tiene dinero, como admitir a quien paga mejor.

5 Porque es de un galán enfadosa costumbre llegar muy ufano a pedir un favor, sin ver que es más fácil sacar un bolsillo $y$, en vez de un sí quiero, decir un sí doy. Tal vez, encarece ligero de ropa

10 un pobre (pobrete) su amante pasión, sin advertir que se muere de frío, sino es que le vistan desnudo al amor. $\mathrm{Si}$ escudos me ofreces con grato semblante, alegre y contenta palabra le doy

15 de no despreciarle, que son los escudos ${ }^{846}$ segura defensa al desdén y al rigor.

Con esto, aunque diga amantes ternezas, mezclando amoroso uno y otro doblón ${ }^{847}$, advertirá que el sabroso requiebro

20 también tomaré reducido a vellón ${ }^{848}$.

\footnotetext{
844 Ver nota 564.

845 Ver nota 843.

${ }^{846}$ Se trata de un equívoco. En su primera aparición (v.13), puede hacer alusión tanto a la moneda que tiene grabado "el escudo de las armas del rey o príncipe soberano" como a "la tarjeta en que se pintan o esculpen las armas e insignias que tiene cada familia" (Aut.); en su segunda aparición (v. 715), parece indicar amparo o patrocinio.

${ }^{847}$ Moneda de oro de España, que "ha tenido diferentes precios según los tiempos, siendo lo más regular equivaler a cuatro pesos escudos" (Aut.).

${ }^{848}$ Moneda de cobre "Provincial de Castilla, que se llamó así según Covarr. porque los romanos, que usaron de esta moneda, estamparon en ella una oveja” (Aut.).
} 
Y, así, si al contrato no contraviniere

de aquesta que llamo capitulación ${ }^{849}$,

callando las barbas y hablando doblones ${ }^{850}$

darele si gusta una mano y, aun, dos ${ }^{851}$.

\title{
79. A una dama porque quemó un papel (127) \#
}

\section{Décima}

\author{
No quieran tus sinrazones, \\ con venganza tan cruel, \\ porque te quemé un papel ${ }^{852}$, \\ decir tales quemaciones ${ }^{853}$. \\ 5 Antes, será bien que abones \\ parecer tan ajustado ${ }^{854}$, \\ pues advirtió mi cuidado \\ que tu papel ${ }^{855}$, niña ${ }^{856}$ mía, \\ justamente merecía \\ por puto salir quemado ${ }^{857}$.
}

\footnotetext{
${ }^{849}$ Podría ser una referencia a las capitulaciones que se tramitaron para el matrimonio entre Carlos II y la Archiduquesa María Antonia de Austria, su sobrina, que se interrumpieron tras la caída de Fernando Valenzuela. La precoz edad de la hija del Emperador Leopoldo I hizo que el heredero español, a pesar de estar en guerra con Francia, terminara casándose en 1679 con María Luisa de Orleans, sobrina de Luis XIV (Francisco 637-644).

${ }^{850}$ Se trata de una moneda que tiene "por una cara, las armas de Castilla y León y, por la otra, la Cruz de Borgoña, y vale dos escudos de oro" (Aut.). Su alusión parece evidenciar la unión dinástica que se produjo tras el enlace de Carlos II con la sobrina del Delfín. Cabe señalar que el monarca francés quiso inmortalizarla con la creación de unos "escudos" (v. 13). En el anverso, se veía el rostro del rey francés y, en el revés, la Audiencia celebrada el 2 de julio, donde el embajador español solicitaba oficialmente la mano de la Princesa y el Rey acepta tomándola de la mano en presencia de su padre, el Duque de Orleans, bajo el letrero "La Paz preside este matrimonio" (Francisco 641-642).

${ }^{851}$ El deseo de dar dos manos (es decir, de celebrar dos posibles enlaces) pondría de manifiesto tanto la inquietud sobre la capacidad de dar sucesión dinástica de Carlos II como los beneficios de establecer pactos ventajosos para España gracias a matrimonios de conveniencia.

${ }^{852}$ Podría ser una metáfora del coito.

${ }^{853}$ Señala la "razón o palabra picante con que se zahiere o provoca a alguno, para que se sienta y sonroje, o el sentimiento que causan semejantes palabras o acciones" (Aut.).

${ }^{854}$ Se emplea en el sentido de "miserable, mezquino y detenido en gastar" (Aut.). Se relaciona con "abonar" (v. 5).

${ }^{855}$ Parece ser una metáfora del cuerpo.

${ }^{856}$ Ver nota 414.

${ }^{857}$ Evoca el verso "como puto muera yo quemado" del soneto de Quevedo "Puto es el hombre que de putas fía" (Quevedo, Sonetos s.p.). En él, como se hace en la presente décima, se ataca a las mujeres que practican la prostitución.
} 


\section{Tono (127v) \&}

\section{Romance}

Del rumbo de Francelina, hermosa ninfa ${ }^{858}$ del Soto ${ }^{859}$, estoy*, zagalejos míos, enamoradito un poco.

5 Al prado salió y, al punto, se halló el jardín vergonzoso ${ }^{860}$; y fue a morir a sus manos, porque se vio en tanto golfo ${ }^{861}$. Mariposas $^{862}$ en sus rayos ${ }^{863}$

10 se hallan y, en afán forzoso, se enlazan en sus guedejas ${ }^{864}$ para morir a su ojos ${ }^{865}$.

\section{Tono (128) \&}

\section{Romance}

Fuera, fuera que Juanilla sale tan altiva al valle que, hoy, a puntapiés ${ }^{866}$ sujeta

5 toda la región del aire. Tan airosa en sus meneos que la envidian los zagales, unos por bailar con ella y los más porque ella baile ${ }^{867}$.

10 Todo es brío cuanto forja, todo es fuego cuanto esparce, ya no es mucho que sus ojos tan a cada paso maten $^{868}$.

\footnotetext{
${ }^{858}$ Ver nota 75.

${ }^{859}$ Parece aludir a Soto del Real, municipio situado en la cuenca del Manzanares (Madrid).

${ }^{860}$ Metáfora de la vagina.

${ }^{861}$ Se emplea en el sentido de abundancia. Esta representaría el placer sexual, pues "el golfo" (parece ser una metáfora del miembro viril) se halla en el "jardín vergonzoso" (v. 6). Tal interpretación contrastaría con la imagen del "golfo de penas", que aparece con recurrencia en la poesía amorosa aurisecular.

${ }^{862}$ El tópico clásico de la metáfora del enamorado transformado en una mariposa que es atraído por la llama "amada" y que acaba pereciendo por acercarse a ella ha sido estudiado por Alán Trueblood (829-837).

863 Ver nota 555.

${ }^{864}$ Ver nota 125.

${ }^{865}$ Las retinas representan el fuego donde perecen las mariposas (v. 9) "los enamorados". Los ojos también podrían considerarse una metáfora del órgano sexual femenino.

866 A puntapiés: "Desconsideradamente, muy mal o con violencia" (DLE).

${ }^{867}$ Se trata de una dilogía que reforzaría la lectura erótica del pasaje, pues el verbo "bailar" posee tanto el significado de "ejecutar movimientos acompasados" como el de "retozar con gozo" (DLE).

${ }^{868}$ Se recurre al tópico popular de los ojos que matan de amor "Oculus sicarii".
} 


\section{Tono (128v) \&}

\section{Romance}

Los ganados de* Fileno ${ }^{869 *}$, mayoral en Guadarrama ${ }^{870}$, en el ardor del estío nievan toda la montaña ${ }^{871}$.

5 Con el aurora amenaza, $\mathrm{y}$, antes que el sol, se levanta* a saquear de las flores todo el tesoro del alba ${ }^{872}$. En el arroyo veloces*,

10 ya se brindan, ya se bañan pagándoles en vellón lo que bebieron en plata ${ }^{873}$.

\section{Tono (129) \&}

\section{Romance}

Genil*, galán de los ríos $^{874}$, que de la Sierra Nevada baja de cristal en copos*, porque el sol te beba en plata.

5 Si fuiste alcaide algún tiempo de esta soberbia montaña, que compite con el cielo y es* en el cielo donde acaba. Narcisa, reina del día, con tanta punta de nácar

${ }^{869}$ Existe una adaptación musical del padre Bernardo Murillo (1620-1660) que contiene más estrofas que las que aparecen en los manuscritos que atribuyen el poema a fray Damián. No obstante, no se puede determinar si la versión más extensa fue hecha o no por Cornejo, que ha sido editada por Mariano Lambea y Lola Josa (61).

${ }^{870}$ Tras el nombre de Fileno y el cargo de "mayoral” se hallaría el rey Felipe IV.

${ }^{871}$ La imagen del ganado poblando toda la montaña de blanco se halla también las Coplas de Mingo Revulgo. Como sucede en estas, se realiza una alegoría de carácter político entre el mayoral y sus súbditos (Lambea y Josa 61).

${ }^{872}$ Se podría tratar de una crítica tanto de la libertina vida sexual que llevó el Rey Planeta (representada a través de la metáfora de "saquear flores") como al grave problema de sucesión "el aurora amenaza" (v. 5) que su reinado planteó. Deleito y Piñuela en El rey se divierte analiza con profundidad tales cuestiones.

${ }^{873}$ Uno de los mayores problemas económicos que Felipe IV tuvo que afrontar, junto a la ayuda del Condeduque de Olivares, en sus primeros años de reinado fue el de la moneda de vellón. Esta había perdido gran parte su valor en el extranjero, donde se comerciaba principalmente con la plata. Como señalan Mariano Lambea y Lola Josa (61), una de las soluciones que se planteó para poder pagar al ejército de Flandes y los víveres que se comerciaban en Europa fue que los asentistas cobraran sus deudas con vellón, pero "sumándole una prima para equilibrar la diferencia entre el valor de tan paupérrima moneda y el de la plata".

${ }^{874}$ Se trata de un popular romance que también fue glosado, en la segunda mitad del XVII, por Pedro González. Sus décimas "Cisnes que al puro cristal” (Paracuellos 210-213) parten de este para tratar el tema de la Purísima Concepción. 
quiere hacer escaramuzas

por la Vega de Granada.

$\mathrm{El}^{*}$ cristalino maestre

ya está para* coronarla

15 al tope con las estrellas,

las almenas de su alcázar ${ }^{875}$.

\section{Tono (129v) \&}

\section{Romance}

Sonoro arroyuelo, que humor de estos mirtos

(tiorba* de plata)

suspende los ríos,

5 si encuentras a Laura ${ }^{876}$, dirás que me has visto; si muerto a pesares, a esperanzas vivo.

No envidio cristales ${ }^{877}$

10 ni sus desperdicios, que corra tan libre 878 es lo que envidio.

\section{De un estudiante que se fue sin hacer cuenta con la huéspeda (130v) \#}

\section{Coplas de pie quebrado}

Un estudiante este curso

se fue sin dar a su ama

las cuentas, que no es amigo

de dar largas ${ }^{879}$.

5 Desde el camino, la envía

a decir por una carta

que le pagara el alcance,

si le alcanza ${ }^{880}$.

Para la guerra camina,

10 y el viernes de esta semana

espera comer pescado

\footnotetext{
${ }^{875}$ Hace referencia al Alcázar Genil (también llamado “Jardín de la Reina”), un palacio fortificado ubicado cerca de la margen izquierda del río Genil y del lugar en el que el último rey nazarí, Boabdil, entregó las llaves de la ciudad a los Reyes Católicos.

${ }^{876}$ Podría ser una referencia a la dama que protagoniza los versos amorosos de Petrarca.

877 Ver nota 10.

878 Ver nota 553.

${ }^{879}$ Dar largas: "Dilación, retardación" (DLE).

${ }^{880}$ Se establece una paranomasia entre "alcance" (v. 7) y "alcanzar" (v. 8). Además, se conforma una dilogía con dicho verbo, ya que hace referencia tanto a la acción de atrapar a alguien como a la de poseer los recursos necesarios para el fin concretado.
} 
en salsas.

Primeramente, confiesa

que se lleva de su casa

15 la sábana, y por no irse

sin una blanca ${ }^{881}$.

Por si corriere tormenta,

en los manteles escapa,

que es bueno en cualquier naufragio

20 una tabla.

En la taberna, se deja

dos camisas empeñadas ${ }^{882}$,

que se las pueden beber

sin ser delgadas ${ }^{883}$.

25 Porque no esté con cuidado,

a la lavandera encarga

que lo que debe, lo raye

en el agua.

Si el zapatero acudiere

30 por los zapatos de marras, puede venir por los pares

a Francia ${ }^{884}$.

Débense los alquileres

de una silla endemoniada,

35 tan falsa que en todo el curso

sufrió ancas ${ }^{885}$.

Quebrado el espejo ${ }^{886}$ deja, porque su luna ${ }^{887}$ dio en brava, y un día con el acero

40 le hizo cara ${ }^{888}$.

Y pues él no ha de pagar

a los pupilos, que en casa

les da la oveja, les puede

echar las cabras ${ }^{889}$.

Y, en fin, dé gracias a Dios

que para salir de trampas

ha tenido a quien volver

881 Ver nota 334.

${ }^{882}$ Se puede relacionar con la frase "Vender la camisa", que se utiliza para exagerar "el ánimo de hacer el último esfuerzo para conseguir alguna cosa o salir de algún empeño" (Aut.).

${ }^{883}$ Se hiperboliza la cantidad de sudor que habrían acumulado las desgastadas camisas.

${ }^{884}$ Podría tratarse de la Guerra de Holanda (ver nota 252). También parece evocar la derrota de los Doces Pares de Francia a manos de los vascona y de los musulmanes.

${ }^{885}$ El daño en las ancas que le produce la "silla endemoniada" (v. 34) parece ser una metáfora de prácticas eróticas homosexuales. Tal lesión se podría relacionar con la frase "No sufre ancas", que hace referencia a "las bestias que no consienten las monten en aquella parte" (Aut.).

${ }^{886}$ Se trata de una dilogía que hace referencia al vidrio que refleja una imagen y al instrumento quirúrgico que sirve para dilatar la vejiga. Esta última acepción se puede asociar con "sufrió ancas" (v. 36).

${ }^{887}$ Dilogía que señala el vidrio de un espejo y una camisa (v. 22).

${ }^{888}$ Hacer cara: "Desafiarlo, oponerse a él, resistir a su autoridad" (DLE).

${ }^{889}$ Echar las cabras: "Se usa cuando uno, que está culpado, se quiere descargar del crimen que se le imputa, echando a otro la culpa para libertarse, en fuerza de su mentira" (Aut.). Se relaciona con "salir de trampas" (v. 46). 
las espaldas ${ }^{890}$.

86. A una dama que cortándose un callo, por acordarse de su galán. se cortó un pie (131) \#

\section{Quintillas}

De un pie escribir quiero en suma, negándole hoy al recato ${ }^{891}$, porque ninguno presuma que andamos yo, el pie, y mi pluma como tres con un zapato ${ }^{892}$.

Si sopla ${ }^{893}$ el discurso mío, mi musa irá en alta mar, mas si calma en tal desvío, fuerza es que dé un bajío ${ }^{894}$

10 para venir a encallar ${ }^{895}$.

Fenisa, cuando en tu fe tan grandes discursos hallo, en hablar hoy de tu pie a la mano no me irére6, aunque me mires que callo.

Cortando un callo ${ }^{897}$, el amor te causó rigores fieros, tiñiendo a tu pie el candor ${ }^{898}$, aunque en $\tan$ grave dolor tuvo muy buenos aceros ${ }^{899}$.

Un corte en suspensión tanta diste, y el rojo matiz a tu pie la flor quebranta ${ }^{900}$,

\footnotetext{
${ }^{890}$ Dar la espalda a alguien: "Desairarlo, ignorarlo, desatenderlo" (DLE). Esta expresión también se puede asociar con prácticas eróticas (v. 36).

${ }^{891}$ Ver nota 339.

892 Como tres con un zapato: "Manifiesta la miseria de algunos cuando no tienen todo lo que necesitan o están precisados a alternar con otro en el uso inexcusable de alguna cosa" (Sbarbi y Osuna s.p.).

${ }^{893}$ Se trata de una dilogía que hace referencia al acto de mover el aire y a la inspiración creativa.

${ }^{894}$ Dar en un bajio: "Tropezar en un grave inconveniente" (DLE).

895 Dilogía que señala tanto la acción de que una nave se atasque en la arena como el estancamiento de algún negocio o propósito. El calambur que se conforma entre "encallar" y "en callar" ayudaría a resaltar el significado de ambas acepciones.

${ }^{896}$ Irse a la mano: "Reñir, batallar" (DLE).

${ }^{897}$ Se trata de un equívoco. En su primera aparición (v.15), indica la acción de callar (v. 10) y, en su segunda (v. 16) y tercera (v. 24), la dureza que se hace en la piel.

${ }^{898}$ La imagen de un pie blanco sangrando por la herida de un acero se halla también en el soneto que dedica Góngora a la sangría de una dama "Herido el blanco pie del hierro breve" (Góngora s.p.).

899 Ver nota 293.

${ }^{900}$ Se parodia el motivo petrarquista del pie de la dama que a su paso hace brotar las flores. Un ejemplo de ello lo encontramos en el romance "Aquí entre la verde juncia” (Góngora s.p.). En él, Góngora nos dice: "y el mismo monte se agravia / de que tus pies no lo pisen, / por el rastro que dejaban / de rosas y de jazmines (vv. 51-54). Estas últimas flores también manifiestan una estrecha relación con los pies en el presente poema atribuido a fray Damián y a Marchante (v. 47).
} 
$\mathrm{y}$, así, al* callo de tu planta

le arrancastes la* raíz*901.

Por dar el amor tributo, pienso que el cortarte fue, pero como el callo bruto ${ }^{902}$ no era a tu amor de algún fruto,

30 le cortaste por el pie ${ }^{903}$.

A tu amante ese dolor

tu firmeza le asegura, pues del acero al rigor, de pensar en el amor ${ }^{904}$, te cortó la coyuntura.

Cuando al tacto y a los ojos prefirió, acuerdo violento, el acero te dio enojos, pues veloz a sus despojos te cortó en un pensamiento ${ }^{905}$.

Descortés, según se ve, dolor te causó inhumano, turbando tu amante fe, pues el acero en tu pie no se mostró cortesano ${ }^{906}$.

Candor el rigor infiel le dio a tu jazmín nevado $\mathrm{y}$, al ir vertiendo el clavel ${ }^{907}$, se miró como el papel,

50 porque se miró cortado.

Ya de cansada reúsa volar mi pluma, pues ve que, cuando de este asunto usa, grulla parece mi musa, pues tanto se está en un pie.

Hoy, mis discursos apuras y así pretendo acaballos, que son en tantas venturas los más versos herraduras, pues siempre dan en los callos ${ }^{908}$.

901 Cortar la raíz: "Frase que, además del sentido recto, vale atajar y prevenir, desde los principios y del todo, los inconvenientes que pueden resultar de alguna cosa, quitando la causa de adonde provine" (Aut.). ${ }^{902}$ Se trata de una referencia a uno de los senadores que asesinó a Julio César, Cayo Bruto, que era pariente cercano del célebre militar.

903 Cortar por el pie: "En los montes es echar abajo los árboles, cortándolos desde que salen de la tierra" (Aut.).

${ }^{904}$ Ver nota 113.

905 En un pensamiento: "Vale brevísima o prontamente". Debe señalarse, además, que "pensamiento" es otra referencia a una flor (v.47 y v. 48).

906 Se conforma un calambur a partir de "corte sano" y "cortesano".

907 Ver nota 94.

908 Alusión al "callo de herradura", que es el pedazo "ya gastado de ella con el mucho ejercicio, el cual por lo trabajado es bueno para hacer herramientas fuertes y firmes" (Aut.). 


\section{De un doctor a un sacristán (133) \#}

\section{Quintillas}

El sacristán, ¡qué desmán!, el doctor, ¡rara figura! ${ }^{909}$, se agasajan con afán, porque entiende el sacristán

5 que el doctor le ha de hacer cura ${ }^{910}$.

No es muy loco su pretexto, esté bien considerado; juzgo lo que acierta en esto, pues con su ayuda, más presto, se verá beneficiado ${ }^{911}$.

$\mathrm{Su}$ dos condiciones fuertes en todo son adecuadas, pues, por mil diversas suertes, si uno tiene muchas muertes,

15 las tiene el otro dobladas ${ }^{912}$.

En el sacristán se encierra malicia bien conocida, pues antes de echarle tierra ${ }^{913}$, dice, a campana tañida,

20 las curas que el doctor yerra.

El doctor, aunque le ofende, sirve al sacristán por puntos ${ }^{914}$; bien se ve lo que pretende, quiere que a Dios encomiende

25 las almas de sus difuntos.

Conformes los dos están en darse a vida y favor, que son, cuando a ganar van, los tuertos que hace el doctor 30 derechos del sacristán ${ }^{915}$.

Correspondencia cortés siempre entre los dos se estila;

${ }^{909}$ La figura del médico en la literatura aurisecular se suele presentar como la de un ser ignorante, avaro, cruel o pedante (habla una jerigonza latino-española) y que solo recomiendan purgas y sangrías (Maire 1217-1228).

${ }^{910}$ Dilogía que señala tanto la acción de sanar como la de hacerse pastor de Dios.

911 Se trata de una dilogía que indica la recepción de algún beneficio y al "canónigo o prebendado de alguna catedral o colegial" (Aut.).

912 Correas recoge numerosos refranes que muestran la codicia y la mezquindad que el imaginario popular atribuía a los médicos: "Sangrarle y purgarle; si se muriere, enterrarle", "Médico, manceba y criados, son enemigos pagados" o "Médicos errados, papeles mal guardados y mujeres atrevidas, quitan las vidas" (Maire 1218).

913 Ver nota 390,

914 Por puntos: "Se expresa que alguna cosa se espera o teme suceda sin dilación o de un instante a otro" (Aut.).

915 Se podría relacionar con el refrán "A tuerto o a derecho nuestra casa hasta el techo", que reprehende "la ambición y codicia desenfrenada de aquellas personas, que por enriquecer y atesorar bienes de fortuna, cometen maldades y hacen muchas injusticias" (Corr.). 
bien claro se muestra, pues, si luce el sacristán, es

porque el doctor despabila ${ }^{916}$.

\section{A Judas (134) \#\#}

\section{Quintillas}

Por tomar Judas el grado, hoy al vejamen ${ }^{917}$ se asienta; venga todo licenciado, que es la propina de a treinta ${ }^{918}$

5 y anda el dinero rodado ${ }^{919}$.

La codicia que en él cupo no sé por dónde concuerde, si el dinero arrojar supo, cuando se fue a dar un verde ${ }^{920}$

10 con las ramas del saúco ${ }^{921}$.

Dice de este desdichado, quien al vivo hacer le ha visto el papel del ahorcado ${ }^{922}$, que anduvo en besar a Cristo ${ }^{923}$ con grandísimo cuidado.

Daba corde ${ }^{924}$ al infiel apóstol el pueblo todo, como era bermejo él,

\footnotetext{
${ }^{916}$ Dilogía que hace referencia a la acción de asesinar y al acto de ejercitar el entendimiento o ingenio para alcanzar un propósito. Cabe señalar, además, que una vela aumenta su luminosidad (v. 34) si se va cortando el pabilo.

917 Durante las ceremonias de graduación "tomar el grado" (v. 1), se realizaban ejercicios paródicos para amenizar el acto solemne y para mezclar con ingenio veras y burlas. Además, los vejámenes servían como "cura de humildad del que acababa de obtener la máxima distinción académica" (Sanz 164).

918 Judas, poco antes de La Última Cena, acordó entregar a Jesús a los sumos sacerdotes a cambio de treinta monedas de plata, las cuales devolvió arrepentido poco después (Mateo 26, 14-15).

${ }^{919}$ Puede relacionarse con la expresión "Venir rodado", que se utiliza para indicar que "sucede casualmente alguna cosa a propósito de lo que se intentaba o deseaba" (Aut.).

920 Ver nota 319.

${ }^{921}$ El saúco en la tradición cristiana representa la pena y la muerte, ya que este árbol habría sido el que eligió Judas para ahorcarse y el que produjo la madera de la cruz de Cristo.

${ }^{922}$ En algunos festejos de la provincia de Guadalajara, especialmente en la localidad de Mandayona, era común que alguien desempeñara el "papel del ahorcado". El sujeto que lo protagonizaba era apresado y humillado públicamente con el propósito de que el pueblo descargara sobre él todas sus culpas y pecados, convirtiéndose tal evento en un acto de "purificación" colectiva (López de los Mozos 765-780).

${ }^{923}$ Evoca el episodio evangélico del prendimiento de Cristo en el Huerto de Getsemaní (Mateo 26, 47-50), donde Judas delató a Jesús mediante un beso en la mano.

${ }^{924}$ Se podría relacionar con las expresiones "dar trato de cordel" o "dar de cuerda", que representan la acción de dar tormento "atando las manos por detrás al reo o al acusado, y colgándole por ellas de una cuerda, que pasaba por una garrucha, con la cual le levantaban en alto, y después le dejaban caer de golpe, sin que llegase al suelo" (DLE).
} 
y apretáronle de modo,

20 que le ahogó tanto cordel ${ }^{925}$.

Jamás persona se ha visto

tan prevenida, y lo sé

de que cuidadoso y listo,

que antes de morir se fue

25 a cenar con Jesucristo ${ }^{926}$.

Después de haber comulgado,

desesperarse es molestia;

mas, si a pensarlo he llegado,

Judas era mala bestia,

30 pues no le enfrenó el bocado.

Después de cena tan pura

poltrón al descanso llama,

la pierna tender ${ }^{927}$ procura,

y el diablo le hizo la cama ${ }^{928}$,

35 pero fue con colgadura.

Y, así, el diablo le tentó, y atento a música tanta, cuanto sobrecena oyó, por sus pasos de garganta ${ }^{929}$

dicen que se suspendió ${ }^{930}$.

\section{A una dama en la primera noche de tal la hizo cerrada la cama (135) \&}

\section{Redondillas}

Musa mía, con astucia, que me has de soplar barrunto, sin parecerte al asunto, porque no la hagamos sucia.

5 Sepan que novia de garbo, ya que la materia se hurga, obró ${ }^{931}$ lo que con la purga, solo con ver el ruibarbo ${ }^{932}$.

\footnotetext{
925 Tras conocerse la sentencia de Jesús, Judas habría decidido ahorcarse (Mateo 27, 5). Tal acción se anuncia en el poema al atribuirle el "papel del ahorcado" (v. 13) y con la mención del saúco (v. 10).

${ }^{926}$ Se trata de La Última Cena.

927 Se relaciona con la expresión "A pierna tendida", que quiere decir "sin preocupación, tranquilamente" (DLE).

${ }^{928}$ Hacer la cama a alguien: "Trabajar en secreto para perjudicarlo" (DLE). Dicha expresión también se utiliza en el poema dubitado de fray Damián "De Francisco por menor".

${ }^{929}$ Pasos de garganta "Los quiebros de la voz, destreza y facilidad con que alguno canta" (Aut.). Esta expresión también se emplea en la poesía dubitada de Cornejo "Al señor Bautista, el jaque".

930 Se trata de una nueva referencia al ahorcamiento de Judas (v. 20).

${ }^{931}$ Dilogía que señala la ejecución de algo y la acción de defecar (v. 12).

${ }^{932}$ Se trata de una metáfora para representar el miembro viril. Además, esta planta poligonácea se utiliza como purgante (v. 7).
} 
El tal figura de mapas ${ }^{933}$

10 intentó exprimir la uva ${ }^{934}$, pero halló al probar la cuba, al primer tapón, zurrapas ${ }^{935}$.

Hizo una cosa indiscreta ella, sin quererla hacer,

15 pero él la vino a saber con hacerla tan secreta.

La dama es de calidad, mas la riqueza no es mucha, pues en la primera lucha ${ }^{936}$

20 mostró su necesidad.

Tuvo los humos que suele, y pesadumbre le dan, por lo menos no dirán, no es marido ni lo huele.

25 Él tiene resolución, y es el mancebo de arrojo, mas la hizo abrir tanto ojo en la primera ocasión.

Disimulando, severa,

30 diría con gran delirio:

"Bien puede encender el cirio ${ }^{937}$, que no ha de faltarle cera".

Pensativa discurría la confusión de este caso,

35 que, antes de romper el vaso ${ }^{938}$, conoció que se salía.

Es amoroso en sus vicios, y ella dice a sus amores:

"Mucho estimo los favores,

40 pero más quiero servicios ${ }^{939}$ ".

Viendo que de raya pasa ${ }^{940}$, quería reconocerla, pero temía cogerla con las manos en la masa ${ }^{941}$.

Descuidado de la balsa ${ }^{942}$, conquistaba su castillo,

\footnotetext{
933 Se emplea en el sentido de "cosa sobresaliente y bizarra" (Aut.).

934 Metáfora del coito.

935 Al primer tapón, zurrapa: "Dícese de los que en la primera ocasión que se ofrece se descubre su poquedad y flaqueza" (Cov.).

936 Ver nota 282.

937 Ver nota 610.

938 Metáfora que representa la pérdida de la virginidad.

939 Dilogía que señala "el vaso en el que se purga el vientre" (Corr.) y la ejecución de actos sexuales.

940 Pasar de raya: "Propasarse, tocar en los términos de la desatención y descortesía, o exceder en cualquiera línea” (Aut.).

${ }^{941}$ Coger con las manos en la masa: "En el momento de estar haciendo algo" (DLE). En el poema se emplea, además, en el sentido de tocar excrementos.

942 Se trata de una dilogía que señala el agua estancada "purga" (v. 7) y el embarazo.
} 
pero al abrirla portillo ${ }^{943}$,

le enseñaron puerta falsa ${ }^{944}$.

Honrado es por mil caminos,

50 no virgen de quita y pon,

que ella no mostró pichón ${ }^{945}$, pero mostró palominos ${ }^{946}$.

Él se daba a Barrabás ${ }^{947}$, aunque a días que la amaba,

55 y sin duda le pesaba

el conocerla de atrás.

$\mathrm{Al}$ ir con ella, se previno, mas la tuvo por infiel,

pues, habiendo de ir con él,

60 se fue por otro camino ${ }^{948}$.

¡Oh qué poco que le vale

la fuerza con que lo encuentra,

si, por un oído, le entra,

por el otro, se le sale ${ }^{949}$ !

Diría sin duda el tal:

"No se admiren de mi amor,

que aquí a cualquiera, en rigor,

se le pegará el pañal".

Como es en guardar prudente,

70 la diría al requebrar ${ }^{950}$ :

"Bueno es, para no prestar,

tener tan buen despidiente".

En aquel debido estruendo,

no conformes han andado:

75 [a él se le está levantando

y a ella se le está cayendo]*951.

Callo mil vulgares modos, que ya mi vena se aplaca, porque el asunto de caca ha andado en boca de todos ${ }^{952}$.

\footnotetext{
943 Metáfora del coito. Se vincula con "conquistaba su castillo" (v. 46).

944 Puerta falsa: "La que no es la principal de la casa, y suele salir a otra calle excusada, que sirve regularmente para el manejo de los menesteres ordinarios de las casas" (Aut.).

945 Alusión al órgano sexual masculino.

946 Es sinónimo de "zurrapas” (v. 12).

947 Dar a Barrabás: "Expresa el desprecio grande que se hace de una persona o cosa" (Aut.).

${ }^{948}$ Se podría relacionar con la expresión "Ir o echar cada cual por su camino", que se dice de "los que están discordes en los dictámenes, y en los medios, cuando cada uno echa por el que le parece más conforme al juicio que ha formado, apartándose del que el otro propone o sigue" (Aut.).

${ }^{949}$ Entrar, o entrarle, a alguien algo por un oído, y salir, o salirle, por el otro: "No hacer caso ni aprecio de lo que le dicen" $(D L E)$. Esta locución sirve, además, como metáfora de la escatológica escena sexual que se representa la composición (vv. 32-36).

950 Se emplea como metáfora del coito.

${ }^{951}$ Se contrapone la imagen de la erección del protagonista (v. 75) con la falta de control de los esfínteres que posee la esposa.

${ }_{952}$ Andar en boca de todos: "Ser objeto de lo que hable o diga" (DLE).
} 


\section{A un religioso, en un locutorio, le vino una correncia y soltó las bragas y, por ello, le compusieron diversos romances, y él respondió con estas décimas (138) \#}

\section{Décimas}

Pues que su entretenimiento 953

es celebrar estos lances, $\mathrm{y}$ andar haciendo romances a que cagué en su convento,

5 hoy de tanto atrevimiento me vengaré, pues me toca, pues ha sido acción muy loca publicar mi porquería ${ }^{954}$, cuando juzgué que no había

10 de salirles de la boca ${ }^{955}$.

Notable el aprieto fue ${ }^{956}$, solo mi valor lo sabe, mas en soltando la llave ${ }^{957}$, qué descansado quedé.

15 No lo pondero, porque lo dejo a la más prudente y así, en la ocasión presente, consideren con cuidado, cual cagara de pensado,

20 quien caga así de repente.

Señoras, este es un vicio antiguo en mí, no lo niego; que en viendo una monja, luego he menester un servicio ${ }^{958}$

25 De cámaras doy indicio si alguna se me avecina, que, como amor no me inclina, las quiero tan al revés que estar yo con monjas es echarme una melicina ${ }^{959}$.

\footnotetext{
${ }^{953}$ La presente composición es la segunda (de un conjunto de cuatro) en la que se cuenta un escatológico altercado entre un religioso y unas monjas. Tales creaciones, las disputa Cornejo con el padre Juan de Avellaneda y han sido editadas y comentadas por Miguel Marañón (Otro testimonio 71-81).

${ }^{954}$ Hace referencia a las décimas "A fraile tan desatento" (Marañón, Otro testimonio 75), donde las monjas critican con dureza la "sucia" acción que acometió el religioso en su locutorio.

${ }^{955}$ No salir algo de la boca de alguien: "Callarlo" (DLE).

${ }^{956}$ En la edición que realiza Miguel Marañón (Otro testimonio 77), la segunda décima editada aquí se halla tras la tercera. El contenido de ambas hace que sea más coherente dicha disposición que la presentada en los testimonios cotejados: $D$ y $S$.

${ }_{957}$ Metáfora de defecar.

958 Dilogía que hace alusión a la necesidad de acudir al baño como a la de recibir favores sexuales. Lo mismo sucede con "cámaras" (v. 25).

${ }^{959}$ El término "melecina" indica el medicamento que se "echa con jeringa o barquino para desembargar el vientre" (Corr.). Este también podría aludir al goce carnal.
} 
Estoy confuso y corrido* ${ }^{* 960}$ $\mathrm{y}$ aun pienso volverme loco considerando lo poco a que las habrá cabido.

35 Pero la falta que ha habido, fácil remedio tendrá; y, pues digo que la habrá, no hay sino afilar el diente ${ }^{961}$, que he de cagar lindamente

40 si vuelvo otra vez allá.

\section{A una monja que pretendía el que un sujeto prosiguiese en sus malos intentos (139) \&}

\section{Décimas}

Nise, a quererte me inclino, $\mathrm{y}$ hace el rigor inhumano que te quiera yo a lo humano, que te mire a lo divino ${ }^{962}$.

5 Pues, cuando me determino a pretenderte obligar, en llegándote a mirar de manera me arrepiento, que aun en amar no consiento,

10 ¡mira que hiciera en pecar!

Nise, en mis impulsos yo... Siempre me han llevado a mí tras mujer perdida, sí, tras monja profesa, no.

15 Nunca el diablo me tentó para lo que a Dios se iguala, que este fuego ${ }^{963}$ que se exhala más me inclina y me condena que a una religiosa buena,

20 a una pecadora mala.

Si del esposo peor teme el cuerdo y el valiente, ¿qué agravio quieres que intente

\footnotetext{
960 Dilogía que señala tanto el "obrar sin la debida reflexión” como el "acosar y maltratar a alguna persona, para perjudicarla en sus intereses" (Aut.). El adjetivo "corrido" también podría interpretarse como "excitado".

${ }^{961}$ Afilar el diente: Trabajar con interés.

962 Se trata de un planteamiento neoplatónico del amor, basado en un componente espiritual y otro puramente humano. La presencia de este en la poesía aurisecular ha sido analizada por Carlos Mata (640$653)$.

${ }_{963}$ La llama que manifiesta el protagonista es fruto de la pasión sexual y no del amor intelectual "misticismo".
} 
contra el esposo mejor ${ }^{964}$ ?

25 Porque si alguno en rigor

como a hombre puedo engañar,

mientras llegaré a dudar

con recato, amor y modo,

de aquel que lo sabe todo,

30 ¿cómo me podré escapar?

Vive, esposa a Dios rendida, aspira a dichosa palma ${ }^{965}$, pues para salvar el alma, salva primero la vida;

35 que, aunque la juzgues perdida, querrá el cielo poco a poco.

Permita con lo que toco,

porque tu pie estrellas pise ${ }^{966}$

que un pecador te lo avise

40 y te lo predique un loco.

\section{En respuesta de las antecedentes $(140 v) \&$}

\section{Septeto}

Acabose el amistad,

ya no andaréis más conmigo,

que no quiero por amigo

a quien no trata verdad;

5 y pues a tanta lealtad

habéis salido traidor,

no más amistad, amor.

No más amistad con quien

es amigo desleal ${ }^{967}$,

10 que a quien me trata tan mal

no es justo quererle bien;

ligero sois al favor,

no más amistad, amor.

Pesadas burlas tenéis,

15 dejaros será castigo,

\footnotetext{
${ }^{964}$ Es una referencia a Dios, que según las teorías neoplatónicas es el símbolo supremo de la perfección, de la belleza y del conocimiento. Su imagen como "Esposo" fue inmortalizada en los célebres versos del "Cántico Espiritual" de san Juan de la Cruz, que han sido analizados por Guillermo Serés (263-284).

965 Según la creencia mística, el alma "Esposa" para alcanzar el triunfo divino "palma" (v. 32) ha de lograr la unión amorosa con el Esposo "Dios".

${ }^{966}$ La imagen no solo parece remitir al alma alcanzando su ascensión celestial a través del amor intelectual, sino también a un plano más terrenal. En germanía, "estrella" significa Iglesia. El deseo del protagonista es que su amada monja viva entregada a ella.

${ }^{967}$ Los galanes de monjas que aparecen en la poesía del Bajo Barroco suelen quejarse de la actitud desdeñosa de sus amadas. Tales réplicas, cuando son rebatidas, permiten dar voz a estas. Antonio de Solís (163) escribe una redondillas en las que una novicia responde con habilidad a las críticas de su pretendiente: "Si maldecís nuestro amor, / por qué en él buscáis, en vano, / lo que halláis en el mundano. / Habláis como pecador" (vv. 8-12).
} 
pues anochecéis conmigo

y con otra amanecéis;

si os quiero, no me queréis,

si os dejo, me irá mejor.

No más amistad, amor.

Lisonjero, amor, entráis

$\mathrm{y}$, después, mudo os fingís ${ }^{968}$.

Desnudo a casa venís;

y en viéndoos vestido, os vais.

25 Si os tratan mal, os estáis, si os regalan, sois traidor.

No más amistad, amor.

\section{Traslado de una carta que un colegial (hallándose cura de cierto lugar) escribió a los de su colegio de Alcalá, dándoles cuenta de lo que le sucedía en el curata, como lo había ofrecido cuando salió de él (141v) \&}

\section{Redondillas}

Reyes míos ${ }^{969}$, desde el día que vine de voluntad a purgar en soledad achaques de compañía,

no puedo escribir en suma, y más asunto de galas, que me cortaron las alas ${ }^{970}$ y no me dejan con pluma ${ }^{971}$.

Mi musa se desespera,

10 viéndome a Dios y a ventura ${ }^{972}$, pues, por venirme locura, ya no viene a ser lo que era ${ }^{973}$.

Gocen de su tierna flor, no malogren lo bizarro,

15 porque se mete a zamarro el que se mete a pastor ${ }^{974}$.

Gente que polaina frisa da mucho en que merecer,

\footnotetext{
${ }^{968}$ La protagonista critica la "ley del silencio" que imponía el amor cortés (ver nota 550).

969 Parece hacer referencia al "Rey de banda", que es "el perdigón que guía a los demás perdigoncillos" (Aut.). En el poema este se representa a través del joven cura, quien es el encargado de informar a los estudiantes de cómo es la vida de religioso fuera del Colegio de Alcalá.

970 Cortar las alas: "Quitar el ánimo o aliento" (DLE).

971 Se podría relacionar con la expresión "Cortar la pluma". Se toma metafóricamente "por escribir con elegancia y primor alguna obra, libro o asunto, probando e ilustrando el argumento con razones y discursos legítimos y oportunos, y usando de términos y voces propias, puras y expresivas" (Aut.).

${ }^{972}$ A Dios y a ventura: "Inciertamente, sin esperanza ni seguridad de feliz éxito en lo que se emprende" (Aut.).

973 Se trata de un calambur: "lo que era" y "loquera". Este se vincula al creado en el verso anterior "lo cura" y "locura", que juega con la profesión de religioso del yo poético y la alteración de las facultades mentales que dicho oficio le ha comportado.

${ }^{974}$ Dilogía que señala tanto el que guía a los fieles como el del ganado.
} 
y es cosa de llanto el ver

que todo es cosa de risa.

Nuestra fruta en sus ardores ${ }^{975}$

no es tan mala cuando encarna,

que yo quisiera la sarna

mejor que los aradores ${ }^{976}$.

Veome en corto retrete,

con paciencia en mis verdores,

a prueba de labradores,

como a prueba de mosquete ${ }^{977}$.

Va de cuentos señalados,

30 viéndose una desmayar,

llamó luego a confesar

por malo de sus pecados.

Yo, que la prisa me ataja,

llega, y me dice un compadre:

35 "Este mal causa la madre,

que se me sube y se baja*".

Cuando vi bostezos de uvas,

la dije por cosa llana:

"Esta no es mi parroquiana,

que lo es del cura de Cubas ${ }^{978}$.

Médicos llama la zaina ${ }^{979}$,

sin advertir que lo yerra,

pues no vienen a esta tierra

los médicos de Lovaina ${ }^{980}$.

45 Luego que la vi la faz,

la consolé de esta suerte:

si es que te lleva la muerte,

no te llevará en agraz ${ }^{981}$.

Con grande humildad, al fin,

50 a todo santo llamaba,

aunque su afecto mostraba

de ordinario a san Martín ${ }^{982}$.

${ }^{975}$ Se podría interpretar como el deseo carnal. Este se relacionaría con el acto de "gozar la flor" y de no "desperdiciar" lo bizarro (vv. 13-14).

${ }^{976}$ El yo poético prefiere los deseos que producen deleites "sarna" (v. 23) que los parásitos que originan la enfermedad de la sarna "aradores".

${ }^{977}$ A prueba de mosquete: "De las armas fuertes; trasladado a otras cosas hechas firmes y de fuerza" (Aut.).

${ }^{978}$ Cubas de la Sagra es un municipio de Madrid, situado en la comarca natural de la Sagra. Con el término "cubas" también se alude a la borrachera "bostezo de uvas" (v. 37).

${ }^{979}$ Dilogía que señala la bolsa del dinero y la persona traidora y poco cautelosa en el trato.

${ }^{980}$ Lovaina (Leuven) es una ciudad situada al este de Bruselas, donde estudió el polémico y popular médico Johannes Baptista van Helmont (1578-1644). El hecho de que padeciera sarna (v.23), que tuviera formación jesuita y capuchina y que decidiera curar gratuitamente a los enfermos (v. 41) parecen relacionarlo con el contenido del poema. Resulta relevante señalar, además, que sus teorías sobre la ineficacia de las reliquias sagradas para sanar le llevaron a prisión y que su transgresora obra, Ortos medicinae (1648), tuvo una gran impacto en el Bajo Barroco.

${ }^{981}$ En agraz: "Explica que una cosa se ha perdido o malogrado fuera de sazón y tiempo. Y también se dice de las cosas que están muy a los principios y sin haber entrado en la sazón que se pretende" (Aut.).

${ }^{982}$ Se vincula con la expresión "llegarle a uno su san Martín", que "da entender que al que vive en placeres le llega el día en que tenga que sufrir o padecer" $(D L E)$. 
Entre toda camarada a aliviarla en su fatiga, que la tiene por amiga, aunque no por paniaguada ${ }^{983}$.

Por un susto que la arroba, con una fuerza inhumana agarraba mi sotana,

60 por conocer que era loba ${ }^{984}$.

Echó espumajos ${ }^{985}$ gran suma, y advertí por buen consejo: "Muy lleno está este pellejo ${ }^{986}$, pues hace en la boca espuma", dijo una vieja fruncida, también de Baco pelota ${ }^{987}$; por ser de imagen devota ${ }^{988}$, yo tomara una medida ${ }^{989}$.

A la hipócrita en lo añejo

70 repitió con gran mesura: "Mi Dios, yo fuera más pura, si estuviera en su pellejo ${ }^{990 "}$ ".

Una viuda muy sencilla la he de echar, por los* $\operatorname{ramos}^{991}$,

75 porque si la destapamos, se irá como una canilla ${ }^{992}$.

Quise absolverla del caso y yo la di por disculpa: "He de absolver una culpa, que hace caer a cada paso ${ }^{993}$ ".

Su esposo pensó rabiar,

\footnotetext{
${ }^{983}$ La "paniguada" es una persona que es favorecida por otra. Por el contenido del poema, parece aludir a una meretriz. Esta interpretación se vería reforzada por la fuerte connotación sexual del vocablo "pan" en los Siglos de Oro, que se utilizaba como metáfora de los genitales masculinos y femeninos.

${ }^{984}$ Dilogía que remite a un tipo de vestimenta que utilizan los eclesiásticos y estudiantes y a una prostituta.

${ }^{985}$ Echar alguien espumarajos por la boca: "Estar muy descompuesto y colérico" (DLE).

${ }^{986}$ Dilogía que hace referencia a un borracho y al cuero que se utiliza para guardar líquidos (vino, vinagre, aceite). Se podría relacionar también con la piel de algunas frutas (v. 21) o del animal "loba" (v. 60) y con la expresión "No caber en el pellejo", que "vale estar muy gordo" (Corr.).

${ }^{987}$ La metáfora de la pelota representa a una mujer que se dedica a la prostitución y, posiblemente, con sobrepeso. Su imagen libertina se potencia al asociarse al dios Dionisio, conocido por su vinculación al mundo del festejo y de la lujuria. Cabe recordar que se mostraba vestido con piel de zorro (v. 63) para evocar la viña y la fauna.

988 Ver nota 201.

989 Tomar a alguno las medidas. "Hacer entero juicio de lo que es un sujeto" (Aut.). También podría asociarse con la expresión "Tomar sus medidas", que significa "premeditar y tantear alguna dependencia o negociado, para lograr el mayor acierto, y que no se malogre" (Aut.).

990 Si yo estuviera o me hallara en su pellejo: "Frase con que se da a entender lo que alguno ejecutara o hiciera en el lance que a otro le sucede, si se hallara en su lugar, como aconsejando lo que debía hacer" (Aut.).

${ }^{991}$ Ver nota 185.

992 Irse como una canilla: "Padecer excesivo flujo de vientre" (DLE).

${ }^{993}$ Se podría vincular al mal de vientre (v. 76) y a la actitud lasciva.
} 
juzgando era flor del berro ${ }^{994}$,

mas como se vio hecha un perro ${ }^{995}$,

le empezaron a ladrar.

La zurrara la badana ${ }^{996}$

a no temer que el barbero,

si él la rompía el cuero,

no sabría echar botana ${ }^{997}$.

\section{Soneto (144) \&}

\section{Soneto}

Esta mañana, en Dios y en hora buena ${ }^{998}$,

salí de casa y vineme al mercado.

Vi un ojo negro, al parecer rasgado ${ }^{999}$,

blanca la frente y rubia la melena ${ }^{1000}$.

$5 \quad$ Llegué y le dije: "Gloria de mi pena ${ }^{1001}$

muerto me tiene vivo tu cuidado.

Vuélveme el alma, pues me la has robado

con ese encanto de áspid o sirena".

Pasó, pasé; miró, miré; vio, vila

10 Dio muestras de querer. Hice otro tanto.

Guiñó, guiñé; tosió, tosí; seguíla.

Fuese a su casa, y sin quitarse el manto, alzó, llegué, toqué, besé, cubrila, dejé el dinero ${ }^{1002}$ y fuime como un santo ${ }^{1003}$.

\footnotetext{
${ }^{994}$ La flor del berro es una de las más apreciadas por el ganado debido a su sabor. Esta da lugar a la expresión "Andarse a la flor del berro", que significa que alguien "no cuida de más que sus gustos" (Corr). Es decir, que se entrega a los vicios y a la vida fácil.

${ }_{995}$ Se puede asociar con la expresión "como un perro", que señala la acción de tratar mal (Corr.).

${ }^{996}$ Zurrar la badana: "Vale lo mismo que tratar a uno mal de palabra o de obra, y de ordinario se entiende por aporrearle" (Aut.). Se asocia con "hecha un perro" (v. 83).

${ }^{997}$ Se emplea la metáfora de tapar con un pequeño tarugo las cubas (para que no se salga el vino) con el objetivo de manifestar la incapacidad del barbero (antiguamente el encargado de hacer curas o cirugías menores en los pueblos) de sanar las heridas que sufriría la mujer por parte del marido.

${ }^{998}$ En Dios y en hora buena: "Juramento más usado de mujeres" (Corr.).

${ }^{999}$ El manuscrito $Q$ (f. 155) contiene la variante tapado (v. 3). Este adjetivo hace más explícita la alusión a las tapadas, que eran prostitutas que recurrían a la estrategia de cubrirse la mitad del rostro para hacerse pasar por damas y para incrementar el interés masculino (Deleito y Piñuela, La mujer 64).

${ }^{1000}$ Se combinan rasgos del ideal femenino renacentista "blanca la frente y rubia la melena" con los ojos negros (propios de las mujeres árabes o sureñas) con el propósito de crear el esbozo de una mujer de apariencia llamativa y singular. Su atractivo y misterio se acrecienta cuando se compara su "encanto" con el del áspid o el de las sirenas (v. 7).

${ }^{1001} \mathrm{El}$ tono solemne y el lenguaje grandilocuente con el que el hombre se dirige a la meretriz, en el segundo cuarteto, recalcan la burla que realiza el autor palentino del "amor cortés" en el presente soneto (Díez Fernández, La poesía 222). Esta se acrecienta en los tercetos tras mostrar la rapidez con la que ella accede a los deseos del yo poético:

${ }^{1002} \mathrm{El}$ dinero entregado a una prostituta en los Siglos de Oro tenía una función purgativa. Se creía que, si se cobraban sus servicios, no se cometía delito ni pecado (Cantizano 29).

${ }^{1003}$ Se podría relacionar con dos dichos populares. Por un lado, "Ser un santo", que significa ser una persona muy virtuosa (Sbarbi y Osuna s.p.). Por otro, "Es un santo", que se utiliza "cuando las mujeres abonan a quien quieren" (Corr.).
} 


\section{Otro (144v) \&}

\section{Soneto}

Lo menos bello y más apetecido ${ }^{1004}$, lo más oculto y menos ignorado, aquello a que el deseo aspira, osado, e invencible es gozándolo al sentido.

Aquel coral ${ }^{1005}$, aquel rubí partido, aquel no sé qué1006 hermoso imaginado, aquello que a la fuerza ha contrastado a sangre rompe el gusto más rendido.

Por lo que muere el hombre y nace el hombre ${ }^{1007}$,

10 lo que trueca las ansias en placeres, por quien pierde la fama su renombre, imitando a la luna (si lo infieres) tiene meses y días, sin que asombre: el paréntesis es de las mujeres ${ }^{1008}$.

\section{A un borracho que salió de una taberna, cayó un jarro lleno de vino de una ventana y le mató (145) \&}

\section{Romance}

De una taberna salía

Toribio desatinado

y, en la tentación del vino, tropezaba a cada paso.

5 Meciéndose parecía que pollos iba atajando, aunque para meter pies ${ }^{1009}$ no había mester atajo. Cuando un cangilón de vino,

${ }^{1004}$ Se trata de una versión del soneto atribuido a Quevedo "Lo más solicitado y más horrendo" (Quevedo, Juguetes 190-91). En ambos, se intenta confeccionar un ingenioso enigma sobre el órgano sexual femenino, como también hizo Jerónimo de Barrionuevo en el romance "Al riqui fue de la dama". Este se irá desvelando, poco a poco, a través del neutro "lo", los deícticos y las dicotomías., hasta llegar a la sugerente imagen del verso final (Díez Fernández, Poesía 223-224).

1005 Quevedo inicia el segundo cuarteto con "Coral partido, como flor del almendro" para potenciar el contraste cromático y para evocar la popular y erótica imagen de la flor que se abre para dar su fruto. Cornejo opta, por el contrario, por incrementar la presencia del color rojo mediante el rubí y, más tarde, por medio de la sangre (v. 8) con el propósito de resaltar su fuerza expresiva y mantener el misterio.

1006 Se trata de una alusión al místico verso de san Juan de la Cruz "un no sé qué que quedan balbuciendo" (v. 35) del "Cántico Espiritual", donde el alma confiesa sus más profundos sentimientos al Esposo tras haber vivido con él un encuentro íntimo (Santo s.p.).

1007 El autor de El Buscón abre el primer terceto con una dicotomía (con tintes de amor idealista) muy similar a la empleada por fray Damián: "Por donde el hombre nace y por quien muere".

${ }^{1008}$ La resolución del acertijo en los sonetos de Cornejo y de Quevedo, aunque ambos se centran en la metáfora del paréntesis, difieren significativamente. El poeta palentino pone su foco en la figura de la mujer, mientras que el escritor madrileño lo hace en la del varón: "Que paréntesis es que cierra el hombre".

${ }^{1009}$ Meter pies: Echar a correr. 
10 que cayó desde lo alto

de su llena calabaza ${ }^{1010}$,

le rompió todos los cascos ${ }^{1011}$.

Mucho se afligió Toribio

de ver en tan triste caso,

15 lo mismo porque moría,

esto le estaba matando.

Rodarte hizo el cangilón,

mas de aquesto no me espanto,

que siempre los cangilones

20 a él lo trajeron rodando.

Cayó en el barro el pobrete

y miró que, en tal fracaso,

con la pez del cangilón ${ }^{1012}$

se le había pegado el barro.

25 Los ojos le derribó

a fuer de cierzo ${ }^{1013}$ al borracho,

pero, cuando a los sarmientos

el cierzo no ha deshojado,

estrágole con el golpe

30 y díjole lastimado:

"Como mudas la costumbre,

me mata a mí lo que es trago ${ }^{1014}$.

El vino golpe me saca

de otro* vino y, aunque hallados

35 los dos siempre en mí estuvieron,

aquesta vez se encontraron.

Muy grande bien me hizo el vino,

pues, al pegarme en los cascos,

lavando en la herida fue

40 un beneficio curado ${ }^{1015}$.

De las veces que en las calles

por borracho me afrentaron,

dándome aqueste en las sienes,

ahora, me ha desafrentado ${ }^{1016}$,

${ }^{1010}$ Dilogía que se señala una forma tosca de llamar la cabeza y la botija (hecha de calabaza seca) que se utiliza para llevar el vino (Aut.).

${ }^{1011}$ Se puede relacionar con la expresión "Cascos de calabaza", que son "los pedazos de calabaza que se ponen en las heridas de la cabeza, que por ser preciso cortar algún pedazo del casco natural, se suple con el de la calabaza. Y porque la cabeza queda débil y flaca, metafóricamente llaman cascos de calabaza a los que tienen poco juicio y asiento" (Aut.).

${ }^{1012}$ Equívoco que, en su primera aparición (v. 17), sirve como metáfora de la cabeza y, en las siguientes (vv. 19, 23 y 44), señala los recipientes en los que se lleva el vino.

${ }^{1013}$ Correas recoge dos refranes relacionados con el cierzo que podrían vincularse al contenido del poema: "El aire cierzo, sana los sanos y mata los enfermos" y "Cierzo y mal señor, destruyen a Aragón". Este último se vincula, principalmente, a los destrozos que causa dicho viento en los sarmientos (v. 27) de la zona.

${ }^{1014}$ Se establece un calambur entre "estrágole" (v. 29) y "es trago".

${ }^{1015}$ Desde la época romana, el vino se ha utilizado (por su contenido de alcohol) para desinfectar las heridas.

${ }^{1016}$ Se juega con la etimología de la palabra afrentar (v. 42) para señalar la herida que el protagonista tiene en la cabeza. Según Covarrubias, este verbo viene de "cuasi en la frente", porque "de la vergüenza que toma el afrentado le salen colores al rostro y, particularmente, a la frente" (Aut.). 
que, como yo el cangilón

tuve por aficionado,

como vio tan solo un vino,

hizo en mi cabeza tantos

\section{Pinta a un tudesco borracho (146v) \#\#}

\section{Redondillas}

Un tudesco ${ }^{1017}$, humana cuba ${ }^{1018}$.

mi musa quiere copiar,

y pues le empieza a pintar

alón, que pinta la uva ${ }^{1019}$.

5 La frente, que con ajobo

espanto causa a la gente,

si alguno mira su frente,

ve las orejas al lobo ${ }^{1020}$.

Como es de Baco vasallo

10 y no hay vino que no emboque,

el un ojo tiene aloque

$\mathrm{y}$ el otro es ojo de gallo ${ }^{1021}$.

Es la nariz embarazo,

donde se sube, sin traza,

15 pocas veces la mostaza ${ }^{1022}$, pero mucha el mostazo.

En el pescuezo y carrillos, granos $^{1023}$ tiene a Barrabás, porque fuera lo demás

20 pedir uvas sin granillos.

Sus manos son muy vulgares y tiene, ahorrando de cuentos, en sus manos diez sarmientos con yemas y con pulgares.

25 La pierna que no adelgaza de pantorrilla le abona, que en todo tiempo a la mona ${ }^{1024}$ no puede faltarle maza ${ }^{1025}$.

1017 Señala a alguien de origen alemán.

1018 Ver nota 182.

1019 Alón, que pinta la uva: "Dícese por los mozos que no quieren servir y dejan el amo en el verano, que hay fruta y que comer en el campo, y no frío" (Aut.).

${ }^{1020}$ Haber visto las orejas al lobo: "Quiere decir ver el peligro y estar cercado de él, y llegar a verse en necesidad, con lo cual se hacen los hombres más cautos para mirar por sí adelante" (Corr.).

1021 Ojo de gallo: "Color que tienen algunos vinos, parecido al ojo del gallo" (DLE). Esta forma se relaciona con "aloque" (v. 11), que es una especie de vino, "cuyo color es rojo subido, que se inclina al tinto" (Aut.). 1022 Se relaciona con el dicho "Subirse la mostaza a las narices", que significa "amostazarse" (Aut.).

${ }^{1023}$ Dilogía que señala tanto la semilla de la uva como una protuberancia que sale en el cuerpo.

1024 Ver nota 193.

1025 Se asocia con la expresión "La maza y la mona", que se "llaman regularmente las personas que andan siempre juntas" (Aut.). 
Sus pies andan en tragedias

$30 \mathrm{y}$, sin darle pesadumbre, caben al pie de una azumbre, porque se meten dos medias ${ }^{1026}$.

$\mathrm{Y}$, en efecto, el que bebiendo solicita retratalle

35 no tiene que ir a rogalle, porque él se vendrá cayendo.

\section{A un novicio que profesó en San Diego de Alcalá (147v) \#\#}

\section{Romance}

Oiga, hermano fray Francisco, pues se viene con tal gracia $^{1027}$

a nuestra casa ${ }^{1028}$, dejando buena hacienda ${ }^{1029}$ hecha en su casa.

5 De las riquezas que deja hacen relaciones varias mucha gente, pero a mí me lo contaron en plata ${ }^{1030}$. Su sangre, quien no la sabe

10 de sus hermanos las capas mire, que con eso solo queda bien encomendada. A San Diego de Alcalá ${ }^{1031}$ viene a hacer su vida santa, 15 cuando pudiera en Toledo, tenerla canonizada.

Del siglo ${ }^{1032}$ se aleja, en fin, y en la religión se enlaza, que allí los juros le ofenden

20 y aquí los votos le agradan. Mas, pues hoy tan exprofeso de ser religioso trata, escuche un consejo de Orden,

${ }^{1026}$ Dilogía que señala tanto la vestidura de la pierna como la medida que equivale a media fanega $(27,75$ litros). Esta última acepción, se relacionaría con la medida de azumbre (v. 31), que equivale a la octava parte de una arroba (2 litros).

${ }^{1027}$ El carácter jocoso y atrevido del poema hacer pensar que el término "gracia" se emplea con el sentido de "gallardía, donaire y despejo en la ejecución de alguna cosa" (Aut.).

${ }^{1028}$ Se trata del desaparecido monasterio franciscano (1453-1835) de Santa María de Jesús o de San Diego, que estaba situado en el centro de la zona amurallada de Alcalá de Henares.

${ }^{1029}$ Buena hacienda: "Se dice cuando alguno hace algún yerro o disparate, de que le pueda resultar perjuicio o daño" (Aut.). Esta expresión en el poema también puede relacionarse con las riquezas materiales que el protagonista deja atrás al ingresar como novicio.

${ }^{1030}$ En plata: "Claramente, sin rodeos ni circunloquios" (Aut.).

${ }^{1031}$ El antiguo monasterio de Santa María de Jesús fue rebautizado con el nombre de uno de sus más célebres frailes, san Diego de Alcalá. Este cambio se produjo tras su canonización en 1588.

1032 Significa "el comercio y trato de los hombres en cuanto toca y mira a vida común política: y así decimos que el que se entra religioso, o se va desengañado a un desierto, huye o deja el siglo" (Aut.). 
pues el de hacienda le enfada.

25 En esta vida, que elige,

tendrá dos muy santas:

a mediodía, su como

$\mathrm{y}$, a medianoche, matraca ${ }^{1033}$.

Sedas, y adornos, arredro,

30 porque aquí para hacer gala, una jerga basta, y sobra, una jerga sobra, y basta.

A la inclemencia del tiempo,

el pie y la pierna descalza

35 ha de traer, que el demonio

suele entrar por la calzada ${ }^{1034}$.

Renuncie [a] los oros ${ }^{1035}$ siempre,

porque Luzbel no haga baza ${ }^{1036}$,

y hágase hombre de caudal ${ }^{1037}$

40 solo con no tener blanca ${ }^{1038}$.

Nunca ha de andar a caballo,

porque aquí las jinetadas

no valen, que en esta Orden

quien monta, no monta nada ${ }^{1039}$.

45 No torciendo la cabeza ${ }^{1040}$,

puede ser santo de chapa ${ }^{1041}$,

que no todas las torcidas

en fuego de Dios se abrasan.

Pero dejo los consejos,

50 y a esta casa dé las gracias,

porque le da puerta rica

a quien le da puerta franca ${ }^{1042}$.

A su costa, la cocina,

del enfermero empleada,

1033 Tanto "como" (v. 27) como "matraca" hacen referencia a instrumentos ruidosos que se emplean para alertar a alguien o para hacerle burla o chasco.

${ }^{1034}$ La representación en el imaginario cristiano del demonio como una serpiente que está al acecho hace que los pies se conviertan en la parte más vulnerable para recibir sus ataques.

${ }^{1035}$ Dilogía que hace referencia al palo de los oros de los naipes (relacionado con asuntos divinos) y al dinero.

${ }^{1036}$ Hacer baza: Esta expresión que tiene su origen en el juego de naipes se emplea con el sentido de evitar que el demonio se salga con la suya.

${ }^{1037}$ Se emplea en el sentido de "juicio y entendimiento, adornado y enriquecido de sabiduría" (Aut.). Cabe señalar que también se ironiza con la acepción de poseer bienes y hacienda "blanca" (v. 40).

${ }^{1038}$ No tener blanca: Expresión para indicar que no se tiene dinero. Proviene de "blanca", que era una moneda de vellón (Aut.).

${ }^{1039}$ Equívoco que, en su primera aparición. se usa cómo sinónimo de "alardear" y, en su segunda, parece aludir a prácticas eróticas "andar a caballo" (v. 41), ya que en germanía "monte" se utilizaba como sinónimo de "mancebía" (Aut.). Cabe señalar, además, que podría ser una nueva referencia a los naipes (vv. 39-40), pues en la época era popular apostar en el "juego de monte".

${ }^{1040}$ Torcer la cabeza: Aunque esta expresión significa lo mismo que "enfermar" (Aut.), en el poema cobra el sentido de desviarse o apartarse del camino recto de la virtud y de la razón.

${ }^{1041}$ En estilo jocoso, "chapa" se emplea para señalar que alguien es una "persona de prendas, valor, juicio y prudencia” (Aut.).

${ }_{1042}$ Puerta franca: "Entrada o salida libre que se concede a todos" (DLE). En el poema parece hacer referencia a prácticas sexuales. Estas se camuflarían mediante la metáfora de "puerta rica" (v. 31). 
pregona que son dos pobres calenturas las tercianas. Aquí las enfermedades, ya se pía, y no se aclama, que han de salir todas ya

60 hueras a puro empolladas ${ }^{1043}$. Vivid con esto contento, vida feliz, y tan larga, que haga, a pesar de los tiempos, más de mil sayales rajas ${ }^{1044}$.

65

\section{Vejamen a san Diego (149v) \#\#}

\section{Quintillas}

Un devoto singular soy suyo, señor san Diego, mas hoy me ha de perdonar, porque a fe que ha de llevar 5 esta vez palo de ciego ${ }^{1045}$.

A quién no parece mal ver con tantos aparatos a un hombre tan trivial, que por no tener un real

10 no se calza unos zapatos ${ }^{1046}$

De contentarse no acaba con tanta magnificencia, y cuando en el mundo estaba sé yo que se contentaba

15 con solo una reverencia.

Dicen no toma dinero, mas debe de ser pandilla, que yo sé que es tan maulero que, con decir no lo quiero, se lo ha echado en su capilla ${ }^{1047}$.

De unas uvas, que regaba, que dan sin granillo el mosto,

\footnotetext{
${ }^{1043}$ El poeta juega con términos relacionados con las aves "piar" (v. 58), "aclamar" (v. 58) y "empollar" (v. 60) para resaltar cómicamente las precarias condiciones en las viven los novicios, pues ni siquiera pueden quejarse de una enfermedad o tratarla cómo es debido.

${ }^{1044}$ La acción de "rajar las sayas" parece admitir dos lecturas no excluyentes. Por un lado, podría señalar las rasgaduras que se producen en las telas humildes (como las que conforman el hábito franciscano) tras llevarlas durante mucho tiempo y someterlas a laboriosas tareas. Por otro, podría indicar la realización de prácticas sodomitas (vv. 44 y 51 ).

${ }^{1045}$ Ver nota 328.

${ }^{1046}$ San Diego pertenecía a la Orden de los Frailes Menores de la Observancia, la cual tenía entre sus votos el de pobreza.

1047 Ver nota 546.
} 
a muchos devotos daba ${ }^{1048}$, y de ellas grano sacaba

para hacer muy bien su agosto ${ }^{1049}$.

Dicen que es santo, y yo dudo

en qué su virtud se encierra,

cuando reparo (aunque rudo)

que por sus cosas no pudo

30 sufrirle muerto la tierra ${ }^{1050}$.

Y aún el pueblo maulero*, viendo que de sus moradas

le arrojó la tierra entero,

todos, a ruin el postrero ${ }^{1051}$,

35 le hicieron dos mil tajadas ${ }^{1052}$.

Y quien no pudo alcanzar

tajada, por su consuelo,

le trató de repelar,

siquiera para llevar,

40 como del lobo, algún pelo.

No es grande ponderación

esta con que ahora hablo,

si miran con atención

que tuvo una condición,

que no le sufriera un diablo.

Quizá algún impertinente

me dirá sin embarazos

que le quieren tiernamente,

pues anda toda la gente

muriendo por sus pedazos.

Pero yo he de refutar esos discursos traviesos, con que la gente seglar, pues se los quieren quebrar, no está muy bien con sus huesos.

Diranme que se enamora

la gente, bien podrá ser, mas no me dirán ahora, cómo, si tanto le adora,

60 ninguno le puede ver.

Y si el caso está ufano, porque la corte postrada

\footnotetext{
${ }^{1048}$ El célebre fraile franciscano plantó en la huerta del convento Santa María de Jesús (Alcalá) una hermosa parra, que durante varios siglos dio codiciadas uvas por "lo milagroso de su virtud medicinal" (González de Torres, Crónica 6: 355).

${ }^{1049}$ Hacer su agosto: "Frase muy usada, que demás del sentido literal vale lograr alguna ocasión de utilidad considerable" (Aut.). Esta se relaciona, además, con el milagro de la vid de san Diego, pues en agosto es cuando se hace la vendimia en España.

${ }^{1050}$ Las circunstancias que llevaron a desenterrar al san Diego tras su fallecimiento (1453) y las milagrosas consecuencias que esto tuvo para sus innumerables fieles son contadas con detalle por Eusebio González de Torres (Crónica 6: 394-399).

${ }^{1051}$ A ruin el postrero: "Hasta la última persona (el más humilde)" (Cornejo, Das lyrische 152).

1052 Ver nota 542.
} 
le visita ${ }^{1053}$, sepa, hermano, que quien le besa la mano se la quiere ver cortada ${ }^{1054}$.

Solo el sacristán ha sido el que por él se desvela, porque, en viendo que han crecido las barbas por él perdido,

70 le quiere que se las pela ${ }^{1055}$.

Y si la tijera empuña, tiene maña tan bizarra que, cortándole una uña, hecho con ella garduña ${ }^{1056}$, anda por Madrid a garra ${ }^{1057}$.

Pero yo, aunque esté enojado, su santo favor invoco, que, aunque sé que no es letrado ${ }^{1058}$, hoy para ser abogado

80 no es falta saber muy poco.

1053 Ver nota 547.

${ }^{1054}$ Se puede relacionar con la expresión "Manos besa el hombre que querría ver cortadas", que significa que una persona "contra su dictamen y gusto hace reverencia al que le es contrario, precisado o del respeto, o de otro motivo que le obliga a disimular y sufrir" (Aut.).

${ }^{1055}$ A lo largo del poema el autor emplea varios vocablos relacionados con el campo semántico del cabello (barbas, repelar, pelar y pelo) para exponer la enorme devoción que suscitaban los restos del santo por su fama de sanadores. La forma "querer que se las pela" también es utilizada por Cornejo en "Un ciego soy desgraciado".

${ }^{1056}$ Dilogía que señala el carácter ratero del sacristán que cuida los restos del santo y la reliquia que conforma a partir de las uñas que hurta. Resulta relevante señalar que el término "garduña" parece provenir de "echar la garra y la uña" (Cov.). Este también es utilizado en las quintillas atribuidas a fray Cornejo "Un ciego soy desgraciado".

${ }^{1057}$ La acción de "andar a garra" (ver nota 17) se relacionaría con "garduña” (v. 74) y remarcaría la voluntad del sacristán de obtener los máximos beneficios de su hurto. Fray Damián emplea esta forma en poemas como "El agosto de un fraile" y "Sueño jocoso".

${ }^{1058}$ San Diego fue un hermano lego y, por tanto, no poseía una formación elevada. Su oficio solo le permitía encargarse de las labores manuales y de los asuntos seculares del convento. 
100. Otro al mismo santo (152) \#\#

\section{Quintillas}

Otra vez tengo la pluma

contra san Diego cortada,

sin que enfadarle presuma,

pues ya se sabe que, en suma,

5 él no se pierde por nada.

Siendo muchacho este lego, que con sus padres vivía, con espíritu andariego, tomó las de Villadiego ${ }^{1059}$

10 y se les fue a montería ${ }^{1060}$.

A una ermita a guarecer se fue, que era tan huraño en todo su proceder, que solo pudiera hacer

15 vida con un ermitaño.

Cansado de las montañas, ser fraile francisco acuerda, con diligencias extrañas, para ejecutar sus mañas mejor, por bajo de cuerda ${ }^{1061}$.

Donde si algo le mandaba el guardián, una de dos, o antes de hacerlo rezaba, o lo hacía, si callaba,

25 como por amor de Dios ${ }^{1062}$.

Siempre andaba con temores ${ }^{1063}$, mas una, entre muchas veces, si no templa los rigores del guardián con pan de flores ${ }^{1064}$, lleva un pan como unas nueces ${ }^{1065}$.

1059 Tomar las de Villadiego: Indica que alguien ha huido de un riesgo o un compromiso. Su origen está relacionado con los judíos que en El Medievo buscaron refugio en la aldea de Villadiego, situada cerca de la ciudad de Burgos. En el poema "Al señor Bautista, el jaque”, Cornejo también la emplea.

${ }^{1060}$ San Diego en su mocedad fue ermitaño en la capilla de san Nicolás de Bari (Sevilla). Eusebio González de Torres relata sus vivencias en esta (Crónica 6: 295-299).

1061 Por debajo de cuerda: "Frase que expresa el modo de hacer alguna cosa por medios reservados y ocultos, para lograr con más seguridad el fin que se desea" (Aut.).

1062 Por amor de Dios: "Frase con que expresamos la piedad con que se hace o se pide se haga alguna cosa con respeto y relación a Dios" (Aut.).

${ }^{1063}$ La extrema generosidad que manifestaba san Diego con los más necesitados provocó que en numerosas ocasiones tuviera que ingeniárselas para hurtar del convento numerosos víveres, que después repartía entre estos.

${ }^{1064}$ El pan de flores (hecho con la flor de la harina de trigo) es una referencia al milagro que se atribuye a san Diego de la transformación de los panes en rosas, que realizó para no ser descubierto por el guardián del convento tras haberlos hurtado. Los detalles de este suceso son contados por González de Torres (Crónica 6: 372).

${ }^{1065}$ Dar un pan como unas nueces: "Castigar o reprender a alguno con aspereza y rigor” (Aut.). 
Baldados de pies y manos, confesaban de mil modos

que eran por su virtud sanos ${ }^{1066}$, pero son testigos vanos, porque los untaba a todos.

Que en esta universidad ${ }^{1067}$, dicen, fue un sabio de Atenas, mas yo no sé qué verdad tenga, si en toda su edad

40 el Cristus ${ }^{1068}$ aprendió apenas.

En fin, no ser nada humano en sus cosas, es muy cierto, por ser un caso bien llano, que si le asienta la mano ${ }^{1069}$,

45 hace dar gritos a un muerto.

Muriose, y miren cuál era, que queriéndole enterrar, para que se le comiera la tierra, fue de manera

50 que no le pudo tragar ${ }^{1070}$.

Por cosa tan peregrina en un arca está guardado, porque, como está cecina ${ }^{1071}$, el sacristán se le inclina

55 y le come medio lado.

Muerto está, y en esta arquilla da en cansarnos tan de veras que sobre que su capilla, sea octava maravilla,

60 levanta dos mil canteras ${ }^{1072}$.

Y tanto a todos molesta, pidiendo cosas extrañas, que sobre que le hagan fiesta, bien que no lo verá en esta, suele haber toros y cañas ${ }^{1073}$.

\footnotetext{
${ }^{1066}$ Las múltiples sanaciones que llevó a término san Diego durante su estancia en Roma por la celebración del Jubileo de 1450 han sido recogidas por González de Torres (Crónica 6: 333-334).

${ }^{1067}$ Se trata de la Universidad de Alcalá de Henares, donde se formaron Damián Cornejo y León Marchante.

${ }^{1068}$ Se llamaba así al abecedario por la cruz que precedía a este en las cartillas escolares.

${ }^{1069}$ Asentar la mano: "Dar golpes a alguno, castigarle o corregirle" (Aut.).

${ }^{1070} \mathrm{La}$ enorme devoción que suscitaba entre los fieles el predicador franciscano hizo que fuese desenterrado pocos días después de su fallecimiento (González de Torres, Crónica 6: 394-399). Tal hecho es evocado mediante la expresión "no poder tragar a alguno", cuyo significado contrasta con el motivo de tan célebre suceso. Esta también es usada en el poema atribuido a Cornejo y Marchante "De una niña la grandeza".

${ }^{1071}$ Se trata de una metáfora sobre el cuerpo incorrupto de san Diego, la cual se relaciona con las referencias sobre la ingestión de alimentos que aparecen en la quintilla anterior ("comiera" y "tragar") y en el verso "le come medio lado" (v. 55).

1072 Ver nota 546.

${ }^{1073}$ Haber toros y cañas: "Haber fuertes disputas sobre algo" (Aut.). Esta locución verbal en el poema también sirve para aludir al popular "juego de toros y cañas", que consistía en soltar unos toros y perseguirlos a caballo para clavarles lanzas, espadas o flechas.
} 
Y, en fin, él busca señores siempre a la Capilla Real ${ }^{1074}$, porque para sus loores, como son todos cantores, es gente muy puntual.

\section{A la Concepción (154) \#\#}

\section{Quintillas}

Hanme mandado una cosa

y que en ella me desvele, que por ser tan prodigiosa, aquesta* me compele

5 a que eche de la gloriosa ${ }^{1075}$.

Crean, pues, una verdad los que otra cosa han creído acerca de esta piedad ${ }^{1076}$, y pues está conferido,

10 ello es así en puridad.

El soberano poder preservó para sí una, y diola en favorecer hasta llegarla a poner

15 en el cuerno de la luna ${ }^{1077}$.

Del árbol que Dios vedó, Eva (como tan liviana) luego al instante comió, y un precepto quebrantó sano como una manzana ${ }^{1078}$.

Y si ella por el pecado acaudaló tanto mal, siendo vos de ella dechado, no concuerda este traslado con aquel original ${ }^{1079}$.

1074 Enrique IV otorgó a san Diego el título de "Enfermero de los Reyes de España" y, desde entonces, fueron muchos los miembros de la realeza hispana que acudieron a él para ser sanados de graves enfermedades (González de la Torres, Crónica 6: 416).

1075 Echar de la gloriosa: "Contar hazañas que no son creídas" (Cov.).

1076 "Opinión piadosa” fue el nombre técnico que recibió la creencia de la Inmaculada Concepción hasta que esta se convirtió en dogma de fe en 1854.

1077 Poner en el cuerno de la luna: "Es alabar excesivamente" (Aut.).

1078 Sano como una manzana: Esta expresión que hace referencia a gozar de una buena salud sirve como alusión jocosa de la ejecución del pecado original por parte de Eva. Este pasaje del Génesis $(3,15)$ es uno de los testimonios bíblicos que se empleó para justificar la pureza de María. Tras identificarla con Eva, los inmaculistas argumentaban que "si Dios estableció enemistad sin restricción entre la Virgen y el demonio, María no pudo poseer el pecado original ni siquiera en el primer instante de su existencia” (López Guil 251).

${ }^{1079}$ En el poema se juega con los términos artísticos “dechado" (v. 23), "traslado" (v. 24) y “original” (v. 25) con el propósito de justificar la pureza de Virgen. Si su hijo "su copia" nació libre de pecado, ella "el original" también debió hacerlo. 
Yo escoto ${ }^{1080}$, aunque no comí

la manzana (según noto),

en fin, pagaré por mí;

de vos, Virgen, no hablo aquí,

30 que así lo siento y escoto.

Francisco, y con gran razón,

administra estos loores;

si es tutor de obligación,

le toca la Concepción

35 como hacienda de menores ${ }^{1081}$.

Por no comer a la una

lo dejo, aunque quede malo,

que ha días que el hombre ayuna,

y así os dejaré a la luna

40 como a vuestro hijo en blanco ${ }^{1082}$.

102. Al mismo asunto $(155 v)^{1083} \# \#$

\section{Quintillas}

La más hidalga hermosura ${ }^{1084}$

hoy miro en vuestro esplendor, pues ser vuestra beldad pura

en vos y en Dios lo asegura

el correspondido amor ${ }^{1085}$.

El soberbio castigado

le hizo tu esplendor divino

al dragón fiero y osado,

pues que deshecho y postrado

10 fue gigante cristalino ${ }^{1086}$.

La más constante mujer ${ }^{1087}$

hoy en vos estoy mirando,

1080 Es una referencia al franciscano Juan Duns Escoto. La excepcional defensa que el escolástico escocés hizo de la Inmaculada Concepción frente a los Maestros de la Universidad de Oxford y el enorme impacto posterior que ello ocasionó le otorgaron la fama de ser el mayor exponente y representante del origen puro de la Virgen. Además, el término "escoto" (v. 30) en el poema también es empleado con el sentido "oscuridad y tinieblas", que es su significado en griego.

${ }^{1081}$ La férrea defensa que realizó el Hermano Menor, Juan Duns Escoto, del origen puro de la Virgen hizo que todos los miembros de la Orden de San Francisco se proclamaran a favor de este. Por ello, hasta la definición dogmática, a la Concepción Inmaculada se la llamó la “opinión franciscana”.

${ }^{1082}$ Libre de pecado.

${ }^{1083}$ Esta composición guarda numerosas semejanzas de forma y contenido con el poema atribuido a Cornejo "En títulos, Virgen pura", pues en ambos se intenta defender el origen "limpio" de la Virgen a través de títulos de comedias o versos de canciones.

${ }^{1084}$ La más hidalga hermosura, de Juan de Zabaleta, Francisco de Rojas Zorrilla y Calderón de la Barca.

1085 Podría ser una reformulación del título de la obra Las durezas de Anaxarte y el amor correspondido, de Calderón de la Barca. Esta hoy es conocida como La fiera, el rayo y la piedra.

1086 Parece aludir al verso inicial de un romancillo del ciclo de "Las Barquillas" de Lope de Vega, que fue incluido en la octava escena del acto tercero de La Dorotea.

${ }^{1087}$ La más constante mujer, de Juan Pérez de Montalbán. 
pues vuestra luz y poder, hasta que llegó a caer, mortal caza le* van dando ${ }^{1088}$.

El prevenido engañado ${ }^{1089}$

se miró con mil temores

entre las flores burlado, porque tus rayos han dado

20 puñaladas a unas flores.

El príncipe perseguido ${ }^{1090}$

fue, puesto que no le vale el estar allí escondido, porque tu esplendor lucido a pisar el prado sale ${ }^{1091}$.

Amor, ingenio y mujer 1092

hoy en vos, Virgen, se igualen, pues le supisteis vencer, $\mathrm{y}$, huyendo, dijo al caer:

30 “'Rayos van!'Fuera, que salen ${ }^{1093 ! ” .}$

El rebelde al beneficio ${ }^{1094}$

se ve a vuestros pies ${ }^{1095}$ sin medra, pues fue en el cielo edificio ${ }^{1096}$, $\mathrm{y}$ hoy se mira por un vicio escollo armado de yedra ${ }^{1097}$.

Ofender con la fineza ${ }^{1098}$

fuera, si Dios soberano

no os diera tanta pureza, pues dijera tu belleza para qué es amor tirano ${ }^{1099}$.

\footnotetext{
${ }^{1088}$ Se trata del noveno verso del poema de Góngora "Según vuelan por el agua" (Góngora s.p.). .

${ }^{1089}$ El prevenido engañado (anónima).

${ }^{1090}$ El príncipe perseguido, de Agustín Moreto.

${ }^{1091}$ Es el primer verso de un romance erótico anónimo (Blecua, Poesías 169).

1092 Amor, ingenio y mujer, de Antonio Mira de Amezcua. También existe una comedia burlesca de Vicente Suárez de Deza y Ávila titulada Amor, ingenio y mujer, en la discreta venganza.

1093 Se trata de una canción anónima recogida en el Libro de Tonos Humanos (Lambea 141).

${ }^{1094}$ El rebelde al beneficio, de Tomas Osorio.

${ }^{1095}$ La iconografía mariana suele representar el triunfo de la Virgen sobre el pecado poniendo bajo sus pies la cabeza de una serpiente (el diablo).

${ }^{1096}$ Lucifer, tras perder sus alas, es desterrado de la lujosa y eterna construcción que, según san Pablo, se está edificando en el Cielo: "son tejos de oro, y ladrillos de plata, y piedras todas preciosas, y finas, que son las obras santas, que hacen cendradas y puras. Los malos labras en el infierno sepulcros eternos de bronce y de hierro" (Aguado 279).

1097 Canción, atribuida a Luis Vélez, que aparece parcial o íntegramente en numerosas obras teatrales del siglo XVII: Hado y divisa de Leonido y de Marfisa, El pintor de su deshonra, Darlo todo y no dar nada, Más vale la amistad que la sangre, Amar es saber vencer y Olimpa y Vireno (Sánchez-Velo 45-53). 1098 Ofender con la fineza, de Jerónimo de Villaizán.

1099 Verso inicial del romance que aparece en la "Fábula de Dafne y Apolo", de Juan de Tarsis.
} 
103. Al mismo asunto (157) \#\#

\section{Quintillas}

La Concepción* este día

quiere un ciego ${ }^{1100}$ celebrar, sin interés y a porfía, porque siendo de María

5 de Gracia ${ }^{1101}$ se ha de cantar.

Sin pecado está probado ${ }^{1102}$

que esta hermosa niña fue, que Dios, que en ella ha encarnado, nunca permitiera que

10 se hiciera fiesta al pecado.

Si la sierpe con fiereza quiso beber su hermosura, ya lo pagó su torpeza, porque como estaba pura

15 se le subió a la cabeza ${ }^{1103}$.

Si el demonio con crueldad hacerla esclava intentó, bien lo pagó su maldad, porque le descalabró

20 con muy grande voluntad.

Arpa $^{1104}$ fue para cantar

Dios de su mano escogida, a quien quiso preservar; y arpa que es de Dios tañida

25 no pudo el diablo tocar.

Si Adán ingrato cayó, llevado de su codicia, y el pecado le cogió,

\footnotetext{
${ }^{1100}$ La relevancia que en el siglo XVII adquirió el personaje del ciego, como motivo burlesco culto, en los poemas religiosos es analizada por Inmaculada Osuna (Las oraciones 334-365).

${ }^{1101}$ Se trata de una advocación mariana que sirve para resaltar las cualidades divinas que puso Dios en María, la cual tiene sus orígenes en la frase que le dijo el Arcángel san Gabriel en el día de la Anunciación: "Dios te salve María, llena eres de gracia". Este es otro de los pasajes bíblicos que servía para defender la “opinión piadosa" (ver nota 1079), pues María habría recibido todas las gracias divinas y, por tanto, estaría exenta del pecado original (Escobar 16). La denominación "María de Gracia” también se halla en el poema atribuido a Cornejo y Marchante "Oigan lo que saca en limpio".

${ }^{1102}$ El poema pudo ser escrito después de la aprobación de la bula "Sollicitudo Omnium Ecclesiarum" por el Papa Alejandro VII en 1661. En ella se apoya "la opinión piadosa". Es decir, la defensa y la celebración de la Inmaculada Concepción y se condena cualquier práctica o publicación que vaya en su contra.

${ }^{1103}$ La recurrente imagen de la Inmaculada Concepción pisando victoriosa la cabeza de la serpiente o del dragón (el diablo) es representada en el poema a través de la derrota, por embriaguez, del Maligno tras intentar fallidamente "beber" de su pureza. Esta podría tener su origen en la relación que se establece entre María y la mujer prometida en el Génesis $(3,15)$, que al final de los tiempos se alzará sobre el cuerpo del demonio, "venciendo la tentación a la que sucumbió la primera Eva" (Escobar 168).

${ }^{1104}$ La Virgen María es considerada en el cristianismo "El arpa del Espíritu Santo".
} 
María de su justicia

30 con gracia ${ }^{1105}$ se le escapó.

El dragón fiero e inmundo

manchar quiso en ella el alma,

mas no logró lo iracundo,

por ver que a entrar en el mundo

35 de reina la hicieron salva ${ }^{1106}$.

Hoy la quieren festejar

los corazones devotos

con ánimo singular, y es lindo modo de entrar

a obligarla echando votos ${ }^{1107}$.

\section{Al propio asunto (158) \#\#}

\section{Romance}

De tu Concepción, señora, quisiera cantar, y pues

os pagáis de corazones, mis afectos atended.

5 Porque en tan divino asunto mi lengua no ha de poder explicar lo que es razón, que todos debemos creer. En tu Concepción la culpa ${ }^{1108}$

10 no tuvo qué oscurecer, pues, antes que ella naciese, ya eráis madre del poder.

La nobleza de la madre al hijo alcanza y se ve

15 que si es esclava la madre, esclavo el hijo es también ${ }^{1109}$. Pues si Dios en cuanto hombre tuvo tan claro su ser,

\footnotetext{
1105 Dilogía que ayuda a resaltar las cualidades de la Virgen. Por un lado, permite destacar sus "dotes divinas" y, por otro, su "gallardía, hermosura y perfección" (Aut.).

${ }^{1106}$ Dilogía que alude a la Virgen como "salvadora" y a la popular y antigua oración "Salve Regina", que sirve a los cristianos para pedir a esta su salvación.

${ }^{1107}$ Echar votos: Esta expresión, para rogar y pedir a Dios alguna gracia, en el poema hace referencia a los juramentos que impulsaron, como señala Rafael Sánchez (1410), algunas universidades (como la de París, Salamanca, Palencia o Santiago) para que sus estudiantes defendieran el misterio de la Concepción.

${ }^{1108}$ Los inmaculistas defendían que la Virgen quedó libre del pecado original "culpa" desde el mismo instante de su Concepción, mientras que los maculistas (en su mayoría dominicos) argumentaban que fue santificada por Dios en el útero materno y, por tanto, sí que en algún momento estuvo "manchada" por este. ${ }^{1109}$ La pureza de la Virgen se justifica en este fragmento apelando al concepto de nobleza hereditaria, transmisible o de sangre "noblesse de parage". Según el cual, los méritos y las cualidades de los antepasados se pasan a los descendientes.
} 
claro $^{1110}$ está que de María

heredó el noble nacer

Quien librarnos de la culpa,

en cayendo, quiso hacer,

quién duda quiso a su madre

preservar sin él caer.

25 Si determinó al eterno

Dios que había de nacer,

en su mente pura*, entonces,

crió al eterno de quien.

$\mathrm{Si}$ sois un pensil cerrado

30 con fruto de vuestro bien, siendo el Verbo ${ }^{1111}$ quien lo guarda,

no entró la culpa a comer.

Si fuente sellada sois

con el sello del poder ${ }^{1112}$,

35 claro está que la serpiente

no pudo entrar a beber ${ }^{1113}$.

Oíd a vuestros devotos,

hermosa flor de Jesé ${ }^{1114}$,

$\mathrm{y}$ haced que de* este misterio

40 no se haga misterio de él ${ }^{1115}$

Y puesto que la piedad ${ }^{116}$

no basta para hacer ley,

haced que la fuerza obre

y que lo mande la fe*1117.

\footnotetext{
${ }^{1110} \mathrm{La}$ antanaclasis de la palabra "clara" se utiliza para reforzar la argumentación sobre la pureza de la madre de Cristo. En su primera ocurrencia (v. 18), se emplea como contraposición de "oscuridad" o "mancha" y, en la segunda (v. 19), como algo que es evidente y que, por tanto, no deja lugar a incertidumbre. ${ }^{1111}$ El Verbo "es la segunda persona de la Santísima Trinidad, el hijo engendrado eternamente por el entendimiento del padre, imagen consustancial suya y concepto de su divinidad (Aut.).

${ }^{1112}$ El sello del poder es el Espíritu Santo. Esta metáfora aparece también en el poema de Cornejo "A su esposa, el alma, escribe".

${ }^{1113}$ La imagen de la Virgen como una fuente sellada de la que el diablo no puede beber es utilizada también en la poesía atribuida a Cornejo y a Marchante "La Concepción este día".

${ }^{1114}$ Una de las primeras formas de representar la pureza de la Inmaculada Concepción de la Virgen fue como flor de la Vara de Jesé (Escobar 72-89).

$1115 \mathrm{La}$ antanaclasis de la palabra "misterio" ayuda reforzar la posición inmaculista. En su primera ocurrencia (v. 39), se emplea en el sentido de "secreto incomprensible de las verdades divinas" y, en la segunda (v. 40), se utiliza la expresión "hacer misterio" para evitar que se hable del origen de la Virgen de manera oculta o errónea.

${ }^{1116}$ Ver nota 1079.

${ }^{1117}$ La teoría de la concepción inmaculada de la madre de Cristo se instauró como dogma de fe en 1854, gracias a la bula "Ineffabilis Deus". Esta señala que la "Virgen María fue preservada inmune de toda mancha de pecado original en el primer instante de su Concepción por singular gracia y privilegio de Dios omnipotente, en atención a los méritos de Jesucristo, Salvador del género humano, es revelada por Dios, y por lo mismo debe creerse firme y constantemente por todos los fieles".
} 


\section{Al mismo asunto (159v) \#\#}

\section{Romance}

Oigan lo que saca en limpio

de Concepción un poeta,

que es mucho [que] en sus borradores

se hallen versos de limpieza.

5 Si en fiesta de Concepción

no dijere cosas nuevas,

no hay que admirarse, que está

apurada $^{1118}$ esta materia.

Que en sábado se celebre

10 con admiración me deja,

que fiestas de Concepción

de domingo ${ }^{1119}$ estén tan cerca.

¿Cómo pudo ser esclava

la que es de los cielos reina?,

15 que echar por tierra su gracia

es darle menos esfera.

Hija es de Adán, pero Dios

de la mancha la preserva,

que sacarla de borrones

20 en limpio $^{1120}$ la gracia ${ }^{1121}$ es esa.

Si la escogió para madre, quién duda que fue perfecta, no sino dejarla en culpa ${ }^{1122}$, por Dios que fuera muy buena.

25 Vio Juan ${ }^{1123}$ que tuvo en su origen con un dragón grande guerra, sin ocasión que María no tuvo la culpa de ella. La serpiente ponzoñosa

30 siempre procuró vencerla, mas para ella vino a ser

\footnotetext{
${ }^{1118}$ Se trata de una dilogía que ayuda a sostener la causa inmaculista, ya que permite defender tanto la idea de que esta está concluida (y que no deja lugar a duda) como resaltar la santidad o pureza del tema.

${ }^{1119}$ Dilogía que, por un lado, sirve como recriminación a la posición maculista de los dominicos y, por otro, recalca las controversias que hubo sobre si se podían o no celebrar ciertas fiestas de la Virgen en domingo, que es el día de la liturgia de Cristo. Esta estrategia retórica también es utilizada en los poemas atribuidos a Cornejo y Marchante "De una niña la grandeza" y "Hoy a la Concepción aclamaciones".

${ }^{1120}$ Se crea un símil entre los borradores (v. 3) y los versos que saca en limpio el poeta (v. 1) al escribir sobre la Concepción y la labor que realiza Dios al liberar a la Virgen del pecado que heredan todos los hombres: "sacarla de borrones en limpio" (v. 20).

${ }^{1121}$ La dilogía de la palabra "gracia" destaca tanto la "habilidad" de Dios para lograr "sacar en limpio" (v. 20) a María como el "don" que esto supone para ella. Esta última interpretación también se da en la anterior aparición de dicho término (v. 15), recalcando con ello el carácter divino de la madre de Jesús.

1122 Ver nota 1010.

${ }^{1123}$ Podría ser una referencia a san Juan de Ávila, arduo predicador de la Inmaculada Concepción (Moreno 1299-1374).
} 
quebradero de cabeza ${ }^{1124}$.

Aunque era la sierpe astuta,

María de Gracia ${ }^{1125}$ llena

venciola, que esta señora

sabe más que las culebras ${ }^{1126}$.

No se dio por entendido

Dios en aquesta pelea,

el diablo la echó la culpa,

40 mas Dios hizo la deshecha ${ }^{1227}$.

Quiso Luzbel la alcanzase

la golosina de Eva,

el chasco se dio a sí mismo,

que él se tomó la culebra.

45 No hay que arguirla de pecado,

porque deshace sus fuerzas,

donde la gigante culpa ${ }^{1128}$

vemos que enana se queda.

\section{Al mismo asunto (161) \#\#}

\section{Romance}

De una niña la grandeza

hoy quisiera ponderar,

que tuvo rara belleza

y, en materia de limpieza,

5 gracia muy particular.

La nieve más blanca y pura

el candor al suyo trueca,

y es tan grande su hermosura,

que con ser tal su blancura

10 no la verán una peca ${ }^{1129}$.

Del viejo Adán trasladado

viene su ser virginal,

pero con ser su traslado ${ }^{1130}$

nada tiene bien mirado

15 que ver con su original.

Que hereda todo viviente

${ }^{1124}$ La construcción "quebradero de cabeza" simboliza cómo la Virgen se alza victoriosa sobre la serpiente (ver nota 1106). Esta es empleada en otros poemas atribuidos a Cornejo con un sentido diferente "Sepan todos y todas que yo adoro" y "Pues vuestra piedad me abriga".

1125 Ver nota 1104.

1126 Sabe más que las culebras: Esta frase proverbial que sirve para indicar que alguien no es fácil de engañar puede asociarse con la figura del demonio. De dicha relación surge también la expresión "saber más que el diablo" (DLE).

1127 Ver nota 15.

${ }^{1128}$ El pecado original.

${ }^{1129}$ Proviene del latín "macula" y se emplea, tanto en su significado original "tacha, falta o pecado" como en el más extendido "señal en la piel", para recalcar la pureza del cuerpo y del alma de la Virgen.

1130 Ver nota 1120 
de Adán la culpa sangrienta

es una cuenta corriente ${ }^{1131}$,

mas ella es tan inocente

que no ha caído en la cuenta ${ }^{1132}$.

Por esto nunca el cruel

Lucifer con ella frisa,

mas ella le da cordel ${ }^{1133}$,

y hace tanto caso de él

25 como de aquello que pisa.

De quererla derribar

se llegaron a ofender

entrambos, con tal pesar,

que ella no le puede ver,

30 ni él la ha podido tragar ${ }^{1134}$.

Bien que tenerla ella en pie ${ }^{1135}$

nada su enojo acrisola,

pues antes daremos fe

a que son tan unos, que

andan siempre pie con bola ${ }^{1136}$.

De la limpieza el blasón,

con ser su abuelo manchado ${ }^{1137}$,

pretendió, y en conclusión

sacó en limpio información

por ser el juez su ahijado ${ }^{1138}$.

$\mathrm{Y}$ aunque hasta ahora la fe

su concepción no asegura,

me atrevo a decir que, aunque

entre dos aguas esté,

${ }^{1131}$ Podría interpretarse como "deuda pendiente" y haría referencia al pecado original, que heredan todos los humanos.

${ }^{1132}$ Caer en la cuenta: "Advertir algún error que se había concebido, y estaba remoto del conocimiento" (Aut.). La Virgen, por tanto, no habría cometido ese fallo. Es decir, no habría pagado la "deuda pendiente". ${ }^{1133}$ Ver nota 927.

${ }^{1134}$ Esta expresión que denota una relación de antipatía sería también una referencia al Apocalipsis (12, 917), donde un dragón "el demonio" intenta atrapar a una mujer (ha dado a luz a un hijo varón) y la tierra se "traga" el río que este había lanzado contra ella. Como venganza, el diablo se propone atacar a todos sus descendientes. El pasaje de la "Mujer apocalíptica" se relacionó en la Edad Media con la Virgen, y marcó la iconografía inmaculista (Escobar 59-71).

1135 Se podría relacionar con la expresión "En pie de guerra", que se utiliza cuando un ejército "en tiempo de paz se halla apercibido y preparado para entrar en campaña" (Aut.).

${ }^{1136}$ La frase "Pie con bola", significa justamente $(\underline{A u t}$.$) , sirve como metáfora de una de las formas más$ populares para representar el triunfo de la Inmaculada Concepción sobre el diablo. Esta consiste en situar a la madre de Cristo sobre un orbe o una luna. Tal imagen "Tota pulcra" parece provenir del "Cantar de los Cantares" (Escobar 89-100).

${ }^{1137}$ Puede remitir a san Joaquín (el padre de la Virgen) por su condición de judío. Además, serviría como contraposición de la imagen de Tota pulcra. A partir del siglo XVI, las creencias que apelaban a libros apócrifos de la Biblia para defender la pureza de María ("El abrazo en la Puerta Dorada" y "La parentela de María") son sustituidas por testimonios procedentes de los textos canónicos (Escobar 79-89).

${ }^{1138}$ La limpieza de sangre "limpieza el blasón" (v. 36) confirma la ausencia de pecado en la Virgen, a pesar de su controvertida genealogía, pues esta tiene como "juez del proceso" (v. 40) a su hijo. La bula "Sollicitudo Omnium Ecclesiarum" (8 de diciembre de 1661) justificaba que María fue inmune de la mancha del pecado original, por singular gracia y privilegio de Dios, en atención a los méritos de su hijo Jesucristo". 
45 se ha de salir con ser pura.

Pues tiene el mundo en querella, amor tan extraordinario, que por casarse con ella pretende, en Roma la Bella,

50 sacarla por el vicario ${ }^{1139}$.

A rezar de Concepción en cualquier día se aplica y a cualquier religión, mas tal conmemoración

55 no se da en la dominica ${ }^{1140}$. Y es que algunos han creído, en las científicas luchas ${ }^{1141}$, que mancha en ella ha cabido; y es falso, aunque su vestido

60 se ve con lámparas ${ }^{1142}$ muchas.

107. Al mismo asunto (163) \#\#

\section{Romance}

Sabed, señora doncella, que hay algunos por acá que, aunque sois tan pura, dicen que en opiniones ${ }^{1143}$ andáis.

5 No sé qué achaque os murmuran, y en su tema pertinaz:

por el hábito que tienen aseguran que es verdad ${ }^{1144}$. Dícenlo así, y el autor

10 de esta doctrina cabal es Tomás ${ }^{1145}$, añaden ellos, pero añaden esto más.

A la gracia ${ }^{1146}$ que os confiesan, por mucho favor le dan

\footnotetext{
1139 Título del Santo Pontífice "Vicario de Jesucristo en la Tierra".

1140 Ver nota 1111.

${ }^{1141}$ Las principales controversias que suscitó el origen de la Virgen a lo largo de la historia fueron recogidas por Pascual Rambla (192-210).

${ }_{1142}$ La Inmaculada Concepción se suele mostrar coronada por estrellas, con un manto azul resplandeciente, el sol cubriendo su cuerpo y una luna menguante bajo sus pies (v. 35). Las "lámparas" simbolizarían todos los elementos lumínicos que se emplean en su iconografía para retratar su pureza (v. 10) y su triunfo frente al demonio (v. 30). La polisemia de dicha palabra también podría evocar las "manchas" que se hallan bajo la imagen de la "Mujer de la Apocalipsis". Esta se alza sobre las estrellas, que representan a los ángeles caídos y a los hombres que son expulsados de la Iglesia (Escobar 61).

1143 Ver nota 1079.

1144 Los religiosos dominicos.

1145 Se establece un calambur con “es Tomás” (v. 11). Santo Tomás de Aquino defendió en sus obras que María contrajo el pecado de origen y que fue santificada posteriormente.

1146 Ver nota 1124.
} 
entre no sé qué priores

cierta por temeridad.

Yo[no]* me conformo con ellos, mas quién se ha de conformar con gente que al más amigo

20 nunca le habla en puridad ${ }^{1147}$. Tomás dicen que lo afirma, mas contra vos juicio tal nunca lo pude creer de las partes de Tomás ${ }^{1148}$.

108. A san Francisco (164) \#\#

\section{Coplas}

De pie quebrado unas coplas quiero cantar, pues me ha dado la materia un penitente muy bien llagado ${ }^{1149}$.

5 Por hombre santo le tienen, aunque estando señalado de mano de Dios ${ }^{1150}$, sin duda, no era muy diablo.

Mucho le agasaja el mundo,

10 pero si él no hubiera hallado tales hijos y terceros ${ }^{1151}$, no fuera tanto.

Preciose de muy de valiente, y una vez que en descampado

15 le cogieron, como a un cristo ${ }^{1152}$ me le dejaron.

Cuatro heridas harto buenas sacó de clavo pasado en manos y pies, sin otra que dejó a un lado.

\footnotetext{
${ }^{1147}$ Se trata de una dilogía que ayuda a atacar la causa maculista. En su primera ocurrencia, evidencia que los defensores de esta tratan el tema con rodeos y, en su segunda acepción, recalca que los dominicos no hablan de la Virgen de manera limpia o pura.

${ }^{1148}$ El poeta remite al apóstol Tomás para continuar su ataque contra la incredulidad del predicador dominico sobre la Inmaculada Concepción, pues la coincidencia del nombre se lo permite. Para ello, evoca el pasaje de Juan (20, 24-29), donde el discípulo de Cristo afirma que no creerá en la Resurrección de su maestro hasta que no toque sus heridas.

${ }^{1149}$ El origen de las llagas impresas en el cuerpo de san Francisco (emulan a las sufridas por Cristo) es relatado por Cornejo (Crónica 1: 456-458).

${ }^{1150}$ Estar señalado por la mano de Dios: Expresión se utiliza para indicar que alguien tiene un defecto corporal (DLE).

${ }^{1151}$ Los terceros son aquellos que profesan la regla de la tercera Orden de San Francisco, Santo Domingo o Nuestra Señora del Carmen.

1152 Un Cristo: "Persona que presenta un estado lastimoso" (DLE). Esta forma recalca las llagas que padeció el santo franciscano con el propósito de emular las que sufrió Jesucristo (v. 4.).
} 
Él las mereció muy bien, porque sepa, bien mirado, una vez cuántas son cinco $^{1153}$, quien es tan bravo.

No se dio por muy sentido, antes dijo de las cuatro heridas: "Para mí aquestas montan tres clavos".

Aun con entrar más en hondo

30 la que cayó en el costado, por un favor la tenía muy señalado.

Tal, en fin, con las señales quedó, que espantara al diablo,

35 que con ellas no podía verle pintado ${ }^{1154}$.

Verdad fue toda esta historia ${ }^{1155}$, y adviértola con cuidado, pues que los terceros hacen

40 fiesta del caso ${ }^{1156}$.

Háganla muy en buen hora, pero sepan que es el santo manirroto y, como hay cielo, les dará el pago ${ }^{1157}$.

\section{Al mismo asunto (165v) \#\#}

\section{Quintillas}

De Francisco por menor ${ }^{158}$ escribir la historia intento, ciego $^{1159}$ soy, mas no es error meterme hoy a historiador, sabiendo escribir atiento.

${ }^{1153}$ No saber cuántas son cinco: "Dícese del hombre simple, que no sabe cuántos dedos tiene en la mano" (Cov.).

${ }^{1154}$ Se relaciona con la expresión "No poder ver ni en pintura", que sirve para decir que una persona no soporta a otra $(D L E)$.

${ }^{1155}$ Incorporar al término "historia" el adjetivo "verdadera" corresponde a la voluntad de algunos escritores de los Siglos de Oro de reafirmar que lo que contaban era un suceso real y no un relato falso. Uno de los ejemplos más conocido es el de la Historia verdadera de la conquista de la Nueva España de Bernal Díez del Castillo. En otros poemas atribuidos a Cornejo "De santa Resurrección” y "Quiero, pues es ocasión” se emplea este mismo recurso.

${ }^{1156}$ Los franciscanos festejan las llagas de su fundador el diecisiete de septiembre.

${ }^{1157}$ El deseo de san Francisco de renunciar a todo para ser fiel seguidor de Cristo y su carácter altruista le hicieron ganar una gran popularidad entre los pobres. Fray Cornejo recoge algunos pasajes donde se muestran tales cualidades (Crónica 1: 30-32).

${ }^{1158}$ Esta locución adverbial es empleada para presentar el breve esbozo que se hará a continuación de la vida de san Francisco y como alusión a los miembros que constituyen su Orden "Menores". La misma forma es usada por en el poema atribuido a Cornejo y a Marchante "De Diego muy por menor".

${ }^{1159}$ Ver nota 1103. 
Hijo fue de un mercader, que pudo bien sin lisonja mucho en el mundo valer, pues tuvo para comer todos los días la lonja ${ }^{1160}$.

Al cielo levantó el vuelo, y de mercader la* cara suerte dejó sin recelo, porque hay mercader que al cielo

15 no llega con una vara.

Ninguno llega a admirarse de ver en Francisco miedo, que no es muy fácil salvarse, y un mercader condenarse

20 lo sabe hacer con un dedo.

En fin, de la tropelía del mundo, en su edad más tierna, tanto el santo se reía ${ }^{1161}$ que de risa quedó un día

25 descalzo de pie y de pierna.

Mucho aborreció el dinero, que es donde el vicio se embosca, $\mathrm{y}$ en descanso verdadero vivió, porque fue el primero

30 a quien no picó la mosca*1162.

De envidia Luzbel movido, trampas ponía a sus huellas, y a mí me tiene aturdido que fuese tan entendido

35 y que no cayese en ellas ${ }^{1163}$.

Entró de dama, fingiendo* que sentía sus desdenes, mas él la dijo riendo: "Oyes, ángel, ya te entiendo, aunque tantas uñas tienes.

\footnotetext{
${ }^{1160}$ Fray Damián dedica varios capítulos del primer tomo de la Crónica seráfica a indagar en los orígenes de san Francisco (14-17) y en la influencia que tuvo en él la condición de mercader de su padre (21-24). ${ }^{1161}$ El carácter jovial de san Francisco en su mocedad queda bien retratado en el episodio en el que él y unos compañeros son encarcelados y él, en lugar de abatirse, se muestra alegre (Cornejo, Crónica 1: 25). 1162 Picar a alguien la mosca: Expresión que se utiliza para decir que alguien está herido o inquieto $(D L E)$. La acepción de la palabra "mosca" como "dinero" también sirve para hacer referencia al voto de pobreza que tomó san Francisco.

${ }^{1163}$ Las numerosas tentaciones que debe afrontar san Francisco en sus primeros años suelen ser solventadas por este con gélidas prácticas. La escena que se recrea en el poema evoca uno de los episodios más extremos que llevó a término el patriarca para apagar su fuego interior. Para ello, se arrojó desnudo sobre unos matorrales que estaban cubiertos de nieve, ocasionándose al hacerlo numerosas heridas en su cuerpo (Cornejo, Crónica 1: 146-149).
} 
No me quiebres la cabeza ${ }^{1164}$, que aunque más hagas la cama ${ }^{1165}$ al delito y la torpeza, eres solo oculta pieza y quieres meterte a dama".

Junto a una zarza vio al diablo, y de él sobornado, a decirle se arrojó: "Vaya al infierno, que yo 50 me quedo aquí zarceando".

Fue su vida esclarecida ${ }^{1166}$ para asombro del profundo ${ }^{1167}$, y lo que hizo en este mundo no lo fue (es cosa sabida) a pagar al otro mundo ${ }^{1168}$.

\section{A santa Clara (167) \#\#}

\section{Quintillas}

Hoy mi devoción aclama, puesto que en estilo nuevo, a una virgen que fue rama ${ }^{1169}$ de san Francisco y se llama

5 lo que no es yema en el huevo.

Su nombre es bien conocido, y tanto en el mundo vale que a mí me tiene aturdido ver que esté tan esparcido

10 quien del cascarón no sale ${ }^{1170}$.

Nació al mundo hermosa Clara, y lo que más me embelesa de su virtud, siempre rara,

\footnotetext{
${ }^{1164}$ Se relaciona con la expresión "quebrantar la cabeza", que representa tanto el deseo de san Francisco de evitar las pláticas necias de Luzbel como la creencia bíblica de acabar con la serpiente (el diablo) pisando su cráneo. Ver nota 1106.

${ }^{1165}$ La expresión "Hacer la cama" (ver nota 931) recalca las argucias que prepara el diablo contra san Francisco para hacerle caer en la lujuria.

${ }^{1166}$ Fray Damián califica a san Francisco y a santo Domingo como los "esclarecidos patriarcas", quienes con sus "ejércitos de estrellas puestas en orden, hicieron frente al infierno" (Cornejo, Crónica 1: 6).

${ }^{1167}$ Metáfora del infierno.

${ }^{1168}$ La estrofa final del poema es casi idéntica a la que da cierre a la composición, atribuida a Cornejo y a Marchante, "Hoy mi devoción aclama". Esta tiene como eje central a santa Clara, destacada discípula del fundador de la Orden Franciscana.

${ }^{1169}$ Santa Clara fue fundadora de la Orden de las Hermanas Pobres (una de las ramas de la Segunda Orden de San Francisco) y fiel seguidora del creador de la Orden Franciscana.

${ }^{1170}$ La comicidad del campo semántico del huevo (clara, yema y cascarón) que aparece en la composición es un guiño a los lúdicos versos que con este se hicieron en el periodo aurisecular. Alatorre (Fortuna varia 483-504) recoge algunos de los ejemplos más señalados.
} 
es que con su buena cara

llegase a ser abadesa ${ }^{1171}$.

Queriéndola dar marido

al* padre que la crió, dijo:

"Siendo Dios servido,

para virgen he nacido,

20 pero para casta no" 1172 .

Viola san Francisco un día

en que bendicen la palma,

y no sé qué la decía,

que la niña lo sentía

que la llegaba hasta el alma ${ }^{1173}$.

Cansada de seda y grana,

trató con este pobrete

trocar las telas en lana,

$\mathrm{y}$ vino a salir la hermana

30 trasquilada y sin copete.

Fuela su buen padre a ver

en un casa portátil,

procurándola volver,

mas no fue fácil vencer,

solo porque no fue fácil ${ }^{1174}$.

Contenta, aunque recogida, con otras vivió, y no admiro

que tuviese buena vida,

pues estaba entretenida

holgándose en el retiro.

Muy a menudo rezaba, de tarde en tarde comía, y si acaso la tentaba su carne flaca, la daba unos chascos que la abría ${ }^{1175}$.

\footnotetext{
${ }^{1171}$ Santa Clara fue abadesa del Convento de San Damián tras la renuncia de san Francisco de dicho cargo y la aprobación de la regla (en 1215) del papa Inocencio III.

${ }^{1172}$ Los privilegios que le otorgaba a santa Clara su alto linaje, era descendiente de la ilustre familia de los Eiumi, fueron rechazados por su voluntad de cumplir con los votos de pobreza y de recogimiento espiritual que defendía san Francisco de Asís. El doble significado de la palabra "casta" sirve como contraste cómico de su actitud recatada. Esta bisemia se halla también en varios poemas atribuidos a Marchante que hablan de la fundadora de las Clarisas (Carreira, La obra 47).

1173 Tras la bendición de las palmas del Domingo de Ramos (1211) que llevó a término el fundador de la Orden Franciscana, santa Clara huyó de su hogar para entregar su vida a Dios. El fuerte impacto que este le había causado en sus anteriores encuentros fue determinante en la toma de su decisión (Cornejo, Crónica 2: 8-9).

${ }^{1174}$ La antanaclasis de la palabra "fácil" sirve para recalcar de nuevo la fortaleza de espíritu de la santa y su actitud honesta.

${ }^{1175}$ Los duros castigos a los que se sometía la fundadora de las Clarisas desde su más tierna edad para expiar sus pecados se extremaron con el paso de los años, llegando a emplear incluso varios cilicios (Cornejo, Crónica 2: 32-34). La acción de golpearse con chascos para "abrir" la carne como forma de penitencia es empleada también en el poema dedicado san Diego de Alcalá "Después que porque se usa".
} 
Muchos milagros obraba ${ }^{1176}$

y jamás sufrió cosquillas

del demonio ${ }^{1177}$, antes si entraba

en los cuerpos, le obligaba

a salir de sus casillas ${ }^{1178}$.

Un cojo con mucha fe

llegole a pedir acaso

remedio para su pie,

y la santa le hizo que

55 saliese de allí a buen paso ${ }^{1179}$.

Un moro escuadrón talando

entró en su convento, y visto

por ella el crimen nefando,

los hizo salir rodando

60

con solo un cuerpo de Cristo ${ }^{1180}$.

La custodia del altar

para reprobar sus yerros

sacó, y es bien de admirar

que no se osaron llegar

65 al arca del pan los perros.

Murió al fin esclarecida ${ }^{1181}$, para asombro del profundo ${ }^{1182}$, mas lo que hizo en esta vida no lo fue (es cosa sabida) a penar al otro mundo ${ }^{1183}$.

\footnotetext{
${ }^{1176}$ Uno de los milagros más conocidos de santa Clara es el de la multiplicación de los panes, el cual es descrito con detalle por Cornejo (Crónica 2: 37-38).

${ }^{1177}$ La ferviente devoción de la santa hizo que se apartara del pecado y que su pureza fuera, incluso, alabada por los cardenales y el papa: "La virginidad, virtud toda celestial, resplandeció en santa Clara en grado tan eminente, que en carne mortal, y corruptible vivió tan sin sentir sus estímulos, como si fuera un espíritu puro, o un animado cielo" (Cornejo, Crónica 2: 38).

1178 Salir de sus casillas: Frase hecha que significa "inquietar, hacer perder la paciencia" y que tendría su origen en el juego de las "tablas reales", donde se han de sacar las piezas de las casas $(D L E)$.

1179 Buen paso: "Vida regalada" (DLE).

${ }^{1180}$ Durante el ataque de los sarracenos al Convento de San Damián (1241), santa Clara ahuyentó a estos con la hostia consagrada. Este episodio es relatado por Cornejo (Crónica 2: 42-44).

${ }^{1181}$ Poco antes de morir santa Clara, sus discípulas confesaron que la vieron en varias ocasiones "coronada con resplandores, ya en forma de alas de fuego, que batían sobre la cabeza, ya en globos de luces que la iluminaban toda" (Cornejo, Crónica 2: 66).

1182 Alude al diablo.

${ }^{1183}$ La estrofa final del poema es casi la misma que la de la composición que dedica fray Damián al guía espiritual de santa Clara "De Francisco por menor".
} 


\section{A san Juan Bautista $(169 v)^{1184} \# \#$}

\section{Romance}

Al señor Bautista, el jaque ${ }^{1185}$, a quien todo el mundo entero reverencia, pero yo como el gran turco le quiero ${ }^{1186}$.

5 El que antes de nacer hizo, por ser muy travieso, cosas que no las hiciera el demonio del infierno. El que a su madre en visita

10 la revolvió todo el cuerpo, y quedó contento como si viniera Dios a verlo ${ }^{1187}$. A su padre quitó el habla al hacer un nombramiento,

15 y otra vez, para enmendarlo, le hizo cantar de misterio. Nació, y siendo grandecito, tomó las de Villadiego ${ }^{1188}$, y de colmena en colmena

20 andaba catas haciendo ${ }^{1189}$. Aunque anduvo entre la miel, nada se le pegó de ello, porque no fueron sabrosos para muchos sus consejos.

25 Metiose a predicador, y quizá tuvo buen celo, mas siempre que predicaba echaba por esos cerros ${ }^{1190}$. Cobró de valiente fama, 30 no sé con qué fundamento, pues muy bien zamarreado en las montañas le vieron. Verdad es que con su primo

${ }^{1184}$ En el título del poemario $E$ se dice que es una jácara. Según la clasificación que propone Bègue ( $L a$ jácara 133-136) sería del primer tipo y se caracterizaría por adoptar rasgos lingüísticas y textuales de las jácaras profanas.

${ }^{1185}$ En las jácaras "el jaque" era un personaje marginal, fanfarrón y bravucón, cuyas desventuras solían ser contadas por una ramera (Bègue, La jácara 128).

${ }^{1186}$ Hace referencia a Solimán el Magnífico, dirigente turco durante el sitio de Rodas (1522). Este célebre otomano fue recreado con honor en piezas dramáticas como La pérdida honrosa y los caballeros de san Juan, donde se muestra como un musulmán que: "se humilla ante las reliquias del gran profeta san Juan (298) y declara que son las reliquias del Bautista el motivo que le ha hecho venir a Rodas (299)" (Sait 110). ${ }^{1187}$ Evoca el pasaje bíblico en el que san Juan, dentro del vientre de Isabel, salta de alegría al recibir la gracia del Espíritu Santo al contacto con la Virgen María, que estaba embarazada (Lucas 1, 41).

${ }_{1188}$ Ver nota 1162.

${ }^{1189}$ Catar las colmenas: "Lo mismo que castrarlas" (Aut.).

${ }^{1190}$ San Juan Bautista predicó por las montañas de Judea. Tal acción se asocia con la expresión "Echar por esos cerros", que señala a "alguna persona descaminada" (Aut.). 
tuvo una vez un encuentro, y le señaló por Dios

solamente con un dedo ${ }^{1191}$. Pero aquesta acción sola no califica su esfuerzo, porque su competidor

40 se estaba como un cordero ${ }^{1192}$

Hízose su grande amigo, y bajó luego al momento a remojar la palabra al Jordán, y cesó el duelo* ${ }^{* 193}$.

45 Dicen que toda su vida trajo los pies por el suelo, pero bien sabemos todos que su calzado era vello. En cuanto a sus virtudes

50 hay pareceres opuestos, que unos dicen que gastaba vestidos de muy buen pelo. Otros (no sé si lo crea) dicen fue tan descompuesto que andaba toda la vida por las montañas en cueros. Dicen que no bebió vino, yo no lo tengo por cierto, porque para su regalo

60 nunca le faltó un pellejo. Virgen fue allá se lo haya ${ }^{1194}$; pero buen vellón sabemos gastaba con una piel de averiguado desuello ${ }^{1195}$.

65 Que no cometió pecado dicen, y yo lo confieso, mas bien sé que más de cuatro de penitencia le oyeron.

Salió en fin de las montañas

70 tan amarillo, en efecto, que un san Juanito de cera parecía pintipuesto.

Fue a predicar a palacio y no se le hizo de nuevo, que estaba bien enseñado

${ }^{1191}$ Simboliza la bendición que se realiza a través de la señal de la cruz.

1192 Dilogía que representa la figura de Cristo "Cordero divino" y la actitud "dócil y mansa" de dicho animal.

${ }^{1193}$ El poeta aprovecha la condición de predicadores de san Juan y Jesucristo para confrontarlos mediante léxico jacaresco: "encuentro" (v. 34), "competidor" (v. 39) y "duelo" (v. 44).

${ }^{1194}$ Allá se lo haya: Expresión "para denotar que quien habla se desliga de la posición o decisión de otro" $(D L E)$. Esta es empleada también en el poema atribuido a Cornejo "De santa Resurrección".

1195 San Juan, según el evangelio de Mateo $(3,4)$, se viste con pieles a semejanza del profeta Elías. Tal característica le permite al poeta confeccionar un campo semántico relacionado con estas: vello (v.48), pelo (v. 52), cueros (v. 56) pellejo (v. 60) y desuello (v. 64). 
a predicar en desierto ${ }^{1196}$.

Vio un baile ${ }^{1197}$, y como si él

fuera de danzar maestro

al rey Herodes le dijo:

80 "Este baile no es bien hecho,

porque esta mujer ${ }^{1198}$ que baila

sienta mal el pie izquierdo

y si repite las vueltas,

se quebrantará el derecho".

85 Viendo Herodes el sarao,

dijo el santo: "Cepos quedos"1199,

mandole prender, y dijo:

"Pues yo no quiero que ande cepos".

[El coleto le pescaron ${ }^{1200}$.

90 Y, en la trena, el carcelero

le echó, en lugar de prisiones,

una cadena por yerro.

Pensando el maldito rey

qué se haría de aquel preso

95 estuvo un poco dudoso,

y diole en cabeza luego ${ }^{1201}$.

Como si bálago fuera,

mandole segar el pescuezo,

e hizo muy bien de segarle,

100 porque era como el pan bueno ${ }^{1202}$.

Este fin tuvo el Bautista,

el que vivió recoleto,

$\mathrm{y}$, a pasos de su garganta ${ }^{1203}$,

se fue subiendo a los cielos]*.

105 Toda su vida tragedia

fue, mas a lo que entiendo,

vida que acabó por baile,

a que fue entremés me atengo ${ }^{1204}$.

\footnotetext{
${ }^{1196}$ Predicar en desierto: "Frase vulgar con la que se da a entender que los oyentes no están dispuestos (...) para admitir la doctrina y consejos que se les da" $(A u t$,$) . Esta recuerda la labor de predicador que desempeñó$ san Juan en las montañas de Judea y recalca el vano intento de este de hacer entrar en razón a Herodes respecto a su relación con Herodías "predicar en palacio" (v. 73).

${ }^{1197}$ Se trata del baile que celebró Herodes por su cumpleaños y que terminó con el ajusticiamiento del Bautista. Tal episodio se narra en los evangelios de Mateo (14, 1-12), Marcos (6, 14-29) y Lucas (9,7-9).

${ }^{1198}$ Salomé (hija de Herodías).

${ }^{1199}$ Cepos quedos: "Expresión coloquial que se usa para decir a alguien que se esté quieto" $(D L E)$.

${ }^{1200}$ Pescar el coleto: "Sujetarlo de manera que no pueda escapar" (DLE).

${ }^{1201}$ Dar en la cabeza a alguien: "Frustrar sus designios, vencerlo" (DLE).

${ }^{1202}$ Remite a la expresión "Ser bueno como el pan" con el propósito de señalar la actitud bondadosa de san Juan. Además, podría vincularse con el "pan de san Juan". Este, al igual que el bálago (v. 97), se utiliza para alimentar el ganado.

${ }^{1203}$. Tal expresión (ver nota 932) no solo evoca la decapitación del santo, también sería un guiño a la célebre cita sobre san Juan "Yo soy la voz que clama en el desierto" (Juan 1, 23).

${ }^{1204}$ Se establece una contraposición entre la sufrida vida del santo "tragedia" (v. 50) y el festejo que precede a su muerte "entremés". Tras este breve y lúdico tránsito, san Juan llegaría a la vida celestial.
} 


\section{Acto de contrición delante de un crucifijo (172) ${ }^{1205} \#$}

\section{Romance}

Un pecador soy, Dios mío, que cuando a vuestros pies llego, a piedades os dispongo con la ofensa que os acuerdo.

5 Un pecador miserable soy que, de sus vicios ciego, a la luz de un desengaño ${ }^{1206}$ busco el tesoro que pierdo. Mas, ¡ay mísero de mí!,

10 si enemigo de mi mesmo ${ }^{1207}$, del incendio que me abrasa estoy atizando el fuego. Mi conocimiento propio me confunde, mas ¿qué temo

15 si para mi amparo, vos, tenéis los brazos abiertos? ${ }^{1208}$ ¡Qué sangriento estáis, Dios mío!, ¡qué desfigurado os veo!, ¿es posible que esos clavos

20 se labraron con mis yerros? ${ }^{1209}$ Vuestro amor y mi delito en tal estado os han puesto, vos, muerto por remediarme, y yo, de dolor no muero.

25 Sin duda ninguna loco me tienen mis devaneos, cuando contra mí irritado vuestros agravios no vengo. Yo vuestro enemigo he sido,

30 y en tan obstinado empeño se está de vuestros rigores todo el impulso suspenso.

\footnotetext{
${ }^{1205}$ La poesía penitencial se convirtió en un tema recurrente en la lírica religiosa del Siglo de Oro. La antología Avisos para la muerte (1634) fue un importante referente para su creación y difusión. En ella participaron autores tan destacados como Lope de Vega, Calderón o Rojas Zorrilla. Inmaculada Osuna ofrece un interesante comentario sobre los actos de contrición que la conforman (Los avisos 45-82).

${ }^{1206}$ Fray Damián creía que a través de "la luz del desengaño" el penitente podía ver los horrores del pecado y, gracias a su devoción por la Pasión de Cristo, acercarse a la virtud: "Tocado de inspiración divina, abriendo los ojos a la luz del desengaño, despreció las conveniencias (...) y abrazó la Cruz de la mortificación para vivir crucificado en humildad, y voluntaria pobreza" (Cornejo, Crónica 3: 148).

${ }^{1207}$ Los manuscritos $A, B$ y $M$ añaden cuatro versos, que no han sido incluidos en la edición por resultar reiterativos y de escaso interés filológico.

${ }^{1208}$ Simboliza tanto la imagen de Cristo en la Cruz como su capacidad para acoger a los fieles.

${ }^{1209}$ Dilogía que alude a cualquier defecto cometido contra los preceptos o las reglas y a una pieza de metal "clavos" (v. 21). La última acepción se relacionaría con la marca que se hacía a los esclavos y que consistía en ponerles "la cifra del nombre esclavo con una 'S' y un clavo enlazados" (Aut.). La misma estrategia retórica es empleada en el poema indubitado de Cornejo "Dulce Jesús, Dios mío".
} 
Mas ya de la omisión vuestra para mi alivio prevengo,

que son de vuestras piedades más crecidos los afectos.

Pequé, mas formado fui

de la tierra ${ }^{1210}$, que el veneno

inficionó de la culpa

40 sus frutos, señor, son estos.

Mas ya que de vuestra sangre

me fecunda el dulce riego,

en sazonadas cosechas

mi inculta maleza ofrezco.

45 Fábrica de inútil barro, me quebré al golpe violento

del apetito ${ }^{1211}$, y la enmienda

busco en el último riesgo.

En vuestras manos me pongo,

50 ved, dulce Jesús, os ruego,

que vos para tales quiebras

la encarnación habéis hecho.

Ya de mis propias pasiones

huyendo el tirano empeño

55 procuro enmendar la vida

con mis propios escarmientos.

Virtud es que a muchos golpes

de divinos llamamientos

tan dormido estuve, que es

60 este reparo primero.

Mas, mi Dios, no llega tarde

quien cumple vuestros deseos, ya con mi dolor respondo y con él os lisonjeo.

65 Lisonja os hago, bien dije, porque en amarme sois tierno, que vuestra satisfacción en mi interés habéis puesto.

Dichoso, si de amoroso

70 puedo lograr el acierto, ya quiero lo que no quise, si quise, lo que no quiero ${ }^{1212}$. Mi vida y mi alma os consagro, mas ¿qué os doy?, nada os ofrezco,

75 pero vos gustáis que sea

liberal con lo que es vuestro.

En pensamientos y en obras

nada os doy y todo os lo debo,

${ }^{1210}$ En el Génesis $(2,7)$ se narra cómo Dios creó al hombre a partir del polvo de la tierra y del espíritu de vida. A este pasaje se vuelve a aludir con la referencia "Fábrica de inútil barro" (v. 45).

${ }^{1211}$ Cae en la concupiscencia.

${ }^{1212} \mathrm{Se}$ crea un retruécano. 
si os pagáis de que la deuda

confiese, ya la confieso ${ }^{1213}$.

Muchos mis delitos son,

pero más que todos ellos

en vuestra misericordia:

haced de ella buen ejemplo.

85 Hoy mi dolor solicita

vuestro mayor lucimiento,

pues logrará la piedad

a más culpas más trofeos.

Perdonadme, Jesús mío,

90 que si en vuestra gracia quedo, negándome a mí, os tendré

eternamente por dueño.

\section{A la Purísima Concepción. Jácara (175) ${ }^{1214} \#$}

\section{Pareados}

Érase una Virgen pura ${ }^{1215}$, casada por su ventura ${ }^{1216}$

con José, otro que tal,

cada uno con su igual. ${ }^{1217}$

5 Escogida para ser

la más constante mujer ${ }^{1218}$

y madre del mejor hijo,

cuando un ángel se lo dijo

sin saber cómo ni cuándo ${ }^{1219}$,

10 José, habladme en entrando ${ }^{1220}$, sin conocer el empeño,

era un celoso extremeño ${ }^{1221}$.

[Pues por todo aquel contorno,

\footnotetext{
${ }^{1213}$ Se trata de una antanaclasis que juega con dos niveles de lectura. El primero, se relaciona con la justicia humana y, el segundo, con la divina, pues en este último se representa el sacramento de la penitencia o de la confesión. Esta misma estrategia se emplea en otro poema atribuido a Cornejo "Dulce Jesús, Dios mío". ${ }^{1214}$ Francesc Civil i Castellví (65) señala que el título de esta composición es "Jácara al Nacimiento de Cristo sobre títulos de comedias" y que su autor fue Francisco Valles (o Valdés). Su contenido parece confirmar que esta no está dedicada a la Purísima Concepción y que pudo ser atribuida a Cornejo y a Marchante por emplear una estrategia similar (usar títulos de comedias para evocar acontecimientos sacros) en los poemas "En títulos, Virgen pura" y "La más hidalga hermosura".

${ }^{1215}$ El verso inicial de esta composición es muy similar al del poema "En títulos, Virgen pura". Además, "Virgen pura" es el inicio de una popular canción barroca "Virgen pura, si el sol, luna y estrellas". Como sostiene Rafael Sánchez (1412), este verso también pone cierre al soneto gongorino "Si ociosa no asistió Naturaleza" dedicado a la Concepción.

${ }^{1216}$ Es el primer verso de la segunda quintilla de una canción anónima de finales del siglo XV "Qué me querréis, caballero", que se halla en el Cancionero Musical de Palacio (Barbieri 96).

${ }_{1217}$ Cada uno con su igual, de Blas Fernández de Mesa.

1218 Ver nota 1190.

${ }^{1219}$ Segundo verso de la canción "En la ciudad de Durango", recopilada por Joaquín Díaz (s.p.).

${ }^{1220}$ Habladme en entrando, de Tirso de Molina.

${ }^{1221}$ El celoso extremeño, de Antonio Coello.
} 
por el sótano y el torno ${ }^{1222}$, sus celos averiguaba, mas mejor está que estaba. Siempre ayuda a la verdad, amor, fineza y lealtad ${ }^{1223}$, halló en la rosa más pura]*

$20 *$ la más noble hermosura ${ }^{1224}$. Y la más noble serrana, mas ya del parto cercana, por aquellos horizontes el príncipe de los montes ${ }^{1225}$

25 a buscar posada va*.

No la halló*, [allá se verá]*, con que quedaron al hielo los dos amantes del cielo ${ }^{1226}$. Las pajas traen de unas azas,

30 hombre pobre, todo es trazas ${ }^{1227}$, no hicieron tal diligencia los Médicis de Florencia ${ }^{1228}$. Pues con la nieve a la boca, cada cual lo que le toca ${ }^{1229}$,

35 hace con fe y esperanza solo en Dios la confianza ${ }^{1230}$. Tienen y dicen los dos obrar bien, que Dios es Dios ${ }^{1231}$, y acercándose a Belén,

40 amar sin saber a quién ${ }^{1232}$. Comenzaron los pastores, no son todos ruiseñores ${ }^{1233}$, que ángeles hay en el nido el príncipe perseguido ${ }^{1234}$.

45 Nació allí a ser adorado, y el amor enamorado ${ }^{1235}$ en un portal sin cubierta halló casa con dos puertas, pero con muchas ventanas.

\footnotetext{
1222 Por el sótano y el torno, de Tirso de Molina

${ }^{1223}$ Se trata de uno de los versos que aparecen al inicio de la primera jornada de la comedia Primero es la honra, de Tirso de Molina.

${ }^{1224}$ Adaptación del título de la comedia La más hidalga hermosura. Ver nota 1187.

${ }^{1225}$ El príncipe de los montes, de Juan Pérez de Montalbán.

${ }^{1226}$ Los dos amantes del cielo, de Calderón de la Barca.

${ }^{1227}$ Hombre pobre, todo es traza, de Calderón de la Barca.

${ }^{1228}$ Los Medicis de Florencia, de Diego Jiménez de Enciso.

${ }^{1229}$ Cada cual lo que le toca, de Francisco Rojas Zorrilla.

${ }^{1230}$ Solo en Dios la confianza, de Pedro Rosete Niño.

${ }^{1231}$ Obrar bien, que Dios es Dios, de Juan Pérez de Montalbán.

${ }^{1232}$ Amar sin saber a quién, de Lope de Vega.

${ }^{1233}$ No son todos ruiseñores, de Lope de Vega.

${ }^{1234}$ Ver nota 1193

${ }^{1235}$ El amor enamorado, de Lope de Vega.
} 
Las vísperas silicianas ${ }^{1236}$

quiso el rey Herodes dallo, y a un tiempo rey y vasallo ${ }^{1237}$.

Vio en la nieve que cae blanca el guante de doña Blanca ${ }^{1238}$,

55 y entre la mula y el buey por la fuerza de la ley ${ }^{1239}$.

Dijo al verse sin abrigo:

"No hay amigo para amigo 1240 , pues en mí se ha de cumplir

60 reinar después de morir ${ }^{241}$.

Pues me hizo hombre porque asombre, la culpa del primer hombre ${ }^{1242}$ fue la causa del de este paso, los empeños de un caso $^{1243}$.

65 Le ha puesto en estos aprietos de una causa dos efectos ${ }^{1244}$, tendrá por grande ventura la cruz de la sepultura ${ }^{1245}$..

\section{Al Nacimiento (177) \#\#}

\section{Romance}

\section{Escriben desde Toledo}

que por San Miguel el Alto ${ }^{1246}$

de los Ángeles La Puebla ${ }^{1247}$

dio en Carabanchel de Abajo ${ }^{1248}$.

5 De Valparaíso ${ }^{1249}$, avisan

que cayó Adán desde un árbol,

${ }^{1236}$ Las vísperas sicilianas y venganza en los agravios (anónima).

${ }^{1237}$ A un tiempo rey y vasallo, de Luis de Belmonte y Bermúdez.

${ }^{1238}$ El guante de doña Blanca, de Lope de Vega.

${ }^{1239}$ La fuerza de la ley, de Agustín Moreto.

${ }^{1240}$ No hay amigo para amigo, de Francisco de Rojas Zorrilla.

${ }^{1241}$ Reinar después de morir, de Luis Vélez de Guevara.

${ }^{1242}$ La culpa del primer hombre, de Mesonero Romanos.

${ }^{1243}$ Los empeños de un caso, de Calderón de la Barca.

${ }^{1244}$ De una causa, dos efectos, de Calderón de la Barca.

${ }^{1245}$ La cruz de la sepultura, de Calderón de la Barca.

${ }^{1246}$ La Iglesia de San Miguel el Alto es una de las antiguas parroquias latinas de la ciudad de Toledo y, en sus inicios, pudo estar relacionada con la Orden del Temple.

${ }^{1247}$ Podría ser una alusión al Cerro de los Ángeles (Madrid), el cual alberga la Ermita de Nuestra Señora de los Ángeles, el Monumento al Sagrado Corazón y el Seminario Diocesano Nuestra Señora de los Apóstoles.

${ }^{1248}$ Carabanchel de Abajo es un antiguo municipio (actualmente pertenece al distrito de Madrid) donde se construyó en el siglo XV la iglesia de San Sebastián Mártir.

${ }^{1249}$ En la provincia de Cuenca, se hallan las localidades de Valparaíso de Abajo (alberga la Iglesia de Nuestra Señora de la Asunción) y de Valparaíso de Arriba (donde se encuentra la Iglesia de San Miguel Arcángel). La semejanza entre el nombre de este territorio con el del jardín del Edén permite al autor introducir el pecado original. 
y que, aun antes de caído, ya estaba descostillado ${ }^{1250}$.

Cuentan de Caín Quijada*1251

10 que dio una gala a su hermano,

toda púrpura las flores,

siendo el campo de Damasco.

De Veraguas ${ }^{1252}$, que Noé

fue del mundo cirujano,

15 pues siendo de agua la herida,

le alegró con vino el casco.

De Babilonia, que un rey

aunque envió a tres muchachos ${ }^{1253}$

a la villa de Hornachuelos*1254,

20 no sé* como se llamaron.

También de Nabuco dicen

en Egipto que fue un asno ${ }^{1255}$,

tan agudo que mostró

ser borrico de gitano.

25 También de este reino avisan

que huyeron unos gitanos,

tan amigos de las ollas

que en Alcorcón los hallaron ${ }^{1256}$.

Que les* dio tránsito el mar,

30 el cual ahogó a sus contrarios,

porque ser el más bermejo

bastaba para anegarlos.

Desde Nazaret, avisan

que porque fue allí por marzo ${ }^{1257}$

35 un grande saludador ${ }^{1258}$

rabiaban todos los diablos.

De Belén, que en un portal

un tierno amante encontraron,

ello con poco pañal,

pero muy enamorado.

\footnotetext{
${ }^{1250}$ Remite al origen de Eva (Génesis 2, 21).

${ }^{1251}$ Recrea la leyenda popular de que Caín asesinó a Abel con una quijada de burro. Las bases sobre las que se sustenta esta fueron analizadas por Meyer Schapiro (205-212).

${ }^{1252}$ Veragua era el nombre que daban los indígenas a una región de la actual República de Panamá. La estructura interna de este sustantivo ("ver" y "agua") le permite al poeta vincularlo con el episodio bíblico del diluvio universal.

${ }^{1253}$ La creencia más extendida es que los Reyes Magos partieron de Babilonia.

${ }^{1254}$ Hornachuelos es un municipio de la provincia de Córdoba donde se construyó en el siglo XV el convento franciscano de Santa María de los Ángeles (XV).

1255 Hace referencia al episodio bíblico en el que supuestamente el rey Nabucodonosor decide abandonar sus privilegios y vivir siete años entre animales para vencer su vanidad (Daniel 4, 28).

${ }^{1256}$ El pasado alfarero de Alcorcón dio origen al escudo de este municipio, donde aparecen tres ollas.

${ }^{1257}$ Según los registros astrónomos de la época y la concepción de san Juan se estima que Jesucristo nació en marzo.

${ }^{1258} \mathrm{El}$ "saludador" era la persona que por oficio saluda "con ciertas preces, ceremonias y soplos para curar el mal de rabia" (Aut.).
} 
Y aunque le llevó a la Inclusa ${ }^{1259}$,

fue tan pobre, que aun estando

con tres reyes a los pies,

no tuvo cuatro ducados.

De Tarsis*1260, avisan que

guió a dos reyes un astro,

porque el otro vino al sol

según llegó de tostado.

[De Jerusalén, que Herodes

50 era un rey tan sosegado

que, por aquietar el reino,

le despojó de muchachos $\left.{ }^{1261}\right]^{*}$.

De España, también escriben

que habrá cosa de tres años

nació tan breve un Oriente,

que no se sintió un ocaso ${ }^{1262}$.

Qué mucho, si dos auroras

vio un labrador muy honrado;

como en Atocha, riendo,

60 en la soledad, llorando ${ }^{1263}$.

Qué mucho, también, si un lego

fue de esta villa a palacio,

parecido a san Antonio,

que llevó un niño en los brazos ${ }^{1264}$.

115. Al desengaño del mundo (179) $)^{1265} \&$

\section{Ovillejo}

Quiero, pues es ocasión, dar en lance tan preciso

aviso,

y para tantas ofensas

5 de Dios, tomando este medio,

${ }^{1259}$ El Hospital de la Inclusa (llamado también Nuestra Señora de la Inclusa) fue un sanatorio para niños expósitos. Estaba situado en las cercanías de la Puerta del Sol de Madrid.

${ }^{1260}$ En la Biblia (libro de Reyes), Tarsis es un lugar situado en el Mar Rojo y que aportaba ricos metales y materiales precioso al rey Salomón.

${ }^{1261}$ Es una referencia al episodio bíblico de la "matanza de los inocentes" (Mateo 2, 16-18).

1262 Se trata del príncipe Felipe Próspero de Austria (1657-1661).

${ }^{1263}$ Felipe IV era gran devoto de la Virgen de Atocha (protectora de la Familia Real y de la Monarquía española) a ella acudió tanto para celebrar el nacimiento como para lamentar la muerte de sus dos herederos: Felipe Próspero y Fernando Tomás Carlos de Austria.

${ }^{1264}$ El poeta compara la imagen de san Antonio de Padua con el niño Jesús en sus brazos con el traslado de las reliquias de san Diego a Alcázar de Madrid (octubre de 1661) para intentar sanar al príncipe Felipe Próspero.

${ }^{1265}$ La composición guarda estrecha relación en contenido y forma con los ovillejos titulados "Desengaño de amor", que fueron publicados en Ramillete de divinas flores para el desengaño de la vida humana (Solís y Valenzuela 378-380). Esta fue duramente criticada por Antonio Alatorre, quien calificó sus versos como "nauseabundos" y "chocarreros" y el humor que contienen como "frailuno", por mezclar "lo devoto y lo obsceno" (Perduración 651). 
remedio,

y de mi musa devota,

invocando con porfía,

guía.

10 Porque todo hombre que fía de mujer sus pensamientos, saque de mis rendimientos aviso, remedio y guía.

Sepa el más galán Adonis

15 que adora, pretende y ama dama,

y el lascivo incontinente que recibe en el tardar pesar,

20 y el que pedir la ocasión que causa sufrimiento tormento

que le digo lo que siento, pues, si logra sus deseos,

25 va alcanzando por rodeos dama, pesar y tormento.

Porque si es desvanecida, le hará, si ve que se rinde, melindre,

30 causando en su corazón, abrasado en su beldad, frialdad,

y haciéndose de rogar al billete y al recado,

35 enfado.

No cometas tal pecado ni caigas en tal locura, pues ves en esa figura melindre, frialdad y enfado.

40 Causárate si es hermosa, con perfecciones su cielo, desvelo,

y si rendido de amores no estás, sino algo picado ${ }^{1266}$,

45 cuidado,

y si en fiestas y saraos no las ves siempre en lo justo, susto,

que aguado tendrá el gusto,

50 habiéndote de costar lo poco que has de gozar desvelo, cuidado y susto.

${ }^{1266}$ Se podría relacionar con estar excitado. 
Yo sé que si el arrojado y el que arriesgado pretende

55 atiende,

y el que rendido a pasiones

del amor menos se aburre

discurre,

y el que siempre cuidadoso

60 trae bigote de alquitira

mira

que muy presto se retira,

no dando por todo un higo ${ }^{1267}$,

si atendiendo a lo que digo,

65 atiende, discurre y mira.

Harate la que más quieres, y te muestra más agrado, venado,

y la más disimulada,

70 no atendiendo a tu decoro,

toro,

y la grave y circunspecta,

sin perdonar ocasión,

cabrón,

75 que todas, en conclusión,

si mi experiencia no miente,

hacen a todo viviente

venado, toro y cabrón.

$\mathrm{Si}$ atiendes a lo interior,

80 te harás, aunque seas peñasco,

asco,

conociendo que lo que amas

es, si miras la verdad,

suciedad,

85 y que es la que más te abate,

gastando tanto sudor,

hedor.

Conviértete, pecador,

pues ves que por las costumbres

90 se derrama por azumbres

asco, suciedad y hedor.

Es la mujer, si es delgada

y de algo débil sujeto,

esqueleto,

95 y si puesta en la ocasión

no muestra mucha alegría,

fría,

y si gorda y muy carnuda,

y en él revolverse terca,

${ }^{1267}$ Se trata de una reelaboración la frase "No se me da un higo", que sirve para denotar "el poco caso que se hace de alguna amenaza o de otras cosa que se desprecia, porque no da cuidado o no tiene estimación" (Aut.). 
puerca.

Hombre, mira que se acerca tu fin, no quieras mujer, que es imposible no ser esqueleto, fría o puerca.

105 Considera en la madeja de los cabellos más rojos piojos, $\mathrm{y}$ en ventanas cristalinas de una nariz, y no pocos,

110 mocos, y en los ojos más hermosos, rutilantes con pestañas, lagañas.

Hombre, mira que te engañas,

115 si acaso no has conocido, que es por lo que andas perdido, piojos, mocos y lagañas ${ }^{1268}$.

Siempre tendrás, sino vano de sobra, muchas basquiñas,

120 riñas,

y en la boca que tú dices que es coral sin resistir, pedir.

Y tal vez donde llegaste

125 tus labios con agasajos, gargajos.

Excúsate estos trabajos, alma, y no quieras pecar, pues ahí donde has de besar

130 riñas, pedir y gargajos.

Que al celebrar tu ventura sepas con quien te inquietas, tetas, que de regocijos sientas,

135 si palpas con gran bonanza, panza, con que desvelo apeteces a lo que ver te sujeta, lana prieta.

140 Del demonio es fuerte treta, del todo no te muda ver en tu dama desnuda tetas, panza y lana prieta.

Es la vecindad que tiene

145 lo que tanto te desvela, mierda,

${ }^{1268}$ La recolección "piojos, mocos y lagañas" es una clara alusión al primer cuarteto del soneto atribuido a Quevedo "Para el desengaño de los hombres": Piojos anida el pelo más pulido, / lagaña cría el ojo más vistoso / y en la nariz del rostro más hermoso / el moco verdinegro está escondido" (Bolaños 269). 
tiene la más cuidadosa,

y las desgracias más vacías,

cazcarrias,

150 cayendo lo que tanto buscas, gastando tantos florines,

orines.

Aunque sean serafines, hombre, lo sensual destierra,

155 pues ves en tan poca tierra mierda, cazcarrias y orines.

Tendrás si acaso tratares con ellas, y en gusto subas, bubas.

160 Y aunque tú más valeroso seas y de fuertes bríos, resfríos,

y si de noche la rondas, sin que un instante reposes,

165 toses.

No tan aprisa te acoses, que tendrás tu juventud sin una* hora de salud, bubas, resfríos y toses.

170 Mira que, si a esto atiendes, sacarás de mi sermón perdón,

y si de su gran doctrina tu atención queda capaz,

175 paz,

y si crees que está solo, es la verdadera historia ${ }^{1269}$, gloria.

Tenla pues en la memoria,

180 alma, si piensas salvarte, y así no podrá faltarte perdón, paz y después gloria ${ }^{1270}$.

\section{A celebrar la Octava del Santísimo Sacramento (183) \#\#}

\section{Estribillo}

- ¡Hola! Qué llega la fiesta, qué falta la solfa ${ }^{1271}$.

- ¡Hola! Qué no hay letra y tenemos la fiesta en casa.

1269 Ver nota 1158

${ }^{1270}$ Se trata de la evolución de la expresión "Aquí gracia y después gloria". En su origen, esta era empleada al final de los sermones para desear a los fieles la paz en este mundo y la gloria en el otro. Quevedo dice ser el primero en popularizar su uso para acabar coplas profanas (Quevedo, Obras 1: 414).

${ }^{1271}$ Los villancicos eran textos destinados a ser representados y cantados y en ellos la música adquiriría mayor importancia que el texto literario. De ahí que estos no dejen de reflejar características sobre la 
- ¡Digo que el Bautista tenemos con Jesucristo!

- ¡Diga cuándo viene el cordero sin el Bautista! ${ }^{1272}$

5 - ¡Hola! Qué llega la fiesta, qué falta la solfa.

- ¡Digo! ¡Diga que los festejamos en este día!

- ¡Digan que canto!

- ¡Tengan que empiezo!

- Yo celebro al Bautista!

$10-i$ Y yo al Cordero!

\section{Coplas}

¡Ah señor, el de la hostia!

Oiga a un montañés poeta,

que con mil suplicaciones

le viene a hablar en la oblea.

Óigame, señor Bautista,

el que la túnica negra

trajo en su cuerpo de guardia

sin ver nunca la bandera ${ }^{1273}$.

En ese pan ${ }^{1274}$ se da al trigo

20 estimación y grandeza,

siendo así que en sus principios

nació del haz de la tierra

Juan es montañés, muy noble ${ }^{1275}$,

$\mathrm{y}$, aunque de todos se acuerda,

$25 \mathrm{y}$, si no es a los hidalgos ${ }^{1276}$,

no envía sus encomiendas ${ }^{1277}$.

Dios es a quien un judío

hizo con mano sangrienta ${ }^{1278}$

el Conde de Puño en rostro ${ }^{1279}$,

30 cuando fue de Salvatierra ${ }^{1280}$.

influencia del acompañamiento musical, "que no figuren, por lo general, los nombres de los autores que los escribieron y que las obras impresas en pliegos presenten peculiaridades tipográficas y textuales" (Bègue, Tres 105).

${ }^{1272}$ El apóstol san Juan es el encargado de desvelar al mundo la identidad y la función del Mesías: "He aquí el Cordero de Dios, que quita el pecado del mundo" (Juan 1, 29).

1273 San Juan "aguardó" (v. 17) la llegada del Mesías realizando el "bautismo de penitencia" (v. 16), para conseguir el perdón de los pecados, y hasta su muerte siguió predicando la palabra de Dios. Su labor, por tanto, no cesó "sin ver nunca la bandera" (v. 18).

${ }^{1274}$ Se emplean varios sinónimos a lo largo del poema para referirse al Sacramento de la Eucaristía: hostia (v. 11), oblea (v.14) y pan (v. 19).

1275 Dilogía que hace alusión al carácter caritativo de Juan Bautista y a su honorable linaje, ya que se cree que sus progenitores (Zacarías e Isabel) descienden de la familia de Aarón.

1276 Hace referencia a los estatutos de limpieza de sangre.

1277 Los cristianos creen que Dios “encomendó” a san Juan la tarea de ser el precursor de Jesús. Su deber era caminar "delante del Señor, preparándole el camino" (Lucas 1, 76).

1278 Remite a la llamada "matanza de los inocentes" que llevó a término Herodes tras conocer que perdería el cargo de rey de los judíos (Mateo 2, 16).

${ }^{1279}$ El Conde de Puño en rostro es un título nobiliario español de carácter hereditario, que se concedió en 1523 al capitán Juan de Arias Dávila (IV señor de Puño en rostro). Este fue otorgado por Carlos I como recompensa a los servicios prestados en la Guerra de las Comunidades de Castilla.

${ }^{1280}$ Sirve como contraposición al título de Conde de Puño en rostro, ya que el condado de Salvatierra (otorgado a Pedro López de Ayala por Isabel de Castilla en 1491) luchó contra el primogénito de Felipe el 
Siendo nuncio del Mesías, trajo Juan la cruz a cuestas en el yermo ${ }^{1281}$, donde tuvo sobre palos penitencia ${ }^{1282}$.

Cristo fue quien en las bodas de Caná ${ }^{1283}$ de Galilea cierto día el agua clara la hizo vino de yema ${ }^{1284}$.

Juan por cubrir desnudez

40 se moría, pues se cuenta que por vestir los desnudos ${ }^{1285}$ daba la piel ${ }^{1286}$ el profeta ${ }^{1287}$.

Dios es el Verbo Divino ${ }^{1288}$, que Moisés en la ley vieja ${ }^{1289}$

45 le quiso echar a la zarza ${ }^{1290}$, y Judas le echó a la venta ${ }^{1291}$.

Precursor es el Bautista, que anduvo por esa sierra ${ }^{1292}$ hecho un Juan de Espera en Dios ${ }^{1293}$, aguardando que naciera.

A Cristo vendió la envidia en un convite por treinta,

Hermoso durante el conflicto de los Comuneros. Este vocablo alude también al papel de redentor que se otorga a Jesucristo.

${ }^{1281}$ En el evangelio de Marcos $(1,4)$, se cuenta cómo san Juan clama en el desierto de Judea la llegada del Mesías.

1282 Podría vincularse a la expresión "Sobre cuernos penitencia", que sirve para señalar que una persona "que, habiendo sufrido una ofensa, daño o desgracia, es maltratada y considerada como si fuera culpable de todo, añadiendo así un daño mayor" (Suazo 185).

${ }^{1283}$ El milagro de la conversión del agua en vino en las bodas de Caná de Galilea es el primer signo que hace que los discípulos de Jesús crean en la Gloria de su Maestro (Juan 2, 1-13).

${ }^{1284}$ El vino de yema es el de "en medio de la cuba o tinaja" (DLE).

${ }^{1285}$ Para los cristianos dar ropa a quien lo necesita es el mayor símbolo de afecto y su práctica conduce a la salvación. San Juan Bautista proclama por ello: "El que tiene dos túnicas, dé al que no tiene" (Lucas 3, 11).

${ }^{1286} \mathrm{La}$ acción de "dar la piel" relaciona la pobre vestimenta de san Juan Bautista (constituida por pieles) con su carácter generoso. Esta se asocia también con la expresión "Dejar alguien la piel" (ver nota 1287).

${ }^{1287}$ Según el evangelio de Marcos (1, 2-3), Juan es el profeta anunciado por Isaías: "Mira, yo envío a mi mensajero delante de ti para prepararte el camino (...) Una voz grita en el desierto: Preparen el camino del Señor, allanen sus senderos".

${ }^{1288}$ El Verbo Divino es "la segunda persona de la Santísima Trinidad, el Hijo engendrado eternamente por el entendimiento del Padre, imagen consustancial suya, y concreto de su Divinidad” (Aut.).

${ }^{1289}$ El Antiguo Testamento.

${ }^{1290}$ La acción de "echar a la zarza" representa para los cristianos un acto de fe hacia Dios, pues en el Éxodo $(3,2)$ se narra que este se apareció ante Moisés: "en una llama de fuego en medio de una zarza; y él miró, y vio que la zarza ardía en fuego, y la zarza no se consumía".

${ }^{1291}$ La traición que acometió Judas contra Cristo (a cambio de treinta monedas) guarda relación con la expresión "Echar a la venta de la zarza". Esta, según Correas, significa "Meterlo a voces y confusión, que no se averigüe".

1292 El desierto de Judea.

${ }^{1293}$ Se trata de un personaje del folclore español, conocido también como "Juan de vota Dios" o de "Juan voto a Dios", que encarna figura de un judío errante, el cual está condenado a vagar eternamente por el mundo por haberse burlado de Cristo mientras lo llevaban a crucificar (Corr.). Enrique Martínez-López analiza la recurrente presencia de este en la literatura de cordel española (1337-1357). 
y descomulgado Judas ${ }^{1294}$

quedó por la bula oncena. ${ }^{2295}$

Con el bautismo el Bautista

tuvo tal fe, que por ella

ante Herodes le metieron

en la fuente de cabeza ${ }^{1296}$.

Aquesto es de Dios y hombre

60 lo que en su muerte nos cuentan, porque lo del nacimiento

a buenas noches se queda.

Y, en fin, Herodías ${ }^{1297}$ quiso

rendir a Juan con finezas,

aunque el santo en este pleito

nunca trató de querellas ${ }^{1298}$.

\section{A la Magdalena (185) ${ }^{1299} \&$}

\section{Romance en ecos}

En tu alabanza mi musa usa de ecos, y en tal fiesta, a esta un afecto hoy iguala, a la devoción ostenta.

5 Cuando sin galas te admiro, miro que tus luces bellas ${ }^{1300}$ ellas admirando están tan peregrina ${ }^{1301}$ belleza.

\footnotetext{
1294 Ver nota 921.

1295 Se trata de una chanza o de una "lectura facilior" de la bula In Coena Domini (1627), que era conocida popularmente como "in cena" por otorgarse el día de Jueves Santo.

1296 Según el evangelio de Marcos (6,17-29), la cabeza de san Juan fue depositada en una bandeja para cumplir el deseo de Salomé (hijastra de Herodes Antipas).

${ }^{1297}$ Herodías fue una princesa idumea de la Dinastía herodiana de Judea, que estuvo casada primero con su tío, Herodes Filipo I, y después con el hermano de este, Herodes Antipas. Su nuevo enlace fue condenado por el Bautista, provocando al hacerlo el anhelo de ella y de su hija (Salomé) de acabar con la vida del predicador. Tal episodios se narra en los evangelios de Mateo (14, 1-12), Marcos (6, 14-29) y Lucas (9, 79).

1298 Podría tratarse de una dilogía que, por un lado, señala el "enfrentamiento" entre Herodías y san Juan, y, por otro, manifiesta la voluntad de la mujer de Herodes de hacer que el Batista se "rindiese" (v. 65) ante sus insinuaciones carnales "la quisiera".

1299 Se enmarca dentro de la tendencia lírica de recrear con ambigüedad y sensualidad la relación entre Cristo y María Magdalena. Este es el caso del jocoso epigrama "Madalena me picó", de Baltasar del Alcázar, de la burlesca Fábula de Cristo y la Magdalena, de Miguel de Barrios, o del soneto "Llegó a los pies de Cristo Madalena", de Quevedo (Sáez 110).

${ }^{1300}$ La metáfora de las "luces bellas" para representar los ojos femeninos se halla en la octava XXIV de la Fábula de Polifemo (Góngora s.p.) y en el estribillo del tono "Campos que sale Belisa”, que según Mariano Lambea (47) posee algunos indicios que permitirían atribuir su autoría a Góngora. Esta se halla también en el poema atribuido a Cornejo "Clavel, pues por tus colores".

1301 Se trata de una dilogía que puede interpretarse como "singular" o "perfecto" y que también evoca al ave de paso. La imagen del "ave peregrina" podría ser una nueva alusión a la poesía de Góngora, ya que esta aparece en las Soledades (Góngora s.p.): "Tú, ave peregrina, / arrogante esplendor, ya que no bello" (vv. 309-310).
} 
Al despreciar tantas galas ${ }^{1302}$, alas dio Cristo a una flecha ${ }^{1303}$, hecha de amor, que dispara para que a la culpa venzas ${ }^{1304}$. Cuando "esposa"1305 Dios te llama, ama, y en que seas se empeña ${ }^{1306}$

15 peña ${ }^{1307}$ que a un fino diamante ${ }^{1308}$ amante venza en firmeza ${ }^{1309}$. Dios, que por ti satisface ${ }^{1310}$, hace de amor en la empresa presa $^{1311}$, y en tus desvaríos ${ }^{1312}$ ríos tus ojos ${ }^{1313}$ se muestran. En fin, eso y tu cabello bello sol, y en su madeja ${ }^{1314}$

${ }^{1302}$ La iconografía de María Magdalena, por su pasado como pecadora, se caracteriza por mostrar su torso semidesnudo y por portar vestimentas toscas. El hecho de que este personaje bíblico no utilice "galas" (v. 5) y las desprecie (v. 10) potencia su posición como penitente.

${ }^{1303}$ El poema parece jugar con el simbolismo de Venus Urania y de Venus Pandémica (Ruíz, Góngora 8485), pues permite establecer tanto un amor divino como uno profano entre Cristo y María Magdalena.

${ }^{1304}$ La imagen de María Magdalena como una prostituta arrepentida que vagaba por el desierto, para expiar sus pecados, tiene su origen en la confusión de este personaje con varias mujeres bíblicas: "María de Magdala, a la que Cristo libera de siete demonios que representan los pecados capitales (Marcos 16, 9; Lucas 8, 1-3 y 24, 3-10; Juan 20, 11-18; María de Betania, la hermana de Lázaro y Marta que lleva a cabo la unción de los pies a Cristo con lágrimas y perfume para después secarlos con sus cabellos (Juan 12, 18); y una pecadora sin nombre que realiza una escena similar de lavatorio en casa de Simón (Mateo 26, 613; Marcos 14, 3-9; Lucas 7, 36-50)” (Sáez 109).

${ }^{1305}$ La teoría de que María Magdalena fue cónyuge de Cristo encuentra sus fundamentos en el evangelio de Felipe (55b): "la compañera del Hijo. El Señor la amaba más que a todos los otros discípulos y la besaba a menudo en su boca". También parece haber evidencias de ello en el Cantar de los cantares (3, 1-4).

${ }^{1306}$ Dilogía que señala tanto el hecho de poner voluntad en la realización de algo como la acción de dar o de dejar una prenda "como garantía del cumplimiento de un compromiso" (DLE). Esta última acepción, relacionada con "galas" (v. 5), podría hacer referencia a un intercambio de favores espirituales y físicos, como sucede con el término "pagar" en el segundo terceto del soneto de Quevedo "Llegó a los pies de Cristo Madalena”, de Quevedo (Sáez 110).

${ }^{1307}$ Metáfora que representa la actitud fiel y persistente de María Magdalena.

${ }^{1308}$ El enfrentamiento que se establece entre la "peña", María Magdalena, y el "fino diamante", Jesús, parece evocar los siguientes versos del tono amoroso "Sobre las altas rocas” de Góngora: “Hasta cuándo, enemiga, / competirá en dureza / tu duro corazón / con las más duras piedras” (Lambea 47).

${ }^{1309}$ Ver nota 282.

${ }^{1310}$ El poeta ofrece dos lecturas del verbo "satisfacer", una sacra y otra profana. En la primera, "satisfacer" implica realizar una obra que merezca el perdón de la pena merecida y, en la segunda, expresa la acción de sosegar o aquietar las pasiones $(D L E)$. Esta última interpretación cobra mayor fuerza al estar seguida de "hace de amor" (v.18).

${ }^{1311}$ Hacer presa: "Asir a una persona, una cosa o un animal y asegurarlo a fin de que no se escape" $(D L E)$. Tal acción se vincularía con los actos de "vencer" (v. 16) y de "satisfacer" (v.17) e implicaría la conquista amorosa del "ave peregrina" (v. 8).

1312 Parece remitir a los eróticos y delirantes episodios de éxtasis que se asocian a santa María Magdalena de Pazzi (1556-1607), los cuales son recogidos y analizados con detalle en la reciente edición de Helena Pizarro y Esther Jiménez.

${ }^{1313}$ La metáfora del llanto como río puede asociarse con el campo semántica de "presa" (v.19) y con la imagen de "derramar perlas" (v. 24). Además, estás palabras habrían sido dichas por Dios a Ezequiel para indicarle qué cosas no debía hacer: "No sean ríos tus ojos, no te quites el cabello, no te descalces, no te cubras el rostro, no comas manjar de viudo: porque en las muertes hacían los antiguos todas estas cosa ceremonias" (Rebolledo 262).

1314 Ver nota 76. 
deja, al hacerte Dios salva ${ }^{1315}$, alba $^{1316}$ que derramas perlas ${ }^{1317}$.

\section{A la Resurrección de Cristo (186) \&}

\section{Romance}

De santa Resurrección ${ }^{1318}$

oigan la vida y suceso,

historia muy verdadera ${ }^{1319}$, porque es el mismo Evangelio ${ }^{1320}$.

5 Era la dicha una santa, mas, según nos dice el Credo, luego al punto que murió se fue a los mismos infiernos ${ }^{1321}$. A sacar ánimas fue

10 de unos patriarcas viejos ${ }^{1322}$, que después de la cuaresma esperaban el Adviento.

No se detuvo por ser tierra caliente el infierno,

15 que, aunque es la vivienda en bajo, no son los cuartos muy frescos.

Murió de unos palos que le pegaron con un leño ${ }^{1323}$, y la mañana de Pascua ${ }^{1324}$

1315 Hacer la salva: "Frase que además del sentido recto, significa brindar y mover al gusto y la alegría". Cabe señalar que el canto "salva" que las aves hacen cuando empieza a amanecer se puede relacionar en el poema con la imagen del "ave peregrina" (v. 8).

${ }^{1316}$ Se establece un símil entre las galas (v. 9) y el alba, ya que el origen de ambas palabras remite al color blanco y también ambas designan vestimentas.

1317 Tanto la imagen de Magdalena derramando perlas como la de su cabello rubio (v. 22) aparecen en el soneto que dedica a esta Quevedo: "lágrimas derramó en copiosa vena. / Soltó del oro crespo la melena" (Sáez 111). El llanto de ella, según el testimonio de Cristóbal Fonseca (429), fue el mejor sacrificio que esta pudo ofrecer a Dios.

${ }^{1318}$ La Resurrección de Jesucristo es descrita con detalle en los evangelios de Mateo (28, 1-20), Marcos (16, 1-19), Lucas (24, 1-51) y Juan (20,1-31, y 21, 1-22).

1319 Ver nota 1158

${ }^{1320}$ Es el mismo Evangelio: "Vale lo mismo que hablar o decir la verdad" (Aut.). Esta expresión ayudaría a reafirmar que se trata de "una historia muy verdadera" (v. 3).

1321 "El Credo" dice que Jesucristo tras ser sepultado descendió a los infiernos "limbo", donde estaban las almas de los muertos que habían fallecidos antes de la Redención.

${ }^{1322}$ Los patriarcas bíblicos, recogidos en el Génesis, inician la historia de la salvación del pueblo judío. Esta está marcada por momentos clave de preparación espiritual como la "Cuaresma" (v. 19) y el "Adviento" (v. 12); el primero, conmemora la liberación de los hebreos promovida por el profeta Moisés "Pascua" y, el segundo, anuncia la llegada del Mesías, quien culminará las tareas que llevaron a término sus predecesores.

${ }^{1323}$ La errónea traducción del griego que se habría empleado para señalar el instrumento utilizado en la muerte de Cristo "madero del tormento" ha llevado a pensar que este no falleció en una cruz, sino en un leño, garrote o palo.

${ }^{1324}$ La mañana de Pascua es el tercer día tras la muerte de Cristo "Domingo de Resurrección". Desde el Concilio de Nicea (año 325), se celebra el primer domingo después de la luna llena producida en el equinoccio de primavera del hemisferio norte. 
20 resucitó de los muertos.

Como no rompió el sepulcro, se fue sin hacer estruendo y sin decir: "Ahí te queda que adobar el monumento".

25 No se supo quién ni cuántos le hurtaron, pero sospecho que serían los capachos ${ }^{1325}$ los que llevaron el cuerpo. Durmiéronse los soldados,

30 no sucediera en Toledo, que allí pasaran la noche toledana ${ }^{1326}$ sin el sueño.

De que se fuese a las guardas no les pesó, a lo que entiendo,

35 y debe de ser verdad, porque ellos no le sintieron. Tres mujeres ${ }^{1327}$ que allí estaban llevaron la nueva al pueblo, que las mujeres son siempre

40 amigas de llevar cuentos. De las dos hermanas ${ }^{1328}$ solo Magdalena vino a verlo, que Marta allá se lo haya con sus pollos a este tiempo ${ }^{1329}$.

45 "No pudo haberse sacado", dijo al momento san Pedro, porque yo tengo las llaves de la Iglesia, y soy portero". Primero llegó san Juan,

50 y no hay que admirarse de ello, que, como era Pedro piedra ${ }^{1330}$, estaba pasado el viejo.

Hiciénrole cortesías al entrar en el entierro,

55 y al pedir licencia a Juan

dijo: "Tú la tienes, Pedro"1331. Los apóstoles entraron,

\footnotetext{
1325 Ver nota 681.

1326 Ver nota 249.

${ }^{1327}$ Los cuatro evangelios señalan que fueron las mujeres las primeras en hallar el sepulcro vacío de Cristo, pero el número varía de uno, María Magdalena (Marcos 16, 9. y Juan 20, 14.), a un número no especificado. ${ }^{1328}$ Hace referencia a María (la madre de Santiago), María Magdalena y Salomé (Marcos 16, 1).

${ }^{1329}$ Parece ser una alusión a los siguientes versos que aparecen en Marta, la piadosa, una obra de Tirso de Molina: "digo que allá se lo haya / con sus pollos y amor Marta” (vv. 1956-1957). Estos, según Anne Cruz (73), harían referencia al proverbio "Con que viene Marta, la que los pollos harta", que se utiliza para mostrar desdén.

${ }^{1330}$ En el evangelio de Mateo (16, 17-19), se identifica a Pedro con la piedra sobre la que se construirá la Iglesia.

${ }^{1331}$ Podría evocar el juego infantil de "La piedra", donde el niño que trata de adivinar quién tiene la piedra se para frente al supuesto poseedor para decirle "Tú la tienes".
} 
y desde entonces creyeron

que "in natura nihil datur

$60 v a c u[u] m$ "1332, según el proverbio.

Encontraron las Marías ${ }^{1333}$

con el unto ya dispuesto,

que no hay mujer que no cuide

de él, en Dios amaneciendo ${ }^{1334}$.

65 Magdalena solamente

encontró con él primero,

y así que le vio las llagas ${ }^{1335}$

quiso aplicarle el ungüento.

Llegó María a tocarle,

70 y la dijo su maestro:

"No me toques ${ }^{1336}$, porque

ahora gana de bailar ${ }^{1337}$ no tengo".

Juntáronse las beatas

con los apóstoles luego,

75 y era de ver Pedro, entre ellas,

ir caminando hacia el huerto ${ }^{1338}$.

Diéronse las buenas Pascuas

y trataron, al momento,

de ir a cortar de la Lonja ${ }^{1339}$

de San Felipe un torrezno ${ }^{1340}$.

1332 La reformulación que se hace en el poema del proverbio "Non datur vacuum ir rerum natura" (en la naturaleza no se da nada vacío) parece proceder de los ocho libros de física de Aristóteles, cuyo comentario es publicado en 1648 por Giovanni Cottunio (631-632).

${ }_{1333}^{1334}$ María (la madre de Santiago) y María Magdalena.

${ }^{1334}$ En Dios amaneciendo: Verso que abre la cuarta estrofa del "Salmo V" (Merino 20). En este, se señala la necesidad de confesar los pecados a Dios por la mañana para hallar la luz y la verdad y aborrecer los vicios.

${ }^{1335}$ Jesucristo recibió cinco heridas en su crucifixión: en vida, le perforaron pies y manos y, tras su muerte, le lancearon el costado derecho.

1336 "Noli me tangere" son las palabras que, en la Vulgata (Juan 20, 17), Cristo dirige a María Magdalena después de su Resurrección. La polisemia del verbo "tocar" y la estrecha relación que al parecer ambos poseían (ver nota 1306) permiten realizar una interpretación erótica de la escena recreada.

1337 Ver nota 870.

${ }^{1338} \mathrm{El}$ huerto ofrece dos niveles de lectura. El primero estaría vinculado con lo sucedido después de que Cristo fuese prendido en el Huerto de los Olivos (espacio que simboliza el comienzo de la redención cristiana) frente a san Pedro y san Juan. Tras abandonar este lugar, el padre de la Iglesia negará por primera vez a su maestro. El segundo nivel podría relacionarse con el "imaginario" popular, que relaciona la acción de ir al huerto (acompañado de mujeres) con el acto sexual.

${ }^{1339}$ La Lonja de San Felipe era el conjunto de locales "mercadillos" que se habilitó alrededor del Convento de San Felipe la Real, levantado en Madrid en honor al dicho apóstol entre los siglos XVI y XVII.

${ }^{1340}$ El día de la Pascua ponía fin al tiempo de abstinencia y de ayuno que debía guardarse durante la Cuaresma e iniciaba una jornada de festejo, que permitía la ingesta de carne. 


\section{Petición a nuestra señora $(188 v) \&$}

\section{Romance}

Divina Madre de Gracia ${ }^{1341}$, señora de cielo y tierra, María, que en este nombre se juntan tus excelencias ${ }^{1342}$, pues del Consejo de Dios ${ }^{1343}$ en los estrados te sientas con título de abogada ${ }^{1344}$ y de la clase primera. Defiende un negocio

10 que ha menester tu defensa, y es una de muchas causas que has defendido como ella. De su calidad informa la petición que dispuesta

15 en un borrador te traigo, que siempre borra quien yerra. Enmiéndala, y haz, señora, que en el tribunal se lea de Dios, poniendo en limpio ${ }^{1345}$

20 primero la penitencia. Muy poderoso señor, un hombre cuya miseria, sin beneficio ninguno, de Adán aceptó la herencia.

25 Por mí y en nombre de todos los míseros hijos de Eva ${ }^{1346}$, consortes en la desdicha que sus palabras heredan ${ }^{1347}$. Con el respeto debido,

30 y usando de la cautela

\footnotetext{
${ }^{1341}$ Ver nota 1104

1342 Santo Tomás de Aquino otorga al nombre de María tres significados: "señora", "iluminada" y "estrella de mar". Este último es una metáfora de cómo la madre de Dios "dirige a los cristianos a la gloria" (Agreda 153).

${ }^{1343}$ El tribunal de justicia que encabeza Dios.

${ }_{1344}$ El título de "abogada" es otorgado a María (Lyon 519) “por la palabra del ángel fue evangelizada para que portase a Dios por la obediencia a su palabra, a fin de que la Virgen María fuese abogada de la virgen Eva; y para que, así como el género humano había sido atado a la muerte por una virgen, así también fuese desatado de ella por la Virgen".

1345 Poner en limpio: Se utiliza con un doble sentido. Por un lado, "copiar alguna cosa que estaba escrita en borrador". Por otro, "aclarar algún negocio o dependencia enmarañada y confusa" (Aut.).

${ }^{1346}$ Esta misma expresión se emplea en la obra de sor María de Jesús de Ágreda (1602-1665), mística y escritora mariana, que sostuvo que María era única y electa como el sol y que "todos los míseros hijos de Eva" debían llegar a él, "para que nos ilustre y encienda. Lleguemos a esta Madre. para que nos reengendre de amor" (156).

${ }^{1347}$ En el manuscrito $R$, se incluyen cuatro versos más que ayudan a recrear el conflicto interno que padecen los descendientes de Eva: "en el pleito original / con dos fiscales de guerra, / uno, el común enemigo, otro, la propia conciencia".
} 
que en su práctica de paz

me está enseñando la Iglesia

de una sentencia suplico

que mis errores condena

no menos que en privación

de vuestra gloria perpetua.

$\mathrm{Y}$ aunque confieso que es justa, porque el acuerdo la ordena, de tres jueces soberanos

40 conformes en una esencia ${ }^{1348}$.

Atento a los muchos autos

que ya, señora, presentan

sin juramento, pues basta

propósito de la enmienda ${ }^{1349}$.

45 Lo primero, inmenso Dios

por la general que alegan

los pecadores, culpando

su frágil naturaleza.

Lo otro, porque nacisteis

50 a perdonar mi ofensa,

y nunca el pecador alcanza

donde el pecado no llega ${ }^{1350}$.

Lo otro, porque es dictamen

de una equidad manifiesta

55 que haga lo que a vos no os daña,

y a mí, señora, me aprovecha.

Por tanto y por lo demás, que favorable me sea,

y en esta suplicación

60 por expresado se tenga.

Con ansía devota os pido

y suplico a vuestra alteza

que en la revista se sirva

de revocar la sentencia.

65 Poniendo a los dos fiscales,

que son las partes adversas ${ }^{1351}$,

perpetuo silencio en todas

las pretensiones que intentan.

Sobre que pido justicia,

70 pues el cumplir la promesa

de no faltar al que os llama,

${ }^{1348}$ La Santísima Trinidad.

${ }^{1349}$ En el manuscrito $R$, se incluyen cuatro versos más que indagan en la voluntad del pecador de ser redimido: "digo que de revocarse, / si de la sala de lleva / de justicia a la otra sala / donde es el juez de clemencia".

${ }^{1350}$ Dios liberó a la Virgen del pecado desde el primer instante de su concepción y la convirtió en mediadora entre él y los pecadores. El manuscrito $R$ contiene ocho versos que continúan recalcando el deseo del protagonista de ser perdonado: "Lo otro, porque su fruto / de vuestra sangre no medra: condenarme es condenaros / en fruto la sangre vuestra. / Lo otro, porque mis culpas he confesado, y es regla / de vuestro derecho santo / que en confesando me absuelvan".

${ }^{1351}$ Los dos fiscales que se enfrentan son el diablo y la propia conciencia. 
será justicia derecha.

Y para ello, acabando

con la cláusula maestra,

señor, el oficio imploro

de vuestra bondad inmensa ${ }^{1352}$.

Serenísima ${ }^{1353}$ María,

mi petición es aquesta,

firmarla tú, que en tu nombre

80 consiste la mayor fuerza.

Y hoy a palacio caminas

a ser abogada, señora,

no olvide este negocio

entre los demás que llevas.

120. A Cristo en la cruz (190) \&

\section{Endechas}

Dulce Jesús, Dios mío, en cuyo amor contemplo

a pechos tan de nieve

favores tan de fuego ${ }^{1354}$.

5 Refiero vuestras penas, mas cuando las refiero

pena me da el decirlas,

pues las llagas renuevo ${ }^{1355}$.

Si son tormentos tantos

10 porque yo no confieso, ya confieso ${ }^{1356}$ mis culpas, cesen vuestros tormentos.

En ese rostro hermoso mano aleve ${ }^{1357}$ os pusieron,

15 ya no será difícil dar puñada en el cielo ${ }^{1358}$.

\footnotetext{
${ }^{1352} \mathrm{El}$ manuscrito $R$ incorpora cuatro versos que muestran el anhelo del protagonista de hacer que su historia sirva de ejemplo a otros: "Y ofrézcome, porque abonen / mi vida las experiencias, / a probar lo necesario / en el término que queda".

${ }^{1353}$ Es "un gran título, más que excelentísimo, debido a los príncipes; contiene en sí una grandeza de ánimo, $\mathrm{y}$ una igualdad en todos los sucesos que ninguno le altera ni le hace mudar el semblante, y en esto se muestra el gran valor y pecho de un príncipe y de un rey" (Cov.).

${ }^{1354}$ Dilogía que hace alusión a la Pasión de Cristo y que se utiliza también para potenciar la pureza evocada a través de la nieve, ya que la llama de Dios "el Espíritu Santo" purifica a quien la recibe. Por ello, Jesús anuncia: "He venido a traer fuego sobre la tierra" (Lucas 12, 49).

${ }^{1355}$ Ver nota 1137.

1356 Ver nota 1216.

${ }^{1357}$ La referencia a la mano aleve (desleal o infiel) remite a la traición que Jesucristo sufrió por parte de Judas. Cabe señalar, además, que esta se asocia con la mano izquierda, la cual ha sido "comúnmente reputada por símbolo de las obras malas, como son las que cometen los facinerosos y aleves" (Aut.).

${ }^{1358}$ Dar puñada en el cielo: "Frase ponderativa, con que se da a entender la imposibilidad de conseguir alguna cosa muy ardua, que se pretende o desea" (Aut.).
} 
Los clavos os fijaron, y cómo que lo creo, mas no porque son clavos, mas sí porque son yerros ${ }^{1359}$.

Sois sumo sacerdote ${ }^{1360}$ muy bien en vos lo atiendo, cuando de cardenales ${ }^{1361}$ tan rodeado os veo.

Divino Isaac ${ }^{1362}$, que humilde al monte vais vos mesmo, llevando al* sacrificio la leña en ese leño ${ }^{1363}$.

$\mathrm{Al}$ raudal del costado ${ }^{1364}$

30 dando de ojos ${ }^{1365}$ me acerco, y ya ciego no me miro, aunque he vivido ciego ${ }^{1366}$

Oíd el llanto triste de este afligido pueblo,

35 escuchad sus sollozos, oíd, oíd sus ruegos.

Piedad $^{1367}$, piedad, Dios mío, piedad, divino dueño, piedad a tantas culpas, piedad a tantos ruegos.

\footnotetext{
${ }^{1359}$ Ver nota 1212.

1360 Cristo reúne en su persona dos formas de gobierno religioso: la del Antiguo Testamento (Sumo sacerdote) y la del Nuevo Testamento (Sumo Pontífice).

${ }^{1361}$ Dilogía que remite tanto a los altos cargos eclesiásticos como a los hematomas que sufrió Cristo durante la Pasión.

1362 Se establece una comparación entre Jesús e Isaac, ya que los padres de ambos (Dios y Abraham) estuvieron dispuestos a sacrificar la vida de su único hijo para lograr un bien mayor.

${ }^{1363}$ Se conforma una paronomasia entre dos elementos relacionados con la muerte: leña (pira) y leño (cruz).

${ }^{1364} \mathrm{El}$ agua y la sangre que brotan del costado de Jesús, durante su crucifixión, se justifican de la siguiente forma: "habiendo pedido Pilatos agua para lavarse, en protestación de su inocencia, y los judíos la sangres de Jesucristo sobre si, en protestación de su odio, quiso nuestro Redentor darles ambas cosas" (Paravicino $65)$.

${ }^{1365}$ Dar de ojos: "Caer sobre el rostro" (Cov.).

${ }^{1366}$ La dilogía que se produce con la palabra "ciego" complementa a la expresión "dar de ojos" (v.30) y al verbo "mirar" (v. 31) al vincularse tanto con la ausencia de vista como con el hecho de actuar de manera irracional. Además, pone en evidencia el gran cambio espiritual que ha sufrido el protagonista al darse cuenta de lo que supuso para los cristianos el sacrificio de Jesús.

${ }^{1367}$ La reiteración de la palabra "Piedad" es una referencia al "Kirie eleison", que es la segunda parte de la misa de réquiem: "Señor, ten piedad, / Cristo, ten piedad, / señor, ten piedad".
} 


\section{Al Santísimo Sacramento (191) \&}

\section{Estribillo $^{1368}$}

- Oigan en jácara ${ }^{1369}$,

- Diga.

- Escuche el crudo.

- Comience.

- Qué salen los triunfos ${ }^{1370}$.

- Salgan.

- De que es Cordero valiente ${ }^{1371}$.

- Qué tiene más.

- Yo lo diré lo que tiene.

10 Atiendan los bravos.

- Vaya.

- Lleguen los que campan.

- Lleguen.

- A quien dio Judas,

15 ya entiendo,

con la de martes en viernes ${ }^{1372}$.

- Qué tiene más.

- Yo lo diré lo que tiene.

\section{Romance}

Oigan que el bravo del cielo ${ }^{1373}$, disfrazado de valiente, por vestirse el velo blanco deja libreas celestes ${ }^{1374}$

\footnotetext{
${ }^{1368}$ Existe una variante del estribillo aquí editado, que es recogida por José Sierra (116). En su artículo, además, se señala que fue Francisco Sanz, maestro de Capilla de la Catedral de Málaga (1684-1732), quien escribió los acordes de este villancico navideño. Su disposición en forma de diálogo se corresponde con la progresiva adopción en los villancicos y en las jácaras del periodo aurisecular de rasgos teatrales (Bègue Tres 99-126).

1369 El villancico-jácara relata las valerosas aventuras de Cristo empleando recursos lingüísticos que recuerdan los textos de las jácaras literarias profanas, aunque siempre dentro del lógico decoro que exige el contexto litúrgico. En el estribillo, puede verse algunos recursos léxicos que en este género eran comunes: crudo (v. 3), valiente (v. 7). bravos (v. 10), campar (v.12). Alain Bègue (La jácara 133) recoge varios ejemplos de cómo se empleaban estos términos en otros poemas similares.

${ }^{1370}$ Para potenciar la imagen victoriosa de Jesucristo se recurre al uso del lenguaje naipesco. En este, los "triunfos" son las cartas que pertenecen al palo que se juega y, por tanto, son las que vencen al resto. El recurrente uso de referencias a los juegos de naipes en poemas sacros ha sido estudiado por Jean Pierre (55104).

1371 Jesucristo es "El Cordero de Dios".

1372 Se recurre a dos días aciagos para los cristianos: el "martes" Judas traicionó a Cristo y el "viernes" este fue ajusticiado. Además, el empleo de la expresión "dar con la del martes" rememora la lanza que atravesó su costado, pues según Correas esta significa "Dar y herir con espada ancha".

1373 Cristo es considerado en el Apocalipsis $(5,5)$ como el vencedor "León de la tribu de Judá". La iconografía de la Edad Media vinculó las características de este animal a la doble naturaleza del Redentor: la divina (asociada a la vigorosa delantera del felino) y la humana, que guardaría relación con la endeble parte trasera de este. Esta caracterización se vincularía también al oxímoron del "Cordero valiente" (v.7).

1374 Dilogía que hace referencia, por un lado, al origen celestial de Jesús y, por otro, al color azul. La vestimenta de la librea celeste sirve como contraposición al "velo blanco" (v. 21).
} 
5 Es valentón ${ }^{1375}$ que entre año tiene a su cargo mil muertes, y si no fuera por él, no hubiera misas de réquiem ${ }^{1376}$. Es quien a sus camaradas ${ }^{1377}$

10 sustenta a mesa y manteles ${ }^{1378}$, aunque un apóstol no supo sacar de mal año el vientre ${ }^{1379}$. Es también dorada espiga ${ }^{1380}$, que nunca producir quiere

15 en la tierra de la Mancha ${ }^{1381}$, aunque hay muchas que la siembren.

Es quien sobre su palabra una noche en un banquete dio una cena a doce amigos,

20 y sabe Dios de qué suerte.

Es quien apuró el guarismo un día, que a tanta gente medio partía los panes, multiplicando los peces ${ }^{1382}$.

25 Es quien a sus camaradas, porque de la mar se alejen, sin haber entonces monjas, los sacaba de las redes ${ }^{1383}$. Es quien rompió del sepulcro

$30 \quad$ la puerta ${ }^{1384}$, y por no creerle Judas se metió en un pleito y murió estando pendiente ${ }^{1385}$.

${ }^{1375} \mathrm{El}$ poeta otorga a Jesucristo en varias ocasiones la cualidad del valor, que es una de las principales características de los protagonistas de las jácaras: valiente (v. 7), bravo (v. 19), valiente (v. 23) y valentón (v. 23).

${ }^{1376}$ Para los cristianos el sacrificio y la Resurrección de Jesucristo suponen la posibilidad de otorgar a las almas de los difuntos el perdón y la vida eterna. La misa de réquiem sirve como mediación antes Dios en este proceso. Se crea, por tanto, una metonimia entre esta y las "muertes" (v. 24).

1377 Se emplea el término "camarada", frecuente en las jácaras, para señalar la cercana relación que Cristo estableció con sus apóstoles.

${ }^{1378}$ A mesa y mantel: "Disfrutando de alojamiento y comida de manera gratuita" $(D L E)$. Esta expresión hace referencia a cómo Cristo intentó satisfacer todas las necesidades de sus discípulos durante La Última Cena.

1379 Judas no se sació con la comida de Cristo, pues lo traicionó.

${ }^{1380}$ Hace referencia a la Eucaristía.

${ }^{1381}$ La tierra del pecado".

${ }^{1382}$ Los diversos milagros relacionados con la multiplicación de los peces y de los panes, tras ser estos bendecidos por Cristo, se cuentan en los evangelios de Mateo (14, 13-21), Marcos (6, 32-44), Juan (6, 115) y Lucas $(9,10-17)$.

${ }^{1383}$ El poeta juega con la polisemia de la palabra redes. Por un lado, se hace alusión a cómo los apóstoles abandonaron su oficio de pescadores para seguir a Cristo y, por otro, se insinúa que los alejó del pecado y los condujo hacia una vida virtuosa. Por último, estas también evocan la reja del locutorio de monjas (v. 45).

${ }^{1384}$ Se trata de una hipérbole, un recurso recurrente en las jácaras, que puede asociarse con la braveza que se atribuye en la composición a Cristo.

${ }^{1385}$ Dilogía que remite al suicidio de Judas por ahorcamiento y al juicio que debió acometerse contra él por haber traicionado a Jesucristo. 
Es el que venció al demonio

que contra Adán inocente ${ }^{1386}$,

35 por tentarle de la hoja ${ }^{1387}$,

quiso sacarle la sierpe.

\section{Letras al Santísimo Sacramento $(193)^{1388} \&$}

\section{Estribillo}

Acudamos sentidos

a la estafeta,

que ha llegado el correo

de cielo y tierra ${ }^{1389}$.

$5 \quad$ Muy de nieve la capa

toda cubierta.

¡Albricias!, ¡albricias!,

que hay buenas nuevas.

$\mathrm{Y}$ en un pliego cerrado

10 con una oblea

una carta de gusto

trae a la Iglesia ${ }^{1390}$.

¡Albricias!, ¡albricias!,

que hay buenas nuevas,

15 acudamos sentidos a la estafeta.

\section{Coplas}

A su esposa, el alma, escribe

el esposo en una ausencia ${ }^{1391}$,

y tan cortés, que la carta

trae su cubierta.

5 Piensan por el sobrescrito

\footnotetext{
1386 Dilogía que remite a la ausencia de pecado original y a la ingenuidad de Adán frente al diablo.

${ }^{1387}$ La acción de "tentar la hoja" sirve para mostrar el intento del demonio de hacer que Adán comiera de la hoja prohibida del Árbol de la Ciencia (Génesis 2, 17). Esta expresión también aparece, empleada en un sentido similar, en el poema atribuido a Cornejo "Hoy con gusto a cantar llego".

${ }^{1388}$ Existe una respuesta jocosa a esta composición, titulada "A vos, dueño de mi vida", que también se atribuye a Cornejo. Esta se halla en los manuscritos $R(43), S$ (141v) y $N(188)$.

${ }^{1389}$ La metáfora del Sacramento de la Eucaristía como una carta amorosa la podemos encontrar explicada con detalle en la obra del obispo José de Barcia y Zambrana (164-183). Esta fue publicada en 1690 (aunque se compuso en 1674) por el mismo editor que imprimió los cuatro primeros tomos de la Crónica Seráfica: Juan García Infanzón.

${ }^{1390}$ El propósito de esta sagrada misiva es el de establecer una relación más estrecha entre Jesucristo y sus seguidores (la Iglesia), para poder acercarlos a la salvación y a la vida eterna. El pliego se halla sellado por una oblea (v. 10), que representa al Espíritu Santo (Barcia y Zambrana 169). La oblea, por tanto, sirve como dilogía del amor divino que se recibe en forma de pan durante la Eucaristía y como recurso que se utiliza para sellar una carta.

${ }^{1391}$ Jesucristo al ascender a los cielos se ausenta de los hombres, pero su amor por estos hacer que también esté entre ellos presente a través de la Eucaristía. Cristo, por tanto, sabe juntar "el subir al cielo en la carroza de su soberana virtud con el quedarse en el trono de aquellos accidentes para comunicarse con el hombre" (Barcia y Zambrana 168).
} 
los sentidos conocerla, mas no es cosa de sustancia lo que ellos piensan ${ }^{1392}$.

Con la cruz empieza

10 dentro a escribirla, por más señas, que acabo otra vez por donde ahora empieza.

Con industria viene escrita, pues nadie puede leerla,

15 si no la pone en la lumbre de la fe nuestra ${ }^{1393}$.

"Mi alma", dice a la esposa, "aunque en breve forma sea, gotas de sangre escribirte

20 sé que me cuestas.

No sé cómo encarecerte de mi pecho las finezas, pues aunque hoy el pan te quito, ¿quién te sustenta?

25 Todo cuanto soy te he dado, y porque tú lo poseas, por ti se ha quedado en blanco ${ }^{1394}$ toda mi hacienda.

Siempre ausente de tu lloro,

30 mas no sentiré la ausencia, si el corazón como esposa pones en esta.

Adiós, y estima esta carta, que pues te doy vida en ella,

35 el no poder ser más largo es cosa cierta".

Cerró el esposo la carta $\mathrm{y}$, porque nadie la lea, con gran misterio echó el sello su omnipotencia ${ }^{1395}$.

1392 Para poder recibir los divinos frutos del Árbol Soberano de la Vida es necesario negar el alma "a la razón natural, al examen y curiosidad de los sentidos (...) solos los percibe quien llega recibirle con fe" (Barcia y Zambrana 172).

${ }^{1393}$ Los sentidos únicamente pueden ver la "cubierta", porque solo perciben "los accidentes del pan en que va cerrada la carta de Jesucristo, Dios y hombre. Este contenido, como viene para la alma, la alma lo lee, valiéndose de la luz de la fe para leerla con mérito" (Barcia y Zambrana 170).

${ }^{1394}$ Ver nota 45.

1395 Dios Padre es el encargado de "echar el sello", es decir, de perfeccionar la recepción del Sacramento de la Eucaristía: "Hunc Pater signavit Deus" (Barcia y Zambrana 170). 


\section{A la procesión que hicieron los padres de Santo Domingo en reverencia de la Concepción de nuestra señora (194v) \#\#}

\section{Soneto}

Hoy a la Concepción aclamaciones

rinde Atocha ${ }^{1396}$, y manifiesta

que llegan a rendir su altiva cresta ${ }^{1397}$, más que razones, buenas quemazones.

Hoy piadosa en alegres procesiones ${ }^{1398}$, de quien ayer escarnios ${ }^{1399}$ hace fiesta, hoy* limpia su opinión ${ }^{1400}$, aunque le cuesta sacar la mancha más de mil jabones ${ }^{1401}$.

Y pues ya fervorosa y abrasada

10 tan santa religión glorias dedica a esta opinión ${ }^{1402}$ en fuego acrisolada, ${ }^{1403}$ hágase a la pureza fiesta rica, que bien sujeta está de ser aguada ${ }^{1404}$, aunque caiga este año en dominica ${ }^{1405}$.

\section{Estando un religioso dominico hablando de la Concepción (195) \#}

\section{Redondillas}

Un dominico, enemigo

de la Concepción (qué yerro), dijo mal de ella, y al perro

\footnotetext{
${ }^{1396}$ Se trata del Colegio de Atocha (conocido también con el nombre de Convento de Santo Tomás), el cual perteneció a los religiosos dominicos. Este se hallaba situado cerca de la madrileña Plaza de Santa Cruz.

1397 Podría ser una referencia al célebre teólogo dominico Juan Gallo (1520-1578), fiel defensor de las teorías de Santo Tomás.

${ }^{1398}$ Daniel Atienza (23-26) recoge algunos de los impresos donde se detallan cómo se celebraron las fiestas dedicadas a la Inmaculada Concepción en el siglos XVII.

${ }^{1399}$ Ver nota 1111.

${ }^{1400}$ Ver nota 1079.

${ }^{1401}$ Se recurre a léxico asociado con la Inmaculada Concepción, como "limpia" (v. 7) o "mancha" (v. 8), para referirse al cambio de posición de sus detractores (entre ellos los dominicos) a mediados del siglo XVII. Además, se afirma con tono burlesco que los numerosos altercados "manchas" que estos produjeron contra la Virgen, destacan los sucedidos en Sevilla (1615-1622), necesitarán "más de mil jabones" (v. 8) para ser limpiados.

1402 Ver nota 1079.

1403 A lo largo del poema se emplean vocablos relacionados con el fuego, como "quemazones" (v. 4), "abrasada" (v. 9) y "acrisolado" (v. 11), para evocar tanto la iconografía de la Inmaculada (una mujer vestida de sol) como su capacidad purificadora. Además, tales términos también hacen referencia a la expiación que tendrán que sufrir los defensores de la postura maculista. El verbo "acrisolar" es también utilizado en otra composición dedicada a la Concepción "De una niña la grandeza", que se atribuye a Cornejo y Marchante.

${ }^{1404}$ Sirve como contraposición a las diversas referencias sobre el fuego que se realizan en el poema (ver nota 1404) y también como aviso de las posibles consecuencias negativas que puede ocasionar entre los opositores a la Inmaculada Concepción realizar un festejo en honor de esta.
}

1405 Ver nota 1122. 
le dio un gato su castigo ${ }^{1406}$.

De este prodigio testigo

es Madrid, ya sin recato

el docto y el mentecato

defiende la Concepción ${ }^{1407}$,

pues esta santa opinión ${ }^{1408}$

10 sabe defender un gato.

Si blanco o si negro era

el gato, no he averiguado.

Solo sé que fue ajustado

tal gatazo a tal perrera,

15 mas yo que es pardo dijera

el que excesos tan bastardos

castigó con pies no tardos,

dándole tan fiera tanda,

pues para el que a oscuras* anda

20 todos los gatos son pardos ${ }^{1409}$.

\section{Al Nacimiento (196) \#\#}

\section{Quintillas}

Haced que la gracia ${ }^{1410}$ encuentre,

María, que aunque trasnoche

del fruto de vuestro vientre

ciego soy ${ }^{1411}$, que canto entre

5 los gallos a medianoche ${ }^{1412}$.

Ya saben cómo el malvado

le dijo a Adán sin segundo:

"Come del manjar vedado,

cuando hagas un pecado

10

será todo lo del mundo".

Cayó desde aqueste día

en la masa universal

el tizón ${ }^{1413}$ que prometía,

\footnotetext{
${ }^{1406}$ El poeta recurre a la popular confrontación entre perros y gatos para mostrar la aversión que sienten los inmaculistas frente a las teorías maculistas que defendieron los dominicos. Uno de ellos es calificado de "perro" (v. 3), que en la época era un vocablo que se empleaba para afrentar, especialmente, a moros y judíos.

${ }^{1407}$ Desde 1622, el rey Felipe IV prohibió exponer, tanto en público como en privado, las ideas maculistas, lo cual favoreció la extensión y defensa en los altos y bajos círculos sociales de España de la Inmaculada Concepción (López Guil 29-30).

1408 Ver nota 1079.

${ }^{1409}$ Es una adaptación de la frase "De noche todos los gatos son pardos", la cual ayuda a recalcar la errónea y oscura visión sobre el origen de la Virgen que sostienen los dominicos.

${ }^{1410}$ Ver nota 1124.

1411 Ver nota 1103

1412 Celebración de la Misa de Gallo.

${ }^{1413}$ Metáfora del pecado original.
} 
y es de advertir que María

fue harina de otro costal ${ }^{1414}$.

En efecto, sucedió

que nuestro padre primero

de aquella fruta ${ }^{1415}$ probó,

pero aunque Adán pecó,

20 Dios vino a pagar el pero.

La forma de humano cobra, y una doncella de espanto hoy le parió sin zozobra, luego dirán que por obra

25 fue del Espíritu Santo.

Estaba papando viento el buey junto a la muleta, $\tan$ mojado que de intento* parece que al Nacimiento

30 vino por mar en carreta.

Diole a José compasión

la vida de su chiquillo, por buscarle con traición Judas y Herodes, los dos

35 señores de horca y cuchillo ${ }^{1416}$.

Bartolo $^{1417}$, que a su entender

fue de Herodes perseguido, dijo, viéndole nacer:

"Niño, bien podéis hacer cuenta ${ }^{1418}$

40 que hoy habéis nacido".

Perote $^{1419}$, que es muy preciado

de cortés en la parola, viendo

que al mundo ha rodado, entró diciendo: "Alabado sea el niño de la bola" ${ }^{1420}$.

Lo que a Dios se le ofrecía cargaba un pastor con ello, y aunque José lo pedía, se lo llevaba y decía:

"A Dios daré cuenta ${ }^{1421} \mathrm{~d}[\mathrm{e}]$ ello".

${ }^{1414}$ Harina de otro costal: "Ser muy ajeno o diferente de otra cosa con que es comparado" (DLE). Sirve para señalar que María no forma parte de "la masa universal" (v. 12), pues su puro origen la diferencian del resto de humanos.

1415 Se trata del "manjar vedado" (la manzana del Edén). Esta fuente del pecado sirve como contraposición del "fruto" (v. 3), que trae la salvación.

1416 Señor de horca y cuchillo: Esta expresión, relacionada con el poder aplicar la pena capital, remite al ahorcamiento de Judas (tras haber traicionado a Cristo) y a la "matanza de los inocentes" que el rey de Judea acometió.

1417 San Bartolomé.

1418 Hacer cuenta: "Vale lo mismo que suponer alguna cosa" (Aut.).

1419 San Pedro.

${ }^{1420}$ Se trata de una advocación de Cristo, que se representa en la iconografía tradicional con la figura del Niño Dios con un orbe en la mano para mostrar su poder sobre el mundo.

${ }^{1421}$ Dar cuenta: "Presentar ante el superior el cargo y data de lo que ha estado al cuidado de alguno" (Aut.). 


\section{A una dama dándola un clavel (197v)}

\section{Décimas}

Clavel, pues por tus colores y por tu grande hermosura mereciste la ventura de ser el rey de las flores ${ }^{1422}$, 5 pasa a gozar los favores hoy de un ángel soberano, donde, aunque estarás ufano, te mirarás tan corrido que te pondrás encendido ${ }^{1423}$ 10 con la nieve de su mano.

Ausente el sol, las estrellas lucen, pero con desmayos, así que muestra sus rayos, perecen sus luces bellas ${ }^{1424}$.

15 A seguir sus mismas huellas tu destino te ha guiado, pues te verás tan postrado mirándote en su presencia que te pondrás de vergüenza, entonces, más encarnado ${ }^{1425}$

\section{A nuestra señora en títulos de comedias $(198)^{1426} \&$}

\section{Quintillas}

En títulos, Virgen pura ${ }^{1427}$, de comedias he de ver que es limpia ${ }^{1428}$ vuestra hermosura, pues en Dios esto asegura amor, honor y poder ${ }^{1429}$.

Dios, Virgen, que os eligió por su madre, como rey,

\footnotetext{
1422 Ver nota 93. ardiente "encendido" (v. 9) deseo que despierta la dama.

1424 Ver nota 1303 119).

${ }^{1427}$ Ver nota 1218

${ }^{1428}$ Ver nota 1120

${ }^{1429}$ Amor, honor y poder, de Pedro Calderón.
}

${ }^{1423}$ El clavel en este poema, como en la tradición renacentista representaba la rosa, es un símbolo del

1425 El color rojo del clavel se intenta evocar a través de las imágenes de "corrido / avergonzado" y "encendido / encarnado", que contrastan con la blancura de la mano de la dama (v. 10).

${ }^{1426}$ Existen numerosas semejanzas de forma y contenido con el poema atribuido a Cornejo y a Marchante "La más hidalga hermosura", ya que en ambos se intenta defender el origen puro de la Virgen a través de títulos de comedias o versos de canciones. La reutilización y la reescritura era una práctica muy habitual "entre los músicos eclesiásticos y los poetas que prestaron ocasionalmente su pluma para la composición de las series de villancicos que serían interpretadas en las diversas capillas de la Península" (Bègue, Tres 
de toda mancha os libró, supuesto que os excluyó de la fuerza de la ley ${ }^{1430}$.

Si es que Dios en vos pusiera de la culpa la ese y clavo ${ }^{1431}$ y tan pura no os hiciera, sin que el poder le valiera,

15 fuera Dios príncipe esclavo ${ }^{1432}$.

Amor, ingenio y mujer ${ }^{1433}$

hoy en vos, Virgen, se igualen, pues le supisteis vencer, y huyendo dijo al caer:

20 "¡Rayos van! ¡Fuera, que salen!'1434”.

[El rebelde al beneficio ${ }^{1435}$

se ve a vuestros pies sin medra, pues fue en el cielo edificio ${ }^{1436}$, $\mathrm{y}$ hoy se mira por un vicio

25 escollo armado de hiedra $\left.{ }^{1437}\right]^{*}$.

Vuestra divina belleza

que vencisteis asegura de la culpa ${ }^{1438}$ la fiereza, siendo, pues, vuestra pureza

30 la más hidalga hermosura. ${ }^{1439}$

Cuando de su gran rigor el dragón dio testimonio por manchar vuestro esplendor, sentenció en vuestro favor

35 Dios el pleito del demonio ${ }^{1440}$.

El dragón ha pretendido vuestra luz oscurecer, pero jamás ha podido, porque vos siempre habéis sido la más constante mujer ${ }^{1441}$.

Cuando a Dios y a tu luz pura se opuso con asechanzas,

\footnotetext{
${ }^{1430}$ Ver nota 1240.

${ }^{1431}$ Se trata de una reformulación de la frase "Echarse una ese y un clavo", que se utiliza para dar a entender la obligación y reconocimiento que uno debe o profesa como agradecido a otro. Esta metáfora tiene su origen en "lo que se hace con el esclavo, a quien se suele herrar en el rostro o parte conocida del cuerpo, y se le pone la cifra del nombre esclavo con una 'S y un clavo enlazados" (Aut.). Tal alusión se halla también los poemas atribuidos a Cornejo "Dulce Jesús, Dios mío" y "Un pecador soy, Dios mío".

${ }^{1432}$ El príncipe esclavo, y hazañas de Escandemberg, de Luis Vélez de Guevara.

1433 Ver nota 1295.

1434 Ver nota 1096.

${ }^{1435}$ Ver nota 1097.

${ }^{1436}$ Ver nota 1099.

1437 Ver nota 1106

1438 Ver nota 111.

${ }^{1439}$ Ver nota 1185

${ }^{1440}$ El pleito del demonio con la Virgen, de Rojas Zorrilla.

1441 Ver nota 1090.
} 
le hollasteis la cerviz dura ${ }^{1442}$, tomando vuestra hermosura

de un castigo dos venganzas ${ }^{1443}$.

Que hubo en Dios poder y amor ${ }^{1444}$

de ser vuestro hijo se infiere,

luego es limpio su esplendor,

porque fuera gran rigor

50 despreciar lo que se quiere ${ }^{1445}$.

Para borrar tu pureza

quiso el demonio ser medio,

disimulando su fiereza,

mas Dios puso con fineza

a gran daño gran remedio ${ }^{1446}$.

De la culpa os libró a vos

Dios mirando por su honra,

porque sois uno de los dos ${ }^{1447}$

y a no hacerlo, fuera Dios

60 el pintor de su deshonra ${ }^{1448}$.

\section{A san Diego de Alcalá (200) \&}

\section{Quintillas}

Hoy con gusto a cantar llego

en esta fiesta precisa

lo milagros de san Diego,

un santo que, siendo lego,

5 se ve con orden de misa ${ }^{1449}$.

Hortelano fue, y le daba

al demonio gran congoja

ver, cuando contra él se armaba,

que cruel le castigaba,

10 si le tentaba la hoja ${ }^{1450}$.

Descalzo $^{1451}$ entre los abrojos

anduvo y en penas tantas;

\footnotetext{
1442 Reitera la imagen de la Concepción pisando la cabeza del diablo "se ve a vuestros pies" (v. 22).

${ }^{1443}$ De un castigo dos venganzas, de Juan Pérez de Montalbán.

${ }^{1444}$ Forma parte del título de la comedia Poder y amor compitiendo, de Juan de la Calle.

1445 Despreciar lo que se quiere, de Juan Pérez de Montalbán.

${ }^{1446}$ A gran daño, gran remedio, de Jerónimo de Villaizán.

${ }^{1447}$ Forma parte de un verso "Sentaos, y alegrad el día / en que sois uno los dos" (vv. 26-27) que aparece al inicio del primer acto de Peribañez y el comendador de Ocaña, de Lope de Vega.

${ }^{1448}$ El pintor de su deshonra, de Pedro Calderón.

${ }^{1449}$ San Diego, por ocupar el oficio de lego (v. 4), no podía realizar la orden de misa, pero su condición de santo hace que los fieles el día trece de noviembre celebren esta en su honor.

${ }^{1450}$ Remite al episodio en el que san Diego, mientras se hallaba en su huerto, tuvo que resistir las lascivas tentaciones a las que le expuso el diablo (Gonzalo de Torres, Crónica 6: 355-358). La acción de "tentar la hoja" también es utilizada en el poema "Oigan que el bravo del cielo" para describir una escena en la que el demonio intenta que Adán caiga en el pecado.

${ }^{1451}$ San Diego perteneció a la Orden de los Frailes Menores de la Observancia, cuyos miembros solían ir descalzos.
} 
curioso era y, sin enojos, siempre ponía los ojos ${ }^{1452}$

donde ponía las plantas ${ }^{1453}$.

Muy bien* a conocer se dio, pues sus milagros no ignoro, en las acciones que obró, que aunque latín no estudió ${ }^{1454}$,

20 tenía mucho decoro ${ }^{1455}$.

La corona ${ }^{1456}$ en amor ciego del martirio en que blasona, pretendió con vivo fuego, que quiso, al mirarse lego, que le abriesen la corona ${ }^{1457}$.

A los pobres con afán pan llevaba, y el rigor temiendo del guardián, en rosas ${ }^{1458}$ convirtió el pan,

30 pero le olieron la flor.

En el hábito traía el pan, y sin embarazos, que cualquier pobre que quería, como tan santo le veía, le quitaba los pedazos.

\section{Una décima $(201)^{1459}$}

\section{Décima}

\section{Guardar la mujer es ley ${ }^{1460}$, siendo el mayor imposible.}

${ }^{1452}$ Poner los ojos: Locución verbal que implica mirar con atención o realizar algo con afición o cariño $(D L E)$. Ambos significados ayudan a resaltar el carácter altruista y detallista del santo.

${ }^{1453}$ La acción de "poner las plantas" no solo remite al acto de sembrar, también es una referencia a la condición de "descalzo" de san Diego y a la perseverancia con la que llevaba a término sus ideas.

${ }^{1454}$ Los hermanos legos no solían recibir una buena formación. Su posición de "iletrados" les impedía acceder al cargo de sacerdote o al de monje de coro.

${ }^{1455}$ Calambur que alude tanto a la cualidad de poseer honor y recato "decoro" como a la ayuda que prestaban los legos en las oraciones de los monjes "de coro".

${ }^{1456}$ San Diego anhelaba que Dios le otorgara la corona de mártir por su deseo de sacrificarse a diario por la defensa de la fe: "escribiéndole en el catálogo eterno de los mártires, y reservándole para servirse de él en los ministerios sagrados de los confesores, ni por esto faltó a san Diego el laurel del martirio (...) cada día estaba pronto al martirio de nuevo" (Rojo 98).

${ }^{1457}$ Abrir la corona: Esta expresión hace referencia a la tonsura que llevan los novicios (DLE) y sirve también como alusión a la "corona" de martirio (v. 21).

${ }^{1458} \mathrm{El}$ atributo con el que la iconografía representa a san Diego de Alcalá es la rosa, debido al milagro de la transformación de los panes en esta flor para no ser descubierto por el guardián del convento (ver nota 1067).

${ }^{1459}$ En el manuscrito $S$ se titula "De cuanto peligro es la mujer" y se atribuye a fray Damián, mientras que en el testimonio $D$ no se incluye en su corpus. Esta aparece justo después de una apostilla (situada en el margen derecho) que reza así: "Hasta aquí del padre Cornejo".

${ }^{1460}$ La Iglesia consideraba el adulterio (masculino y femenino) como un pecado y, por tanto, como un delito, pero la justicia civil únicamente lo estimaba así cuando lo cometía la mujer. Desde la Edad Media, 
Es tan fiera, es tan horrible

que de un hombre forma un buey.

$5 \quad$ El marido de esta grey ${ }^{1461}$

que confía y no lo sabe

tiene disculpa muy grave,

pues es peligro notorio

honor que está en escritorio

$10 \mathrm{de}[1]$ que todos tienen llave ${ }^{1462}$.

si una esposa era infiel, "la justicia entregará a los adúlteros -junto con los bienes de la esposa- al marido para que él hiciese con ellos lo que desease, sin excluir que pudiese matarlos" (Sánchez-Pérez 289).

${ }^{1461}$ Metáfora que representa que el honor del marido "rebaño" se halla a merced de la voluntad de la mujer "pastor".

1462 Podría ser una alusión al adulterio que comete la protagonista de la comedia Los comendadores de Córdoba, doña Beatriz, la cual expresa su infidelidad mediante la metáfora del mobiliario de su lecho: “¡Ay, don Jorge! Enjuga presto cuatro sábanas de Holanda. / Saca pastillas, pues sabes, del escritorio pequeño / haz fiestas al nuevo dueño. ¿Qué aguardas? Toma las llaves” (Kirschner 551). 


\section{1. "Oye, Catuja, dulce hechizo mío" [A, B, M, D, S]}

3. mi $[\mathrm{S}]$.

4. mal [A, B, M, S]: malos [D].

4. scritos $[\mathrm{A}]$.

7. fuego [A].

13. $\sim \mathrm{mi}[\mathrm{A}, \mathrm{B}, \mathrm{M}]$.

16. bien $[\mathrm{M}]$.

23. ^de $[\mathrm{B}]$.

26. porque es $[\mathrm{S}]$.

27. pues [S].

27. sordas [A, B, M, S]: gordas [D].

33. pensar [A, B, M]: pesar [D]: papar [S].

35. cosa $[\mathrm{S}]$.

37. que [B].

42. ^todas $[\mathrm{A}, \mathrm{B}, \mathrm{M}]$.

42. están $[\mathrm{D}, \mathrm{S}]$.

43. están a nuestra $[S]$.

44. sienten [A].

45. calores $[\mathrm{A}]$ : rigores $[\mathrm{S}]$.

46. abrasan [S].

46. calores $[\mathrm{A}]$.

47. $\sim \mathrm{y}[\mathrm{B}, \mathrm{S}]$

47. como de que se caen el temor me asombra [S].

49. ^he $[\mathrm{M}]$.

52. echó [A, B, M, S]: ha hecho [D].

55. en $[\mathrm{S}]$.

56. pedazos [S].

57. desparra [A].

58. un [S].

68. haciendo gestos $[\mathrm{A}]$.

69. Vi [M].

69. Virgen [B].

73. Pero [A, B, M, D]: Porque [S].

78. un $[\mathrm{S}]$.

79. Yo [M].

80. como yo [S].

85. Ítem [S].

88. ^que es $[\mathrm{M}]$.

88. ^gran $\sim \mathrm{S}]$.

91. imit $[\mathrm{A}, \mathrm{M}]$ : imita $[\mathrm{B}, \mathrm{S}]$ :

92. y [S].

114. coma [S].

116. me da [S].

122. -muy [S].

131. a [B].

143. jamás [A]. 
147. ^en $[\mathrm{A}, \mathrm{B}, \mathrm{M}]$.

151. en ver que es tal $[\mathrm{A}, \mathrm{B}, \mathrm{M}]$ : viéndome que es tanto $[\mathrm{S}]$.

155. a manos $[\mathrm{A}]$.

157. y [S].

157. yo [A, B, M].

163. aquí $[\mathrm{A}]$ : en él [S].

165. en $[A, B, M]$.

165. saltan $[\mathrm{A}, \mathrm{B}]$.

166. ^ ${ }^{\wedge}[\mathrm{A}, \mathrm{B}, \mathrm{M}]$.

174. era cama $[\mathrm{A}, \mathrm{B}, \mathrm{M}, \mathrm{S}]$.

174. un $[\mathrm{A}, \mathrm{B}]$.

176. que $[S]$.

179. tenían malas, aunque gordas piernas $[\mathrm{A}, \mathrm{B}, \mathrm{D}, \mathrm{M}]$ : tenían, aunque gordas, malas piernas $[\mathrm{S}]$.

183. es [B].

185. en $[\mathrm{S}]$.

187. que a patadas el sueño me atropella

190. y [A, B, D, M]: en [S].

190. aplacalle [A, B].

191. ^a $[\mathrm{S}]$.

195. ^ ${ }^{\wedge}$ le da el sueño tan fuertes azabadas / que en ellas doy algunas cabezadas [S].

198. miralle [S].

201. yo [M].

209. y [S].

210. prevenida [A]:preveída [B, M].

211. todito su aderezo [S].

214. vedriada [B, M, S]

218. en que $[\mathrm{S}]$

218. vino [A].

222. resiste fuerte y no se da a partida $[S]$.

223. ^dan $[\mathrm{A}]$.

223. aun $[\mathrm{A}]$.

238. y el tal [S].

241. pues la fineza del [S].

244. $\sin [\mathrm{A}, \mathrm{B}, \mathrm{M}, \mathrm{S}]$.

248. la olla no [S].

248. para [S].

249-254. Pues la ración de oveja, que es mocosa; / pues de jamón el trozo, que no es cosa. / Antes, en cierto día que mohíno / curioso pregunté por el tocino, / la huéspeda me dijo: 'No en mis días, / que no echamos acá esas porquerías' [A, B, M, S].

261-281. [A, B, M, S].

285. estas [M].

290. zapato ramplón [A, B, S]: zapatos ramplones [D, M].

291. y su capa y con capilla [A]: y capa con capilla [B, M]: y su capazón capilla [D]: con capa y con capilla [S].

295. de [A, B, M]

295. los mostachos [S].

295. divididos [S].

296. los mostachos [S].

299. más [A, B, M, S]. 
301. pues $[\mathrm{A}]$.

308. acabarlas [A]: cascarlas [B, M]: casarlas [D]: cazarlas [S].

308. aun $[\mathrm{A}, \mathrm{M}, \mathrm{S}]$.

312. atrás $[\mathrm{B}, \mathrm{M}]$.

312. ^al aire siempre las gargantas prietas $[\mathrm{S}]$.

315. meterle $[\mathrm{B}]$.

327. y [S].

328. gastan [S]

331. ^niña $[\mathrm{M}]$.

335-345. ^Aquí al agosto vine y he quedado / sin hacer agosto y agostado / por lo que he referido, mas espero / volverme en primavera, si no muero. / Ruego, Catuja mía, más que a tus ojos, / vaya a volver en hora los enojos, que aquí me cansa todo cuanto veo. / Y a Dios hasta que logre este deseo, / que es solo el que templar hace mis males, y sírvete con estos madrigales $[\mathrm{S}]$.

\section{2. "Sepan, todos y todas, que yo adoro" [A, B, M, D, S]}

6. mucho $[\mathrm{A}]$ : que siempre $[\mathrm{S}]$.

6. pintadico [B, M].

8. ustedes $[\mathrm{A}]$.

19. pero qué $[\mathrm{A}, \mathrm{B}, \mathrm{M}]$ : mas yo qué $[\mathrm{S}]$.

21. murmura $[\mathrm{A}, \mathrm{M}]$ : mormura $[\mathrm{B}, \mathrm{D}, \mathrm{S}]$.

22. la $[\mathrm{A}]$.

27. ^más $[\mathrm{A}, \mathrm{B}, \mathrm{M}]$.

31. el $[\mathrm{M}]:$ a el $[\mathrm{S}]$.

32. al $[\mathrm{B}, \mathrm{M}]$.

33. hierro [M]: cerro $[\mathrm{S}]$.

43. ${ }^{\wedge} \mathrm{y}[\mathrm{M}]$.

44. la [A].

50. arrecadas $[\mathrm{A}]$.

51. piensen $[\mathrm{A}, \mathrm{B}, \mathrm{M}]$ : pienso $[\mathrm{D}, \mathrm{S}]$.

58. decirla $[\mathrm{A}, \mathrm{B}, \mathrm{M}]$.

71. pues [A].

81. el $[\mathrm{A}, \mathrm{B}, \mathrm{M}]$.

86. o ninfo [S].

88. cosa [S].

89. ^por [B]: ^a mí [S].

91. tontoloco [A, B, M, S].

93. enojo [S].

96. de [A].

98. asiento [A, B, M].

$106 \sim \tan [\mathrm{A}, \mathrm{B}, \mathrm{M}]$.

106. agudezas $[\mathrm{A}, \mathrm{B}, \mathrm{M}]$.

110. ese $[B, M]$.

114. mas [A].

129. no [A, B, D, M]: no [S].

130. no fui tan dichoso [A, B, M].

133. esta [S].

137. olvidadas [A, B, M]: olviadas [D]: olivadas [S].

137. ^dejaba $[\mathrm{A}, \mathrm{B}, \mathrm{M}]$. 
137. las [S].

141. que [S].

141. el [A, B, M, S]: de [D].

141. ^las [S].

153. que $[\mathrm{A}, \mathrm{B}, \mathrm{M}]$.

161. en $[A]$ : con [B, D, M, S].

166. la [B, M].

170. pie [A]: pies [B, D, M, S].

172. por poco temí [A].

173. meñique [A, B, M, S]: miñique [D].

174- alfeñique [A, B, M, S]: alfiñique [D].

177. lo [A]

185. baste [A, B, M].

\section{3. "Desde que el sol ardiente" [A, B, M, D, S]}

6. ^ni dejo el llano ni el dolor me deja $[\mathrm{A}, \mathrm{B}, \mathrm{M}]$.

19. fuiste [A, B, M, S].

22. a mi mal [A, B, M, S]: animal [D].

23. ^siempre a mi bien mudable, siempre errante [A, B, M, S].

33. ^solo [A, B, M, S].

38. si [A, B, M, S]: así [D].

41. cielo [A, B, M, S].

43. en $[S]$.

59. trémulos $[\mathrm{A}, \mathrm{B}, \mathrm{M}]$ : mustios $[\mathrm{D}, \mathrm{S}]$.

61 ondas [A, B, M, S].

63. juegue $[A, B, M]$ : juzgue $[D, S]$.

70. que $[\mathrm{A}]$.

76. ^si $[\mathrm{A}, \mathrm{B}, \mathrm{M}, \mathrm{S}]$.

81. mi [S].

86. primera $[\mathrm{A}, \mathrm{B}, \mathrm{M}]$ : primavera $[\mathrm{D}, \mathrm{S}]$.

87. ^que [A, B, M, S].

111. decilde $[\mathrm{B}]$.

112. contadle [A, M, S]: contalde [B]

112. lo que aquí estoy (contadle) padeciendo [S].

113. decilde [B].

115. $\sim \mathrm{me}[\mathrm{A}, \mathrm{M}]$.

119. ^y $[\mathrm{A}, \mathrm{B}, \mathrm{M}, \mathrm{S}]$.

\section{4. "Dulce Lisis de mis ojos" $[A, B, M, D, S]$}

3. ya $[A, B, M]$.

3. te $[\mathrm{A}, \mathrm{B}, \mathrm{M}]$.

4. en $[A, B, M]$.

9. De [A, M]: Del [B, D, S].

15. copo a copo $[A, B, M, S]$ : poco a poco [D].

18. metades $[\mathrm{B}]$.

26. ^se [A, B, M].

36. paró $[\mathrm{A}, \mathrm{B}, \mathrm{M}, \mathrm{S}]$ : para [D].

39. en que $[A, B, M]$. 
7. que $[S]$.

9. puede $[\mathrm{S}]$.

15. al $[\mathrm{B}, \mathrm{M}]$.

16. es $[B, M]$ : el $[D, S]$.

16. errar $[\mathrm{S}]$.

18. ^es [B, M]: ^anda [S].

18. ^tullido $[\mathrm{B}, \mathrm{M}]:{ }^{\wedge}$ cojo $[\mathrm{S}]$.

38. su [B, M].

49. enjugar $[\mathrm{S}]$.

49-52. [M].

55. in $[B, M]$ : en $[D, S]$.

69. Atose $[\mathrm{B}, \mathrm{M}]$ : Atase $[\mathrm{D}, \mathrm{S}]$.

69. sus [B, M]

69. piernas [S].

74. excederá $[\mathrm{B}, \mathrm{M}]$.

75. a el $[\mathrm{B}, \mathrm{M}]$.

79. remendón $[\mathrm{B}, \mathrm{M}]$ : remiendo $[\mathrm{D}, \mathrm{S}]$.

79. romances $[\mathrm{D}]$.

6. “Éranse dos licenciados" [B, M, D, S]

23. tenían $[\mathrm{B}, \mathrm{M}]$.

23. $\operatorname{las}[\mathrm{M}]$.

56. gurapa [B].

7. “Óiganme, damas, que empuño" [B, D, S]

3. dos [B].

27. gente $[\mathrm{B}, \mathrm{S}]$ : gentes $[\mathrm{D}]$.

8. "A uno que se hace una uva" $[A, B, M, D, S]$

9. canjilón [A, B, M, S]: canjiloro [D].

10. con $[\mathrm{A}, \mathrm{B}, \mathrm{M}]$.

14. como [A, B, M]: no [D, S].

25. apurados $[\mathrm{A}, \mathrm{B}, \mathrm{M}]$ : aforados $[\mathrm{D}, \mathrm{S}]$.

38. terrible $[\mathrm{A}, \mathrm{B}, \mathrm{M}]$ : tremendo $[\mathrm{D}, \mathrm{S}]$.

9. "Clodio, del mundo en la plaza" [A, B, M, D, S]

7. $\sim \mathrm{y}[\mathrm{S}]:$

8. lo [A, B, M, S]: la [D].

13. lo [A, B, M].

13. $\tan [\mathrm{A}, \mathrm{M}, \mathrm{S}]: \operatorname{tal}[\mathrm{B}, \mathrm{D}]$.

16. letor $[\mathrm{B}, \mathrm{S}]$.

18. del $[\mathrm{B}, \mathrm{S}]$ :

22. ta $[\mathrm{A}]$. 
24. ^te $[\mathrm{A}, \mathrm{B}, \mathrm{M}]$.

24. paras $[\mathrm{A}, \mathrm{B}, \mathrm{M}]$.

36. a $[\mathrm{A}, \mathrm{B}, \mathrm{M}]$.

37. bocanal [D].

47. aun $[\mathrm{A}, \mathrm{B}, \mathrm{M}]$.

52. debo $[\mathrm{A}, \mathrm{B}, \mathrm{M}]$.

53. despicarte que no es nuevo $[\mathrm{A}, \mathrm{B}, \mathrm{M}]$.

10. “Un estudiante de hogaño" [A, B, M, D, S ]

6. $\sim \mathrm{y}[\mathrm{A}, \mathrm{B}, \mathrm{M}, \mathrm{S}]$.

11. más que para $[\mathrm{A}, \mathrm{B}, \mathrm{M}]$.

12. lavar [B, M, S].

17. echándole $[\mathrm{A}]$.

23. trujeron $[\mathrm{A}, \mathrm{B}, \mathrm{M}]$.

31. y era vicio cual mascaba $[\mathrm{A}, \mathrm{B}, \mathrm{M}]$.

32. $\sim \mathrm{y}[\mathrm{B}, \mathrm{M}]$.

11. "Cansado anoche de estar" $[A, B, D, M, S]$

19. resuelto $[\mathrm{S}]$.

23. ideas $[\mathrm{S}]$.

41. del [A].

46. falta $[\mathrm{A}]$.

48. años [A, B, M].

48. volaba $[\mathrm{A}]$.

52. vastos despechos brotaba [A].

58. de [S].

66. tiraba [S].

63. de [A, B].

65. despecho [A, B, M]: despacho [D, S].

66. tirano $[\mathrm{A}, \mathrm{B}, \mathrm{M}]$.

72. a el $[\mathrm{B}, \mathrm{M}]$.

73. repasé $[A, B, M]$.

75. pues [A, B, M].

83. imagen $[\mathrm{M}]$.

84. margen gracia $[\mathrm{M}]$.

85. lechuza [A, B, M]: le hacía $[\mathrm{D}, \mathrm{S}]$.

87. en lentos [A, B, M]: a lentos [D]: alientos [S].

87. sorbos $[\mathrm{A}, \mathrm{B}, \mathrm{M}]$ : sordos $[\mathrm{D}, \mathrm{S}]$.

88. pingué $[\mathrm{A}, \mathrm{B}, \mathrm{M}]$.

93. El Dios cegara $[\mathrm{A}, \mathrm{B}, \mathrm{M}]$ : Él dice garra $[\mathrm{D}, \mathrm{S}]$.

103. para [S].

104. ^ingrata $[\mathrm{S}]$.

116. pues $[\mathrm{A}]$.

118. jamás $[\mathrm{A}]$.

130. carbón $[\mathrm{A}]$.

135. dígalo $[\mathrm{A}, \mathrm{B}, \mathrm{M}]$ : dígolo $[\mathrm{D}, \mathrm{S}]$.

138. tenéis [D].

141-142. ^ponerme, y que yo salida / buscase, pues me dio entrada [A, B, M, S]. 
145. cualquier $[\mathrm{A}, \mathrm{B}, \mathrm{M}]$ : cualquiera $[\mathrm{D}, \mathrm{S}]$.

149. ^a [A, B, M].

150. caza $[A, B, M]$ : casa $[D, S]$.

159. de [A]: del [B].

162. hiriendo [A, B, M].

168. inundaba $[A, B, M, S]$ : inundaban [D].

170. ^la [A, B, M].

170. almohadas [A, B, M]: almohada [D, S].

180. ^a $[\mathrm{A}, \mathrm{B}]$.

225. minando $[\mathrm{A}]$.

225. de [A].

232, libertad [A, B, M].

239. ofrezca [A].

244. para miedo [A].

248. playa $[\mathrm{A}, \mathrm{B}, \mathrm{M}]$ : plaza $[\mathrm{D}, \mathrm{S}]$.

256. [A, B, M, S].

264. mentí $[\mathrm{A}, \mathrm{B}]$.

274. Helicona [A, M, S]: Licona [B, D].

278. al [A].

280. le [A]: la [D, B, M, S].

286. Pues [A]: Por [B, M]: Pero [D, S].

292. le [A, B, M, S]: la [D].

294. el [A, B, D, M]: al [S].

321. tener [A].

326. pero $[\mathrm{M}]$.

333. $\operatorname{del}[\mathrm{A}, \mathrm{B}, \mathrm{M}]$.

353. bobosa $[\mathrm{A}, \mathrm{B}]$.

353. alma [S].

363. subalternada [A, B, M, S].

364. toda excesiva blancura [A].

364. ampo [B, M].

364. armiño [B, M].

365. la [A].

365. median $[\mathrm{A}]$.

365. a [A].

371. muelle [A, B, M].

390. que $[\mathrm{A}]$.

390. caminando $[\mathrm{A}]$.

410. traías [A, B, M].

412. mis [A, B, M].

412. desvelos [A, B, M].

413. la [D, S].

419. gateabas [B, M].

420. ^hacer [A, B, M].

422. lección $[\mathrm{A}, \mathrm{S}]$ : lición [B, M]: licción [D].

429. ventajas [A, B, M].

431. ejecutalla [A, B, M, S]: ejercitarla [D].

473. cual [A, B, M, S]: cuan [D].

475. sus $[\mathrm{A}, \mathrm{B}, \mathrm{M}]$.

475. cucharadas $[\mathrm{A}, \mathrm{B}, \mathrm{M}]$. 
499. abatana [A].

509. ^en [A, B, M, S].

515. siempre [A, B, D, S]: sangre [M].

516. Roma [A, B, M]: ropa [D, S].

520. harto [A, B, M, S]: harta [D].

12. "Vengar quiero mis rencillas" $[A, B, D, S]$

2. en $[A, B]: \sin [D, S]$.

9. iten $[\mathrm{A}]$.

10. que $[\mathrm{S}]$.

26. En [A].

17. la $[A, S]$.

30. $\sin [\mathrm{A}, \mathrm{B}]$.

53. puesto $[\mathrm{A}]$.

57.de el [B].

58. ^que me hiciste sin razón [A, B, S].

66. ^aun $[\mathrm{A}]$.

66. el [S].

77. bullas $[\mathrm{A}]$.

78. cueste $[\mathrm{A}, \mathrm{B}]$ : cause $[\mathrm{D}, \mathrm{S}]$.

80. sino [A]: son [B]: es [D]: se [S].

80. puede ser $[\mathrm{A}]$.

80. pullas [A, B]: empulla [D, S].

13. "A la desatada llaga" $[A, B, M, D, S]$

2. tormento $[\mathrm{A}]$.

4. ^he $[\mathrm{A}, \mathrm{B}, \mathrm{M}, \mathrm{S}]$.

4. dicho [A, B, M, S]: echo [D].

14. "Desde que tus niñas bellas" $[A, B, D, S]$

15. "Tu arroz, Marica, me enfada" [A, B, D, M, S]

16. “Cien reales por mí perdiste" [A, B, D, M, S]

3. por $[A, B, M]: \operatorname{par}[D, S]$.

6. con $[\mathrm{A}, \mathrm{B}, \mathrm{M}]$ : en $[\mathrm{D}, \mathrm{S}]$.

8. ^de $[\mathrm{S}]$.

8. diste [A, B, M]: de este [D]: este [S].

17. "Un ciego soy desgraciado" $[A, B, D, M, S]$

13. aun al que $[\mathrm{A}, \mathrm{B}, \mathrm{M}]$ : aunque al $[\mathrm{D}, \mathrm{S}]$.

22. postradas $[\mathrm{S}]$.

36. monjas $[\mathrm{A}, \mathrm{B}, \mathrm{M}]$ : monja $[\mathrm{D}, \mathrm{S}]$.

36. suele $[A, B, M]$ : suelen $[D, S]$.

45. $\operatorname{los}[\mathrm{A}]$.

59. y sin que $[\mathrm{A}, \mathrm{B}, \mathrm{D}, \mathrm{S}]$ : ya que $\sin [\mathrm{M}]$. 
59. le [A, B, D, S]: se [M].

18. "En el mar de tu hermosura" [A, B, D, M, S]

25. puede $[\mathrm{A}, \mathrm{B}, \mathrm{M}]$.

27. raya $[\mathrm{M}]$.

28. darla [A, B, M].

30. te se $[A, D]$.

42. temerlas $[\mathrm{A}]$.

19. "Mi bien, juro por mi amor" [A, B, D, M, S]

14. quiero [A, B, M].

19. al tuyo $[\mathrm{A}, \mathrm{B}, \mathrm{M}]$ : altivo $[\mathrm{D}, \mathrm{S}]$.

20. el [A, B, M, S].

26. vertía $[\mathrm{A}, \mathrm{B}, \mathrm{M}]$.

27. corría $[\mathrm{A}, \mathrm{B}, \mathrm{M}]$.

28. es [A, B, M]: en [S].

28. mía [A, B, M, S].

35. al $[\mathrm{A}]$.

36. ${ }^{\wedge} \mathrm{y}[\mathrm{A}]$.

46. de $[\mathrm{A}, \mathrm{B}, \mathrm{M}]$ : que $[\mathrm{D}, \mathrm{S}]$.

47. cielos [A, B, M, S]: ojos [D].

53. empeño [A, B, M, S]: empleo [D].

59. mismo [A, B, M, S]: mesmo [D].

\section{0. "Es de Fausto la fiereza" $[A, B, M, D, S]$}

1. fiereza [A, B, M, S]: fuerza [D].

5. crudeza $[\mathrm{A}, \mathrm{B}, \mathrm{M}, \mathrm{S}]$ : rudeza $[\mathrm{D}]$.

18. pues es justo [A, B, M].

21. anda [A, B, M, S]: andan [D].

25. galleando [A, B, M, S]: gallando [D].

30. que [A, B, M, S].

36. quienes $[\mathrm{D}, \mathrm{S}]$.

43. condena $[\mathrm{S}]$.

46. obliga [A, B, M]: obligó [D].

50. me hile a mí para un braguero $[\mathrm{A}]$.

\section{1. "De Pinto para un festejo" [D, B, S]}

18. $\sim \mathrm{a}[\mathrm{B}, \mathrm{S}]$.

19-23. ^les hizo que levantasen / el cerco más que de paso. / Aguizgarle llegan todos, / mas el monstruo, que es huraño $[\mathrm{B}, \mathrm{S}]$.

\section{2. "Dios te socorra, Marica" [B, D, S]}

11. siente $[B, S]$.

17. mullidor [B].

59. las $[\mathrm{S}]$. 
67. fueras [S].

\section{3. "Para qué es tu atrevimiento" $[A, B, D, M, S]$}

5. Deje $[\mathrm{B}, \mathrm{M}]$.

17. razón $[A, B, M]$ : rencor $[D]$ : rigor $[S]$.

28. ^lo [A, B, M, S].

30. perece $[A, B, M]$ : padece $[D, S]$.

33. amarte $[\mathrm{A}, \mathrm{B}, \mathrm{M}]$ : amante $[\mathrm{D}, \mathrm{S}]$.

\section{4. "A una reja qué ventura" $[A, B, D, M, S]$}

6. libertad [A, B, M].

26. se $[\mathrm{A}]$ : le $[\mathrm{B}, \mathrm{M}]$.

26. retoza $[\mathrm{B}, \mathrm{M}]$.

28. y $[\mathrm{A}]$.

35. aqueja [A, B, M]: deja [D]: queja [S].

36. en $[\mathrm{A}, \mathrm{B}, \mathrm{M}, \mathrm{S}]$.

44. tu [A, B, M, S]: la [D].

50. asido de tu cabello [A].

60. ^ me [A, B, M, S].

\section{5. “Con modo ya más humano" $[A, B, D, M, S]$}

1. y $[\mathrm{A}]$.

1. $\operatorname{armas}[\mathrm{A}]$.

10. cuajares $[\mathrm{A}, \mathrm{B}, \mathrm{M}, \mathrm{S}]$ : cuajadas $[\mathrm{D}]$.

16. no $[\mathrm{S}]$.

18. del [A, B, M]: de [D, S].

\section{6. "Solo el silencio testigo" $[A, B, D, M, S]$}

2. ^es $[\mathrm{A}, \mathrm{B}, \mathrm{M}, \mathrm{S}]$.

6. abrigo [A, B, M, S]: averiguo [D].

21. llame $[\mathrm{A}, \mathrm{B}, \mathrm{M}]$.

22. la $[\mathrm{A}, \mathrm{B}, \mathrm{M}]$ : lo $[\mathrm{D}, \mathrm{S}]$.

23. $\wedge^{\wedge}$ no acredita lo que siente $[\mathrm{A}, \mathrm{B}, \mathrm{M}]$.

28. [A, B, M].

27. "Marica, que a decir mal" [A, B, D, M, S]

9. Resabios [A, B, M].

20. todo cuanto tiene pilla [S].

62. medrada [S].

67. gustastes [A].

\section{8. “Quisimí quisimona, hola” $[A, B, D, M, S]$}

1. quisimona $[\mathrm{A}, \mathrm{B}, \mathrm{M}]$ : que si mona $[\mathrm{D}]$ : quesimona [S].

24. guardadas $[\mathrm{A}]$. 
24. oficiosas [A].

38-42. ^El mancebo, poco cuerdo, / que elige por mujer propia / una viuda, que es el plato / que ha servido en otra boda $[\mathrm{A}, \mathrm{B}, \mathrm{M}, \mathrm{S}]$.

45. apala el cabe $[\mathrm{A}, \mathrm{B}, \mathrm{M}]$.

58. quien $[\mathrm{A}]$.

58. ganas $[\mathrm{A}]$.

29. “Oye, tarazón de frailes" [A, B, D, S ]

1. fraile $[\mathrm{A}, \mathrm{B}]$.

10. formados $[\mathrm{A}]$.

18. en $[\mathrm{A}, \mathrm{B}]$.

18 vano $[\mathrm{A}, \mathrm{B}, \mathrm{S}]$ : bueno [D].

20. ^has $[\mathrm{A}, \mathrm{B}, \mathrm{S}]$.

40. te $[A, B]:$ le $[D, S]$.

51. ventura $[\mathrm{A}]$.

62. murmura $[\mathrm{A}, \mathrm{B}]$ : mormura $[\mathrm{D}, \mathrm{S}]$.

30. "Ya, Fabio, que hemos llegado" [A, B, D, S]

7. juzgues $[A, B]$ : juegues $[D, S]$.

8. las [A, B]: mis [D, S].

8. pues tan presto $[\mathrm{A}, \mathrm{B}]$ : que te ha puesto $[\mathrm{D}, \mathrm{S}]$.

16. palma [A, B]: alma [D, S].

31. “Tu romance, Andrés, leí” [A, B, D, S]

2. engaña $[A, B]$ : engañó $[D, S]$.

14. mas $[\mathrm{A}]$.

20. los $[\mathrm{A}, \mathrm{B}, \mathrm{S}]:$ le $[\mathrm{D}, \mathrm{S}]$.

32. "El pañuelo desembolsa" $[A, B, D, S]$

33. "Marica, no desdeñosa" $[A, B, D, S]$

34. "Queridas, mucho me enfada" $[A, B, D, S]$

2. sea descortés $[\mathrm{A}, \mathrm{B}]$.

3. $\operatorname{los}[\mathrm{A}]$.

18. tomáis $[\mathrm{A}, \mathrm{B}, \mathrm{S}]$ : tomas $[\mathrm{D}]$.

28. $\wedge^{\wedge}$ os $[\mathrm{A}, \mathrm{B}]$.

28. ven [A, B]: sois [D, S].

29. quieren $[\mathrm{A}, \mathrm{B}, \mathrm{S}]$ : queren $[\mathrm{D}]$.

39. doncellas sois $[\mathrm{A}]$.

35. "Pedro, mi ingenio recela" $[B, D, M, S]$

15. licción [S].

20. la [B, M, S]: lo [D].

21. cesan [B, M, S]: usan [D]. 
29. nos [B, M, S]: no [D].

29. hagas [B, M, S]: salga [D].

38. tú [B, M, S]: da [D].

39. espantas [B, M, S]: espantes [D].

\section{6. “Escúchenme unos esdrújulos" [B, D, S]}

14. páparo $[\mathrm{B}, \mathrm{S}]:$ papiro $[\mathrm{D}]$

18. si $[\mathrm{B}, \mathrm{S}]$ : se $[\mathrm{D}]$.

19. mirifico $[\mathrm{B}]$ : marífico $[\mathrm{D}, \mathrm{S}]$.

27. ^el [B, S].

55. lega $[\mathrm{B}, \mathrm{S}]$ : liga $[\mathrm{D}]$.

63. límite $[\mathrm{B}, \mathrm{S}]$ : siste [D].

37. "Pues vuestra piedad me abriga" $[A, B, D, S]$

9. es porque quiero $[\mathrm{A}]$

9. a $[\mathrm{B}]$.

10. hallar $[\mathrm{A}]$.

10. con $[\mathrm{A}, \mathrm{B}]$.

10. $\operatorname{los}[\mathrm{A}]$.

38. "María, viéndote hermosa" [A, B, D, M, S]

1. Marica $[A, B, M]$.

20. ${ }^{\wedge}$ me $[\mathrm{A}, \mathrm{B}, \mathrm{M}]$.

38. reñir $[\mathrm{A}]$.

45. es $[B, M, S]$.

53. pues $[\mathrm{A}]$.

\section{9. "Malo me siento, Marica" [B, D, M, S]}

22. regazo $[\mathrm{B}, \mathrm{M}]$ : ragazo $[\mathrm{S}]$.

35. salto $[\mathrm{B}, \mathrm{M}]$.

40. "Después que por qué se usa" $[B, D, S]$

2. he gastado [B]: gastada [S].

5. malas [B].

30. grave $[B, S]$.

\section{1. "Bien puede, Lisis, un triste" $[A, B, D, S]$}

22. ya que $[\mathrm{A}, \mathrm{B}, \mathrm{S}]$ : aunque [D].

40-55. ^A tus rayos triste muero, / mas en tan gallarda acción / que mucho que a rayos muera / quien al cielo se atrevió. / Si a tus luces atrevido / soy soberbio Faetón, / ya en horribles precipicios / se castiga mi ambición. / Porque registro a tus luces /quise hacerme, ciego estoy, / mas siempre cegó quien quiso / registrar la luz del sol. / Si triunfar solo pretendes / de un altivo corazón, / pues ya la victoria gozas, / suspende la ejecución [A, B, S].

66. triste $[A, B, S]$ : tristeza [D]. 
42. "Licencia solo me has dado" [A, B, D, M, S]

12. ^la $[\mathrm{A}]$.

15. tu [A, B, M, S]: la [D].

25. camina $[A, B, M, S]$ : camino [D].

26. amar [A, B, M, S]: amor [D].

29. cebar [A, B, M, S].

30. pasión $[\mathrm{A}, \mathrm{B}, \mathrm{M}]$ : pensión $[\mathrm{D}, \mathrm{S}]$.

31. me [A, B, M, S]: no [D].

34. ^y $[\mathrm{A}, \mathrm{B}, \mathrm{M}, \mathrm{S}]$.

36. en $[A, B, M, S]$ : a [D].

43. "Anfriso, con atención" $[A, B, D, M, S]$

17. presumir bozal [A, B, M]: presumía bocal [D, S].

19. no $[\mathrm{A}, \mathrm{B}, \mathrm{M}, \mathrm{S}]$.

33. güera $[A, B, M, S]$ : guerra $[D]$.

34. fina $[A, B, M, S]$ : fría $[D]$.

38. ya $[A, B, M]$ : y a $[D, S]$.

44. "Palma, en viendo tu beldad" [A, B, D, S]

5. deidad $[\mathrm{A}, \mathrm{B}]$.

45. "Don Juan, no tengo por bueno" $[A, D, M, S]$

46. "Hoy, Clori, pretendo amarte" [B, D, S]

47. "Ya que tan galante has sido" [B, D, M, S]

8. ofrezco [B].

11. ofrecí [B, M, S]: ofrece [D].

18. que [B, M, S]: quie [D].

18. aunque $[\mathrm{S}]$.

19. haré $[\mathrm{B}, \mathrm{M}]$ : harán $[\mathrm{D}, \mathrm{S}]$.

48. "De pedir (nunca yo fuera)" [A, B, D, M, S]

2. vine $[A, B, M]$ : toda $[D, S]$.

27. ^más [A, B, M, S].

39. estés $[\mathrm{A}]$.

49. "María, a tu sucia cara" $[A, B, D, M, S]$

4. muy $[\mathrm{A}]$.

50. "Un galán corto de talle" $[B, D, S]$

35. pudiera [B]: supiera $[D, S]$. 
3. Pues [B].

10. sabes $[A, B, M]$ : sabrás $[D, S]$.

12. ^en $[\mathrm{A}]$.

12. que $[\mathrm{A}]$.

12. ponerlas $[\mathrm{A}]$.

18. necias [A, B, M, S]: necesias [D].

19. por $[A, B, M]$ : para $[D, S]$.

19. tuve [S].

28. queda $[\mathrm{A}, \mathrm{B}, \mathrm{M}]$ : queja $[\mathrm{D}, \mathrm{S}]$.

32. hice $[\mathrm{A}, \mathrm{B}, \mathrm{M}]$ : hizo $[\mathrm{D}, \mathrm{S}]$.

37. Pues $[\mathrm{A}]$.

46. su [S].

46. se $[\mathrm{A}]$.

46. tenga[A].

48. mi [A, B, M]: muy [D, S].

\section{2. "Clori, que para ser linda" [A, B, D, M, S]}

3. si $[\mathrm{A}]$.

13. el [A, B, M]: al [D, S].

14. suelen $[\mathrm{S}]$.

20. trajes [B].

21. valerte $[A, B, M, S]$ : valiente $[D]$.

21. ^en su [A, B, M, S].

21. paño [S].

22. gente $[\mathrm{A}, \mathrm{B}, \mathrm{M}, \mathrm{S}]$ : gentes $[\mathrm{D}]$.

22. ^y $[\mathrm{A}, \mathrm{B}, \mathrm{M}, \mathrm{S}]$.

32. con ellas [B].

\section{3. "En aquesta soledad" $[A, B, D, S]$}

Glosa 1:

6. veo $[A, B]$ : ves $[D, S]$.

29. conoce $[\mathrm{A}, \mathrm{B}]$ : conocí $[\mathrm{D}, \mathrm{S}]$.

30. te $[\mathrm{S}]$.

31. apartó [A, B, S].

Glosa 2:

1. Elisa [A, B, S].

1. $\sim \mathrm{y}[\mathrm{S}]$.

38. contigo $[\mathrm{B}, \mathrm{S}]$.

54. "Pues que me han dado licencia" $[A, B, D, M, S]$

10. Yo [A, B, M, S].

14. callándole $[\mathrm{A}, \mathrm{B}]$.

14. le [M].

14. encareces [A, B, M]. 
18 , que $[\mathrm{A}]$.

19. forman $[\mathrm{A}]$.

20. suspendiendo $[\mathrm{A}, \mathrm{B}, \mathrm{M}]$.

33 , pues $[\mathrm{A}]$.

40. necia $[\mathrm{B}]$.

55. “Un mal francés, Marica, tan grosero" $[A, B, D, M, S]$

14. $\sim \mathrm{y}[\mathrm{S}]$.

56. "A todos tu beldad rigores flecha" [A, B, D, M, S]

Redondillas

1-8. ^Lisis, tu favor invoco / cuando con tu desdén lucho, / porque, ya que rezas mucho, / reces también por mí un poco. / Y no tira mi intención / a estorbar tu santa vida, / antes mi amor te convida / a que tengas devoción [A, B, M, S].

Soneto

3. $\sim \mathrm{y}[\mathrm{S}]$.

5. ^no $[\mathrm{S}]:{ }^{\wedge} \mathrm{de}[\mathrm{B}]$.

12. $\sim \mathrm{S}]$.

57. "Suelto el cabello por el aire ufano" [A, B, D, M, S]

15. a $[\mathrm{A}]$

15. rodapelo $[\mathrm{A}, \mathrm{B}, \mathrm{S}]$.

17. tomar $[\mathrm{A}, \mathrm{B}, \mathrm{M}]$ : $\operatorname{lograr}[\mathrm{D}, \mathrm{S}]$.

58. “Amoroso, prudente y cortesano" [A, B, D, M, S]

59. "Rudo pincel de mano inadvertida" $[A, B, D, M, S]$

2. copia $[\mathrm{A}]$.

8. si [B].

60. "Por los yerros, Lisis bella, de un traslado" [A, B, D, M, S]

1. Lisis bella [A]: Yisbella [B, D, M, S].

11. constante $[\mathrm{A}, \mathrm{B}, \mathrm{M}]$.

13. El manuscrito $A$ no contiene este verso.

61. "De emboscado entre matas de tu pelo" [A, B, D, M, S]

4. en blanco [A, B, M]: armada [D]: armado [S].

4. $\wedge^{\wedge}$ vi que $[\mathrm{S}]$.

12. ^ $\mathrm{a}[\mathrm{A}, \mathrm{B}, \mathrm{M}]$.

13. la $[\mathrm{A}]$.

14. ves $[\mathrm{A}, \mathrm{B}, \mathrm{M}, \mathrm{S}]$ : ve $[\mathrm{D}]$.

62. "Breve pie reducido a cárcel breve" [A, B, D, M, S] 
5. ^es $[\mathrm{B}, \mathrm{M}]$.

7. sobró $[\mathrm{B}, \mathrm{M}]$.

8. guardó $[\mathrm{A}, \mathrm{B}, \mathrm{M}]$.

12. escandaloso $[\mathrm{A}, \mathrm{B}, \mathrm{M}]$.

63. “Cómo quieres, Anarda, que sea casto" [A, B, D, M, S]

10. puesto [A, B, M, S].

64. "Ya no puedo vivir si no me capo" [A, D, M, S]

9. destapada $[\mathrm{A}]$.

12. quedara $[\mathrm{A}, \mathrm{B}, \mathrm{M}]$.

13. ^es $[\mathrm{A}, \mathrm{S}]$.

13. pija $[\mathrm{A}]$.

65. "Disparates, Antón, muy mal zurcidos" [A, B, D, M, S]

6. librados $[\mathrm{M}]$.

10. te $[A, B, M, S]$ : el lenguaje [D].

11. ingenio $[\mathrm{A}, \mathrm{B}, \mathrm{M}, \mathrm{S}]$ : lenguaje $[\mathrm{D}]$.

12. musa $[A, B, M]$ : saya $[D, S]$.

12. saya huera $[A]$ : sayaguesa $[B, S]$ : saya gusa $[D]$ : saya güera $[M]$.

66. "Cruz, si cristiano soy" [A, B, D, M, S ]

8. ^tú $[\mathrm{A}, \mathrm{D}, \mathrm{S}]$.

13. dicho $[\mathrm{M}]$

67. "Apenas, señor, te viste" [A, B, D, M, S]

8. está tu ciencia $[\mathrm{S}]$.

8. ${ }^{\wedge}$ ya $[\mathrm{B}, \mathrm{M}]$.

28. inexorable $[\mathrm{B}, \mathrm{M}]$ : mejorable $[\mathrm{D}]$ : miserable $[\mathrm{S}]$.

29. ^al dar aprieta la mano $[\mathrm{B}, \mathrm{M}]$.

33. meta $[\mathrm{S}]$.

68. "Pedite, mi buen Cruz, suelas" [A, B, D, M, S]

3. ^es $[\mathrm{D}, \mathrm{S}]$.

4. sin darme suela, me asuelas $[\mathrm{A}, \mathrm{B}, \mathrm{M}]$ : pedir, y sin darme asuelas $[\mathrm{D}, \mathrm{S}]$.

14. pidan [S].

43. contigo [B].

43. [A].

57. por $[\mathrm{M}]$.

69. "Estaba Lisis en campal batalla" [A, B, D, M, S]

10. exceso $[\mathrm{M}]$.

12. seso $[\mathrm{A}, \mathrm{B}, \mathrm{M}, \mathrm{S}]$ : deseo $[\mathrm{D}]$. 
70. "De mis finezas el bajel incierto" [A, B, D, M, S]

4. porque $[\mathrm{A}]$.

71. "Hoy sin más ni más me allano" [B, D]

31. en $[B]$.

72. "Señor, jurador he sido" $[B, D, S]$

6. comprendo [B, D]: comprehendo [S].

7. esta [B, D]: aquesta [S].

8. sabor [B, S]: amor [D].

11. altar [B]: alma $[\mathrm{D}, \mathrm{S}]$.

73. "A Pascuala dijo Bras" [A, B, D, M, S]

3. la $[\mathrm{A}]$.

16. contrapás $[\mathrm{A}, \mathrm{B}, \mathrm{M}]$ : contrapaz $[\mathrm{D}, \mathrm{S}]$.

26. ${ }^{\wedge} \mathrm{y}[\mathrm{A}]$.

31. Una $[\mathrm{A}, \mathrm{M}]$.

31. Marta $[\mathrm{A}, \mathrm{M}]$.

31: aforre $[\mathrm{A}, \mathrm{M}]$.

32. Ursón $[\mathrm{A}, \mathrm{B}, \mathrm{M}]$ : hurón $[\mathrm{D}, \mathrm{S}]$.

34. con $[\mathrm{A}]$.

39. un $[A, B, M]$ : con $[D, S]$.

44. con $[\mathrm{A}]$.

50. ambar gris [A, B, M, S]: ambraguis [D].

63. alcuoza [B].

74. rue señor $[\mathrm{A}]$.

75. hidalgas $[\mathrm{A}]$.

76. galgos [S].

84-85. [A].

74. "En la villa de Carrión" $[A, B, D, M]$

4. Laurencio [A, B, M].

35. oyen $[\mathrm{A}, \mathrm{B}, \mathrm{M}]$.

41. enfermamos $[\mathrm{M}]$.

47. $\sim \mathrm{y}[\mathrm{A}, \mathrm{B}, \mathrm{M}]$.

52. ^el [A, B, M]

54. y $[\mathrm{A}, \mathrm{M}]$.

55. y $[\mathrm{A}, \mathrm{M}]$.

58. saludable $[\mathrm{A}, \mathrm{M}]$.

55. consejo $[\mathrm{A}, \mathrm{M}]$.

75. "En Málaga vi a Rufina" [A, B, D, M, S]

14. a $[\mathrm{A}, \mathrm{M}]$. 
21-24. [A, M].

76. "Fernando, a quien por soberbio" [A, B, D, M, S]

10. ^en $[\mathrm{A}, \mathrm{B}, \mathrm{M}]$.

20. ensayó $[A, B, M]$ : engañó $[D, S]$.

22. cuan $[\mathrm{A}]$.

28. puentes [A, B, M].

54. a $[\mathrm{A}]$.

77. "En la ruda política mía" [A, B, D, S]

1. ruda $[\mathrm{A}, \mathrm{B}, \mathrm{S}]$ : rueda $[\mathrm{D}]$.

4. Anarda [A]: Antandra [B]: Atandra [D].

7. sabes [S].

7. en $[S]$.

10. cuasi $[\mathrm{A}]$.

10. injusto $[\mathrm{A}]$ : justo $[\mathrm{B}, \mathrm{D}, \mathrm{S}]$.

78. "En la firme política nuestra" $[A, B, D, S]$

2. firmes $[\mathrm{A}]$.

12. el $[\mathrm{A}]$.

79. "No quieran tus sinrazones" [A, B, D, M, S]

7. advierte [A, B, M].

80. "Del rumbo de Francelina" $[A, B, D, M, S]$

3. estoy [A, B, M, S]: estos [D].

81. "Fuera, fuera que Juanilla" [A, B, D, M, S]

10. brío [A].

82. "Los ganados de Fileno" $[A, B, D, S]$

1. de [A, B, S]: del [D].

1. Fileno $[\mathrm{A}, \mathrm{B}, \mathrm{S}]$ : buen mayoral $[\mathrm{D}]$.

5. amanece $[\mathrm{A}, \mathrm{B}, \mathrm{S}]$.

6. levanta $[\mathrm{A}, \mathrm{B}, \mathrm{S}]$ : levante $[\mathrm{D}]$.

9. veloces $[\mathrm{A}, \mathrm{B}, \mathrm{S}]$ : veloz [D].

83. “Genil, galán de los ríos" $[\mathrm{A}, \mathrm{B}, \mathrm{D}, \mathrm{S}]$

1. Genil [A, B]: Gentil [D, S].

3. copos $[\mathrm{A}, \mathrm{B}]$ : campos $[\mathrm{D}, \mathrm{S}]$.

4. que $[S]$.

8. ^ es $[\mathrm{A}, \mathrm{B}]$. 
13. el $[A, B]$ : es $[D, S]$.

14. para $[\mathrm{A}, \mathrm{B}, \mathrm{S}]$ : pura $[\mathrm{S}]$.

84. "Sonoro arroyuelo" $[A, B, D, S]$

3. tiorba $[A, B]$ : tiorba $[D, S]$.

4. $\operatorname{riscos}[\mathrm{A}, \mathrm{B}]: \operatorname{rizos}[\mathrm{S}]$.

85. "Un estudiante este curso" $[D, S]$

27. escriba [S].

86. "De un pie escribir quiero en suma" $[D, S]$

2. el $[\mathrm{S}]$.

7. altar $[\mathrm{S}]$.

17. le [S].

25. de [D]: la [S].

25. matiz [D]: raíz [S].

31. la [S].

33. al [S].

87. “El sacristán qué desmán” [D]

88. “Por tomar Judas el grado" [D, S ]

17. en [S].

24. que [S].

89. "Musa mía, con astucia" $[D, S]$

58. Jubel [S].

75-76. a ella se le está cayendo / y él se le está levantando [D]: a él se le está levantando / y a ella se le está cayendo [S].

90. "Pues que su entretenimiento" $[\mathrm{D}, \mathrm{S}]$

2. a $[\mathrm{S}]$.

19. cegara [S].

24. es [S].

31. Corrido estoy y confuso [D]: Estoy confuso y corrido [S].

91. "Nise, a quererte me inclino" $[\mathrm{D}, \mathrm{S}]$

92. "Acabose el amistad" [D, S ]

93. "Reyes míos, desde el día” [D, S]

21. amores [S].

24. ${ }^{\wedge}$ no $[\mathrm{S}]$. 
24. ardores [S].

31. llama [S].

36. y con la radal se ataja [D]: que se me sube y se baja [S].

66. pelota [S].

74. lo [S]: los [D].

74. de $[S]$.

94. "Esta mañana en Dios y en hora buena" [D, S ]

8. de $[\mathrm{S}]$.

95. "Lo menos bello y más apetecido" [D, S $]$

13. mesar [S].

96. "De una taberna salía" $[D, S]$

34. otros [D]: otro [S].

36. $\operatorname{voz}[\mathrm{S}]$

97. "Un tudesco, humana cuba" [D, S]

98. "Oiga, hermano fray Francisco" [A, B, D, M, S ]

1. padre $[\mathrm{A}]$.

6. largas $[\mathrm{A}, \mathrm{B}, \mathrm{M}]$.

23. paco [A]: como [B, M, S].

29. adredo [S].

33. cielo [A].

35. tener $[\mathrm{S}]$.

51. le $[\mathrm{A}, \mathrm{B}, \mathrm{M}]$.

99. "Un devoto singular" $[B, D, S]$

10. nunca compró $[\mathrm{B}, \mathrm{S}]$.

15. sola [B].

26. yo [S].

27. qué en [S].

31. maulero [B]: mauelero [D]: novelero [S].

47. dará [S].

54. quiere $[\mathrm{S}]$.

56. le [B].

100. "Otra vez tengo la pluma" $[A, B, D, M, S]$

5. de $[\mathrm{A}]$.

19. su maña $[S]$.

44. una $[\mathrm{A}, \mathrm{M}]$.

53. donde [A, B, M, S]. 
53. ^en [A, B, M, S].

101. "Hanme mandado una cosa" [A, B, D, M, S]

4. aquesta [A, B, M]: aunque es tal [D]: aunque ella [S].

6. sentido $[\mathrm{A}, \mathrm{B}, \mathrm{M}]$.

30. que [A, B, M, S].

37. le $[\mathrm{A}]$.

37. manco [A, B, M, S].

102. "La más hidalga hermosura" $[A, B, D, M, S]$

15. le $[\mathrm{A}, \mathrm{B}, \mathrm{M}]$ : lo $[\mathrm{D}, \mathrm{S}]$.

19. tres $[\mathrm{A}]$.

28. les $[\mathrm{B}, \mathrm{M}]$.

103. "La Concepción este día” $[A, B, D, M, S]$.

1. en $[\mathrm{A}, \mathrm{B}, \mathrm{M}]$.

5. contar $[\mathrm{B}, \mathrm{M}]$.

20. libertad [A, B, M].

35. palma [S].

104. "De tu Concepción, Señora" [A, B, D, M, S]

8. debamos [A, B, M]: debo [S].

16. es $[\mathrm{S}]$.

27. pura $[A, B, M]$ : para $[D, S]$.

39. en [B]: de $[\mathrm{M}]$ : aqueste $[\mathrm{S}]$.

44. fe [A, B, M].

105. "Oigan lo que saca en limpio" [A, B, D, M, S]

38. con $[\mathrm{A}]$.

39. le [S].

46. las [B].

106. "De una niña la grandeza" $[A, B, D, S]$

31. tenerle [S].

107. "Sabed, Señora doncella" [A, B, D, M, S]

17. ${ }^{\wedge}$ no $[\mathrm{A}, \mathrm{B}, \mathrm{M}, \mathrm{S}]$.

108. "De pie quebrado unas coplas" $[A, B, D, S]$

9. diablo [B].

14. escampado [A].

35. y $[\mathrm{A}]$. 
41. Háganle [A].

109. "De Francisco por menor" [A, B, D, M, S]

10. su [A, B, M].

12. la $[\mathrm{A}, \mathrm{B}, \mathrm{M}]$ : de $[\mathrm{D}, \mathrm{S}]$.

30. la mosca [A, B, M]: las moscas [D].

36. sintiendo [D]: diciendo [M]: fingiendo [S].

41. $\wedge^{\wedge}$ me $[\mathrm{A}]$.

46. ^gran $[\mathrm{A}]$ : de $[\mathrm{M}]$.

\section{0. "Hoy mi devoción aclama" $[A, B, D, M, S]$}

2. stilo $[\mathrm{A}]$.

45. hundía $[\mathrm{A}]$.

66. siendo [A, B, M].

\section{1. “Al señor Bautista, el jaque" [A, B, D, M, S]}

5. Este $[\mathrm{A}]$.

14. el [S].

22. ellos [A].

44. duelo [A, B, M]: luego [D, S].

58. y $[\mathrm{A}]$.

68. le vieron $[\mathrm{A}]$.

69. la montaña [A, B, M, S].

70. gesto $[\mathrm{S}]$.

86. al [A]

87-99. ^El coleto le pescaron. / en la trena el carcelero / le echó, en lugar de prisiones, / una cadena por yerro. / Pensando el maldito rey / qué se haría de aquel preso / estuvo un poco dudoso, / y diole en cabeza luego. / Como si bálago fuera, / mandole segar el pescuezo, /e hizo muy bien de segarle, / porque era como el pan bueno. / Este fin tuvo el Bautista, / el que vivió recoleto, / y, a pasos de su garganta, / se fue subiendo a los cielos [A, B, M].

\section{2. “Un pecador soy, Dios mío" [A, B, D, M, S]}

10-14. ^que rendida al grave peso / de mis delitos el alma / tiene postrado el aliento. / Quién me librara de mí [A, B, M].

37. son $[\mathrm{B}]$.

46. primero $[\mathrm{A}]$.

54. imperio $[\mathrm{A}, \mathrm{B}, \mathrm{M}]$.

67. y $[\mathrm{A}]$.

74. ¿qué os doy?, nada os ofrezco [S].

\section{3. "Érase una Virgen pura" [A, B, D, M, S]}

10. entre tanto $[\mathrm{A}, \mathrm{B}, \mathrm{M}]$ : en entrando $[\mathrm{S}]$.

12-18. ^Pues por todo aquel contorno / por el sótano y el torno / sus celos averiguaba, / mas mejor está que estaba. / Siempre ayuda a la verdad, / amor, fineza y lealtad, / halló en la rosa más pura $[\mathrm{A}, \mathrm{B}, \mathrm{M}]$ : 
13. hidalga $[\mathrm{A}, \mathrm{B}, \mathrm{M}]$.

18. va $[\mathrm{A}, \mathrm{B}, \mathrm{M}]$ : van $[\mathrm{D}]$ : fuera $[\mathrm{S}]$.

19. no la halló, allá se verá $[\mathrm{A}, \mathrm{B}, \mathrm{M}]$ : no la hallaron $[\mathrm{D}]$ : no la halló, donde pariera $[\mathrm{S}]$.

20. $\sim \mathrm{y}[\mathrm{A}, \mathrm{B}, \mathrm{M}]: \mathrm{y}[\mathrm{D}, \mathrm{S}]$.

40. cubiertas $[\mathrm{A}, \mathrm{B}, \mathrm{M}]$.

46. $\sim \mathrm{y}[\mathrm{A}]$.

47. franca $[\mathrm{A}, \mathrm{B}, \mathrm{M}]$.

49-53. ^quiso con sus niñas bellas / oponerse a las estrellas, / la rosa de Alejandría, / mañana será otro día $[\mathrm{A}, \mathrm{B}, \mathrm{M}]$.

59. [S].

62-63. ^porque al fin la vida es sueño" [A, B, M].

\section{4. "Escriben desde Toledo" [A, B, D, M, S]}

4. Caramanchel [A, B, S].

9. Quijada [A, B, M]: Quijadas [D, S].

11. de $[S]$.

12. en $[\mathrm{A}, \mathrm{B}, \mathrm{M}]$.

16. la [S].

19. Hornachuelos [A, S]: Urnachuelos [B, M, D].

20. los [A, B, D, M]: sé [S].

26. vieron $[A, S]$.

29. los [A, B, D]: les [M, S].

38. ^a $[\mathrm{M}, \mathrm{S}]$.

41. enclusa [M, $\mathrm{S}]$.

43. sus [M, S].

45. Tarsis [A, B, M, S]: Tursis [D].

49-52. ^De Jerusalén, que Herodes / era un rey tan sosegado, / que por aquietar el reino / le despojó de muchachos [A, B, M, S].

54. avisan [A].

58. temprano [A, B, M, S].

59. riyendo [B, $\mathrm{M}, \mathrm{S}]$.

64. pues [A, B, M, S].

\section{5. “Quiero, pues es ocasión” [A, B, D, M, S]}

12. rudimentos $[\mathrm{A}, \mathrm{B}, \mathrm{M}]$.

80. hará $[\mathrm{M}]$.

120. enganas $[\mathrm{M}]$.

124. tiene [A, B, M, S].

138. ${ }^{\wedge}$ son $[\mathrm{A}]$.

138. con $[\mathrm{B}]$ : por $[\mathrm{M}]$.

138. lo [B].

140. sientes [A, B, M].

147. pues [A, B, M, S]

147. mudas [S].

151. lo que quieres que te pierda $[\mathrm{A}, \mathrm{B}, \mathrm{M}, \mathrm{S}]$.

156. cae en [A, B, S]: caen en [M]

170. mitante [S].

168. una $[\mathrm{A}, \mathrm{B}, \mathrm{M}]$ : un $[\mathrm{D}, \mathrm{S}]$. 
170. ^bien [S].

176. solo está [A, B, M]: solo esto [S].

116. “Hola! Qué llega la fiesta, qué falta la solfa” [D, S ]

17. trujo [S].

25. y cosi es bueno de [S].

26. envidian $[\mathrm{S}]$.

32. trujo $[\mathrm{S}]$.

117. "En tu alabanza mi musa" [D, S ]

3. hasta [S].

118. “De Santa Resurrección” [D, S]

2. sigan [S].

36. lo [S].

43. había [S].

59. D sustituyó "nia verum natura datur vac[u]um" por "in natura nihil datur vacu[u]m": niaverum natura datur vac[u]um [S].

68. ingüento [S].

73. juntamente [D]: juntáronse [S].

76. hasta $[\mathrm{S}]$.

79. de lonja $[\mathrm{S}]$.

119. "Divina madre de Gracia" $[D, S]$

9. Defiéndeme $[\mathrm{S}]$.

42. Señor [S].

58. Señor [S].

84. nuestra $[S]$.

120. “Dulce Jesús, Dios mío” [D, S ]

121. “Oigan en jácara" [D, S]

3. Credo [S].

122. "Acudamos sentidos" $[D, S]$

123. "Hoy a la Concepción aclamaciones" [A, B, D, M, S]

7. hoy $[\mathrm{A}, \mathrm{B}, \mathrm{M}]$ : se $[\mathrm{D}, \mathrm{S}]$.

10. abrasada $[\mathrm{A}, \mathrm{B}, \mathrm{S}]$ : abrasadas $[\mathrm{M}]$.

14. segura $[A, B, M]$.

124. "Un dominico enemigo" $[A, B, D, S]$

8. defienda $[\mathrm{A}, \mathrm{B}, \mathrm{S}]$. 
19. oscuras $[\mathrm{A}, \mathrm{S}]$ : escuras $[\mathrm{B}, \mathrm{D}]$.

\section{5. "Haced que la Gracia encuentre" [D, S $]$}

4. $\mathrm{y}[\mathrm{S}]$.

28. qué intento tan mojado [D]: tan mojado que de intento [S].

126. "Clavel, pues por tus colores" [D, S]

14. parecen $[S]$.

\section{7. "En títulos Virgen pura" [D, S]}

21-25. ^ El rebelde al beneficio / se ve a vuestros pies sin medra, / pues fue en el cielo edificio / y hoy se mira por un vicio / escollo armado de hiedra [A, B, M, S]. 42. acechanzas [S].

53. simulando $[\mathrm{S}]$.

128. "Hoy con gusto a cantar llego" $[D, S]$

16. ^bien $[\mathrm{S}]$.

16. $\sim \mathrm{se}[\mathrm{S}]$.

24. morirse [S].

129. "Guardar la mujer es ley" [D, S $]$ 
A la desatada llaga. $\mathrm{N}^{\circ} 13$.

A Pascuala dijo Bras. $\mathrm{N}^{\mathrm{o}} 73$.

A todos tu beldad rigores flecha. $\mathrm{N}^{\circ} 56$.

A una reja qué ventura. $\mathrm{N}^{\circ} 24$.

A uno que se hace una uva. $\mathrm{N}^{\mathrm{o}} 8$.

Acabose el amistad. $\mathrm{N}^{\circ} 92$.

Acudamos sentidos. $\mathrm{N}^{\circ} 122$.

Al señor Bautista, el jaque. $\mathrm{N}^{\mathrm{o}} 111$.

Amoroso, prudente y cortesano. $\mathrm{N}^{\circ} 58$.

Anfriso, con atención. $\mathrm{N}^{\circ} 43$.

Apenas, señor, te viste. $\mathrm{N}^{\mathrm{o}} 67$.

Bien puede, Lisis, un triste. $\mathrm{N}^{\circ} 41$.

Breve pie reducido a cárcel breve. $\mathrm{N}^{\circ} 62$.

Cansado anoche de estar. $\mathrm{N}^{\circ} 11$.

Clavel, pues por tus colores. $\mathrm{N}^{\mathrm{o}} 126$.

Clodio, del mundo en la plaza. $\mathrm{N}^{\circ} 9$.

Clori, que para ser linda. $\mathrm{N}^{\circ} 52$.

Cómo quieres, Anarda, que sea casto. $\mathrm{N}^{\mathrm{o}} 63$.

Con modo ya más humano. $\mathrm{N}^{\mathrm{o}} 25$.

Cruz, si cristiano soy. $\mathrm{N}^{\mathrm{o}} 66$.

Dando chasco a un borracho. $\mathrm{N}^{\circ} 9$.

De emboscado entre matas de tu pelo. $\mathrm{N}^{\mathrm{o}} 61$.

De Francisco por menor. $N^{\circ} 109$.

De mis finezas el bajel incierto $\mathrm{N}^{\circ} 70$.

De pedir nunca yo fuera. $\mathrm{N}^{\circ} 48$.

De pie quebrado unas coplas. $\mathrm{N}^{\mathrm{o}} 108$.

De Pinto para un festejo. $N^{\circ} 21$.

De santa Resurrección. N ${ }^{\circ} 118$.

De tu Concepción, Señora. No 103.

De un pie escribir quiero en suma. $\mathrm{N}^{\mathrm{o}} 86$.

De una niña la grandeza. № 106.

De una taberna salía. $\mathrm{N}^{\circ} 96$.

Del rumbo de Francelina. $N^{\circ} 80$.

Desde que el sol ardiente. $\mathrm{N}^{\circ} 3$.

Desde que tus niñas bellas. $\mathrm{N}^{\circ} 14$.

Después que por qué se usa. $\mathrm{N}^{\circ} 40$.

Dios te socorra, Marica. $\mathrm{N}^{\circ} 22$.

Disparates, Antón, muy mal zurcidos. № 65.

Divina madre de Gracia. No 119.

Don Juan, no tengo por bueno. $\mathrm{N}^{\circ} 45$.

Dulce Jesús, Dios mío. Nº 190.

Dulce Lisis de mis ojos. $\mathrm{N}^{\circ} 4$.

El pañuelo desembolsa. No 37 . 
El sacristán qué desmán. № 87.

En aquesta soledad. № 53.

En el mar de tu hermosura. $\mathrm{N}^{\circ} 18$.

En la firme política nuestra. $\mathrm{N}^{\mathrm{o}} 78$.

En la ruda política mía. No 77 .

En la villa de Carrión. N ${ }^{\circ} 74$.

En Málaga vi a Rufina. No 75.

En títulos, Virgen pura. $\mathrm{N}^{\circ} 127$.

En tu alabanza mi musa. $\mathrm{N}^{\circ} 117$.

Éranse dos licenciados. $\mathrm{N}^{\mathrm{o}} 6$.

Érase una Virgen pura. № 113.

Es de Fausto la fiereza. $N^{\circ} 20$.

Escriben desde Toledo. $\mathrm{N}^{\circ} 114$.

Escúchenme unos esdrújulos. $\mathrm{N}^{\mathrm{o}} 36$.

Esta mañana en Dios y en hora buena. № 94.

Estaba Lisis en campal batalla. $\mathrm{N}^{\mathrm{o}} 69$.

Fernando, a quien por soberbio. $\mathrm{N}^{\mathrm{o}} 76$.

Fuera, fuera que Juanilla. $N^{\circ} 81$.

Genil, galán de los ríos. $\mathrm{N}^{\circ} 83$.

Guardar la mujer es ley. $\mathrm{N}^{\mathrm{o}} 129$.

Haced que la Gracia encuentre. $\mathrm{N}^{\mathrm{o}} 125$.

Hanme mandado una cosa. № 101.

¡Hola! Qué llega la fiesta, qué falta la solfa. №116.

Hoy a la Concepción aclamaciones. $\mathrm{N}^{\circ} 123$.

Hoy con gusto a cantar llego. $\mathrm{N}^{\circ} 128$.

Hoy mi devoción aclama. $\mathrm{N}^{\circ} 110$.

Hoy, Clori, pretendo amarte. $\mathrm{N}^{\mathrm{o}} 46$.

Hoy sin más ni más me allano. $\mathrm{N}^{\mathrm{o}} 71$.

La Concepción este día. $\mathrm{N}^{\circ} 103$.

La más hidalga hermosura. $\mathrm{N}^{\mathrm{o}} 10$.

Licencia solo me has dado. $\mathrm{N}^{\mathrm{o}} 42$.

Lo menos bello y más apetecido. $\mathrm{N}^{\circ} 95$.

Los ganados de Liseno. $\mathrm{N}^{\circ} 82$.

Malo me siento, Marica. $\mathrm{N}^{\circ} 39$.

María, a tu sucia cara. $\mathrm{N}^{\circ} 49$.

María, viéndote hermosa. $\mathrm{N}^{\mathrm{o}} 38$.

Marica, no desdeñosa. $\mathrm{N}^{\circ} 33$.

Marica, que a decir mal. $\mathrm{N}^{\mathrm{o}} 27$.

Mi bien, juro por mi amor. $\mathrm{N}^{\mathrm{o}} 19$.

Musa mía, con astucia. $\mathrm{N}^{\circ} 89$.

Nise, a quererte me inclino. $\mathrm{N}^{\circ} 91$.

No quieran tus sinrazones. $\mathrm{N}^{\mathrm{o}} 79$.

Oiga, hermano fray Francisco. $\mathrm{N}^{\circ} 98$.

Oigan en jácara. № 191.

Oigan lo que saca en limpio. $\mathrm{N}^{\circ} 105$.

Óiganme damas que empuño. $\mathrm{N}^{\circ} 7$. 
Otra vez tengo la pluma. $\mathrm{N}^{\mathrm{o}} 100$.

Oye, Catuja, dulce hechizo mío. $\mathrm{N}^{\circ} 1$.

Oye, tarazón de frailes. $\mathrm{N}^{\mathrm{o}} 29$.

Palma, en viendo tu beldad. $\mathrm{N}^{\circ} 44$.

Para qué es tu atrevimiento. $\mathrm{N}^{\circ} 23$.

Pedite, mi buen Cruz, suelas. $\mathrm{N}^{\circ} 68$.

Pedro, mi ingenio recela. $\mathrm{N}^{\circ} 35$.

Por los yerros, Lisis bella, de un traslado. $\mathrm{N}^{\circ} 60$.

Por tomar Judas el grado. $\mathrm{N}^{\circ} 88$.

Pues que me han dado licencia. $\mathrm{N}^{\circ} 54$.

Pues que su entretenimiento. $\mathrm{N}^{\circ} 90$.

Pues vuestra piedad me abriga. $\mathrm{N}^{\circ} 37$.

Queridas, mucho me enfada. $\mathrm{N}^{\mathrm{o}} 34$.

Quisímí quisimona, hola. $\mathrm{N}^{\circ} 28$.

Quiero, pues es ocasión. $N^{\circ} 115$.

Reyes míos, desde el día. № 93.

Rudo pincel de mano inadvertida. № 59 .

Sabed, Señora doncella. No 107.

Señor, jurador he sido. $N^{\circ} 72$.

Sepan todos y todas que yo adoro. $\mathrm{N}^{\mathrm{o}} 2$.

Solo el silencio testigo. $\mathrm{N}^{\circ} 26$.

Sonoro arroyuelo. $\mathrm{N}^{\mathrm{o}} 84$.

Suelto el cabello por el aire ufano. $\mathrm{N}^{\mathrm{o}} 57$.

Tu arroz, Marica, me enfada. № 34 .

Tu romance, Andrés, leí. № 31.

Un ciego soy desgraciado. $\mathrm{N}^{\mathrm{o}} 17$.

Un devoto singular. № 99.

Un dominico enemigo. $\mathrm{N}^{\circ} 124$.

Un estudiante de hogaño. $\mathrm{N}^{\circ} 10$.

Un estudiante este curso. $\mathrm{N}^{\circ} 85$.

Un galán corto de talle. $\mathrm{N}^{\circ} 50$.

Un mal francés, Marica, tan grosero. $\mathrm{N}^{\mathrm{o}} 55$.

Un pecador soy, Dios mío. N $^{\circ} 112$.

Un tudesco, humana cuba. $\mathrm{N}^{\circ} 97$.

Vengar quiero mis rencillas. $\mathrm{N}^{\mathrm{o}} 12$.

Ya no puedo vivir si no me capo. $\mathrm{N}^{\circ} 64$.

Ya que tan galante has sido. $\mathrm{N}^{\circ} 47$.

Ya, Fabio, que hemos llegado. $\mathrm{N}^{\mathrm{o}} 30$.

Yo soy, ilustre Academia. $\mathrm{N}^{\circ} 5$. 


\section{CONCLUSIONES}

Los novedosos caminos hacia un modelo de conocimiento (más racional y experimental) que se estaban trazando en la España de Carlos II quedaron reflejados en la poesía. Aunque los escritores de la segunda mitad del siglo XVII se encontraban bajo el dominio y la influencia de sus geniales predecesores, intentaron desarrollar "una nueva sensibilidad y una nueva percepción del mundo que los rodeaba" (Bègue y Mata 15). La renovación estética que impulsaron autores como León Marchante, José Pérez de Montoro, Francisco de la Torre y Sevil o Damián Cornejo buscaba entretener y sorprender a todo tipo de públicos a través de versos lúdicos y sugerentes. Estos se acercan a lo cotidiano y requieren de un lector u oyente cómplice, que sepa desentrañar los múltiples y diversos juegos conceptuales que albergan.

A pesar de que muchos de los poetas de dicho periodo imprimieron sus poesías en vida y de que estas fueran editadas o reeditadas (póstumamente) en el primer tercio del XVIII, su estilo cercano y próximo a la oralidad, su temática intrascendente, su métrica popular, la presencia en ellas de rasgos descriptivos y narrativos y su tono jocoso y frívolo hicieron que fueran consideradas como una "degeneración" del género poético y condenadas al casi total olvido. Los diversos estudios, congresos y publicaciones que se han llevado a término, en este siglo y en los últimos años del anterior, han ayudado a divulgarlas y a reivindicar su valor, pero todavía queda mucho camino por recorrer.

La presente tesis ha pretendido aportar algo de luz sobre la poesía hispana que se cultivó en el Bajo Barroco mediante la edición crítica de un manuscrito (“2245” de la BNE) que recopila gran parte de la producción lírica (sacra y profana) de un relevante clérigo y cronista: Damián Cornejo. Su amplio bagaje cultural, su habilidad para la palabra y su carácter transgresor quedaron reflejados tanto en sus versos como en su prosa. El obispo de Orense sabía que era necesario adaptar la escritura a los gustos del momento para poder captar la atención del público. Por ello, no dudó en aligerar el estilo de las crónicas religiosas y del lenguaje poético e introducir en sus creaciones su atrevido e ingenioso sentido del humor.

No obstante, solo sus narraciones sacras fueron publicadas en vida y elogiadas ampliamente (ocupan un lugar relevante en el Diccionario de Autoridades) por la crítica y los investigadores y eruditos que durante varias centurias desearon aportar datos relacionados con su figura o su producción literaria. Su faceta de poeta festivo fue silenciada 
por estos hasta bien entrado el siglo XX. Quizás, creían que dañaba la imagen de ilustre religioso, Consejero Real y hagiógrafo que poseía fray Damián o que sus versos no tenían la calidad de sus crónicas y, por tanto, no debían ser mencionados en su biografía. Además, el hecho de que no se conserven testimonios autógrafos y que un número destacado de poemas (setenta y seis) ${ }^{291}$ que a él se atribuyen se imprimieran poco después de su muerte con el nombre de un afamado poeta y dramaturgo contemporáneo, León Marchante era otro poderoso argumento para ocultar que también cultivó el género poético a lo largo de toda su vida y para justificar que su obra lírica no se hubiera llevado a la imprenta.

Los cerca de doscientos poemas, principalmente de temática profana ${ }^{292}$, que se atribuyen al obispo de Orense (sesenta y un indubitados, noventa y tres dubitados ${ }^{293}$ y menos de medio centenar que no aparecen en al menos cuatro manuscritos integri) circularon por España y por el extranjero (Inglaterra, Italia, Portugal y Estados Unidos) a través de numerosos manuscritos, que pueden datarse entre las últimas décadas del XVII y la segunda mitad del XVIII. Estos convivieron con las diversas reediciones de su prosa, creando entre los lectores la doble visión que poseen algunos autores clásicos (Góngora, Quevedo, Lope o Cervantes): "De un lado la obra seria y elevada, de otro la obra satírica, burlesca. Dos polos antitéticos, dos polos de discurso son puestos en relaciones de tensión equivalencia y reflejándose lateralmente el uno sobre el otro componen una vasta metáfora barrocas" (Nicolás 82).

Pero la transmisión manuscrita de su poesía, el gusto de fray Damián por cultivar poemas jocosos y eróticos y la posibilidad de que sus versos se difundieran por los mismos círculos (la Universidad de Alcalá) y de manera simultánea a los compuestos por el maestro León pudieron propiciar que muchos de ellos se confundieran de autoría. Además, hay que tener en cuenta diversos factores que habrían fomentado sus problemas de atribución. Por un lado, la decisión de Marchante de quemar su obra poética poco antes de morir y la casi total ausencia de testimonios manuscritos que le atribuyen poesías ${ }^{294}$. Por otro, la forma en

\footnotetext{
291 En los tres volúmenes que constituyen las Obras poéticas póstumas de Marchante (1722 y 1733), se imprimieron veintitrés poemas sacros y cincuenta y cuatro profanos que se atribuyen en manuscritos a fray Damián. Además, existen otros díez dubitados entre ambos que no se incluyen en estas: seis de temática divina y cuatro de humana.

${ }^{292}$ Los poemas indubitados de fray Damián están constituidos por nueve de temática divina y cincuenta y dos de humana, mientras que los dubitados los conforman veinticuatro sacros y sesenta y nueve profanos "Anexo: 8.3.2.".

${ }^{293}$ A las ochenta y seis poesías que se atribuyen a Cornejo y al maestro León, se han de sumar diez (nueve profanas y una sacra) cuya autoría disputa el poeta palentino con otros autores: Quevedo, Francisco Vallés, Francisco de Porras, Juan de Avellaneda y José Pérez de Montoro (ver apartado “3.2.”).

294 Las atribuciones manuscritas de poemas (sacros y profanos) al dramaturgo manchego se hallan, principalmente, en manuscritos que recogen la lírica de Cornejo y aparecen, en su mayoría, sobreescritas con
} 
la que se recopilaron las composiciones (principalmente de temática sacra) que integran sus Obras poéticas póstumas, pues el propio editor confiesa que lo hizo a partir de múltiples fuentes que le enviaron y que algunos de los textos que las conforman pudieron ser adjudicados al dramaturgo manchego con el propósito de autorizarlos.

Las primeras impresiones de poesías que se atribuyen a Cornejo aparecieron como anónimas (probablemente, por alguno de los motivos que se han mencionado) a finales del siglo XVIII y en el primer tercio del XIX. No fue hasta la segunda mitad de esta última centuria que se publicaron con su nombre múltiples composiciones en periódicos, cancioneros o ensayos. Estas suscitaron cierta controversia en la prensa decimonónica y de principios del XX, dejando importantes testimonios de la popularidad que gozaba su lírica festiva y del morbo y de las críticas (positivas y negativas) que provocaba. Con el transcurso de las décadas, sus versos empezaron a ocupar un pequeño espacio en las antologías de destacados estudiosos y editores (Joaquín López Barbadillo, Marcos Ricardo Barnatán o Pierre Alzieu, Robert Jammes e Yvan Lissorgues) y a despertar entre diversos investigadores internacionales el interés por editar el conjunto de su producción poética.

Klaus Pörtl, en 1978, publicó en Alemania la primera parte de la edición crítica del fragmentario manuscrito que descubrió en la Biblioteca de la Real Colegiata de Roncesvalles, recopilando en ella relevantes materiales para el estudio y la divulgación de la poesía del fraile franciscano. Estos y los aportados por otros investigadores posteriores (Miguel Marañón, Antonio Carreira, Ignacio Díez Fernández, Itziar López y Alain Bègue) han resultado fundamentales para realizar el presente trabajo. En él, se ofrece una edición crítica más completa y precisa que la creada por el filólogo alemán (al ampliar considerablemente el número de poemas editados hasta la fecha y dar más información sobre ellos) ${ }^{295}$ y se incluyen más datos sobre las veintinueve fuentes manuscritas ${ }^{296}$ (se han

su primer apellido "León” en estos. El número de poemas que en ellos se atribuyen a Marchante (tanto de poesías dubitadas con fray Damián que aparecen en sus Obras póstumas como de las que no llegaron a la imprenta) resultan bastante reducido y, en gran parte de los casos, parece estar condicionado por la edición de estas (ver apartado "3.2.1.").

${ }^{295}$ Los ciento veinte nueve poemas editados (veintinueve sacros y cien profanos) van acompañados de una serie de marcas que señalan si son indubitados, apócrifos o dubitados (se indica la autoría que les ha asignado las pruebas de estilometría realizadas) y de un aparato filológico que aporta datos lingüísticos, literarios o culturales y que pone de manifiesto las expresiones o motivos que se reiteran en ellos.

${ }^{296}$ Exceptuando el llamado manuscrito de "Manuel Benito" (no se ha tenido acceso a él), todos los testimonios han sido catalogados e indexados "Anexo: 8.1. y 8.2.". También se han analizado y comparado las características y el contenido de los manuscritos integri y establecido su filiación (ver apartado "5.1.2.”). 
localizado tres nuevas) $)^{297}$ que reúnen su obra, sobre el corpus de poemas que las conforman $^{298}$ y sobre las características de estos.

Los análisis cuantitativos aplicados a la producción literaria de fray Damián (basados en la morfosintaxis, en la combinación de bigramas, en rasgos léxico-semánticos y en la métrica) permiten conocer con gran detalle y precisión sus rasgos estilísticos. Además, logran establecer objetivamente tanto semejanzas entre poemas de distinta temática y longitud como diferencias, incluso, con los creados por otro autor con un estilo, una formación y un contenido similar. Este tipo de pruebas también ha conseguido delimitar parámetros lingüísticos comunes y distintivos entre su obra narrativa y sus versos. Los principales resultados que se han obtenido al estudiar un corpus (veintiséis mil palabras) ${ }^{299}$ del cronista palentino y al intentar determinar la autoría de los poemas dubitados con León (incluidos en el códice editado) se sintetizan a continuación.

Las composiciones indubitadas (en verso y en prosa) que se han analizado del escritor palentino utilizan más la combinación de un nombre y un adjetivo y manifiestan un porcentaje más elevado de posesivos y de conjunciones subordinadas introducidas por "que" y una menor proporción del resto de nexos subordinantes, de artículos, de clíticos y de negaciones que las de Marchante. Además, presentan una riqueza léxica más alta y las palabras distintivas que emplea Cornejo (respecto a los textos poéticos y narrativos estudiados del dramaturgo manchego) muestran un especial interés por retratar la psicología y el físico de los personajes y el entorno ${ }^{300}$.

Si nos centramos únicamente en los rasgos que distancian estilísticamente sus poemas, se puede concluir lo siguiente. Fray Damián en sus versos religiosos emplea más sustantivos y preposiciones que el maestro León, mientras que en los de contenido humano (como sucede en la Crónica Seráfica) recurren más a adjetivos y adverbios. Las poesías profanas y sacras del cronista franciscano comparten también un mayor porcentaje de los bigramas $\mathrm{N}+\mathrm{N}$ y $\mathrm{V}+\mathrm{V}$ y una frecuencia menor de $\mathrm{A}+\mathrm{A}, \mathrm{V}+\mathrm{A}$ y $\mathrm{V}+\mathrm{N}$ que las de Marchante. La alta proporción de autorreferencias y la baja de palabras sociales son otro elemento que

\footnotetext{
${ }^{297}$ Los tres poemarios que anteriormente no habían sido incluidos como parte de las fuentes manuscritas que recogen poemas de fray Damián han sido marcados como "inéditos" en el "Anexo: 8.1. y 8.2.".

${ }^{298}$ Se han conformado una serie de tablas en las que se señala la temática (sacra o profana) de los poemas que se atribuyen a Cornejo, se indica si son dubitados o indubitados, su tipo de métrica y su localización (manuscrita e impresa).

${ }^{299}$ Se ha empleado un corpus de lírica indubitada de Cornejo de dieciséis mil palabras (seis mil de sacra y diez mil de profana) y de quince mil del primer tomo de la Crónica Seráfica. Este se ha contrastado con un volumen de términos similar (escritos en verso y en prosa) de León Marchante (ver apartados “4.2. y 4.4.”).

${ }^{300}$ El dramaturgo de Pastrana utiliza un léxico distintivo que se centra más en identificar materiales, profesiones y atributos o estados de individuos (ver apartado "4.2.").
} 
tienen en común los versos del obispo de Orense y que los singulariza, ya que las creaciones de Comisario de la Inquisición manifiestan un mayor interés en hacer partícipe al público y recurren con más frecuencia a emociones (positivas y negativas) para intentar conmoverlo con más fuerza.

Por último, se observan diferencias significativas en la elección que hacen de los metros ambos autores. Cornejo en sus poesías de temática divina opta más por la quintilla y el romance y el poeta de Pastrana por la copla y la endecha. En las poesías humanas del cronista franciscano, se mantiene su tendencia de recurrir más al romance e incorpora un alto porcentaje de sonetos, mientras que el maestro manchego tiende a elegir décimas y redondillas.

Gran parte de los datos comentados coinciden con los de las poesías dubitadas que se atribuyen al poeta palentino en los análisis de clasificación (veinte sacras y doce profanas), manifestando así una huella de autor común. Todas muestran un mayor uso del nexo subordinante "que", de la combinación de dos sustantivos, emplean más autorreferencias y menos palabras sociales y poseen una mayor diversidad de vocabulario que las atribuidas a León. Estos resultados deberían compararse en un futuro con los del resto de poemas dubitados fray Damián con el propósito de intentar esclarecer también su autoría. Gracias a tales pruebas, se podrá delimitar con más exactitud su corpus de lírica y, por tanto, concretar mejor sus características.

Los versos del cronista palentino son un fiel testigo del diálogo que intentaron establecer los poetas del Bajo Barroco entre tradición e innovación, pues parecen jugar a aceptar y a burlarse al mismo tiempo de distintas herencias. Sus pinturas de damas subvierten con humor los tópicos de belleza clásicos e incluyen referencias sobre el acto creativo y sus protagonistas (masculinos y femeninos) suelen transgredir las bases del fino amor o la moral imperante y moverse en ambientes vulgares. Un ejemplo claro de ello nos lo ofrece el soneto "Esta mañana en Dios y en hora buena”, donde se combina el neoplatonismo y los tópicos petrarquistas más recurrentes con la parodia y la frivolidad más descaradas para recrear el encuentro sexual con una meretriz.

Fray Damián no renuncia al gusto barroco de ahondar, con un lenguaje polisémico y metafórico, en lo raro o lo marginal (borrachos, estudiantes sin recursos, homosexuales, enfermos de sífilis, prostitutas...), pero también se adentra en lo más elevado y candente de su tiempo (la polémica de la Inmaculada Concepción o la caída de Fernando Valenzuela) a través de un tono conversacional y desenfadado. El obispo de Orense busca siempre a un cómplice y avispado receptor que sepa leer "entre líneas" una cierta verdad camuflada y que 
también logre reconocer las referencias cultas (principalmente de obras serias de Quevedo, Góngora, Lope o Calderón) y populares (refranes, jergas y dichos) que incluye.

Como ocurre con la obra posterior de Gerardo Lobo ${ }^{301}$, Cornejo desdramatiza las discusiones estilísticas de sus geniales predecesores, juega modernamente con los tópicos y modelos estéticos y extiende su indolencia hacia su propia persona y obra. Composiciones como "Oye, Catuja, dulce hechizo mío" o "Cansado anoche de estar" muestran un yo lírico (parece encarnar el álter ego del autor) que se sitúa al mismo nivel que su público (manifestando sus debilidades, infortunios, pensamientos y deseos) y combinan lo culto, lo vulgar, lo coloquial y lo metapoético para impresionar y divertir. Cabe señalar que algunas de sus poesías, sobre todo las sacras, posiblemente fueron escritas para ser interpretadas y acompañadas de elementos musicales y parateatrales, conformando así ante sus oyentes una especie de "retórica de performance" (Bègue, Hacia la modernidad 64).

Muchos de los rasgos mencionados, como señala Álvarez Amo (635-636), son comunes en la poesía contemporánea y arrancan no solo de Espronceda y del prosaísmo de los poetas del siglo XVIII, sino de un eslabón "el Bajo Barroco" necesario en la trayectoria estilística de la poesía en lengua castellana. Los cambios que sufre el lenguaje lírico en dicho periodo y la progresiva inclusión de la mujer en los salones también ofrecen una transformación del imaginario femenino en las producciones en verso. En ellas, se consolida la desidealización de la mujer y las damas comienzan a adquirir ciertas capacidades sociales, intelectuales y literarias ${ }^{302}$ y una nueva forma de interactuar con los hombres, la cual alcanzará su máximo auge en el chischisbeo ${ }^{303}$.

La lírica del Bajo Barroco se erige, por tanto, como un valioso testimonio literario y cultural de una sociedad cambiante, que intenta establecer un puente entre el culto a la antigüedad y la necesidad de avanzar hacia nuevos cauces de pensamiento, de estudio y de expresión. Esta requiere de un público que sepa desentrañar "los efectos potenciales del texto", basados en su estructura anamórfica, para que sea interpretada y valorada correctamente (Nicolás 85). Al emplear una metodología multidisciplinar en la presente

\footnotetext{
${ }^{301}$ Las características de la poesía del poeta soldado han sido estudiadas por Francisco Javier Álvarez Amo (621-636).

302 Basta mencionar títulos como "Habiendo enviado Celio a Clori un conejo muerto y dentro unos guantes de quintas esencias con un hueso, diciendo era pistola, para que tirase; ella le envió un rosario de avellanas vanas, unos guantes de alcorza y un corazón pintado en un abano de papel con estos versos", de Pérez de Montoro (224), para comprobar que los poetas ya no buscan idealizar a la dama. Esta comienza a adquirir autonomía, a manifestar astucia y a tomar la palabra.

${ }^{303}$ Pedro Ruiz (Deidades 109-149) indaga en la presencia del chichisbeo en la poesía del Bajo Barroco y en cómo se representó a través de él un nuevo imaginario de mujer.
} 
tesis, se ha pretendido no solo contribuir en la reconstrucción de ese puente, sino también continuar trazando otro entre la filología tradicional y las humanidades digitales. 


\section{BIBLIOGRAFÍA}

\subsection{BIBLIOGRAFÍA TEMÁTICA}

\subsubsection{CONTEXTO HISTÓRICO-LITERARIO}

Álvarez Amo. Francisco Javier. Las obras poéticas líricas (1738) de Eugenio Gerardo Lobo: Edición y estudio, Córdoba: Servicio de publicaciones de la Universidad de Córdoba, 2014. Tesis. Web. 14 set. 2017.

Alzieu, Pierre. Jammes, Robert. y Lissorgues, Yvan. Poesía erótica del Siglo de Oro, Barcelona: Crítica, 1984. Impreso.

Bègue, Alain. “Aproximación a la lengua poética de la segunda mitad del siglo XVII: el ejemplo de José Pérez de Montoro”. Criticón, 97-9 (2006): 153-170. Impreso.

Bègue, Alain. "Los límites de la poesía epidíctica: la poesía jocoseria de José Pérez de Montoro". Criticón, 100 (2007): 143-166. Web. 6 oct. 2017.

Bègue, Alain. "Degeneración y prosaísmo de la escritura poética de finales del siglo XVII y principios del XVIII: análisis de dos nociones heredadas”. Criticón, 103-104 (2008): 2138. Web. 1 oct. 2017.

Bègue, Alain. "Albores de un tiempo nuevo: la escritura poética de entre los siglos (XVIIXVIII)". La luz de la razón: literatura y cultura del siglo XVIII: a la memoria de Ernest Lluch. Coord. Aurora Egido, Zaragoza: IFC, 2010. 37-69. Impreso.

Bègue, Alain. “Relación de la poesía española publicada entre 1648 y 1750”. La luz de la razón: literatura y cultura del siglo XVIII: a la memoria de Ernest Lluch. Coord. Aurora Egido, Zaragoza: IFC, 2010. 399-477. Impreso.

Bègue, Alain. La poésie espagnole de la fi du XVII siècle: José Pérez de Montoro (1627-1694), membre d'un Parnasse oublié, Sarrebruck: Éditions Universitaires Européennes. 2010. Impreso.

Bègue, Alain. “Contra el diablo: Los villancicos-jácaras para la Inmaculada Concepción”. Los poderes de la palabra: el improperio en la cultura hispánica del Siglo de Oro. Coords. Carmela Pérez-Salazar Resano, Cristina Tabernero y Jesús María Usunáriz Garayoa, Bern: Peter Lang. 2013. 27-39. Impreso. 
Bègue, Alain. "Tres o cuatro villancicos de las mejores letras: transmisión y recepción de los villancicos en el Barroco tardío". Criticón, 11 (2013): 99-126. Impreso.

Bègue, Alain. "La jácara en los villancicos áureos". Literatura y música del hampa en los Siglos de Oro. Coords. Luisa Lobato y Alain Bègue, Madrid: Visor Libros. 2014. 125-155. Web. 11 may. 2018.

Bègue, Alain. "Hacia la modernidad: nuevas actitudes del yo lírico en la poesía española entre Barroco y Neoclasicismo", Cuadernos AISPI: Estudios de lenguas y literaturas hispánicas, 1 (2013): 63-88. Web. 16 dic. 2017.

Bègue, Alain. "Parece que lo jocoserio / se me introduce el estilo» La modalidad jocoseria como expresión de modernidad entre Barroco y Neoclasicismo”. Hacia la Modernidad. La construcción de un nuevo orden teórico literario entre Barroco y Neoclasicismo (16511750). Dirs. Alain Bègue y Carlos Mata Induráin, 2, Vigo: Academia del Hispanismo. 2018. 69-96. Impreso.

Bègue, Alain y Croizat-Viallet, Jean. "Presentación”. Criticón, 103-104 (2008): 5-8. Web. 25 oct. 2015.

Bègue, Alain y Mata Induráin, Carlos. "Introducción”. Hacia la Modernidad. La construcción de un nuevo orden teórico literario entre Barroco y Neoclasicismo (1651-1750). Dirs. Alain Bègue y Carlos Mata Induráin, 2, Vigo: Academia del Hispanismo, 2018. 13-22. Impreso.

Blecua, José Manuel. Poesías varias de grandes ingenios españoles. Edición basada en la de Zaragoza (1654), Zaragoza: Institución Fernando El Católico, 1946. Web. 12 oct. 2017.

Blasco Pascual, Javier. Arte de Amor: primera traducción al castellano del Ars amandi de Ovidio, Valladolid: Agilice digital, 2016. Impreso.

Borges, Jorge Luis. Otras inquisiciones, Buenos Aires: Sur, 1952. Impreso.

Cacho Casal, Rodrigo. "Poesía burlesca del Siglo de Oro y sus modelos italianos". Nueva revista de filología hispánica, 51, 2 (2003): 465-491. Impreso.

Cacho Casal, Rodrigo. "El ingenio del arte: introducción a la poesía burlesca del Siglo de Oro". Criticón, 100 (2007): 9-26. Impreso.

Cantizano Pérez, Félix. El erotismo en la poesía de adúlteros y cornudos en el Siglo de Oro, Madrid: Editorial Complutense, 2007. Impreso.

Carreira, Antonio. “Introducción”. Luis de Góngora. Romances, 1, Barcelona: Quaderns crema, 1998. 15-48. Impreso. 
Carreira, Antonio. "El manuscrito como transmisor de las humanidades en los siglos de oro". Boletín del Instituto de Investigaciones Bibliográficas - UNAM, 1-2, 6 (2000): 21-46. Impreso.

Carreira, Antonio. “Juan de Ibaso y Malagón: inventario y muestra de su obra poética". El Siglo de Oro en escena. Homenaje a Marc Vitse. Coords. Odette Gorsse y Frédéric Serralta, Tolouse: Université de Toulouse II-Le Mirail, 2006. 155-178. Web. 7 oct. 2016

Cañas Murillo, Jesús. "Corte y academias literarias en la España de Felipe IV”. Anuario de Estudios Filológicos, 35 (2012): 5-26. Impreso.

Cruz, Juana Inés De la. Obras escogidas, Alicante: Biblioteca Cervantes Virtual, 2003. Web. 3 dic. 2017.

Cruz, Juana Inés De la. Inundación Castálida, Alicante: Biblioteca Cervantes Virtual, 2003. Web. 3 dic. 2017.

Cruz, Juana Inés De la. Villancicos. Lírica coral, México: Fondo de Cultura Económica, 2006. Web. 4 dic. 2017.

Cruz, Juana Inés De la. Poemas, Barcelona: Linkgua, 2009. Web. 2 dic. 2017.

Cruz, Juana Inés De la. Obras completas de Sor Juana Inés de la Cruz. Lírica personal. Ed. Antonio Alatorre, 1, México: Fondo de Cultura Económica, 2012. Web. 3 dic. 2017.

Dadson, Trevor. J. "La difusión de la poesía española impresa en el siglo XVII", Bulletin Hispanique, 113, 1 (2011): 13-42: Web. 30 oct. 2016.

De Solís, Antonio. Varias poesías sagradas y profanas. Ed. Juan de Goyeneche, Madrid. Imprenta de Manuel Fernández, 1732. Web. 16 nov. 2016.

Deleito y Piñuela, José. La vida religiosa española bajo el cuarto Felipe: santos y pecadores, Madrid: Espasa-Calpe, 1952. Impreso.

Deleito y Piñuela, José. La mujer, la casa y la moda (en la España del rey poeta), Madrid: Espasa-Calpe, 1966. Impreso.

Díez Fernández, José Ignacio. La poesía erótica de los Siglos de Oro, Madrid: Ediciones del Laberinto, 2003. Impreso.

Díez Fernández, José Ignacio. "Compilar y desleír la poesía erótica de los Siglos de Oro: los cancioneros de Amancio Peratoner". e-Humanista, 15 (2010): 302-320. Web. 13 dic.

Díez Fernández, José Ignacio. "Libros de poesía en bibliotecas del Siglo de Oro (1600-1650)". Revista de filología española, 90, 1 (2010): 107-136. Impreso.

Egido Martínez, Aurora. "Literatura efímera: oralidad y escritura en los certámenes y academias de los siglos de oro". Edad de oro, 7 (1988): 69-88. Impreso. 
Etienvre, Jean-Pierre. Márgenes literarios del juego: una poética del naipe siglos XVI-XVIII, Londres: Támesis, 1990. Web. 15 en. 2016.

García Arellano, Ignacio. "Anexo". Poesía y edición en el Siglo de Oro. Ed. Ignacio Aguilar, Madrid: Calambur, 2009. 355-365. Impreso.

Garrote Bernal, Gaspar. "E-bibliografía y esquema para una historia de la literatura erótica (o sexual) española”. Anmal, 29 (2010): n.p. Web. 25 oct. 2015.

Guerra, Juan Carlos De. Ensayo de un padrón histórico de Guipúzcoa: según el orden de sus familias pobladoras, San Sebastián: Joaquín Muñoz-Baroja, 1928. Web. 16 feb. 2019.

Jammes, Robert. "Palabras sucias y deshonestas en la poesía de Góngora". Hilaré tu memoria entre las gentes. Coord. Alain Bègue, Zaragoza: Universidad de Zaragoza, 2014. 95-116. Impreso.

Jiménez Belmonte, Javier. “Amateurs preclaros de la España postbarroca: nostalgias de un modelo socioliterario". Calíope, 18, 1 (2012): 78-101. Web. 12 feb. 2016.

Juste Sánchez, María Rosario, Edición y estudio de la obra de José Tafalla y Negrete, Zaragoza: Universidad de Zaragoza, 1991. Tesis inédita.

León Marchante, Manuel De. Habiendo tomado una purga un Ingenio de la Universidad de Alcalá, la participa la noticia a un amigo suyo en este romance, n.p., n.d. Web. 26 feb. 2016.

León Marchante, Manuel De. Un jurador arrepentido, n.p. Web. 27 feb. 2016.

León Marchante, Manuel De. Letras de villancico de Navidad que se han de cantar en la Santa Iglesia de Toledo, n.p., 1662. Web. 15 mzo. 2017.

León Marchante, Manuel De. Relación de la fiesta de toros, que corrió la villa de Meco a siete de Junio deste año, y la guerra que tuvo con los de Alcalá de Henares..., n.p., 1670. Web. 11 mzo. 2017.

León Marchante, Manuel De. Obras poéticas póstumas que a diversos asuntos escribió el maestro León Marchante, 1, Madrid: Real Capilla de su Majestad, 1722. Web. 9 may. 2016.

León Marchante, Manuel De. Obras poéticas póstumas que a diversos asuntos escribió el maestro León Marchante, 2, Madrid: Real Capilla de su Majestad, 1733. Web. 9 may. 2016.

León Marchante, Manuel De. Obras poéticas póstumas que a diversos asuntos escribió el maestro León Marchante, 3, Madrid: Real Capilla de su Majestad, 1733. Web. 10 may. 2016. 
León Marchante, Manuel De. “La picaresca”. Revue Hispanique, 38 (1916): 532- 612. Web. 21 abr. 2017.

León Marchante, Manuel De. Manuel de León Marchante. Obras complutenses. Ed. Manuel Sánchez, Alcalá de Henares: Institución de Estudios Complutenses, 2016. Impreso.

López Guil, Itziar. Poesía religiosa cómico-festiva del bajo barroco español: estudio y antología, Bern: Peter Lang, 2011. Impreso.

Maravall, José Antonio. La cultura del barroco: análisis de una estructura histórica, Barcelona: Ariel, 1975. Impreso.

Martín, Adrienne. "La poesía burlesca femenina y la revisión del canon". Cánones críticos en la poesía de los Siglos de Oro. Coord. Pedro Ruiz. Vigo: Academia del Hispanismo, 2008. 247-267. Impreso.

Martín, Puya, Ana Isabel. y Ruiz Pérez, Pedro. "El nombre de la cosa títulos, modelos poéticos y estrategias autoriales en el bajo barroco". Criticón, 125 (2015): 25-48. Impreso.

Martínez Deyros, María. Sánchez Mateos, Zoraida. y Herrero Diéguez, Juan. “Aquel coger a la dama a oscuras": Mujeres en la poesía erótica del Siglo de Oro, Valladolid: Agilice Digital, 2018. Impreso.

Moral de Calatrava, Paloma. "El cuerpo del deseo. El discurso médico medieval sobre el placer sexual”. Studium Medievale: Revista de Cultura visual-Cultura escrita, 1 (2008): 135-147. Impreso.

Muñoz, María José. “Erotismo y celo Inquisitorial. Expedientes de escritos obscenos censurados por la Inquisición en el siglo XVIII y principios del XIX”. Cuadernos de Historia del Derecho, 10 (2003): 157-207. Impreso.

Navarrete, Ignacio. Los huérfanos de Petrarca: poesía y teoría en la España renacentista, Madrid: Gredos, 1997. Impreso.

Navarro, Ana. Antología poética de escritoras de los siglos XVI y XVII, Madrid: Castalia, 1989. Impreso.

Nicolás Rubio, César. Estrategias y lecturas. La anamorfosis de Quevedo, Extremadura: Universidad de Extremadura, 1986. Impreso.

Osuna, Inmaculada. "Juan de Ibaso y las formas burlescas en justas poéticas a mediados del siglo XVII”. Criticón, 100 (2007): 91-114. Web. 6 jun. 2016.

Osuna, Inmaculada. "Las justas poéticas en la primera mitad del siglo XVII". El canon poético en el siglo XVII: IX Encuentro Internacional sobre Poesía del Siglo de Oro. Coord. Begoña López, Sevilla: Grupo A.I.S.O, 2010. 323-366. Web. 2 jun. 2016. 
Plata Parga, Fernando. "Nuevas versiones manuscritas de la poesía quevediana nuevos poemas atribuidos: en torno al manuscrito BMP 108”. La Perinola, 4 (2000): 285-307. Impreso.

Peinador Marín, Jesús. "Los Fragmentos del Ocio, de Juan Gaspar Enríquez de Cabrera. (Ms.3.956)". Manuscrt.Cao, 1 (2010) 1-14. Web. 19 may. 2016.

Pérez de Montoro, José. Obras póstumas líricas humanas, Madrid: Imprenta de Antonio Marín, 1736. Web. 5 may. 2017.

Quevedo, Francisco De. Parnaso español: monte en dos cumbres dividido, con las nueve musas castellanas, Madrid: Imprenta de Diego Díaz de la Carrera, 1648. Web. 12 ene. 2016.

Quevedo, Francisco De. Obras inéditas de don Francisco de Quevedo Villegas, 11, Madrid: Imprenta de Sancha, 1794. Web. 22 ene. 2016.

Ramos, Carlos. "Secretos (re)velados. Lecturas del sueño erótico”. Jardines secretos. Estudios en torno al sueño erótico. Eds. Julián Acebrón y Pere Solà, Lérida: Edicions de la Universitat de Lleida, 2008. 13-32. Impreso.

Rodríguez-Moñino, Antonio. Construcción crítica y realidad histórica en la poesía española de los siglos XVI y XVII, Madrid: Castalia, 1968. Impreso.

Roncero, Victoriano. "El humor y la risa en las preceptivas de los Siglos de Oro". Demócrito áureo: los códigos de la risa en el Siglo de Oro. Coords. Ignacio Arellano y Victoriano Roncero, Sevilla: Renacimiento, 2006. 285-328. Impreso.

Ruiz Pérez, Pedro. "La Boscarecha de Pedro Espinosa del canto del pastor a la escritura del poeta". A zaga de tu huella: homenaje al prof. Cristóbal Cuevas. Coord. Salvador Montesa, 1, Madrid: Asociación para el Estudio, Difusión e Investigación de la Lengua y Literatura Españolas, 2005. 231-262. Web. 26 jun. 2019.

Ruiz Pérez, Pedro. "Subversión erótica y subversión poética: a propósito de unos límites". Revista de dialectología y tradiciones populares, 60, 1 (2005): 73-84. Impreso.

Ruiz Pérez, Pedro. "Entre dos parnasos: poesía, institución y canon”. Caliope, 103-104 (2007): 207-231. Impreso.

Ruiz Pérez, Pedro. La rúbrica del poeta: la expresión de la autoconciencia poética de Boscán a Góngora, Valladolid: Universidad de Valladolid, 2009. Impreso.

Ruiz, María Jesús. "Repertorio tradicional infantil de Cádiz: texto, rito, gesto y símbolo", Revista OCNOS, 5 (2009): 69-86. Web. 22 jun. 2019.

Ruiz Pérez, Pedro. "Para la historia y la crítica de un período oscuro: la poesía del Bajo Barroco". Caliope, 18, 1 (2012): 9-25. Web. 26 abr. 2016.

Ruiz Pérez, Pedro. "Para una caracterización del romance en el bajo Barroco". Edad de Oro, 32 (2013): 379-406. Web. 15 abr. 2016. 
Ruiz Pérez, Pedro. "De Solís a Lobo: la mujer en la poesía bajobarroca". Perspectives on Early Modern Women in Iberia and the Americas. Studies in Law, Society, Art and Literature in honor of Anne. J. Cruz. Eds. Adrienne. Martín y María Cristina Quintero, Nueva York: Escribana Books, 2014. 486-505. Web. 15 may. 2016.

Ruiz Pérez, Pedro. "Deidades apeadas: un nuevo patrón de género para la poesía bajobarroca". Arte Nuevo. Revista de Estudios Áureos, 3 (2016): 109-149. Web. 2 feb. 2017.

Ruiz Pérez, Pedro. “¿Góngora erótico? El retrete del poeta”. En la concha de Venus amarrado: erotismo y literatura en el Siglo de Oro. Coord. Patricia Marín Cepeda, Madrid: Visor Libros, 2017. 61-90. Impreso.

Sáez, Adrián. "La vuelta del camino o la máscara de Demócrito: apostillas de poesía religiosa burlesca”. Versants: revue suisse des littératures romanes, 60, 3 (2013): 71-82. Impreso.

Sánchez, Vicente. Lira Poética. Ed. Jesús Duce García, Zaragoza: Publicaciones de la Universidad de Zaragoza, 2003. Impreso.

Sánchez Mateos, Zoraida. "En la calle, honestos ángeles y, en la intimidad, Venus retozonas". Lasciva est nobis pagina... Ed. Javier Blasco, Vigo: Academia del Hispanismo, 2015. 6782. Impreso.

Sánchez Mateos, Zoraida. "La mujer en la poesía festiva del Bajo Barroco: Damián Cornejo y León Marchante". Todos los siglos de la lluvia. El canon en la literatura hispánica, Sevilla: Renacimiento, 2018. 163-176. Impreso.

Tafalla y Negrete, José. Ramillete poética de las discretas flores, Zaragoza: Universidad de Zaragoza, 1706. Web. 12 feb. 2018.

Tenorio, Martha Lilia. "Sor Juana y León Marchante", Nueva Revista de Filología Hispánica, 50, 2 (2002): 543-561. Impreso.

Torre y Sevil, Francisco. Edición y estudio del Entretenimiento de las Musas de Don Francisco de la Torre y Sevil. Ed. Manuel Alvar, Valencia: Universidad de Valencia, 1987. Impreso. Villalón, Francisco. El Crotalón, Barcelona. Lingkua digital, 2014. Impreso.

Vidorreta Torres, Almudena. Estudio y edición de "Poesías varias" de José Navarro (1654), Zaragoza: Zaguan. Repositorio Institucional de Documentos, 2014. Web. 9 may. 2019.

Vivas, Agustín. y Arias, Luis. "Fuentes documentales para el estudio de la prostitución en los siglos XVI y XVII en el Archivo y Biblioteca de Salamanca”. Brocar: Cuadernos de investigación histórica, 22 (1988): 51-62. Impreso. 


\subsection{TESTIMONIOS SOBRE LA VIDA Y LA OBRA DE FRAY DAMIÁN CORNEJO}

AA. VV. “Agosto que pintó un ingenio". El correo literario de Murcia. 11 de feb. 1794: 91-95. Web. 17 sep. 2018.

AA. VV. "Bibliografía”. La Ilustración Católica. 7 nov. 1881:131-134. Web. 14 jun. 2016.

AA. VV. Cancionero de obras de burlas provocantes a risa. Ed. Antonio Pérez, Madrid: Librería de Victoriano Suárez, 1951. Impreso.

AA. VV. Cancionero moderno de obras alegres. Ed. Eduardo Lustonó, Londres: H. W. Spirtual, 1875. Web. 12 mzo. 2016.

AA. VV. "De todo un poco". Madrid cómico. 29 may. 1881: 2-3. Web. 15 jun. 2016.

AA. VV. "De Madrid, el 24 de mayo de 1707”. Gazette. 11 jun. 1707: 269- 271. Web. 6 jun. 2016.

Álvarez, Diego. “Capítulo 3: Memorias de V. P. fray Antonio Rojo...”. Memorial ilustre de los famosos hijos del convento de Sta. María de Jesús (vulgo San Diego de Alcalá) primado... Ed. Vicente Julián Bentura de Alfaro, 6, Alcalá: Universidad de Alcalá, 1753. 474-476. Web. 17 jun. 2016.

Álvarez, Diego. “Capítulo 7: Religiosísima memoria de V. P. fray Juan de Salcedo...”. Memorial ilustre de los famosos hijos del convento de Sta. María de Jesús (vulgo San Diego de Alcalá) primado... Ed. Vicente Julián Bentura de Alfaro, 6, Alcalá: Universidad de Alcalá, 1753. 494-498. Web. 17 jun. 2016.

Álvarez, Diego. “Capítulo 14: Memorias de la venerable madre Catalina de Jesús...”. Memorial ilustre de los famosos hijos del convento de Sta. María de Jesús (vulgo San Diego de Alcalá) primado... Ed. Vicente Julián Bentura de Alfaro, 6, Alcalá: Universidad de Alcalá, 1753. 521-525. Web. 17 jun. 2016.

Alzieu, Pierre. Jammes, Robert. y Lissorgues, Yvan. Poesía erótica del siglo de oro, Barcelona: Crítica, 1984. Impreso.

Barnatán, Marcos y García Sánchez, Jesús. Poesía erótica castellana del Siglo X a nuestros días, Gijón: Júcar, 1974. Impreso.

Bègue, Alain. "Poetas de la segunda mitad del siglo XVII". Diccionario Filológico de Literatura Española. Siglo XVII. Ed. Pablo Jauralde, 2, 2011, 707-741, Madrid: Castalia. Impreso. Carreira, Antonio. "La obra poética de Damián Cornejo: cuatro manuscritos más y uno menos". Criticón, 103-104 (2008): 39-54. Web. 25 oct. 2015.

Cela, Camilo José. (1988). Diccionario de erotismo, Barcelona: Grijalbo. Impreso. 
Cornejo, Damián. Crónica Seráfica vida del glorioso patriarca san Francisco y de sus primeros discípulos... escrita por el R. P Fr. Damián Cornejo... examinador sinodal de este Arzobispado y cronista general de su Orden. Parte primera, Madrid: Juan García Infanzón, 1682. Web. 20 nov. 2015.

Cornejo, Damián. Crónica Seráfica: vida del glorioso patriarca san Francisco y de sus primeros discípulos... escrita por el $R$ P Fr. Damián Cornejo examinador sinodal de este Arzobispado y cronista general de su Orden. Parte segunda, Madrid: Juan García Infanzón, 1684. Web. 2. nov. 2015.

Cornejo, Damián. Crónica Seráfica: vida del glorioso patriarca san Francisco y de sus primeros discípulos... escrita por el r[everendísimo] P[adre] f[ray] Damián Cornejo... examinador sinodal de este Arzobispado y cronista general de su Orden. Parte tercera, Madrid: Juan García Infanzón, 1686. Web. 21 nov. 2015.

Cornejo, Damián. Crónica Seráfica: vida del glorioso patriarca san Francisca de sus primeros discípulos... escrita por el r[everendísimo] P[adre] f[ray] Damián Cornejo... examinador sinodal de este Arzobispado y cronista general de su Orden. Parte cuarta. Madrid: Juan García Infanzón, 1698. Web. 21 nov. 2015.

Cornejo, Damián. Das lyrische Werk des Damián Cornejo (1629-1707). Erster Teil. Ed. Klaus Pörtl, München: Wilhelm Fink, 1978. Impreso.

Cornejo, Damián. Obras poéticas del padre Cornejo, n.p., n.d. Manuscrito “2245” de la BNE. Web. 25 oct. 2019.

Cotarelo, Emilio. “Poesías inéditas”. Hispania, 5 (1899): 20. Web. 19 feb. 2016.

Díez Fernández, José Ignacio. "La poesía erótica de curas, frailes y monjas”. La poesía erótica de los Siglos de Oro, Madrid: Ediciones del Laberinto, 2003. 175-224. Impreso.

Eiján, Samuel. "Padre Damián Cornejo". La poesía franciscana en España, Portugal y América (siglos XIII-XIX): nuestros juglares del señor, Santiago de Compostela: El eco Franciscano, 1935. 300-302. Impreso.

Fernández, Benito. "Damián Cornejo”. El pontificado gallego su origen y vicisitudes; seguido de una Crónica de los obispos de Orense, Orense: Imprenta de "El Derecho", 1897. 514521. Impreso.

Flórez, Enrique. "Fr. Damián Cornejo". España Sagrada: Orense, XVII. 195-196. Madrid: Oficina de Pedro Marín, 1789. Web. 12 dic. 2015.

Foulché-Delbosc, Raimundo. "Varia”. Revue Hispanique, 10, (1903): 226-268. Impreso.

González de la Torre, Eusebio. Crónica seráfica, 5, Madrid: Imprenta de la viuda de Juan García Infanzón, 1719. Web. 11 nov. 2015. 
López Guil, Itziar. "Damián Cornejo". Poesía religiosa cómico-festiva del bajo barroco español: estudio y antología, Bern: Peter Lang, 2011. 249-266. Impreso.

López de Barbadillo, Joaquín. Cancionero de amor y de risa: en que van juntas las más alegres, libres y curiosas poesías eróticas del parnaso español, muchas jamás impresas hasta ahora y las restantes publicadas en rarísimos libros, Madrid: Akal, 1917. 199-200. Impreso.

Marañón Ripoll, Miguel. "Sonetos satíricos atribuidos a Damián Cornejo en los mss. de la Biblioteca Nacional de Madrid”. Manuscrt. Cao, 5 (1993): 25-37. Impreso.

Marañón Ripoll, Miguel. "Otro testimonio manuscrito de una serie de poesías escatológicas atribuida a Damián Cornejo”. Manuscrt. Cao, 7 (1996-1998): 71-81. Impreso.

Martínez, Ramón. “La supuesta Papisa Juana”. La Ilustración católica. 5 feb. 1889: 39-40. Web. 20 mzo. 2016.

Maurel, Danièle y Maurel, Michel. Obras de fray Damián Cornejo. Ms. 5566 de la BNM, Toulouse: Université de Toulouse-Le Mirail, 1970. Tesis inédita.

Muñoz de la Cueva, Joan. "Libro sexto. Capítulo cuarto: De la restauración de la iglesia de Orense y obispos sucesores". Noticias históricas de la Santa Iglesia Catedral de Orense, Madrid: Imprenta Real, 1727. 237-296. Web. 22 mzo. 2016.

Nogales, José. “Crónica frivolidad”. El Liberal. 27 ene. 1905: 1. Web. 23 mzo. 2016.

Ossorio y Bernard, Manuel. "Variedades". El Pabellón Nacional. 19 mzo. 1867: 3. Web. 21 mzo. 2016.

Pazos, Manuel. "Fray Damián Cornejo". El episcopado gallego: a la luz de documentos romanos. II Obispos de Tuy y Orense (1540-1855 y 1542-1851), Madrid: Instituto Jerónimo, 1946. 448-461. Impreso.

Pérez, Lorenzo. "Bibliografía. Renedo Agustín. O.S.A. Escritores valentinos". Revista AIA, 26, 2 (1926): 403-408. Impreso.

Pérez de la Sala, Pedro. “Costumbres españolas en el siglo XVII”. Revista de España, 125, 1889. 45. Web. 22 mzo. 2016.

Pérez de la Sala, Pedro. "Una réplica”. Revista de España, 130, 1890. 428-430. Web. 16 mzo. 2016.

Pérez de Guzmán, Juan. "Los príncipes de la poesía española". Revista Contemporánea, 78 (1890): 374. Web. 22 mzo. 2016.

Pörtl, Klaus. "La obra poética de fray Damián Cornejo (1629-1707). Los problemas de una edición crítica de los apógrafos”. Actas del Sexto Congreso Internacional de Hispanistas. 
Coords. Evelyn Rugg y Alan M. Gordon, Toronto: University of Toronto, 1980. 583586. Web. 23 oct. 2015.

Renedo Martino, Agustín. "Damián Cornejo”, Escritores palentinos (Datos bio-bibliográficos), 1, Madrid: Helénica, 1919. 159-162. Impreso.

Rojo Sánchez, Guillermo. "Análisis cuantitativo de las citas de obras en el Diccionario de Autoridades”. Boletín de la Real Academia Española, 310 (2014) 137-196. Web. 11 mzo. 2016.

San José, Diego. “Un capellán poeta”. El Liberal. 3 jul. 1915. 3. Web. 17 abr. 2016.

San José, Diego. “La vieja España galante”. Flirt, 4 (1922): 11. Web. 16 abr. 2016.

San José, Diego. “Un don Juan con sotana”. Flirt, 39 (1922): 6. Web. 16 abr. 2016.

Santoyo-Santiago Asenjo, Julio-César. "Una primicia desconocida de la impresa alavesa: La vida de santa Coleta de fray Damián Cornejo (1722)", Sancho el sabio: Revista de cultura e investigación vasca, 13 (2000): 209-228. Web. 15 nov. 2016.

Serna, José De. "Varias cartas jocosas". El Bufón de la corte, Madrid: Gabriel Ramírez. 1767. 97-112. Web. 22 mzo. 2016.

Soares de Silva, José. Diario métrico en aplauso de la Inmaculada Concepción de María Santísima, Lisboa occidental: Imprenta Pascual de Silva, 1717. Impreso.

\subsubsection{CATÁLOGOS DONDE APARECE RECOGIDA LA OBRA DE CORNEJO}

AA.VV. Catálogo de manuscritos de la Biblioteca Nacional con poesía en castellano de los siglos XVI y XVII, 1-4, Madrid: Arco Libros, 1998. Impreso.

AA.VV. MANUS OnLine. Censimento dei manoscritti delle biblioteche italiane, Milán: Università degli studi di Milano, Dipartimento di Informatica e Comunicazion, 19882020. Web. 22 jun. 2017.

Allen, Eduardo. Catálogo da Biblioteca Publica do Porto. Índice preparatorio do catalogo dos manuscritos..., 6, Oporto: Imprensa Civilisação, 1983. Impreso.

Artigas y Ferrando, Miguel. "Catálogo de los manuscritos de la Biblioteca". Boletín de la Biblioteca Menéndez Pelayo, Santander: Biblioteca Menéndez, 1926. 376-384. Web. 16 feb. 2017.

Barrera, Cayetano Alberto De la. Catálogo bibliográfico y biográfico del teatro antiguo español desde sus orígenes hasta mediados del siglo XVIII, Madrid: Gredos, 1969. Impreso. 
Castro y Castro, Manuel De. Manuscritos franciscanos de la Biblioteca Nacional de Madrid, Madrid: Ministerio de Educación y Ciencia, 1973. Impreso.

Díaz, José Simón. Bibliografía de la literatura hispánica, 8, Madrid: C.S.I.C., Instituto Miguel de Cervantes de Filología, 1960-1994. Impreso.

Esteve, Francisco. Catálogo de la colección de manuscritos Borbón-Lorenzana, Madrid: Biblioteca Pública de Toledo, 1942. Impreso.

Gallardo, Bartolomé. Ensayo de una biblioteca española de libros raros y curiosos, 2, Madrid: Gredos, 1968. 582-583.

Gayangos, Pascual De. Catalogue of the manuscripts in the Spanish language in the British museum, Londres: University of California Libraries, 1875. Web. 16 feb. 2016.

López Guil, Itziar. Poesía religiosa cómico-festiva del bajo barroco español: estudio y antología, Bern: Peter Lang, 2011. Impreso.

Rodríguez-Moñino, Antonio. Catálogo de los manuscritos castellanos existentes en la Biblioteca de The Hispanic Society of America (Siglos XV, XVI y XVII), Nueva York: The Hispanic Society of America, 1965. Impreso.

Zarco, Julián. Catálogo de los manuscritos castellanos de la Real Biblioteca de El Escorial, 1, Madrid: Imprenta Helénica. 1924. Impreso.

Zarco, Julián. Catálogo de los manuscritos castellanos de la Real Biblioteca de El Escorial, 3 , Madrid: Imprenta Helénica, 1929. Impreso.

\subsubsection{ANÁLISIS CUANTITATIVOS}

Blasco Pascual, Javier. “Avellaneda desde la estilometría”. Cervantes, los viajes y los días. Ed. Pedro Ruiz, Sial Ediciones: Madrid. 2016. 97-116. Impreso.

Burrows, John. y Love, Harold. "Attribution Tests and the Editing of Seventeenth-Century Poetry". The Yearbook of English Studies, Modern Humanities Research Association: Cambridge, 29 (1999): 151-175. Web. 26 ene. 2018.

Chao-Lin, Liu. "Flexible Computing Services for Comparisons and Analyses of Classical Chinese Poetry”. Digital Humanities, 2017. 507-510. Web. 13 ene. 2018.

Craig, Hugh. y Kinney, Arthur. Shakespeare, Computers, and the Mystery of Authorship, Nueva York: Cambridge University Press, 2009. Web. 19 ene. 2018.

Craig, Hugh. "George Chapman, John Davies of Hereford, William Shakespeare, and «A Lover's Complaint»". Shakespeare Quarterly, 63, 2 (2012):147-174. Web. 28 ene. 2018. 
Eder, Maciej. "Does size matter? Authorship attribution, small samples, big problema". Literary and Linguistic Computing, 30, 2 (2015) 167-182. Web. 1 mzo. 2018.

Eder, Maciej. "Short Samples in Authorship Attribution: A New Approach". Digital Humanities, 2017. 341-342. Web.13 ene. 2018.

Hernández Lorenzo, Laura. "The Poetic Word of Fernando de Herrera. An Approach through Corpus and Computational Linguistics". EPiC Series in Language and Linguistics, 1 (2016): 170-180. Web. 2 feb. 2018.

Jockers, Matthew. Macroanalysis. Digital Methods and Literary History, Illinois: University of Illinois Press, 2013. Web. 26 ene. 2018.

Kao, Justin. y Jurasfsky, Dan. "A computational analysis of poetic style: Imagism and its influence on modern professional and amateur poetry”. LILT, 12, 3 (2015): 1-31. Web. 18 ene. 2018

Lescasse, Marie-Eglantine. "L'emploi du concept de «propiedad» dans la polémique gongorine". e-Spania, 29 (2018): n.p. Web. 23 mzo. 2018.

Moretti, Franco. Distant Reading, Verso: Londres, 2013. Web. 15 dic. 2017.

Navarro, Borja. "Hacia un análisis distante del endecasílabo áureo: patrones métricos, frecuencias y evolución histórica". Rhythmica. Revista española de métrica comparada, 14 (2016): 89-118. Web. 20 dic. 2018.

Opara, Karol. "Grammatical rhymes in Polish poetry: A quantitative analysis”. Digital Scholarship in the Humanities, 30, 4 (2015): 589-598. Web. 25 ene. 2018.

Rezaei, Sorab. y Kashanian, Nasim. "A stylometric analysis of iranian poets", Theory and Practice in Language Studies, 7, 1 (2017): 55-64. Web. 15 en, 2018.

Rojas, Antonio. "Luis de Góngora y la fábula mitológica del Siglo de Oro: clasificación de textos y análisis léxico con métodos informáticos”. Studia Aurea, 11 (2017): 111-142. Web. 25 ene. 2018.

Ruiz, Pablo. Martínez, Clara. y Poibeau, Thierry. "Distant Rhythm: Automatic Enjambment Detection on Four Centuries of Spanish Sonnets”. Digital Humanities, 2017. 572-576. Web. 13 ene. 2018.

Sánchez Mateos, Zoraida. "Análisis cuantitativos aplicados a poesía: la lírica indubitada sacra de Damián Cornejo y León Marchante”, Studea Aurea, 12. (2018): 287-306. Web. 21 feb. 2019.

Sánchez Mateos, Zoraida. "Análisis cuantitativos aplicados a la lírica: la poesía indubitada profana de Damián Cornejo y de León Marchante”. Humanidades digitales: una mirada 
desde la interdisciplinariedad. Coord. por Eva Álvarez Ramos, Berna: Peter Langg, 2019. 7-11. Impreso.

Sánchez Mateos, Zoraida. "Análisis cuantitativos aplicados a la poesía: la lírica dubitada sacra de Damián Cornejo". Anuario de estudios filológicos, 42 (2019): 247-263. Impreso.

Smarandache, Florentin. "Linguistic-Mathematical Statistics in Recent Romanian Poetry". Collected Papers, 1, Ed. Florentin Smarandache, Ann Arbor: InfoLearnQuest, 2007.

Web. 24 ene. 2018.

Smith, Michael. "The Authorship of «A Lover's Complaint»: An Application of Statistical Stylometry to Poetry". Computers and the Humanities, 18, 1 (1984): 23-37. Web. 26 ene. 2018 .

\subsubsection{EDICIÓN}

AA.VV. “Álbum de las bellas”. Gaceta de las mujeres, 24 sep. 1845. 6-7. Web. 25 ene. 2019. AA.VV. "Poesías selectas". Géneros de varias tiendas u otro novísimo cajón de sastre. Ed. Felipe Ropavejero. Barcelona, Imprenta de Oliveres y Monmany, 1835. 28-38. Web. 4 jun. 2019. AA.VV. Refranero multilingüe. Dirs. Julia Sevilla Muñoz y Zurdo Ruiz-Ayúcar. Madrid: Instituto Cervantes (Centro Virtual Cervantes), 2009. Web. 16 jul. 2019.

AA.VV. Romancero viejo, Alicante: Biblioteca Virtual Miguel de Cervantes, 2005. Web: 8 jun. 2019.

AA. VV. Tonos a lo divino y a lo humano. Ed. Rita Goldberg, Madrid: Támesis, 1981. Web. 16 ene. 2019.

Agreda, María de Jesús De. "Prólogo galeato". Mística ciudad de Dios, milagro de su omnipotencia y abismo de la gracia: historia divina, y vida de la Virgen Madre de Dios, 1, Lisboa: Imprenta de Antonio Craesbeeck de Mello, 1681. 35-162. Web:16 oct. 2018.

Aguado, Francisco. "Capítulo 8. El Santísimo Sacramento es medicina de los desmayos del alma”. Sumo sacramento de la Fe, Madrid: Imprenta de Francisco Martínez, 1640. 274-279. Web. 15 mzo. 2019.

Agulló y Cobo, Mercedes. "El convento de San Diego de Alcalá". Cuadernos de arte e iconografía, 12, 23 (2003): 3-76. Web. 26 ene. 2019.

Alatorre, Antonio. "Fortuna varia de un chiste gongorino". Nueva revista de filología hispánica, 15, 3-4 (1961): 483-504. Web. 27. nov. 2018. 
Alatorre, Antonio. El sueño erótico en la poesía española de los siglos de oro, México: Fondo de Cultura Económica, 2003.

Alatorre, Antonio. "Perduración del ovillejo cervantino". Nueva revista de filología hispánica, 38, 2 (1990): 643-673. Web. 25 nov. 2018.

Alonso Hernández, José Luis. Léxico del marginalismo del Siglo de Oro, Salamanca: Universidad de Salamanca, 1976. Impreso.

Alonso Venoso, María José. "La hagiografía germanesca en el siglo XVII: las jácaras de Cáncer, Solís, Montoro y Sor Juana”. Boletín de la Real Academia Española, 96, 313 (2016): 5-35. Web. feb. 6. 2019.

Alzieu, Pierre. Jammes, Robert. y Lissorgues, Yvan. Poesía erótica del siglo de oro, Barcelona: Crítica, 1984. Impreso.

Argente del Castillo, Concepción. "Celos y embustes en la escena barroca”. La pasión de los celos en el teatro del Siglo de Oro: Actas del II Curso sobre teoría y práctica del teatro. Coords. Remedios Morales Raya y Miguel González Dengra, Granada: Universidad de Granada, 2007. 9-24. Web. 8 mzo. 2019.

Astrana Marín, Luis. "El traje de Sancho Panza". Cervantinas y otros ensayos, Madrid: Afrodisio Aguado, 1944. 117-124. Web. 8 set. 2019.

Atienza Atienza, Daniel. La controversia de la Inmaculada Concepción a través de los impresos de los siglos XVII y XVIII, Madrid: Documentos de trabajo U.C.M. Biblioteca Histórica, 2016. Web. 16 nov. 2018.

Barbieri, Francisco. Cancionero musical de los siglos XV y XVI, Madrid: Real Academia de Bellas Artes de San Fernando, 1890. Web. 14 may. 2019.

Barcia y Zambrana, José. "Sermón quinto: Del Santísimo Sacramento del altar en metáfora de carta amorosa a las almas". Despertador cristiano eucarístico de varios sermones del Santísimo, Madrid: Imprenta de Juan Infanzón, 1690. 163-184. Web. 3 feb. 2019.

Bedford Tanner, Raymon. "La poesía como un idioma divino: Fray Luis de León y su Noche serena”. Espéculo, 33 (2006): s.p. Web. 5 jun. 2019.

Bègue, Alain. "Contra el diablo: los villancicos-jácaras para la Inmaculada Concepción”. Los poderes de la palabra: el improperio en la cultura hispánica del Siglo de Oro. Ed. Cristina Tabernero Sala, Carmela Pérez-Salazar Resano y Jesús María Usunáriz, Nueva York: Peter Lang, 2013. 27-39. Web. 26 ene. 2019.

Bègue, Alain. "Tres o cuatro villancicos de las mejores letras: transmisión y recepción de los villancicos en el Barroco tardío”. Criticón, 11 (2013): 99-126. Impreso. 
Bègue, Alain. "La jácara en los villancicos áureos". Literatura y música del hampa en los Siglos de Oro. Coords. Luisa Lobato y Alain Bègue, Madrid: Visor Libros, 2014. 125-155. Web. 19 dic. 2019.

Blecua, José Manuel. Poesías varias de grandes ingenios españoles. Edición basada en la de Zaragoza (1654), Zaragoza: Institución Fernando El Católico, 1946. Web. 6 ene. 2018.

Blecua, Alberto. Estudios sobre crítica textual, Madrid: Gredos, 2012. Impreso.

Blecua, Alberto. Manual de crítica textual, Madrid: Castalia, 1983. Impreso.

Bolaños Donoso, Piedad. "Nota sobre un soneto de Quevedo". Philologia hispalensis, 24 (2010): 267-270. Web. 19 nov. 2018.

Cacho Casal, Rodrigo. "Quevedo y la filología de autor: edición de la silva El pincel”. Criticón, 114 (2012): 179-212. Web. 7 jun. 2019.

Calderón de la Barca, Pedro. "La estatua de Prometeo". Las comedias de d. Pedro Calderón de la Barca. Ed. Johann Georg Keil, 3, s.l: Leipsique, Ernesto Fleischer, 1829. 321-342. Web. 8 abr. 2019.

Cantizano, Félix. "De las ninfas del Olimpo a las ninfas de las tasqueras: una visión de la prostitución en la España del Siglo de Oro”, eHumanista, 15 (2010): 154-177. Impreso.

Cara, Giovanni. "La forma vejamen y la dificultad de una definición unitaria de género". AISO. Actas V. Coord. Christoph Strosetzki, Madrid: Iberoamericana, 2001. 267-274. Web. 15 nov. 2018.

Carreira, Antonio. "La obra poética de Damián Cornejo: cuatro manuscritos más y uno menos". Criticón, 103-104 (2008): 39-54. Web. 13 oct. 2018.

Cervantes, Miguel De. Don Quijote de la Mancha. Ed. Francisco Rico, Alicante: Biblioteca Virtual, 1998. Web. 11 dic. 2018.

Civil i Castellví, Francesc. “A propòsit d'una 'Jácara al Nacimiento de Xto' -s. XVII, conservada a l'arxiu de la cathedral de Girona". Revista de Girona, 94 (1981): 65-66. Web. 19 nov. 2018 .

Civil, Pierre. "Ut pictura poesis en los preliminares del libro español del Siglo de Oro: del poema al retrato grabado". AISO. Actas IV. Eds. María Cruz García de Enterría y Alicia Cordón Mesa, 1, Alcalá de Henares: Universidad de Alcalá, 1998. 419-432. Web. 14 dic. 2018.

Cottunio, Giovanni. "Libro IV: Capítulo 6". Commentarii lucidissimi in octo libros Aristotelis De physico auditu vnà cum quaestionibus, Padua. Imprenta de Pauli Frambotti, 1648. 631-632. Web. 22. ene. 2019.

Cornejo, Damián. "Capítulo 18. De la impresión maravillosa de sus llagas”. Crónica Seráfica, 1, Madrid: Imprenta de la viuda de Juan García Infanzón, 1682. 456-458. Web. 29 nov. 2018. 
Cornejo Damián. "Capítulo 3. Vocación de santa Clara al estado religioso”. Crónica Seráfica, 2, Madrid: Imprenta de la viuda de Juan García Infanzón, 1684. 6-9. Web. 14. oct. 2018.

Correas, Gonzalo. Vocabulario de refranes y frases proverbiales (1627). Ed. Louis Combet, Bordeaux: Université de Bordaux, 1967. Impreso.

Covarrubias, Sebastián De. Tesoro de la Lengua Castellana o Española, Madrid: Turner, 1977. Impreso.

Cruz, Juana Inés De la. Antología de Sor Juana Inés de la Cruz. Ed. María Luisa Pérez Walker, San Francisco de Chile: Editorial Universitaria, 1993. Web. 14 mzo. 2019.

De Solís y Valenzuela, Pedro. El desierto prodigioso y prodigio del desierto. Ed. Rubén, Páez Patiño, Bogotá: Instituto Caro y Cuervo, 1, 1977. 378-380. Impreso.

Deleito y Piñuela, José. El rey se divierte (recuerdos de hace tres siglos), Madrid: Espasa-Calpe, 1964. Impreso.

Díez Fernández, José Ignacio. La poesía erótica de los Siglos de Oro, Madrid: Ediciones del Laberinto, 2003. Impreso.

Domínguez, Ramón-Joaquín. Diccionario nacional o gran diccionario clásico de la lengua española (etc.), 1, Madrid: Mellado. 1846. Web. 5 mzo. 2019.

Etienvre, Jean-Pierre. Márgenes literarios del juego: una poética del naipe siglos XVI-XVIII, Londres: Támesis, 1990. Web. 15 set. 2019.

Escobar Correa, Juan Gonzalo. Ave Maria, Gratia Plena: Iconología e iconografía de la Inmaculada Concepción, Medellín: Universidad Nacional de Colombia Sede Medellín. 2012. Web. 22 oct. 2018.

Fernández Giménez, Camino. "Fernando Valenzuela y Enciso". Diccionario Biográfico electrónico, Madrid: Real Academia de la Historia, 2018.

Foulché-Delbosc, Raimundo. "Coplas de Trescientas cosas más”. Revue Hispanique, 9 (1902): 261-268. Impreso.

Foulché-Delbosc, Raimundo. "Varia”. Revue Hispanique, 10 (1903): 226-268. Impreso.

Francisco Olmos, José María de. "La sucesión de Carlos II y la Archiduquesa María Antonia de Austria, 1669-1692. Una Reina de España en potencia”. Hidalguía: la revista de genealogía, nobleza y armas, 354, 2 (2012): 613-683. Web. 9 jun. 2019.

Fonseca, Cristóbal De. “Libro 2: Capítulo 15: De la conversión de la Magdalena”. Segunda parte de la vida de Cristo, señor nuestro que trata de sus milagros, Barcelona: Imprenta de la viuda de Jaime Cendrat, 1602. 382-428. Web. 13 oct. 2018.

Gallego Zarzosa, Alicia. "El erotismo en la poesía amorosa de Quevedo: los objetos del deseo". La Perinola, 16 (2012): 65-75. Web. 22 abr. 2019. 
García-Reidy, Alejandro. "Eros y oros, o el intercambio sexual en la poesía erótica de los siglos de oro". En la concha de Venus amarrado: erotismo y literatura en el Siglo de Oro. Coord. Patricia Marín Cepeda, Madrid: Visor Libros, 2017. 27-60. Impreso.

Goldberg, Rita. "Notas". Tonos a lo divino y a lo humano. Ed. Rita Goldberg. Madrid: Támesis, 1981. 160-189. Web. 16 ene. 2019.

Gómez Trueba, Teresa. El sueño literario en España: consolidación y desarrollo del género, Madrid: Cátedra, 1999.

Góngora y Argote, Luis De. Todo Góngora, Barcelona: Universitat Pompeu Fabra, 2015. Web. 6 set. 2019.

González de Torres, Eusebio. "Capítulo 25. Glorioso entierro y prodigios inmediatos a la muerte del santo Regalado". Crónica Seráfica, 6, Madrid: Imprenta de la viuda de Juan García Infanzón, 1725. 109-113. Web. 21. feb. 2019.

Gracián, Baltasar. Obras de Lorenzo Gracián. Tomo segundo, que contiene 'La agudeza, y arte de ingenio', 'El Discreto', 'El Político don Fernando el Católico' y 'Meditaciones varias par antes y después de la Sagrada Comunión que hasta ahora han corrido con título de Comulgado', Madrid: Imprenta Real, 1663. Web. 26 mzo. 2019.

Horozco, Sebastián De. Cancionero de Sebastián de Horozco. Eds. José Labrador, Ralph DiFranco y Ramón Morillo-Velarde, Toledo: Consejería de Educación, Ciencia y Cultura, 2010. 274275. Impreso.

Hipona, san Agustín De. "Libro I: Amor de Dios". Meditaciones de san Agustín, Madrid: Yvory Falls Books, 2018. 7-36. Web. 1 jun. 2019.

Jauralde, Pablo. "Las silvas de Quevedo". La silva. Coord. Begoña López Bueno, Sevilla: Universidad de Sevilla, 1991. 157-180. Web. 17 feb. 2019.

Madoka, Tanabe. "Entre la pastoril y la piscatoria". Imágenes del mar en la poesía de Góngora: de los romances piscatorios a las Soledades, Córdoba: Universidad de Córdoba, 2016. 9-56. Tesis. Web. 5 abr. 2019.

Kirschner, Teresa. "El discurso sexual como subversión del amor en Lope de Vega", Estado actual de los estudios sobre El Siglo de Oro. Ed. Manuel García Martín, Salamanca. Ediciones de la Universidad de Salamanca, 1993. 549-560. Web. 16 ene. 2019.

Labrador Herraiz, José Julián. y Di Franco Ralph. Cancionero sevillano de Lisboa, Sevilla: Universidad de Sevilla, 2003. Impreso.

Lambea, Mariano. y Josa, Lola. La música y poesía en cancioneros polifónicos del siglo XVII, IV. Libro de tonos humanos, 1, Barcelona: Consejo Superior de Investigaciones Científicas, Institución "Milá y Fontanals", 2005. Web. 11 feb. 2019. 
Lara Garrido, José. “Columnas de cristal: códigos y discursividades entre un soneto de Lope y un famoso romance anónimo". El cortejo de Afrodita: ensayos sobre literatura hispánica y erotismo. Coord. Antonio Cruz Casado, Málaga: Universidad de Málaga, 1997, 23-68. Web. 6 mzo. 2019.

León Marchante, Manuel De. Obras poéticas póstumas que a diversos asuntos escribió el maestro León Marchante, 3, Madrid: Real Capilla de su Majestad, 1733. Web. 10 my. 2016.

López de los Mozos, José Ramón, “Sobre los posibles orígenes de la fiesta de 'El Ahorcado' (Mandayona, Guadalajara)". X Encuentro de Historiadores del Valle del Henares. Libro de Actas, Alcalá de Henares: Institución de Estudios Complutenses, Institución Provincial de Cultura "Marqués de Santillana” y Centro de Estudios Seguntinos, 2006. 765-780. Impreso. López Guil, Itziar. Poesía religiosa cómico-festiva del bajo barroco español: estudio y antología, Bern: Peter Lang, 2011. Impreso.

Lyon, Ireneo De. “La Economía por la obediencia de María”. Contra los herejes, 5, 519. Web. 5 dic. 2018.

Maire Bobes, Jesús. "El doctor, figura cómica de los entremeses". Memoria de la palabra: actas del VI Congreso de la Asociación Internacional Siglo de Oro. Coords. Francisco Domínguez Matito y María Luisa Lobato López, 2, Madrid: Iberoamericana Vervuet. 2004. 1217-1228. Web. 14 jun. 2019.

Mata, Juan. "La pluma y el pincel de Sor Juana Inés de la Cruz". Verba hispánica, 9 (2001): 91110. Web. 25 nov. 2018.

Marañón Ripoll, Miguel. "Otro testimonio manuscrito de una serie de poesías escatológicas atribuida a Damián Cornejo". Manuscrt. Cao, 7 (1996-1998): 71-81. Impreso.

Marañón Ripoll, Miguel. “El Entremetido y la Dueña y el Soplón de Quevedo. Texto, notas e introducción”. Cuadernos para investigación de la literatura hispánica, 31 (2006): 15-132. Web. 1 jun. 2019.

Maravall, José Antonio. La cultura del barroco: análisis de una estructura histórica, Barcelona: Ariel, 1975. Impreso.

Marín, Diego. "Función dramática de la versificación en el teatro de Calderón”. Calderón: actas del Congreso Internacional sobre Calderón y el teatro español del Siglo de Oro, 1, Madrid: CSIC, 1981. 1139-1146. Web. 11. feb. 2019.

Martín, Adrienne. "Erotismo felino: Las gatas de Lope de Vega". Analecta Malacitana (AnMal electrónica), 32 (2012): 405-420. Web. 3. sept. 2018. 
Martínez-López, Enrique. "La leyenda del judío errante en la literatura de cordel española". AIH. Actas X. Coord. Antonio Vilanova, 2, Barcelona: Universidad Pompeu Fabra, 1992. 13371354. Web. 16 dic. 2018.

Merino, Antolín. Parafrástica explicación y traducción de los salmos, himnos y canciones, 1, Madrid: Imprenta de los nietos de Ibarra, 1809. Web. 27 nov. 2018.

Molina, Tirso De. Marta la Piadosa. Ed. Blanca de los Ríos. Alicante: Biblioteca Virtual Miguel de Cervantes, 1999. Web. 4 feb. 2019.

Montero Delgado, Juan. y Ruiz Pérez, Pedro. "La silva entre el metro y el género". La silva. Dir. Begoña López Bueno, Sevilla: Universidad de Sevilla, 1991. 19-56. Web. 1 set. 2018.

Morros Mestres, Bienvenido. "Bartolomé Leonardo de Argensola, poeta petrarquista". Argensola: Revista de Ciencias Sociales del Instituto de Estudios Altoaragoneses, 119 (2009): 107-132. Web. 5 jun. 2019.

Nicolás Rubio, César. Estrategias y lecturas la anamorfosis de Quevedo, Extremadura: Universidad de Extremadura, 1986. Impreso.

Núñez, Hernán. Refranes o proverbios en castellano por el orden alfabético que juntó y glosó el comendador Hernán Núñez, 3, Lérida: Luis Manescal, 1621. Web. 3 feb. 2019.

Osuna, Inmaculada. "Las oraciones y coplas de ciego como motivo burlesco culto en la poesía religiosa del siglo XVII". Eros divino: estudios sobre la poesía religiosa iberoamericana del siglo XVII. Ed. Julián Olivares, Zaragoza: Universidad de Zaragoza, 2010. 335-366. Impreso.

Paracuellos Cabeza de Vaca. Luis De. "Décimas de fr. Pedro González". Elogios a María Santísima. Conságralos en suntuosas celebridades devotamente Granada a la limpieza pura de su Concepción, y dedícalos a la Majestad Católica de Filip IV, rey y s.n., Granada: Francisco Sánchez y Baltasar de Bolibar, 1651. 2010-2014. Web. 9. nov. 2018.

Paravicino, Hortensio. "Sermón del Santísimo Sacramento. Al ilustrísimo cardenal Legado don Francisco Barberino". Oraciones evangélicas en las festividades de Cristo, Madrid: Imprenta del Reino, 1640. 54-66. Web. 28. nov. 2018.

Pena Sueiro, Nieves. "Estado de la cuestión sobre el estudio de las Relaciones de sucesos". Pliegos de bibliofilia, 13 (2001): 43-66. Web. 13. set. 2018.

Peña Álvarez, Javier De la. Flores en la poesía española del Renacimiento y Barroco, Madrid: Repositorio de la Universidad Complutense de Madrid, 2010. Tesis. Web. 15. oct. 2018.

Pérez de Montoro, José. Obras póstumas líricas humanas. Ed. Juan de Mayo, 1, Madrid: Imprenta de Antonio Marín, 1736. 280. Web. 16 abr. 2019. 
Pérez de Montoro, José. Obras póstumas líricas humanas. Ed. Juan de Mayo, 2, Madrid: Imprenta de Antonio Marín, 1736. 311. Web. 5 my. 2019.

Pérez Lasheras, Antonio. "Silva y soledad (análisis comparativo de algunos pasajes de Ginovés y Góngora)". Revista de Filología Española, 68, 1-2 (1988): 119-140. Web. 19 mzo. 2019.

Pérez Martínez, Herón. “Tradición y oralidad en el refranero mexicano”. La tradición hoy en día: memorias, México: Universidad Iberoamericana. 1998. Web. 7 abr. 2019.

Pino Polo, Francisco. "Cicerón contra Clodio: el lenguaje de la invectiva”. Gerión, 9, 1991. 131150. Web. 9 my. 2019.

Pizarro Llorente, Henar. y Jiménez Pablo, Esther. Santa María Magdalena de Pazzi: Imagen y Mística, Roma: Edizioni Carmelitane, 2016. Web. 13 ene. 2019.

Polo de Medina, Jacinto. Fábula de Apolo y Dafne, Alicante: Biblioteca Virtual Miguel de Cervantes, 2002. Web. 15 mzo. 2019.

Polo de Medina, Jacinto. El buen humor de las musas. Alicante: Biblioteca Virtual Miguel de Cervantes, 2002. Web. 1 mzo. 2019.

Ponce Cárdenas, Jesús. "La canción de ausencia en el petrarquismo hispano". Evaporar contempla un fuego helado. Género, enunciación lírica y erotismo en una canción gongorina, Málaga: Universidad de Málaga, 2006. 31-44. Impreso.

Porteiro Chouciño, Ana María. Estudio y edición de "La Arcadia" (1615) de Lope de Vega, La Coruña: Repositorio de la Universidad de Coruña. Web. 27 my. 2019.

Quevedo, Francisco De. "El mundo por de dentro" Sueños. Ed. Franscisco Induráin, Zaragoza: Editorial Ebro. 70-86. Web. 15 dic. 2018.

Quevedo, Francisco De. Juguetes y travesuras de ingenio de D. Francisco de Quevedo Villegas, extractadas de sus obras poéticas por su humilde admirador (...), finalizando con la preciosa composición de Bretón de los Herreros “¿Quién es ella?”. Ed. Amancio Peratoner, Barcelona: José Codina, 1876. Web. 23 set. 2019.

Quevedo, Francisco De. Poesías de don Francisco de Quevedo Villegas, Caballero de la Orden de Santiago, Señor de la Villa de la Torre de Juan-Abad, 3, Bruselas: Imprenta de Francisco Foppens, 1670. Web. 15 jun. 2019.

Quevedo, Francisco De. Sonetos de Quevedo. Ed. Ramón García González, Alicante: Biblioteca Virtual Miguel de Cervantes, 2003. Web. 7 feb. 2019.

Quevedo, Francisco De. Obras de don Francisco de Quevedo Villegas, Caballero de la Orden de Santiago, Señor de la Villa de la Torre de Juan-Abad, 1, Amberes: Henrico y Cornelio Verdussen, 1699. Web. 14 jun. 2019. 
Quevedo, Francisco De. Obras de don Francisco de Quevedo Villegas, Caballero de la Orden de Santiago, Señor de la Villa de la Torre de Juan-Abad, 4: Madrid: Joaquín de Cámara, 1772. Web. 23 feb. 2019.

Rambla, Pascual. "Tratado popular sobre la Santísima Virgen”. Historia del dogma de la Inmaculada Concepción, Barcelona: Vilamala, 1954. 92-210. Web. 13 dic. 2018.

Real Academia Española y Asociación de Academias de la Lengua Española. Diccionario Panhispánico de Dudas, Madrid: Santillana, 2005. Web. 4. nov. 2018.

Real Academia Española. Diccionario de Autoridades, Madrid: Imprenta de Francisco del Hierro, 1729-1736. Web. 22. set. 2019.

Real Academia Española y Asociación de Academias de la Lengua Española. Diccionario de la lengua española, Polinyà: Espasa-Calpe, 2018. Web. 1 oct. 2019.

Rebolledo, Juan De. Cincuenta oraciones funerales. En que se considera la vida y sus miserias, la muerte y sus provechos. Ed. Juan Quartanet, s.d., 1608. Web. 11. ene. 2019.

Roig Miranda, Marie. "La Lisi de Quevedo". La Perinola: Revista de investigación quevediana, 16, (2012): 97-106. Web. 21 ene. 2019.

Rojas Zorrilla, Francisco. "Los bandos de Verona”. Obras completas. Volumen IV: Segunda parte comedias. Dirs. Felipe B. Pedraza y Rafael González Cañal, Cuenca: Ediciones de la Universidad de Castilla y la Mancha, 2011. 207-321. Web. 3 abr. 2019.

Rojo, Antonio. Historia de San Diego de Alcalá, fundación y frutos de santidad, que ha producido su convento de Santa María de Jesús (etc.), Madrid: Imprenta Real, 1663. Web. 9 ene. 2019.

Ruiz, María Jesús. "Repertorio tradicional infantil de Cádiz: texto, rito, gesto y símbolo”, Revista OCNOS, 5 (2009): 69-86. Web. 22 jun. 2019.

Ruiz Pérez, Pedro. “¿Góngora erótico?: el retrete del poeta”. En la concha de Venus amarrado: erotismo y literatura en el Siglo de Oro. Coord. Patricia Marín Cepeda, Madrid: Visor Libros, 2017. 61-90. Impreso.

Ruiz Pérez, Pedro. "La Boscarecha de Pedro Espinosa del canto del pastor a la escritura del poeta". A zaga de tu huella: homenaje al prof. Cristóbal Cuevas. Coord. Salvador Montesa, 1, Madrid: Asociación para el Estudio, Difusión e Investigación de la Lengua y Literatura Españolas, 2005. 231-262. Web. 26 jun. 2019.

Sáez, Adrián. "La vuelta del camino o la máscara de Demócrito: apostillas de poesía religiosa burlesca". Versants: revue suisse des littératures romanes, 60, 3 (2013): 71-82. Impreso.

Sáez, Adrián. "El perdón de la Magdalena: erotismo y pintura en un soneto de Quevedo". En la concha de Venus amarrado: erotismo y literatura en el Siglo de Oro. Coord. Patricia Marín Cepeda, Madrid :Visor Libros, 2017. 107-120. Impreso. 
Sait Sener, Mehmet. "Las obras turquescas del teatro áureo". El tema turco en el teatro español de los siglos XVI-XVII, Madrid: Universidad Complutense de Madrid, 2017. 101-251. Tesis. Web. 17 dic. 2018.

Santo, Juan de la Cruz. Poesías, Alicante: Biblioteca Virtual Miguel de Cervantes, 2004. Web. 21 ene. 2019.

Sanz Hermida, Jacobo. "Vejámenes y gallos en las ceremonias universitarias salmantinas en los Siglos de Oro". Grados y ceremonias en las universidades hispánicas: homenaje a Águeda Rodríguez Cruz. Coords. Luis Enrique Rodríguez San Pedro Bezares y Juan Luis Polo Rodríguez, 2004. 155-173. Web. 7 jun. 2019.

Sánchez-Pérez, María. "El adulterio y la violencia femenina en algunos pliegos sueltos poéticos del siglo XVI". Revista de dialectología y tradiciones populares, 68, 2 (2013): 287-303. Web. 14. ene. 2018.

Sánchez Martínez, Rafael. "La Inmaculada en la poesía barroca española”. La Inmaculada Concepción en España: religiosidad, historia y arte. Actas del symposium. Coords. Francisco Javier Campos y Fernández de Sevilla, 2, San Lorenzo de El Escorial: Real Centro Universitario Escorial-María Cristina, 2005. 1407-1416. Web. 29 nov. 2018

Sánchez-Velo, Julio. "Escollo armado de yedra. Tradición musical y función dramática de la poesía lírica en el teatro calderoniano”. Jornadas de Investigación Literaria y Lingüística de los estudiantes graduados del Programa de Español. Coord. Louise Stein, 2005. 45-53. Web. 8. dic. 2018.

Santiago Fernández, Javier De. "Moneda y fiscalidad en castilla durante el siglo XVII". IV Jornadas Científicas sobre Documentación de Castilla e Indias en el siglo XVI. Coord. José María de Francisco Olmos, Javier de Santiago Fernández y Juan Carlos Galende Díaz, 2005. 409-433. Web. 1 set. 2019.

Sbarbi y Osuna, José María. Florilegio o Ramillete alfabético de refranes y modismos comparativos y ponderativos de la lengua castellana definidos razonadamente y en estilo ameno, Madrid: Imprenta de A. Gómez Fuentenebro, 1873. Web. 7 set. 2019.

Serés, Guillermo. La transformación de los amantes: imágenes del amor de la Antigüedad al Siglo de Oro, Barcelona: Crítica, 1996. Impreso.

Serna, José De. "Varias cartas jocosas". El Bufón de la corte, Madrid: Gabriel Ramírez, 1767. 97112. Web. 2 feb. 2019.

Schapiro, Meyer. "Cain's Jaw-Bone that Did the First Murder". The Art Bulletin, 24, 3 (1942): 205-212. Web. 13 dic. 2018. 
Sierra Pérez, José. “Textos eucarísticos castellanos del siglo XVII en el Archivo de Música del Monasterio de San Lorenzo el Real del Escorial”. Religiosidad y ceremonias en torno a la eucaristía: Actas del symposium. Coord. Francisco Javier Campos y Fernández de Sevilla, 1, San Lorenzo de El Escorial: Real Centro Universitario Escorial-María Cristina, 2003. 71130. Web. 9 dic. 2018.

Suárez Miramón, Ana. "Variaciones dramáticas en Calderón sobre un tema popular". Actas del VIII Congreso de la Asociación Internacional del Siglo de Oro. Coords. Antonio Azaustre Galiana, Santiago Fernández Mosquera, 3, Santiago de Compostela: Servizo de Publicacións da Universida de Santiago de Compostela, 2011. 439-446. Web. 6 ene. 2019.

Suazo Pascual, Guillermo. Abecedario de dichos y frases hechas, Madrid: Edaf, 1999. Web. 17 ene. 2019.

Tenorio, Martha Lilia. “Sor Juana y Pérez de Montoro: el caso de los romances de celos”. Actas del XIV Congreso de la Asociación Internacional de Hispanistas. Coords. Isaías Lerner, Roberto Nival y Alejandro Alonso, 4, Nueva Jersey: Juan de la Cuesta, 2004. 665-675. Web. 11 my. 2019.

Tenorio, Martha Lilia. “Sor Juana y León Marchante”. NRFH, 50, 2 (2002): 543-561. Impreso.

Terreros y Pando, Esteban. Diccionario castellano con las voces de ciencias y artes y sus y sus correspondientes en las tres lenguas francesa, latina e italiana: E-O, Madrid: Imprenta de la Viuda de Ibarra, 1787. Web. 12 dic. 2018.

Trambaioli, Marcella. “Quevedo, Lope y la mujer fea”. La Perinola, 19 (2015): 271-305. Web. 13 jun. 2018.

Trueblood, Alan. "La mariposa y la llama: motivo poético del Siglo de Oro”. Actas del Quinto Congreso Internacional de Hispanistas. Coords. François López, Joseph Pérez, Noel Salomón y Maxime Chevalier, 2, Burdeos: Université de Bordeaux, 1977. 829-837.

Vega, Garcilaso De la. Sonetos. Ed. Ramón García González, Alicante: Biblioteca Virtual Miguel de Cervantes, 2004. Web. 3 mzo. 2019.

Vega, Lope De. “Comedia famosa de Angélica en el Catay”. El Fénix de España Lope de Vega Carpio, Familiar del Santo Oficio, 8, Barcelona: Sebastián de Cermellas al Call, 1617. 225239. Web. 7 my. 2019.

Vega, Lope De. Peribáñez y el Comendador de Ocaña. El mejor alcalde, el rey. Ed. Teresa Ferrer. Alicante: Biblioteca Virtual Miguel de Cervantes, 2002. Web. 5 abr. 2019.

Vega, Lope De. El perro del Hortelano, Alicante: Biblioteca Virtual Miguel de Cervantes, 2002. Web. 23 abr. 2019. 
Vega, Lope De. El Milagro por los celos y D. Álvaro de Luna, Barcelona: Imprenta de Carlos Sapera, 1770. Web. 19 jun. 2019.

Vega, Lope De. Sonetos. Ed. Ramón García González, Alicante: Biblioteca Virtual Miguel de Cervantes, 2003. Web. 2 jul. 2019.

Vidorreta Torres, Almudena. Estudio y edición de "Poesías varias" de José Navarro (1654), Zaragoza: Zaguán. Repositorio Institucional de Documentos, 2014. Web. 9 my. 2019.

Vivalda, Nicolás. "Sor Juana y el pernicioso modelo de Faetón. Lecciones epistemológicas del escarmiento en Primero sueño”. Calíope, 16, 2 (2010):103-125. Web. 1 jun. 2019.

Vivas, Agustín. y Arias, Luis. "Fuentes documentales para el estudio de la prostitución en los siglos XVI y XVII en el Archivo y Biblioteca de Salamanca”. Brocar: Cuadernos de investigación histórica, 22 (1988): 51-62. Impreso.

Zafra, Enriqueta. Prostituidas por el texto: Discurso prostibulario en la picaresca femenina, Indiana: Purdue University Press, 2009. Impreso.

\subsubsection{EDICIÓN EN LENGUAJE MARCADO (XML-TEI)}

Burnard, Lou. "Introduction". En Burnard, L. What is the Text Encoding Initiative. How to add intelligent markup to digital resources, Marserille: Open Edition, 2014. Impreso.

Burnard, Lou. "The Evolution of the Text Encoding Initiative: From Research Project to Research Infrastructure", Journal of the Text Encoding Initiative, 5 (2013): 3. Web. 12, ene. 2019.

Pezzini, Sara y Ruiz, Héctor. "Editar a Góngora con instrumentos digitales: bases metodológicas y perspectivas teóricas para un hipertexto de la polémica gongorina". Revista de Humanidades Digitales, 1 (2017): 35-56. Web. 10, ene. 2019.

Sperberg-McQueen, Michael y Burnard, Lou. Guidelines for Electronic Text Encoding and Interchange, Chicago: Text Encoding Initiative, 1994. Web. 19 ene. 2019. 


\subsection{BIBLIOGRAFÍA COMPLETA}

AA. VV. "Agosto que pintó un ingenio". El correo literario de Murcia. 11 de feb. 1794: 91-95. Web. 17 sep. 2018.

AA.VV. “Álbum de las bellas”. Gaceta de las mujeres, 24 sep. 1845: 6-7. Web. 25 ene. 2019.

AA. VV. “Bibliografía”. La Ilustración Católica. 7 nov. 1881:131-134. Web. 14 jun. 2016.

AA. VV. Cancionero de obras de burlas provocantes a risa. Ed. Antonio Pérez, Madrid: Librería de Victoriano Suárez, 1951. Impreso.

AA. VV. Cancionero moderno de obras alegres. Ed. Eduardo Lustonó, Londres: H. W. Spirtual, 1875. Web. 12 mzo. 2016.

AA.VV. Catálogo de manuscritos de la Biblioteca Nacional con poesía en castellano de los siglos XVI y XVII, 1-4, Madrid: Arco Libros, 1998. Impreso.

AA. VV. "De Madrid, el 24 de mayo de 1707”. Gazette. 11 jun. 1707: 269- 271. Web. 6 jun. 2016.

AA. VV. "De todo un poco". Madrid cómico. 29 may. 1881: 2-3. Web. 15 jun. 2016.

AA.VV. MANUS OnLine. Censimento dei manoscritti delle biblioteche italiane, Milán: Università degli studi di Milano, Dipartimento di Informatica e Comunicazion, 1988-2020. Web. 22 jun. 2017.

AA.VV. "Poesías selectas”. Géneros de varias tiendas u otro novísimo cajón de sastre. Ed. Felipe Ropavejero, Barcelona: Imprenta de Oliveres y Monmany, 1835. 28-38. Web. 4 jun. 2019.

AA.VV. Refranero multilingüe. Dirs. Julia Sevilla Muñoz y Zurdo Ruiz-Ayúcar. Madrid: Instituto Cervantes (Centro Virtual Cervantes), 2009. Web. 16 jul. 2019.

AA.VV. Romancero viejo, Alicante: Biblioteca Virtual Miguel de Cervantes, 2005. Web: 8 jun. 2019.

AA. VV. Tonos a lo divino y a lo humano. Ed. Rita Goldberg, Madrid: Támesis, 1981. Web. 16 ene. 2019.

Agreda, María de Jesús De. "Prólogo galeato". Mística ciudad de Dios, milagro de su omnipotencia y abismo de la gracia: historia divina, y vida de la Virgen Madre de Dios, 1, Lisboa: Imprenta de Antonio Craesbeeck de Mello, 1681. 35-162. Web:16 oct. 2018.

Aguado, Francisco. "Capítulo 8. El Santísimo Sacramento es medicina de los desmayos del alma”. Sumo sacramento de la Fe, Madrid: Imprenta de Francisco Martínez, 1640. 274-279. Web. 15 mzo. 2019.

Agulló y Cobo, Mercedes. "El convento de San Diego de Alcalá”. Cuadernos de arte e iconografía, 12, 23 (2003): 3-76. Web. 26 ene. 2019. 
Alatorre, Antonio. "Fortuna varia de un chiste gongorino". Nueva revista de filología hispánica, 15, 3-4 (1961): 483-504. Web. 27. nov. 2018.

Alatorre, Antonio. "Perduración del ovillejo cervantino". Nueva revista de filología hispánica, 38, 2 (1990): 643-673. Web. 25 nov. 2018.

Alatorre, Antonio. El sueño erótico en la poesía española de los siglos de oro, México: Fondo de Cultura Económica, 2003.

Allen, Eduardo. Catálogo da Biblioteca Publica do Porto. Índice preparatorio do catalogo dos manuscritos..., 6, Oporto: Imprensa Civilisação, 1983. Impreso.

Alonso Hernández, José Luis. Léxico del marginalismo del Siglo de Oro, Salamanca: Universidad de Salamanca, 1976. Impreso.

Alonso Venoso, María José. "La hagiografía germanesca en el siglo XVII: las jácaras de Cáncer, Solís, Montoro y Sor Juana”. Boletín de la Real Academia Española, 96, 313 (2016): 5-35. Web. feb. 6. 2019.

Álvarez Amo, Francisco Javier. Las obras poéticas líricas (1738) de Eugenio Gerardo Lobo: Edición y estudio, Córdoba: Servicio de publicaciones de la Universidad de Córdoba, 2014. Tesis. Web. 14 set. 2017.

Álvarez, Diego. “Capítulo 3: Memorias de V. P. fray Antonio Rojo...”. Memorial ilustre de los famosos hijos del convento de Sta. María de Jesús (vulgo San Diego de Alcalá) primado... Ed. Vicente Julián Bentura de Alfaro, 6, Alcalá: Universidad de Alcalá, 1753. 474-476. Web. 17 jun. 2016.

Álvarez, Diego. “Capítulo 8: Religiosísima memoria de V. P. fray Juan de Salcedo...”. Memorial ilustre de los famosos hijos del convento de Sta. María de Jesús (vulgo San Diego de Alcalá) primado... Ed. Vicente Julián Bentura de Alfaro, 6, Alcalá: Universidad de Alcalá, 1753. 494-498. Web. 17 jun. 2016.

Álvarez, Diego. “Capítulo 14: Memorias de la venerable madre Catalina de Jesús...”. Memorial ilustre de los famosos hijos del convento de Sta. María de Jesús (vulgo San Diego de Alcalá) primado... Ed. Vicente Julián Bentura de Alfaro, 6, Alcalá: Universidad de Alcalá, 1753. 521-525. Web. 17 jun. 2016.

Alzieu, Pierre. Jammes, Robert. y Lissorgues, Yvan. Poesía erótica del Siglo de Oro, Barcelona: Crítica, 1984. Impreso.

Argente del Castillo, Concepción. "Celos y embustes en la escena barroca”. La pasión de los celos en el teatro del Siglo de Oro: Actas del II Curso sobre teoría y práctica del teatro. Coords. 
Remedios Morales Raya y Miguel González Dengra, Granada: Universidad de Granada, 2007. 9-24. Web. 8 mzo. 2019.

Artigas y Ferrando, Miguel. "Catálogo de los manuscritos de la Biblioteca". Boletín de la Biblioteca Menéndez Pelayo, Santander: Biblioteca Menéndez, 1926. 376-384. Web. 16 feb. 2017.

Astrana Marín, Luis. "El traje de Sancho Panza". Cervantinas y otros ensayos, Madrid: Afrodisio Aguado, 1944. 117-124. Web. 8 set. 2019.

Atienza, Daniel. La controversia de la Inmaculada Concepción a través de los impresos de los siglos XVII y XVIII, Madrid: Documentos de trabajo U.C.M. Biblioteca Histórica, 2016. Web. 16 nov. 2018.

Barbieri, Francisco. Cancionero musical de los siglos XV y XVI, Madrid: Real Academia de Bellas Artes de San Fernando, 1890. Web. 14 may. 2019.

Barcia y Zambrana, José. "Sermón quinto: Del Santísimo Sacramento del altar en metáfora de carta amorosa a las almas". Despertador cristiano eucarístico de varios sermones del Santísimo, Madrid: Imprenta de Juan Infanzón, 1690. 163-184. Web. 3 feb. 2019.

Barnatán, Marcos y García Sánchez, Jesús. Poesía erótica castellana del Siglo X a nuestros días, Gijón: Júcar, 1974. Impreso.

Barrera, Cayetano Alberto De la. Catálogo bibliográfico y biográfico del teatro antiguo español desde sus orígenes hasta mediados del siglo XVIII, Madrid: Gredos, 1969. Impreso.

Bedford Tanner, Raymon. "La poesía como un idioma divino: Fray Luis de León y su Noche serena”. Espéculo, 33 (2006): s.p. Web. 5 jun. 2019.

Bègue, Alain. "Aproximación a la lengua poética de la segunda mitad del siglo XVII: el ejemplo de José Pérez de Montoro". Criticón, 97-9 (2006): 153-170. Impreso.

Bègue, Alain. "Los límites de la poesía epidíctica: la poesía jocoseria de José Pérez de Montoro". Criticón, 100 (2007): 143-166. Web. 6 oct. 2017.

Bègue, Alain. "Degeneración y prosaísmo de la escritura poética de finales del siglo XVII y principios del XVIII: análisis de dos nociones heredadas”. Criticón, 103-104 (2008): 21-38. Web. 1 oct. 2017.

Bègue, Alain y Croizat-Viallet, Jean. "Presentación”. Criticón, 103-104 (2008): 5-8. Web. 25 oct. 2015 .

Bègue, Alain. "Albores de un tiempo nuevo: la escritura poética de entre los siglos (XVII-XVIII)". La luz de la razón: literatura y cultura del siglo XVIII: a la memoria de Ernest Lluch. Coord. Aurora Egido. Zaragoza: IFC, 2010. 37-69. Impreso. 
Bègue, Alain. "Relación de la poesía española publicada entre 1648 y 1750”. La luz de la razón: literatura y cultura del siglo XVIII: a la memoria de Ernest Lluch. Coord. Aurora Egido. Zaragoza: IFC, 2010. 399-477. Impreso.

Bègue, Alain. La poésie espagnole de la fi du XVII siècle: José Pérez de Montoro (1627-1694), membre d'un Parnasse oublié, Sarrebruck: Éditions Universitaires Européennes. 2010. Impreso.

Bègue, Alain. "Poetas de la segunda mitad del siglo XVII". Diccionario Filológico de Literatura Española. Siglo XVII. Ed. Pablo Jauralde, 2, 2011, 707-741, Madrid: Castalia. Impreso.

Bègue, Alain. "Tres o cuatro villancicos de las mejores letras: transmisión y recepción de los villancicos en el Barroco tardío”. Criticón, 11 (2013): 99-126. Impreso.

Bègue, Alain. “Contra el diablo: los villancicos-jácaras para la Inmaculada Concepción”. Los poderes de la palabra: el improperio en la cultura hispánica del Siglo de Oro. Ed. Cristina Tabernero Sala, Carmela Pérez-Salazar Resano y Jesús María Usunáriz, Nueva York: Peter Lang, 2013. 27-39. Web. 26 ene. 2019.

Bègue, Alain. "Hacia la modernidad: nuevas actitudes del yo lírico en la poesía española entre Barroco y Neoclasicismo", Cuadernos AISPI: Estudios de lenguas y literaturas hispánicas, 1 (2013): 63-88. Web. 16 dic. 2017.

Bègue, Alain. "La jácara en los villancicos áureos". Literatura y música del hampa en los Siglos de Oro. Coords. Luisa Lobato y Alain Bègue, Madrid: Visor Libros, 2014. 125-155. Web. 19 dic. 2019.

Bègue, Alain. "Parece que lo jocoserio / se me introduce el estilo» La modalidad jocoseria como expresión de modernidad entre Barroco y Neoclasicismo". Hacia la Modernidad. La construcción de un nuevo orden teórico literario entre Barroco y Neoclasicismo (16511750). Dirs. Alain Bègue y Carlos Mata Induráin, 2, Vigo: Academia del Hispanismo, 2018. 69-96. Impreso.

Bègue, Alain y Mata Induráin, Carlos. "Introducción”. Hacia la Modernidad. La construcción de un nuevo orden teórico literario entre Barroco y Neoclasicismo (1651-1750). Dirs. Alain Bègue y Carlos Mata Induráin, 2, Vigo: Academia del Hispanismo, 2018. 13-22. Impreso.

Blasco Pascual, Javier. Arte de Amor: primera traducción al castellano del Ars amandi de Ovidio, Valladolid: Agilice digital, 2016. Impreso.

Blasco Pascual, Javier. “Avellaneda desde la estilometría”. Cervantes, los viajes y los días. Ed. Pedro Ruiz, Sial Ediciones: Madrid, 2016. 97-116. Impreso.

Blecua, José Manuel. Poesías varias de grandes ingenios españoles. Edición basada en la de Zaragoza (1654), Zaragoza: Institución Fernando El Católico, 1946. Web. 6 ene. 2018. 
Blecua, Alberto. Manual de crítica textual, Madrid: Castalia, 1983. Impreso.

Blecua, Alberto. Estudios sobre crítica textual, Madrid: Gredos, 2012. Impreso.

Bolaños Donoso, Piedad. "Nota sobre un soneto de Quevedo". Philologia hispalensis, 24 (2010): 267-270. Web. 19 nov. 2018.

Borges, Jorge Luis. Otras inquisiciones, Buenos Aires: Sur, 1952. Impreso.

Burnard, Lou. "Introduction”. En Burnard, L. What is the Text Encoding Initiative. How to add intelligent markup to digital resources, Marserille: OpenEdition, 2014. Impreso.

Burnard, Lou. "The Evolution of the Text Encoding Initiative: From Research Project to Research Infrastructure", Journal of the Text Encoding Initiative, 5 (2013): 3. Web. 12, ene. 2019.

Burrows, John. y Love, Harold. "Attribution Tests and the Editing of Seventeenth-Century Poetry". The Yearbook of English Studies, Modern Humanities Research Association: Cambridge, 29 (1999): 151-175. Web. 26 ene. 2018.

Cacho Casal, Rodrigo. "El ingenio del arte: introducción a la poesía burlesca del Siglo de Oro". Criticón, 100 (2007): 9-26. Impreso.

Cacho Casal, Rodrigo. "Poesía burlesca del Siglo de Oro y sus modelos italianos". Nueva revista de filología hispánica, 51, 2 (2003): 465-491. Impreso.

Cacho Casal, Rodrigo. "Quevedo y la filología de autor: edición de la silva El pincel". Criticón, 114 (2012): 179-212. Web. 7 jun. 2019.

Calderón de la Barca, Pedro. "La estatua de Prometeo". Las comedias de d. Pedro Calderón de la Barca. Ed. Johann Georg Keil, 3, s.l.: Leipsique, Ernesto Fleischer, 1829. 321-342. Web. 8 abr. 2019.

Cantizano Pérez, Félix. El erotismo en la poesía de adúlteros y cornudos en el Siglo de Oro, Madrid: Editorial Complutense, 2007. Impreso.

Cantizano, Félix. "De las ninfas del Olimpo a las ninfas de las tasqueras: una visión de la prostitución en la España del Siglo de Oro”, eHumanista, 15 (2010): 154-177. Impreso.

Cañas Murillo, Jesús. "Corte y academias literarias en la España de Felipe IV”. Anuario de Estudios Filológicos, 35 (2012): 5-26. Impreso.

Cara, Giovanni. "La forma vejamen y la dificultad de una definición unitaria de género". AISO.

Actas V. Coord. Christoph Strosetzki, Madrid: Iberoamericana, 2001. 267-274. Web. 15 nov. 2018.

Carreira, Antonio. "El manuscrito como transmisor de las humanidades en los siglos de oro". Boletín del Instituto de Investigaciones Bibliográficas - UNAM, 1-2, 6 (2000): 21-46. Impreso. 
Carreira, Antonio. "Introducción”. Luis de Góngora. Romances, 1, Barcelona: Quaderns crema, 1998. 15-48. Impreso.

Carreira, Antonio. "Juan de Ibaso y Malagón: inventario y muestra de su obra poética". El Siglo de Oro en escena. Homenaje a Marc Vitse. Coords. Odette Gorsse y Frédéric Serralta, Tolouse: Université de Toulouse II-Le Mirail, 2006. 155-178. Web. 7 oct. 2016.

Carreira, Antonio. "La obra poética de Damián Cornejo: cuatro manuscritos más y uno menos". Criticón, 103-104 (2008): 39-54. Web. 13 oct. 2018.

Castro y Castro, Manuel De. Manuscritos franciscanos de la Biblioteca Nacional de Madrid, Madrid: Ministerio de Educación y Ciencia, 1973. Impreso.

Cela, Camilo José. Diccionario de erotismo, Barcelona: Grijalbo, 1988. Impreso.

Cervantes, Miguel De. Don Quijote de la Mancha. Ed. Francisco Rico, Alicante: Biblioteca Virtual, 1998. Web. 11 dic. 2018.

Chao-Lin, Liu. "Flexible Computing Services for Comparisons and Analyses of Classical Chinese Poetry”. Digital Humanities, 2017. 507-510. Web. 13 ene. 2018.

Civil i Castellví, Francesc. “A propòsit d'una 'Jácara al Nacimiento de Xto' -s. XVII, conservada a l'arxiu de la catedral de Girona". Revista de Girona, 94 (1981): 65-66. Web. 19 nov.2018.

Civil, Pierre. "Ut pictura poesis en los preliminares del libro español del Siglo de Oro: del poema al retrato grabado". AISO. Actas IV. Eds. María Cruz García de Enterría y Alicia Cordón Mesa, 1, Alcalá de Henares: Universidad de Alcalá, 1998. 419-432. Web. 14 dic. 2018.

Cornejo Damián. "Capítulo 3. Vocación de santa Clara al estado religioso”. Crónica Seráfica, 2, Madrid: Imprenta de la viuda de Juan García Infanzón, 1684. 6-9. Web. 14. oct. 2018.

Cornejo, Damián. "Capítulo 18. De la impresión maravillosa de sus llagas”. Crónica Seráfica, 1, Madrid: Imprenta de la viuda de Juan García Infanzón, 1682. 456-458. Web. 29 nov. 2018. Cornejo, Damián. Crónica Seráfica vida del glorioso patriarca san Francisco y de sus primeros discípulos... escrita por el R. P Fr. Damián Cornejo... examinador sinodal de este Arzobispado y cronista general de su Orden. Parte primera, Madrid: Juan García Infanzón, 1682. Web. 20 nov. 2015.

Cornejo, Damián. Crónica Seráfica: vida del glorioso patriarca san Francisco y de sus primeros discípulos... escrita por el R P Fr. Damián Cornejo examinador sinodal de este Arzobispado y cronista general de su Orden. Parte segunda, Madrid: Juan García Infanzón, 1684. Web. 2. nov. 2015.

Cornejo, Damián. Crónica Seráfica: vida del glorioso patriarca san Francisco y de sus primeros discípulos... escrita por el r[everendísimo] P[adre] f[ray] Damián Cornejo... examinador 
sinodal de este Arzobispado y cronista general de su Orden. Parte tercera, Madrid: Juan García Infanzón, 1686. Web. 21 nov. 2015.

Cornejo, Damián. Crónica Seráfica: vida del glorioso patriarca san Francisca de sus primeros discípulos... escrita por el r[everendísimo] P[adre] f[ray] Damián Cornejo... examinador sinodal de este Arzobispado y cronista general de su Orden. Parte cuarta. Madrid: Juan García Infanzón, 1698. Web. 21 nov. 2015.

Cornejo, Damián. Das lyrische Werk des Damián Cornejo (1629-1707). Erster Teil. Ed. Klaus Pörtl, München: Wilhelm Fink, 1978. Impreso.

Cornejo, Damián. Obras poéticas del padre Cornejo, n.p., n.d. Manuscrito. Web. 25 oct. 2019

Correas, Gonzalo. Vocabulario de refranes y frases proverbiales (1627). Ed. Louis Combet, Bordeaux: Université de Bordaux, 1967. Impreso.

Cotarelo, Emilio. "Poesías inéditas”. Hispania, 5 (1899): 20. Web. 19 feb. 2016.

Cottunio, Giovanni. "Libro IV: Capítulo 6". Commentarii lucidissimi in octo libros Aristotelis De physico auditu vnà cum quaestionibus, Padua: Imprenta de Pauli Frambotti, 1648. 631-632. Web. 22. ene. 2019.

Covarrubias, Sebastián De. Tesoro de la Lengua Castellana o Española, Madrid: Turner, 1977. Impreso.

Craig, Hugh. "George Chapman, John Davies of Hereford, William Shakespeare, and «A Lover's Complaint»". Shakespeare Quarterly, 63, 2 (2012):147-174. Web. 28 ene. 2018.

Craig, Hugh. y Kinney, Arthur. Shakespeare, Computers, and the Mystery of Authorship, Nueva York: Cambridge University Press, 2009. Web. 19 ene. 2018.

Cruz, Juana Inés De la. Antología de Sor Juana Inés de la Cruz. Ed. María Luisa Pérez Walker, San Francisco de Chile: Editorial Universitaria, 1993. Web. 14 mzo. 2019.

Cruz, Juana Inés De la. Inundación Castálida, Alicante: Biblioteca Cervantes Virtual, 2003. Web. 3 dic. 2017.

Cruz, Juana Inés De la. Obras escogidas, Alicante: Biblioteca Cervantes Virtual, 2003. Web. 3 dic. 2017.

Cruz, Juana Inés De la. Villancicos. Lírica coral, México: Fondo de Cultura Económica, 2006. Web. 4 dic. 2017.

Cruz, Juana Inés De la. Poemas, Barcelona: Linkgua, 2009. Web. 2 dic. 2017.

Cruz, Juana Inés De la. Obras completas de Sor Juana Inés de la Cruz. Lírica personal. Ed. Antonio Alatorre, 1, México: Fondo de Cultura Económica, 2012. Web. 3 dic. 2017.

Dadson, Trevor. J. "La difusión de la poesía española impresa en el siglo XVII", Bulletin Hispanique, 113, 1 (2011): 13-42: Web. 30 oct. 2016. 
De Solís, Antonio. Varias poesías sagradas y profanas. Ed. Juan de Goyeneche, Madrid: Imprenta de Manuel Fernández, 1732. Web. 16 nov. 2016.

De Solís y Valenzuela, Pedro. El desierto prodigioso y prodigio del desierto. Ed. Rubén, Páez Patiño. Bogotá: Instituto Caro y Cuervo, 1, 1977. 378-380. Impreso.

Deleito y Piñuela, José. La vida religiosa española bajo el cuarto Felipe: santos y pecadores, Madrid: Espasa-Calpe, 1952. Impreso.

Deleito y Piñuela, José. El rey se divierte (recuerdos de hace tres siglos), Madrid: Espasa-Calpe, 1964. Impreso.

Deleito y Piñuela, José. La mujer, la casa y la moda (en la España del rey poeta), Madrid: EspasaCalpe, 1966. Impreso.

Díaz, José Simón. Bibliografía de la literatura hispánica, 8, Madrid: C.S.I.C., Instituto Miguel de Cervantes de Filología, 1960-1994. Impreso.

Díez Fernández, José Ignacio. "Compilar y desleír la poesía erótica de los Siglos de Oro: los cancioneros de Amancio Peratoner". e-Humanista, 15 (2010): 302-320. Web. 13 dic.

Díez Fernández, José Ignacio. "La poesía erótica de curas, frailes y monjas". La poesía erótica de los Siglos de Oro, Madrid: Ediciones del Laberinto, 2003. 175-224. Impreso.

Díez Fernández, José Ignacio. "Libros de poesía en bibliotecas del Siglo de Oro (1600-1650)". Revista de filología española, 90, 1 (2010): 107-136. Impreso.

Díez Fernández, José Ignacio. La poesía erótica de los Siglos de Oro, Madrid: Ediciones del Laberinto, 2003. Impreso.

Domínguez, Ramón-Joaquín. Diccionario nacional o gran diccionario clasico de la lengua espanola (etc.), 1, Madrid: Mellado. Web. 5 mzo. 2019.

Eder, Maciej. "Does size matter? Authorship attribution, small samples, big problema". Literary and Linguistic Computing, 30, 2 (2015): 167-182. Web. 1 mzo. 2018.

Eder, Maciej. "Short Samples in Authorship Attribution: A New Approach”. Digital Humanities, 2017. 341-342. Web.13 ene. 2018.

Egido Martínez, Aurora. "Literatura efímera: oralidad y escritura en los certámenes y academias de los siglos de oro". Edad de oro, 7 (1988): 69-88. Impreso.

Eiján, Samuel. "Padre Damián Cornejo". La poesía franciscana en España, Portugal y América (siglos XIII-XIX): nuestros juglares del señor, Santiago de Compostela: El eco Franciscano, 1935. 300-302. Impreso.

Escobar Correa, Juan Gonzalo. Ave Maria, Gratia Plena: Iconología e iconografía de la Inmaculada Concepción, Medellín: Universidad Nacional de Colombia Sede Medellín, 2012. Web. 22 oct. 2018. 
Esteve, Francisco. Catálogo de la colección de manuscritos Borbón-Lorenzana, Madrid: Biblioteca Pública de Toledo, 1942. Impreso.

Etienvre, Jean-Pierre. Márgenes literarios del juego: una poética del naipe siglos XVI-XVIII, Londres: Támesis, 1990. Web. 15 set. 2019.

Fernández Giménez, Camino. "Fernando Valenzuela y Enciso". Diccionario Biográfico electrónico, Madrid: Real Academia de la Historia, 2018.

Fernández, Benito. "Damián Cornejo”. El pontificado gallego su origen y vicisitudes; seguido de una Crónica de los obispos de Orense, Orense: Imprenta de "El Derecho", 1897. 514-521. Impreso.

Flórez, Enrique. “Fr. Damián Cornejo”. España Sagrada: Orense, XVII, Madrid: Oficina de Pedro Marín, 1789. 195-196. Web. 12 dic. 2015.

Fonseca, Cristóbal De. “Libro 2: Capítulo 15: De la conversión de la Magdalena”. Segunda parte de la vida de Cristo, señor nuestro que trata de sus milagros, Barcelona: Imprenta de la viuda de Jaime Cendrat, 1602. 382-428. Web. 13 oct. 2018.

Foulché-Delbosc, Raimundo. "Coplas de Trescientas cosas más”. Revue Hispanique, 9 (1902): 261-268. Impreso.

Foulché-Delbosc, Raimundo. "Varia”. Revue Hispanique, 10 (1903): 226-268. Impreso.

Francisco Olmos, José María de. "La sucesión de Carlos II y la Archiduquesa María Antonia de Austria, 1669-1692. Una Reina de España en potencia”. Hidalguía: la revista de genealogía, nobleza y armas, 354, 2 (2012): 613-683. Web. 9 jun. 2019.

Gallardo, Bartolomé. Ensayo de una biblioteca española de libros raros y curiosos, 2, Madrid: Gredos, 1968. 582-583.

Gallego Zarzosa, Alicia. "El erotismo en la poesía amorosa de Quevedo: los objetos del deseo". La Perinola, 16 (2012): 65-75. Web. 22 abr. 2019.

García Arellano, Ignacio. "Anexo”. Poesía y edición en el Siglo de Oro. Ed. Ignacio Aguilar, Madrid: Calambur, 2009. 355-365. Impreso.

García-Reidy, Alejandro. "Eros y oros, o el intercambio sexual en la poesía erótica de los siglos de oro". En la concha de Venus amarrado: erotismo y literatura en el Siglo de Oro. Coord. Patricia Marín Cepeda, Madrid: Visor Libros, 2017. 27-60. Impreso.

Garrote Bernal, Gaspar. "E-bibliografía y esquema para una historia de la literatura erótica (o sexual) española". Anmal, 29 (2010): n.p. Web. 25 oct. 2015.

Gayangos, Pascual De. Catalogue of the manuscripts in the Spanish language in the British museum, Londres: University of California Libraries, 1875. Web. 16 feb. 2016. 
Goldberg, Rita. "Notas". Tonos a lo divino y a lo humano. Ed. Rita Goldberg. Madrid: Támesis, 1981. 160-189. Web. 16 ene. 2019.

Gómez Trueba, Teresa. El sueño literario en España: consolidación y desarrollo del género, Madrid: Cátedra, 1999.

Góngora y Argote, Luis De. Todo Góngora, Barcelona: Universitat Pompeu Fabra, 2015. Web. 6 set. 2019.

González de Torres, Eusebio. Crónica seráfica, 5, Madrid: Imprenta de la viuda de Juan García Infanzón, 1719. Web. 11 nov. 2015.

González de Torres, Eusebio. "Capítulo 25. Glorioso entierro y prodigios inmediatos a la muerte del santo Regalado". Crónica Seráfica, 6, Madrid: Imprenta de la viuda de Juan García Infanzón, 1725. 109-113. Web. 21. feb. 2019.

Gracián, Baltasar. Obras de Lorenzo Gracián. Tomo segundo, que contiene 'La agudeza, y arte de ingenio', 'El Discreto', 'El Político don Fernando el Católico' y 'Meditaciones varias par antes y después de la Sagrada Comunión que hasta ahora han corrido con título de Comulgado’, Madrid: Imprenta Real, 1663. Web. 26 mzo. 2019.

Guerra, Juan Carlos De. Ensayo de un padrón histórico de Guipúzcoa: según el orden de sus familias pobladoras, San Sebastián: Joaquín Muñoz-Baroja, 1928. Web. 16 feb. 2019.

Hernández Lorenzo, Laura. "The Poetic Word of Fernando de Herrera. An Approach through Corpus and Computational Linguistics”. EPiC Series in Language and Linguistics, 1 (2016): 170-180. Web. 2 feb. 2018.

Hipona, san Agustín De. "Libro I: Amor de Dios". Meditaciones de san Agustín, Madrid: Yvory Falls Books, 2018. 7-36. Web. 1 jun. 2019.

Horozco, Sebastián De. Cancionero de Sebastián de Horozco. Eds. José Labrador, Ralph DiFranco y Ramón Morillo-Velarde, Toledo: Consejería de Educación, Ciencia y Cultura, 2010. 274275. Impreso.

Jammes, Robert. "Palabras sucias y deshonestas en la poesía de Góngora". Hilaré tu memoria entre las gentes. Coord. Alain Bègue, Zaragoza: Universidad de Zaragoza, 2014. 95-116. Impreso.

Jauralde, Pablo. "Las silvas de Quevedo". La silva. Coord. Begoña López Bueno, Sevilla: Universidad de Sevilla, 1991. 157-180. Web. 17 feb. 2019.

Jiménez Belmonte, Javier. "Amateurs preclaros de la España postbarroca: nostalgias de un modelo socioliterario". Calíope, 18, 1 (2012): 78-101. Web. 12 feb. 2016.

Jockers, Matthew. Macroanalysis. Digital Methods and Literary History, Illinois: University of Illinois Press, 2013. Web. 26 ene. 2018. 
Juste Sánchez, María Rosario, Edición y estudio de la obra de José Tafalla y Negrete, Zaragoza: Universidad de Zaragoza, 1991. Tesis inédita.

Kao, Justin. y Jurasfsky, Dan. “A computational analysis of poetic style: Imagism and its influence on modern professional and amateur poetry". LILT, 12, 3 (2015): 1-31. Web. 18 ene. 2018.

Kirschner, Teresa. "El discurso sexual como subversión del amor en Lope de Vega", Estado actual de los estudios sobre El Siglo de Oro. Ed. Manuel García Martín, Salamanca. Ediciones de la Universidad de Salamanca, 1993. 549-560. Web. 16 ene. 2019.

Labrador Herraiz, José Julián. y Di Franco Ralph. Cancionero sevillano de Lisboa, Sevilla: Universidad de Sevilla, 2003. Impreso.

Lambea, Mariano. y Josa, Lola. La música y poesía en cancioneros polifónicos del siglo XVII, IV. Libro de tonos humanos, 1, Barcelona: Consejo Superior de Investigaciones Científicas, Institución "Milá y Fontanals", 2005. Web. 11 feb. 2019.

Lara Garrido, José. “Columnas de cristal: códigos y discursividades entre un soneto de Lope y un famoso romance anónimo". El cortejo de Afrodita: ensayos sobre literatura hispánica y erotismo. Coord. Antonio Cruz Casado, Málaga: Universidad de Málaga, 1997. 23-68. Web. 6 mzo. 2019.

León Marchante, Manuel De. Habiendo tomado una purga un Ingenio de la Universidad de Alcalá, la participa la noticia a un amigo suyo en este romance, n.p., n.d. Web. 26 feb. 2016.

León Marchante, Manuel De. Un jurador arrepentido, n.p. Web. 27 feb. 2016.

León Marchante, Manuel De. Letras de villancico de Navidad que se han de cantar en la Santa Iglesia de Toledo. n.p., 1662. Web. 15 mzo. 2017.

León Marchante, Manuel De. Relación de la fiesta de toros, que corrió la villa de Meco a siete de Junio deste año, y la guerra que tuvo con los de Alcalá de Henares..., n.p., 1670. Web. 11 mzo. 2017.

León Marchante, Manuel De. Obras poéticas póstumas que a diversos asuntos escribió el maestro León Marchante, 1, Madrid: Real Capilla de su Majestad, 1722. Web. 9 may. 2016.

León Marchante, Manuel De. Obras poéticas póstumas que a diversos asuntos escribió el maestro León Marchante, 2, Madrid: Real Capilla de su Majestad, 1733. Web. 9 may. 2016.

León Marchante, Manuel De. Obras poéticas póstumas que a diversos asuntos escribió el maestro León Marchante, 3, Madrid: Real Capilla de su Majestad, 1733. Web. 10 may. 2016.

León Marchante, Manuel De. “La picaresca”. Revue Hispanique, 38 (1916): 532- 612. Web. 21 abr. 2017. 
León Marchante, Manuel De. Manuel de León Marchante. Obras complutenses. Ed. Manuel Sánchez, Alcalá de Henares: Institución de Estudios Complutenses, 2016. Impreso.

Lescasse, Marie-Eglantine. "L'emploi du concept de «propiedad» dans la polémique gongorine”. e-Spania, 29 (2018): n.p. Web. 23 mzo. 2018.

López de Barbadillo, Joaquín. Cancionero de amor y de risa: en que van juntas las más alegres, libres y curiosas poesías eróticas del parnaso español, muchas jamás impresas hasta ahora y las restantes publicadas en rarísimos libros, Madrid: Akal, 1917. 199-200. Impreso.

López de los Mozos, José Ramón, "Sobre los posibles orígenes de la fiesta de 'El Ahorcado' (Mandayona, Guadalajara)". X Encuentro de Historiadores del Valle del Henares. Libro de Actas, Alcalá de Henares: Institución de Estudios Complutenses, Institución Provincial de Cultura "Marqués de Santillana” y Centro de Estudios Seguntinos, 2006. 765-780. Impreso. López Guil, Itziar. Poesía religiosa cómico-festiva del bajo barroco español: estudio y antología, Bern: Peter Lang, 2011. Impreso.

López Guil, Itziar. "Damián Cornejo". Poesía religiosa cómico-festiva del bajo barroco español: estudio y antología, Bern: Peter Lang, 2011. 249-266. Impreso.

Lyon, Ireneo De. "La Economía por la obediencia de María". Contra los herejes, 5, 519. Web. 5 dic. 2018.

Madoka, Tanabe. "Entre la pastoril y la piscatoria". Imágenes del mar en la poesía de Góngora: de los romances piscatorios a las Soledades, Córdoba: Universidad de Córdoba, 2016. 956. Tesis. Web. 5 abr. 2019.

Maire Bobes, Jesús. "El doctor, figura cómica de los entremeses". Memoria de la palabra: actas del VI Congreso de la Asociación Internacional Siglo de Oro. Coords. Francisco Domínguez Matito y María Luisa Lobato López, 2, Madrid: Iberoamericana Vervuet. 2004. 1217-1228. Web. 14 jun. 2019.

Marañón Ripoll, Miguel. “El Entremetido y la Dueña y el Soplón de Quevedo. Texto, notas e introducción”. Cuadernos para investigación de la literatura hispánica, 31 (2006): 15-132. Web. 1 jun. 2019.

Marañón Ripoll, Miguel. "Otro testimonio manuscrito de una serie de poesías escatológicas atribuida a Damián Cornejo". Manuscrt.Cao, 7 (1996-1998): 71-81. Impreso.

Marañón Ripoll, Miguel. "Sonetos satíricos atribuidos a Damián Cornejo en los mss. de la Biblioteca Nacional de Madrid”. Manuscrt.Cao, 5 (1993): 25-37. Impreso.

Maravall, José Antonio. La cultura del barroco: análisis de una estructura histórica, Barcelona: Ariel, 1975. Impreso. 
Marín, Diego. "Función dramática de la versificación en el teatro de Calderón”. Calderón: actas del Congreso Internacional sobre Calderón y el teatro español del Siglo de Oro, 1, Madrid: CSIC, 1981. 1139-1146. Web. 11. feb. 2019.

Martín, Adrienne. "Erotismo felino: Las gatas de Lope de Vega". Analecta Malacitana (AnMal electrónica), 32 (2012): 405-420. Web. 3. sept. 2018.

Martín, Adrienne. "La poesía burlesca femenina y la revisión del canon". Cánones críticos en la poesía de los Siglos de Oro. Coord. Pedro Ruiz. Vigo: Academia del Hispanismo, 2008. 247-267. Impreso.

Martín, Puya, Ana Isabel. y Ruiz Pérez, Pedro. "El nombre de la cosa títulos, modelos poéticos y estrategias autoriales en el bajo barroco". Criticón, 125 (2015): 25-48. Impreso.

Martínez Deyros, María. Sánchez Mateos, Zoraida. y Herrero Diéguez, Juan. “Aquel coger a la dama a oscuras": Mujeres en la poesía erótica del Siglo de Oro, Valladolid: Agilice Digital, 2018. Impreso.

Martínez, Ramón. "La supuesta Papisa Juana”. La Ilustración católica. 5 feb. 1889: 39-40. Web. 20 mzo. 2016.

Martínez-López, Enrique. "La leyenda del judío errante en la literatura de cordel española”. AIH. Actas X. Coord. Antonio Vilanova, 2, Barcelona: Universidad Pompeu Fabra, 1992. 13371354. Web. 16 dic. 2018.

Mata, Juan. "La pluma y el pincel de Sor Juana Inés de la Cruz". Verba hispánica, 9 (2001): 91110. Web. 25 nov. 2018.

Maurel, Danièle y Maurel, Michel. Obras de fray Damián Cornejo. Ms. 5566 de la BNM, Toulouse: Université de Toulouse-Le Mirail, 1970. Tesis inédita.

Merino, Antolín. Parafrástica explicación y traducción de los salmos, himnos y canciones, 1, Madrid: Imprenta de los nietos de Ibarra, 1809. Web. 27 nov. 2018.

Molina, Tirso De. Marta la Piadosa. Ed. Blanca de los Ríos. Alicante: Biblioteca Virtual Miguel de Cervantes, 1999. Web. 4 feb. 2019.

Montero Delgado, Juan. y Ruiz Pérez, Pedro. "La silva entre el metro y el género”. La silva. Dir. Begoña López Bueno, Sevilla: Universidad de Sevilla, 1991. 19-56. Web. 1 set. 2018.

Moral de Calatrava, Paloma. "El cuerpo del deseo. El discurso médico medieval sobre el placer sexual". Studium Medievale: Revista de Cultura visual-Cultura escrita, 1 (2008): 135-147. Impreso.

Moretti, Franco. Distant Reading, Verso: Londres, 2013. Web. 15 dic. 2017. 
Morros Mestres, Bienvenido. "Bartolomé Leonardo de Argensola, poeta petrarquista". Argensola: Revista de Ciencias Sociales del Instituto de Estudios Altoaragoneses, 119 (2009): 107-132. Web. 5 jun. 2019.

Muñoz, María José. "Erotismo y celo Inquisitorial. Expedientes de escritos obscenos censurados por la Inquisición en el siglo XVIII y principios del XIX”. Cuadernos de Historia del Derecho, 10 (2003): 157-207. Impreso.

Muñoz de la Cueva, Joan. "Libro sexto. Capítulo cuarto: De la restauración de la iglesia de Orense y obispos sucesores". Noticias históricas de la Santa Iglesia Catedral de Orense, Madrid: Imprenta Real, 1727. 237-296. Web. 22 mzo. 2016.

Navarrete, Ignacio. Los huérfanos de Petrarca: poesía y teoría en la España renacentista, Madrid: Gredos, 1997. Impreso.

Navarro, Ana. Antología poética de escritoras de los siglos XVI y XVII, Madrid: Castalia, 1989. Impreso.

Navarro, Borja. "Hacia un análisis distante del endecasílabo áureo: patrones métricos, frecuencias y evolución histórica". Rhythmica. Revista española de métrica comparada, 14 (2016): 89118. Web. 20 dic. 2018.

Nicolás Rubio, César Estrategias y lecturas. La anamorfosis de Quevedo, Extremadura: Universidad de Extremadura, 1986. Impreso.

Nogales, José. “Crónica frivolidad”. El Liberal. 27 ene. 1905: 1. Web. 23 mzo. 2016.

Núñez, Hernán. Refranes o proverbios en castellano por el orden alfabético que juntó y glosó el comendador Hernán Núñez, 3, Lérida: Luis Manescal, 1621. Web. 3 feb. 2019.

Opara, Karol. "Grammatical rhymes in Polish poetry: A quantitative analysis". Digital Scholarship in the Humanities, 30, 4 (2015): 589-598. Web. 25 ene. 2018.

Ossorio y Bernard, Manuel. "Variedades". El Pabellón Nacional. 19 mzo. 1867: 3. Web. 21 mzo. 2016.

Osuna, Inmaculada. "Juan de Ibaso y las formas burlescas en justas poéticas a mediados del siglo XVII”. Criticón, 100 (2007): 91-114. Web. 6 jun. 2016.

Osuna, Inmaculada. "Las justas poéticas en la primera mitad del siglo XVII". El canon poético en el siglo XVII: IX Encuentro Internacional sobre Poesía del Siglo de Oro. Coord. Begoña López, Sevilla: Grupo A.I.S.O, 2010. 323-366. Web. 2 jun. 2016.

Osuna, Inmaculada. "Las oraciones y coplas de ciego como motivo burlesco culto en la poesía religiosa del siglo XVII". Eros divino: estudios sobre la poesía religiosa iberoamericana del siglo XVII. Ed. Julián Olivares, Zaragoza: Universidad de Zaragoza, 2010. 335-366. Impreso. 
Paracuellos Cabeza de Vaca. Luis De. "Décimas de fr. Pedro González”. Elogios a María Santísima. Conságralos en suntuosas celebridades devotamente Granada a la limpieza pura de su Concepción, y dedícalos a la Majestad Católica de Filip IV, rey y s.n., Granada: Francisco Sánchez y Baltasar de Bolibar, 1651. 2010-2014. Web. 9. nov. 2018.

Paravicino, Hortensio. "Sermón del Santísimo Sacramento. Al ilustrísimo cardenal Legado don Francisco Barberino". Oraciones evangélicas en las festividades de Cristo, Madrid: Imprenta del Reino, 1640. 54-66. Web. 28. nov. 2018.

Pazos, Manuel. "Fray Damián Cornejo". El episcopado gallego: a la luz de documentos romanos. II Obispos de Tuy y Orense (1540-1855 y 1542-1851), Madrid: Instituto Jerónimo, 1946. 448-461. Impreso.

Peinador Marín, Jesús. "Los Fragmentos del Ocio, de Juan Gaspar Enríquez de Cabrera. (Ms.3.956)". Manuscrt.Cao, 1 (2010): 1-14. Web. 19 may. 2016.

Pena Sueiro, Nieves. "Estado de la cuestión sobre el estudio de las Relaciones de sucesos". Pliegos de bibliofilia, 13 (2001): 43-66. Web. 13. set. 2018.

Peña Álvarez, Javier De la. Flores en la poesía española del Renacimiento y Barroco, Madrid: Repositorio de la Universidad Complutense de Madrid, 2010. Tesis. Web. 15. oct. 2018.

Pérez de Guzmán, Juan. “Los príncipes de la poesía española”. Revista Contemporánea, 78 (1890): 374. Web. 22 mzo. 2016.

Pérez de la Sala, Pedro. "Costumbres españolas en el siglo XVII”. Revista de España, 125, 1889. 45. Web. 22 mzo. 2016.

Pérez de la Sala, Pedro. "Una réplica”. Revista de España, 130, 1890. 428-430. Web. 16 mzo. 2016.

Pérez de Montoro, José. Obras póstumas líricas humanas, Madrid: Imprenta de Antonio Marín, 1736. Web. 5 may. 2017.

Pérez Lasheras, Antonio. "Silva y soledad (análisis comparativo de algunos pasajes de Ginovés y Góngora)”. Revista de Filología Española, 68, 1-2 (1988): 119-140. Web. 19 mzo. 2019.

Pérez Martínez, Herón. “Tradición y oralidad en el refranero mexicano”. La tradición hoy en día: memorias, México: Universidad Iberoamericana, 1998. Web. 7 abr. 2019.

Pérez, Lorenzo. "Bibliografía. Renedo Agustín. O.S.A. Escritores valentinos". Revista AIA, 26, 2 (1926): 403-408. Impreso.

Pezzini, Sara y Ruiz, Héctor. "Editar a Góngora con instrumentos digitales: bases metodológicas y perspectivas teóricas para un hipertexto de la polémica gongorina". Revista de Humanidades Digitales, 1 (2017): 35-56. Web. 10, ene. 2019. 
Pino Polo, Francisco. "Cicerón contra Clodio: el lenguaje de la invectiva". Gerión, 9, 1991. 131150. Web. 9 my. 2019.

Pizarro Llorente, Henar. y Jiménez Pablo, Esther. Santa María Magdalena de Pazzi: Imagen y Mística, Roma: Edizioni Carmelitane, 2016. Web. 13 ene. 2019.

Plata Parga, Fernando. "Nuevas versiones manuscritas de la poesía quevediana nuevos poemas atribuidos: en torno al manuscrito BMP 108". La Perinola, 4 (2000): 285-307. Impreso.

Polo de Medina, Jacinto. Fábula de Apolo y Dafne, Alicante: Biblioteca Virtual Miguel de Cervantes, 2002. Web. 15 mzo. 2019.

Polo de Medina, Jacinto. El buen humor de las musas, Alicante: Biblioteca Virtual Miguel de Cervantes, 2002. Web. 1 mzo. 2019.

Ponce Cárdenas, Jesús. "La canción de ausencia en el petrarquismo hispano”. Evaporar contempla un fuego helado. Género, enunciación lírica y erotismo en una canción gongorina, Málaga: Universidad de Málaga, 2006. 31-44. Impreso.

Porteiro Chouciño, Ana María. Estudio y edición de "La Arcadia" (1615) de Lope de Vega, La Coruña: Repositorio de la Universidad de Coruña. Web. 27 my. 2019.

Pörtl, Klaus. "La obra poética de fray Damián Cornejo (1629-1707). Los problemas de una edición crítica de los apógrafos". Actas del Sexto Congreso Internacional de Hispanistas. Coords. Evelyn Rugg y Alan M. Gordon, Toronto: University of Toronto, 1980. 583-586. Web. 23 oct. 2015.

Quevedo, Francisco De. Parnaso español: monte en dos cumbres dividido, con las nueve musas castellanas, Madrid: Imprenta de Diego Díaz de la Carrera, 1648. Web. 12 ene. 2016.

Quevedo, Francisco De. Poesías de don Francisco de Quevedo Villegas, Caballero de la Orden de Santiago, Señor de la Villa de la Torre de Juan-Abad, 3, Bruselas: Imprenta de Francisco Foppens, 1670. Web. 15 jun. 2019.

Quevedo, Francisco De. Obras de don Francisco de Quevedo Villegas, Caballero de la Orden de Santiago, Señor de la Villa de la Torre de Juan-Abad, 1, Amberes: Henrico y Cornelio Verdussen, 1699. Web. 14 jun. 2019.

Quevedo, Francisco De. Obras de don Francisco de Quevedo Villegas, Caballero de la Orden de Santiago, Señor de la Villa de la Torre de Juan-Abad, 4, Madrid: Joaquín de Cámara, 1772. Web. 23 feb. 2019.

Quevedo, Francisco De. Obras inéditas de don Francisco de Quevedo Villegas, 11, Madrid: Imprenta de Sancha, 1794. Web. 22 ene. 2016.

Quevedo, Francisco De. Juguetes y travesuras de ingenio de D. Francisco de Quevedo Villegas, extractadas de sus obras poéticas por su humilde admirador (...), finalizando con la 
preciosa composición de Bretón de los Herreros “¿Quién es ella?”. Ed. Amancio Peratoner, Barcelona: José Codina, 1876. Web. 23 set. 2019.

Quevedo, Francisco De. "El mundo por de dentro" Sueños. Ed. Franscisco Induráin, Zaragoza: Editorial Ebro, 1967. 70-86. Web. 15 dic. 2018.

Quevedo, Francisco De. Sonetos de Quevedo. Ed. Ramón García González, Alicante: Biblioteca Virtual Miguel de Cervantes, 2003. Web. 7 feb. 2019.

Rambla, Pascual. "Tratado popular sobre la Santísima Virgen”. Historia del dogma de la Inmaculada Concepción, Barcelona: Vilamala, 1954. 92-210. Web. 13 dic. 2018.

Ramos, Carlos. "Secretos (re)velados. Lecturas del sueño erótico". Jardines secretos. Estudios en torno al sueño erótico. Eds. Julián Acebrón y Pere Solà, Lérida: Edicions de la Universitat de Lleida, 2008. 13-32. Impreso.

Real Academia Española. Diccionario de Autoridades, Madrid: Imprenta de Francisco del Hierro, 1729-1736. Web. 22. set. 2019.

Real Academia Española y Asociación de Academias de la Lengua Española. Diccionario Panhispánico de Dudas, Madrid: Santillana, 2005. Web. 4. nov. 2018.

Real Academia Española y Asociación de Academias de la Lengua Española. Diccionario de la lengua española, Polinyà: Espasa-Calpe, 2018. Web. 1 oct. 2019.

Rebolledo, Juan De. Cincuenta oraciones funerales. En que se considera la vida y sus miserias, la muerte y sus provechos. Ed. Juan Quartanet, s.d., 1608. Web. 11. ene. 2019.

Renedo Martino, Agustín. "Damián Cornejo”, Escritores palentinos (Datos bio-bibliográficos), 1, Madrid: Helénica, 1919. 159-162. Impreso.

Rezaei, Sorab. y Kashanian, Nasim. "A stylometric analysis of iranian poets", Theory and Practice in Language Studies, 7, 1 (2017): 55-64. Web. 15 en, 2018.

Rodríguez-Moñino, Antonio. Catálogo de los manuscritos castellanos existentes en la Biblioteca de The Hispanic Society of America (Siglos XV, XVI y XVII), Nueva York: The Hispanic Society of America, 1965. Impreso.

Rodríguez-Moñino, Antonio. Construcción crítica y realidad histórica en la poesía española de los siglos XVI y XVII, Madrid: Castalia, 1968. Impreso.

Roig Miranda, Marie. "La Lisi de Quevedo". La Perinola: Revista de investigación quevediana, 16, (2012): 97-106. Web. 21 ene. 2019.

Rojas Zorrilla, Francisco. "Los bandos de Verona”. Obras completas. Volumen IV: Segunda parte comedias. Dirs. Felipe B. Pedraza y Rafael González Cañal, Cuenca: Ediciones de la Universidad de Castilla y la Mancha, 2011. 207-321. Web. 3 abr. 2019. 
Rojas, Antonio. "Luis de Góngora y la fábula mitológica del Siglo de Oro: clasificación de textos y análisis léxico con métodos informáticos”. Studia Aurea, 11 (2017): 111-142. Web. 25 ene. 2018.

Rojo Sánchez, Guillermo. "Análisis cuantitativo de las citas de obras en el Diccionario de Autoridades". Boletín de la Real Academia Española, 310 (2014): 127-166. Web. 11 mzo. 2016.

Rojo, Antonio. Historia de San Diego de Alcalá, fundación y frutos de santidad, que ha producido su convento de Santa María de Jesús (etc.), Madrid: Imprenta Real, 1663. Web. 9 ene. 2019.

Roncero, Victoriano. "El humor y la risa en las preceptivas de los Siglos de Oro". Demócrito áureo: los códigos de la risa en el Siglo de Oro. Coords. Ignacio Arellano y Victoriano Roncero, Sevilla: Renacimiento, 2006. 285-328. Impreso.

Ruiz Pérez, Pedro. "La Boscarecha de Pedro Espinosa del canto del pastor a la escritura del poeta". A zaga de tu huella: homenaje al prof. Cristóbal Cuevas. Coord. Salvador Montesa, 1, Madrid: Asociación para el Estudio, Difusión e Investigación de la Lengua y Literatura Españolas, 2005. 231-262. Web. 26 jun. 2019.

Ruiz Pérez, Pedro. "Subversión erótica y subversión poética: a propósito de unos límites". Revista de dialectología y tradiciones populares, 60, 1 (2005): 73-84. Impreso.

Ruiz Pérez, Pedro. "Entre dos parnasos: poesía, institución y canon”. Caliope, 103-104 (2007): 207-231. Impreso.

Ruiz Pérez, Pedro. La rúbrica del poeta: la expresión de la autoconciencia poética de Boscán a Góngora, Valladolid: Universidad de Valladolid, 2009. Impreso.

Ruiz, María Jesús. "Repertorio tradicional infantil de Cádiz: texto, rito, gesto y símbolo", Revista OCNOS, 5 (2009): 69-86. Web. 22 jun. 2019.

Ruiz Pérez, Pedro. "Para la historia y la crítica de un período oscuro: la poesía del Bajo Barroco". Caliope, 18, 1 (2012): 9-25. Web. 26 abr. 2016.

Ruiz Pérez, Pedro. "Para una caracterización del romance en el bajo Barroco". Edad de Oro, 32 (2013): 379-406. Web. 15 abr. 2016.

Ruiz Pérez, Pedro. "De Solís a Lobo: la mujer en la poesía bajobarroca". Perspectives on Early Modern Women in Iberia and the Americas. Studies in Law, Society, Art and Literature in honor of Anne. J. Cruz. Eds. Adrienne. Martín y María Cristina Quintero, Nueva York: Escribana Books, 2014. 486-505. Web. 15 may. 2016.

Ruiz Pérez, Pedro. "Deidades apeadas: un nuevo patrón de género para la poesía bajobarroca". Arte Nuevo. Revista de Estudios Áureos, 3 (2016): 109-149. Web. 2 feb. 2017. 
Ruiz Pérez, Pedro. “¿Góngora erótico? El retrete del poeta”. En la concha de Venus amarrado: erotismo y literatura en el Siglo de Oro. Coord. Patricia Marín Cepeda, Madrid: Visor Libros, 2017. 61-90. Impreso.

Ruiz, Pablo. Martínez, Clara. y Poibeau, Thierry. "Distant Rhythm: Automatic Enjambment Detection on Four Centuries of Spanish Sonnets”. Digital Humanities, 2017. 572-576. Web. 13 ene. 2018.

Sáez, Adrián. "La vuelta del camino o la máscara de Demócrito: apostillas de poesía religiosa burlesca". Versants: revue suisse des littératures romanes, 60, 3 (2013): 71-82. Impreso.

Sáez, Adrián. "El perdón de la Magdalena: erotismo y pintura en un soneto de Quevedo". En la concha de Venus amarrado: erotismo y literatura en el Siglo de Oro. Coord. Patricia Marín Cepeda, Madrid: Visor Libros, 2017. 107-120. Impreso.

Sait Sener, Mehmet. "Las obras turquescas del teatro áureo". El tema turco en el teatro español de los siglos XVI-XVII, Madrid: Universidad Complutense de Madrid, 2017. 101-251. Tesis. Web. 17 dic. 2018.

San José, Diego. “Un capellán poeta”. El Liberal. 3 jul. 1915. 3. Web. 17 abr. 2016.

San José, Diego. “Un don Juan con sotana”. Flirt, 39 (1922): 6. Web. 16 abr. 2016.

San José, Diego. “La vieja España galante”. Flirt, 4 (1922): 11. Web. 16 abr. 2016.

Sánchez Martínez, Rafael. "La Inmaculada en la poesía barroca española”. La Inmaculada Concepción en España: religiosidad, historia y arte. Actas del symposium. Coords. Francisco Javier Campos y Fernández de Sevilla, 2, San Lorenzo de El Escorial: Real Centro Universitario Escorial-María Cristina, 2005. 1407-1416. Web. 29 nov. 2018

Sánchez Mateos, Zoraida. "En la calle, honestos ángeles y, en la intimidad, Venus retozonas". Lasciva est nobis pagina... Ed. Javier Blasco, Vigo: Academia del Hispanismo, 2015. 6782. Impreso.

Sánchez Mateos, Zoraida. "La mujer en la poesía festiva del Bajo Barroco: Damián Cornejo y León Marchante”. Todos los siglos de la lluvia. El canon en la literatura hispánica, Sevilla: Renacimiento, 2018. 163-176. Impreso.

Sánchez Mateos, Zoraida. "Análisis cuantitativos aplicados a poesía: la lírica indubitada sacra de Damián Cornejo y León Marchante”, Studea Aurea, 12. (2018): 287-306. Web. 21 feb. 2019. Sánchez Mateos, Zoraida. "Análisis cuantitativos aplicados a la lírica: la poesía indubitada profana de Damián Cornejo y de León Marchante". Humanidades digitales: una mirada desde la interdisciplinariedad. Coord. Eva Álvarez Ramos, Berna: Peter Lang, 2019. 7-11. Impreso. Sánchez Mateos, Zoraida. "Análisis cuantitativos aplicados a la poesía: la lírica dubitada sacra de Damián Cornejo”. Anuario de estudios filológicos, 42 (2019): 247-263. Impreso. 
Sánchez, Vicente. Lira Poética. Ed. Jesús Duce García, Zaragoza: Publicaciones de la Universidad de Zaragoza, 2003. Impreso.

Sánchez-Pérez, María. "El adulterio y la violencia femenina en algunos pliegos sueltos poéticos del siglo XVI”. Revista de dialectología y tradiciones populares, 68, 2 (2013): 287-303. Web. 14. ene. 2018.

Sánchez-Velo, Julio. "Escollo armado de yedra. Tradición musical y función dramática de la poesía lírica en el teatro calderoniano". Jornadas de Investigación Literaria y Lingüística de los estudiantes graduados del Programa de Español. Coord. Louise Stein, 2005. 45-53. Web. 8. dic. 2018.

Santiago Fernández, Javier De. "Moneda y fiscalidad en castilla durante el siglo XVII". IV Jornadas Científicas sobre Documentación de Castilla e Indias en el siglo XVI. Coord. José María de Francisco Olmos, Javier de Santiago Fernández y Juan Carlos Galende Díaz, 2005. 409-433. Web. 1 set. 2019.

Santo, Juan de la Cruz. Poesías, Alicante: Biblioteca Virtual Miguel de Cervantes, 2004. Web. 21 ene. 2019.

Santoyo-Santiago Asenjo, Julio-César. "Una primicia desconocida de la impresa alavesa: La vida de santa Coleta de fray Damián Cornejo (1722)", Sancho el sabio: Revista de cultura e investigación vasca, 13 (2000): 209-228. Web. 15 nov. 2016.

Sanz Hermida, Jacobo. "Vejámenes y gallos en las ceremonias universitarias salmantinas en los Siglos de Oro". Grados y ceremonias en las universidades hispánicas: homenaje a Águeda Rodríguez Cruz. Coords. Luis Enrique Rodríguez San Pedro Bezares y Juan Luis Polo Rodríguez, 2004. 155-173. Web. 7 jun. 2019.

Sbarbi y Osuna, José María. Florilegio o Ramillete alfabético de refranes y modismos comparativos y ponderativos de la lengua castellana definidos razonadamente y en estilo ameno, Madrid: Imprenta de A. Gómez Fuentenebro, 1873. Web. 7 set. 2019.

Schapiro, Meyer. "Cain's Jaw-Bone that Did the First Murder". The Art Bulletin, 24, 3 (1942): 205-212. Web. 13 dic. 2018.

Serés, Guillermo. La transformación de los amantes: imágenes del amor de la Antigüedad al Siglo de Oro, Barcelona: Crítica, 1996. Impreso.

Serna, José De. "Varias cartas jocosas". El Bufón de la corte, Madrid: Gabriel Ramírez, 1767. 97 112. Web. 2 feb. 2019.

Sierra Pérez, José. “Textos eucarísticos castellanos del siglo XVII en el Archivo de Música del Monasterio de San Lorenzo el Real del Escorial”. Religiosidad y ceremonias en torno a la eucaristía: Actas del symposium. Coord. Francisco Javier Campos y Fernández de Sevilla, 
1, San Lorenzo de El Escorial: Real Centro Universitario Escorial-María Cristina, 2003. 71130. Web. 9 dic. 2018.

Smarandache, Florentin. "Linguistic-Mathematical Statistics in Recent Romanian Poetry". Collected Papers. Ed. Florentin Smarandache, 1, Ann Arbor: InfoLearnQuest, 2007.

Smith, Michael. "The Authorship of «A Lover's Complaint»: An Application of Statistical Stylometry to Poetry". Computers and the Humanities, 18, 1 (1984): 23-37. Web. 26 ene. 2018.

Soares de Silva, José. Diario métrico en aplauso de la Inmaculada Concepción de María Santísima, Lisboa occidental: Imprenta Pascual de Silva, 1717. Impreso.

Sperberg-McQueen, Michael y Burnard, Lou. Guidelines for Electronic Text Encoding and Interchange, Chicago: Text Encoding Initiative, 1994. Web. 19 ene. 2019.

Suárez Miramón, Ana. "Variaciones dramáticas en Calderón sobre un tema popular". Actas del VIII Congreso de la Asociación Internacional del Siglo de Oro. Coords. Antonio Azaustre Galiana, Santiago Fernández Mosquera, 3, Santiago de Compostela: Servizo de Publicacións da Universida de Santiago de Compostela, 2011. 439-446. Web. 6 ene. 2019.

Suazo Pascual, Guillermo. Abecedario de dichos y frases hechas, Madrid: Edaf, 1999. Web. 17 ene. 2019.

Tafalla y Negrete, José. Ramillete poética de las discretas flores, Zaragoza: Universidad de Zaragoza, 1706. Web. 12 feb. 2018.

Tenorio, Martha Lilia. “Sor Juana y Pérez de Montoro: el caso de los romances de celos”. Actas del XIV Congreso de la Asociación Internacional de Hispanistas. Coords. Isaías Lerner, Roberto Nival y Alejandro Alonso, 4, Nueva Jersey: Juan de la Cuesta, 2004. 665-675. Web. 11 my. 2019.

Tenorio, Martha Lilia. "Sor Juana y León Marchante", Nueva Revista de Filología Hispánica, 50, 2 (2002): 543-561. Impreso.

Terreros y Pando, Esteban. Diccionario castellano con las voces de ciencias y artes y sus y sus correspondientes en las tres lenguas francesa, latina e italiana: E-O, Madrid: Imprenta de la Viuda de Ibarra, 1787. Web. 12 dic. 2018.

Torre y Sevil, Francisco. Edición y estudio del Entretenimiento de las Musas de Don Francisco de la Torre y Sevil. Ed. Manuel Alvar, Valencia: Universidad de Valencia, 1987. Impreso.

Trambaioli, Marcella. “Quevedo, Lope y la mujer fea”. La Perinola, 19 (2015): 271-305. Web. 13 jun. 2018. 
Trueblood, Alan. "La mariposa y la llama: motivo poético del Siglo de Oro". Actas del Quinto Congreso Internacional de Hispanistas. Coords. François López, Joseph Pérez, Noel Salomón y Maxime Chevalier, 2, Burdeos: Université de Bordeaux, 1977. 829-837.

Vega, Lope De. “Comedia famosa de Angélica en el Catay”. El Fénix de España Lope de Vega Carpio, Familiar del Santo Oficio, 8, Barcelona: Sebastián de Cermellas al Call, 1617. 225239. Web. 7 my. 2019.

Vega, Lope De. El Milagro por los celos y D. Álvaro de Luna, Barcelona: Imprenta de Carlos Sapera, 1770. Web. 19 jun. 2019.

Vega, Lope De. El perro del Hortelano, Alicante: Biblioteca Virtual Miguel de Cervantes, 2002. Web. 23 abr. 2019.

Vega, Lope De. Peribáñez y el Comendador de Ocaña. El mejor alcalde, el rey. Ed. Teresa Ferrer, Alicante: Biblioteca Virtual Miguel de Cervantes, 2002. Web. 5 abr. 2019.

Vega, Lope De. Sonetos. Ed. Ramón García González, Alicante: Biblioteca Virtual Miguel de Cervantes, 2003. Web. 2 jul. 2019.

Vega, Garcilaso De la. Sonetos. Ed. Ramón García González, Alicante: Biblioteca Virtual Miguel de Cervantes, 2004. Web. 3 mzo. 2019.

Vidorreta Torres, Almudena. Estudio y edición de "Poesías varias" de José Navarro (1654), Zaragoza: Zaguan. Repositorio Institucional de Documentos, 2014. Web. 9 may. 2019.

Villalón, Francisco. El Crotalón, Barcelona. Lingkua digital, 2014. Impreso.

Vivalda, Nicolás. "Sor Juana y el pernicioso modelo de Faetón. Lecciones epistemológicas del escarmiento en Primero sueño”. Calíope, 16, 2 (2010):103-125. Web. 1 jun. 2019.

Vivas, Agustín. y Arias, Luis. "Fuentes documentales para el estudio de la prostitución en los siglos XVI y XVII en el Archivo y Biblioteca de Salamanca”. Brocar: Cuadernos de investigación histórica, 22 (1988): 51-62. Impreso.

Zafra, Enriqueta. Prostituidas por el texto: Discurso prostibulario en la picaresca femenina, Indiana: Purdue University Press, 2009. Impreso.

Zarco, Julián. Catálogo de los manuscritos castellanos de la Real Biblioteca de El Escorial, 1, Madrid: Imprenta Helénica. 1924. Impreso.

Zarco, Julián. Catálogo de los manuscritos castellanos de la Real Biblioteca de El Escorial, 3, Madrid: Imprenta Helénica, 1929. Impreso. 


\section{ANEXOS}

\subsection{CATALOGACIÓN DE LOS MANUSCRITOS POÉTICOS DE FRAY DAMIÁN CORNEJO}

\subsubsection{Bibliotecas españolas}

- $\quad$ Biblioteca Nacional de España, ms. 2100

Poesías varias manuscritas compuestas por diferentes autores. S. XVII-XVIII. $477 \mathrm{~h}$. (280 x 190). Enc. Holandesa. Fol. Moderna. Olim: G. 392. Se trata de un cancionero napolitano escrito en español y en italiano a varias manos. La mayor parte de las poesías son de D. Juan Vélez de León, poeta de Cámara de los Duques de Medinaceli. En el folio 37 una apostilla parece indicar el poseedor del manuscrito en la fecha señalada: "Vicálvaro y julio 28 de 1817. D[o]n. Antonio Elías Lozano". Cf. AA. VV. Catálogo 1: 141-166.

- $\quad$ Biblioteca Nacional de España, ms. 2245

Obras poéticas del padre Cornejo. S. XVIII, 225 h. (215 x 154). Enc. Pergamino. Fol. Antigua. Olim: G. 408. Se trata de un manuscrito, escrito a una mano, que incluye poemas atribuidos a fray Damián Cornejo hasta el folio 201v, donde una apostilla señala: "Desde aquí adelante poesías de Eugenio Gerardo Lobo”. En la segunda hoja de guarda, una nota firmada por "Méndez" parece indicar su poseedor: "Este libro es propiedad de Don Miguel de Arratiguibel y Gorospe”. Cf. AA. VV. Catálogo 1: 215-256.

- Biblioteca Nacional de España, ms. 3884

Poesías castellanas varias. Vol. I, XVII (2 mitad), 423 h. (205 x 145). Enc. Moderna. Fol. Moderna. Olim: M. 78. Procede de la Biblioteca Real. Se trata de un manuscrito, escrito a varias manos, que contiene una extensa y variada colección de poesías en español y algunas obras de teatro. Se pueden observar que varias páginas han sido guillotinadas. Cf. AA. VV. Catálogo 2: 913. 
- Biblioteca Nacional de España, ms. 3921

Parnaso Español. Vol. 10. S. XVII y XVIII (principios). 347 h. (205 x 145). Enc. Pergamino. Fol. Antigua. Olim: M 13. Se trata de un manuscrito, escrito a varias manos, que incluye poemas de múltiples autores (Bances Candamo, Martín Rodríguez de Ledesma, Quevedo, José Pellicer, Jerónimo Altamirano, Matos, Borge y Clavería, Eugenio Gerardo Lobo y Damián Cornejo) y textos satíricos del reinado de Carlos II. Cf. AA. VV. Catálogo 2: 12011214.

- Biblioteca Nacional de España, ms. 3922

Parnaso Español. Vol. 11. S. XVII y XVIII (principios). 499h. (210 x 150). Enc. Pergamino. Fol. Antigua. Olim: n.d. Se trata de un manuscrito apógrafo, escrito a varias manos, que incluye poemas de múltiples autores (Juan de Vera y Zúñiga, Góngora, Paravicino, Quevedo, Juan de Salinas, Antonio de Mendoza, Juan de Silva, Damián Cornejo, Villamediana. Luis de Ulloa, Diamante, Conde de Salinas...), algunas piezas breves de teatro y diversas composiciones impresas. Cf. AA. VV. Catálogo 2: 1214-1230.

- Biblioteca Nacional de España, ms. 3929

Papeles poéticos. S. XVIII (mediados). 144 h. (210 x 150). Enc. Holandesa. Fol. Antigua. Olim: G-A-8. Se trata de un manuscrito, escrito a varias manos, que incluye el "Coloquio entre galán y la dama de la Comedia de las Amazonas" de Lope de Vega (atribuida en este códice a Antonio Solís), un elenco de términos gitanos, diversos impresos de poesías y algunas composiciones en prosa y en verso manuscritas. En el folio 1 la siguiente nota: "Este tomo consta del número de 48 papeles, los más son de poesías varias y otros curiosos". Cf. AA. VV. Catálogo 2: 1264-1272.

- Biblioteca Nacional de España, ms. 3930

Poesías varias de diferentes autores. S. XVIII (1 $\left.{ }^{\circ} \mathrm{mitad}\right) .201$ h. (210 x 145). Enc. Moderna. Fol. Antigua. Olim: M-254. Se trata de un manuscrito, escrito a una mano, que incluye obras en prosa y en verso de diversos autores (Gonzalo Pacheco de Padilla, Eugenio Gerardo Lobo, Pedro Calderón de la Barca, Juan de Vera Tassis y Villarroel...). Estas están divididas en 
tres libros: el primero "místico"; el segundo "de diferentes versos amorosos" y el tercero "jocoso". En la portada se indica el nombre del compilador y el año: "Por Sierra 1722” y en el fol. 1 hay un retrato de Calderón de la Barca dibujado a pluma. Cf. AA. VV. Catálogo 2: 1273-1276.

- Biblioteca Nacional de España, ms. 3931

Poesías varias y obra poética de Damián Cornejo. S. XVII (finales) - XVIII, 214 h. (200 x 145). Enc. Moderna. Fol. Moderna. Olim: M 254. Se trata de un manuscrito, escrito a dos manos, que contiene una traducción del Remedia Amoris de Melchor de la Serna, la" Fábula de Faetón del Conde" de Villamediana y "Poesías varias escritas por R.M. Cornejo, cronista g[eneral] d[e] S[a]n Francisco". Cf. AA.VV. Catálogo 2: 1276-1281.

- Biblioteca Nacional de España, ms. 4052

Poesías varias. S. XVII ( $2^{\circ}$ mitad). 299 h. (220 x 155). Enc. Holandesa. Fol. Antigua. Olim: M 200. Se trata de un manuscrito, escrito a varias manos, que reúne composiciones en prosa y en verso de temática distinta (satírica, histórica, política, esotérica...). Destacan las glosas a las "Coplas" de Jorge Manrique y el "Sueño político" de Quevedo. En la primera tapa de la encuadernación, hay una nota autógrafa de Rodríguez Marín acerca del interés de algunas de sus obras. Cf. AA.VV. Catálogo 2: 1562-1570.

- Biblioteca Nacional de España, ms. 4062

Poesías divinas. S. XVIII. 78 h. (220 x 15 5). Enc. Holandesa. Fol. Moderna. Olim: M 343. Se trata de un manuscrito, escrito a una mano, en el que se reúnen poesías de temática religiosa, principalmente, vinculadas a de la Orden Franciscana y a eventos litúrgicos que sucedieron en Alcalá de Henares en la segunda del siglo XVII. Gran parte de las composiciones que en él aparecen se atribuyen en otros manuscritos $(2245,3931,4258$, 5566 y 17666) a Damián Cornejo. Falta la cuartilla 76. Cf. AA. VV. Catálogo 3: 384.

- Biblioteca Nacional de España, ms. 4135 
Obras poéticas de Manuel León Marchante y de fr[ay] Damián Cornejo. S. XVIII. 188 h. (200 x 140). Enc. Pergamino del S. XVIII. Fol. Moderna. Olim: Jj. Su 65. Procede de la Biblioteca del Duque de Osuna. Se trata de un manuscrito, escrito a dos manos, que incluye composiciones poéticas del maestro León y de Damián Cornejo. Las obras que se atribuyen a León Marchante aparecen en otros manuscritos (2245, 3884, 3931, 4258 y 5566) asignadas Cornejo. En el primer folio, a modo de portada, aparece escrito: "Obras del maestro León hasta la página doce. Y todo lo demás restante de esta obra del padre Cornejo". En el lomo, puede leerse: "Cornejo sus obras poéticas. Y algunas del maestro León”. Varias páginas han sido guillotinadas. Cf. AA.VV. Catálogo 4: 1950-1953.

- Biblioteca Nacional de España, ms. 4258

Obras jocosas de Cornejo. S. XVII (finales) - S. XVIII, 202 h. (200 x 140). Enc. Pergamino. Fol. Moderna. Olim: M. 358. Procedente de la biblioteca de Böhl de Faber. Exlibris: Don Luis Bernardo Álvarez. Se trata de un manuscrito, escrito a dos manos, que contiene poesías atribuidas a Damián Cornejo. En el fol. 202 se indica a modo de colofón: "Escrito por Felipe de Valdivia y Manrique". Notas marginales en los folios “16, 36, 46, 47v, 60, 82 y 123”, que atribuyen al maestro León las composiciones que en ellos aparecen. El primer folio está mutilado, pero se puede identificar la composición "Oye, Catuja, dulce hechizo mío", ya que esta aparece en otros manuscritos de la BNE: 2245, 3922, 4135 y 5566. Cf. AA.VV. Catálogo 4: 2063-2068.

- Biblioteca Nacional de España, ms. 5566

Cancionero. S. XVII -XVIII. 736 h (295 x 215). Enc. Holandesa. Fol. Moderna. Olim: Q. 21. Se trata de un cancionero, escrito a varias manos, que contiene las siguientes composiciones en verso: "Poesías jocosas", de Cornejo; la "Fábula de Acis y Galatea", de Alonso del Castillo; "Antídoto contra las Soledades”, de Juan de Jáuregui; "Contra el Antídoto, y en favor de Don Luis de Góngora": "Examen del Antídoto", de Francisco de Córdoba; “Obras”, de Diego Hurtado de Mendoza; poesías anónimas. Cf. AA.VV. Catálogo 4: 2144-2156.

- Biblioteca Nacional de España, ms. 5862 
Obras selectas de Antonio da Fonseca Soares. S. XVIII. 241h. (20 x 15). Enc. Pergamino. Fol. Moderna. Olim: Supl. 232. Se trata de un manuscrito, escrito a varias manos, que contiene múltiples obras en verso de autoría anónima y otras atribuidas a Antonio Zamora y a Francisco Bances Candamo. En el segundo folio una nota indica: "Varias poesías españolas en varios metros y a diversos asuntos de autor anónimo". Las poesías que aparecen en los folios 227-228 se atribuyen a Damián Cornejo en los siguientes manuscritos de la BNE: 2245 (138), 4135 (111), 4258 (131v), 5566 (129) y 18470 (72). Cf. AA.VV. Catálogo 4: 2191-2199.

- Biblioteca Nacional de España, ms. 12980 /1

Poesías varias. S. XVII (finales) - XVIII (principios). 12 h. (21 x 15). Enc. Sin encuadernar. Fol. Antigua. Olim: V. $4^{\circ}$. C.59., $n^{\circ} 1$. Se trata de un manuscrito, escrito a una mano, en el que se recoge "La exhortación política cristiana a la Nación española" de Eugenio Gerardo Lobo, "Agosto" de Damián Cornejo y "Cuarteta que pusieron en Zaragoza a Don Lucas Espínola”. Cf. Castro (520-521).

- Biblioteca Nacional de España, ms. 12981/35

Relación burlesca: Escuchen y tengan cuenta / que empiezo por el principio. S. XVIII. 7 h. (21 x 15). Enc. Sin encuadernar. Fol. Antigua. Olim: V. $4^{\circ}$ C.60., n. 35. Se trata de un manuscrito, escrito a dos manos, que contiene los siguientes poemas satíricos: "Relación en alabanza y vituperio de la mujer, en forma de argumento", "Controversia que tuvieron dos licenciados, de los cuales el uno alababa y el otro vituperaba a la mujer", "La siguiente dijo Cornejo a una monjas que cantando una Salve y alternando con los religiosos estas entonaron «Oh, dulcis» y los religiosos «Virgo»" y "Décima de Lope de Vega Carpio en alabanza de un autor franciscano llamado Vascones".

- Biblioteca Nacional de España, 17666

Varias poesías curiosas de diferentes autores. S. XVIII. Enc. Pergamino. 925h. (25 x 17). Fol. Antigua. Olim. n.d. Se trata de un manuscrito, escrito a una mano, que contiene obras en prosa y en verso (sacro y profano) de diversos escritores. Muchas de ellas aparecen sin atribución. Algunos de los poemas que se incluyen como anónimos se atribuyen a Cornejo 
en otros manuscritos. El poemario es una copia del manuscrito D-249 de la Biblioteca Central de Zúrich. En nota autógrafa, Pascual de Gayangos señala que: "Ninguna de las poesías contenidas en este tomo es posterior al año 1663 (h. I)”. Cf. Gayangos (259-260).

- Biblioteca Nacional de España, ms. 18470

Poesías varias. Vol. 2. S. XVIII. 97 h. (25 x 18). Enc. Holandesa. Fol. Moderna. Olim: 146. Exlibris: Don Pascual de Gayangos. Se trata de un manuscrito, escrito a dos manos, que contiene obras de temas históricos, literarios y culturales: Descripciones de Soria y de Galicia «en verso» del padre Butrón; Observaciones sobre las fábulas literarias de Tomás de Iriarte; Alejandro en África: drama trágico; y diversas composiciones satíricas y jocosas anónimas. Las obras escatológicas que aparecen en los folios 66-69 son atribuidas a Cornejo en los siguientes manuscritos de la BNE: 2245 (138), 4135 (111), 4258 (131v) y 5566 (129). Cf. Castro (644-645).

- Biblioteca Nacional de España, ms. 20813/4

Soneto: Esta mañana en Dios y en hora buena. S. XIX-XX, 1h. (21 x 15). Enc. Sin encuadernar. Fol. Moderna. Olim: n.d. Se trata de un manuscrito, escrito a una mano, que alberga el soneto "Esta mañana en Dios y en hora buena" y el primer verso de "Lo menos bello y más apetecido". En la parte superior contiene la siguiente nota: "De fr. Damián Cornejo".

- Biblioteca Real de la Colegiata de Roncesvalles, ms. 410

Poesías divinas y humanas, serias y jocosas, que a diferentes asuntos escribió el r[reverendísimo] padre fr[ay] Damián Cornejo del Orden de nuestro p[adr]e s[a]n Franc[isc]o año 1737. S. XVII-XVIII. 195 h. (155 x 215). Enc. Pergamino. Fol. Antigua. Olim. n.d. Se trata de un manuscrito, escrito a varias manos y en diferentes épocas, que contiene poesías de carácter sacro y festivo atribuidas a Damián Cornejo. Esta obra incluye algunas notas marginales que informan de las personas que proporcionaron los poemas. Algunos de ellos se hallan repetidos y otros son apócrifos. Cf. Cornejo (Das lyrische 3037). 
- Biblioteca Real de la Colegiata de Roncesvalles, ms. 28-C-7-6p22 (inédito)

Enamorando a una dama cuyo nombre era Palma. S. XVII ( $\left.2^{\circ} \mathrm{mitad}\right)-$ XVIII. 23h. (22 x 16). Enc. Sin encuadernar. Fol. Antigua. Olim. n.d. Se trata de un manuscrito, escrito a varias manos, que contiene poesías de carácter sacro y festivo atribuidas a Damián Cornejo en otros manuscritos. Está constituido por dos cuadernillos que presentan errores en la foliación (de la hoja 67 pasa a 78) y que posee saltos de página significativos (del folio 91 pasa al 7).

- Biblioteca Fundación Bartolomé March, ms. 406

Obras poéticas m[anuscrita]s del rev[erendísi]mo y il[ustrísi]mo señor don fray Damián Cornejo, obispo de Orense, que también compuso la Crónica de nuestro padre san Francisco con el acierto que es notorio. S. XVII, 346h. (16 x 20). Enc. Pergamino. Fol. Antigua. Olim. 23/4/2. Procede de la Biblioteca de Medinaceli, $\mathrm{n}^{\circ}$ 145. Se trata de un manuscrito, escrito a una mano, que contiene poesías sacras y profanas atribuidas a Damián Cornejo. Cf: Carreira (La obra 42).

- Real Biblioteca del Monasterio del Escorial, ms. Z. IV.18

Relación del convento de Monjas Jerónimas de Palma. Descripción de las ocho maravillas del mundo. Descripción de España y su corte. Coplas y glosas de España y Francia. Sermón para la dominica quinta de Cuaresma [...]. S. XVI-XVIII. 461h. (21 x 15). Enc. Pergamino. Fol. Antigua. Olim. n.d. Se trata de un manuscrito misceláneo, escrito a varias manos, que contiene obras en prosa y en verso. En él se incluyen varios poemas sacros y profanos atribuidos a Damián Cornejo. En la $3^{\mathrm{a}} \mathrm{h}$. de guarda del principio consta la siguiente anotación: "Ms. compuesto por el Bibliotecario Félix Rozanski". Cf. Zarco (Catálogo 1: 276-277 y Catálogo 3: 168-173).

- Biblioteca de la Real Academia Española, ms. RM-6654

Obras del padre Cornejo. Asuntos sacros. S. XVIII. 113 h. (22 x 16). Enc. Piel burdeos. Fol. Moderna. Olim: n.d. Se trata de un manuscrito, escrito a una mano, que contiene poesías de carácter sacro y festivo atribuidas a Damián Cornejo. En la hoja de guarda se lee: “Algunos 
versos son demasiado alegres, hay juegos de palabras, algún equívoco”. Exlibris al inicio y al final: "Soy de José Antonio García, cura de Barbolla". Cf. Carreira (La obra 42).

- Biblioteca Menéndez Pelayo, ms. 156

Obras líricas, humanas y sagradas, por el reverendísimo padre Damián Cornejo... año de 1737. S. XVIII. 149 h. (21 x 15). Enc. En pasta. Fol. Antigua. Olim: M 70. Se trata de un manuscrito, escrito a dos manos, que contiene poesías de carácter sacro y festivo atribuidas a Damián Cornejo. Incluye una dedicatoria de Barbieri a Menéndez Pelayo, la cual está fechada en 1893. Cf. Artigas y Ferrando (376-384); Aguilar Piñal (560-564).

- Biblioteca Pública de Toledo, ms. 447

Versos de varios autores. S. XVIII. 130 h. (23 x 16). Enc. Pergamino. Fol. Antigua. Olim. n.d. Se trata de un manuscrito, realizado a varias manos de distinta época, que recopila de manera aleatoria poemas sacros y profanos atribuidos a Damián Cornejo y a León Marchante [referencia posterior al texto] y poesías Jerónimo de Sosa y de Eugenio Gerardo Lobo y Francisco de Toledo. Incluye, además, Vergel florido y ameno jardín [fray Francisco de Toledo] y el Entremés de las sombras. Cf. Esteve (477).

\subsubsection{Archivos españoles}

- Archivo Histórico Nacional, ms. L. 1053 (inédito)

Noticias varias de Galicia. S. XVIII-XIX. 290 h. (22 x 16). Enc. Moderna. Fol. Moderna. Se trata de un manuscrito, realizado a varias manos, que alberga diversos documentos administrativos, judiciales y eclesiásticos relacionados con la comunidad de Galicia, una colección de poesías sacadas del teatro moral y político de la noble academia compostelana y las "Obras de fray Damián Cornejo del Orden de san Francisco de la observancia, lector jubilado y cronista de su religión, obispo que fue de Mondoñedo".

\subsubsection{Bibliotecas e instituciones extranjeras}


- British Library, ms. E 1889

Obras poéticas M. S. del reverendísimo padre fr [ay] Damián Cornejo, que también compuso la Crónica de nuestro padre san Francisco. S. XVIII. 116 h. (110 x 160). Enc: En pasta. Fol. Antigua. Olim: n.d. Se trata de un manuscrito, escrito a varias manos, que contiene mayoritariamente poesías de temática sacra y profana atribuidas a Damián Cornejo, algunos poemas humanos de Luis de Ulloa y León Marchante y diversas anotaciones sobre Enfrosina de Jorge Ferreira. En la segunda hoja de guarda contiene una nota que indica que en el siglo XIX perteneció a un editor londinense "H. Baillerie”. Cabe señalar que los últimos poemas (95-115) no aparecen en el índice, pues se añadieron al manuscrito con posterioridad. Cf. Gayangos (56-62).

- Biblioteca Pública Municipal de Oporto, ms. 647

Poesías varias del padre fray Damián Cornejo. S. XVII (2º mitad). 301h. (210 x 145). Enc. Pergamino. Fol. Antigua. Olim: n.d. En el catálogo de Eduardo Allen es el no 629. Se trata de un manuscrito escrito a varias manos que contiene poemas atribuidos a Cornejo (1-71). Incluye dos índices. Antes de cada uno se dejan dos grupos de páginas en blanco (131-143 y 279-299). Cf. Carreira (La obra 43).

- Biblioteca Central de Zúrich, ms. D-249

Poesías varias. S. XVII. 398 h. (220 x 150). Enc. Pasta. Fol. Antigua. Olim: n.d. Se trata de un manuscrito, escrito a varias manos, que contiene obras en prosa y en verso (sacro y profano) de diversos autores. Muchas de ellas aparecen sin atribución. Algunos de los poemas que se incluyen como anónimos se atribuyen a Cornejo en otros manuscritos. El poemario guarda estrecha relación con el 17666 de la BNE, el cual se cree que es una copia posterior de este. Cf: López Guil (391-426).

- Hispanic Society Of America, ms. Nr. XCV

Romances, sonetos y papeles varios. S. XVIII. 400 h. (220 x 153). Enc. Pergamino. Fol. Antigua. Olim: n.d. Procede del Marqués de Jerez de Archez. Se trata de un manuscrito, escrito a varias manos, que contiene obras en prosa y en verso (sacro y profano) de diversos 
autores. Muchas de ellas aparecen sin atribución. Algunos de los poemas que en él se incluyen como anónimos se atribuyen a Cornejo en otros manuscritos. Cf. RodríguezMoñino (Catálogo 22-26).

- Biblioteca Estense-Universitaria de Modena, ms. Est. 199= Epsilon 32.3.6 (inédito).

Tonos diversos. S. XVII-XVIII. 190 h. 33 (208 x 147), 111 (215 x 150), 152 (215 x 150). Enc. Pergamino. Fol. Antigua. Olim: 2020 n.22. Procede de la Biblioteca de la Villa Falcò Pio de Mombello. Se trata de un manuscrito que contiene obras en verso (sacro y profano) de diversos autores. Muchas de ellas aparecen sin atribución. Algunos de los poemas que se incluyen como anónimos se atribuyen a Cornejo en otros manuscritos. Contiene un Exlibris impreso (probablemente en la mitad del siglo XX) en el que aparece el escudo de la casa Pío de Saboya. Este se halla rodeado por un marco bajo, el cual incluye en su centro la letra "M" (Villa Mombello). Cf. AA.VV. (Manus, s.p.).

\subsection{INDEXACIÓN DE LOS MANUSCRITOS QUE CONTIENEN POESÍA ATRIBUIDA A FRAY DAMIÁN CORNEJO}

\subsubsection{Bibliotecas españolas}

\subsubsection{Biblioteca Nacional de España, ms. 2100}

Poesías varias manuscritas compuestas por diferentes autores. S. XVII-XVIII. 477 h. (280 x 190). Enc. Holandesa. Fol. Moderna. Olim: G. 392, Se trata de un cancionero napolitano escrito en español y en italiano a varias manos. La mayor parte de las poesías son de D. Juan Vélez de León, poeta de Cámara de los Duques de Medinaceli. En el folio 37 una apostilla parece indicar el poseedor del manuscrito en la fecha señalada "Vicálvaro y julio 28 de 1817. Don. Antonio Elías Lozano". Cf. AA.VV. Catálogo 1: 141-166.

—1. De Cornejo, "Pobre de mis mulas" (232v.). 


\subsubsection{Biblioteca Nacional de España, ms. 2245}

Obras poéticas del padre Cornejo. S. XVIII. 225 h. (215 x 154). Enc. Pergamino. Antigua. Olim: G. 408. Se trata de un manuscrito, escrito a una mano, que incluye poemas atribuidos a fray Damián Cornejo hasta el folio 201v, donde una apostilla señala: "Desde aquí adelante poesías de Eugenio Gerardo Lobo". En la segunda hoja de guarda una nota firmada por "Méndez" parece indicar su poseedor: "Este libro es propiedad de Don Miguel de Arratiguibel y Gorospe”. Cf. AA.VV. Catálogo 1: 215-256.

-1. El agosto del fraile en Madrigales, "Oye, Catuja, dulce hechizo mío" (1). - 2. Pintura a una dama, "Sepan todos y todas que yo adoro" (11). - 3. Otra pintura a una ausencia de una dama, "Desde que el sol ardiente" (17). - 4. Pintura a una dama, "Dulce Lisis de mis ojos" (20v). - 5. Habiendo pedido asunto en una Academia para escribir, no se lo dieron por estar todos repartidos y le dijeron que tomase por pie el no habérsele dado y vistiese a una dama que otro dejaba desnuda a orillas de un río, "Yo soy, ilustre Academia" (22v). — 6. Sátira a unos colegiales que dieron a unas damas moscas confitadas, "Éranse dos licenciados" (25). - 7. Sátira a estas damas por hartarse de las sobredichas moscas quedaron ahítas, "Óiganme damas que empuño" (28). — 8. A un borracho, "A uno que se hace una uva" (29v). - 9. Dando chasco a un borracho, "Clodio, del mundo en la plaza" (30v). - 10. Sátira a un estudiante que comió menudo, "Un estudiante de hogaño" (32v). - 11. Sueño jocoso, "Cansado anoche de estar" (33v). - 12. Quintillas jocosas, "Vengar quiero mis rencillas" (48v). — 13. El mismo autor a sus quintillas, "En la desatada llaga" (51). —14. Epigrama a ojos azules, "Desde que tus niñas bellas" (51v). — 15. A una dama fácil, "Tu arroz, Marica, me enfada" (51v). — 16. Habiendo perdido una dama por causa del autor cien reales, él la envió dos y al no quererlos recibir escribió esta décima, "Cien reales por mí perdiste" (52). - 17. Contra monjas, "Un ciego soy desgraciado" (52v). — 18. Al haber visto el pie a una dama, "En el mar de tu hermosura" (54). - 19. A una dama que, estando ausente y sangrada, pedía celos a su galán, "Mi bien, juro por mi amor" (55v). - 20. A uno muy preciado de valiente siendo gallina, "Es de Fausto la fiereza" (57v). - 21. A unos mozos que salieron a torear, "De Pinto para un festejo" (59). — 22. A una dama que, siendo galanteada de muchos, se casó con un sacristán, "Dios te socorra, Marica" (60). —23. Amorosa soledad, "Para qué es tu atrevimiento" (62v). — 24. A una dama que, estando destocada, se asomó a una reja y su galán la asió una mata de cabellos, “A una reja qué ventura” (63). —25. A una 
dama que se casaba con un capón, "Con modo ya más humano" (65v). — 26. Amante callado y sospechoso, "Solo el silencio testigo" (66). — 27. Sátira a una dama que gastó lo mejor de su mocedad con frailes y a la vejez decía mal de ellos y se había empeñado con un sacristán, "Marica, que a decir mal” (67). —28. Sátira a otro asunto, "Quisimí quisimona, hola" (69). -29. A un hombre en abreviatura fraile meñique que, hipócrita de estatura, se engrandece a costa del alcornoque, "Oye, tarazón de frailes" (71). — 30. Convidando una dama a su galán a finezas amorosas, en metáfora de un juego de hombres, "Ya, Fabio, que hemos llegado" (73). - 31. Habiendo un poeta hecho un sátiro contra otro pobrete, se le respondió cagándose en él y con estas, “Tu romance, Andrés, leí” (74v). — 32. Epigrama gracioso a una dama, "El pañuelo desembolsa" (75). - 33. Otro a otra dama que no correspondía a las finezas amorosas con que su galán la pretendía, "Marica, no desdeñosa” (75v). — 34. A unas doncellas que querían bien a unos portugueses, "Queridas, mucho me enfada" (75v). — 35 . A un catedrático secular, siendo en la condición muchacho, no quería leer algunas veces enfadándose de muy pocas cosas, "Pedro, mi ingenio recela" (77). - 36. A una dama que por interés se daba a todos, "Escúchenme unos esdrújulos" (78v). - 37. Pidiendo a una señora un poco de arrope para dar a una dama, "Pues vuestra piedad me abriga" (80). — 38 . Sátira a cierta dama por quien su galán padecía las penas del purgatorio, "María, viéndote hermosa" (80v). - 39. Otra al mismo intento, "Malo me siento, Marica" (82v). — 40. A san Diego de Alcalá, "Después que por qué se usa" $(84 \mathrm{v})$. — 41. Un amante a su amada, "Bien puede, Lisis, un triste" $(85 \mathrm{v})$. - 42. A una dama que dio licencia a su galán para que la quisiera, "Licencia solo me has dado" (87). - 43. Fraterna exhortatoria a un galán que gastaba con su dama poco dinero y mucha prosa, "Anfriso, con atención" (88v). - 44 . Enamorando a una dama cuyo nombre era Palma, "Palma, en viendo tu beldad" (89v). 45. Pidiendo celos una dama a su galán de un fraile italiano, de quien el dicho galán confesaba era muy querido. Y, siendo muy lindo, se alababa de ello, "Don Juan, no tengo por bueno" (91). - 46. A una dama que lloraba mucho de dolor de un divieso que le salió en la mano, "Hoy, Clori, pretendo amarte" $(91 \mathrm{v})$. - 47. A una dama que dio a su galán unas pelotas, "Ya que tan galante has sido" (93). - 48. Enviando a una dama una vela blanca al tiempo que estaba para ausentarse de ella, "De pedir nunca yo fuera" (94). - 49. A una dama, "María, a tu sucia cara" (95v). - 50. A un corcovado que galanteaba a una dama y la daba músicas y ella le aborrecía y desde su casa le cantaron esta sátira, "Un galán corto de talle" (95). — 51. Despedida de una dama, "Adiós, Leonor de mi vida" (98). — 52. A una fea presumida, "Clori, que para ser linda (100). —53. A una ausencia, "En aquesta soledad" (101). - 54. Manifiesta un amante a la dama su pasión, "Pues que me han dado licencia" 
(103v). - 55. A una pobre que salió muy estropeada de un mal francés habido en buena guerra del mismo autor, "Un mal francés, Marica, tan grosero" (105). — 56. A una monja hermosa, desdeñosa, "A todos tu beldad rigores flecha" (105v). - 57. A una dama que, estando destocada, se asomó a una reja y su galán la asió una mata de cabello, "Suelto el cabello por el aire ufano" (106). — 58. Habiendo pedido una mano un galán y no habiéndola conseguido, le pide un dedo, "Amoroso, prudente y cortesano" (107). — 59. Desmiente las desconfianzas de una dama un galán con un retrato suyo algo desparecido, "Rudo pincel de mano inadvertida" (107v). - 60. Al mismo asunto, "Por los yerros, Yisbella, de un traslado" (108). - 61. Al ponerse una dama en la guedeja unos jazmines que aún no habían salido botón y a pocas horas se abrieron en el mismo pelo, "De emboscado entre matas de tu pelo" (108v). - 62. Soneto panegírico que a uno le viene a la media pierna al dueño del asunto, "Breve pie reducido a cárcel breve" (109). — 63. Al mismo asunto, "Cómo quieres, Anarda, que sea casto" (109v). — 64. Otro soneto, "Ya no puedo vivir si no me capo" (110). — 65 . Al desaliño de los versos de un poeta de polainas y greguescos, "Disparates, Antón, muy mal zurcidos" (110v). - 66. A uno que se llamaba Cruz y perseguía al autor por haberle pedido unas suelas, "Cruz, si cristiano soy" (111). —67. Al mismo asunto, “Apenas, señor, te viste" (111v). - 68. Al mismo asunto, "Pedite, mi buen Cruz, suelas" (113). —69. Soneto jocoso, "Estaba Lisis en campal batalla" (114v). - 70. A una monja pidiendo celos a un hombre que tenía por sobrenombre Puerto, "De mis finezas el bajel incierto" (115). — 71. A los escribanos, "Hoy sin más ni más me allano" (115v). — 72. A un jurador, "Señor, jurador he sido" (117). — 73. Letra burlesca, "A Pascuala dijo Bras" (118). — 74. Desengaño del deleite sensual. Jácara, "En la villa de Carrión” (121). —75. Sátira, "En Málaga vi a Rufina” (123). — 76. Sátira a don Fernando Valenzuela, "Fernando, a quien por soberbio" (123v). 77. Pregón, "En la rueda política mía” (125v). — 78. Otro pregón, "En la firme política nuestra" (126v). - 79. A una dama porque quemó un papel, "No quieran tus sinrazones" (127). — 80. Tono, "Del rumbo de Francelina" (127v). — 81. Tono, "Fuera, fuera que Juanilla" (128). — 82. Tono, "Los ganados del buen mayoral” (128v). — 83. Tono, "Gentil galán de los ríos" (129). — 84. Tono, "Sonoro arroyuelo" (129v). — 85. De un estudiante que se fue sin hacer cuenta con la huéspeda, "Un estudiante este curso" (130v). — 86. A una dama que cortándose un callo por acordarse de su galán se cortó un pie, "De un pie escribir quiero en suma" (131). — 87. De un doctor a un sacristán, “El sacristán qué desmán” (133). -88. A Judas, "Por tomar Judas el grado" (134). — 89. A una dama en la primera noche de tal la hizo cerrada la cama, "Musa mía, con astucia" (135). — 90. A un religioso, en un locutorio, le vino una correncia y soltó las bragas y, por ello, le compusieron diversos 
romances, y él respondió con estas décimas, "Pues que su entretenimiento" (138). —91. A una monja que pretendía el que un sujeto prosiguiese en sus malos intentos, "Nise, a quererte me inclino" (139). —92. En respuesta de las antecedentes, "Acabose el amistad" (140v). 93. Traslado de una carta a los colegiales de Alcalá, "Reyes míos, desde el día" (141v). 94. Soneto, "Esta mañana en Dios y enhorabuena" (144). — 95. Otro, "Lo menos bello y más apetecido" (144v). —96. A un borracho, "De una taberna salía" (145). —97. Pinta a un tudesco borracho, "Un tudesco, humana cuba." (146v). — 98. A un novicio que profesó en san Diego de Alcalá, “Oiga, hermano fray Francisco" (147v). —99. Vejamen a san Diego, "Un devoto singular" (149v). —-100. Otro al mismo santo, "Otra vez tengo la pluma" (152). —101. A la Concepción, "Hanme mandado una cosa" (154). —102. Al mismo asunto, "La más hidalga hermosura" (155v). —103. Al mismo asunto, "La Concepción este día" (157). -104. Al propio asunto, "De tu concepción, Señora" (158). - 105. Al mismo asunto, "Digan lo que saca en limpio" (159v). - 106. Al mismo asunto, "De una niña la grandeza" (161). — 107. Al mismo asunto, "Sabed, Señora doncella" (163). — 108. A san Francisco, "De pie quebrado unas coplas" (164). - 109. Al mismo asunto, De Francisco por menor" (165v). - 110. A santa Clara, "Hoy mi devoción aclama" (167). —111. A san Juan Bautista, “Al señor Bautista, el jaque" (169v). —112. Acto de contrición delante de un Crucifijo, "Un pecador soy, Dios mío” (172). —113. A la Purísima Concepción. Jácara, “Érase una Virgen pura" (175). —114. Al Nacimiento, "Escriben desde Toledo" (177). —115. Al desengaño del mundo, "Quiero, pues es ocasión” (179). —-116. A celebrar la octava del Santísimo Sacramento, "Que llega la fiesta, que falta la solfa" (183). —117. A la Magdalena, "En tu alabanza mi musa" (185). —118. A la Resurrección de Cristo, "De santa Resurrección" (186). —119. Petición a nuestra Señora, "Divina madre de Gracia" (188v). —120. A Cristo en la cruz, "Dulce Jesús, Dios mío" (190). —121. Al Santísimo Sacramento, “Oigan en jácara, diga" (191). — 122. Letras al Santísimo Sacramento, “Acudan sentidos” (193). 123. A la procesión que hicieron los padres de Santo Domingo en reverencia de la Concepción de nuestra Señora, "Hoy a la Concepción aclamaciones” (194v). - 124. Estando un religioso dominico hablando de la Concepción poco decente en una visita un gato que estaba en la sala le saltó al pescuezo y le maltrató mucho, "Un dominico enemigo." (195). -125. Al Nacimiento, "Haced que la Gracia encuentre" (196). - 126. A una dama dándola un clavel, "Clavel, pues por tus colores" (197v). — 127. A Nuestra Señora en títulos de comedias, "En títulos Virgen pura" (198). - 128. A san Diego de Alcalá, "Hoy con gusto a cantar llego" (200). —129. Una décima, “Guardar la mujer es ley.” (201). 


\subsubsection{Biblioteca Nacional de España, ms. 3884}

Poesías castellanas varias. Vol. 1. S. XVII (2 mitad). 423 h. (205 x 145). Enc. Moderna. Fol. Moderna. Olim: M. 78. Procede de la Biblioteca Real. Se trata de un manuscrito, escrito a varias manos, que contiene una extensa y variada colección de poesías en español y algunas obras de teatro. Se pueden observar que varias páginas han sido guillotinadas. Cf. AA.VV. Catálogo 2: 913.

-1. El diablo anda en Cantillana y nos la quiere pegar, "Fernando, a quien los soberbios" (81). - 2. Es un sueño, "Cansado anoche de estar" (250). - 3. Contra monjas, "Con monjas no se resbala" (255). — 3. De fray Damián Cornejo, “Tu arroz, Marica, me enfada" (282v) 4. De fray Damián Cornejo, "Don Juan, no tengo por bueno" (305v). - 5. A una puerca, "Marica, a tu sucia cara" (305v). - 6. A unos ojos azules, "Desde que tus niñas bellas" (305v). - 7. Del mismo, "Los franciscos suelen ser" (305v). - 8. Otra del mismo, "Pidiste un cuarto y dijiste" (306). - 9. A uno que se llamaba Cruz y perseguía mucho a un fraile, "Si cristiano soy, qué me persigues" (309). — 10. Contra monjas, "Un ciego soy desgraciado" (309). - 11. De una dama que dio licencia a su galán para que la amase, "Licencia solo me has dado" (331). —12. Jácara de san Juan Bautista, “A san Juan Bautista, el jaque" (331v). — 13. Décimas amorosas, "Para qué es tu atrevimiento" (333). - 14. A una dama por quien su galán padecía las penas del purgatorio, "Marica, viéndote hermosa" (365). -15. Sátira a una dama que galanteada de muchos se casó con un sacristán, "Dios te socorra, Marica" (368). - 16. A las llagas de nuestro padre san Francisco, "De pie quebrado unas coplas" (378v). - 17. Pintura de una dama, "Oye, Amarilis, discreta” (380v).

\subsubsection{Biblioteca Nacional de España, ms. 3921}

Parnaso Español. Vol. 10. S. XVII y XVIII (principios). 347h. (205 x 145). Enc. Pergamino. Fol. Antigua. Olim: M 13. Se trata de un manuscrito, escrito a varias manos, que incluye poemas de múltiples autores (Bances Candamo, Martín Rodríguez de Ledesma, Quevedo, José Pellicer, Jerónimo Altamirano, Matos, Borge y Clavería, Eugenio Gerardo Lobo y Damián Cornejo) y textos satíricos del Reinado de Carlos II. Cf. AA.VV. Catálogo 2: 12011214. 
-1. Pintura a una dama, "Sepan todos y todas que yo adoro" (214). - 2. Otra a una ausencia de cierta dama, "Desde que el sol ardiente" (219). - 3. Otra pintura al mismo asunto, "Pues que me han dado licencia" (222).

\subsubsection{Biblioteca Nacional de España, ms. 3922}

Parnaso Español. Vol. 11. S. XVII y XVIII (principios). 499h. (210 x 150). Enc. Pergamino. Fol. Antigua. Olim: M 14. Se trata de un manuscrito, escrito a varias manos, que incluye poemas de múltiples autores (Juan de Vera y Zúñiga, Góngora, Paravicino, Quevedo, Juan de Salinas, Antonio de Mendoza, Juan de Silva, Damián Cornejo, Villamediana. Luis de Ulloa, Diamante, Conde de Salinas...), algunas piezas breves de teatro y diversas composiciones impresas. Cf. AA.VV. Catálogo 2: 1214-1230.

-1. A una dama que, estando destocada, se asomó a una ventana y su galán la asió de una mata de cabello, "Suelto el cabello por el aire ufano" (189). —2. Desmiente las desconfianzas de una dama su galán con un retrato de él algo desparecido, "Rudo pincel de mano inadvertida" (189v). - 3. Al mismo asunto, "Por los yerros, Ysbella, de un traslado" (190). - 4. Al ponerse una dama en la guedeja unos jazmines que aún no habían salido del botón y a pocas horas se abrieron en el mismo pelo, "De emboscado entre matas de tu pelo" (190v). - 5. Soneto panegírico que le viene a la media pierna al dueño del asunto, "Breve pie reducido a cárcel breve" (191). — 6. Al mismo asunto, "Cómo quieres, Anarda, que sea casto" (191v). — 7. Soneto, "Ya no puedo vivir si no me capo" (192). — 8. Soneto, "Esta mañana en Dios en enhorabuena" (192v). — 9. Soneto, "Lo menos vello y más apetecido" (193). - 10. Soneto, "Estaba Lisis en campal batalla" (193v). - 11. Al desaliño de unos versos de un poeta de polaina y greguescos, "Disparates, Antón, muy mal zurcidos" (194). -12. A uno que se llamaba Cruz y perseguía al autor porque se le debía unas suelas, "Cruz, si cristiano soy, qué me persigues" (194v). — 13. A una pobre que salió mal parada de un mal francés habido en buena guerra, "Un mal francés Marica tan grosero" (195). —14. A una monja hermosa y desdeñosa, "A todos tu beldad rigores flechas" (195v). - 15. A un escribano, "Hoy sin más ni más me allano" (196). — 16. Un jurador arrepentido, "Señor, jurador he sido" (197). — 18. Suelto el cabello por el aire ufano (197). — 19. El agosto del fraile en Madrigales, "Oye, Catuja, dulce hechizo mío" (199). — 20. Pintura a una dama, "Sepan todos y todas que yo adoro" (205). - 21. Del padre Cornejo, obispo de Orense, 
Cronista de su Orden Seráfica hízole en sus juveniles años. Sueño, "Cansado anoche de estar" (318).

\subsubsection{Biblioteca Nacional de España, ms. 3929}

Papeles poéticos. S. XVIII (mediados). 144 h. (210 x 150). Enc. Holandesa. Fol. Antigua. Olim: G-A-8. Se trata de un manuscrito, escrito a varias manos, que incluye el "Coloquio entre Galán y la Dama de la Comedia de las Amazonas" de Lope de Vega (atribuida en este códice a Antonio Solís), un elenco de términos gitanos, diversos impresos de poesías y algunas composiciones en prosa y en verso manuscritas. En el folio 1 la siguiente nota: "Este tomo consta del número de 48 papeles, los más son de poesías varias y otros curiosos”. Cf. AA.VV. Catálogo 2: 1264-1272.

—1. Sermón burlesco de Cornejo, "Las palabras que sirven hoy de asunto" (108).

\subsubsection{Biblioteca Nacional de España, ms. 3930}

Poesías varias de diferentes autores, S. XVIII (1º mitad), 201h. (210 x 145). Enc. Moderna. Fol. Antigua. Olim: M-254. Se trata de un manuscrito, escrito a una mano, que incluye obras en prosa y en verso de diversos autores (Gonzalo Pacheco de Padilla, Eugenio Gerardo Lobo, Pedro Calderón de la Barca, Juan de Vera Tassis y Villarroel...). Estas están divididas en tres libros: el primero "místico"; el segundo "de diferentes versos amorosos"; y el tercero "jocoso". En la portada se indica el nombre del compilador y el año "Por Sierra 1722" y en el 1 hay un retrato de Calderón de la Barca dibujado a pluma. Cf. AA.VV. Catálogo 2: 1273 1276.

-1. A la brevedad del mayor anhelo, "Esta mañana en Dios y enhorabuena" (179v).

\subsubsection{Biblioteca Nacional de España, ms. 3931}

Poesías varias y obra poética de Damián Cornejo. S. XVII (finales) - XVIII. 214 h. (200 x 145). Enc. Moderna. Fol. Moderna. Olim: M 254. Se trata de un manuscrito, escrito a dos 
manos que contiene una traducción del Remedia Amoris de Melchor de la Serna, la "Fábula de Faetón del Conde" de Villamediana y "Poesías varias escritas por R.M. Cornejo, cronista g[eneral] d[e] S[a]n Francisco". Cf. AA.VV. Catálogo 2: 1276-1281.

-1, "Oye, Catuja, dulce hechizo mío" (61). - 2. Pintura a una dama, "Sepan todos y todas que yo adoro $(69 \mathrm{v})$. ." - 3. Pintura a la ausencia de cierta dama, "Desde que el sol ardiente" (75v). - 4. Pintura a una dama, "Dulce Lisis de mis ojos" (78v). - 5. Habiendo pedido asunto en una academia para escribir, no se lo dieron por estar ya repartidos y le dijeron que tomase por pie el no habérsele dado y vistiese una dama que otro dejaba desnuda a orillas de un río, "Yo soy, ilustre Academia" (79v). - 6. A unos colegiales que dieron a unas damas moscas confitadas. Sátira como para ellos, "Éranse dos licenciados" (82). - 7. A estas damas que por hartarse de las otras moscas quedaron hartas. Jeringa en Sátira, “Óiganme damas que empuño" (84v). - 8. A un borracho, "A uno que se hace una uva" (86). — 9. Dando chasco a un borracho, "Clodio, del mundo en la plaza" (87). - 10. Sátira a un estudiante que comió menudo, "Un estudiante de hogaño" (88v). — 11. Sueño jocoso, "Cansado anoche de estar hecho un panarra" (89v). - 12. Quintillas jocosas, "Vengar quiero mis rencillas" (102v). — 13. El mismo autor a sus quintillas, "A la desatada llaga" ( 105)___ 14. Epigrama a unos ojos azules "Desde que tus niñas bellas" (105). — 15. A una dama fácil, "Tu arroz, Marica, me enfada" (105v). — 16. Habiendo perdido una dama por causa del autor cien reales, él la envió dos y al no quererlos recibir escribió esta décima, "Cien reales por mí perdiste" (106). — 17. Contra monjas, "Un ciego soy desgraciado" (106v). —18. Al haber visto el pie de una dama, "En el mar de tu hermosura" (108). - 19. A una dama que, estando ausente y sangrada, pedía celos a su galán, "Mi bien, juro por mi amor" (109v). - 20. A uno muy preciado de valiente siendo gallina, "Es de Fausto la fiereza" (111). - 21. A unos mozos que salieron a torear y cayeron, "De Pinto para un festejo" $(112 \mathrm{v})$. — 22. Sátira a una dama que, siendo galanteada de muchos, se casó con un sacristán, "Dios te socorra, Marica" (113v). - 23. Décimas amorosas, "Para qué es tu atrevimiento" (116). —24. A una dama que, estando destocada, se asomó a una reja y su galán la asió una mata de cabellos, "A una reja qué ventura" (117). - 25. A una dama, "Con modo ya más humano"-26. Amante callado y sospechoso, "Solo el silencio testigo" (119). —27. A una dama que gastó lo mejor de su mocedad con frailes y a la vejez decía mal de ellos y se había empeñado con un sacristán. Sátira, "Marica, que a decir mal” (120). —28. Sátira, "Quisimí quisimona, hola" $(122 v) .-29$. A un hombre en abreviatura fraile que, hipócrita de estatura, se engrandece a costa del alcornoque. Sátira, "Oye, tarazón de frailes" (125). - 30. Convidando una dama a 
su galán a finezas amorosas en metáfora de un juego de hombre, "Ya, Fabio, que hemos llegado" (127). - 31. Habiendo un poeta hecho un sátiro contra otro pobrete, le respondió cagándose en él y con estas, “Tu romance, Andrés, leí” (128). —32. Epigrama gracioso a una dama, "El pañuelo desembolsa" (129). —33. Otro a diferente asunto, "Marica, no desdeñosa" (129). — 34. A unas doncellas que querían bien a unos portugueses y estuvieron por ellos encerradas en una cuadra, "Queridas, mucho me enfadan" (129v). - 35. A un catedrático secular, siendo en la condición muchacho, no quería leer algunas veces, enfadándose de muy pocas cosas, "Pedro, ingenio me recela" (130v). - 36. A una dama que por el interés se daba a todos. Sátira en esdrújulos, "Escúchenme unos esdrújulos" (132v). -37. Pidiendo a una dama unas medias por haber roto otras, "Belisa el chasco celebra" (133v). - 38. Pidiendo a una señora un poco de arrope para dar a una dama, "Pues vuestra piedad me abriga" (135). — 39. Otro a otro asunto, "Bizarro amor me desvela" (135v). — 40. Sátira a cierta dama por quien su galán sufría las penas del purgatorio, "María viéndote hermosa" (136). - 41. Otra al mismo intento, "Malo me siento, Marica" (137v). — 42. De un amante a su dama, "Bien puede, Lisis" (139v). - 43. A una dama que dio licencia a su galán que la quisiera, "Licencia Solo me has dado" (141). - 44. Fraterna exhortatoria a un galán que gastaba con su dama poco dinero y mucha prosa, "Anfriso, con atención" (142). 45. Enamorando a una dama cuyo nombre era Palma, "Palma, en viendo tu beldad" (143v). - 46. Pidiendo celos a una dama a su galán de un fraile italiano, de quien era muy querido. Y, siendo muy lindo, se alababa de ello, "Don Juan, no tengo por bueno" (144v). -47. A una dama que lloraba mucho del dolor de un divieso que le salió en la mano, "Hoy, Cloris, pretendo amante" (145). - 48. A una dama que dio a su galán unas pelotas, "Ya que tan galante has sido" (146v). - 49. Enviando a una dama una vela al tiempo que estaba para ausentarse de ella, "De pedir nunca yo fuera" $(147 \mathrm{v})$. — 50. A una dama, "María, a tu sucia cara" (149). - 51. A un corcovado que galanteaba a una dama y la daba músicas y ella le aborrecía desde su casa le cantaron estas. Sátira, "Un galán corto de talle" (149) — 52 . Despedida de una dama "Adiós, Leonor de mi vida" (150). - 53. A una fea presumida, “Clori, que para ser linda" (152v). — 54. A una ausencia, "En aquesta soledad" (153v). _ 55. A un amante callado y sospechoso, "Solo el silencio es testigo" (154v). - 56. Manifiesta un amante a su dama su pasión, "Lucinda, tus ojos bellos" (156). — 57. A una pobre que salió muy estropeado de un francés habido en buena guerra, "Un mal francés, Marica, tan grosero" (157). - 58. A una monja hermosa y desdeñosa, "A todos tu beldad rigores flechas" (157v). - 59. A una dama que, estando destocada, se asomó a una ventana y su galán la asió una mata de cabello, "Suelto el cabello por el aire ufano" (158). —60. Habiéndole pedido 
una mano un galán a su dama y no habiéndola conseguido, le pide un dedo, "Amoroso, prudente, cortesano" (158v). — 61. Desmiente las desconfianzas de una dama su galán con un retrato suyo algo desparecido, "Rudo pincel de mano inadvertida" (159). - 62. Otro soneto al mismo asunto, "Por los yerros, Ysbella, de un traslado" (159v). —63. Al ponerse una dama en la guedeja unos jazmines que aún no habían salido del botón y a pocas horas se abrieron en el mismo pelo, "De emboscado entre matas de tu pelo" (160). - 64. Soneto panegírico que a uno le viene a la media pierna al dueño del asunto, "Breve pie reducido a cárcel breve" (160v). — 65. Al mismo asunto, "Cómo quieres, Anarda, que sea" (161). — 66. Otro, "Ya no puedo vivir si no me capo" (161v). — 67. Al desaliño de unos versos de un poeta de polaina, "Disparates, Antón, muy mal jurados" (162). —68. A uno que se llamaba Cruz y perseguía al autor por haber pedido unas suelas, "Cruz, si cristiano soy, qué me persigues" (162v). — 69. Al mismo asunto, “Apenas señor te viste” (163). - 70. Otras al mismo asunto, "Pediste, mi bien Cruz, suelas" (164). — 71. Soneto jocoso, "Estaba Lisis en campal batalla" (165v). - 72. A una monja pidiéndole celos a un hombre que tenía por sobrenombre Puerto, "De mis bajezas el bajel incierto" (165v). - 73. A los escribanos, "Hoy sin más y más me allano" (166). — 74. De un jurador, "Señor, jurador he sido" (167). — 75. Letra burlesca “A Pascuala dijo Bras” (168). — 76. Desengaño del deleite sensual. Jácara, “En la villa de Carrión” (170v). — 77. Sátira, “En Málaga vi a Rufina” (172). —78. Sátira a Don Fernando Valenzuela, "Fernando, a quien por soberbio" (172v). — 79. Pregón, "En la ruda política mía" (174). — 80. Otro pregón, "En la firma política señora" (175). — 81. A una dama porque quemó un papel, "No quieran tus sinrazones" (174v). —82. Tono, "Del rumbo de Francelisa" (176). — 83. Tono, "Fuera, fuera que Juanilla" (176). — 84. Otro, "Los ganados de Liseno" (176v). —85. Otro, "Genil, galán de los ríos” (177). — 86. Otro, "Sonoro arroyuelo" (177). - 87. A un novicio que profesó en san Diego de Alcalá, “Oiga, hermano san Francisco" (177v). — 88. Vejamen a san Diego, "Un devoto singular" (179). — 89. Otro vejamen al mismo santo, "Otra vez tengo la pluma” (181). — 90. Al mismo san Diego, "San Diego sí hace milagros" (183). — 91 . Otra al mismo, "Diego sí, que supo bien” (184). — 92. Al mismo santo, "De Diego muy por menor" (185v). —93. Al mismo santo pidiéndolo un tuerto remedio para su ojo, "Un tuerto soy desgraciado" (187). —94. Otro que se cantó en Alcalá año de 1662, "Un corcovado poeta" (188). —95. Al mismo santo, "Después de por qué se usa" (190). —96. Al mismo santo, "Todo el mundo conmovido" (191). —97. Al mismo santo al haberle enviado nuestra Señora una medalla de oro, "Es el asunto una medalla" (192). — 98. A la jornada que hizo el santo a Madrid, "San Diego, si me remedias" (194). — 99. Letra que se cantó en la misma fiesta, "Conjurar estas nubes" (196v). — 100. A 
la Concepción, "Hanme mandado una cosa" (198). — 101. Al mismo asunto, "La más hidalga hermosura" (199). —102. Otras, "La Concepción este día" (200). —103. A lo mismo, "De tu concepción, señora" (201). - 104. Otro a la Concepción, "Oigan lo que saca en limpio" (202). — 105. A lo mismo, "De una niña la grandeza" (203). — 106. A lo mismo, "Sabed, señora doncella" (204v).

\subsubsection{Biblioteca Nacional de España, ms. 4052}

Poesías varias. S. XVII (2 mitad). 299 h. (220 x 155). Enc. Holandesa. Fol. Antigua. Olim: M 200. Se trata de un manuscrito, escrito a varias manos, que reúne composiciones en prosa y en verso de temática distinta (satírica, histórica, política, esotérica...). Destacan las glosas a las "Coplas" de Jorge Manrique y el "Sueño político" de Quevedo. En la primera tapa de la encuadernación, hay una nota autógrafa de Rodríguez Marín acerca del interés de algunas de sus obras. Cf. AA.VV. Catálogo 2: 1562-1570.

-1. Del padre Cornejo, obispo de Montoñedo y cronista de su Orden Seráfica. Sueño, "Cansado anoche de estar" (280).

\subsubsection{Biblioteca Nacional de España, ms. 4062}

Poesías divinas. S. XVIII. 78 h. (220 x 155). Enc. Holandesa. Fol. Moderna. Olim: M 343. Se trata de un manuscrito, escrito a una mano, en el que se reúnen poesías de temática religiosa, principalmente, vinculadas a de la Orden Franciscana y a eventos litúrgicos que sucedieron en Alcalá de Henares en la segunda del siglo XVII. Gran parte de las composiciones que en él aparecen como anónimas se atribuyen a Damián Cornejo en otros manuscritos de la BNE $(2245,3931,4258,5566$ y 17666). Falta la cuartilla 76 . Cf. AA.VV. Catálogo 3: 384.

-1. A la procesión que hicieron los padres de Santo Domingo en reverencia de la Concepción, después de la segunda quema de la cocina del convento de Atocha, "Hoy a la Concepción aclamaciones" (1). - 2. A un novicio que profesó en San Diego de Alcalá, "Oiga, hermano fray Francisco" (1v). - 3. Vejamen a san Diego, "Un devoto singular" (3). -4. Otro al mismo santo, "Otra vez tengo la pluma" (4). — 5. Al mismo asunto, "De Diego muy por menor" (6v). —6. Al mismo santo, "Todo el mundo conmovido" (8). — 7. Otro al 
mismo santo, "Hoy con gusto a cantar llego" (9v). — 8. De pie quebrado al santo, "Después que por qué se usa" (10v). —9. Ojo, "Un tuerto soy desgraciado" (11v). —10. Al mismo san Diego cuando se hizo una capilla, "San Diego sí hace milagros" (12). —11. Al mismo otro, “Diego sí, que supo bien” (13). —-12. Otro que se cantó Alcalá, "Un corcovado poeta” (14v). -13. Al mismo santo en asunto de una medalla de oro que envió la Reina nuestra Señora, "La Reina nuestra señora" (16). - 14. Otro en títulos de comedia a la jornada que hizo el santo a Madrid por la enfermedad del príncipe, "San Diego, si me remedias" (17v). — 15 . Otra letra que se cantó en esta misma fiesta, "A Conjurar estas nubes" (20). - 16. A san Francisco, "De pie quebrado unas coplas" (21v). — 18. A san Francisco, "De Francisco por menor" (23). - 19. A santa Clara, "Hoy mi devoción aclama" (24). —20. A san Juan Bautista, “Al señor Bautista, el jaque” (26). —21. Al nacimiento de nuestra Reina, "Escriben desde Toledo" (28). — 23. A la Concepción, "Hanme mandado una cosa" (29v). — 24. Otras al mismo asunto en títulos de comedias, "La más hidalga hermosura" (30v). - 25. Otras al mismo asunto, "La Concepción este día" (31v). — 26. Otras al mismo asunto, "De una niña la grandeza" (32v). — 27. Al mismo asunto, "De tu concepción, señora" (34). —28. Otro a lo mismo, "Oigan lo que saca en limpio" (35). - 29. Acto de contrición delante de un crucifijo, "Un pecador soy, Dios mío" (37). —30. Jácara a nuestra señora en títulos de comedia, "Érase una Virgen pura" (39v). - 31. Al mismo asunto, "Agua es mi tema señores" (41). — 32. Primer sueño jocoso, "Cansado anoche de estar" (43). — 33. Trova del tono de Don Pedro a quien los crueles a la pasión de Cristo, "El pueblo a quien de crueles" (53). 34. Tono al Santísimo Sacramento, "Pues tu hermosura me mata" (53v). - 35. Al mismo asunto otro, "Un fullero vino al mundo" (54v). - 36. A Judas, "Por tomar Judas el grado" (55). - 37. De un jurador, "Señor, jurador he sido" (56). - 38. A santa María Magdalena, "En tu alabanza mi musa" (57). - 39. Petición a esta Virgen santísima nuestra Señora, "Divina madre de Gracia” (57v). — 40. Petición, "Muy poderoso señor” (50). — 41. A Jesucristo nuestro bien, "Dulce Jesús, Dios mío" (60). — 42. Al Nacimiento de nuestro Señor, "Hacer que la Gloria encuentre" (61). — 43. A la Resurrección de Jesucristo nuestro, "De santa resurrección" (62). — 44. A san Antonio de Padua, "Amante antorcha de Padua" (64). - 45. A la profesión de una religiosa de Santa Clara, "Una doncella resuelta" (64v). 46. Estando un religioso dominico hablando de la Concepción poco decente en una visita, un gato que estaba en la sala le saltó al pescuezo y le maltrató mucho, "Un dominico enemigo" (66). - 47. A lo mismo, "Gato ilustre, que a fieras manotadas (66v). - 48. En la celebridad de la octava del santísimo santo día de san Juan Bautista, "Hola, que llega la fiesta” (67). - 49. Yo celebro al Bautista y yo al Cordero. Coplas, "A Señor el de la hostia" 
(68v). - 50. Coplas, "Amante el más perfecto" (70). - 51. Al Santísimo Sacramento, "Amor, amor, cielos, amor" (70v). — 52. Estribillo, "Qué linda gracia es decir que das vida" (71) - 53. Otro estribillo al mismo asunto, "Un jilguerillo soy cuya apacible voz" (72). 54. Otras al mismo asunto, "En estas ardientes cenizas” (72v). - 55. Al mismo asunto, "Aquí de Dios que un incendio me abrasa" (73). — 56. Coplas, "El más poderoso incendio" (73). —57. Al mismo asunto. Otras, "Al Real convite divino" (74). — 58. Gaceta nueva y curiosa: Letra para el santísimo Nacimiento de nuestro Señor Jesucristo en el día de los santos Reyes, "Quien me la compra, quien me la lleva" (74v). — 59. A la adoración de los santísimos Reyes, "De Oriente vienen tres Reyes" (76). - 60. A Nuestra Señora en títulos de comedia, "En títulos, Virgen pura" (77).

\subsubsection{Biblioteca Nacional de España, ms. 4135}

Obras poéticas de Manuel León Marchante y de fr[ay] Damián Cornejo. S. XVIII. 188 h. (200 x 140). Enc. Pergamino del S. XVIII. Fol. Moderna. Olim: Jj. Su 65. Procede de la Biblioteca del Duque de Osuna. Se trata de un manuscrito, escrito a dos manos, que incluye composiciones poéticas del maestro León y de Damián Cornejo. Las obras que se atribuyen a León Marchante aparecen en otros manuscritos de la BNE. (2245, 3884, 3931, 4258 y 5566) asignadas Cornejo. En el primer folio, a modo de portada, aparece escrito: "Obras del maestro León hasta la página doce. Y todo lo demás restante de esta obra del padre Cornejo". En el lomo, puede leerse: “Cornejo sus obras poéticas. Y algunas del maestro León”. Varias páginas han sido guillotinadas. Cf. AA.VV. Catálogo 4: 1950-1953.

—1. Al misterio de la Purísima Concepción. Del maestro León, "Hanme mandado una cosa" (2). - 2. Otras al mismo asunto, "La más hidalga hermosura" (3v). - 3. Al mismo asunto, "Sabed, señora doncella" (5). - 4. Jácara a nuestra señora en títulos de comedias, "Érase una Virgen pura" (6). — 5. A la adoración de los reyes, "De Oriente vienen tres Reyes" (8v). 6. A la profesión que hicieron los padres de Santo Domingo en reverencia de la Concepción de nuestra Señora, después de la segunda quema de la cocina del convento de Atocha, "Hoy a la Concepción aclamaciones" (10). - 7. Consideración sobre el motivo que pudo haber para achacar a la madre de Dios siempre pura siempre santa el pecado original, "Virgen, nadie culpada os ha creído" (10v). — - Estando en una visita un religioso dominico hablando de la Concepción poco decentemente, un gato que allí estaba le saltó al pescuezo y le maltrató, "Un dominico enemigo" (11v). - 9. A este devoto gato, "Gato ilustre, que a fieras 
manotadas" (12v). - 10. Pintura del lugar de Madrilejos donde fue a pedir el agosto, "Oye, Catuja, dulce hechizo mío" (13). - 11. Otra pintura a una dama, "Sepan todos y todas que yo adoro" (22). - 12. Del maestro León, "Desde que el sol ardiente" (28). — 13. A una monja desdeñosa y capacha, "Lisis, tu favor invoco" (31v). - 14. Soneto, "A todos tu beldad rigores flechas" $(31 \mathrm{v})$. - 15. A una pobre que salió muy estropeado de un francés habido en buena guerra, "Un mal francés, Marica, tan grosero" (32). —16. Un galán pidió a una dama la mano y no habiéndola conseguido, le pide un dedo, "Amoroso prudente cortesano" (33). -17. Desmiente las desconfianzas de una dama su galán con un retrato suyo algo desparecido, "Rudo pincel de mano inadvertida" (34). - 18. Otro al mismo asunto, "Por los yerros, Ysbella, de un traslado" (34). - 19. Soneto panegírico que a uno le viene a la media pierna al dueño del asunto, "Breve pie reducido a cárcel breve" $(34 \mathrm{v})$. — 20. A lo mismo otro jocoso, "Cómo quieres, Anarda, que sea casto" (35). — 21. Otro jocoso y licencioso, "Ya no puedo vivir si no me capo" (35v). — 22. Otro del mismo modo, "Casose de un arzobispo el dispensero" (36). - 23. Otro igual en todo, "Estaba Lisis en campal batalla" (36v). - 24. Al ponerse una dama en la guedeja unos jazmines que aún no habían salido del botón y a pocas horas se abrieron en el mismo pelo, "De emboscado entre matas de tu pelo" (37). - 25. Otro con cola. A una dama que, estando destocada, se asomó a una ventana y su galán la asió una mata de cabello, "Suelto el cabello por el aire ufano" (37v). — 26. A una monja pidiéndola celos a un hombre que tenía por sobrenombre Puerto, "De mis finezas el bajel incierto" $(38 \mathrm{v})$. - 27. Al desaliño de unos versos de un poeta de polainas y greguescos. Soneto satírico, "Disparates, Antón, muy mal zurcidos" (39)—28. A uno que se llamaba Cruz y perseguía al autor por haber pedido unas suelas, "Cruz, si cristiano soy, qué me persigues" (39v). - 29. Al mismo asunto, "Pediste, mi bien Cruz, suelas" (40). - 30. Otras pidiendo a una dama unas medias por haber roto otras suyas, "Belisa el chasco celebra" (42). -31. Pidiendo a una señora un poco de arrope para dar a una dama, "Pues una, señora, piedad me abriga" (43v). - 32. Otra a una dama llamada Josefa su querida, "Bizarro amor me desvela" (44). —33. A la pintura a una dama, "Dulce Lisis de mis ojos" (44v). — 34 . Otro a lo mismo, "Pues que me han dado licencias" (46v). - 34. Otro de pintura diferente, "Cuenta con el retrato" (48). - 35. Otras seguidillas de una pintura, "Con licencia de Silvia" (50v). - 36. A una dama por quien su galán sufría las penas del purgatorio, "Marica, viéndote hermosa" (51). - 37. A una dama que dio licencia a su galán para que la quisiera, "Licencia solo me has dado" (53). - 38. A un galán que gastaba con su dama poco dinero y mucha prosa, "Anfriso, con atención” (54v). - 39. Otras enamorando a una dama cuyo nombre era Palma, "Palma, en viendo tu beldad" (56). - 40. Pidiendo celos una dama a su 
galán de un fraile italiano, de quien era muy querido. Y, siendo muy lindo, se alababa de ello, "Don Juan, no tengo por bueno" (57v). — 41. Otras a una dama que dio a su galán unas bolas, "Ya que tan galante has sido" (58). - 42. Otra a una dama puerca "María, a tu sucia cara” (59v). - 43. Otras de un galán enviando a una dama una vela al tiempo que estaba para ausentarse de ella, "De pedir nunca yo fuera" (60). — 44. Despedida de una dama de pie quebrado, "Adiós, Leonor de mi vida" (62). - 45. Otro a una dama fiera presumida, "Clori, que para ser linda" — 46. A una ausencia, "En aquesta soledad" (62). - 47. Amante callado y sospechoso, "Solo el silencio testigo" (65v). — 48. Igual glosa al mismo asunto, "En sospechoso amor toca" (68). - 49. A un borracho, "A uno que se hace una uva" (70). — 50. Chasqueando al mismo, "Clodio, del mundo en la plaza" (71v). — 51. A un estudiante que comió menudo, "Un estudiante de hogaño" (73v). — 52. Romance jocoso de un sueño, "Cansado anoche de estar hecho un panarra" (75).__53. Al desengaño del mundo del mundo versos en ecos, "Quiero, pues es ocasión" (92v). — 54. A unos ojos azules, "Desde que tus niñas bellas" (99). — 55. Otro gracioso, "El pañuelo desembolsa" (99). — 56. Otro algo libre, “Marica, no desdeñosa" (99v). — 57. A una dama fácil, “Tu arroz, Marica, me enfada” (100). -58. Una dama pidió cien reales por el autor, él la envió dos y no queriéndolos recibir escribió esta décima, "Cien reales por mí perdiste” (100v). — 59. Contra monjas, "Un ciego soy desgraciado" (101). —60. Décima amorosa, "Para qué es tu atrevimiento" (103v) —61. Otras a una dama que, estando destocada, se asomó a una ventana y su galán la asió una mata de cabellos, “A una reja qué ventura” (105). —62. Sátira de chirinola, "Quisimí quisimona, hola" (107). - 63. A un romance satírico que hizo uno contra él, le responde en estas dos décimas cagándose en él, "Tu romance, Andrés, leí” (110v). —64. Habiendo vaciado el vientre en un locutorio, le escribieron las monjas un romance y él respondió en estas décimas, "Pues que en su entretenimiento" (111v). —65. A otras décimas respondieron las monjas y a su papel respondió el autor en el siguiente ovillejo, "Ello en ese convento desgraciado" (113.). — 66. Letra burlesca, "A Pascuala dijo Bras" (115v). —67. Desengaño del deleite sensual. Jácara, "En la villa de Carrión” (118v). — 68. Romance satírico, "En Málaga vi a Rufina" (121). - 69. Otro igual a una dama que, habiendo gastado su mocedad con frailes a la vejez, decía mal de ellos y se había empeñado con un sacristán, "Marica, que a decir mal" (122.). - 70. Sátira a Valenzuela, "Fernando, a quien por soberbio" (124v). - 71. Pregón, "En la ruda política mía" (127). — 72. Otro, "En la firme política nuestra" (128). — 73. Al haber visto el pie de una dama, "En el mar de tu hermosura" (128v). - 74. A una dama que, estando ausente y sangrada, pedía celos a su galán, "Mi bien, juro por mi amor” (130v). 75. Otra a una dama porque la quemó un papel, "No quieran tus sinrazones" (133). $\_76$. 
Otras dos a una dama, "De modo más humano" (133v). - 77. Otras a uno que siendo gallina se preciaba de valiente, "Es de Fausto la fineza" (134). - 78. Convidando a una dama a su galán a finezas amorosas, "Ya, Fabio, que hemos llegado" (136). - 79. Otras a unas doncellas que querían bien a unos portugueses y estuvieron por ellos encerradas en una cuadra, "Queridas, muchas me enfadan" (138). — 80. Tono, "Del rumbo de Francelisa" (140). — 81. Otro, "Fuera, fuera que Juanilla" (140v). — 82. Otro, "Bellísimo Narciso" (141). -83. A unos mozos que salieron a torear y cayeron todos, "De Pinto para un festejo" (144). -84. Sátira a una dama que, siendo galanteada de muchos, se casó con un sacristán, "Dios te socorra, Marica" (145v). — 85. A una monja que pretendía el que un sujeto prosiguiese en sus malos intentos le hablase, "Nise, a quererte me obligo" (149). — 86. En respuesta del antecedente de la monja y acaba, "No más amistad, amor" (150v). — 87. Traslado de una carta de un colegial que, hallándose cura de cierto lugar, escribió a los de su colegio del Alcalá dándoles cuenta de lo que les sucedía en el curato como lo había ofrecido cuando salió de Alcalá, "No puedo escribir en suma" (151v). — 88. Soneto, "Esta mañana en Dios y enhorabuena" (155). - 89. La melancolía de España, año de 1643, "Yo, un ermitaño pobre, sí contento" (156).

\subsubsection{Biblioteca Nacional de España, ms. 4258}

Obras jocosas de Cornejo. S. XVII (finales) - S. XVIII. 202 h. (200 x 140). Enc. Pergamino. Fol. Moderna. Olim: M. 358. Procedente de la biblioteca de Böhl de Faber. Exlibris: Don Luis Bernardo Álvarez. Se trata de un manuscrito, escrito a dos manos, que contiene poesías atribuidas a Damián Cornejo. En el folio 202 se indica a modo de colofón: "Escrito por Felipe de Valdivia y Manrique". Notas marginales en los folios " $16,36,46,47 \mathrm{v}, 60,82$ y 123”, que atribuyen al maestro León las composiciones que en ellos aparecen. El primer folio está mutilado, pero se puede identificar la composición "Oye, Catuja, dulce hechizo mío", ya que esta aparece en otros manuscritos de la BNE: 2245, 3922, 4135 y 5566. Cf. AA.VV. Catálogo 4: 2063-2068.

-1. [Mutilada 1 h.] "Oye, Catuja, dulce hechizo mío" (1). - 2. Pintura a una dama. Del mismo autor, "Sepan todos y todas que yo adoro" (6v). - 3. Otra pintura. A una ausencia de cierta dama. Del mismo autor. "Desde que el sol ardiente" (10). - 4. Pintura a una dama, "Dulce Lisis de mis ojos" (12). — 5. Habiendo pedido asunto en una Academia para escribir no se le dieron por estar todos repartidos y le dijeron que tomase por pie el no habérsele dado 
y vistiese a una dama que otro dejaba desnuda a orillas de un río, "Yo soy, ilustre Academia" (13). - 6. A unos colegiales que dieron a unas damas moscas confitadas. Sátira como para ellos. Del mismo autor, "Éranse dos licenciados" (14v). - 7. A estas damas por hartarse de las sobredichas moscas quedaron ahítas, "Óiganme damas que empuño" (16). —8. A un borracho, "A uno que se hace una uva" (17). - 9. Dando chasco a un borracho, "Clodio, del mundo en la plaza" (17v). - 10. Sátira a un estudiante que comió menudo, "Un estudiante de hogaño" (18v). — 11. Sueño jocoso, "Cansado anoche de estar" (19v). — 12. Quintillas jocosas, "Vengar quiero mis rencillas" (36). — 13. El mismo autor a sus quintillas, "A la desatada llaga" (37). — 14. A unos ojos azules, "Desde que tus niñas bellas" (37v). — 15. A una dama fácil, "Tu arroz, Marica, me enfada" (38). —16. Habiendo perdido una dama por causa del autor cien reales, él la envió dos y al no quererlos recibir escribió esta décima, “Cien reales por mí perdiste" (38). — 17. Contra monjas, "Un ciego soy desgraciado" (18v). -18. Al haber visto el pie a una dama, "En el mar de tu hermosura" (141). —19. A una dama que, estando ausente y sangrada, pedía celos a su galán, "Mi bien, juro por mi amor" (42v). - 20. A uno muy preciado de valiente siendo gallina, "Es de Fausto la fiereza" (44v). -21. A unos mozos que salieron a torear y cayeron todos, "De Pinto para un festejo" (46). -22. Sátira a una dama que, siendo galanteada de muchos, se casó con un sacristán, "Dios te socorra, Marica" $(47 \mathrm{v})$. - 23. Décimas amorosas a una dama, "Para qué es tu atrevimiento" (50). —-24. A una dama que, estando destocada, se asomó a una reja y su galán la asió una mata de cabellos, "A una reja qué ventura" (51v). — 25. A una dama, "Con modo ya más humano" (53v). — 26. Amante callado y sospechoso, "Solo el silencio testigo" (54v). -27. A una dama que gastó lo mejor de su edad con frailes y a la vejez decía mal de ellos y se había empeñado con un sacristán, "Marica que a decir mal” (56). —28. Sátira, "Quisimí quisimona, hola" (58). — 29. Sátira a un hombre en abreviatura fraile meñique que, hipócrita de estatura, se engrandece a costa del alcornoque, "Oye, tarazón de frailes" (60). — 30. Convidando una dama a su galán a finezas amorosa. En metáfora de un juego de hombre, "Ya, Fabio, que hemos llegado" (62). - 31. Habiendo un poeta hecho un sátiro contra otro pobrete, se le respondió cagándose en él y con estas, “Tu romance, Andrés, leí" (63). — 32. Epigrama gracioso a una dama, "El pañuelo desembolsa" (64). - 33. Otro a otro asunto, "Marica, no desdeñosa" (64). - 34. A unas doncellas que querían bien a unos portugueses y estuvieron por ellas encerrados en una cuadra, "Queridas, mucho me enfada" (64v). — 35. A un catedrático secular, siendo en la condición muchacho, no quería leer a veces enfadándose de muy pocas cosas, "Pedro, mi ingenio recela" (66). - 36. A una dama que por el interés se daba a todos. Sátira en esdrújulos, "Escucha unos esdrújulos" (67v). — 37. Pidiendo a una 
dama unas medias por haber roto otras, "Belisa el chasco celebra" (69v). — 38. Pidiendo a una señora un poco de arrope para dar a una dama, "Pues vuestra piedad me abriga" (71v). -39. Otra a otro asunto, "Bizarro amor me desvela" (71v) — 40. Sátira a cierta dama por quien su galán padecía las penas del purgatorio, "Marica, viéndote hermosa" (72). — 41 . Otra al mismo intento, "Malo me siento, Marica" (74). - 42. De un amante a su dama, "Bien puede, Lisis, un triste" (76). - 43. A una dama que dio licencia a su galán para que la quisiera, "Licencia solo me has dado" (78). — 44. Fraterna exhortatoria a un galán que gastaba con su dama poco dinero y mucha prosa, "Anfriso, con atención" (79v). -45 . Enamorando a una dama cuyo nombre era Palma, "Palma, en viendo tu beldad" (80v). 46. Pidiendo celos una dama a su galán de un fraile italiano, de quien el dicho galán confesaba era muy querido. Y, siendo muy lindo, se alababa de ello, "Don Juan, no tengo por bueno" (82). - 47. A una dama que lloraba mucho de dolor de un envieso que le salió en la mano, "Hoy, Clori, pretendo amarte" $(82 \mathrm{v})$. — 48. A una dama que dio a su galán unas pelotas, "Ya que tan galante has sido" (84). - 49. Enviando a una dama una vela blanca al tiempo que estaba para ausentarse de ella, "De pedir nunca yo fuera" (85v). - 50. A una dama, "María, a tu sucia cara" (87). — 51. Sátira a un corcovado que galanteaba a una dama y la daba música y ella le aborrecía y desde su casa le cantaron estas, "Un galán corto de talle" (88v). — 52. Despedida de una dama, “Adiós, Leonor de mi vida" (95). — 53. A una fea presumida, "Clori, que para ser linda" (91). — 54. A una ausencia, "En aquesta soledad" (93). —55. Amante callado y sospechoso, "Solo el silencio testigo" (94). — 56. Manifiesta un amante a la dama su pasión, "Pues que me han dado licencia" (95v). — 57. A una pobre que salió muy estropeada de un mal francés habido en buena guerra del mismo autor, "Un mal francés, Marica, tan grosero" $(95 \mathrm{v})$. - 58. A una monja hermosa desdeñosa: soneto y corónase con estas, "Lisis, tu favor invoco" $(97 \mathrm{v})$. — 59. Soneto, "A todos tu beldad rigores flecha" (98). - 60. A una dama que, estando destocada, se asomó a una reja y su galán la asió una mata de cabello: soneto con cola, "Suelto el cabello por el aire ufano" (98v). - 61 . Habiéndole pedido una mano un galán a una dama y no habiéndola conseguido, le pide un dedo, "Amoroso, prudente y cortesano" (99v). —62. Desmiente las desconfianzas de una dama un galán con un retrato suyo algo desparecido, "Rudo pincel de mano inadvertida" (100). - 63. Otro soneto al mismo asunto, "Por los yerros, Ysbella, de un traslado" (100v). -64. Al ponerse una dama en la guedeja unos jazmines que aún no habían salido del botón y a pocas horas se abrieron en el mismo pelo, "De emboscado entre matas de tu pelo" (101). -65. Soneto panegírico que a uno le viene a la media pierna al dueño del asunto, "Breve pie reducido a cárcel breve" (101v). —66. Al mismo asunto, “Cómo quieres, Anarda, que 
sea casto" (102). —67. Otro, "Ya no puedo vivir si no me capo" (102). —68. Al desaliño de los versos de un poeta de polaina y greguescos, "Disparates, Antón, muy mal zurcidos" (103). - 69. A uno que se llamaba Cruz y perseguía a autor por haberle pedido una suelas, "Cruz, si cristiano soy" (103v). — 70. Al mismo asunto, “Apenas, señor, te viste" (104). 71. Otras al mismo asunto, "Pedite, mi buen Cruz, suelas" (105). - 72. Soneto jocoso, "Estaba Lisis en campal batalla" (107v). — 73. A una monja pidiéndole celos de un hombre que tenía por sobrenombre Puerto, "De mis finezas el bajel incierto" (108). — 74. A los escribanos, "Hoy sin más ni más me allano" (108v). — 75. De un jurador, "Señor, jurador he sido" (109). - 76. Letra burlesca, “A Pascuala dijo Bras" (111). — 77. Desengaño al deleite sensual. Jácara, “En la villa de Carrión” (114). — 78. Sátira a una dama, "En Málaga vi a Rufina" (115v). - 79. Sátira don Fernando Valenzuela, "Fernando, a quien por soberbio" (117v). — 80. Pregón, "En la ruda política mía” (118v). — 81. Otro pregón, "En la firme política nuestra" $(119 \mathrm{v})$. - 82. A una dama porque quemó un papel, "No quieran tus sinrazones" (120v). —83. Tono, "Del rumbo de Francelina" (120). — 84. Otro tono, "Fuera, fuera que Juanilla" (121). —85. Tono, "Los ganados de Liseno" (121v). —86. Otro tono, “Genil, galán de los ríos" (122). — 87. Otro tono, "Sonoro arroyuelo" (129v). — 88. De un estudiante que se fue sin hacer cuenta con la huéspeda, "Un estudiante este curso" (123). 89. A una dama que cortándose unos cabellos por acordarse de su galán se cortó un pie, "De un pie escribir quiero en suma" (folio 125). — 90. De un doctor y un sacristán, "El sacristán qué desmán" (126v). —91. A Judas, "Por tomar Judas el grado" (127v). —92. De repente que a una dama en la primera noche de tal la hizo cerrada en la cama, "Musa mía, con astucia" (128v). —93. Décimas compuestas a que un religioso estando en un locutorio de monjas le vino una correncia y soltó las bragas y por lo cual le compusieron diversos romances, y él respondió con estas décimas, "Pues que su entretenimiento" (130v). — 94 . A una monja que pretendía el que un sujeto prosiguiese y que en sus malos intentos la hablase, "Nise, a quererte me animo" (132). — 95. En respuesta de las antecedentes de la monja y acaba: No más amistad, amor, “Acabose el amistad” (133v). — 96. Traslado de una carta que un colegial escribió a los de su colegio de Alcalá dándole cuenta de lo que le sucedía en el curto como lo había ofrecido cuando salió de Alcalá, "Reyes míos, desde el día" (135). 97. Soneto, "Esta mañana en Dios y enhorabuena" (137v). — 98. Otro, "Lo menos bello y más apetecido" (138). — 99. A un borracho que saliendo de una taberna [le] cayó un jarro lleno de vino de una ventana y le mató, "De una taberna salía” (138v). — 100. Pinta a un tudesco borracho, "Un tudesco, humana cuba" (140). - 101. A un novicio que profesó en San Diego de Alcalá, "Oiga, hermano fray Francisco" (141v). —102. Vejamen a san Diego, 
"Un devoto singular" (143v). — 103. Otro a san Diego, "Otra vez tengo la pluma” (145). 104. Al mismo san Diego, "San Diego sí hace milagros" (147). —105. Al mismo santo otro, “Diego sí, que supo bien" (148v). — 106. Al mismo santo, “De Diego muy por menor" (150). -107. Al mismo santo pidiéndole un tuerto remedio para su ojo, "Un tuerto soy desgraciado" (152v). — 108. Otro que se cantó en Alcalá: año de 1662, “Un corcovado poeta" (154). — 109. Al mismo santo, "Después de por qué se usa" (156v). —110. Al mismo santo, "Todo el mundo conmovido (158). —111. Al mismo santo. Es el asunto una medalla de oro que envió la Reina nuestra Señora, "La Reina nuestra Señora” (159v). - 112. Otro a la jornada que hizo el santo a Madrid, "San Diego, si me remedias" (162). —113. Otra letra que se cantó en la misma fiesta, “A conjurar estas nubes” (165v). — 114. A la Concepción, "Hanme mandado una cosa" (168). — 115. Otras al mismo asunto, "La más hidalga hermosura" (170). — 116. Otras, "La Concepción este día” (171). —117. A lo mismo, "De tu concepción, Señora" (172v). — 118. Otro a la Concepción, "Oigan lo que saca en limpio" (174.). —119. Al mismo asunto, "De una niña la grandeza" (176). —120. Al mismo asunto, "Sabed, Señora doncella" (178). — 121. A san Francisco, "De pie quebrado unas coplas" (179). —122. Al mismo asunto, "De Francisco por menor" (181v). — 123. A santa Clara, "Hoy mi devoción aclama" (182v). — 124. A san Juan Bautista, “Al señor Bautista, el jaque” (184). - 125. Acto de contrición delante de un crucifijo, "Un pecador soy, Dios mío" (188v). -126. Jácara a nuestra Señora en títulos de comedias, "Érase una Virgen pura" (192). 127. Al Nacimiento, "Escribir desde Toledo" (194). — 128. A la procesión que hicieron los padres de Santo Domingo en reverencia de la concepción de nuestra Señora después de la segunda quema de la cantina de Atocha, "Hoy a la Concepción aclamaciones" - 129. Versos al desengaño del mundo en ecos, "Quiero, pues ya es ocasión” (196). —130. A san Diego de Alcalá, "Hoy con gusto a cantar llego" (201).

\subsubsection{Biblioteca Nacional de España, ms. 5566}

Cancionero. S. XVII -XVIII. 736 h (295 x 215). Enc. Holandesa. Fol. Moderna. Olim: Q. 21. Se trata de un cancionero, escrito a varias manos, que contiene las siguientes composiciones en verso: : "Poesías jocosas", de Cornejo; la "Fábula de Acis y Galatea”, de Alonso del Castillo; "Antídoto contra las Soledades", de Juan de Jáuregui; "Contra el Antídoto, y en favor de Don Luis de Góngora": "Examen del Antídoto", de Francisco de Córdoba; “Obras”, de Diego Hurtado de Mendoza; poesías anónimas. Cf. AA.VV. Catálogo 4: $2144-2156$. 
-1. El agosto del fraile en Madrigales, "Oye, Catuja, dulce hechizo mío" (2). - 2. Pintura a una dama, "Sepan todos y todas que yo adoro" (18). - 3. Otra pintura a una ausencia de cierta dama, "Desde que el sol ardiente" (29). - 4. Pintura a una dama, "Dulce Lisis de mis ojos" (36). - 5. Habiendo pedido asunto en una academia para escribir, no se lo dieron por estar todos repartidos y le dijeron que tomase por pie el no habérsele dado y vistiese a una dama que otro dejaba desnuda a orillas de un río, "Yo soy, ilustre Academia" (39). - 6. A unos colegiales que dieron a unas damas moscas confitadas. Sátira como para ellos del mismo autor, "Eranse dos licenciados" (41). - 7. A estas damas que por hartarse de las sobredichas moscas quedaron ahítas. Jeringa en sátira, "Óiganme damas, que empuño" (43). -8. A un borracho, "A uno que se hace una uva" (44). - 9. Dando chasco a un borracho, "Clodio, del mundo en la plaza" (45). — 10. Sátira a un estudiante que comió menudo, "Un estudiante de hogaño" (46). —11. Sueño jocoso, "Cansado anoche de estar" (47.). — 12. Quintillas jocosas, "Vengar quiero mis rencillas" (59). —13. El mismo autor a sus quintillas, "A la desatada llaga" (61). — 14. A unos ojos azules, "Desde que tus niñas bellas" (61). 15. A una dama fácil, "Tu arroz, Marica, me enfada" (61). — 16. Habiendo perdido una dama por causa del autor cien reales, él la envió dos y al no quererlos recibir escribió esta décima, “Cien reales por mí perdiste" (62). — 17. Contra monjas, "Un ciego soy desgraciado" (62.). —18. Al haber visto el pie a una dama, "En el mar de tu hermosura" (64). — 19. A una dama que, estando ausente y sangrada, pedía celos a su galán, "Mi bien, juro por mi amor" (65). -20. A uno muy preciado de valiente siendo gallina, "Es de Fausto la fiereza" (66). — 21. A unos mozos que salieron a torear y cayeron todos, "De Pinto para un festejo" (67). —22. A una dama que, siendo galanteada de muchos, se casó con un sacristán, "Dios te socorra, Marica" (69). - 23. Décimas amorosas, "Para qué es tu atrevimiento" (70v). —24. A una dama que, estando destocada, se asomó a una reja y su galán la asió una mata de cabellos, “A una reja qué ventura" (71). —25. A una dama, "Con modo ya más humano" (73). —26. Amante callado y sospechoso, "Solo el silencio testigo" (73). —27. Sátira a una dama que gastó lo mejor de su mocedad y a la vejez decía mal de ellos y se había empeñado con un sacristán, "Marica, que a decir mal” (74). —28. Sátira, "Quisimí quisimona, hola” (76). — 29. A un hombre en abreviatura fraile meñique que, hipócrita de estatura, se engrandece a costa del alcornoque, "Oye, tarazón de frailes" (78). — 30. Convidando una dama a su galán a finezas amorosas. En metáfora de un juego de hombre, "Ya, Fabio, que hemos llegado" (79). - 31. Habiendo un poeta hecha un romance sátiro contra otro pobrete, le respondió cagándose en él y con estas décimas, "Tu romance, Andrés, leí” (80). —32. Epigrama 
gracioso a una dama, "El pañuelo desembolsa" (81). - 33. Otro a diferente asunto, "Marica, no desdeñosa" (81). - 34. A unas doncellas que querían bien a unos portugueses y estuvieron por ellos encerradas en una cuadra, "Queridas, mucho me enfada" (82). - 35. A un catedrático secular, siendo en la condición muchacho, no quería leer algunas veces enfadándose de muy pocas cosas, "Pedro, mi ingenio recela" (83). - 36. A una dama que por interés se daba a todos, "Escúchenme unos esdrújulos" (84) - 37. Pidiendo a una Dama unas medias por haber roto otras, "Belisa el chasco celebra" (85). —39. Pidiendo a una señora un poco de arrope para dar a una dama, "Pues vuestra piedad me abriga" (87). — 40. Sátira a cierta dama por quien su galán padecía las penas del Purgatorio, "María, viéndote hermosa" (87). - 41. Otra al mismo intento, "Malo me siento, Marica" (89). — 42. De un amante a su dama, "Bien puede, Lisis, un triste" (90). - 43. A una dama que dio licencia a su galán para que la quisiera, "Licencia solo me has dado" (92). - 44. Fraterna exhortatoria a un galán que gastaba con su dama poco dinero y mucha prosa, "Anfriso, con atención" (93). - 45. Enamorando a una dama cuyo nombre era Palma, "Palma, en viendo tu beldad" (94). - 46. Pidiendo celos una dama a su galán de un fraile italiano, de quien el otro galán confesaba era muy querido. Y, siendo muy lindo, se alababa de ello, "Don Juan, no tengo por bueno" (95). - 47. A una dama que lloraba del dolor de un divieso que le salió en la mano, "Hoy, Clori, pretendo amarte" (95). - 48. A una dama que dio a su galán unas pelotas, "Ya que tan galante has sido" (95v). - 49. Enviando a una dama una vela blanca al tiempo que estaba para ausentarse de ella, "De pedir nunca yo fuera" (96). — 50. A una dama, "María, a tu sucia cara" (97). — 51. Sátira a un corcovado que galanteaba a una dama, "Un galán corto de talle" (97). — 52. Despedida de una dama, "Adiós, Leonor de mi vida" (98). -53. A una fea presumida, "Clori, que para ser linda (100). — 54. A una ausencia, "En aquesta soledad" (101). — 55. Amante callado [y] sospechoso, "Solo el silencio testigo" (102). - 56. Manifiesta un amante a la dama su pasión, "Pues que me han dado licencia" (103). - 57, A una pobre que salió muy estropeada estropeado de un francés habido en buena guerra, "Un mal francés, Marica, tan grosero" (104). - 58. A una monja hermosa, desdeñosa, "Lisis, a tu favor invoco" (104). — 59. Soneto, "A todos tu beldad rigores flecha" (105.). 60. A una dama que, estando destocada, se asomó a una ventana y su galán la asió una mata de cabello, "Suelto el cabello por el aire ufano" (106). - 61. Habiendo pedido una mano un galán a una dama y no habiéndola conseguido, le pide un dedo, “Amoroso, prudente y cortesano" (106). — 62 Desmiente las desconfianzas de una dama un galán con un retrato suyo algo desparecido, "Rudo pincel de mano inadvertida" (106). - 63. Otro soneto al mismo asunto, "Por los yerros, Ysbella, de un traslado" (106). - 64. Al ponerse una dama 
en la guedeja unos jazmines que aún no habían salido del botón y a pocas horas se abrieron en el mismo pelo, "De emboscado entre matas de tu pelo" (107.). —65. Soneto panegírico que a uno no le viene a la media pierna al dueño del asunto, "Breve pie reducido a cárcel breve" (107). —66. Al mismo asunto, "Cómo quieres, Anarda, que sea casto" (108). —67. Otro soneto jocoso, "Ya no puedo vivir si no me capo" (110). —68. Al desaliño de los versos de un poeta de polaina y greguescos, "Disparates, mi buen Antón, suelas" (108). — 69. A uno que se llamaba Cruz y perseguía al autor por haber pedido unas suelas, "Cruz, si cristiano soy" (109). — 70. Al mismo asunto, "Apenas, señor, te viste" (109). —71 Otro al mismo asunto, "Pedite, mi bien Cruz, suelas (110). — 72. Soneto jocoso, "Estaba Lisis en campal batalla" (111). - 73. A una monja pidiéndole celos a un hombre que tenía por sobrenombre Puerto, "De mis finezas el bajel incierto" (112). — 74. A los escribanos, "Hoy sin más ni más me allano" (112). — 75. A un jurador, "Señor, jurador he sido" (113). — 76. Letra burlesca, "A Pascuala dijo Bras" (114). — 77. Desengaño del deleite sensual. Jácara, "En la villa de Carrión" (116). — 78. Sátira, "En Málaga vi a Rufina" (117). — 79. Otra sátira a don Fernando Valenzuela, "Fernando, a quien por soberbio" (118). — 80. Pregón, "En la ruda política mía" (119). — 81. Otro pregón, "En la firme política nuestra" (120). —82. A una dama porque quemó un papel, "No quieran tus sinrazones" (123). —83. Tono, "Del rumbo de Francelina" (121.). — 84. Tono, "Fuera, fuera que Juanilla" (121). —85. Tono, “Los ganados del buen mayoral” (121). — 86. Tono, “Genil, galán de los ríos” (122). —87. Otro, "Sonoro arroyuelo" (122). — 88. De un estudiante que se fue sin hacer cuenta con la huéspeda, "Un estudiante este curso" (122). — 89. A una dama que cortándose un callo por acordarse de su galán se cortó un pie, "De un pie escribir quiero en suma" (folio 124). — 90. A un doctor a un sacristán, "El sacristán qué desmán” (125). —91. A Judas, "Por tomar Judas el grado" (126). —92. De repente que a una dama en la primera noche de tal la hizo cerrada la cama, "Musa mía, con astucia" (127). — 93. Décimas compuestas a que a un religioso, estando en un locutorio de monjas, le vino una correncia y soltó las bragas y por lo cual le compusieron diversos romances y él respondió con estas décimas, "Pues que su entretenimiento" (129). — 94. A una monja que pretendía el que un sujeto prosiguiese en sus malos intentos, "Nise, a quererte me inclino" (130). —95. En respuesta de la antecedente de la monja y acaba "No más amistad, amor" (131). — 96. Traslado de una carta de un colegial que, hallándose cura de cierto lugar, escribió a los de su colegio del Alcalá dándoles cuenta de lo que les sucedía en el curto como lo que había ofrecido cuando salió de Alcalá, "Reyes míos desde el día" (132). — 97. Soneto, "Esta mañana en Dios en enhorabuena” (133). — 98. Otro, "Lo menos bello y más apetecido" (134). — 99. A un borracho que salió de una 
taberna y le cayó un jarrón lleno de vino de una ventana y le mató, "De una taberna salía" (134). - 100. Pinta a un tudesco borracho, "Un tudesco, humana cuba." (135) - 101. A un novicio que profesó en San Diego de Alcalá, “Oiga, hermano fray Francisco” (136.). — 102. Vejamen a san Diego, "Un devoto singular" (138). — 103. Otro vejamen al mismo santo, “Otra vez tengo la pluma” (139). — 104. Al mismo santo, "San Diego sí hace milagros" 105. Al mismo santo otro, "Diego sí, que supo bien" (142). —106. Al mismo santo, "De Diego muy por menor" (143). — 107. Al mismo santo pidiéndole un tuerto remedio para su ojo, "Un tuerto soy desgraciado" (145). —108. Otro que se cantó en Alcalá año de 1662, "Un corcovado poeta" (146). — 109. Al mismo santo, "Después de por qué se usa" (148). 110. Al mismo santo, "Todo el mundo conmovido" (148). —111. Al mismo santo, "Es el asunto una medalla" (150). — 112. Otro a la jornada que hizo el santo a Madrid, "San Diego, si me remedias" (151). — 113. Otra lira que se cantó en la misma fiesta, "A conjurar estas nubes" (153). - 114. A la Concepción, "Hanme mandado una cosa" (155). — 115. Otras al mismo asunto, "La más hidalga hermosura" (156). - 116. Otras, "La Concepción este día" (157). — 117. A lo mismo, "De tu concepción señora" (158). — 118. Otro a la Concepción, "Oigan lo que haca* en limpio" (159). - 119. Al mismo asunto, "De una niña la grandeza" (160). —120. Al mismo asunto, "Sabed, señora doncella" (161). —122. A san Francisco, "De pie quebrado unas coplas" (162). — 123. Al mismo asunto, "De Francisco por menor" (163). —123. A santa Clara, "Hoy mi devoción aclama" (164). —124. A san Juan Bautista “Al señor Bautista, el jaque" (165). — 125. Acto de contrición delante de un crucifijo, "Un pecador soy, Dios mío" (168). — 126. A nuestra señora en títulos de comedia. Jácara, "Érase una Virgen pura" (170). —127. Al Nacimiento, "Escribir desde Toledo" (171). —128. A la profesión que hicieron los padres de Santo Domingo en reverencia de la concepción de nuestra Señora, después de la segunda quema de la cocina del convento de Atocha, "Hoy a la Concepción aclamaciones" (172). — 129. Estando un religioso dominico hablando de la Concepción poco decente en una visita, un gato que estaba en la sala le saltó al pescuezo y le maltrató mucho, "Un dominico enemigo" (173). —130. A este devoto gato, "Gato ilustre, que a fieras manotadas" (173). —-131. Al desengaño del mundo, "Quiero, pues es ocasión" (174). - 132. A celebrar la octava del santísimo santo en el día de san Juan Bautista, "Hola, que llega la fiesta" (178). — 133. Coplas, “Ah, Señor, el de la hostia” (178). —134. A la Magdalena, "En tu alabanza mi musa" (179). —135. A la resurrección del santo Señor nuestro, "De santa resurrección" (180). — 136. Petición a nuestra Señora, "Divina madre de Gracia" (182). — 137. A Cristo en la cruz, "Dulce Jesús, Dios mío” (184). —138. Al Santísimo Sacramento, "Oigan en jácara" (178). — 139. Jácara, "Oigan que el bravo cielo" 
(185). - 140. Al Santísimo Sacramento en metáfora de una carta, “Acudan sentidos” (186). —141. Coplas, "A su esposa el alma escribe” (187). —142. Respuesta de la carta, "Oigan, oigan” (188). - 143. Coplas, "A vos dueño de mi vida” (188). —144. Al Nacimiento, "Haced que la Gracia encuentre" (189). —145. A un clavel dándole a una dama, "Clavel, pues por tus colores" (190). — 146. A nuestra Señora en títulos de comedia, "En títulos, Virgen pura" (191). — 147. A san Diego, "Hoy con gusto a cantar llego" (192).

\subsubsection{Biblioteca Nacional de España, ms. 5862}

Obras selectas de Antonio da Fonseca Soares. S. XVIII. 241 h. (209 x 150). Enc. Pergamino. Fol. Moderna. Olim: Supl. 232. Se trata de un manuscrito, escrito a varias manos, que contiene múltiples obras en verso de autoría anónima y otras atribuidas a Antonio Zamora y a Francisco Bances Candamo. En el segundo folio una nota indica: "Varias poesías españolas en varios metros y a diversos asuntos de autor anónimo". La poesía que aparece en el folio 227v se atribuye a Damián Cornejo en los siguientes manuscritos de la BNE: 2245 (138), 4135 (111), 4258 (131v) y 5566 (129). Cf. AA. VV. Catálogo 4: 2191-2199.

-1. Papel de unas monjas a un fraile que, estando en grado, pidió agua a una monja con quien estaba y, yendo a traerla la monja, el fraile se enriscó en la grada y se fue sin aguardarlas, "A fraile tan desatento" (227). - 2. Responde el fraile, "Pues que su entretenimiento" (227v) - 3. Segundo papel de las monjas, "Ya en sus versos habemos conocido" (228). - 4. Responde el fraile. $2^{\circ}$ papel, "Ello es ese convento desgraciado" $(228 v)$.

\subsubsection{Biblioteca Nacional de España, ms. 12980/1}

Poesías varias. S. XVII (finales) - XVIII (principios). 12 h. (21 x 15). Enc. Sin encuadernar. Fol. Antigua. Olim: V. $4^{\circ}$. C.59., $\mathrm{n}^{\circ}$ 1. Se trata de un manuscrito, escrito a una mano, en el que se recoge "La exhortación política cristiana a la Nación española" de Eugenio Gerardo Lobo, "Agosto" de Damián Cornejo y "Cuarteta que pusieron en Zaragoza a Don Lucas Espínola”. Cf. Castro (1973, Web. 520-521).

-1. Agosto de Cornejo, "Oye, Catuja, dulce hechizo mío" (203v).

8.2.1.16. Biblioteca Nacional de España, ms. 12981/35 
Relación burlesca: Escuchen y tengan cuenta / que empiezo por el principio. S. XVIII. $7 \mathrm{~h}$. (21 x 15). Enc. Sin encuadernar. Fol. Antigua. Olim: V. $4^{\circ}$ C.60., n. 35. Se trata de un manuscrito, escrito a dos manos, que contiene los siguientes poemas satíricos: "Relación en alabanza y vituperio de la mujer, en forma de argumento", "Controversia que tuvieron dos licenciados, de los cuales el uno alababa y el otro vituperaba a la mujer", "La siguiente dijo Cornejo a una monjas que cantando una Salve y alternando con los religiosos estas entonaron «Oh, dulcis» y los religiosos «Virgo»" y "Décima de Lope de Vega Carpio en alabanza de un autor franciscano llamado Vascones".

-1. La siguiente dijo Cornejo a una monjas, que cantando una Salve y alternando con los religiosos estas entonaron «Oh dulcis» y los religiosos «Virgo», "Muy bien la Salve cantasteis" $(7 \mathrm{v})$. - 2. Otra del mismo Cornejo a dos damas, "Qué lindo par de chiquillas" $(7 \mathrm{v})$.

\subsubsection{Biblioteca Nacional de España, ms. 17666}

Varias poesías curiosas de diferentes autores. S. XVIII. 925h. (25 x 17). Enc. Pergamino. Fol. Antigua. Olim. n.d. Se trata de un manuscrito, escrito a una mano, que contiene obras en prosa y en verso (sacro y profano) de diversos escritores. Muchas de ellas aparecen sin atribución. Algunos de los poemas que se incluyen como anónimos se atribuyen a Cornejo en otros manuscritos. El poemario es una copia del manuscrito D-249 de la Biblioteca Central de Zúrich. En nota autógrafa, Pascual de Gayangos señala que: "Ninguna de las poesías contenidas en este tomo es posterior al año 1663 (h. I)”. Cf. Gayangos (259-260).

-1. A la concepción purísima de nuestra señora en títulos de Comedias, "La más hidalga hermosura" (277). — 2. A lo mismo, "De una niña la pureza" (278). - 3. A santa Clara. "Hoy mi devoción aclama" (358). - 4. Quintillas al mismo santo. "Otra vez tengo la pluma" (366). —5. Al mismo santo en su traslación (maestro León). "Musa mía, Dios te dé” (370). — 6 . Pintura de una dama. "Oye, Amarilis, discreta" (483) - 7. A un escribano. "Hoy sin más ni más me allano (506). — 8. A las monjas. "Un ciego soy desgraciado (511). —9. A una dama. "De una niña quiero hablar" (513). - 10. A un dominico que estaba hablando poco decentemente de Nuestra Señora un gato le saltó al pescuezo y le maltrató (Cornejo). "Un dominico enemigo" (545). —-11. A una estudiante que comió menudo (maestro León). "Un estudiante de hogaño" (566). — 12. A san Judas. "Por tomar Judas el grado" (605). —13. A 
un caballero tenido de impotente y se casó con una dama hermosa (maestro León). "Casose Menga con Bras" (607). - 14. Enviando un devoto a una monja una vela. "De pedir, nunca yo fuera" (673). —-15. Pidiendo a un galán a una dama unas medias por habérsele roto otras. "Belisa el chasco celebra" (674).

\subsubsection{Biblioteca Nacional de España, ms. 18470}

Poesías varias. Vol. 2. Siglo XVIII, 97 h. (25 x 18). Enc. Holandesa. Fol. Moderna. Olim: 146. Exlibris: Don Pascual de Gayangos. Se trata de un manuscrito, escrito a dos manos, que contiene obras de temas históricos, literarios y culturales: Descripciones de Soria y de Galicia «en verso» del padre Butrón; Observaciones sobre las fábulas literarias de Tomás de Iriarte; Alejandro en África: drama trágico; y diversas composiciones satíricas y jocosas anónimas. La poesía escatológica que aparece en el folio 66v es atribuida a Cornejo en otros manuscritos de la BNE: 2245 (138), 4135 (111), 4258 (131v) y 5566 (129).

-1. Versos de una monja a un fraile y de éste a aquélla con motivo de haber hecho su necesidad en el locutorio, "A fraile tan desatento" (66). - 2. Responde el fraile, "Caúnsanme dasabrimiento" (66v) - 3. Réplica de la monja, "Ya en sus versos habemos conocido" (67v).

-4. Respuesta del fraile en el mismo metro, "Cierto que ese convento desgraciado" (68v).

\subsubsection{Biblioteca Nacional de España, ms. 20813/4}

Soneto: Esta mañana en Dios y en hora buena. S. XIX-XX, 1h. (21 x 15). Enc. Sin encuadernar. Fol. Moderna. Olim: n.d. Se trata de un manuscrito, escrito a una mano, que alberga el soneto "Esta mañana en Dios y en hora buena" y el primer verso de "Lo menos bello y más apetecido". En la parte superior contiene la siguiente nota: "De fr. Damián Cornejo".

—1. "Esta mañana en Dios y en hora buena" (1). — 2. Lo menos bello y más apetecido (1).

8.2.1.20. Biblioteca Real de la Colegiata de Roncesvalles, ms. 410 
Poesías divinas y humanas, serias y jocosas, que a diferentes asuntos escribió el reverendísimo padre fray Damián Cornejo del Orden de nuestro padre san Francisco año 1737. S. XVII-XVIII, 195 h. (155 x 215). Enc. Pergamino. Fol. Antigua. Olim. n.d. Se trata de un manuscrito, escrito a varias manos y en diferentes épocas, que contiene poesías sacras y humanas atribuidas a Damián Cornejo. Esta obra incluye algunas notas marginales que informan de las personas que proporcionaron los poemas. Algunos de ellos se hallan repetidos y otros son apócrifos. Cf. Cornejo (Das lyrische 30-37).

-1. A un clavel dándosele a una dama, "Clavel, pues por tus colores" (1). - 2. A una dama que cortándose un callo por acordarse de su galán se cortó un pie, "De un pie escribir quiero en suma" $(1 \mathrm{v})$. - 3. A un borracho que saliendo de una taberna le cayó un jarro lleno de vino de una ventana y le mató, "De una taberna salía" (2). - 4. De un estudiante que se fue sin hacer cuenta con la huéspeda, "Un estudiante este curso" (2v). - 5. Pinta un tudesco borracho, "Un tudesco, humana cuba" (3). - 6. A cierta dama por quien su galán padecía las penas del purgatorio, "Marica, viéndote hermosa" (3v). - 7. A una dama fácil, "Tu arroz, Marica, me enfada" (4v). - 8. Enamorado un galán de una dama cuyo sobrenombre era Palma, "Palma, en viendo tu beldad" (4v). — 9. A unos ojos azules, "Desde que tus niñas bellas" (5). - 10. De un doctor y un sacristán, “EI sacristán qué desmán” (5). —11 De repente que a una dama que la primera noche la hizo serrada en la cama, "Musa mía, con astucia" $(5 \mathrm{v})$. - 12. A una monja que pretendía el que un sujeto prosiguiese a que en sus malos intentos la hablase, "Nise, a quererte me obligo" (7). — 13. En respuesta de las de arriba escribe la monja las siguientes acabándolas todas con: "No más amistad, amor", "Acabose el amistad" (7v). - 14. Pintura de un pueblo donde cierto religioso fue a pedir el agosto (que es en el lugar de Madrigales). Escribiola a una monja su devota, "Oye, Catuja, dulce hechizo mío" (8). - 15. Traslado de una carta de un colegial que, hallándose cura de cierto lugar, escribió a los de su colegio del Alcalá dándoles cuenta de lo que le sucedió en el curato como lo que había ofrecido cuando salió de Alcalá, "Reyes míos, desde el día" (16). — 16. Pintura a una dama de Cornejo, "Sepan todos y todas que yo adoro" (17). — 17. A el cabello de una dama, "Suelto el cabello por el aire ufano" (21v). - 18. Pintura que hizo a un lugar mal hallado en él por el agosto llamado por mal nombre Achilla, "Oye, Fenisa, dulce echado mío" (22). - 19. A Judas fue asunto de Academia, "Por tomar Judas el grado" (26v). - 20. En celebración de la octava del santísimo santo en el día de san Juan Bautista, "Hola, que se llega la fiesta" (28). - 21. A nuestra Señora empecemos con un título de comedia y acabando con el principio de un romance, "La más hidalga hermosura" $(29 \mathrm{v})$. - 
22. A nuestra Señora en títulos de comedia, "En títulos, Virgen pura" (30v). — 23. A la Magdalena, "En tu alabanza mi musa" (32). —24. A san Diego de Alcalá, "Hoy con gusto a cantar llego" (33). - 25. A la concepción de nuestra Señora, "De una niña la grandeza" (33v). — 26. A la resurrección de Cristo señor Nuestro, "De santa resurrección” (35). — 27. Quintillas de ciego a santa Clara, "Hoy ni devoción aclama" (37). —28. Petición a nuestra señora Madre de Dios y Virgen santísima, concebida sin mancha de pecado original, de un devoto suyo, "Divina madre de Gracia" (39). — 29. A Cristo nuestro bien en la Cruz, "Dulce Jesús, Dios mío" (41v). — 30. Jácara al Santísimo Sacramento, “Oigan en jácara” (42v). 31. Letra al Santísimo Sacramento en metáfora de una carta, "Acudamos sentidos" (44). 32. Respuesta de la carta, "Oigan, oigan" (45v). - 33. Al santo nacimiento de nuestro Redentor, "Haced que la Gracia encuentre" (48). - 34. A Judas fue asunto de Academia, "Por tomar Judas el grado" (48). - 35. A san Diego de Alcalá, "Después que por qué se usa" -36. A san Diego pidiéndole un tuerto remedio para un ojo, "Un tuerto soy desgraciado" (50). - 37. A san Diego de un corcovado cantose en Alcalá, "Un corcovado poeta" (50v). -38. Vejamen a san Diego, "Un devoto singular" (52v). - 39. Otro vejamen a san Diego, "Otra vez tomo la pluma" (54v). — 40. A san Diego de Alcalá, "Diego sí, que supo bien" (56v). - 41. Al mismo santo, "De Diego muy por menor" (58). — 42. A san Diego otras, "Todo el mundo conmovido" (60) -43. Al mismo santo Diego, "A conjurar estas nubes" (61v). - 44. A la concepción de nuestra Señora, "Hanme mandado una cosa" (63). - 45. A san Diego de Alcalá, "San Diego sí hace milagros” (64). — 46. Al mismo santo. Es el asunto una medalla de oro que envía la Reina, nuestra Señora, "La Reina, nuestra Señora" (65). 47. A la jornada que hizo el Santo a Madrid, "San Diego, si me remedias" (66v). — 48. A la concepción de nuestra Señora, "La Concepción con este día" (69). —49. A mismo asunto, "De tu concepción, Señora" (70). — 50. A la concepción de nuestra Señora, "Oigan lo que saca en limpio" (71). — 51. Al mismo asunto, "Sabed, señora doncella" (72). —52. A san Francisco, "De Francisco por menor" (73). — 53. Al mismo Santo, "De pie quebrado unas coplas” (74). —54. A san Juan Bautista, “Al señor Bautista, el jaque” (75). — 55. Acto de contrición delante de un crucifijo, "Un pecador soy, Dios mío" (78). - 56. A nuestra Señora en títulos de comedias, "Érase una Virgen pura" (80). — 57. Al Nacimiento, "Escriben desde Toledo" (82). — 58. A la adoración de los reyes, "De Oriente vienen tres reyes" (83). — 59. A la profesión de una religiosa de Santa Clara, "Una doncella resuelta" (84v). —60, "Pues satirizarme usa" (85). —61. Pintura a una dama, "Escúcheme unos esdrújulos" (85v). — 62. A unos toreadores nuevos de Pinto, "De Pinto para un festejo" (86). —63. A una dama, "Vengar quiero mis rencillas" (86v). - 64. A una que siendo galanteada se casó con un 
sacristán, "Dios te socorra, Marica" (87v). —65. A una dama que gastó su mocedad con frailes y a la vejez decía mal de ellos y se empeñó con un sacristán, "Marica, que a decir mal" (88v). - 66. A un fraile chiquito que se levantaba con cacho, "Oye, tarazón de fraile" (89v). —67. De un amante a su dama, "Bien puede, Lisis, en triste" (90). —68. A unas damas que las dieron moscas confitadas, "Óiganme, damas, que empuño" (91). —69. A una dama que lloraba mucho un divieso que le salió en la mano, "Hoy, Clori, pretendo amarte" (91v). -70. A un corcovado que galanteaba a una dama y la daba músicas y ella le aborrecía, "Un galán corto de talle" (92). —71. Madrigales, "Qué dice Europa del poder de España" (93). -72. A un novicio que profesó en San Diego de Alcalá, "Oiga, hermano fray Francisco" (93v). - 73. A la profesión que hicieron los padres de Santo Domingo en reverencia de la concepción de nuestra Señora, después de la segunda quema de la cocina del convento de atocha, "Hoy a la Concepción aclamaciones" (94v). — 74. Estando un religioso dominico hablando de la Concepción poco decente en una visita, un gato que estaba en la sala le saltó al pescuezo y le maltrató mucho, "Un dominico enemigo" (95). — 75. A este devoto gato, "Gato ilustre, que a fieras manotadas" (95). - 76. Al desengaño del mundo, "Quiero, pues es ocasión" (95v). — 77. Pintura a una dama, "Dulce Lisis de mis ojos" (96v). — 78. Habiendo pedido asunto en una Academia para escribir, no se le dieron por estar todos repartidos y le dijeron que tomase por pie el no haberle dado asunto y vistiese una dama que otro dejaba desnuda a orillas de un río, "Yo soy, ilustre Academia" (97v). — 79. A unos colegiales que dieron a unas damas moscas confitadas. Sátira como para ellos, "Eranse dos licenciados (98). - 80. A un borracho, "A uno que se hace una uva" (99). - 81. Dando chasco a un borracho, "Clodio, del mundo en la plaza "(99v). - 82. Sátira a un estudiante que comió menudo, "Un estudiante de hogaño" (100). — 83. Al haberse soltado la sangría de una dama, "A la desatada llaga" (100). — 84. Habiendo perdido una dama por causa del autor cien reales, él que envió dos y al no quererlos recibir escribió esta décima, "Cien reales por mí perdiste" (100v). — 85. Contra monjas, "Un ciego soy desgraciado" (100v). — 86. Al haber visto el pie de una dama, "En el mar de tu hermosura" (101). —87. A una dama que, estando ausente y sangrada, pedía celos a su galán, "Mi bien, juro por mi amor" (101v). 88. A uno muy preciado de valiente siendo gallina, "Es de Fausto la fiereza" (102). — 89. Décimas amorosas, "Para qué es tu atrevimiento" (102v). — 90. A una dama que, estando destocada, se asomó a una reja y su galán la asió una mata de cabellos, "A una reja qué ventura" (103). —91. A una dama, "Con modo ya más humano" (103v). —92. Amante callado y sospechoso, "Solo el silencio testigo" (103v). —93. Sátira, "Quisimí quisimona, hola" (104). — 94. Convidando una dama a su galán a finezas amorosas. En metáfora de un 
juego de hombre, "Ya Fabio que hemos llegado" (105). — 95. Habiendo un poeta hecho un satírico contra otro pobrete, se le respondió en estas décimas, "Tu romance, Andrés, leí" (105v). —96. Epigrama gracioso a una dama, "El pañuelo desembolsa" (105v). — 97. Otro a otra dama, "Marica no desdeñosa" (105v). —98. A unas doncellas que querían bien a unos portugueses y estuvieron por ellos encerradas en una cuadra, "Queridas, mucho me enfada" (105v). - 99. A un catedrático secular, siendo en la condición muchacho, no quería leer algunas veces enfadándose de muy pocas cosas, "Pedro, mi ingenio recela" (106v). -100 . Pidiendo a una dama unas medias habiendo roto otras, "Belisa el chasco celebra" (106v). 101. Pidiendo a una señora un poco de arrope para otra dama, "Pues vuestra piedad me abriga $(107 \mathrm{v})$. - 102. Haciendo un amante alarde de su amor, "Bizarro amor me desvela (107v). -103. Quejas a una dama de que le había pegado una catalina, "Malo me siento, Marica" $(107 v)$. - 104. A una dama que le dio licencia a su galán para que la quisiera, "Licencia Solo me has dado" (108v). - 105. Fraterna exhortatoria a un galán que gastaba con su dama poco dinero y mucha prosa, "Anfriso, con atención” (108v). — 106. Pidiendo celos una dama a su galán de un fraile italiano, de quien el dicho galán confesaba era muy querido. Y, siendo muy lindo, se alababa de ello, "Don Juan, no tengo por bueno" (109v). — 107. A una dama que dio a su galán unas pelotas, "Ya que tan galante has sido" (109v). —108. Enviando a una dama una vela blanca al tiempo porque estaba para ausentarse della, "De pedir nunca yo fuera" $(109 \mathrm{v}) .-109$. A una dama que tenía la casa muy puerca, "Marica, a tu sucia cara" (110). - 110. A la despedida de una dama, "Adiós, Leonor de mi vida" (110v). — 111. A una fiera presumida, "Clori, que para ser linda" (111). - 112. A una ausencia, "En aquesta soledad" (111v). —113. Amante callado y sospechoso, "Solo el silencio testigo" (112). 114. Manifiesta un amante a su dama su pasión, "Pues que me han dado licencia" (112v). 115. Letra burlesca, “A Pascuala dijo Bras" (113). - 116. Desengaño del deleite sensual. Jácara, “En la villa Carrión” (113v). —117. Sátira, "En Málaga vi a Rufina” (114). —118. Sátira a Don Fernando Valenzuela, "Fernando, a quien por soberbio" (114v). — 119. Pregón, "En la ruda política mía" (115). — 120. Otro pregón, "En la firme política nuestra” (115v). -121. A una dama porque le quemaron un papel, "No quieran tus sinrazones" (116). — 122. Un tono, "Del rumbo de Francelisa" (116). — 123. Otro, "Fuera, fuera que Juanilla" (116). —124. Otro, "Los ganados de Liseno" (116v). — 125. Otro, “Genil, galán de los ríos” (116v). —126. Otro, "Sonoro arroyuelo" (116v). — 127. Una pobre que salió muy estropeada de un mal francés habido en buena guerra del mismo autor, "Un mal francés, Marica" (116v). 128. A una monja hermosa y desdeñosa, "Lisis, tu favor invoco" (117). — 129. A una dama que, estando destocada, se asomó a una reja y su galán la asió una mata de cabello, "Suelto 
el cabello por el aire ufano $(117 \mathrm{v})$. — 130. Habiendo pedido una mano un galán a una dama y no habiéndola conseguido, le pide un dedo, "Amoroso, prudente y cortesano" (118). 131. Desmiente las desconfianzas de una dama a su galán con un retrato suyo algo desparecido, "Rudo pincel de mano inadvertida" (118v). —132. Al mismo asunto, "Por los yerros, Ysbella, de un traslado" (118v). — 133. Al ponerse una dama en las guedejas unos jazmines que aún no habían salido del botón y a pocas horas se abrieron en el mismo pelo, "De emboscada entre matas de tu pelo" (119). - 134. Soneto panegírico que a uno le viene a la media pierna al dueño del asunto, "Breve pie reducido a cárcel breve" (119v). — 135 . Al mismo asunto, "Cómo quieres, Anarda, que sea casto" (119v). —136. Al mismo asunto, "Apenas, señor, te viste" (122v). — 137. Al mismo asunto, "Pediste, mi bien Cruz, suelas" (122v). —138. A los escribanos, "Hoy sin más ni más me allano” (123). —139. A un jurador, "Señor, jurador he sido" (123v). - 140. Canción a una perdida esperanza, "Ufano, altivo, alegre enamorado" (123v). - 141. Quejas a una ausencia, "Desde que el sol ardiente" (126). —142. Al desengaño del mundo. Sátira contra el amor desordenado de las mujeres, "Quiero, pues es ocasión" (132). — 143. "Aprende olvido, pastor" (137). —144. A una dama que gastó lo mejor de su juventud con frailes y a la vejez decía mal de ellos y se casó con un sacristán, "Marica, que a decir mal" (138). — 145. Pintase un agosto que dijo un fraile de san Francisco, “Oye, Catuja, dulce hechizo mío" (139). —146. A un sabañón de una ingle, "Malo me siento, Marica" (144v) - 147. Retrato a una dama en metáfora de confitería, "Confitero del amor" (145v). — 148. "Pues tu hermosura me mata" (148v). — 149. Otra divina, "Un fullero vino al mundo" (149v). — 150. Coplas de pie quebrado, "A cierto galán su dama" (150). - 151. Otro humano, "Ayer Angélica, supe" (151). —152. Otro al mismo, "Señor, jurador he sido" (152). — 153. Otras al mismo, “Agua es mi tema, señores" (153). — 154 . Romance, "Bebe al compás mi llanto" (154v). — 155. Otro humano, "Cristal desecho a pedazos" (155). - 156. Otro humano, "Forzado de mis deseos" (155v). - 157. Otro, "Genil, galán de los ríos" (156). —158. Otro humano, "Montes de Tajo, escuchad" (156). —159. Otro humano, "Perlas lloraba la niña" (156v). - 160. Otra letrilla humana, "Esa rosa que ve, zagalejo" (157v). - 161. Otro humano, "Aprended flores de mí” (158). — 162, "Flores que apenas nacéis" (158). — 163. Otro humano, "Anarda, a quien mis favores" (159). —164. Otro, "No sé a qué memorias me rendí" (159v). - 165. Tono trovado de... a quien los crueles, "El pueblo a quien de crueles" (161). — 166. Otro trovado de no sé a qué sombras me dormí, "No sé a qué sombras" (161v). - 167. Tono trovado en el de *, "Don Pedro, a quien los rebeldes" (163) - 168. "Dejadme memorias tristes" (164). — 169. Otro humano, "Cauteloso pajarillo" (164v). — 170. Otro humano, "El retrato de Filis hermosa" (165). - 171. Otro 
humano, "En Málaga vi a Rufina” (166). - 172. Otro humano, "En la ruda política nuestra" (166v). — 173. Otro trovado, "En la docta república vuestra" (167v). —174. Otro, "Bebe al compás mi llanto" (168v). — 175. Otro, "Quiero ver a mi tristeza" (169). —176. Otro, "Un verdugo a otro verdugo" (170). —177. Otro, "Suspended libre arroyuelo (171) - 178. Otro, “Canta, pajarillo alegre" (171v). — 179. Otro, “Amante el más perfecto" (172). - 180. Otro, "De achaque de una fineza" (172v). — 181. Otro, "Las luces que en mí ocultas" (173). — 182. Otro, "Yo que en la prisión dorada" (173v). — 183. Otro, "En las ardientes cenizas" (174v). — 184. Otro, "El más poderoso incendio" (175). — 185. Otro, "Al real convite divino" (175v). — 186. Para amante el más perfecto, "Amor, amor, cielos amor" (176). — 187. Estribillo, "Qué linda gracia es decir que das vida" (176). —188. Otro estribillo, "Un jilguerillo soy cuya apacible voz" (176). — 189. Otro estribillo, "Aquí de Dios que un incendio me abrasa” (176). —190. “* soldado fue a espulgarse” (177). — 191. Laura que yo te maldiga, "Hoy la academia me manda" (178). — 192. Sueño, "Cansado anoche de estar" (179). —193. A una dama muy interesada, "De una niña quiero hablar" (188). — 194. A un sabañón de ingle, "Marica, viéndote hermosa" (188v). — 195. A una dama que después de haber gastado lo mejor de su vida en devoción de frailes decía mal de ellos y se casó con un sacristán, "Marica, que a decir mal" (189v). —196. Otro a un sabañón de ingle, "Malo me siento, Marica" (190v). — 197. Nuestra Señora de la Concepción, "La más hidalga hermosura" (194).

\subsubsection{Biblioteca Real de la Colegiata de Roncesvalles, ms. 28-C-7-6p22 (inédito)}

Enamorando a una dama cuyo nombre era Palma. S. XVII ( $\left.2^{\circ} \mathrm{mitad}\right)-$ XVIII. 23h. $(22 \mathrm{x}$ 16). Enc. Sin encuadernar. Fol. Antigua. Olim. n.d. Se trata de un manuscrito, escrito a varias manos, que contiene poesías de carácter sacro y festivo atribuidas a Damián Cornejo en otros manuscritos. Está constituido por dos cuadernillos que presentan errores en la foliación (de la hoja 67 pasa a 78) y que posee saltos de página significativos (del folio 91 pasa al 7).

-1. Enamorando a una dama cuyo nombre era Palma, "Palma, en viendo tu beldad" (64). -2. Pidiendo celos una dama a su galán de un fraile italiano, de quien el dicho galán confesaba era muy querido. Y, siendo muy lindo, se alababa de ello, "Don Juan, no tengo por bueno" (65). - 3. Pintura a una dama, "Pues que me has dado licencia" (65). - 4. Otra pintura, "Cuenta con el retratro" (66). —5. Otro, "Con licencia de Silvia" (78). —6. A una 
dama que dio a su galán unas velas, "Ya que tan galán has sido" (78v). — 7. Un galán enviando a una dama una vela blanca al tiempo que estaba para ausentarse de ella, "De pedir nunca yo fuera" (79v). — 8. A una dama, "Marica, a tu sucia cara" (80v). — 9. Despedida a una dama, "Adiós, Leonor de mi vida" (81). — 10. A una dama presumida, "Clori, que para ser linda" (82v). - 11. A una ausencia, "En aquesta soledad" (83v). - 12. Amante callado y sospechoso, "Solo el silencio testigo" $(84 \mathrm{v})$. - 13. A un borracho, "A uno que se hace una uva" (85v). - 14. Dando chasco a un borracho, "Clodio, del mundo en la plaza" (86v). 15. Sátira a un estudiante que comió menudo, "Un estudiante de hogaño" (88). - 16. Sueño jocoso, "Cansado anoche de estar hecho un panarra" (87). —17. A lo mismo, "De una niña la grandeza" (7). - 18. Al mismo asunto, "Sabed, señora doncella" (8v). — 19. A nuestro padre san Francisco, "De pie quebrado unas coplas" (9). - 20. Al mismo asunto, "De Francisco por mayor" (10).

\subsubsection{Biblioteca Fundación Bartolomé March, ms. 406}

Obras poéticas m[anuscrita]s del rev[erendísi]mo y il[ustrísi]mo señor don fray Damián Cornejo, obispo de Orense, que también compuso la Crónica de nuestro padre san Francisco con el acierto que es notorio. S. XVII, 346 h. (16 x 20). Enc. Pergamino. Fol. Antigua. Olim. 23/4/2. Procede de la Biblioteca de Medinaceli, $\mathrm{n}^{\circ}$ 145. Se trata de un manuscrito, escrito a una mano, que contiene poesías sacras y profanas atribuidas a Damián Cornejo. Cf: Carreira (La obra 42).

-1. A la concepción de María santísima, "De tu concepción, Señora" (2). —2. Al mismo asunto, "Oigan lo que saca en limpio" (3). - 3. Al mismo asunto, "Sabed, señora doncella" (5). - 4. Al mismo asunto, "Hanme mandado una cosa" (7). - 5. Al mismo asunto en títulos de comedias, "La más hidalga hermosura" (9). —6. Al mismo asunto, "La Concepción este día" (11). - 7. A nuestro padre san Francisco, "De Francisco por menor" (13). —8. A santa Clara, "Hoy mi devoción aclama” (14). —9. A san Juan Bautista, “Al señor Bautista, el jaque" (19). — 10. A san Diego de Alcalá, "Otra vez tengo la pluma” (24). —11. Al mismo santo, "San Diego sí hace milagros" (27). - 12. Al mismo santo, siendo el asunto una medalla de oro que le envió la Reina, nuestra Señora, "La Reina, nuestra Señora" (29). 13. Al mismo santo, a la jornada que hizo a Madrid, "San Diego, si me remedias" (33). 14. A nuestra Señora en títulos de comedias, "Érase una Virgen pura" (37). — 15. Al Nacimiento, "Escriben desde Toledo" (41). — 16. A la adoración de los Reyes, "De Oriente 
vienen tres reyes" (44). - 17. Acto de contrición delante de un Crucifijo, "Un pecador soy, Dios mío" (46). —18. Al Santísimo Sacramento, "Un cojo soy Dios mío" (51). — 19. Sobre el motivo que pudo tener achacar a la Virgen madre de Dios, siempre pura, siempre santa: el pecado original, "Virgen, nadie culpada os ha creído" (53). —-20. A la profesión que hicieron los padres de Santo Domingo en reverencia de la concepción de nuestra Señora, después de la segunda quema de la cocina del convento de Atocha, "Hoy a la Concepción aclamaciones" (54). - 21. A un religioso dominico que, estando en una visita hablando poco decentemente de la concepción de la Virgen, un gato que estaba en la sala le saltó al pescuezo y le maltrató mucho, "Un dominico enemigo" (55). —22. A este devoto gato, "Gato ilustre, que a fieras manotadas" (56). —23. A un novicio que profesó en San Diego de Alcalá, "Oiga, hermano fray Francisco" (57). - 24. Convidando una dama a su galán a finezas amorosas. En metáforas de un juego de hombre, "Ya, Fabio, que hemos llegado" (60). —25. A una dama, "Marica, a tu sucia cara" (62). - 26. Romance en el que el autor da cuenta a un amigo suyo de una grave enfermedad que tuvo, "Válgame, doña Talía" (63). —27. Melancolías del año 1643: María Manchega, "Yo un ermitaño pobre, si contento" (83). —28. Pintura de un lugar adonde el autor pidió un agosto, "Oye, Catuja, dulce hechizo mío" (119). —29. Pintura a una dama, "Sepan todas y todos que yo adoro" (133). - 30. Quejándose de una ausencia, "Desde que el sol ardiente" (142). — 31. Sermón para monjas, "Per signum crucis de la vara" (147). - 32. A una pobre que salió muy estropeada de un mal francés habido en buena guerra del mismo autor, "Un mal francés, Marica," (159). — 33. A una monja hermosa, desdeñosa y capacha, "Lisis, tu favor invoco" (160). - 34. A una dama que, estando destocada, se asomó a una reja y su galán la asió una mata de cabello, "Suelto el cabello por el aire ufano" (161). - 35. Habiéndole pedido una mano un galán a una dama y no habiéndola conseguido, le pide un dedo, “Amoroso, prudente y cortesano" (162). - 36. Desmiente las desconfianzas de una dama su galán con un retrato suyo algo desparecido, "Rudo pincel de mano inadvertida" (163). —37. Al mismo asunto, "Por los yerros, Ysbella, de un traslado" (164). -38. Al ponerse una dama en la guedeja unos jazmines que aún no habían salido del botón y a pocas horas se abrieron entre el mismo pelo, "De emboscada entre matas de su pelo" (165). - 39. A uno le viene a la media pierna al dueño del asunto, "Breve pie, reducido a cárcel breve" (166). — 40. Al mismo asunto, "Cómo quieres, Anarda, que sea casto" (167). -41. Soneto jocoso, "Ya no puedo vivir si no me capo" (168). — 42. En el casamiento del despensero de un obispo "Casó de un arzobispo el despensero" (168). —43. Al desaliño de los versos de un poeta de polaina y greguescos, "Disparates, Antón, muy mal zurcidos" (169). - 44. Soneto jocoso, "Estaba Lisis en campal batalla" (170). — 45. A una monja 
pidiéndole celos de un hombre que tenía por sobrenombre Puerto, "De mis finezas el bajel incierto" (171). - 46. A uno que se llamaba Cruz y perseguía al autor por haberle pedido unas suelas, "Cruz, si cristiano soy, qué me persigues" (172). — 47. Al mismo asunto, “Apenas, señor, te viste" (173). — 48. Al mismo asunto, "Pedite, mi buen Cruz, suelas" (176). - 49. A una dama pidiendo unas medias, "Belisa el chasco celebra" (177). — 50. Pidiendo a una señora un poco de arrope para dar a una dama, "Pues que me han dado licencias" (180). — 51. A una dama, "Bizarro amor me desvela" (181). — 52. A una dama que dio licencia a su galán para que la quisiera, "Licencia solo me has dado" (182). — 53. Fraterna exhortatoria a un galán que gastaba con su dama poco dinero y mucha prosa, “Anfriso, con atención" (184). - 54. Enamorando a una dama cuyo nombre era Palma, "Palma, en viendo tu beldad" (186). — 55. Pidiendo celos una dama a su galán de un fraile italiano, de quien el dicho galán confesaba era muy querido. Y, siendo muy lindo, se alababa de ello, "Don Juan, no tengo por bueno" (188). — 56. A una dama que dio a su galán unas pelotas, "Ya que tan galante has sido" (189). — 57. Enviando a una dama una vela blanca al tiempo que estaba para ausentarse de ella, "De pedir nunca yo fuera" (191). — 58. A una ausencia, "En aquesta soledad" (193). — 59. A un amante callado y sospechoso, "Solo el silencio testigo" (195). - 60. Dando chasco a un borracho, "Clodio, del mundo en la plaza" (198). —61. Dando vejamen a unas del autor, "A la desatada llaga” (201). —62. A una dama fácil, “Tu arroz, Marica, me enfada" (201). —63. Habiendo perdido una dama por causa del autor cien reales, él la envió dos y al no quererlos recibir escribió esta décima, "Cien reales por mí perdiste" (202). - 64. Al haber visto el pie a una dama, "En el mar de tu hermosura" (203). - 65. A una dama que, estando ausente y sangrada, pedía celos a su galán, "Mi bien, juro por mi amor" (205). - 66. A una dama porque quemó un papel, "No quieran tus sinrazones" (208). - 67. A uno muy preciado de valiente siendo gallina, "Es de Fausto la fiereza" (209). —68. Décimas amorosas, "Para qué es tu atrevimiento" (211). —69. A una dama que, estando destocada, se asomó a una reja y su galán la asió una mata de cabellos, “A una reja qué ventura" (213). — 70. A una dama, "Con modo ya más humano" (216). 71. A un amante receloso, "Solo el silencio testigo" (217). - 72. A una doncellas que querían bien a unos portugueses y estuvieron por ellos encerradas en una cuadra, "Queridas, mucho me enfada" (220) - 73. A un catedrático secular, siendo en la condición muchacho, no quería leer algunas veces, enfadándose de muy pocas cosas, "Pedro, mi ingenio recela" (222). - 74. Pintando a una dama, "Dulce Lisis de mis ojos" (224). —75. Al haber pedido asunto en una Academia para escribir y no habiéndosele dado por estar ya repartidos le dijeron que tomase por pie el no habérsele dado y vistiese a una dama que otro dejaba 
desnuda a orillas de un río, "Yo soy, ilustre Academia" (227). — 76. Sátira a una dama por quien su galán padecía las penas del purgatorio, "Marica, viéndote hermosa" (232). — 77. Sátira al mismo asunto, "Malo me siento, Marica" (234). - 78. Despidiéndose de una dama, “Adiós, Leonor de mi vida" (237). - 79. A una fea presumida, "Clori, que para ser linda" (241). - 80. A una dama que se casó con un impotente, "Casose Menga con Blaso" (243). -81. A unos colegiales que dieron a unas damas moscas confitadas, "Éranse dos licenciados" (247). — 82. A un sueño que tuvo el autor, "Cansado anoche de estar" (251). —90. Al desengaño del mundo, "Quiero, pues es ocasión" (275). — 83. A una dama que gastó lo mejor de su mocedad con frailes a la vejez diciendo mal de ellos y se había empeñado con un sacristán, "Marica, que a decir mal” (284). —84. Quisimí quisimona, “Quisimí quisimona, hola” (287). — 85. Letra burlesca, “A Pascuala dijo Bras” (291). — 86. Desengaño del deleite sensual. Jácara, "En la villa Carrión” (295). — 87. Sátira a unas putas, "En Málaga vi a Rufina” (298). — 88. Sátira a Valenzuela, "Fernando, a quien por soberbio" (299). - 89. A una dama, "Pues que me han dado licencia" (302). —90. Pintura a una dama, "Cuenta con el retrato" (304). — 91. A un borracho, "A uno que se hace una uva" (308). 92. Contra monjas, "Un ciego soy desgraciado" (310). - 93. A un estudiante que comió menudo, "Un estudiante de hogaño" (313). —94. Tono, "Del rumbo de Francelisa" (314). —95. Tono, "Fuera, fuera que Juanilla" (315). —96. En alabanza del autor, "De Apolo en la facultad" (316).

\subsubsection{Real Biblioteca del Monasterio del Escorial, ms. Z. IV.18.}

Relación del convento de Monjas Jerónimas de Palma. Descripción de las ocho maravillas del mundo. Descripción de España y su corte. Coplas y glosas de España y Francia. Sermón para la dominica quinta de Cuaresma [...]. S. XVI-XVIII. 461h. (21 x 15). Enc. Pergamino. Fol. Antigua. Olim. n.d. Se trata de un manuscrito misceláneo, escrito a varias manos, que contiene obras en prosa y en verso. En él se incluyen varios poemas sacros y profanos atribuidos a Damián Cornejo. En la $3^{\mathrm{a}} \mathrm{h}$. de guarda del principio consta la siguiente anotación: "Ms. compuesto por el Bibliotecario Félix Rozanski". Cf. Zarco (Catálogo 1: 276-277 y Catálogo 3: 168-173).

-1. Asunto humorístico. Pintura de un lugar de donde el ilustrísimo Cornejo pidió un agosto, "Oye, Catuja, dulce hechizo mío" (32). — 2. A santa Clara, "Hoy mi devoción aclama" (37v). - 3. A nuestro padre san Francisco, "De Francisco por menor" (38). — 4. A 
la Purísima Concepción, "De una niña la grandeza" (40) - 6. Acto de contrición delante de un crucifijo, "Un pecador soy, Dios mío" (42).

\subsubsection{Biblioteca de la Real Academia Española, ms. E-39-6654}

Obras del padre Cornejo. Asuntos sacros. S. XVIII. 113 h. (220 x 160). Enc. Piel burdeos. Fol. Moderna. Olim. n.d. Se trata de un manuscrito, escrito a una mano, que contiene poesías de carácter sacro y festivo atribuidas a Damián Cornejo. En la hoja de guarda se lee: "Algunos versos son demasiado alegres, hay juegos de palabras, algún equívoco". Exlibris al inicio y al final: "Soy de José Antonio García, cura de Barbolla". Cf. Carreira (La obra $42)$.

-1. Acto de contrición delante de un Crucifijo, "Un pecador soy, Dios mío" (1). —2. Al misterio de la Purísima Concepción, "Hanme mandado una cosa" (6). - 3. Al mismo asunto, "La más hidalga hermosura" (4). — 4. Al mismo asunto, "La Concepción este día" (4v). 5. Al mismo asunto, "De tu concepción, Señora" (5v). - 6. Al mismo asunto, "Oigan lo que saca en limpio" (6v). - 7. Al mismo asunto, "De una niña la grandeza" (7v). — 8. Al mismo asunto, "Sabed, señora doncella" (8v). — 9. A nuestro padre san Francisco, "De pie quebrado unas coplas" (9v). - 10. Al mismo asunto, "De Francisco por menor" (10). —11. A santa Clara, "Hoy mi devoción aclama" (11). —12. A san Juan Bautista, "Al señor Bautista, el jaque" (12v). - 13. A nuestra señora en títulos de comedia. Jácara, "Érase una Virgen pura" (14v). - 14. Al Nacimiento, "Escriben desde Toledo" (16). - 15. A la adoración de los reyes, "De Oriente vienen tres reyes" (17). - 16. A un novicio que profesó en San Diego de Alcalá, "Oiga, padre fray Francisco" (18). — 17. Vejamen a san Diego de Alcalá, "Otra vez tengo la pluma" (18v). — 18. Al mismo santo, "San Diego sí hace milagros" (21v). — 19. Al mismo santo pidiéndole un tuerto remedio para su ojo, "Un tuerto soy desgraciado" (22v). —20. Otro que se cantó en Alcalá año de 1662, "Un corcovado poeta" (23). —21. Al mismo santo en asunto de una medalla de oro que envió la Reina, nuestra Señora, "La Reina, nuestra Señora" (24v) - 22. A la jornada que hizo el santo a Madrid, "San Diego, si me remedias" (25). - 23. Otra letra que se cantó en la misma fiesta, "A conjurar estas nubes" (27). - 24 . A la procesión que hicieron los padres de Santo Domingo en reverencia de la Concepción, después de la segunda quema de la cocina del convento de Atocha, "Hoy a la Concepción aclamaciones" $(27 \mathrm{v})$. — 25. Estando un religioso dominico hablando de la Concepción poco decente en una visita un gato que estaba en la sala le saltó al pescuezo y le maltrató mucho, 
"Un dominico enemigo" (28). - 26. A ese devoto gato, "Gato ilustre, que a fieras manotadas" (28v). - 27. Consideración sobre el motivo que pudo haber para achacar a la madre de Dios siempre pura siempre santa el pecado original, "Virgen, nadie culpada os ha creído" (29v). - 28. Pintura de un lugar adonde el autor pidió un agosto, "Oye, Catuja, dulce hechizo mío" (31). - 29. Otra pintura a una dama, "Sepan todos y todas que yo adoro" (37). -30. Quejándose de una ausencia, "Desde que el sol ardiente" (40v). —31. A una pobre que salió muy estropeada de un mal francés habido en buena guerra del mismo autor, "Un mal francés, Marica, tan grosero" (43). - 32. A una monja desdeñosa y capacha, "Lisis, tu favor invoco" (43). — 33. A una dama que, estando destocada, se asomó a una ventana y su galán la asió una mata de cabello, "Suelto el cabello por el aire ufano" (43v). — 34 . Habiéndole pedido una mano un galán a una dama y no habiéndola conseguido, le pide un dedo, "Amoroso, prudente y cortesano" (44). —35. Desmiente las desconfianzas de una dama un galán con un retrato suyo algo desparecido, "Rudo pincel de mano inadvertida" (44v). - 36. Al mismo asunto otro, "Por los yerros, Lisis bella, de un traslado" (45). — 37. Al ponerse una dama en la guedeja unos jazmines que aún no habían salido del botón y a pocas horas se abrieron en el mismo pelo, "De emboscada entre matas de tu pelo" (45). 38. Que a uno le viene a la media pierna al dueño del asunto, "Breve pie reducido a cárcel breve" (45v). - 39. Al mismo asunto. Otro jocoso, "Cómo quieres, Anarda, que sea casto" (46). - 40. Otro jocoso, "Ya no puedo vivir si no me capo" (46). —41. Al desaliño de los versos de un poeta de polaina y greguescos, "Disparates, Antón, muy mal zurcidos" (46v). -42. A uno que se llamaba Cruz y perseguía a autor por haberle pedido unas suelas, "Cruz, si cristiano soy" (47). — 43. Al mismo asunto, "Pedite, mi buen Cruz, suelas" (47). — 44. Soneto jocoso, "Estaba Lisis en campal batalla" (48v). — 45. A una monja pidiéndole celos de un hombre que tenía por apellido Puertopobre, "De mis finezas el bajel incierto" (48v). -46. Pintura a una dama, "Dulce Lisis de mis ojos" (49). - 47. Pidiendo a una dama unas medias por haber roto otras, "Belisa el chasco celebra" (50). - 48. Pidiendo a una señora un poco de arrope para dar a una dama, "Pues vuestra piedad me abriga" (51v). — 49. Otro a otro asunto, "Bizarro amor me desvela" $(51 \mathrm{v})$. — 50. Sátira a una dama por quien su galán padecía las penas del purgatorio, "Marica, viéndote hermosa" (52). — 51. De un amante a su dama, "Bien puede, Lisis, un triste" (53). — 52. A una dama que dio licencia a su galán para que la quisiera, "Licencia solo me has dado" (54v). — 53. A un galán que gastaba con su dama poco dinero y mucha prosa, "Anfriso, con atención” (55v). — 54. Enamorando a una dama cuyo nombre era Palma, "Palma, en viendo tu beldad" (56v). —55. Pidiendo celos una dama a su galán de un fraile italiano, de quien el otro galán confesaba era muy querido. Y, 
siendo muy lindo, se alababa de ello, "Don Juan, no tengo por bueno" (57v). — 56. Pintura a una ama, "Pues que me han dado licencia" (57v). - 57. Otra pintura, "Cuenta con el retrato", (59). - 58. Otra, "Con licencia de Silvia" (60). — 59. A una dama que dio a su galán unas pelotas, "Ya que tan galante has sido" (60v). —60. De un galán que estando para ausentarse de una dama la envió una vela blanca, "De pedir nunca yo fuera" (61). —61. A una dama, "Marica, a tu sucia cara" (62v). —62. Despedida de una dama, "Adiós, Leonor de mi vida" (62v). —63. A una dama presumida, "Clori, que para ser linda" (64). —64. A una ausencia, "En aquesta soledad" (65). —65. Amante callado y sospechoso, "Solo el silencio testigo" (65v). - 66. A un borracho, "A uno que se hace una uva" (66v). - 67. Dando chasco a un borracho, "Clodio, del mundo en la plaza" $(67 \mathrm{v})$. - 68. A un estudiante que comió menudo, "Un estudiante de hogaño" (68v). —69. Sueño jocoso "Cansado anoche de estar" (69). — 70. Al desengaño del mundo del mundo, "Quiero, pues es ocasión" (79). -71. Quintillas jocosas, "Vengar quiero mis rencillas" (82). — 72. El mismo autor a sus quintillas, "A la desatada llaga" (84). — 73. A unos ojos azules, "Desde que tus niñas bellas" (84). — 74. A una dama fácil, "Tu arroz, Marica, me enfada" (84v). — 75. Habiendo perdido una dama por causa del autor cien reales, él la envió dos y al no quererlos recibir escribió esta décima, "Cien reales por mí perdiste" (84v). — 76. Contra monjas, "Un ciego soy desgraciado" (85). — 77. Décimas amorosas, "Para qué es tu atrevimiento" (86). —78. A una dama que, estando destocada, se asomó a una reja y su galán la asió una mata de cabellos, "A una reja qué ventura" (87). —79. Sátira, "Quisimí, quisimona, hola" (88). —80. Epigrama gracioso, "El pañuelo desembolsa" (89v). - 81. A diferente asunto. Otro. "Marica, no desdeñosa" $(89 \mathrm{v})$. - 82 . Habiendo un poeta hecho un satírico contra otro poeta, se le respondió cagándose en él y con estas dos buenas, "Tu romance, Andrés, leí” (90). — 83. Letra burlesca, “A Pascuala dijo Bras” (90v). — 84. Desengaño del deleite sensual. Jácara, "En la villa de Carrión” (92v). — 85. Sátira, "En Málaga vi a Rufina” (93v). — 86. A Valenzuela. Sátira, "Fernando, a quien por soberbio" (94). — 87. Pregón, "En la ruda política mía" (95). — 88. Otro pregón, "En la firme política nuestra" (95v). — 89. Habiendo visto el pie a una dama, dijo estas décimas, "En el mar de tu hermosura" (96). — 90. A una dama que, estando ausente y sangrada, pedía celos a su galán, "Mi bien, juro por mi amor" (97). -91. A una dama porque quemó un papel, "No quieran tus sinrazones" (98v). — 92. A uno muy preciado de valiente, siendo gallina, "Es de Fausto la fiereza” (98v). — 93. A una dama, “Con modo ya más humano" (99v). — 94. Amante, callado y sospechoso, "En sospechoso amor toca" (100). - 95. A una dama que habiendo gastado su mocedad con frailes a la vejez decía mal de ellos y se había empeñado con un sacristán. Sátira, "Marica que a decir mal" 
(101). —96. Soneto, "Casose de un arzobispo el despensero" (102). —97. A un hombre en abreviatura fraile meñique que, hipócrita de estatura, se engrandece a costa del alcornoque. Sátira, "Oye, tarazón de frailes" (102v). — 98. Convidando una dama a su galán a finezas amorosas. En metáfora de un juego de hombres, "Ya, Fabio, que hemos llegado" (104). 99. A unas doncellas que querían bien a unos portugueses y estuvieron encerrados por ellos en una cuadra, "Queridas, mucho me enfada" (104v). —-100. Sermón para monjas, "Per signum crucis de la vara" (106). — 101. Tono, "Del rumbo de Francelisa" (110v). — 102. Tono, "Fuera, fuera, fuera que Juanilla" (111). —103. Otro tono, "Bellísimo Narciso" (111v). — 104. Otro tono, "Los ganados de Fileno" (112). — 105. Otro tono, "Genil, galán de los ríos" (112v). - 106. Otro tono, "Sonoro arroyuelo" (113). —107. Juicio de un aficionado, "Este libro bien mirado" (113).

\subsubsection{Biblioteca Menéndez Pelayo, ms. 156}

Obras líricas, humanas y sagradas, por el reverendísimo padre Damián Cornejo... año de 1737. S. XVIII. 149 h. (210 x 150). Enc. En pasta. Fol. Antigua. Olim: M 70. Se trata de un manuscrito, escrito a dos manos, que contiene poesías de carácter sacro y festivo atribuidas a Damián Cornejo. Incluye una dedicatoria de Barbieri a Menéndez Pelayo, la cual está fechada en 1893. Cf. Artigas y Ferrando (376-384).

-1. El agosto del fraile, "Oye, Catuja, dulce hechizo mío" (2). - 2. Pintura a una dama, "Sepan todos y todas que yo adoro" (8). - 3. Lamentando la ausencia de cierta dama, "Desde que el sol ardiente" (12). - 4. Pintura a una dama, "Dulce Lisis de mis ojos" (15). — 5 . Pidiendo asunto en una academia no se le dieron por estar todos repartidos y le encargaron vistiese una dama, que a orillas de un río, "Yo soy, ilustre academia" (16). — 6. Sátira a unos colegiales, como para ellos, que dieron moscas confitadas a unas damas, "Éranse dos licenciados" (18). - 7. Jeringa en sátira a estas damas que habiéndose hartado de moscas quedaron ahítas. Jeringa en sátira, "Óiganme damas que empuño" (20). — 8. Sátira a un borracho, "A uno que se hace una uva" (21). - 9. Dando a otro borracho vaya, "Clodio, del mundo en la plaza" (22). — 10. Sátira a un estudiante porque comió menudo, "Un estudiante de hogaño" (23v). - 11. Sueño jocoso, "Cansado anoche de estar" (24). — 12. A una dama que estando sangrada y entrando a verla su amante se le soltó la sangría, "Vengar quiero mis rentillas" (35v). — 13. A estas quintillas, "A la desatada llaga" (37v). - 14. Epigrama a ojos azules, "Desde que tus niñas bellas" (38). —15. A una dama fácil, “Tu arroz, Marica, me 
enfada" (38v). - - 16. Habiendo perdido una dama cien reales por causa del autor, él la envió dos y al no quererlos recibir escribió esta décima, "Cien reales por mí perdiste" (38v). — 17. Contra unas monjas, "Un ciego soy desgraciado" (38v). - 18. Al haber visto el pie a una dama, "En el mar de tu hermosura" (40). - 19. A una dama que, estando ausente y sangrada, pedía celos a su galán, "Mi bien, juro por mi amor" (41v). — 20. A uno muy preciado de valiente, siendo gallina, "Es de Fausto la fiereza" (43). - 21. A unos mozos que salieron a torear y se cayeron todos, "De Pinto para un festejo" (44). - 22. Sátira a una dama que, siendo galanteada de muchos, se casó con un sacristán, "Dios te socorra, Marica" (45). 23. Soliloquio amoroso, "Para qué es tu atrevimiento" (47). - 24. A una dama que, estando destocada, se asomó a una reja y su galán la asió una mata de cabellos, "A una reja qué ventura" (47v). - 25. A una dama pidiendo celos, "Con modo ya más humano" (49). —26. Amante callado y sospechoso, "Solo el silencio testigo" (50). —27. A una dama que gastó lo mejor de su mocedad, y a la vejez decía mal de ellos, y se había empeñado con un sacristán, "Marica, que a decir mal” (51). —28. Sátira contra varias personas, "Quisimí quisimona, hola" (52). - 29. Sátira a un hombre en abreviatura, fraile meñique que, hipócrita de estatura, se engrandece a costa del alcornoque, "Oye, tarazón de frailes" (54). — 30. Al convidar una dama a su galán a finezas amorosas. En metáfora de un juego de hombre, "Ya Fabio que hemos llegado" (55). - 31. Habiendo un poeta hecho un romance sátiro contra otro pobrete, se le respondió cagándose en él y con estas décimas, "Tu romance, Andrés, leí" (57). - 32. Epigrama gracioso a una dama, "El pañuelo desembolsa" (57v). - 33. Otro a diferente asunto, "Marica, no desdeñosa" (58). - 34. A unas doncellas que querían bien a unos portugueses, y estuvieron por ellos encerradas en una cuadra, "Queridas, mucho me enfada" (58). - 35. A un catedrático secular, siendo en la condición muchacho, no quería leer algunas veces enfadándose de muy pocas cosas, "Pedro, mi ingenio recela" (59). — 36. A una dama que por interés se daba a todos, "Escúchenme unos esdrújulos" (60). — 37. Pidiendo a una dama unas medias por haber roto otras, "Belisa el chasco celebra" (61v). 39. Pidiendo a una señora un poco de arrope para dar a una dama, "Pues vuestra piedad me abriga" (63). - 40. Sátira a cierta dama por quien su galán padecía insufribles penas, "María, viéndote hermosa" (63v). — 41. Al mismo asunto, "Malo me siento, Marica" (65). — 42. Declarando su pasión a una dama, "Bien puede Lisis un triste" (66v). — 43. A una dama que dio licencia a su galán para que la quisiera, "Licencia solo me has dado" (68). — 44. Fraterna exhortatoria a un galán que gastaba con su dama poco dinero y mucha prosa, “Anfriso, con atención" (69). — 45. Enamorando a una dama cuyo nombre era Palma, "Palma, en viendo tu beldad" (70). — 46. Pidiendo celos una dama a su galán, por haberla dicho era muy querido 
de un fraile italiano. Y, siendo muy lindo, se alababa de ello, "Don Juan, no tengo por bueno" (71). - 47. A una dama que lloraba del dolor de un divieso que le salió en la mano, "Hoy, Clori, pretendo amarte" (71). — 48. A una dama que dio a su galán unas pelotas, "Ya que tan galante has sido" $(72 \mathrm{v})$. - 49. Enviando a una dama una vela blanca estando para ausentarse de ella, "De pedir nunca yo fuera" (73). - 50. A una dama fea y puerca, "Marica, a tu sucia cara" (74v). - 51. Sátira que se le cantó a un corcovado estando presente en la calle, desde la reja de una dama que galanteaba y ella le aborreció, "Un galán corto de talle" (75). — 52. Despedida de un galán a su dama, "Adiós, Leonor de mi vida" (76). — 53. A una fea y presumida, "Clori, que para ser linda (77). —54. Lamentando una ausencia, "En aquesta soledad" $(78 \mathrm{v}) .-55$. Al mismo asunto glosando esta redondilla, "Solo el silencio testigo" $(79 v)$. - 56. Manifiesta un amante a la dama su pasión, "Pues que me han dado licencia" (80v). - 57. A una pobre que salió muy estropeada de un mal francés habido en buena guerra, "Un mal francés, Marica, tan grosero" (81v). - 58. A una monja hermosa y desdeñosa, "A todos tu beldad rigores flecha" (82). — 59. Para coronar el soneto, "Lisis, a tu favor invoco" $(82 v)$. - 60. A una dama que, estando destocada, se asomó a una reja y su galán la asió una mata de cabello, "Suelto el cabello por el aire ufano" (82v). —61. Habiendo pedido un galán a su dama la mano, no se la quiso dar y después la pidió un dedo, “Amoroso, prudente y cortesano" (83). — 62 Desmintiendo un galán las desconfianzas de su dama con un retrato suyo algo desparecido, "Rudo pincel de mano inadvertida" (83v). —63. Al mismo asunto, "Por los yerros, Ysbella, de un traslado" (84). - 64. Al ponerse una dama unos jazmines en botón y a pocas horas se abrieron en ella, "De emboscado entre matas de tu pelo" $(84 \mathrm{v})$. - 65. Soneto panegírico que a uno le venía a la media pierna a la dama concepto del asunto, "Breve pie reducido a cárcel breve" (85). —66. Al mismo asunto, "Cómo quieres, Anarda, que sea casto" (85). - 67. Soneto jocoso, "Ya no puedo vivir si no me capo" (85v). -68. A los desaliñados versos de un poeta de polaina y greguescos. Soneto satírico, "Disparates, mi buen Antón, suelas" (86). — 69. A uno que se llamaba Cruz y perseguía al autor porque le había pedido unas suelas, "Cruz, si cristiano soy" (86v). — 70. Al mismo asunto, "Apenas, señor, te viste" (86v). —-71 Al mismo asunto, "Pedite, mi bien Cruz, suelas" (87v). - 72. Soneto jocoso, "Estaba Lisis en campal batalla" (88v). — 73. A una monja pidiéndole celos a un hombre que tenía por sobrenombre Puerto, "De mis finezas el bajel incierto" (89). — 74. Sátira a un jurador, "Señor, jurador he sido" (89v). — 75. Letra burlesca, “A Pascuala dijo Bras" (90). — 77. Sátira, "En Málaga vi a Rufina” (117). — 78. Sátira a don Fernando Valenzuela, "Fernando, a quien por soberbio" (92v). — 79. Pregón, "En la ruda política mía" (94). — 80. Otro pregón, "En la firme política nuestra" (94v). - 
81. A una dama porque quemó un papel, "No quieran tus sinrazones" (95). — 82. Tono, "Del rumbo de Francelisa" (95v). — 83. Otro tono, "Fuera, fuera que Juanilla" (95v). — 84. Otro tono, "Los ganados de Liseno" (95v). — 85. Otro tono, "Gentil, galán de los ríos" (96). 86. Otro tono, "Sonoro arroyuelo" (96v). — 87. A un estudiante que se fue sin hacer cuenta con la huéspeda, "Un estudiante este curso" (96v). — 88. A una dama que cortándose un callo por acordarse de su galán se hirió un pie, "De un pie escribir quiero en suma" (97v). —89. A Judas, "Por tomar Judas el grado" (98v). — 90. A una que en la primera noche de tal, la hizo cerrada la cama, "Musa mía, con astucia" (99v). — 91. Sacudiéndose un fraile de diferentes romances que satirizaron, porque estando en la visita con unas monjas, le dio gana de obra y soltó las bragas en el locutorio, "Pues que su entretenimiento" (101). —92. A una monja que pretendía que cierto sujeto prosiguiese en hablarle, "Nise, a quererte me inclino" (102). —93. En respuesta a los antecedente de la monja "No más amistad, amor" (103). 94. Traslado de una carta enviada a su colegio de la Universidad de Alcalá por un colegial, dándole cuenta de lo que les sucedía en su curato, pues así lo tenía ofrecido, "Reyes míos, desde el día" (103v). — 95. Soneto, "Esta mañana en Dios en enhorabuena" (105). —96. Soneto, "Lo menos bello y más apetecido" (105v). — 97. A un borracho que saliendo de la taberna, de una ventana cayó un jarrón lleno de vino y le mató, "De una taberna salía" (106). —98. Pintando un tudesco borracho, "Un tudesco, humana cuba." (107) - 99. A la profesión que en culto del misterio de Purísima Concepción de nuestra Señora después de la segunda quema de la coruña del convento de Atocha, de los padres de Santo Domingo, "Hoy a la Concepción aclamaciones" $(107 \mathrm{v}) .-100$. Estando un religioso dominico hablando poco decente en una visita del misterio de la Concepción un gato que había en la sala le saltó al pescuezo, y le maltrató mucho, "Un dominico enemigo." (108). A este devoto gato, "Gato ilustre que a fieras manotadas" (108v). - 101. Dando un clavel a una dama, "Clavel, pues por tus colores" (108v). — 102. De cuanto peligro es la mujer, "Guardar la mujer es ley." (109). —103. Versos al desengaño del mundo, “Quiero, pues es ocasión” (109v). —103. A un novicio que profesó en San Diego de Alcalá, "Oiga, hermano fray Francisco" (112). 104. Vejamen a san Diego, "Un devoto singular" (138). — 103. Otro vejamen al mismo santo, "Otra vez tengo la pluma" (114v). — 104. Al mismo San Diego, "San Diego sí hace milagros" (115v). — 105. Al mismo santo otro, "Diego sí que supo bien" (116v). — 106. Al mismo santo, "De Diego muy por menor" $(117 \mathrm{v})$. —107. Al mismo santo, pidiéndole un tuerto remedio para su ojo, "Un tuerto soy desgraciado" (118v). - 108. En Alcalá, año de 1662, se cantó este romance, "Un corcovado poeta” (119). —109. Al mismo santo, "Después de por qué se usa" (120v). — 110. Al mismo santo, "Todo el mundo conmovido" (121). - 
111. Habiendo enviado la reina al santo una medalla, "Es el asunto una medalla" (122). 112. A la jornada que hizo el santo a Madrid, "San Diego, si me remedias" (123). —113. Al mismo santo en su fiesta, "A conjurar estas nubes" (123v). —114. A la Concepción de nuestra señora, "Hanme mandado una cosa" (125v). — 115. Al mismo asunto, "La más hidalga hermosura" (126v). — 116. Al mismo asunto, "La Concepción este día” (127). 117. Al mismo asunto, "De tu Concepción, Señora" (127v). - 118. Al mismo asunto, "Oigan lo que hace en limpio" (128v). —119. Al mismo asunto, "De una niña la grandeza" (129). -120. Al mismo asunto, "Sabed, señora doncella" (130). — 121. Al mismo asunto. En títulos de comedias, "Érase una virgen pura" (131v). —122. A María santísima. En títulos de comedias, "En títulos virgen pura" (132v). —123. A San Diego de Alcalá, "Hoy con gusto a cantar llego" (133). - 124. A san Francisco de Asís, "De pie quebrado unas coplas” (133). —125. Al mismo asunto, "De Francisco por menor" (134). —126. A santa Clara, "Hoy mi devoción aclama” (135). — 127. A san Juan Bautista "Al señor Bautista, el jaque” (138). 128. Al celebrar la Octava del Santísimo Sacramento en el día de señor san Juan, "Hola, que llega la fiesta y falta la solfa" (138). - 129. Al mismo asunto, "Haced que la gracia encuentre" $(143 \mathrm{v})$. - 130. A la resurrección de nuestro señor, "De santa resurrección" (144v). - 131. A Cristo señor nuestro en la cruz, "Dulce Jesús mío". -132. Acto de contrición delante de un crucifijo, "Un pecador soy, Dios mío" (146v). —133. Petición a nuestra señora, "Divina madre de gracia" $(149 \mathrm{v}$,$) . - 134. Pintura de un lugar donde pidió el$ padre Damián Cornejo un agosto, "Oye, Catuja, dulce hechizo mío” (150).

\subsubsection{Biblioteca Pública de Toledo, ms. 447}

Versos de varios autores. S. XVIII. 130 h. (23 x 16). Enc. Pergamino. Fol. Antigua. Olim. n.d. Se trata de un manuscrito, realizado a varias manos de distinta época, que recopila de manera aleatoria poemas sacros y profanos atribuidos a Damián Cornejo y a León Marchante [referencia posterior al texto] y poesías Jerónimo de Sosa y de Eugenio Gerardo Lobo y Francisco de Toledo. Incluye, además, Vergel florido y ameno jardín [fray Francisco de Toledo] y el Entremés de las sombras. Cf: Esteve (477).

-1. Pintura a una dama del ingenioso Cornejo, "Sepan todos y todas que yo adoro" (1). 2. Quejándose de una ausencia (León), "Desde que el sol ardiente" (2v). —3. Pintura a una dama (León), "Dulce Lisis de mis ojos" (5). - 4. Habiendo pedido asunto en una Academia y no habiéndosele dado por estar repartido, dijéronle que * por asunto el no haberle dado pie que vistiese a una dama que otro dejaba a la orilla de un río (León), "Yo soy, ilustre 
Academia" (6v). - 5. A un catedrático siendo la condición muchacho no quería leer algunas veces, enfadándose de muy pocas cosas, "Pedro, mi ingenio recela" $(8 \mathrm{v})$. —6. A una dama que estando sangrada pedía celos a su galán (León), "Mi bien, juro por mi amor” (9). — 7 . A uno muy preciado de valiente siendo un gallina (León), "Es de Fausto la fiereza" (10v). -8. De unos mozos que salieron a torear y cayeron todos del ingenioso Cornejo (León), "De Pinto para un festejo" (10v). — 9. Sátira a un hombre, en abreviatura fraile meñique que, hipócrita de estatura, se engrandece a costa del alcornoque de Cornejo (León contra Cornejo), "Oye, tarazón de fraile" (11). - 10. Versos en eco al desengaño del mundo, "Quiero, pues es ocasión" (11v). - 11. A la Concepción (León), "Hanme mandado una cosa" (32v). - 12. Vejamen a san Diego (León), "Un devoto singular" (33). —13. Otra de (León), "Otra vez tengo la pluma" (33v). — 14. Al mesmo (León), "San Diego, si hacer milagros" (34). —15. Al mesmo santo (León), "Diego sí que supo bien" (34v). — 16. Al mesmo santo pidiendo un tuerto remedio para su ojo (León), "Un tuerto soy desgraciado" (35v). - 17. Al mesmo santo pidiendo un corcovado remedio para la corcova (León), "Un corcovado poeta" (35v). — 18. Al mesmo (León), "Después que porque se usa" (36v). — 19. Al mesmo santo, "Todo el mundo conmovido" (36v). - 20. Al santo tomando por asunto de una medalla de oro que le envió la Reina (León), "La Reina, nuestra Señora” (37). —21. A la jornada que hizo san Diego a Madrid (León), "San Diego, si me remedia” (37v). — 22. A la Concepción en títulos de comedia, "La más hidalga hermosura" (38v). — 23. Letra a san Diego de Alcalá, "A conjurar estas nubes" (39). —-24. A la Concepción, "La Concepción este día" (39v). 25. A lo mesmo, "De tu concepción, Señora" (39v).

\subsubsection{Archivos españoles}

\subsubsection{Archivo Histórico Nacional, L 1053 (inédito)}

Noticias varias de Galicia, S. XVIII-XIX, 290 h. (22 x 15). Enc. Moderna. Moderna. Se trata de un manuscrito, realizado a varias manos, que alberga diversos documentos administrativos, judiciales y eclesiásticos relacionados con la comunidad de Galicia, una colección de poesías sacadas del teatro moral y político de la noble academia compostelana y las "Obras de fray Damián Cornejo del Orden de san Francisco de la observancia, lector jubilado y cronista de su religión, obispo que fue de Mondoñedo". 
-1. Pintura de una ausencia de una dama, "Desde que el sol ardiente" (186). —2. Pintura a una dama, "Sepan todos y todas que yo adoro" (188v). - 3. A una pobre que salió muy estropeada, "Un mal francés, María, tan grosero" (192). - 4. A una monja hermosa desdeñosa: soneto que se corona con estas dos, "Lisis, tu favor invoco" (192v). — 5. A una dama que, estando destocada, se asomó a una reja y su galán la asió una mata de cabellos, "Suelto el cabello por el aire ufano" (193). - 6. Al ponerse una dama en la guedeja unos jazmines que aún no habían salido del botón y a pocas horas se abrieron en el mismo pelo, "De emboscado entre matas de tu pelo" $(194 \mathrm{v})$. - 7. Soneto panegírico que a uno le viene a la media pierna al dueño del asunto, "Breve pie reducido a cárcel breve" (195). — 8. A uno que se llamaba Cruz y perseguía al autor por haber pedido unas suelas, "Cruz, si cristiano soy, qué me persigues" (195). — - Al mismo asunto, “Apenas, señor, te viste” (195v). — 10. Al mismo asunto, "Pediste, mi bien Cruz, suelas" (196v). - 11. A una monja pidiéndola celos a un hombre que tenía por sobrenombre Puerto, "De mis finezas el bajel incierto" (197v). - 12. A la procesión que hicieron los padres de Santo Domingo en reverencia de la Concepción, después de la segunda quema de la cocina del convento de Atocha, "Hoy a la Concepción aclamaciones" (198). — 13. Estando un religioso dominico hablando de la Concepción poco decente en una visita, un gato que estaba en la sala le saltó al pescuezo y le maltrató mucho. A este asunto, "Un dominico enemigo" (198v). —-14. A este devoto gato, "Gato ilustre, que a fieras manotadas" (199). —15. Habiendo el autor pedido asunto en una Academia para escribir, no se le dieron por estar todos repartidos y le dijeron que tomase por pie el no habérsele dado y vistiese a una dama que otro dejaba desnuda a orillas de un río, "Yo soy, ilustre Academia" (199). - 16. A unos colegiales que dieron a unas damas moscas confitadas. Sátira como para ellos del mismo autor, "Eranse dos licenciados" (201). -18. A estas damas por hartarse de las sobredichas moscas quedaron ahítas. Jeringa en sátira, "Óiganme damas que empuño" (203). — 19. A un borracho, "A uno que se hace una uva" (202v). — 20. Dando chasco a un borracho, "Clodio, del mundo en la plaza" (203). 21. Sátira a un estudiante que comió menudo, "Un estudiante de hogaño" (203v). — 23. Sueño jocoso, "Cansado anoche de estar" (204). — 24. Quintillas jocosas, "Vengar quiero mis rencillas" $(209 \mathrm{v})$. — 25. El mismo autor a sus quintillas, "A la desatada llaga" (210v). -26. A unos ojos azules. Epigrama, "Desde que tus niñas bellas" (210v). - 27. Contra monjas, "Un ciego soy desgraciado" (210v). — 28. Al haber visto el pie a una dama, "En el mar de tu hermosura (211). - 29. A una dama que, estando ausente y sangrada, pedía celos a su galán, "Mi bien, juro por mi amor” (211v). - 30. A unos mozos que salieron a torear y cayeron todos, "De Pinto para un festejo" (212v). - 31. Sátira a una dama que, siendo 
galanteada de muchos, se casó con un sacristán, "Dios te socorra, Marica" (213). — 32 . Décimas amorosas, "Para qué es tu atrevimiento" (216v). - 33. A una dama que, estando destocada, se asomó a una reja y su galán la asió una mata de cabellos, "A una reja qué ventura" (217). - 34. A una dama, "Con modo ya más humano" (214v). —35, "Amante, callado y sospechoso, "Solo el silencio testigo" (215). - 36. Sátira a una dama que gastó lo mejor de su mocedad con frailes y a la vejez decía mal de ellos y se había empeñado con un sacristán, "Marica, que a decir mal” (215v). —37. Sátira, "Quisimí quisimona, hola." (216). -38. Sátira a un hombre en abreviatura fraile que, hipócrita de estatura, engrandece a costa del alcornoque, "Oye, tarazón de frailes" (216v). - 39. Habiendo un poeta hecho un satírico contra otro pobrete, se le respondió cagándose en él y con estas, "Tu romance, Andrés, leí" $(217 \mathrm{v})$. - 40. Epigrama gracioso a una dama, "El pañuelo desembolsa" (218). - 41. Otro a diferente asunto, "Marica, no desdeñosa" (218). — 42. A unas doncellas que querían bien a unos portugueses y estuvieron por ellas encerrados en una cuadra, "Queridas, mucho me enfada" (218). - 43. A un catedrático secular, siendo en la condición muchacho, no quería leer algunas veces enfadándose de muy pocas cosas, "Pedro, mi genio recela" (218v) — 44 . Sátira a una dama que por el interés se daba a todos, "Escúchense unos esdrújulos" (219). 45. Pidiendo a una dama unas medias por haber roto otras, "Belisa el chasco celebra" (220). - 46. Sátira a cierta dama por quien su galán padecía las penas del purgatorio, "Marica, viéndote hermosa" (220v). — 47. Otra sátira al mismo intento, "Malo me siento, Marica" (221). - 48. Amante a su dama, "Bien puede, Lisis, un triste" (222). - 49. A una dama que dio licencia a su galán para que la quisiera, "Licencia solo me has dado" (222). 50. Fraterna exhortatoria a un galán que gastaba con su dama poco dinero y mucha prosa, “Anfriso con atención" (223). - 51. Enamorando a una dama cuyo nombre era Palma, "Palma, en viendo tu beldad" (223v). - 52. A una dama que lloraba mucho de dolor de un divieso que la salió en una mano, "Hoy, Clori, pretendo amarte" (324). — 53. A una dama que dio a su galán unas pelotas, "Ya que tan galante has sido" (224v). — 54. Enviando a una dama una vela blanca a tiempo que está para ausentarse de ella, "De pedir nunca yo fuera" (225). - 55. A una dama, "Marica, a tu sucia cara" (224v). - 56. A un corcovado que galanteaba a una dama y la daba música y ella le aborrecía y desde su casa le cantaron esta sátira, "Un galán corto de talle" (225). — 57. Despedida de una dama, "Adiós, Leonor de mi vida" (226). — 58. A una ausencia, "En aquesta soledad" (227). —59. Amante, callado y sospechoso, "Solo el silencio testigo" (227v). —60. Pintura a una dama, "Pues que me han dado licencia" (228). —61. Décima, "De Apolo en la facultad" (228v). —62. A la boda de un despensero de un señor arzobispo, "Casose de un arzobispo el despensero" (228v). —63. 
A Pepa, "Bizarro amor me desvela" (229). —64. Del desengaño del mundo y retrato de las mujeres, "Quiero, pues es ocasión" (229v). —65. Habiendo perdido una dama por causa del Cornejo cien reales, la envió dos y al no quererlos recibir escribió a nuestro padre esta décima, "Cien reales por mí perdiste" (232v). —66. Estando el padre Cornejo convaleciente de una enfermedad da cuenta de ella a un amigo en el siguiente, "Válgame, doña Talía" (233). —67. Una dama que casó con un impotente, "Casose Menga con Blaso" (243v). 68. Pintura a una dama, "Dulce Lisis de mis ojos" (244v). - 69. Pintando a una dama, "Cuenta con el retrato" (246). - 70. Otro, "Con licencia de Silvia" (247v). — 70. Soneto, "Estaba Lisis en campal batalla" (248). — 71. "Por el ordinario avisa" (248v). — 72, "En busca de un mayorazgo" (249). — 73. Soneto, "Ya no puedo vivir si no me capo" (249). 74. Otro al pie de una dama, "Cómo quieres, Anarda, que sea casto" (249v). - 75. Pintura de un agosto, "Oye, Catuja, dulce hechizo mío" (249v). — 76. "Es su boca tamañita" (255v). —77. Jácara al desengaño del deleite sensual, "En la villa de Carrión” (256). — 78. A una fea presumida, "Clori, que para ser linda (257). — 79. Sátira a Rufina, "En Málaga vi a Rufina” (258). — 80. Letra burlesca, “A Pascuala dijo Blaso" (259). —81. Sermón para monjas, "Per signum crucis de la vara" (260). — 82. A una dama porque quemó un papel, "No quieran tus sinrazones" (266). — 83. Tono, "Del rumbo de Francilisa" (266v). — 84. Otro, "Fuera, fuera que Juanilla" (266v). — 85. Otro tono, “Bellísimo Narciso” (267).

\subsubsection{Bibliotecas internacionales}

\subsubsection{British Library, ms. Egerton 1889}

Obras poéticas M. S. del reverendísimo padre fr [ay] Damián Cornejo, que también compuso la Crónica de nuestro padre san Francisco. S. XVIII. 116 h. (110 x 160). Enc: En pasta. Fol. Antigua. Olim: n.d. Se trata de un manuscrito, escrito a varias manos, que contiene mayoritariamente poesías de temática sacra y profana atribuidas a Damián Cornejo, algunos poemas humanos de Luis de Ulloa y de León Marchante y diversas anotaciones sobre la obra Enfrosina de Jorge Ferreira. En la segunda hoja de guarda contiene una nota que indica que en el siglo XIX perteneció a un editor londinense "H. Baillerie". Cabe señalar que los últimos poemas (95-115) no aparecen en el índice, pues se añadieron al manuscrito con posterioridad. Cf: Gayangos (56-62). 
—1. Tratado poético compuesto por un religioso minorita. Pintura de un lugar donde el autor pidió un agosto, "Oye, Catuja, dulce hechizo mío" (2). - 2. Otra pintura a una dama, "Sepan todas y todos que yo adoro" (8). - -3. Quejándose de una ausencia, "Desde que el sol ardiente" (11). - 4. A una pobre que salió muy estropeada de un mal francés habido en buena guerra. Del mismo autor, "Un mal francés, Marica" (14). — 5. A una monja hermosa, desdeñosa y capacha, "Lisis, tu favor invoco" (14). - 6. A una dama que, estando destocada, se asomó a una reja, y su galán la asió una mata de cabello, "Suelto el cabello por el aire ufano" (15). - 7. Habiéndole pedido una mano un galán a una dama y no habiéndola conseguido, le pide un dedo, "Amoroso, prudente y cortesano" (15). — 8 . Desmiente las desconfianzas de una dama su galán con un retrato suyo algo desparecido, "Rudo pincel de mano inadvertida" (16). — 9. Otro soneto al mismo asunto, "Por los yerros, Ysbella, de un traslado" (16). — 10. Al ponerse una dama en la guedeja unos jazmines que aún no habían salido del botón y a pocas horas se abrieron entre el mismo pelo, “'De emboscada entre matas de su pelo" (16). - 11. Soneto panegírico que a uno le viene a la media pierna al dueño del asunto, "Breve pie reducido a cárcel breve" (17). — 12. Al mismo asunto, "Cómo quieres, Anarda, que sea casto" (17). —13. Otro, "Ya no puedo vivir si no me capo (17). —14. Al desaliño de los versos de un poeta de polaina y greguescos, "Disparates, Antón, muy mal zurcidos" (18). - 15. A uno que se llamaba Cruz y perseguía al autor por haberle pedido unas suelas, "Cruz, si cristiano soy, qué me persigues" (18). —-16. Al mismo asunto, "Apenas, Señor, te viste" (18). — 17. Otras al mismo asunto, "Pedite, mi buen Cruz, suelas" (19) - 18. Soneto jocoso, "Estaba Lisis en campal batalla" (19). — 19. A una dama pidiéndole celos de un hombre que tenía por sobrenombre Puerto, "De mis finezas el bajel incierto" (20). - 20. A la procesión que hicieron los padres de Santo Domingo en reverencia de la Concepción de Nuestra Señora después de la segunda quema del convento de Atocha, "Hoy a la Concepción aclamaciones" (20). - 21. Estando un religioso dominico hablando de la Concepción poco decentemente en una visita, un gato que estaba en la sala le saltó al pescuezo y le maltrató mucho, "Un dominico enemigo" (20v). - 22. A este devoto gato, "Gato ilustre, que a fieras manotadas" (21). — 23. Pintura a una dama, "Dulce Lisis de mis ojos" (21). - 24. Habiendo pedido asunto en una Academia para escribir, no se lo dieron por estar ya repartidos, y le dijeron que tomase por pie el no habérsele dado, y vistiese una dama que otro dejaba desnuda orillas de un río, "Yo soy, ilustre Academia" (21v). — 25. A una dama que se casó con un hombre impotente. Del maestro León, "Casosé Menga con Bras" (23v). - 26. A unos colegiales que dieron a unas damas moscas confitadas. Sátira como para ellos, "Éranse dos licenciados" $(24 \mathrm{v})$. - 27. A estas damas que por hartarse de las 
sobredichas moscas quedaron ahítas. Jeringa en sátira, "Óiganme, damas, que empuño" (25). -28. A un borracho, "A uno que se hace una uva" (25v). - 29. Dando chasco a un borracho, "Clodio, del mundo en la plaza" (26). — 30. Sátira a un estudiante que comió menudo, "Un estudiante de hogaño" (26v). - 31. Sueño jocoso, "Cansado anoche de estar" (27). - 32 . Versos en ecos al desengaño del mundo, "Quiero, pues es ocasión” (32). —33. Quintillas jocosas, "Vengar quiero mis rencillas" (33v). - 34. El mismo autor dando vejamen a sus quintillas, "A la desatada llaga" (34). — 35. A unos ojos azules, "Desde que tus niñas bellas" (34). - 36. A una dama fácil, "Tu arroz, Marica, me enfada" (34v). — 37. Habiendo perdido una dama por causa del autor cien reales, él la envió dos y, al no quererlos recibir, escribió esta décima, "Cien reales por mí perdiste" (34v). — 38. Contra monjas, "Un ciego soy desgraciado" (34v). - 39. Al haber visto el pie de una dama, "En el mar de tu hermosura" (35). - 40. A una dama que, estando ausente y sangrada, pedía celos a su galán, "Mi bien, juro por mi amor" (35v). - 41. A una dama porque quemó un papel, "No quieran tus sinrazones" (36). - 42. A uno muy preciado de valiente, siendo gallina, "Es de Fausto la fiereza" (36). - 43. A unos mozos que salieron a torear y cayeron todos, "De Pinto para un festejo" (36v). - 44. Sátira a una dama que, siendo galanteada de muchos poderosos, se casó con un sacristán, "Dios te socorra, Marica" (37). - 45. A una dama que, estando destocada, se asomó a una reja y su galán la asió una mata de cabellos, "A una reja qué ventura" (38). -46. A una dama, "Con modo ya más humano" (38v). - 47. Amante callado, sospechoso, "Solo el silencio testigo" (39). — 48. A una dama que gastó lo mejor de su mocedad con frailes y a la vejez decía mal de ellos, y se había empeñado con un sacristán, "Marica, que a decir mal" (39v). — 49. Sátira, "Quisimí quisimona, hola" (40). —50. A un hombre en abreviatura, fraile meñique, que, hipócrita de estatura, se engrandece a costa del alcornoque. Sátira, "Oye, tarazón de fraile" (40v). — 51. Convidando una dama a su galán a finezas amorosas. En metáforas de un juego de hombre, "Ya, Fabio, que hemos llegado" (41v). 52. Habiendo un poeta hecho un romance satírico contra otro pobrete, se le respondió cagándose en él y con estas dos décimas, “Tu romance, Andrés, leí” (42). —53. Epigrama gracioso, "El pañuelo desembolsa" (42). — 54. Otro a diferente asunto, "Marica, no desdeñosa" (42). — 55. A unas doncellas que querían bien a unos portugueses y estuvieron por ellos encerradas en una cuadra, "Queridas, mucho me enfada" (42). - 66. A un catedrático secular que, siendo en la condición muchacho, no quería leer algunas veces, enfadándose de muy pocas cosas, "Pedro, mi ingenio recela" (42v). — 57. A una dama que por el interés se daba a todos. Sátira en esdrújulos, "Escúchenme unos esdrújulos" (42). 58. Pidiendo a una dama unas medias por haber roto otras, "Belisa, el chasco celebra" (44). 
-59. Pidiendo a una señora un poco de arrope para dar a una dama, "Pues vuestra piedad me abriga" $(44 v)$. — 60. Otra a otro asunto, "Bizarro amor me desvela" (44v). —61. Sátira a cierta dama por quien su galán padecía las penas del Purgatorio, "Marica, viéndote hermosa" (44v). - 62. Otra al mismo intento, "Malo me siento, Marica" (45v). —63. De un amante a su dama, "Bien puede, Lisis, un triste" (45). - 64. A una dama que dio licencia a su galán para que la quisiera, "Licencia Solo me has dado" (47). —65. Fraterna exhortatoria a un galán que gastaba con su dama poco dinero y mucha prosa, "Anfriso, con atención" (47). - 66. Enamorando a una dama cuyo nombre era Palma, "Palma, en viendo tu beldad" (47v). - 67. Pidiendo celos una dama a su galán de un fraile italiano, de quien el dicho galán confesaba era muy querido. Y, siendo muy lindo, se alababa de ella, "Don Juan, no tengo por bueno.” (47). - 68. A una dama que lloraba mucho de dolor de un divieso que le salió en la mano, "Hoy, Clori, pretendo amarte" (47). —69. A una dama que dio a su galán unas pelotas, "Ya que tan galante has sido" (48v). - 70. Enviando a una dama una vela blanca a tiempo que estaba para ausentarse de ella, "De pedir nunca yo fuera" (49). — 71. A una dama, "Marica, a tu sucia cara" (49v). - 72. Sátira a un corcovado que galanteaba a una dama y la daba músicas, y ella le aborrecía y desde su casa le cantaron esta, "Un galán corto de talle" (50). —73. Despedida de una dama, "Adiós, Leonor de mi vida" (50v). — 74. A una fea presumida, "Clori, que para ser linda" (51). — 75. A una ausencia, "En aquesta soledad" (51v). - 76. Amante callado, sospechoso, "Solo el silencio testigo" (52). — 77. A un amigo que profesó en San Diego de Alcalá, "Oiga, hermano fray Francisco" (52v). — 78. Vejamen a san Diego, "Un devoto singular" (53). — 79. Otro vejamen al mismo asunto, "Otra vez tengo la pluma" (53v). — 80. Al mismo santo, "San Diego sí hace milagros" (54). — 81. Al mismo santo otro, "Diego sí, que supo bien" (55). — 82. Al mismo santo, "De Diego muy por Menor" $(55 \mathrm{v})$. — 83. Al mismo santo pidiéndole un tuerto remedio para su ojo, "Un tuerto soy desgraciado" (56). — 84. Otro. Cantose en Alcalá. Año de 1662, “Un corcovado poeta" (56v). — 85. Al mismo santo, "Después que por qué se usa" $(57 \mathrm{v})$. — 86. Al mismo santo, "Todo el mundo conmovido" (57v). — 87. Al mismo santo. Es el asunto una medalla de oro que envió la Reina, nuestra Señora, "La Reina, nuestra Señora" (58). — 88. Otro a la jornada que hizo el santo a Madrid, "San Diego, si me remedias" (59v). — 89. Otra letra que se cantó en la mesma fiesta, "A conjurar estas nubes" (60). — 90. A la Concepción, "Hanme mandado una cosa" (61). — 91. Otras al mismo asunto, "La más hidalga hermosura" (61). -92. Otras a lo mismo, "La Concepción este día" (62). —93. A lo mismo, "De tu concepción, Señora” (62v). — 94. A lo mismo otro, "Oigan lo que saca en limpio" (63). — 95. Al mismo asunto, "De una niña la grandeza" (63v). — 96. Al mismo asunto, "Sabed, 
señora doncella" (64). —97. A nuestro padre san Francisco, "De pie quebrado unas coplas" (64v). — 98. Al mismo asunto, "De Francisco por menor" (65). —99. A santa Clara, "Hoy de mi devoción aclama” (65v). - 100. A san Juan Bautista, “Al señor Bautista, el jaque” (66v). - 101. Acto de Contrición delante de un Crucifijo, "Un pecador soy, Dios mío" (67v). -102. Jácara a nuestra Señora en títulos de Comedias, "Érase una Virgen pura" (68v). 103. Sermón para las monjas. Del maestro León, "Per agnum crucis de a vara" (69v). 104. De un Jurador, "Señor, jurador he sido" (75v). —105. Al Nacimiento, "Escriben desde Toledo" (76). — 106. A la adoración de los Reyes, "De Oriente vienen tres Reyes" (76v). — 107. Letra burlesca, "A Pascuala dijo Bras" (77). —108. Desengaño del deleite sensual. Jácara, "En la villa de Carrión” (78). — 109. Sátira, "En Málaga vi a Rufina” (79). —110. Otra sátira a Valenzuela, "Fernando, a quien por soberbio" (79). — 111. Pregón, "En la ruda política mía” (80v). - 112. Otro pregón, "En la firme política nuestra” (81v). - 113. Tono, "Del rumbo de Francelisa" (82). —114. Otro tono, "Fuera, fuera que Juanilla" (82). —115. Otro, "Bellísimo Narciso" (82). —116. Otro, "Los ganados de Fileno" (83). —117. Otro, "Genil, galán de los ríos" (83). —118. Otro, "Sonoro arroyuelo" (83). —119. Soneto, "Casó de un arzobispo el despensero" (94). - 120. Melancolías del año 1643, "Yo un ermitaño pobre, si contento" (95). - 121. Amante, callado y sospechoso, "Solo el silencio testigo" (113). - 122. Pinturas de fray Damián Cornejo del Orden de san Francisco, "Pues que me han dado licencia" (114). — 123. Otra pintura, "Cuenta con el retrato" (114v). —124. Otro, "Con licencia de Filis" (115).

\subsubsection{Biblioteca Pública Municipal de Oporto, ms. 647}

Poesías varias del padre fray Damián Cornejo. S. XVII (2º mitad). 301h. (210 x 145). Enc. Pergamino. Fol. Antigua. Olim: n.d. En el catálogo de Eduardo Allen es el no 629. Se trata de un manuscrito escrito a varias manos que contiene poemas atribuidos a Cornejo (1-71). Incluye dos índices. Antes de cada uno se dejan dos grupos de páginas en blanco (131-143 y 279-299). Cf. Carreira (La obra 43).

—1. Agostillo, "Oye, Catuja, dulce hechizo mío" (1). —2. Sueño jocoso, "Cansado anoche de estar" (15). - 3. Tonos, "Quien ama correspondido" (41). - 4. Tonos, "De la villa vino Antón” (41). —5. Tonos, "Tierno ruiseñor que lloras" (44). - 6. A la concepción de María santísima, "De tu concepción, Señora" (46). - 7. Quintillas al mismo asunto, "De una niña 
la grandeza" (47). - 8. Al haber visto el pie de una dama, "En el mar de tu hermosura" (50) -9. Pidiendo unas medias a una dama por haber roto las que tenías, "Belisa, el chasco celebra" (53). - 10. A una dama que dio a su galán unas pelotas, "Ya que tan galante has sido" (56). —11. Décimas, "De pedir (nunca yo fuera)" (58). —12. Despedida de una dama, “Adiós, Leonor de mi vida" (61). —13. Pintura a una dama, "Oye, Amarilis discreta" (64). -14. A las peticiones no proveídas de una dama, "Una dama a su galán” (69).

\subsubsection{Hispanic Society Of America, ms. Nr. XCV}

Romances, sonetos y papeles varios. S. XVIII. 400 h. (220 x 153). Enc. Pergamino. Fol. Antigua. Olim: n.d. Procede del Marqués de Jerez de Archez. Se trata de un manuscrito, escrito a varias manos, que contiene obras en prosa y en verso (sacro y profano) de diversos autores. Muchas de ellas aparecen sin atribución. Algunos de los poemas que se incluyen como anónimos se atribuyen a Cornejo en otros manuscritos. Cf. Rodríguez-Moñino (Catálogo 22-26).

-1. A una dama que estando destocada se asomó a una reja y su galán le asió de una mata de cabello, "Suelto el cabello por el aire ufano" (8v). - 2. Desmiente un galán la desconfianzas de su dama con un retrató de él algo desapercibido, "Duro pincel de mano inadvertida" (9). - 3. Al mismo asunto, "Por los yerros, Ysbella, de un traslado" (9v). — 4. Al ponerse una dama unos jazmines en las guedejas que aún no habían salido del botón y pocas horas se abrieron en el mismo pelo, "Emboscado entre matas de tu pelo" (10). — 5. A una pobre que salió estropeada de un mal francés habido en buena guerra, "Un mal francés, Marica, tan grosero" (10v).

\subsubsection{Biblioteca Central de Zúrich, ms. D-249}

Poesías varias. S. XVII. 398 h. (220 x 150). En pasta. Fol. Antigua. Olim: n.d. Se trata de un manuscrito, escrito a varias manos, que contiene obras en prosa y en verso de diversos autores. Los poemas que en él aparecen son de temática sacra y profana. El poemario guarda estrecha relación con el 17666 de la BNE, el cual se cree que es una copia posterior de este. Cf: López Guil (391-426). 
-1. A la Concepción Purísima de nuestra señora en títulos de Comedias, "La más hidalga hermosura" (277). - 2. A lo mismo, "De una niña la pureza" (278). - 3. A santa Clara. "Hoy mi devoción aclama" (358). - 4. Quintillas al mismo santo. "Otra vez tengo la pluma" (366). —5. Al mismo santo en su traslación (maestro León). "Musa mía, Dios te dé” (370). — 6 . Pintura de una dama. "Oye, Amarilis, discreta" (483) - 7. A un escribano. "Hoy sin más ni más me allano (506). —8. A las monjas. "Un ciego soy desgraciado (511). —9. A una dama. "De una niña quiero hablar" (513). - 10. A un dominico que estaba hablando poco decentemente de Nuestra Señora un gato le saltó al pescuezo y le maltrató (Cornejo). "Un dominico enemigo" (545). — 11. A una estudiante que comió menudo (maestro León). "Un estudiante de hogaño" (566). — 12. A san Judas. "Por tomar Judas el grado" (605). —13. A un caballero tenido de impotente y se casó con una dama hermosa (maestro León). "Casose Menga con Bras" (607). - 14. Enviando un devoto a una monja una vela. "De pedir, nunca yo fuera" (673). — 15. Pidiendo a un galán a una dama unas medias por habérsele roto otras. "Belisa el chasco celebra" (674).

8.2.3.5. Biblioteca Estense-Universitaria de Modena, ms. Est. 199 = Epsilon 32.3.6 (inédito)

Tonos diversos. S. XVII-XVIII. 190 h. 33 (208 x 147), 111 (215 x 150), 152 (215 x 150). Enc. Pergamino. Fol. Antigua. Olim: 2020 n.22. Procede de la Biblioteca de la Villa Falcò Pio de Mombello. Se trata de un manuscrito que contiene obras en verso (sacro y profano) de diversos autores. Muchas de ellas aparecen sin atribución. Algunos de los poemas que se incluyen como anónimos se atribuyen a Cornejo en otros manuscritos. Contiene un Exlibris impreso (probablemente en la mitad del siglo XX) en el que aparece el escudo de la casa Pío de Saboya. Este se halla rodeado por un marco bajo, el cual incluye en su centro la letra "M" (Villa Mombello). Cf. AA.VV. (Manus, s.p.).

-1. A la procesión que hicieron los padres de $\mathrm{S}$ [anto] Domingo en reverencia de la Concepción de nuestra Señora, después de la quema de la cocina del convento de Atoc[h]a, "Hoy a la Concepción aclamaciones" (4v). —2. Estando un religioso dominico hablando de la Concepción poco decentemente en una visita, un gato que estaba en la sala le saltó al pescuezo y le maltrató mucho, "Un dominico enemigo" (5). - 3. A la Concepción, "Hanme mandado una cosa" (5v). — 4. Otras quintillas a lo mismo, "La más hidalga hermosura" (6v). -5. Otras a lo mismo, "La Concepción este día" (7v). — 6. A lo mismo, "Sabed, señora 
doncella" (9) - 7. Otro a lo mismo, "Oigan lo que saca en limpio" (9v). — 8. Jácara a nuestra Señora, "Érase una Virgen pura" (10v). — 9. De pie quebrado al mismo santo, "De pie quebrado unas coplas" (16). —10. A santa Clara, "Hoy mi devoción aclama" (17). —11. A una pobre que sabio muy estropeada de un mal francés habido en buena guerra, "Un mal francés, María" (22). - 12. A una monja desdeñosa y capacha, "Lisis, tu favor invoco" (22v). -13. A un galán que habiendo pedido una mano a una dama y no consiguiéndolo la pide un dedo, "Amoroso, prudente y cortesano" (23). - 14. "Pajarillo, que explicas alegre" (23v). -15. A una niña que por el interés se daba a todos. Sátira en esdrújulos, "Escúc[h]enme unos esdrújulos" (24). — 16. Sátira a los escribanos, "Hoy sin más ni más me allano" (25v) -17. Soneto jocoso, "Estaba Lisis en campal batalla" (29v). — 18. "Los ganados de Fileno" (34). —19. "Sonoro Arroyuelo" (36). — 20. “Genil, galán de los ríos” (38). —21. “Ayer Angélica supe" (39v). — 22. "En Málaga vi a Rufina" (43v). —23. De cierto autor a una dama que le maltrató en una lucha, "Marica, viéndote hermosa" (47). —24. Sátira, "Marica, que a decir mal" $(50 \mathrm{v})$. - 25. A un preciado de valiente siendo gallina, "Hállase en las cuchilladas" $(51 \mathrm{v})$. - 26. Sátira a un do[c]tor y a un sacristán, "Un sacristán que a deman" (54v). - 27. Quesimí, que simona, hola, hola, con su pan, con su pan se lo coma, "Vaya, vaya de bureo" (67v). - 28. A un diverso que tenía una dama en la mano, "Hoy, Clori, pretendo amante" (70). - 29. A una dama qui siendo galanteada de muchos se casó con un sacristán, "Dios te socorra, Marica" (70v). — 30. A un corcovado que galantea, "A un galán corto de talle" (72). —31. A un enano, "Oye tarazón de hombre" (73v). - 32. Sueño, "Cansado a noche de estar" (74). —33. Pintura a una dama, "Sepan todos y todos que yo adoro" (94v). - 34. Pintura de un lugar a donde el autor pidió un agosto, "Oye, Catuja, dulce hechizo mío" (86v). - 35. Sátira a un impotente, "Casose Menga con Bras" (99v). — 36. Vejamen de un ciego a san Diego, "Un devoto singular" (107v). - 37. Otras al mismo santo, "Otra vez tengo la pluma" (109). - 38. Otras al mismo santo, "De Diego muy por menor" (110). - 39. Otras al mismo santo, "Todo el mundo conmovido" (112). - 40. Al mismo santo, "Después que porque se usa" (113). — 41. Al mesmo santo romance, y es el asunto a una medalla de oro que envió la reina, nue[s]tra Señora, "La reina, nuestra Señora" (114). 42. A la jornada que hizo s[an] Diego a Madrid, "San Diego, si me remedias" (116). 43. A lo mismo otra letra, "Señor, jurador he sido" $(119 \mathrm{v})$. — 44. Acto de contrición, "Un pecador soy Dios mío" (120v). — 45. A la Concepción de nuestra Señora, "De una niña la grandeza" (124v). — 46. Otro tono, "Bellísimo Narciso" (130). — 47. Sátira a unos colegiales que dieron a unas damas moscas confitadas en colación como para ellos, "Éranse dos licenciados" (138). — 48. A una dama que estando destocada se asomó a una reja y su galán 
la asió una mata de cabello, "Suelto el cabello por el aire ufano" (140). — 49. A uno que se llam[a]ba Cruz y perseguía a el autor por haberle pedido unas suelas "Cruz, si cristiano soy" (140v). - 50. Al mismo asunto, "Apenas, señor, te viste" (140v). 


\subsection{TABLAS SOBRE LA OBRA POÉTICA DE CORNEJO}

8.3.1. Tabla de referencias de los manuscritos

\begin{tabular}{|c|c|c|c|}
\hline Signatura $^{304}$ & Localización & Codificación & $\begin{array}{l}\text { Número de poemas } \\
\text { que se atribuyen a } \\
\text { Cornejo }{ }^{305}\end{array}$ \\
\hline E-39-6654 & $\begin{array}{l}\text { Biblioteca de la Real } \\
\text { Academia Española }\end{array}$ & $\mathrm{A}$ & 107 \\
\hline Egerton 1889 & British Library & $\mathrm{B}$ & 124 \\
\hline $28-C-7-6 \mathrm{p} 22$ & $\begin{array}{lll}\text { Biblioteca Real de la } \\
\text { Colegiata } & \text { de } \\
\text { Roncesvalles } & & \\
\end{array}$ & $\mathrm{C}$ & 20 \\
\hline $\begin{array}{l}\text { Est. } 199=\text { Epsilon } \\
\text { 32.3.6 }\end{array}$ & $\begin{array}{l}\text { Biblioteca Estense- } \\
\text { Universitaria de Modena }\end{array}$ & Ç & 50 \\
\hline 2245 & $\begin{array}{l}\text { Biblioteca Nacional de } \\
\text { España }\end{array}$ & $\mathrm{D}$ & 129 \\
\hline 3884 & $\begin{array}{l}\text { Biblioteca Nacional de } \\
\text { España }\end{array}$ & $\mathrm{E}$ & 17 \\
\hline 3921 & $\begin{array}{l}\text { Biblioteca Nacional de } \\
\text { España }\end{array}$ & $\mathrm{F}$ & 3 \\
\hline 3922 & $\begin{array}{l}\text { Biblioteca Nacional de } \\
\text { España }\end{array}$ & G & 21 \\
\hline 3931 & $\begin{array}{l}\text { Biblioteca Nacional de } \\
\text { España }\end{array}$ & $\mathrm{H}$ & 105 \\
\hline 4052 & $\begin{array}{l}\text { Biblioteca Nacional de } \\
\text { España }\end{array}$ & I & 1 \\
\hline Nr. XCV & $\begin{array}{lll}\text { Hispanic Society of } \\
\text { America }\end{array}$ & $\mathrm{J}$ & 5 \\
\hline 4062 & $\begin{array}{l}\text { Biblioteca Nacional de } \\
\text { España }\end{array}$ & K & 60 \\
\hline L-1053 & $\begin{array}{ll}\text { Archivo } & \text { Histórico } \\
\text { Nacional } & \\
\end{array}$ & LL & 85 \\
\hline 406 & $\begin{array}{l}\text { Biblioteca Fundación } \\
\text { Bartolomé March }\end{array}$ & $\mathrm{M}$ & 96 \\
\hline 5566 & $\begin{array}{l}\text { Biblioteca Nacional de } \\
\text { España }\end{array}$ & $\mathrm{N}$ & 147 \\
\hline 4258 & $\begin{array}{l}\text { Biblioteca Nacional de } \\
\text { España }\end{array}$ & $\tilde{\mathbf{N}}$ & 130 \\
\hline 647 & $\begin{array}{l}\text { Biblioteca Pública } \\
\text { Municipal de Oporto }\end{array}$ & $\mathrm{O}$ & 13 \\
\hline
\end{tabular}

${ }^{304}$ Los manuscritos marcados en cursiva incluyen poesías anónimas que en otros manuscritos se atribuyen a Cornejo.

${ }^{305}$ Se ha computado el número total de poesías que se atribuyen a fray Damián en los diversos testimonios conservados. Estas pueden aparecer como anónimas o con el nombre de otro autor. 


\begin{tabular}{|c|c|c|c|}
\hline Z. IV.18 & $\begin{array}{lr}\text { Real } & \text { Biblioteca } \\
\text { Monasterio del Escorial }\end{array}$ & $P$ & 6 \\
\hline 4135 & $\begin{array}{l}\text { Biblioteca Nacional de } \\
\text { España }\end{array}$ & Q & 89 \\
\hline 410 & $\begin{array}{lll}\text { Biblioteca Real de la } \\
\text { Colegiata } & & \text { de } \\
\text { Roncesvalles } & & \end{array}$ & $\mathrm{R}$ & 197 \\
\hline 156 & $\begin{array}{ll}\text { Biblioteca } & \text { Menéndez } \\
\text { Pelayo } & \\
\end{array}$ & $S$ & 147 \\
\hline 447 & $\begin{array}{l}\text { Biblioteca Pública De } \\
\text { Toledo }\end{array}$ & $\mathrm{T}$ & 25 \\
\hline 18470 & $\begin{array}{l}\text { Biblioteca Nacional de } \\
\text { España }\end{array}$ & U & 4 \\
\hline $20813 / 4$ & $\begin{array}{l}\text { Biblioteca Nacional de } \\
\text { España }\end{array}$ & V & 2 \\
\hline 3930 & $\begin{array}{l}\text { Biblioteca Nacional de } \\
\text { España }\end{array}$ & W & 1 \\
\hline 3929 & $\begin{array}{l}\text { Biblioteca Nacional de } \\
\text { España }\end{array}$ & $X$ & 1 \\
\hline 17666 & $\begin{array}{l}\text { Biblioteca Nacional de } \\
\text { España }\end{array}$ & $\mathrm{Y}$ & 13 \\
\hline D-249 & $\begin{array}{lll}\text { Biblioteca Central de } \\
\text { Zúrich }\end{array}$ & Z & 14 \\
\hline
\end{tabular}

Tabla 28: Referencias de los manuscritos

\subsubsection{Tablas de la lírica indubitada de Cornejo}

Las tablas sobre la poesía de fray Damián que se muestran en el presente apartado y en los siguientes tienen como base la lista de referencias que incluye Klaus Pörtl al final de su edición (Cornejo, Das lyrische 212-226). En este estudio se ha ampliado el número de manuscritos y de atribuciones (dubitadas e indubitadas ${ }^{306}$ ) que en ella aparecen y se ha señalado si los poemas que se incluyen han sido impresos (en caso afirmativo se ha indicado el autor al que se asocian) y se ha determinado también su métrica.

\subsubsection{Poesía sacra}

\footnotetext{
${ }^{306}$ Se han considerado como poesías indubitadas aquellas que exclusivamente se atribuyen a fray Damián y que se incluyen en cuatro o más manuscritos integri.
} 


\section{Poesía sacra indubitada}

Primer verso

Manuscritos

Edición

Métrica

\begin{tabular}{|c|c|c|c|}
\hline $\begin{array}{l}\text { 1. A su esposa, el alma, } \\
\text { escribe }\end{array}$ & $\begin{array}{l}\text { D (193v), N (187), R (45), S } \\
(140 v)\end{array}$ & $\begin{array}{l}\text { Cornejo (Das } \\
\text { lyrische 137) }\end{array}$ & Copla \\
\hline $\begin{array}{l}\text { 2. } \\
\text { De santa } \\
\text { resurrección }\end{array}$ & $\begin{array}{l}\mathrm{D}(186), K(62), \mathrm{N}(180), \mathrm{R} \\
(35), \mathrm{S}(144 \mathrm{v})\end{array}$ & $\begin{array}{l}\text { Cornejo (Das } \\
\text { lyrische 124) }\end{array}$ & Romance \\
\hline $\begin{array}{l}\text { 3. Divina Madre de } \\
\text { gracia }\end{array}$ & $\begin{array}{l}\mathrm{D}(188 \mathrm{v}), K(57), \mathrm{N}(182), \mathrm{R} \\
(39), \mathrm{S}(148)\end{array}$ & $\begin{array}{l}\text { Cornejo (Das } \\
\text { lyrische 129) }\end{array}$ & Romance \\
\hline 4. Dulce Jesús, Dio mío & $\begin{array}{l}\mathrm{D}(190), K(60), \mathrm{N}(184), \mathrm{R} \\
(41 \mathrm{v}), \mathrm{S}(146)\end{array}$ & $\begin{array}{l}\text { Cornejo (Das } \\
\text { lirische 132) }\end{array}$ & Endecha \\
\hline $\begin{array}{l}\text { 5. En títulos, Virgen } \\
\text { pura }\end{array}$ & $\begin{array}{l}\mathrm{D}(198), K(77), \mathrm{N}(191), \mathrm{R} \\
(31), \mathrm{S}(131 \mathrm{v})\end{array}$ & $\begin{array}{l}\text { Cornejo (Das } \\
\text { lyrische 117) }\end{array}$ & Quintilla \\
\hline $\begin{array}{l}\text { 6. En tu alabanza mi } \\
\text { musa }\end{array}$ & $\begin{array}{l}\mathrm{D}(185), K(57), \mathrm{N}(179), \mathrm{R} \\
(32 \mathrm{v}), \mathrm{S}(136)\end{array}$ & $\begin{array}{l}\text { Cornejo (Das } \\
\text { lyrische } 119)\end{array}$ & $\begin{array}{l}\text { Romance } \\
\text { en eco }\end{array}$ \\
\hline $\begin{array}{l}\text { 7. Haced que la Gracia } \\
\text { encuentre }\end{array}$ & $\begin{array}{l}\text { D (196), K (61), N (189), R } \\
(47 \mathrm{v}), \mathrm{S}(143 \mathrm{v})\end{array}$ & $\begin{array}{l}\text { Cornejo (Das } \\
\text { lyrische 141) }\end{array}$ & Quintilla \\
\hline $\begin{array}{l}\text { 8. Hoy con gusto a } \\
\text { cantar llego }\end{array}$ & $\begin{array}{l}\mathrm{D}(200), K(9 v), \mathrm{N}(192), \tilde{\mathrm{N}} \\
(206), \mathrm{R}(33), \mathrm{S}(132 \mathrm{v})\end{array}$ & $\begin{array}{l}\text { Cornejo (Das } \\
\text { lyrische 120), }\end{array}$ & Quintilla \\
\hline $\begin{array}{l}\text { 9. Oigan que el bravo } \\
\text { del cielo }\end{array}$ & $\begin{array}{l}\text { D (191v), N (185), R (43), S } \\
(139 v)\end{array}$ & $\begin{array}{l}\text { Cornejo (Das } \\
\text { lyrische } 134)\end{array}$ & Romance \\
\hline
\end{tabular}

Tabla 29: Poesía sacra indubitada de Cornejo

\subsubsection{Poesía profana}

\section{Poesía profana indubitada}

\section{Primer verso}

Manuscrito

Edición

Métrica

1. A la desatada llaga

A (84), B (34), D (51), H (105), LL (210v), M (201), N (37), R (100), S (37) A (43), B (14v), D (105v), G

2. A todos tu beldad rigores flecha (195v), H (158), M (163v), N (105), $\tilde{\mathrm{N}}$ (98), Q (31v), R (117v), S (82)

3. Acabose el amistad D (140v), N (131), N (133v), Q (150v), R (7v), S (103)

4. Amoroso, prudente $\mathrm{y}$ cortesano A (44), B (15v), D (107), H (159), M (162), N (106), N (99v), Q (33), R (118), S (83v)

\begin{tabular}{|l|c|} 
Marañón (Sonetos 28) & Soneto \\
\hline $\begin{array}{l}\text { Cornejo (Das Lyrische } \\
77)\end{array}$ & Septeto \\
\hline $\begin{array}{l}\text { AA.VV. (Gaceta 6), } \\
\text { Alzieu et al. (64), } \\
\text { Marañón (Sonetos 27) }\end{array}$ & Soneto \\
\hline
\end{tabular}




\begin{tabular}{|c|c|c|c|}
\hline $\begin{array}{l}\text { 5. Apenas, señor, } \\
\text { te viste }\end{array}$ & $\begin{array}{l}\text { B (18v), D (111v), H (163), LL } \\
(195 v), \text { M (173), N (109), N } \\
(104), R(122), S(86 v)\end{array}$ & & Décima \\
\hline $\begin{array}{l}\text { 6. } \\
\text { reducido pie } \\
\text { cárcel breve }\end{array}$ & $\begin{array}{l}\text { A (45v), B (17), D (109), G } \\
(195), H(160 v), \text { LL (195), M } \\
(166), N(107), \tilde{N}(101 v), Q \\
(34 v), R(119 v), S(85)\end{array}$ & $\begin{array}{l}\text { Lara (41), Marañón } \\
\text { (Sonetos 29) }\end{array}$ & Soneto \\
\hline $\begin{array}{l}\text { 7. Cansado } \\
\text { anoche de estar }\end{array}$ & $\begin{array}{l}\text { A (69), B (27), C (87v), D } \\
(33 v), E(250), G(318), \mathrm{H} \\
(89 v), \mathrm{I}(280), \mathrm{K}(43), \mathrm{LL} \\
(188 \mathrm{v}), \mathrm{M}(251), \mathrm{N}(47), \tilde{\mathrm{N}} \\
(19 \mathrm{v}), \mathrm{O}(15), \mathrm{T}(1) \mathrm{Q}(75) \mathrm{R} \\
(179), \mathrm{S}(40)\end{array}$ & & Romance \\
\hline $\begin{array}{l}\text { 8. Clavel, pues } \\
\text { por tus colores }\end{array}$ & $\begin{array}{l}\text { D (197v), N (190), R (1), S } \\
(108 v)\end{array}$ & $\begin{array}{l}\text { Cornejo (Das lyrische } \\
\text { 51) }\end{array}$ & Décima \\
\hline $\begin{array}{l}\text { 9. ¿Cómo quieres, } \\
\text { Anarda, que } \\
\text { sea casto? }\end{array}$ & $\begin{array}{l}\text { A (46), B (17v), D (109v), G } \\
\text { (191v), H (161), LL (229v), M } \\
(167), \tilde{N}(102), N(108), Q(35), \\
\text { R (119v), S (85) }\end{array}$ & Marañón (Sonetos 30) & Soneto \\
\hline $\begin{array}{l}\text { 10. Cruz, si } \\
\text { cristiano soy }\end{array}$ & $\begin{array}{l}\text { A (47), B (18), D (111), E } \\
\text { (390), G (190v), H (162v), Q } \\
\text { (39v), LL (195), M (172), N } \\
(109), N(103 v), R(122), S(86)\end{array}$ & $\begin{array}{l}\text { Cotarelo (20), } \\
\text { Marañón (Sonetos 32) }\end{array}$ & Soneto \\
\hline $\begin{array}{l}\text { 11. De emboscado } \\
\text { entre matas de } \\
\text { tu pelo }\end{array}$ & $\begin{array}{l}\text { A (45), B (116v), D (108v) G } \\
(194 v), H(160), J(10), \text { LL } \\
(194 v), \text { M (165), N (107), N } \\
(101), Q(37), R(119), S(84 v)\end{array}$ & $\begin{array}{l}\text { Marañón (Sonetos 33), } \\
\text { Pérez de Guzmán } \\
\text { (374) }\end{array}$ & Soneto \\
\hline $\begin{array}{l}\text { 12. De mis finezas } \\
\text { el bajel incierto }\end{array}$ & $\begin{array}{l}\text { A (27), B (48v), D (115), H } \\
(165 \mathrm{v}), \text { LL (197v), M (171), N } \\
(112), \text { Q (38v), S (89) }\end{array}$ & Marañón (Sonetos 29) & Soneto \\
\hline $\begin{array}{l}\text { 13. Del rumbo de } \\
\text { Francelina }\end{array}$ & $\begin{array}{l}\text { A (110v), B (82), D (127v), H } \\
\text { (176), LL (226v), M (314), N } \\
(121), \tilde{N}(120 v), Q \text { (140), R } \\
(116), S(95),\end{array}$ & & Romance \\
\hline $\begin{array}{l}\text { 14. De una taberna } \\
\text { salía }\end{array}$ & $\begin{array}{l}\mathrm{D}(145 \mathrm{v}), \mathrm{N}(134), \tilde{N}(138 \mathrm{v}), \mathrm{R} \\
(2 \mathrm{v}), \mathrm{S}(106)\end{array}$ & $\begin{array}{l}\text { Cornejo (Das lyrische } \\
\text { 55) }\end{array}$ & Romance \\
\hline $\begin{array}{l}\text { 15. Disparates, } \\
\text { Antón, muy } \\
\text { mal zurcidos }\end{array}$ & $\begin{array}{l}\text { A (46), B (20), D (110v), H } \\
(162 \mathrm{v}), \mathrm{LL}(197 \mathrm{v}), \mathrm{M}(169), \mathrm{N} \\
(108), \mathrm{Q}(38 \mathrm{v}), \mathrm{S}(89), \mathrm{LL} \\
(197 \mathrm{v})\end{array}$ & Marañón (Sonetos 34) & Soneto \\
\hline $\begin{array}{l}\text { 16. Don Juan, no } \\
\text { tengo por } \\
\text { bueno }\end{array}$ & $\begin{array}{l}\mathrm{A}(57 \mathrm{v}), \mathrm{C}(65), \mathrm{D}(91), \mathrm{H} \\
(148 \mathrm{v}), \tilde{\mathrm{N}}(82), \mathrm{N}(95), \mathrm{M} \\
(188), \mathrm{R}(109), \mathrm{S}(71)\end{array}$ & $\begin{array}{l}\text { AA. VV. (Cancionero } \\
\text { de obras 298) }\end{array}$ & Décima \\
\hline $\begin{array}{l}\text { 17. El pañuelo } \\
\text { desembolsa }\end{array}$ & $\begin{array}{l}\text { A (89v), B (42), D (127v), H } \\
(129), \text { LL (226v), N (81), N } \\
(64), Q \text { (99), R (105v), S (57v) }\end{array}$ & & Redondilla \\
\hline $\begin{array}{l}\text { 18. En aquesta } \\
\text { soledad. } \\
\text { Glosas. }\end{array}$ & $\begin{array}{l}\text { A (50), B (51v), C (83v), D } \\
(101), \mathrm{H}(153 \mathrm{v}), \mathrm{LL}(227), \mathrm{M} \\
(193), \mathrm{N}(101), \tilde{\mathrm{N}}(92), \mathrm{Q}(65 \mathrm{v}), \\
\mathrm{R}(111 \mathrm{v}), \mathrm{S}(78 \mathrm{v})\end{array}$ & & Décima \\
\hline $\begin{array}{l}\text { 19. En la firme } \\
\text { política nuestra }\end{array}$ & $\begin{array}{l}\text { A (94v), B (81v), D (126v), H } \\
(175), N(120), \tilde{N}(119 v), Q \\
(128), R(115 v), S(94 v)\end{array}$ & & Romance \\
\hline
\end{tabular}




\begin{tabular}{|c|c|c|c|}
\hline $\begin{array}{l}\text { 20. En la ruda } \\
\text { política mía }\end{array}$ & $\begin{array}{l}\text { A (94), B (80v), D (125v), H } \\
(174), \text { N (119), N (118v), Q } \\
(127), R(115), S(94)\end{array}$ & & Romance \\
\hline $\begin{array}{l}\text { 21. En la villa de } \\
\text { Carrión }\end{array}$ & $\begin{array}{l}\text { A (92v), B (78v), D (121), H } \\
(170 v), \text { LL (256), M (295), N } \\
(117), \tilde{N}(114), \text { Q (118v), R } \\
(113 v)\end{array}$ & & Romance \\
\hline $\begin{array}{l}\text { 22. En Málaga vi a } \\
\text { Rufina }\end{array}$ & $\begin{array}{l}\text { A (93v), B (79), D (123), H } \\
(172), \text { LL (258), M (298), N } \\
(117), \tilde{N}(115 v), R(114), S(92)\end{array}$ & Martínez et al. (105) & Romance \\
\hline $\begin{array}{l}\text { 23. Esta mañana } \\
\text { en Dios y en } \\
\text { hora buena }{ }^{307}\end{array}$ & $\begin{array}{l}\mathrm{D}(144), \mathrm{G}(192 \mathrm{v}), \mathrm{N}(133), \tilde{N} \\
(137 \mathrm{v}), \mathrm{Q}(155), \mathrm{S}(105), \mathrm{V}(1), \\
\mathrm{W}(179 \mathrm{v})\end{array}$ & $\begin{array}{l}\text { AA.VV. (Cancionero } \\
\text { de obras 63), Barnatán } \\
\text { (67), Barrera (95), Cela } \\
\text { (340), Díez Fernández } \\
\text { (La poesía 220), } \\
\text { Gallardo (583), López } \\
\text { de Barbadillo (199), } \\
\text { Marañón (Sonetos 34), } \\
\text { Martínez et al. (105) }\end{array}$ & Soneto \\
\hline $\begin{array}{l}\text { 24. Estaba Lisis en } \\
\text { campal batalla }\end{array}$ & $\begin{array}{l}\text { A (48v), B (19v), D (114v), G } \\
(193 v), H(165 v), \text { LL (248), M } \\
(f, 170), N(111), \tilde{N}(207 v), Q \\
(36 v), S(88 v)\end{array}$ & $\begin{array}{l}\text { AA.VV. (Cancionero } \\
\text { de obras 67), } \\
\text { AA.VV. (Cancionero } \\
\text { moderno 302), } \\
\text { Alzieu et al (36), } \\
\text { Barrera (96), } \\
\text { Cela (362), López de } \\
\text { Barbadillo (199), } \\
\text { Marañón (Sonetos 32), } \\
\text { San José, } \\
\text { (La vieja 11) }\end{array}$ & Soneto \\
\hline $\begin{array}{l}\text { 25. Fernando, a } \\
\text { quien por } \\
\text { soberbio }\end{array}$ & $\begin{array}{l}\text { A (94), B (79v), D (123v), E } \\
(81), H(172 v), M(299), N \\
(118), \tilde{N}(116 v), Q(124 v), R \\
(114 v), S(92 v)\end{array}$ & $\begin{array}{l}\text { AA.VV. (Tonos 148), } \\
\text { Foulché-DelBosc } \\
\text { (Poesías 279) }\end{array}$ & Romance \\
\hline $\begin{array}{l}\text { 26. Fuera, fuera, } \\
\text { fuera que } \\
\text { Juanilla }\end{array}$ & $\begin{array}{l}\text { A (111), B (82), D (128), H } \\
(176), \text { LL (266v), M (314), N } \\
(121), \tilde{N}(121), \text { Q (140v), R } \\
(116), S(95 v)\end{array}$ & & Romance \\
\hline $\begin{array}{l}\text { 27. Genil, galán de } \\
\text { los ríos }\end{array}$ & $\begin{array}{l}\text { A (112v), B (83), D (129), H } \\
(177), N(122), \tilde{N}(122), \mathrm{R} \\
(116 \mathrm{v} \text { y } 156), \mathrm{S}(96)\end{array}$ & Lambea y Josa (61) & Romance \\
\hline $\begin{array}{l}\text { 28. Licencia solo } \\
\text { me has dado }\end{array}$ & $\begin{array}{l}\text { A (54v), B (47), D (87), E } \\
(331), \text { H (141), M (182), N } \\
(92), \tilde{N}(78), Q(53), R(108 v), \\
\text { S (68) }\end{array}$ & & Décima \\
\hline $\begin{array}{l}\text { 29. Lisis, tu favor } \\
\text { invoco }\end{array}$ & $\begin{array}{l}\text { A (27), B (14v), H (157v), LL } \\
(192 \mathrm{v}), \mathrm{M}(160), \mathrm{N}(104), \tilde{N} \\
(97 \mathrm{v}), \mathrm{Q}(31 \mathrm{v}), \mathrm{R}(117), \mathrm{S}(82 \mathrm{v})\end{array}$ & Martínez et al. (82) & Soneto \\
\hline
\end{tabular}

${ }^{307}$ Aunque el poema fue atribuido a Quevedo en el último tomo de las Obras coleccionadas de Juan Isidro Fajardo (201v), se ha incluido en el corpus de indubitadas de Cornejo. El motivo de tal decisión ha sido que se trata del único testimonio (1724) en el que este se vincula al autor de El Buscón. 


\begin{tabular}{|c|c|c|c|}
\hline $\begin{array}{l}\text { 30. Lo menos bello } \\
\text { y más } \\
\text { apetecido }\end{array}$ & $\begin{array}{l}\text { D (114v), G (193), N (134), N } \\
(138), S(105 v), V(1)\end{array}$ & $\begin{array}{l}\text { AA.VV. (Cancionero } \\
\text { de obras 65), Barrera } \\
\text { (95), Díez Fernández } \\
\text { (La poesía 223), } \\
\text { Gallardo (583), López } \\
\text { de Barbadillo (199), } \\
\text { Marañón (Sonetos 31), } \\
\text { San José (La vieja } 11)\end{array}$ & Soneto \\
\hline $\begin{array}{l}\text { 31. Los ganados } \\
\text { de Fileno }\end{array}$ & $\begin{array}{l}\text { A (112), B (83), D (128v), H } \\
(176 \mathrm{v}), \mathrm{N}(121), \tilde{N}(121 \mathrm{v}), \mathrm{R} \\
(116 \mathrm{v}), \mathrm{S}(95 \mathrm{v})\end{array}$ & $\begin{array}{l}\text { AA.VV. (Tonos 35), } \\
\text { Lambea y Josa. (123) }\end{array}$ & Romance \\
\hline $\begin{array}{l}\text { 32. Malo me } \\
\text { siento, Marica }\end{array}$ & $\begin{array}{l}\text { B (45v), D (84v), H (137v), M } \\
(234), N(89), \tilde{N}(74), R \text { (ff 107, } \\
144 \text { y 190v), S (65) }\end{array}$ & & Romance \\
\hline $\begin{array}{l}\text { 33. Marica, no } \\
\text { desdeñosa }\end{array}$ & $\begin{array}{l}\text { A (89v), B (42), D (75v), H } \\
(129), \text { LL (218), N (81), N (64), } \\
\text { Q (99v), R (105v), S (57v) }\end{array}$ & & Redondilla \\
\hline $\begin{array}{l}\text { 34. Marica, que a } \\
\text { decir mal }\end{array}$ & $\begin{array}{l}\text { A (100), B (37), D (67), H } \\
(120 v), \text { LL (215v), M (284), N } \\
(74), \tilde{N}(56), Q(122), R(f f 88 v, \\
138 v \text { y 189v), S (51) }\end{array}$ & $\begin{array}{l}\text { AA.VV. (Cancionero } \\
\text { de obras 296) }\end{array}$ & Romance \\
\hline $\begin{array}{l}\text { 35. María, viéndote } \\
\text { hermosa }\end{array}$ & $\begin{array}{l}\text { A (52), B (45v), D (80v), E } \\
(365), \text { H (136), LL (220v), M } \\
(232), N(87), \tilde{N}(72), Q(51), R \\
\text { (ff 3v y 188v), S (63v) }\end{array}$ & $\begin{array}{l}\text { Cornejo (Das lyrische } \\
61 \text { ) }\end{array}$ & Redondilla \\
\hline $\begin{array}{l}\text { 36. Musa mía, con } \\
\text { astucia }\end{array}$ & $\begin{array}{l}\mathrm{D}(135 \mathrm{v}), \mathrm{N}(127), \tilde{N}(128 \mathrm{v}), \mathrm{R} \\
(5 \mathrm{v}), \mathrm{S}(99 \mathrm{v})\end{array}$ & $\begin{array}{l}\text { Cornejo (Das lyrische } \\
69 \text { ) }\end{array}$ & Redondilla \\
\hline $\begin{array}{l}\text { 37. Nise, a quererte } \\
\text { me inclino }\end{array}$ & $\begin{array}{l}\mathrm{D}(139), \mathrm{N}(130), \tilde{N} \text { (132), Q } \\
(149), \mathrm{R}(7), \mathrm{S}(102)\end{array}$ & $\begin{array}{l}\text { Cornejo (Das lyrische } \\
75 \text {, Martínez et al. } \\
\text { (79) }\end{array}$ & Décima \\
\hline $\begin{array}{l}\text { 38. Oye, Catuja, } \\
\text { dulce hechizo } \\
\text { mío }\end{array}$ & $\begin{array}{l}\text { A (30), B (2), D (1), G (199), H } \\
\text { (61), LL (249v), M (119), N } \\
(1), \tilde{N}(1), Q \text { (13), R (ff 8, } 22 \\
\text { y139), S (1 y 150), X (5v) }\end{array}$ & $\begin{array}{l}\text { Cornejo (Das lyrische } \\
\text { 204), AA.VV. (Agosto } \\
\text { que pintó 91) }\end{array}$ & Ovillejo \\
\hline $\begin{array}{l}\text { 39. Palma, en } \\
\text { viendo tu } \\
\text { beldad }\end{array}$ & $\begin{array}{l}\text { A (56v), B (47v), C (64), D } \\
(89 v), H(143 v), \text { LL (223v), N } \\
(94), \tilde{N}(81), \text { O (1), Q (56), R } \\
(4 v), S(70)\end{array}$ & $\begin{array}{l}\text { Cornejo (Das lyrische } \\
65 \text { ) }\end{array}$ & Décima \\
\hline $\begin{array}{l}\text { 40. Para qué es tu } \\
\text { atrevimiento }\end{array}$ & $\begin{array}{l}\text { A (86), B (38), D (62v), E } \\
(333), H(116), \text { LL (216v), M } \\
(211), N(70), \tilde{N}(50), Q(103 v), \\
R(102 v), S(47 v)\end{array}$ & & Décima \\
\hline $\begin{array}{l}\text { 41. Pedite, mi buen } \\
\text { Cruz, suelas }\end{array}$ & $\begin{array}{l}\text { A (47), B (19), D (113), H } \\
\text { (164), LL (196v), M (176), N } \\
(110), \tilde{N}(105 v), Q(40), R \\
(122 v), S(87 v)\end{array}$ & & Décima \\
\hline $\begin{array}{l}\text { 42. Pues que me } \\
\text { han dado } \\
\text { licencia }\end{array}$ & $\begin{array}{l}\text { A (57v), B (114), C (65), D } \\
(104), F(222), H(156), \text { LL } \\
(216 \mathrm{v}), \mathrm{M}(302), \mathrm{N}(103), \tilde{N} \\
(95 \mathrm{v}), \mathrm{Q}(46 \mathrm{v}), \mathrm{R}(112 \mathrm{v}), \mathrm{S} \\
(81 \mathrm{v})\end{array}$ & & Romance \\
\hline $\begin{array}{l}\text { 43. Quiero, pues es } \\
\text { ocasión }\end{array}$ & $\begin{array}{l}\text { A (79), B (32), D (179), LL } \\
(229 \mathrm{v}), \mathrm{M}(275), \mathrm{N}(174), \tilde{\mathrm{N}}\end{array}$ & & Ovillejo \\
\hline
\end{tabular}




\begin{tabular}{|c|c|c|c|}
\hline & $\begin{array}{l}\text { (196), Q (92v), R (95v), S } \\
(109 v), T(11 v)\end{array}$ & & \\
\hline $\begin{array}{l}\text { 44. Quisimí } \\
\text { quisimona, } \\
\text { ¡hola! }\end{array}$ & $\begin{array}{l}\text { A (88), B (40), D (69), H } \\
(122 v), \text { LL (216), M (287), N } \\
(76), \tilde{N}(58), Q \text { (107), R (104), } \\
\text { S (52v) }\end{array}$ & & Romance \\
\hline $\begin{array}{l}\text { 45. Reyes míos, } \\
\text { desde el día }{ }^{308}\end{array}$ & $\begin{array}{l}\text { D (141v), N (132v), N (134v), } \\
\text { R (16), S (103v), Y (508) }\end{array}$ & $\begin{array}{l}\text { Cornejo (Das lyrische } \\
90)\end{array}$ & Redondilla \\
\hline $\begin{array}{l}\text { 46. Sepan todos y } \\
\text { todas que yo } \\
\text { adoro }\end{array}$ & $\begin{array}{l}\text { A (37), B (8), D (11), F (214), } \\
\text { G (205), H (69v), LL (188v), M } \\
(133), N(18), \tilde{N}(6 v), Q \text { (22), R } \\
(17), S(8), T(1)\end{array}$ & $\begin{array}{l}\text { Cornejo (Das lyrische } \\
94 \text { ) }\end{array}$ & Ovillejo \\
\hline $\begin{array}{l}\text { 47. Sonoro } \\
\text { arroyuelo }\end{array}$ & $\begin{array}{l}\mathrm{A}(113), \mathrm{B}(83), \mathrm{D}(129 \mathrm{v}), \mathrm{H} \\
(177), \mathrm{N}(122), \tilde{N}(122 \mathrm{v}), \mathrm{R} \\
(116 \mathrm{v}), \mathrm{S}(96 \mathrm{v})\end{array}$ & & Romance \\
\hline $\begin{array}{l}\text { 48. Suelto el } \\
\text { cabello por el } \\
\text { aire ufano }\end{array}$ & $\begin{array}{l}\text { A (43v), B (15), D (106), G } \\
(189), H(158), \mathrm{J}(8 \mathrm{v}), \mathrm{LL} \\
(193), \mathrm{M}(161), \mathrm{N}(105), \tilde{N} \\
(98 \mathrm{v}), \mathrm{Q}(37 \mathrm{v}), \mathrm{R}(\mathrm{ff} 21 \mathrm{v} \text { y } \\
117 \mathrm{v}), \mathrm{S}(82)\end{array}$ & Marañón (Sonetos 33) & $\begin{array}{l}\text { Soneto } \\
\text { con cola }\end{array}$ \\
\hline $\begin{array}{l}\text { 49. Tu arroz, } \\
\text { Marica, me } \\
\text { enfada }\end{array}$ & $\begin{array}{l}\text { A (104v), B (34v), D (51v), E } \\
(282 v), H(105 v), M \text { (ff } 201 \text { y } \\
220), \text { N (61), N (38), Q (100), } \\
\text { R (4v), S (38), }\end{array}$ & $\begin{array}{l}\text { Cornejo (Das lyrische } \\
\text { 64), Martínez et al. } \\
\text { (71) }\end{array}$ & Décima \\
\hline $\begin{array}{l}\text { 50. Un ciego soy } \\
\text { desgraciado }\end{array}$ & $\begin{array}{l}\text { A (85), B (34v), D (52v), E } \\
(309), \mathrm{H}(106 \mathrm{v}), \mathrm{LL}(210 \mathrm{v}), \mathrm{M} \\
(310), \mathrm{N}(62), \tilde{\mathrm{N}}(38), \mathrm{Q}(101), \\
\mathrm{R}(100 \mathrm{v}), \mathrm{S}(39), \mathrm{Y}(511), \mathrm{Z} \\
(511)\end{array}$ & $\begin{array}{l}\text { AA.VV. (Cancionero } \\
\text { de obras 294), } \\
\text { Martínez et al. (80) }\end{array}$ & Quintilla \\
\hline $\begin{array}{l}\text { 51. Un mal } \\
\text { francés, } \\
\text { Marica, tan } \\
\text { grosero }\end{array}$ & $\begin{array}{l}\text { A (43), B (14), D (105), G } \\
(191), H(157), J(10 v), L L \\
(192), M(159), N(104), \tilde{N} \\
(97), Q(32 v), R(116 v), S(81 v)\end{array}$ & $\begin{array}{l}\text { Marañón (Sonetos 28), } \\
\text { Martínez et al. (137) }\end{array}$ & Soneto \\
\hline $\begin{array}{l}\text { 52. Ya no puedo } \\
\text { vivir si no me } \\
\text { capo }\end{array}$ & $\begin{array}{l}\text { A (46), D (110), G (192), H } \\
(161 \mathrm{v}), \mathrm{LL}(249 \mathrm{v}), \mathrm{M}(168), \mathrm{N} \\
(96), \tilde{\mathrm{N}}(102 \mathrm{v}), \mathrm{Q}(35 \mathrm{v}), \mathrm{R} \\
(109 \mathrm{v}), \mathrm{S}(85 \mathrm{v})\end{array}$ & $\begin{array}{l}\text { AA.VV. (Cancionero } \\
\text { moderno 68), AA.VV. } \\
\text { (Cancionero de obras } \\
\text { 293), Barnatán (68), } \\
\text { Marañón (Sonetos 30) }\end{array}$ & Soneto \\
\hline
\end{tabular}

Tabla 30: Poesía profana indubitada de Cornejo

308 Este poema está publicado en las Obras complutenses (León 384). No obstante, se trata de una atribución actual y no aparece en ningún otro testimonio con el nombre de Marchante. Por ello, no se ha considerado como dubitado. 
8.3.3. Tablas de la lírica dubitada de Cornejo

\subsubsection{Poesía dubitada con León Marchante}

\subsection{Poesía sacra publicada a nombre de Marchante}

\begin{tabular}{|c|c|c|c|c|c|}
\hline \multicolumn{6}{|c|}{ Poesía dubitada sacra } \\
\hline $\begin{array}{l}\text { Primer } \\
\text { verso }\end{array}$ & $\begin{array}{l}\text { Atribuida a } \\
\text { LM en } \\
\text { impresos }\end{array}$ & $\begin{array}{l}\text { Atribuida } \\
\text { a LM en } \\
\text { manuscrit } \\
\text { os }\end{array}$ & $\begin{array}{l}\text { Atribuida a } \\
\text { Cornejo en } \\
\text { manuscritos }\end{array}$ & $\begin{array}{l}\text { Atribuida a } \\
\text { Cornejo en } \\
\text { impresos }\end{array}$ & Métrica \\
\hline $\begin{array}{l}\text { 1. A } \\
\text { conjurar } \\
\text { estas nubes }\end{array}$ & $\begin{array}{l}\text { León (Obras } \\
\text { poéticas 1: } \\
\text { 148) } \\
\text { León (Obras } \\
\text { complutenses } \\
372)\end{array}$ & $\mathrm{T}(39)$ & $\begin{array}{l}\text { A (27), B (60), } \\
\text { H (196v), } K \\
(26), N(153), \tilde{N} \\
(165 \mathrm{v}), \mathrm{R}(61 \mathrm{v}), \\
\text { S (124v) }\end{array}$ & $\begin{array}{l}\text { Cornejo (Das } \\
\text { lyrische 161) }\end{array}$ & Romance \\
\hline $\begin{array}{l}\text { 2. Al señor } \\
\text { Bautista, el } \\
\text { jaque }\end{array}$ & $\begin{array}{l}\text { León (Obras } \\
\text { poéticas 2: } \\
308) \\
\text { León (Obras } \\
\text { complutenses } \\
241)\end{array}$ & & $\begin{array}{l}\text { A (12v), B } \\
(66 v), D(169 v), \\
\text { E (331), M (19), } \\
\text { N (165), N } \\
(185), R(75 v), \\
\text { S (136v) }\end{array}$ & $\begin{array}{l}\text { AA.VV. } \\
\text { (Tonos 72), } \\
\text { Cornejo (Das } \\
\text { lyrische 185), }\end{array}$ & Romance \\
\hline $\begin{array}{l}\text { 3. De Diego } \\
\text { muy por } \\
\text { menor }\end{array}$ & $\begin{array}{l}\text { León (Obras } \\
\text { poéticas 1: } \\
82)\end{array}$ & $\mathrm{T}(35)$ & $\begin{array}{l}\mathrm{H}(185 \mathrm{v}), K \\
(6 v), \mathrm{N}(143), \tilde{\mathrm{N}} \\
(150 \mathrm{v}), \mathrm{R}(58 \mathrm{v}), \\
\mathrm{S}(55 \mathrm{v})\end{array}$ & $\begin{array}{l}\text { Cornejo (Das } \\
\text { lyrische 158) }\end{array}$ & Quintilla \\
\hline $\begin{array}{l}\text { 4. De } \\
\text { Francisco } \\
\text { por menor }\end{array}$ & $\begin{array}{l}\text { León (Obras } \\
\text { poéticas 2: } \\
318 \text { ) }\end{array}$ & & $\begin{array}{l}\text { A (10), B (56), } \\
\text { D (165v), E } \\
(38 v), M(13), \\
\text { N (163), N } \\
(180 v), R(73), \\
\text { S (134) }\end{array}$ & $\begin{array}{l}\text { Cornejo (Das } \\
\text { lyrische 181) }\end{array}$ & Quintilla \\
\hline $\begin{array}{l}\text { 5. De una } \\
\text { niña la } \\
\text { grandeza }\end{array}$ & $\begin{array}{l}\text { León (Obras } \\
\text { poéticas 2: } \\
285)\end{array}$ & & $\begin{array}{l}\mathrm{A}(7 \mathrm{v}), \mathrm{B}(63 \mathrm{v}), \\
C(7), \mathrm{E}(40), \mathrm{D} \\
(161), \mathrm{H}(203), \\
K(32 v), \mathrm{N} \\
(160), \tilde{\mathrm{N}}(176), \\
\mathrm{O}(47), \mathrm{R}(33 \mathrm{v}), \\
\mathrm{S}(129 \mathrm{v}), \mathrm{Y} \\
(278), \mathrm{Z}(278)\end{array}$ & $\begin{array}{l}\text { Cornejo (Das } \\
\text { lyrische 122), } \\
\text { López Guil } \\
(250)\end{array}$ & Quintilla \\
\hline $\begin{array}{l}\text { 6. De pie } \\
\text { quebrado } \\
\text { unas coplas }\end{array}$ & $\begin{array}{l}\text { León (Obras } \\
\text { poéticas 1: } \\
79)\end{array}$ & & $\begin{array}{l}\text { A (9v), B (64v), } \\
\text { D (164), E } \\
(378 v), K(21),\end{array}$ & $\begin{array}{l}\text { Cornejo (Das } \\
\text { lyrische } 183 \text { ) }\end{array}$ & $\begin{array}{r}\text { Copla de pie } \\
\text { quebrado }\end{array}$ \\
\hline
\end{tabular}




\begin{tabular}{|c|c|c|c|c|c|}
\hline & & & $\begin{array}{l}\text { N (162), N } \\
(179), R(74), S \\
(133)\end{array}$ & & \\
\hline $\begin{array}{l}\text { 7. De tu } \\
\text { concepción, } \\
\text { Señora }\end{array}$ & $\begin{array}{l}\text { León (Obras } \\
\text { poéticas 2: } \\
\text { 279) }\end{array}$ & $\mathrm{T}(39 \mathrm{v})$ & $\begin{array}{l}\mathrm{A}(5 \mathrm{v}), \mathrm{B}(62 \mathrm{v}), \\
\mathrm{D}(158), \mathrm{H} \\
(201), K(34), \mathrm{M} \\
(2), \mathrm{N}(158), \tilde{\mathrm{N}} \\
(172), \mathrm{O}(46), \mathrm{R} \\
(70), \mathrm{S}(127)\end{array}$ & $\begin{array}{l}\text { Cornejo (Das } \\
\text { lyrische 176) }\end{array}$ & Romance \\
\hline $\begin{array}{l}\text { 8. Después } \\
\text { que porque } \\
\text { se usa }\end{array}$ & $\begin{array}{l}\text { León (Obras } \\
\text { poéticas 1: } \\
80)\end{array}$ & $\mathrm{T}(36 \mathrm{v})$ & $\begin{array}{l}\mathrm{B}(57 \mathrm{v}), \mathrm{D} \\
(84 \mathrm{v}), \mathrm{H}(190), \\
K(10 \mathrm{v}), \mathrm{N} \\
(148), \tilde{\mathrm{N}}(156 \mathrm{v}), \\
\mathrm{R}(49), \mathrm{S}(120 \mathrm{v})\end{array}$ & $\begin{array}{l}\text { Cornejo (Das } \\
\text { lyrische } 144)\end{array}$ & $\begin{array}{r}\text { Redondilla } \\
\text { de pie } \\
\text { quebrado }\end{array}$ \\
\hline $\begin{array}{l}\text { 9. Diego sí } \\
\text { que supo } \\
\text { bien }\end{array}$ & $\begin{array}{l}\text { León (Obras } \\
\text { poéticas 1: } \\
81) \\
\text { León (Obras } \\
\text { complutenses } \\
239)\end{array}$ & $\mathrm{T}(34 \mathrm{v})$ & $\begin{array}{l}\mathrm{B}(55), \mathrm{H}(184), \\
K(13), \mathrm{N}(142), \\
\tilde{N}(148 \mathrm{v}), \mathrm{R} \\
(56 \mathrm{v}), \mathrm{S}(116 \mathrm{v})\end{array}$ & $\begin{array}{l}\text { Cornejo (Das } \\
\text { lyrische 154) }\end{array}$ & Romance \\
\hline $\begin{array}{l}\text { 10. Escriben } \\
\text { desde Toledo }\end{array}$ & $\begin{array}{l}\text { León (Obras } \\
\text { poéticas 2: } \\
248) \\
\text { León (Obras } \\
\text { complutenses } \\
67)\end{array}$ & & $\begin{array}{l}\text { A (16), B (76), } \\
\text { D (177), K (28), } \\
\text { M (41), N } \\
(171), \tilde{N}(194), \\
\text { R (82), S (142) }\end{array}$ & $\begin{array}{l}\text { Cornejo (Das } \\
\text { lyrische 196) }\end{array}$ & Romance \\
\hline $\begin{array}{l}\text { 11. Hanme } \\
\text { mandado una } \\
\text { cosa }\end{array}$ & $\begin{array}{l}\text { León (Obras } \\
\text { poéticas 1: } \\
34)\end{array}$ & $\begin{array}{l}\mathrm{Q}(2), \mathrm{T} \\
(32 \mathrm{v}) .\end{array}$ & $\begin{array}{l}\mathrm{A}(6), \mathrm{B}(61), \mathrm{D} \\
(154), \mathrm{H}(198), \\
K(29 v), \mathrm{M}(7), \\
\mathrm{N}(155), \tilde{\mathrm{N}} \\
(168), \mathrm{R}(63), \mathrm{S} \\
(125 \mathrm{v}), \mathrm{Y}(279)\end{array}$ & $\begin{array}{l}\text { Cornejo (Das } \\
\text { lyrische 164) }\end{array}$ & Quintilla \\
\hline $\begin{array}{l}\text { 12. ¡Hola! } \\
\text { Qué llega la } \\
\text { fiesta, qué } \\
\text { falta la solfa }\end{array}$ & $\begin{array}{l}\text { León (Obras } \\
\text { poéticas 2: } \\
270)\end{array}$ & & $\begin{array}{l}\mathrm{D}(183 \mathrm{v}), K \\
(68), \mathrm{N}(178), \mathrm{R} \\
(28 \mathrm{v}), \mathrm{S}(138 \mathrm{v})\end{array}$ & $\begin{array}{l}\text { Cornejo (Das } \\
\text { lyrische 111) }\end{array}$ & Copla \\
\hline $\begin{array}{l}\text { 13. Hoy mi } \\
\text { devoción } \\
\text { aclama }^{309}\end{array}$ & $\begin{array}{l}\text { León (Obras } \\
\text { poéticas 2: } \\
353)\end{array}$ & & $\begin{array}{l}\text { A (11), B (65v), } \\
\text { D (167), E } \\
(37 v), M(14), \\
\text { N (164), N } \\
(182 v), R(37), \\
\text { S (135) }\end{array}$ & $\begin{array}{l}\text { Cornejo (Das } \\
\text { lyrische 127), } \\
\text { López Guil } \\
\text { (262) }\end{array}$ & Quintilla \\
\hline $\begin{array}{l}\text { 14. La } \\
\text { Concepción } \\
\text { este día }\end{array}$ & $\begin{array}{l}\text { León (Obras } \\
\text { poéticas 2: } \\
284)\end{array}$ & $\mathrm{T}(39 \mathrm{v})$ & $\begin{array}{l}\text { A (4v), B (62), } \\
\text { D (157), H } \\
(200), K(31 v), \\
\text { M (11), N } \\
(157), \tilde{N}(171), \\
\text { R (69), S (127) }\end{array}$ & $\begin{array}{l}\text { Cornejo (Das } \\
\text { lyrische } 175 \text { ) }\end{array}$ & Quintilla \\
\hline
\end{tabular}

${ }^{309}$ Aparece como anónima en los manuscritos $Y$ (358) y Z (358). 


\begin{tabular}{|c|c|c|c|c|c|}
\hline $\begin{array}{l}\text { 15. La } \\
\text { Reina, } \\
\text { nuestra } \\
\text { Señora }\end{array}$ & $\begin{array}{l}\text { León (Obras } \\
\text { poéticas 2: } \\
342) \\
\text { León (Obras } \\
\text { complutenses } \\
347)\end{array}$ & $\mathrm{T}(37)$ & $\begin{array}{l}\text { A (24), B (58), } \\
\text { H (192), K (16), } \\
\text { M (29), N } \\
(150), \tilde{N}(159 v), \\
\text { R (65), S (122) }\end{array}$ & $\begin{array}{l}\text { Cornejo (Das } \\
\text { lyrische 167) }\end{array}$ & Romance \\
\hline $\begin{array}{l}\text { 16. Otra vez } \\
\text { tengo la } \\
\text { pluma }\end{array}$ & $\begin{array}{l}\text { León (Obras } \\
\text { poéticas 2: } \\
339) \\
\text { León (Obras } \\
\text { complutenses } \\
\text { 339) }\end{array}$ & $\mathrm{T}(33 \mathrm{v})$ & $\begin{array}{l}\text { A (18), B (53), } \\
\text { D (152), H } \\
(181), K(4), \mathrm{M} \\
(24), \mathrm{N}(139), \tilde{\mathrm{N}} \\
(144 \mathrm{v}), \mathrm{R}(54 \mathrm{v}), \\
\mathrm{S}(114 \mathrm{v})\end{array}$ & $\begin{array}{l}\text { Cornejo (Das } \\
\text { lyrische 151), } \\
\text { López Guil } \\
(257)\end{array}$ & Quintilla \\
\hline $\begin{array}{l}\text { 17. Oigan lo } \\
\text { que saca en } \\
\text { limpio }\end{array}$ & $\begin{array}{l}\text { León (Obras } \\
\text { poéticas 2: } \\
280)\end{array}$ & & $\begin{array}{l}\text { A (6v), B (63), } \\
\text { D (195v), H } \\
(202), M(3), N \\
(159), \tilde{N}(174), \\
\text { R (71), S (128v) }\end{array}$ & $\begin{array}{l}\text { Cornejo (Das } \\
\text { lyrische } 177 \text { ) }\end{array}$ & Romance \\
\hline $\begin{array}{l}\text { 18. Por } \\
\text { tomar Judas } \\
\text { el grado } \\
\text { g11 }\end{array}$ & $\begin{array}{l}\text { León (Obras } \\
\text { poéticas 3: } \\
\text { 22) }\end{array}$ & & $\begin{array}{l}\text { D (107), N } \\
(106), \tilde{N}(100 v), \\
\text { R (26v), S (99) }\end{array}$ & $\begin{array}{l}\text { Cornejo (Das } \\
\text { lyrische 109) }\end{array}$ & Quintilla \\
\hline $\begin{array}{l}\text { 19. San } \\
\text { Diego, si a } \\
\text { hacer } \\
\text { milagros }\end{array}$ & $\begin{array}{l}\text { León (Obras } \\
\text { poéticas 2: } \\
337) \\
\text { León (Obras } \\
\text { complutenses } \\
\text { 391) }\end{array}$ & $\mathrm{T}(34)$ & $\begin{array}{l}\text { A (21v), B } \\
(54 v), H(183), \\
M(27), N \\
(115 v), \tilde{N}(147), \\
\text { R (64) }\end{array}$ & $\begin{array}{l}\text { Cornejo (Das } \\
\text { lyrische 166) }\end{array}$ & Romance \\
\hline $\begin{array}{l}\text { 20. San } \\
\text { Diego, si me } \\
\text { remedia }\end{array}$ & $\begin{array}{l}\text { León (Obras } \\
\text { poéticas 2: } \\
340) \\
\text { León (Obras } \\
\text { complutenses } \\
258)\end{array}$ & $\mathrm{T}(37 \mathrm{v})$ & $\begin{array}{l}\text { A (25), B (59), } \\
\text { H (194), M } \\
(33), \text { N (151), N } \\
(162), \text { R (66v) }\end{array}$ & $\begin{array}{l}\text { AA.VV. } \\
\text { (Tonos 162), } \\
\text { Cornejo (Das } \\
\text { lyrische 170) }\end{array}$ & Redondilla \\
\hline $\begin{array}{l}21 . \text { Todo el } \\
\text { mundo } \\
\text { conmovido }\end{array}$ & $\begin{array}{l}\text { León (Obras } \\
\text { poéticas 1: } \\
83) \\
\text { León (Obras } \\
\text { complutenses } \\
256)\end{array}$ & $\mathrm{T}(36 \mathrm{v})$. & $\begin{array}{l}\mathrm{B}(57 \mathrm{v}), \mathrm{H} \\
(191), \mathrm{N}(148), \\
\tilde{N}(158), \mathrm{R}(60), \\
\mathrm{S}(121)\end{array}$ & $\begin{array}{l}\text { Cornejo (Das } \\
\text { lyrische 160) }\end{array}$ & Quintilla \\
\hline $\begin{array}{l}\text { 22. Un } \\
\text { devoto } \\
\text { singular }\end{array}$ & $\begin{array}{l}\text { León (Obras } \\
\text { poéticas 1: } \\
83 \text { ) }\end{array}$ & T (33). & $\begin{array}{l}\text { B (53), D } \\
(149 \mathrm{v}), \mathrm{H}(179), \\
\mathrm{N}(138), \tilde{\mathrm{N}} \\
(143), \mathrm{R}(52 \mathrm{v}), \\
\mathrm{S}(114 \mathrm{v})\end{array}$ & $\begin{array}{l}\text { Cornejo (Das } \\
\text { lyrische } 150)\end{array}$ & Quintilla \\
\hline
\end{tabular}

310 Aparece como anónima en los manuscritos $Y$ (366) y $Z$ (366).

311 Aparece como anónima en los manuscritos $Y(605)$ y $Z$ (605). 


\begin{tabular}{|l|l|l|l|l|l|}
\hline & $\begin{array}{l}\text { León (Obras } \\
\text { complutenses } \\
389)\end{array}$ & & & \\
& & & & \\
\hline 23. Un & León (Obras & & $\mathrm{A}(1), \mathrm{B}(67 \mathrm{v})$, & Cornejo (Das & Romance \\
pecador soy, & poéticas 2: & $\mathrm{D}(172), \mathrm{E}(42)$, & lyrische 189) & \\
Dios mío & $383)$ & $K(37), \mathrm{M}(46)$, & & \\
& & $\mathrm{N}(168), \tilde{\mathrm{N}}$ & & \\
& & $(188 \mathrm{v}), \mathrm{R}(78)$, & & \\
& & $\mathrm{S}(146 \mathrm{v})$ & & \\
\hline
\end{tabular}

Tabla 31: Poesía sacra publicada en las $O P L M$

\subsection{Poesía profana publicada a nombre de Marchante}

\begin{tabular}{|c|c|c|c|c|c|}
\hline \multicolumn{6}{|c|}{ Poesía dubitada profana } \\
\hline $\begin{array}{l}\text { Primer } \\
\text { verso }\end{array}$ & $\begin{array}{l}\text { Atribuida } \\
\text { a LM en } \\
\text { Impresos }\end{array}$ & $\begin{array}{l}\text { Atribuida a } \\
\text { LM en } \\
\text { manuscritos }\end{array}$ & $\begin{array}{l}\text { Atribuida a } \\
\text { Cornejo en } \\
\text { Manuscritos }\end{array}$ & $\begin{array}{l}\text { Atribuida } \\
\text { a Cornejo } \\
\text { en } \\
\text { impresos }\end{array}$ & Métrica \\
\hline $\begin{array}{l}\text { 1. A una reja, } \\
\text { qué ventura }\end{array}$ & $\begin{array}{l}\text { León (Obras } \\
\text { poéticas 3: } \\
13 \text { ) }\end{array}$ & & $\begin{array}{l}\text { A (87), B (38), D } \\
(29 v), H(86), \\
\text { LL (217), M } \\
(213), N \text { (71), N } \\
(51 v), Q(105), \\
\text { R (99), S (48) }\end{array}$ & & Décima \\
\hline $\begin{array}{l}\text { 2. A uno que } \\
\text { se hace una } \\
\text { uva }\end{array}$ & $\begin{array}{l}\text { León (Obras } \\
\text { poéticas 3: } \\
\text { 31) }\end{array}$ & & $\begin{array}{l}\text { A (66v), B } \\
(25 \mathrm{v}), C \text { ( }(84 \mathrm{v}), \\
\text { D (29v), H (86), } \\
\text { LL (202v), M } \\
(308), N(44), \tilde{N} \\
(17), Q(70), R \\
(99), S(21)\end{array}$ & $\begin{array}{l}\text { AA.VV. } \\
\text { (Tonos } \\
\text { 146). }\end{array}$ & Quintilla \\
\hline $\begin{array}{l}\text { 3. Adiós, } \\
\text { Leonor de mi } \\
\text { vida }\end{array}$ & $\begin{array}{l}\text { León (Obras } \\
\text { poéticas 3: } \\
44)\end{array}$ & & $\begin{array}{l}\text { A (62v), B } \\
(50 v), C \text { ( }(81), D \\
(98), H(150 v), \\
\text { LL }(226), M \\
(237), N(98), \tilde{N} \\
(89), O(61), Q \\
(62), R(110 v), S \\
(76)\end{array}$ & & $\begin{array}{r}\text { Copla de } \\
\text { pie } \\
\text { quebrado }\end{array}$ \\
\hline $\begin{array}{l}\text { 4. Ayer, } \\
\text { Angélica, } \\
\text { supe }\end{array}$ & $\begin{array}{l}\text { León (Obras } \\
\text { poéticas 3: } \\
36)\end{array}$ & & $\mathrm{R}(151)$ & & Romance \\
\hline
\end{tabular}




\begin{tabular}{|c|c|c|c|c|}
\hline $\begin{array}{l}\text { 5. Belisa el } \\
\text { chasco } \\
\text { celebra }\end{array}$ & $\begin{array}{l}\text { León (Obras } \\
\text { poéticas 3: } \\
14)\end{array}$ & & $\begin{array}{l}\text { A (50), B (44), H } \\
(133 \mathrm{v}), \mathrm{LL} \\
(220), \mathrm{M}(177), \\
\mathrm{N}(85), \tilde{\mathrm{N}}(69 \mathrm{v}), \\
\mathrm{O}(53), \mathrm{Q}(42), \mathrm{R} \\
(106 \mathrm{v}), \mathrm{S}(61 \mathrm{v})\end{array}$ & Décima \\
\hline $\begin{array}{l}\text { 6. Bien } \\
\text { puede, Lisis, } \\
\text { un triste }\end{array}$ & $\begin{array}{l}\text { León (Obras } \\
\text { poéticas 1: } \\
167)\end{array}$ & & $\begin{array}{l}\text { A (53), B (46), D } \\
(85), H(139 v), \\
\text { LL }(222), N \\
(90), \tilde{N}(76), R \\
(90 v), S(66)\end{array}$ & Romance \\
\hline $\begin{array}{l}\text { 7. Bizarro } \\
\text { amor me } \\
\text { desvela }\end{array}$ & $\begin{array}{l}\text { León (Obras } \\
\text { poéticas 3: } \\
19)\end{array}$ & & $\begin{array}{l}\text { A (51v), B } \\
(44 v), H(135 v), \\
\text { LL (229), M } \\
(181), \tilde{N}(71 v), \\
Q(44), R \\
(107 v), S(63 v)\end{array}$ & Décima \\
\hline $\begin{array}{l}\text { 8. Casose } \\
\text { Menga con } \\
\text { Bras }\end{array}$ & $\begin{array}{l}\text { León (Obras } \\
\text { poéticas 3: } \\
47)\end{array}$ & $\begin{array}{l}\text { B (23v), Y } \\
(607), Z \\
(607)\end{array}$ & $\begin{array}{l}\text { LL (242v), M } \\
(243)\end{array}$ & Romance \\
\hline $\begin{array}{l}\text { 9. Cien } \\
\text { reales por mí } \\
\text { perdiste }\end{array}$ & $\begin{array}{l}\text { León (Obras } \\
\text { poéticas 3: } \\
18)\end{array}$ & & $\begin{array}{l}\mathrm{A}(84 \mathrm{v}), \mathrm{B} \\
(34 \mathrm{v}), \mathrm{D}(52), \mathrm{H} \\
(106), \mathrm{LL} \\
(232 \mathrm{v}), \mathrm{M}(202), \\
\mathrm{N}(62), \tilde{N}(38 \mathrm{v}), \\
Q(100 \mathrm{v}), \mathrm{R} \\
(100 \mathrm{v}), \mathrm{S}(38 \mathrm{v})\end{array}$ & Décima \\
\hline $\begin{array}{l}\text { 10. Clodio, } \\
\text { del mundo en } \\
\text { la plaza }\end{array}$ & $\begin{array}{l}\text { León (Obras } \\
\text { poéticas 3: } \\
25)\end{array}$ & & $\begin{array}{l}\text { A (67v), B (26), } \\
C(86 v), D(30), \\
\text { H }(87 v), \text { LL } \\
(203), M(198), \\
\text { N (45), N }(17 v), \\
Q(71), R(99 v), \\
\text { S (22) }\end{array}$ & Décima \\
\hline $\begin{array}{l}\text { 11. Clori, } \\
\text { que para ser } \\
\text { linda }\end{array}$ & $\begin{array}{l}\text { León (Obras } \\
\text { poéticas 3: } \\
\text { 35) }\end{array}$ & & $\begin{array}{l}\text { A (64), B (51v), } \\
C ̧(82 v), \text { D (100), } \\
\text { H (152v), LL } \\
(257), M(241), \\
\text { N (100), N (91), } \\
\text { Q (64), R (111), } \\
\text { S (77v) }\end{array}$ & Romance \\
\hline $\begin{array}{l}\text { 12. Con } \\
\text { licencia de } \\
\text { Silvia }\end{array}$ & $\begin{array}{l}\text { León (Obras } \\
\text { poéticas } 3 \text { : } \\
58)\end{array}$ & & $\begin{array}{l}\mathrm{A}(60), \mathrm{B} \\
(115 \mathrm{v}), C(78), \mathrm{F} \\
(223 \mathrm{v}), \mathrm{LL} \\
(247 \mathrm{v}), \mathrm{Q}(50 \mathrm{v})\end{array}$ & Seguidilla \\
\hline $\begin{array}{l}\text { 13. Con } \\
\text { modo ya más } \\
\text { humano }\end{array}$ & $\begin{array}{l}\text { León (Obras } \\
\text { poéticas 3: } \\
19)\end{array}$ & & $\begin{array}{l}\mathrm{D}(65 \mathrm{v}), \mathrm{H} \\
(118 \mathrm{v}), \mathrm{Q} \\
(133 \mathrm{v}), \tilde{N}(53 \mathrm{v}), \\
\text { N (73), A (99v) } \\
\text { B (38v), LL }\end{array}$ & Décima \\
\hline
\end{tabular}

312 Aparece como anónima en los manuscritos $Y$ (674) y Z (674). 


\begin{tabular}{|c|c|c|c|c|c|}
\hline & & & $\begin{array}{l}\text { (219), M (216), } \\
\text { R (103v), S (49), }\end{array}$ & & \\
\hline $\begin{array}{l}14 \text { Cuenta } \\
\text { con el retrato }\end{array}$ & $\begin{array}{l}\text { León (Obras } \\
\text { poéticas 3: } \\
\text { 57) }\end{array}$ & & $\begin{array}{l}\text { A (59), B } \\
(114 v), C \text { (66), F } \\
(222 \mathrm{v}), \mathrm{LL} \\
(246), \mathrm{M}(304), \\
\mathrm{Q}(48)\end{array}$ & & Seguidilla \\
\hline $\begin{array}{l}\text { 15. De pedir } \\
\text { (nunca yo } \\
\text { fuera) })^{313}\end{array}$ & $\begin{array}{l}\text { León (Obras } \\
\text { poéticas 3: } \\
21)\end{array}$ & & $\begin{array}{l}\text { A (61), B (49), Ç } \\
(79 v), \mathrm{D}(164), \\
\mathrm{H}(147 \mathrm{v}), \mathrm{LL} \\
(225), \mathrm{M}(191), \\
\mathrm{N}(96), \tilde{N}(85 \mathrm{v}), \\
\mathrm{O}(58), \mathrm{Q}(60), \mathrm{R} \\
(109 \mathrm{v}), \mathrm{S}(73)\end{array}$ & & Décima \\
\hline $\begin{array}{l}\text { 16. De Pinto } \\
\text { para un } \\
\text { festejo }\end{array}$ & $\begin{array}{l}\text { León (Obras } \\
\text { poéticas 1: } \\
182)\end{array}$ & $\begin{array}{l}\tilde{N}(46) \\
\mathrm{T}(10),\end{array}$ & $\begin{array}{l}\text { D (59), H } \\
(112 \mathrm{v}), \mathrm{Q}(144), \\
\mathrm{N}(67), \mathrm{B}(36 \mathrm{v}), \\
\text { LL (213), R } \\
(86), \text { S (44) }\end{array}$ & & Romance \\
\hline $\begin{array}{l}\text { 17. De un pie } \\
\text { escribir } \\
\text { quiero en } \\
\text { suma }\end{array}$ & $\begin{array}{l}\text { León (Obras } \\
\text { poéticas } 3 \text { : } \\
34)\end{array}$ & & $\begin{array}{l}\mathrm{D}(131), \mathrm{H} \\
(203), \mathrm{N}(124), \\
\tilde{\mathrm{N}}(124 \mathrm{v}), \mathrm{R} \\
(1 \mathrm{v}), \mathrm{S}(97 \mathrm{v})\end{array}$ & $\begin{array}{l}\text { Cornejo } \\
\text { (Das } \\
\text { lyrische } \\
52)\end{array}$ & Quintilla \\
\hline $\begin{array}{l}\text { 18. Desde } \\
\text { que el sol } \\
\text { ardiente }\end{array}$ & $\begin{array}{l}\text { León (Obras } \\
\text { poéticas 3: } \\
81)\end{array}$ & $\begin{array}{l}\mathrm{Q}(28), \\
\mathrm{T}(2 \mathrm{v})\end{array}$ & $\begin{array}{l}\text { A (40v), B } \\
(11 v), D(17), F \\
(219), H(75 v), \\
\text { LL (186), M } \\
(14), N \text { (29), N } \\
(10), R(126), S \\
(12)\end{array}$ & & Sexta lira \\
\hline $\begin{array}{l}19 . \text { Desde } \\
\text { que tus niñas } \\
\text { bellas }\end{array}$ & $\begin{array}{l}\text { León (Obras } \\
\text { poéticas } 3 \text { : } \\
42)\end{array}$ & & $\begin{array}{l}\text { A (84), B (34), D } \\
(51 \mathrm{v}), \mathrm{H}(105), \\
\text { Q (99), LL } \\
(210 \mathrm{v}), \mathrm{N}(61), \\
\tilde{N}(37 \mathrm{v}), \mathrm{R}(5), \mathrm{S} \\
(38)\end{array}$ & & Redondilla \\
\hline $\begin{array}{l}\text { 20. Diego } \\
\text { (Anfriso) que } \\
\text { con atención }\end{array}$ & $\begin{array}{l}\text { León (Obras } \\
\text { poéticas } 3 \text { : } \\
20)\end{array}$ & & $\begin{array}{l}\text { A (55v), B (47) } \\
\text { D (88v), H } \\
(141), M(184), \\
\text { N (93), N (79v), } \\
\text { Q (54v), R } \\
(108 v), S(69)\end{array}$ & $\begin{array}{l}\text { AA.VV. } \\
\text { (Poesías } \\
\text { 28) }\end{array}$ & Décima \\
\hline $\begin{array}{l}\text { 21. Dios te } \\
\text { socorra, } \\
\text { Marica }\end{array}$ & $\begin{array}{l}\text { León (Obras } \\
\text { poéticas 1: } \\
172)\end{array}$ & $\tilde{\mathrm{N}}(47 \mathrm{v})$ & $\begin{array}{l}\text { B (37), D (60), E } \\
(368), H(113 v), \\
\text { LL (213), N } \\
(69), Q \text { (146), R } \\
(87 v), S(45)\end{array}$ & & Romance \\
\hline $\begin{array}{l}\text { 22. Dulce } \\
\text { Lisis de mis } \\
\text { ojos }\end{array}$ & $\begin{array}{l}\text { León (Obras } \\
\text { poéticas 3: } \\
\text { 53) }\end{array}$ & $\mathrm{T}(5)$ & $\begin{array}{l}\text { A (49), B (21), D } \\
(20 \mathrm{v}), \mathrm{H}(78 \mathrm{v}), \\
\text { LL (244v), M }\end{array}$ & $\begin{array}{l}\text { AA.VV. } \\
\text { (Gaceta 6) }\end{array}$ & Romance \\
\hline
\end{tabular}

${ }^{313}$ Aparece como anónima en los manuscritos $Y$ (605) y Z (605). 


\begin{tabular}{|c|c|c|c|c|c|}
\hline & & & $\begin{array}{l}(224), N(36), \tilde{N} \\
(22), Q(44 v), R \\
(96 v), S \text { (15) }\end{array}$ & & \\
\hline $\begin{array}{l}\text { 23. En el } \\
\text { mar de tu } \\
\text { hermosura }\end{array}$ & $\begin{array}{l}\text { León (Obras } \\
\text { poéticas 3: } \\
18)\end{array}$ & & $\begin{array}{l}\text { A (96), B (35), D } \\
(54), H(108), \\
\text { LL (211), M } \\
(203), N(64), \tilde{N} \\
(41), O(50), Q \\
(128 v), R(101), \\
\text { S (40) }\end{array}$ & $\begin{array}{l}\text { AA. VV. } \\
\text { (De todo } \\
\text { 2) }\end{array}$ & Décimas \\
\hline $\begin{array}{l}24 \text { Éranse } \\
\text { dos } \\
\text { licenciados }\end{array}$ & $\begin{array}{l}\text { León (Obras } \\
\text { poéticas 3: } \\
33) \\
\text { León (Obras } \\
\text { complutenses } \\
275)\end{array}$ & & $\begin{array}{l}\text { B (24v), D (25), } \\
\text { H (82), LL } \\
(201), \text { M }(247), \\
\text { N (41), N (14v), } \\
\text { R (98), S (18) }\end{array}$ & & Romance \\
\hline $\begin{array}{l}25 . \text { Es de } \\
\text { Fausto la } \\
\text { fiereza }\end{array}$ & $\begin{array}{l}\text { León (Obras } \\
\text { poéticas 3: } \\
27)\end{array}$ & $\mathrm{T}(10 \mathrm{v})$ & $\begin{array}{l}\text { A (98v), B (36), } \\
\text { D (57v), H } \\
(111), M(209), \\
\text { N }(66), \tilde{N}(44 v), \\
\text { Q (134), R } \\
(102), S(43)\end{array}$ & & Décima \\
\hline $\begin{array}{l}26 . \\
\text { Escúchenme } \\
\text { unos } \\
\text { esdrújulos }\end{array}$ & $\begin{array}{l}\text { León (Obras } \\
\text { poéticas 1: } \\
168)\end{array}$ & & $\begin{array}{l}\text { B (43), D (78), H } \\
(132), \text { LL (219), } \\
\text { N (84), N (67v), } \\
\text { R (85v), S (60) }\end{array}$ & & $\begin{array}{r}\text { Octosílabo } \\
\text { en } \\
\text { esdrújulo }\end{array}$ \\
\hline $\begin{array}{l}\text { 27. Hoy, } \\
\text { Clori, } \\
\text { pretendo } \\
\text { amante }\end{array}$ & $\begin{array}{l}\text { León (Obras } \\
\text { poéticas 1: } \\
170)\end{array}$ & $\tilde{\mathrm{N}}(82 \mathrm{v})$ & $\begin{array}{l}\text { B (f 48), D } \\
\text { (91v), H (149), } \\
\text { LL (220), N (95) } \\
\text { R (91v), S (71) }\end{array}$ & & $\begin{array}{r}\text { Redondilla } \\
\text { con glosa }\end{array}$ \\
\hline $\begin{array}{l}\text { 28. Hoy, sin } \\
\text { más ni más } \\
\text { me allano }\end{array}$ & $\begin{array}{l}\text { León (Obras } \\
\text { poéticas 1: } \\
180) \\
\text { León } \\
\text { (Relación } 15 \\
\text { ) }\end{array}$ & & $\begin{array}{l}\text { B (75v), D } \\
(115 v), G(196), \\
H(166 v), N \\
(112), \tilde{N}(108 v), \\
R(123)\end{array}$ & & Quintilla \\
\hline $\begin{array}{l}\text { 29. María, a } \\
\text { tu sucia cara }\end{array}$ & $\begin{array}{l}\text { León (Obras } \\
\text { poéticas 3: } \\
\text { 22) }\end{array}$ & & $\begin{array}{l}\text { A (62v), B } \\
(49 \mathrm{v}), C \text { ( }(80 v), D \\
(95 \mathrm{v}), \mathrm{H}(149), \\
\text { LL (224v), N } \\
(97), \tilde{N}(87), \mathrm{Q} \\
(59 \mathrm{v}), \mathrm{R}(110), \mathrm{S} \\
(74 \mathrm{v})\end{array}$ & $\begin{array}{l}\text { AA. VV. } \\
\text { (Cancione- } \\
\text { ro de } \\
\text { obras 299) }\end{array}$ & Décima \\
\hline $\begin{array}{l}\text { 30. Mi bien, } \\
\text { juro por mi } \\
\text { amor }\end{array}$ & & $\mathrm{T}(9)$ & $\begin{array}{l}\text { A (97), B (35v), } \\
\text { D (55v), H } \\
(109 v), Q\end{array}$ & & Décima \\
\hline
\end{tabular}

${ }^{314}$ Aparece como anónima en los manuscritos $Y$ (506) y Z (506). 


\begin{tabular}{|c|c|c|c|c|c|}
\hline & $\begin{array}{l}\text { León (Obras } \\
\text { poéticas 3: } \\
15)\end{array}$ & & $\begin{array}{l}\text { (130v), LL } \\
(211 v), M(205), \\
N(65), \tilde{N}(42 v), \\
R(101 v), S \\
(41 v)\end{array}$ & & \\
\hline $\begin{array}{l}\text { 31. No } \\
\text { quieran tus } \\
\text { sinrazones }\end{array}$ & $\begin{array}{l}\text { León (Obras } \\
\text { poéticas 3: } \\
\text { 22) }\end{array}$ & & $\begin{array}{l}\text { A (98v), B (36), } \\
\text { D (127v), H } \\
(175 v), \text { LL } \\
(266), M(208), \\
\tilde{N}(120 v), N \\
(121), Q \text { (133), } \\
\text { R (116), S (95) }\end{array}$ & & Décima \\
\hline $\begin{array}{l}\text { 32. Oiga, } \\
\text { hermano fray } \\
\text { Francisco }\end{array}$ & $\begin{array}{l}\text { León (Obras } \\
\text { poéticas 2: } \\
374) \\
\text { León (Obras } \\
\text { complutenses } \\
364)\end{array}$ & & $\begin{array}{l}\text { A (18), B (52v), } \\
\mathrm{D}(147 \mathrm{v}), \quad \mathrm{H} \\
(177 \mathrm{v}), \mathrm{M}(57), \\
\mathrm{N}(136), \quad \tilde{\mathrm{N}} \\
(141 \mathrm{v}), \mathrm{R}(93 \mathrm{v}), \\
\mathrm{S}(112)\end{array}$ & & Romance \\
\hline $\begin{array}{l}\text { 33. Óiganme, } \\
\text { damas, que } \\
\text { empuño }\end{array}$ & $\begin{array}{l}\text { León (Obras } \\
\text { poéticas 1: } \\
171)\end{array}$ & $\tilde{N}(16)$ & $\begin{array}{l}\text { B (25), D (28), H } \\
(84 v), \text { LL (203), } \\
\text { N (43), R (91), S } \\
(20)\end{array}$ & & Romance \\
\hline $\begin{array}{l}\text { 34. Oye, } \\
\text { tarazón de } \\
\text { fraile }\end{array}$ & $\begin{array}{l}\text { León (Obras } \\
\text { poéticas 1: } \\
183) \\
\text { León (Obras } \\
\text { complutenses } \\
374)\end{array}$ & $\begin{array}{l}\tilde{N}(60), \\
T(11)\end{array}$ & $\begin{array}{l}\text { A (102v), B } \\
(41), D \text { (71), H } \\
(125), \text { LL } \\
(216 v), N(78), \\
\text { R (89v), S (54v) }\end{array}$ & & Romance \\
\hline $\begin{array}{l}\text { 35- Pedro, } \\
\text { mi ingenio } \\
\text { recela }\end{array}$ & $\begin{array}{l}\text { León (Obras } \\
\text { poéticas 3: } \\
28)\end{array}$ & $\mathrm{T}(8 \mathrm{v})$ & $\begin{array}{l}\text { B (42), D (77), H } \\
(130), L L \\
(218 v), M(222), \\
N(83), \tilde{N}(66), R \\
(106 v), S(59)\end{array}$ & & Décima \\
\hline $\begin{array}{l}\text { 36. Por los } \\
\text { yerros, Lisis } \\
\text { bella, un } \\
\text { traslado }\end{array}$ & $\begin{array}{l}\text { León (Obras } \\
\text { poéticas 3: } 6)\end{array}$ & & $\begin{array}{l}\text { A (45), B (16), D } \\
(108), G(190), \\
H(159 v), J(9 v), \\
M(164), N \\
(106), \tilde{N}(100 v), \\
Q(34), R \\
(118 v), S(84 v)\end{array}$ & $\begin{array}{l}\text { Marañón } \\
\text { (Sonetos } \\
37 \text { ) }\end{array}$ & Soneto \\
\hline $\begin{array}{l}\text { 38. Solo el } \\
\text { silencio } \\
\text { testigo }\end{array}$ & $\begin{array}{l}\text { León (Obras } \\
\text { poéticas 3: } \\
11)\end{array}$ & & $\begin{array}{l}\text { A (100), B (37), } \\
\text { D (66), H (119), } \\
\text { N (73), N (54), } \\
\text { Q (69), R (104), } \\
\text { S (50) }\end{array}$ & & Décimas \\
\hline $\begin{array}{l}\text { 39. Queridas, } \\
\text { mucho me } \\
\text { enfada }\end{array}$ & $\begin{array}{l}\text { León (Obras } \\
\text { poéticas 3: } \\
17)\end{array}$ & & $\begin{array}{l}\text { A (104v), B } \\
(42), D(75 v), H \\
(129 v), \text { LL } \\
(218), N(82), \tilde{N} \\
(64 v), Q(138), \\
R(105 v), S(58)\end{array}$ & & Décima \\
\hline
\end{tabular}




\begin{tabular}{|c|c|c|c|c|c|}
\hline $\begin{array}{l}\text { 40. Quiero } \\
\text { ver a mi } \\
\text { tristeza }\end{array}$ & $\begin{array}{l}\text { León (Obras } \\
\text { poéticas 3: } \\
\text { 37) }\end{array}$ & & R (169) & & Romance \\
\hline $\begin{array}{l}\text { 41. Rudo } \\
\text { pincel de } \\
\text { mano } \\
\text { inadvertida }\end{array}$ & $\begin{array}{l}\text { León (Obras } \\
\text { poéticas 3: 5) }\end{array}$ & & $\begin{array}{l}\text { A (44v), B (16), } \\
\text { D (107v), G } \\
(189 v), H \\
(159 v), J(9), M \\
(163), N(106), \\
\tilde{N}(100), Q \\
(33 v), R(118), S \\
(83 v)\end{array}$ & $\begin{array}{l}\text { AA.VV. } \\
\text { (Cancione- } \\
\text { ro } \\
\text { moderno } \\
66 \text { ), } \\
\text { Marañón } \\
\text { (Sonetos } \\
\text { 37) }\end{array}$ & Soneto \\
\hline $\begin{array}{l}\text { 42. Señor, } \\
\text { jurador he } \\
\text { sido }\end{array}$ & $\begin{array}{l}\text { León (Obras } \\
\text { poéticas 1: } \\
\text { 180) } \\
\text { León (Un } \\
\text { jurador } 1)\end{array}$ & & $\begin{array}{l}\text { A (60v), B } \\
(75 v), C(78 v), D \\
(117), G(197), \\
\text { H (197), N } \\
(113), \widetilde{N}(109), \\
R(123 v \text { y 152), } \\
\text { S (89v) }\end{array}$ & & Quintilla \\
\hline $\begin{array}{l}\text { 43. Tu } \\
\text { romance, } \\
\text { Andrés, leí }\end{array}$ & $\begin{array}{l}\text { León (Obras } \\
\text { poéticas 3: } \\
26)\end{array}$ & & $\begin{array}{l}\text { A (90), B (42), D } \\
(74 v), H(128), \\
\text { LL (217v), N } \\
(61), \tilde{N}(38), Q \\
(110), R(105 v), \\
\text { S (57) }\end{array}$ & & Décima \\
\hline $\begin{array}{l}\text { 44. Un } \\
\text { corcovado } \\
\text { poeta }\end{array}$ & $\begin{array}{l}\text { León (Obras } \\
\text { poéticas 1: } \\
149) \\
\text { León (Obras } \\
\text { complutenses: } \\
393)\end{array}$ & $\mathrm{T}(35 \mathrm{v})$ & $\begin{array}{l}\text { A (23), B (56v), } \\
\text { H (188), N } \\
(146), \tilde{N}(154), \\
\text { R (50v), S } \\
(119 v)\end{array}$ & $\begin{array}{l}\text { Cornejo } \\
\text { (Das } \\
\text { lyrische } \\
147)\end{array}$ & Romance \\
\hline $\begin{array}{l}\text { 45. Un } \\
\text { estudiante } \\
\text { este curso }\end{array}$ & $\begin{array}{l}\text { León (Obras } \\
\text { poéticas 1: } \\
\text { 181) } \\
\text { León (Obras } \\
\text { complutenses: } \\
277) \\
\text { León } \\
\text { (Relación 16) }\end{array}$ & $\tilde{\mathbf{N}}(123)$ & $\begin{array}{l}\text { D (129v), G } \\
(198), N(122), \\
\text { R (2v), S (96v) }\end{array}$ & $\begin{array}{l}\text { Cornejo } \\
\text { (Das } \\
\text { lyrische } \\
57)\end{array}$ & $\begin{array}{r}\text { Copla de } \\
\text { pie } \\
\text { quebrado }\end{array}$ \\
\hline $\begin{array}{l}46 . \text { Un } \\
\text { estudiante de } \\
\text { hogaño }\end{array}$ & $\begin{array}{l}\text { León (Obras } \\
\text { poéticas 3: } \\
73 \text { ) }\end{array}$ & $\begin{array}{l}\text { Y (566), } \\
Z \text { Z (566) }\end{array}$ & $\begin{array}{l}\text { A (68v), B (27), } \\
\text { Ç (88v), D } \\
(32 v), H(88 v), \\
\text { LL (203v), M } \\
(313), N(46), Q \\
(73 v), R(100), S \\
(23 v)\end{array}$ & & Redondilla \\
\hline $\begin{array}{l}\text { 47. Un galán } \\
\text { corto de talle }\end{array}$ & $\begin{array}{l}\text { León (Obras } \\
\text { poéticas 1: } \\
179)\end{array}$ & & $\begin{array}{l}\text { B (50), D (96), H } \\
\text { (149), LL (225), }\end{array}$ & $\begin{array}{l}\text { AA. VV. } \\
\text { (Cancione }\end{array}$ & Romance \\
\hline
\end{tabular}




\begin{tabular}{|c|c|c|c|c|c|}
\hline & & & $\begin{array}{l}\mathrm{N}(97), \tilde{N}(87 \mathrm{v}), \\
\mathrm{R}(92), \mathrm{S}(97)\end{array}$ & $\begin{array}{l}\text { ro de } \\
\text { obras 299) }\end{array}$ & \\
\hline $\begin{array}{l}\text { 48. Un } \\
\text { tudesco, } \\
\text { humana cuba }\end{array}$ & $\begin{array}{l}\text { León (Obras } \\
\text { poéticas 1: } \\
\text { 185) } \\
\text { León } \\
\text { (Relación 15) }\end{array}$ & & $\begin{array}{l}\text { B (107), D } \\
(146 v), N(135), \\
\tilde{N}(140), \text { R (3) }\end{array}$ & $\begin{array}{l}\text { Cornejo } \\
\text { (Das } \\
\text { lyrische } \\
59)\end{array}$ & Redondilla \\
\hline $\begin{array}{l}\text { 49. Un } \\
\text { tuerto soy } \\
\text { desgraciado }\end{array}$ & $\begin{array}{l}\text { León (Obras } \\
\text { poéticas 1: } \\
149)\end{array}$ & $\mathrm{T}(35 \mathrm{v})$ & $\begin{array}{l}\text { A (22v), B } \\
(56 v), H(187), \\
\text { N (145), N } \\
(153), R(50), S \\
(118 v)\end{array}$ & $\begin{array}{l}\text { AA.VV. } \\
\text { (Cancione- } \\
\text { ro } \\
\text { moderno } \\
392 \text { ), } \\
\text { Cornejo } \\
\text { (Das } \\
\text { lyrische } \\
145)\end{array}$ & Redondilla \\
\hline $\begin{array}{l}50 . \text { Vengar } \\
\text { quiero mis } \\
\text { rencillas }\end{array}$ & $\begin{array}{l}\text { León (Obras } \\
\text { poéticas 1: } \\
169)\end{array}$ & $\tilde{\mathrm{N}}(36)$ & $\begin{array}{l}\text { A (82), B (33v), } \\
\text { D (48v), H } \\
(102 v), \text { LL } \\
(209 v), N(59), \\
\text { R (86), S (35v) }\end{array}$ & & Quintilla \\
\hline $\begin{array}{l}\text { 51. Ya que } \\
\text { tan galante } \\
\text { has sido }\end{array}$ & $\begin{array}{l}\text { León (Obras } \\
\text { poéticas } 3 \text { : } \\
20)\end{array}$ & & $\begin{array}{l}\text { B (48v), D (93), } \\
\text { H (146v), LL } \\
(224 v), \text { M (189), } \\
\text { N (95v), N (84), } \\
\text { O (56), Q (58), R } \\
(109), S \text { (72v) }\end{array}$ & & Décima \\
\hline $\begin{array}{l}\text { 52. Ya, } \\
\text { Fabio, que } \\
\text { hemos } \\
\text { llegado }\end{array}$ & $\begin{array}{l}\text { León (Obras } \\
\text { poéticas 3: } \\
\text { 23) }\end{array}$ & & $\begin{array}{l}\text { A (104), B } \\
(48 v), D(93), H \\
(146 v), N(96), \\
\tilde{N}(84), Q \text { (58), R } \\
(109 v), S(72 v)\end{array}$ & & Décima \\
\hline $\begin{array}{l}\text { 53. Yo soy, } \\
\text { ilustre } \\
\text { Academia }\end{array}$ & $\begin{array}{l}\text { León (Obras } \\
\text { poéticas 3: 7) }\end{array}$ & $\mathrm{T}(6 \mathrm{v})$ & $\begin{array}{l}\text { B (21v), D } \\
(22 v), H(79 v), \\
\text { LL (199), M } \\
(227), N(39), \tilde{N} \\
(23), R(97 v), S \\
(16)\end{array}$ & & Romance \\
\hline
\end{tabular}

Tabla 32: Poesía profana publicada en la $O P L M$ 


\section{Obras poéticas de León Marchante}

\begin{tabular}{|c|c|c|}
\hline Vol. I (1722) & Vol. II (1733) & Vol. III (1733) \\
\hline $\begin{array}{l}\text { 1. A conjurar estas } \\
\text { nubes }(148)\end{array}$ & $\begin{array}{l}\text { 1. Al señor Bautista, el } \\
\text { jaque (308) }\end{array}$ & $\begin{array}{l}\text { 1. A una reja, qué ventura } \\
\text { (13) }\end{array}$ \\
\hline $\begin{array}{l}\text { 2. Bien puede, Lisis, } \\
\text { un triste (167) }\end{array}$ & $\begin{array}{l}\text { 2. De Francisco por menor } \\
\text { (318) }\end{array}$ & $\begin{array}{l}\text { 2. A uno que se hace una } \\
\text { uva (31) }\end{array}$ \\
\hline $\begin{array}{l}\text { 3. Después porque } \\
\text { se usa ( } 80)\end{array}$ & \multirow{3}{*}{$\begin{array}{l}\text { 3. De tu concepción, } \\
\text { Señora (279) } \\
\text { 4. De una niña/ María la } \\
\text { grandeza (285) } \\
\text { 5. Escriben desde Toledo } \\
\text { (248) }\end{array}$} & $\begin{array}{l}\text { 3. Anfriso/ Diego que con } \\
\text { atención (20) }\end{array}$ \\
\hline $\begin{array}{l}\text { 4. Diego sí que } \\
\text { supo bien }(81)\end{array}$ & & $\begin{array}{l}\text { 4. Adiós, Clori/Leonor de } \\
\text { mi vida (44) }\end{array}$ \\
\hline $\begin{array}{l}\text { 5. Dios te socorra, } \\
\text { Marica (172) }\end{array}$ & & $\begin{array}{l}\text { 5. Ayer, Angélica, supe } \\
\text { (36) }\end{array}$ \\
\hline $\begin{array}{l}\text { 6. De pie quebrado } \\
\text { unas coplas (79) }\end{array}$ & \multirow{2}{*}{$\begin{array}{l}\text { 6. ¡Hola! Qué llega la } \\
\text { fiesta, qué falta la solfa } \\
(270)\end{array}$} & $\begin{array}{l}\text { 6. Belisa el chasco celebra } \\
\text { (14) }\end{array}$ \\
\hline $\begin{array}{l}\text { 7. De Diego тиу por } \\
\text { menor (82) }\end{array}$ & & $\begin{array}{l}\text { 7. Bizarro amor me desvela } \\
\text { (19) }\end{array}$ \\
\hline $\begin{array}{l}\text { 8. Escúchenme unos } \\
\text { esdrújulos (168) }\end{array}$ & $\begin{array}{l}\text { 7. Hoy mi devoción aclama } \\
(364)\end{array}$ & $\begin{array}{l}\text { 8. Casose Menga con Bras } \\
\text { (47) }\end{array}$ \\
\hline $\begin{array}{l}\text { 9. En Pinto para un } \\
\text { festejo (182) }\end{array}$ & $\begin{array}{l}\text { 8.La Concepción este día } \\
(284)\end{array}$ & $\begin{array}{l}\text { 9. Con licencia de Silvia } \\
(58)\end{array}$ \\
\hline $\begin{array}{l}\text { 10. Hanme mandado } \\
\text { una cosa (34) }\end{array}$ & $\begin{array}{l}\text { 9. La reina, nuestra Señora } \\
(342)\end{array}$ & $\begin{array}{l}\text { 10. Cien reales por mí } \\
\text { perdiste }(18)\end{array}$ \\
\hline \multirow{2}{*}{$\begin{array}{l}11 \text { Hoy, Clori, } \\
\text { pretendo amante } \\
(170)\end{array}$} & $\begin{array}{l}\text { 10. Oigan lo que saco en } \\
\text { limpio }(280)\end{array}$ & \multirow{2}{*}{$\begin{array}{l}\text { 11. Clodio, del mundo en la } \\
\text { plaza (25) } \\
\text { 12. Clori, que para ser linda } \\
\text { (35) }\end{array}$} \\
\hline & $\begin{array}{l}\text { 11. Otra vez tengo la pluma } \\
\text { (339) }\end{array}$ & \\
\hline \multirow{3}{*}{$\begin{array}{l}\text { más me allano (180) } \\
\text { 13. Óiganme, damas, } \\
\text { que empuño (171) }\end{array}$} & $\begin{array}{l}\text { 12. San Diego, si } \\
\text { remedia (340) }\end{array}$ & \multirow{2}{*}{$\begin{array}{l}\text { 13. Con modo ya más } \\
\text { humano (19) }\end{array}$} \\
\hline & \multirow{3}{*}{$\begin{array}{l}\text { 13. San Diego, si a hacer } \\
\text { milagros } \\
\text { (337) } \\
\text { 14. Un pecador soy, Dios } \\
\text { mío ( } 383)\end{array}$} & \\
\hline & & $\begin{array}{l}\text { 14. Cuenta con el retrato } \\
\text { (57) }\end{array}$ \\
\hline $\begin{array}{l}\text { 14. Oye, tarazón de } \\
\text { fraile (183) }\end{array}$ & & $\begin{array}{l}\text { 15. De pedir nunca yo } \\
\text { fuera (21) }\end{array}$ \\
\hline $\begin{array}{l}\text { 15. Señor, jurador he } \\
\text { Sido (180) }\end{array}$ & & $\begin{array}{l}\text { 16. De un pie escribir } \\
\text { quiero en suma ( } 34 \text { ) }\end{array}$ \\
\hline $\begin{array}{l}\text { 16. Todo el mundo } \\
\text { conmovido (83) }\end{array}$ & & $\begin{array}{l}\text { 17. Desde que el sol } \\
\text { ardiente }(81)\end{array}$ \\
\hline $\begin{array}{l}\text { 17. Un corcovado } \\
\text { poeta }(149)\end{array}$ & & \multirow{2}{*}{$\begin{array}{l}\text { 18. Desde que tus niñas } \\
\text { bellas (42) }\end{array}$} \\
\hline $\begin{array}{l}\text { 18. Un devoto } \\
\text { singular }(83)\end{array}$ & & \\
\hline \multirow{2}{*}{$\begin{array}{l}\text { 19. Un estudiante este } \\
\text { curso (181) }\end{array}$} & & $\begin{array}{l}\text { 19. Dulce Lisis de mis } \\
\text { ojos }(53)\end{array}$ \\
\hline & & $\begin{array}{l}\text { 20. En el mar de tu } \\
\text { hermosura (18) }\end{array}$ \\
\hline $\begin{array}{l}\text { 20. Un galán corto } \\
\text { de talle (179) }\end{array}$ & & 21. Éranse dos licenciados \\
\hline
\end{tabular}

${ }^{315}$ Los poemas marcados en cursiva se han incorporado a la lista aportada por Klaus Pörtl (Cornejo, Das lyrische 212-226), 


\begin{tabular}{|c|c|}
\hline \multirow{4}{*}{$\begin{array}{l}\text { 21. Un tudesco, } \\
\text { humana cuba (185) } \\
\text { 22. Un tuerto soy } \\
\text { desgraciado (149) }\end{array}$} & $(33)$ \\
\hline & \multirow{2}{*}{$\begin{array}{l}\text { 22. Es de Fausto la } \\
\text { fiereza (27) }\end{array}$} \\
\hline & \\
\hline & \multirow{2}{*}{$\begin{array}{l}\text { 23. Marica, a tu sucia cara } \\
(22)\end{array}$} \\
\hline \multirow{16}{*}{$\begin{array}{l}\text { 23. Vengar quiero mis } \\
\text { rencillas (169) }\end{array}$} & \\
\hline & $\begin{array}{l}\text { 24. Mi bien, juro por mi } \\
\text { amor (15) }\end{array}$ \\
\hline & $\begin{array}{l}\text { 25. No quieran tus } \\
\text { sinrazones (22) }\end{array}$ \\
\hline & $\begin{array}{l}\text { 26. Pedro, mi ingenio recela } \\
\text { (28) }\end{array}$ \\
\hline & $\begin{array}{l}\text { 27. Por tomar Judas el grado } \\
\text { (22) }\end{array}$ \\
\hline & $\begin{array}{l}\text { 28. Por los yerros, Lisis bella, } \\
\text { un traslado (6) }\end{array}$ \\
\hline & $\begin{array}{l}29 . \text { Pues vuestra piedad me } \\
\text { abriga (15) }\end{array}$ \\
\hline & 30. Solo el silencio testigo (11) \\
\hline & $\begin{array}{l}\text { 31. Queridas, mucho me } \\
\text { enfada (17) }\end{array}$ \\
\hline & $\begin{array}{l}\text { 32. Quiero ver a mi } \\
\text { tristeza (37) }\end{array}$ \\
\hline & $\begin{array}{l}\text { 33. Rudo pincel de mano } \\
\text { inadvertida (5) }\end{array}$ \\
\hline & $\begin{array}{l}\text { 34. Tu romance, Andrés, } \\
\text { leí (26) }\end{array}$ \\
\hline & $\begin{array}{l}\text { 35. Un estudiante de } \\
\text { hogaño (73) }\end{array}$ \\
\hline & $\begin{array}{l}\text { 36. Ya que tan galante has } \\
\text { sido }\end{array}$ \\
\hline & $\begin{array}{l}\text { 37.Ya, Fabio, que hemos } \\
\text { llegado (23) }\end{array}$ \\
\hline & $\begin{array}{l}\text { 38. Yo soy, ilustre Academia } \\
\text { (7) }\end{array}$ \\
\hline
\end{tabular}

Tabla 33: Clasificación de los poemas publicados en $O P L M$ 


\subsection{Poesía dubitada no publicada en las Obras poéticas de Marchante}

\section{Poesía dubitada no publicada en las OPLM}

\begin{tabular}{|c|c|c|c|c|}
\hline Primer verso & $\begin{array}{l}\text { Atribuida a } \\
\text { LM en } \\
\text { manuscritos }\end{array}$ & $\begin{array}{l}\text { Atribuida a Cornejo } \\
\text { en manuscritos }\end{array}$ & $\begin{array}{l}\text { Impresa a } \\
\text { nombre de } \\
\text { Cornejo }\end{array}$ & Métrica \\
\hline \multicolumn{5}{|c|}{ Temática sacra } \\
\hline $\begin{array}{l}\text { 1. Érase una } \\
\text { Virgen pura } \\
316\end{array}$ & Q (6) & $\begin{array}{l}\text { A (14v), B (68v), D } \\
(175), M(37), N(170) \\
\tilde{N}(192), R(80), S \\
(130 v)\end{array}$ & $\begin{array}{l}\text { Cornejo } \\
\text { (Das lyrische } \\
\text { 192) }\end{array}$ & Pareado \\
\hline $\begin{array}{l}\text { 2. Hoy a la } \\
\text { Concepción } \\
\text { aclamaciones }\end{array}$ & Q (10) & $\begin{array}{l}\text { A (28v), B (20), D } \\
(194 v), M(54), N(172), \\
\tilde{N}(195 v), R(94 v), S \\
(107 v)\end{array}$ & & Soneto \\
\hline $\begin{array}{l}\text { 3. La más } \\
\text { hidalga } \\
\text { hermosura }\end{array}$ & $Q(3 v)$ & $\begin{array}{l}\text { A (4), D (155v), H } \\
(199 \mathrm{r}), \mathrm{M}(9), \mathrm{N}(156), \\
\tilde{N}(169 \mathrm{v}), \mathrm{R}(\mathrm{ff} 29 \mathrm{v} \mathrm{y} \\
194), \mathrm{S}(126 \mathrm{v}), \mathrm{T}(38 \mathrm{v}) \\
\mathrm{Y}(277), \mathrm{Z}(277)\end{array}$ & $\begin{array}{l}\text { Cornejo } \\
\text { (Das lyrische } \\
114)\end{array}$ & Quintilla \\
\hline $\begin{array}{l}\text { 4. Sabed, señora } \\
\text { doncella }\end{array}$ & Q (5) & $\begin{array}{l}\mathrm{A}(8 \mathrm{v}), \mathrm{B}(64), C(8), \mathrm{D} \\
(165), \mathrm{H}(204), \mathrm{M}(5), \mathrm{N} \\
(161), \tilde{N}(178), \mathrm{R}(72), \\
\mathrm{S}(130 \mathrm{v})\end{array}$ & $\begin{array}{l}\text { Cornejo } \\
\text { (Das lyrische } \\
179)\end{array}$ & Romance \\
\hline $\begin{array}{l}\text { 5. Virgen, nadie } \\
\text { culpada os ha } \\
\text { creído }\end{array}$ & $\mathrm{Q}(10 \mathrm{v})$ & A (29v), M (53) & & Soneto \\
\hline $\begin{array}{l}\text { 6. De Oriente } \\
\text { vienen tres } \\
\text { reyes }^{317}\end{array}$ & Q (8) & $\begin{array}{l}\text { A (17), B (76v), M } \\
(44), \text { R (84) }\end{array}$ & $\begin{array}{l}\text { Cornejo } \\
\text { (Das lyrische } \\
199)\end{array}$ & Romance \\
\hline \multicolumn{5}{|c|}{ Temática profana } \\
\hline $\begin{array}{l}\text { 1. Gato ilustre, } \\
\text { que a fieras } \\
\text { manotadas }\end{array}$ & $\mathrm{Q}(12 \mathrm{v})$ & $\begin{array}{l}\text { A (28v), B (21r), M } \\
(69), N(173), R(95), S \\
(108 v)\end{array}$ & $\begin{array}{l}\text { Marañón } \\
\text { (Sonetos 35) }\end{array}$ & Soneto \\
\hline $\begin{array}{l}\text { 2. Musa mía, } \\
\text { Dios te dé }\end{array}$ & $\begin{array}{l}\text { Y (370), Z } \\
(370)\end{array}$ & & & Romance \\
\hline $\begin{array}{l}\text { 3. Un dominico } \\
\text { enemigo }^{318}\end{array}$ & $\mathrm{Q}(11 \mathrm{v})$ & $\begin{array}{l}\text { A (29), B (20v), D } \\
(195 v), M(55), N(173), \\
\text { R (95), S (108) }\end{array}$ & & Redondilla \\
\hline $\begin{array}{l}\text { 4. Per signum } \\
\text { crucis de avara }\end{array}$ & B (69) & $\begin{array}{l}\text { A (106), LL (260), M } \\
(147)\end{array}$ & & Pareado \\
\hline
\end{tabular}

Tabla 34: Poesía sacra y profana no publicada en $O P L M$

${ }^{316}$ Esta composición también se atribuye a Francisco Valles o Valdés (Civil i Castellvi 65).

${ }^{317}$ Este poema está publicado en las Obras complutenses (León, Obras complutenses 189).

${ }^{318}$ Aparece como anónima en los manuscritos $Y$ (545) y Z (545). 


\section{Poesía dubitada con otros autores}

\begin{tabular}{|c|c|c|c|c|}
\hline $\begin{array}{l}\text { Primer } \\
\text { verso }\end{array}$ & $\begin{array}{l}\text { Atribuida } \\
\text { a otros } \\
\text { autores }\end{array}$ & $\begin{array}{l}\text { Atribuida a Cornejo en } \\
\text { Manuscritos }\end{array}$ & $\begin{array}{l}\text { Impresa a } \\
\text { nombre de } \\
\text { Cornejo }\end{array}$ & Métrica \\
\hline $\begin{array}{l}\text { 1. A fraile tan } \\
\text { desatento }\end{array}$ & $\begin{array}{l}\text { Juan de } \\
\text { Avellaneda } \\
319\end{array}$ & & $\begin{array}{l}\text { Marañón (Otro } \\
75)\end{array}$ & Décima \\
\hline $\begin{array}{l}\text { 2. Casó de un } \\
\text { arzobispo el } \\
\text { despensero }\end{array}$ & $\begin{array}{l}\text { Quevedo/ } \\
\text { Francisco } \\
\text { Porras de } \\
\text { Cámara }^{320}\end{array}$ & $\begin{array}{l}\text { A (102), B (94), LL } \\
(228 v), \text { M (168), Q (36) }\end{array}$ & $\begin{array}{l}\text { Marañón } \\
\text { (Sonetos 31) }\end{array}$ & Soneto \\
\hline $\begin{array}{l}\text { 3. Érase una } \\
\text { Virgen pura }\end{array}$ & $\begin{array}{l}\text { Francisco } \\
\text { Valles (o } \\
\text { Valdés) } \\
\end{array}$ & $\begin{array}{l}\text { A (14v), B (68v), D } \\
(175), \text { M (37), N (170), N } \\
(192), R(80), \text { S (130v) }\end{array}$ & $\begin{array}{l}\text { Cornejo (Das } \\
\text { lyrische 192) }\end{array}$ & Pareado \\
\hline $\begin{array}{l}\text { 4. El sacristán } \\
\text { qué desmán }\end{array}$ & $\begin{array}{l}\text { José Pérez de } \\
\text { Montoro }^{321}\end{array}$ & $\begin{array}{l}\mathrm{D}(133), \mathrm{N}(125), \mathrm{Q} \\
(126 \mathrm{v}), \mathrm{R}(5)\end{array}$ & $\begin{array}{l}\text { Cornejo (Das } \\
\text { lyrische 67) }\end{array}$ & Quintilla \\
\hline $\begin{array}{l}\text { 5. He yo en ese } \\
\text { convento } \\
\text { desgraciado }\end{array}$ & $\begin{array}{l}\text { Juan de } \\
\text { Avellaneda }\end{array}$ & Q (113) & $\begin{array}{l}\text { Marañón (Otro } \\
\text { 79) }\end{array}$ & $\begin{array}{l}\text { Silva de } \\
\text { consonantes }\end{array}$ \\
\hline $\begin{array}{l}\text { 6. Pues que su } \\
\text { entretenimiento }\end{array}$ & $\begin{array}{l}\text { Juan de } \\
\text { Avellaneda }\end{array}$ & $\begin{array}{l}\mathrm{D}(138), \mathrm{N}(129), \tilde{N} \\
(130 \mathrm{v}), \mathrm{Q}(111 \mathrm{v}), \mathrm{R}(7), \mathrm{S} \\
(29), \mathrm{U}(66)\end{array}$ & $\begin{array}{l}\text { Marañón (Otro } \\
76)\end{array}$ & Décima \\
\hline $\begin{array}{l}\text { 7. Ya en sus } \\
\text { versos habemos } \\
\text { conocido }\end{array}$ & $\begin{array}{l}\text { Juan de } \\
\text { Avellaneda }\end{array}$ & & $\begin{array}{l}\text { Marañón (Otro } \\
78)\end{array}$ & Ovillejo \\
\hline
\end{tabular}

Tabla 35: Lírica dubitada con otros autores

\footnotetext{
${ }^{319}$ Los problemas que plantean los poemas disputados con Juan de Avellaneda son analizados por Miguel Marañón en la edición que realiza de estos (Otro 71-81).

${ }^{320}$ Miguel Marañón (Sonetos 31) edita este soneto a nombre de Cornejo e indica las publicaciones que se han hecho de este firmadas por otros autores.

${ }^{321}$ El poema se halla publicado en las Obras poéticas de José Pérez de Montoro (273).
} 
8.3.3.3. Total de poesías dubitadas e indubitadas

\begin{tabular}{|c|c|c|c|c|c|c|}
\hline Mss. & $\begin{array}{r}\text { Sacra } \\
\text { dubitada }\end{array}$ & $\begin{array}{l}\text { Profana } \\
\text { dubitada }\end{array}$ & $\begin{array}{l}\text { Total de } \\
\text { dubitados }\end{array}$ & $\begin{array}{c}\text { Sacra } \\
\text { indubitada }\end{array}$ & $\begin{array}{r}\text { Profana } \\
\text { indubitada }\end{array}$ & $\begin{array}{c}\text { Total de } \\
\text { indubitados }\end{array}$ \\
\hline A & 23 & 42 & 65 & 0 & 41 & 41 \\
\hline B & 23 & 52 & 75 & 0 & 43 & 43 \\
\hline D & 20 & 47 & 67 & 9 & 51 & 60 \\
\hline H & 4 & 47 & 51 & 0 & 43 & 43 \\
\hline LL & 0 & 38 & 38 & 0 & 32 & 32 \\
\hline M & 20 & 31 & 51 & 0 & 35 & 35 \\
\hline $\mathbf{N}$ & 27 & 52 & 79 & 9 & 51 & 60 \\
\hline$\tilde{\mathbf{N}}$ & 26 & 51 & 77 & 1 & 49 & 50 \\
\hline Q & 6 & 37 & 43 & 0 & 39 & 39 \\
\hline $\mathbf{R}$ & 27 & 55 & 82 & 9 & 47 & 56 \\
\hline$S$ & 25 & 50 & 75 & 9 & 48 & 57 \\
\hline
\end{tabular}

Tabla 36: Total de poesías dubitadas e indubitadas

8.3.3.4. Total de poesías sacras y profanas atribuidas a Cornejo

\begin{tabular}{|c|c|c|c|c|c|c|}
\hline Mss. & $\begin{array}{r}\text { Sacra } \\
\text { dubitada }\end{array}$ & $\begin{array}{c}\text { Sacra } \\
\text { indubitada }\end{array}$ & $\begin{array}{l}\text { Total } \\
\text { de sacra }\end{array}$ & $\begin{array}{l}\text { Profana } \\
\text { dubitada }\end{array}$ & $\begin{array}{l}\text { Profana } \\
\text { indubitada }\end{array}$ & $\begin{array}{l}\text { Total de } \\
\text { profana }\end{array}$ \\
\hline A & 23 & 0 & 23 & 42 & 41 & 83 \\
\hline B & 23 & 0 & 23 & 52 & 43 & 95 \\
\hline D & 20 & 9 & 29 & 47 & 51 & 98 \\
\hline $\mathbf{H}$ & 4 & 0 & 4 & 47 & 43 & 90 \\
\hline $\mathbf{L L}$ & 0 & 0 & 0 & 38 & 32 & 70 \\
\hline $\mathbf{M}$ & 20 & 0 & 20 & 31 & 35 & 66 \\
\hline $\mathbf{N}$ & 27 & 9 & 36 & 52 & 51 & 103 \\
\hline$\tilde{\mathbf{N}}$ & 26 & 1 & 27 & 51 & 49 & 100 \\
\hline Q & 6 & 0 & 6 & 37 & 39 & 76 \\
\hline $\mathbf{R}$ & 27 & 9 & 36 & 55 & 47 & 102 \\
\hline S & 25 & 9 & 34 & 50 & 48 & 98 \\
\hline
\end{tabular}

Tabla .7: Total de poesías sacras y profanas 
8.3.3.5. Métrica de la lírica dubitada e indubitada (sacra y profana) atribuidas a Cornejo

\begin{tabular}{|c|c|c|c|c|c|c|}
\hline Métrica & $\begin{array}{l}\text { Sacra } \\
\text { indubitada }\end{array}$ & $\begin{array}{l}\text { Profana } \\
\text { indubitada }\end{array}$ & $\begin{array}{l}\text { Total } \\
\text { indubitadas }\end{array}$ & $\begin{array}{l}\text { Sacra } \\
\text { dubitada }\end{array}$ & $\begin{array}{l}\text { Profana } \\
\text { dubitada }\end{array}$ & $\begin{array}{l}\text { Total } \\
\text { dubitada }\end{array}$ \\
\hline Copla & 1 & 0 & 1 & 2 & 2 & 4 \\
\hline Décima & 0 & 10 & 10 & 0 & 21 & 21 \\
\hline Endecha & 1 & 0 & 1 & 0 & 0 & 0 \\
\hline Lira & 0 & 0 & 0 & 0 & 1 & 1 \\
\hline $\begin{array}{l}\text { Octosílabos } \\
\text { esdrújulos }\end{array}$ & 0 & 0 & 0 & 0 & 1 & 1 \\
\hline Ovillejo & 0 & 3 & 3 & 0 & 0 & 0 \\
\hline Pareados & 0 & 0 & 1 & 1 & 1 & 2 \\
\hline Quintilla & 3 & 3 & 6 & 11 & 5 & 16 \\
\hline Redondilla & 0 & 5 & 5 & 2 & 6 & 8 \\
\hline Romance & 4 & 16 & 20 & 12 & 16 & 28 \\
\hline Septeto & 0 & 1 & 1 & 0 & 0 & 0 \\
\hline Seguidilla & 0 & 0 & 0 & 0 & 2 & 2 \\
\hline Sonetos & 0 & 15 & 15 & 2 & 1 & 3 \\
\hline
\end{tabular}

Tabla 38: Métrica de la lírica dubitada e indubitada (sacra y profana)

\subsection{ESTUDIO DE AUTORÍA: GRÁFICOS Y TABLAS}

\subsubsection{Poesía profana indubitada}

\section{Corpus de poesía profana indubitada}

\begin{tabular}{|c|c|c|c|c|}
\hline Primer verso & Localización & Extensión & Métrica & re ${ }^{\text {Nomb }}$ \\
\hline \multicolumn{5}{|c|}{ Damián Cornejo } \\
\hline $\begin{array}{l}\text { Cansado anoche de } \\
\text { estar }\end{array}$ & $\begin{array}{l}\text { BNE: Mss. / } 4052 \\
(280)\end{array}$ & 2.370 & Romance & C_pi3 \\
\hline $\begin{array}{l}\text { Sepan todos y todas } \\
\text { que yo adoro }\end{array}$ & Cornejo (Obras 11) & 1.233 & Ovillejo & C_pi4 \\
\hline $\begin{array}{l}\text { Oye, Catuja, dulce } \\
\text { hechizo mío }\end{array}$ & Cornejo (Obras 1) & 2.161 & Ovillejo & C_pi5 \\
\hline $\begin{array}{l}\text { Musa mía, con } \\
\text { astucia }\end{array}$ & $\begin{array}{ll}\text { Cornejo } & \text { (Obras } \\
135 \mathrm{v}) & \\
\end{array}$ & 386 & Redondilla & C_pi6 \\
\hline $\begin{array}{l}\text { Quisimí quisimona, } \\
\text { ¡hola! }\end{array}$ & Cornejo (Obras 69) & 342 & Romance & C_pi7 \\
\hline $\begin{array}{l}\text { Malo me siento, } \\
\text { Marica }\end{array}$ & Cornejo (Obras 84v) & 305 & Romance & C_pi9 \\
\hline
\end{tabular}




\begin{tabular}{|c|c|c|c|c|}
\hline \multicolumn{5}{|c|}{ León Marchante } \\
\hline $\begin{array}{l}\text { Ya la palestra del } \\
\text { siguiente día }\end{array}$ & $\begin{array}{l}\text { León (Obras } \\
\text { poéticas 1: 144) }\end{array}$ & 534 & Pareado & L_pi1 \\
\hline $\begin{array}{l}\text { Pues el pintar los } \\
\text { toros no se excusa }\end{array}$ & $\begin{array}{l}\text { León (Obras } \\
\text { poéticas 1: 155) }\end{array}$ & 1.887 & Pareado & L_pi2 \\
\hline $\begin{array}{l}\text { Para correr los, } \\
\text { bisojos }\end{array}$ & $\begin{array}{l}\text { León (Obras } \\
\text { poéticas 1: 138) }\end{array}$ & 399 & Redondilla & L_pi3 \\
\hline $\begin{array}{l}\text { Prima mía, estos } \\
\text { pollitos }\end{array}$ & $\begin{array}{l}\text { León (Obras } \\
\text { poéticas 3: 23) } \\
\end{array}$ & 430 & Décimas & L_pi4 \\
\hline $\begin{array}{l}\text { Ya que el festejo de } \\
\text { hoy me ofrece asunto }\end{array}$ & $\begin{array}{l}\text { León (Obras } \\
\text { poéticas 3: 83) }\end{array}$ & 1.993 & Ovillejo & L_pi5 \\
\hline $\begin{array}{l}\text { Murió una monja, } \\
\text { reciba }\end{array}$ & $\begin{array}{l}\text { León (Obras } \\
\text { poéticas 1: 178) }\end{array}$ & 392 & Quintillas & L_pi6 \\
\hline \multicolumn{5}{|c|}{ Sor Juana Inés de la Cruz } \\
\hline $\begin{array}{l}\text { Piramidal, funesta de } \\
\text { la tierra }\end{array}$ & Cruz (Poemas 152) & 4.844 & Silva & SJ_pi1 \\
\hline $\begin{array}{l}\text { Si acaso, príncipe } \\
\text { excelso, }\end{array}$ & $\begin{array}{l}\text { Cruz (Inundación } \\
\text { n.p.) }\end{array}$ & 300 & Romance & SJ_pi2 \\
\hline $\begin{array}{l}\text { Ya que para de } \\
\text { pedirme, }\end{array}$ & Cruz (Obras n.p.) & 523 & Romance & SJ_pi3 \\
\hline $\begin{array}{l}\text { Dime, vencedor } \\
\text { rapaz, }\end{array}$ & Cruz (Poemas 50) & 211 & Redondilla & SJ_pi4 \\
\hline $\begin{array}{l}\text { Hombres necios que } \\
\text { acusáis }\end{array}$ & Cruz (Obras n.p.) & 335 & Redondilla & SJ_pi5 \\
\hline $\begin{array}{l}\text { Finjamos que soy } \\
\text { feliz }\end{array}$ & Cruz (Obras n.p.) & 683 & Romance & SJ_pi6 \\
\hline
\end{tabular}

Tabla 39: Corpus de poesías profanas indubitadas

\subsubsection{Poesía profana dubitada}

\begin{tabular}{|l|l|r|l|l|}
\multicolumn{5}{|c|}{ Poesía profana dubitada } \\
\multicolumn{1}{|c|}{ Localización } & \multicolumn{1}{c|}{ Extensión } & \multicolumn{1}{c|}{ Metro } & \multicolumn{1}{c|}{ Nombre } \\
\hline $\begin{array}{l}\text { A una reja qué } \\
\text { ventura }\end{array}$ & Cornejo (Obras 63v) & 274 & Décima & D_p1 \\
\hline $\begin{array}{l}\text { A uno que se hace } \\
\text { una uva }\end{array}$ & Cornejo (Obras 29v) & 184 & Quintilla & D_p2 \\
\hline $\begin{array}{l}\text { Adiós, Leonor de mi } \\
\text { vida }\end{array}$ & Cornejo (Obras 98) & 292 & $\begin{array}{l}\text { Copla de pie } \\
\text { quebrado }\end{array}$ & D_p3 \\
\hline $\begin{array}{l}\text { Bien puede, Lisis, } \\
\text { un triste }\end{array}$ & Cornejo (Obras 85) & 233 & Romance & D_p4 \\
\hline $\begin{array}{l}\text { Cien reales por mí } \\
\text { perdiste }\end{array}$ & Cornejo (Obras 52) & 49 & Décima & D_p5 \\
\hline $\begin{array}{l}\text { Clodio, del mundo } \\
\text { en la plaza }\end{array}$ & Cornejo (Obras 30) & 295 & Décima & D_p6 \\
\hline $\begin{array}{l}\text { Clori, que para ser } \\
\text { linda }\end{array}$ & Cornejo (Obras 100) & 213 & Romance & D_p7 \\
\hline $\begin{array}{l}\text { Con modo ya más } \\
\text { humano }\end{array}$ & Cornejo (Obras 65v) & 98 & Décima & D_p8 \\
\hline
\end{tabular}




\begin{tabular}{|c|c|c|c|c|}
\hline $\begin{array}{l}\text { De pedir (nunca yo } \\
\text { fuera) }\end{array}$ & Cornejo (Obras 94) & 249 & Décima & D_p9 \\
\hline $\begin{array}{l}\text { De un pie escribir } \\
\text { quiero en suma }\end{array}$ & Cornejo (Obras 131) & 304 & Quintilla & D_p10 \\
\hline $\begin{array}{l}\text { Desde que el sol } \\
\text { ardiente }\end{array}$ & Cornejo (Obras 17) & 646 & $\begin{array}{l}\text { Redondilla } \\
\text { con glosa }\end{array}$ & D_p11 \\
\hline $\begin{array}{l}\text { Desde que tus niñas } \\
\text { bellas }\end{array}$ & Cornejo (Obras 51v) & 38 & Redondilla & D_p12 \\
\hline $\begin{array}{l}\text { Diego (Anfriso) que } \\
\text { con atención }\end{array}$ & Cornejo (Obras 88v) & 198 & Décima & D_p13 \\
\hline $\begin{array}{l}\text { Dios te socorra, } \\
\text { Marica }\end{array}$ & Cornejo (Obras 60) & 193 & Romance & D_p14 \\
\hline $\begin{array}{l}\text { Dulce Lisis de mis } \\
\text { ojos }\end{array}$ & Cornejo (Obras 20v) & 267 & Romance & D_p15 \\
\hline $\begin{array}{l}\text { En el mar de tu } \\
\text { hermosura }\end{array}$ & Cornejo (Obras 54) & 234 & Décima & D_p16 \\
\hline $\begin{array}{l}\text { En Pinto para un } \\
\text { festejo }\end{array}$ & Cornejo (Obras 59) & 188 & Romance & D_p17 \\
\hline $\begin{array}{l}\text { En sospechoso amor } \\
\text { toca (glosa de "Solo } \\
\text { el silencio testigo") }\end{array}$ & Cornejo (Obras 66) & 213 & Décimas & D_p18 \\
\hline $\begin{array}{l}\text { Éranse dos } \\
\text { licenciados }\end{array}$ & Cornejo (Obras 25) & 397 & Romance & D_p19 \\
\hline $\begin{array}{l}\text { Escúchenme unos } \\
\text { esdrújulos }\end{array}$ & Cornejo (Obras 178) & 222 & Quintilla & D_p20 \\
\hline $\begin{array}{l}\text { Hoy sin más ni más } \\
\text { me allano }\end{array}$ & Cornejo (Obras 115v) & 196 & Quintilla & D_p21 \\
\hline $\begin{array}{l}\text { Marica, a tu sucia } \\
\text { cara }\end{array}$ & Cornejo (Obras 95v) & 47 & Décima & D_p22 \\
\hline $\begin{array}{l}\text { Mi bien, juro por mi } \\
\text { amor }\end{array}$ & Cornejo (Obras 55v) & 286 & Décima & D_p23 \\
\hline $\begin{array}{l}\text { No quieran tus } \\
\text { sinrazones }\end{array}$ & Cornejo (Obras 127v) & 39 & Décima & D_p24 \\
\hline $\begin{array}{l}\text { Oiga, hermano fray } \\
\text { Francisco }\end{array}$ & Cornejo (Obras 147v) & 313 & Romance & D_p25 \\
\hline $\begin{array}{l}\text { Óiganme, damas, } \\
\text { que empuño }\end{array}$ & Cornejo (Obras 28) & 211 & Romance & D_p26 \\
\hline $\begin{array}{l}\text { Oye, tarazón de } \\
\text { fraile }\end{array}$ & Cornejo (Obras 71) & 316 & Romance & D_p27 \\
\hline $\begin{array}{l}\text { Pedro, mi ingenio } \\
\text { recela }\end{array}$ & Cornejo (Obras 77) & 185 & Décima & D_p28 \\
\hline $\begin{array}{l}\text { Por los yerros, Lisis, } \\
\text { bella un traslado }\end{array}$ & Cornejo (Obras 107) & 98 & Soneto & D_p29 \\
\hline $\begin{array}{l}\text { Pues vuestra piedad } \\
\text { me abriga }\end{array}$ & Cornejo (Obras 80) & 44 & Décima & D_p30 \\
\hline $\begin{array}{l}\text { Queridas, mucho me } \\
\text { enfada }\end{array}$ & Cornejo (Obras 75v) & 210 & Décima & D_p31 \\
\hline $\begin{array}{l}\text { Rudo pincel de } \\
\text { mano inadvertida }\end{array}$ & Cornejo (Obras 107v) & 175 & Soneto & D_p32 \\
\hline $\begin{array}{l}\text { Señor, jurador he } \\
\text { sido }\end{array}$ & Cornejo (Obras 117) & 90 & Quintilla & D_p33 \\
\hline $\begin{array}{l}\text { Tu romance, } \\
\text { Andrés, leí }\end{array}$ & Cornejo (Obras 74v) & 92 & Décima & D_p34 \\
\hline
\end{tabular}




\begin{tabular}{|l|l|r|l|l|}
\hline $\begin{array}{l}\text { Un estudiante este } \\
\text { curso }\end{array}$ & Cornejo (Obras 129v) & 212 & $\begin{array}{l}\text { Copla de } \\
\text { pie quebrado }\end{array}$ & D_p35 \\
\hline $\begin{array}{l}\text { Un estudiante de } \\
\text { hogaño }\end{array}$ & Cornejo (Obras 32v) & 170 & Redondilla & D_p36 \\
\hline $\begin{array}{l}\text { Un galán corto de } \\
\text { talle }\end{array}$ & Cornejo (Obras 92) & 97 & Quintilla & D_p37 \\
\hline $\begin{array}{l}\text { Un tudesco humana } \\
\text { cuba }\end{array}$ & Cornejo (Obras 146v) & 178 & Redondilla & D_p38 \\
\hline $\begin{array}{l}\text { Vengar quiero mis } \\
\text { rencillas }\end{array}$ & Cornejo (Obras 48v) & 407 & Quintilla & D_p39 \\
$\begin{array}{c}\text { Ya que tan galante } \\
\text { has sido }\end{array}$ & Cornejo (Obras 93) & 203 & Décimas & D_p40 \\
\hline $\begin{array}{c}\text { Ya, Fabio, que } \\
\text { hemos llegado }\end{array}$ & Cornejo (Obras 93) & Cócimas & D_p41 \\
\hline $\begin{array}{c}\text { Yo soy ilustre } \\
\text { Academia }\end{array}$ & Cornejo (Obras 22v) & 401 & Romance & D_p42 \\
\hline
\end{tabular}

Tabla 40: Poesía profana dubitada

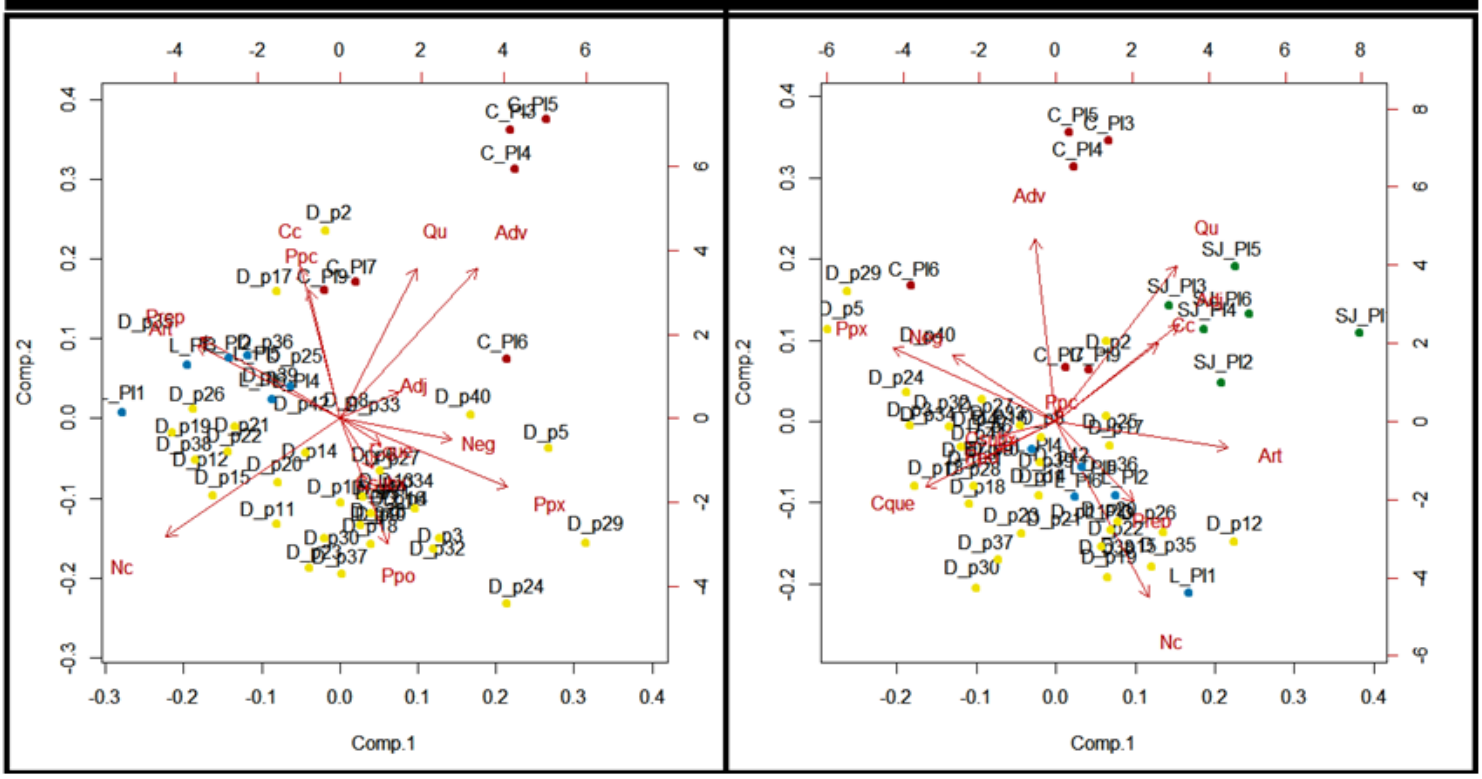

Gráfico 17: Poemas dubitados e indubitados de Cornejo y Marchante e indubitados de Sor Juana $^{322}$

\footnotetext{
${ }^{322}$ Los poemas indubitados de León manifiestan una mayor similitud morfosintáctica con los textos dubitados que las poesías que únicamente se atribuyen a fray Damián. De estas, las más extensas (C_pi3, C_pi4 y C_pi5) son las que muestran mayores diferencias estilísticas respecto a las dubitadas. Si se incorporan al corpus analizado las composiciones de Sor Juana (biplot de la derecha), los datos comentados previamente (biplot de la izquierda) se ratifican con más claridad. Además, cabe señalar que las creaciones de la poeta mexicana conforman un grupo unificado y apartado de los versos dubitados e indubitados de Cornejo y de Marchante.
} 
Poemas breves indubitados de Cornejo, León y Sor Juana y dubitados de fray Damían y Marchante

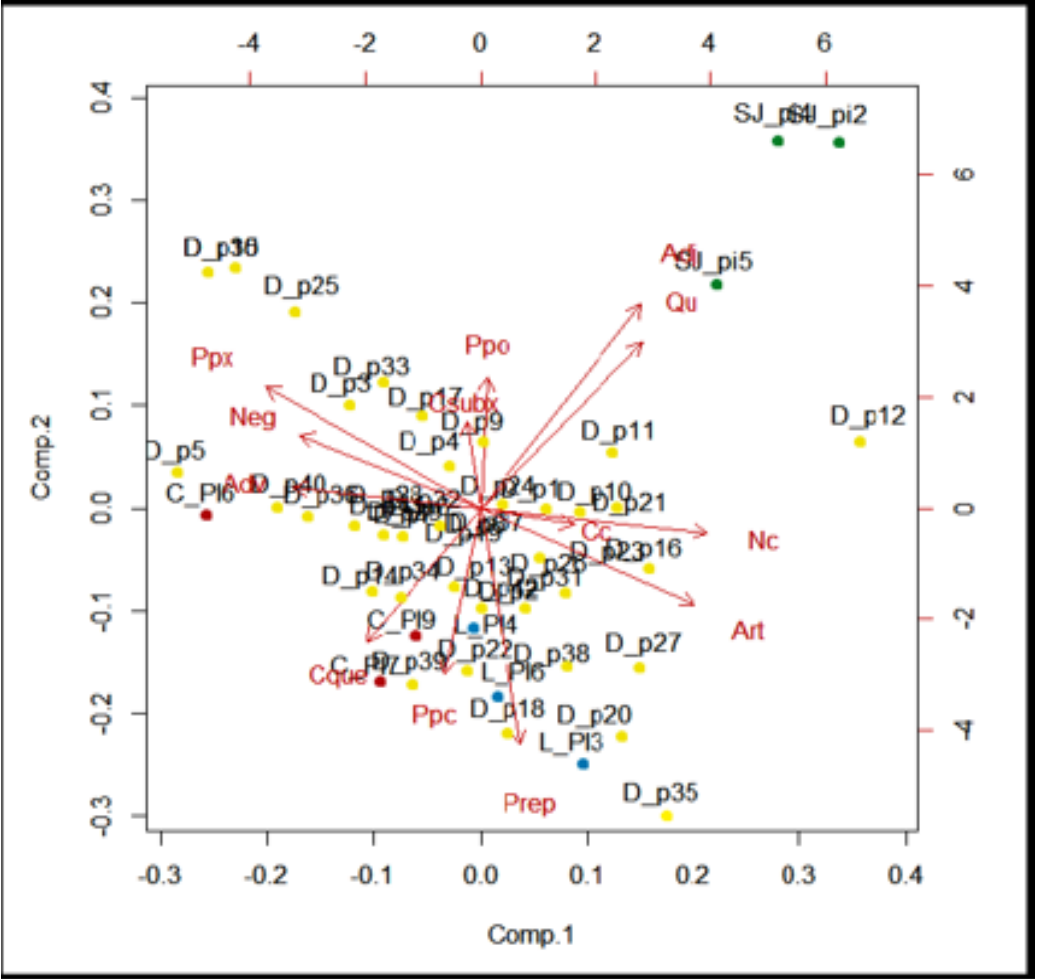

Gráfico 18: Poemas breves indubitados de León, Cornejo y Sor Juana y dubitados de fray Damián y Marchante 323

${ }^{323}$ Los poemas profanos de menor extensión de Sor Juana poseen rasgos morfosintácticos muy diferentes de las poesías dubitadas e indubitadas (breves) de León y de Cornejo. Resulta relevante señalar también que el gran grueso de los textos disputados entre ambos se distancian de forma significativa de las creaciones que se atribuyen exclusivamente a ellos. Dicho resultado parece evidenciar que la brevedad de las composciones dubitadas impide que manifiesten huellas de autor relevantes. 
Análisis de clasificación

\begin{tabular}{|c|c|c|}
\hline Case Number & Cluster & Distance \\
\hline D_P1 & 2 & 3,400 \\
\hline D_p2 & 2 & 9,482 \\
\hline D_p3 & 1 & 6,115 \\
\hline D_p4 & 2 & 6,643 \\
\hline D_p6 & 2 & 3,410 \\
\hline D_p6 & 2 & 9,552 \\
\hline D_p7 & 1 & 6,063 \\
\hline D_p8 & 2 & 6,654 \\
\hline D_p9 & 1 & 8,946 \\
\hline D_p 10 & 2 & 4,496 \\
\hline D_D11 & 2 & 6,349 \\
\hline D_p12 & 2 & 4,276 \\
\hline D_p13 & 2 & 4,758 \\
\hline D_p14 & 2 & 4,934 \\
\hline D_p15 & 2 & 4,804 \\
\hline D_p16 & 2 & 11,668 \\
\hline D_p17 & 2 & 4,786 \\
\hline D_p18 & 1 & 6,074 \\
\hline D_p19 & 1 & 6,739 \\
\hline D_p20 & 2 & 5,980 \\
\hline D_p21 & 2 & 6,445 \\
\hline D_p22 & 2 & 6,369 \\
\hline D_p23 & 2 & 7.215 \\
\hline D_p24 & 2 & 7,624 \\
\hline D_p25 & 2 & 6,184 \\
\hline D_p26 & 2 & 8,769 \\
\hline D_p27 & 2 & 11,396 \\
\hline D_p28 & 2 & 5,902 \\
\hline D_p29 & 1 & 10,759 \\
\hline D_p30 & 2 & 3,990 \\
\hline D_p31 & 2 & 6,744 \\
\hline D_p32 & 1 & 5,723 \\
\hline D_p33 & 2 & 4,262 \\
\hline D_p34 & 1 & 6,739 \\
\hline D_p35 & 2 & 10,957 \\
\hline D_p36 & 1 & 5,937 \\
\hline D_p37 & 1 & 4,803 \\
\hline D_p38 & 1 & 4,520 \\
\hline D_p39 & 2 & 8,969 \\
\hline D_p 40 & 1 & 6,799 \\
\hline D_p41 & 2 & 7,642 \\
\hline D_p42 & 2 & 6,544 \\
\hline & 2 & 8,639 \\
\hline & 2 & 6,218 \\
\hline & 2 & 4,708 \\
\hline C_pi6 & 1 & 9,217 \\
\hline C_pi7 & 1 & 11,185 \\
\hline C pig & 1 & 11,341 \\
\hline
\end{tabular}

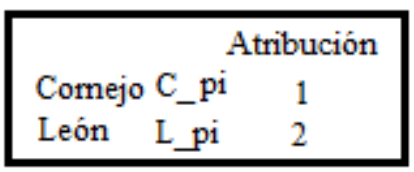

Análisis discriminante

\begin{tabular}{|c|c|c|c|c|}
\hline & Case Number & $\begin{array}{l}\text { Actual } \\
\text { Group } \\
\end{array}$ & $\begin{array}{c}\text { Predicted } \\
\text { Group }\end{array}$ & $p$ \\
\hline \multirow[t]{48}{*}{ Original } & D_p1 & 2 & 2 & ,584 \\
\hline & D_92 & 2 & 2 & 863 \\
\hline & D_93 & 1 & 1 &, 526 \\
\hline & D_p4 & 2 & 2 &, 537 \\
\hline & D_p5 & 2 & 2 &, 585 \\
\hline & D_96 & 2 & 2 &, 863 \\
\hline & D_97 & 1 & 1 & .530 \\
\hline & D_p8 & 2 & 2 &, 526 \\
\hline & 9_p9 & 1 & 1 &, 096 \\
\hline & D_910 & 2 & 2 & .221 \\
\hline & D_911 & 2 & 2 & 150 \\
\hline & D_12 & 2 & 2 &, 448 \\
\hline & D_p13 & 2 & 2 &, 333 \\
\hline & D_914 & 2 & 2 & 670 \\
\hline & D_915 & 2 & 2 & .690 \\
\hline & D_p16 & 2 & 2 &, 020 \\
\hline & D_p17 & 2 & 2 &, 544 \\
\hline & D_918 & 1 & 1 & .706 \\
\hline & D_919 & 1 & 1 & 253 \\
\hline & D_20 & 2 & 2 & 221 \\
\hline & D_p21 & 2 & 2 &, 504 \\
\hline & D_\$22 & 2 & 2 & .612 \\
\hline & D_p23 & 2 & 2 &, 782 \\
\hline & D_224 & 2 & 2 &, 163 \\
\hline & D_926 & 2 & 2 &, 328 \\
\hline & D_26 & 2 & 2 &, 317 \\
\hline & D_27 & 2 & 2 &, 428 \\
\hline & D_928 & 2 & 2 & .660 \\
\hline & D_929 & 1 & 1 & .572 \\
\hline & D_930 & 2 & 2 &, 731 \\
\hline & D_31 & 2 & 2 & , 149 \\
\hline & D_932 & 1 & $2^{-}$ & , 146 \\
\hline & D_,33 & 2 & 2 & .653 \\
\hline & D_p34 & 1 & 1 & .253 \\
\hline & D_935 & 2 & 2 &, 759 \\
\hline & D_936 & 1 & $2^{-1}$ &, 302 \\
\hline & D_937 & 1 & 1 & ,347 \\
\hline & D_ 38 & 1 & $2^{\prime \prime}$ & , 129 \\
\hline & 1939 D. & 2 & 2 &, 205 \\
\hline & D_940 & 1 & 1 & 647 \\
\hline & D_941 & 2 & 2 & .920 \\
\hline & D_, 42 & 2 & 2 & .717 \\
\hline & L_pi3 & 2 & 2 & ,433 \\
\hline & L_pi4 & 2 & 2 & 342 \\
\hline & L_pi6 & 2 & 2 &, 541 \\
\hline & C_pis & 1 & 1 & ,639 \\
\hline & C_pi7 & 1 & 1 &, 007 \\
\hline & C pig & 1 & 1 & .779 \\
\hline
\end{tabular}

324

Tabla 21: Análisis clúster y de discriminantes

${ }^{324}$ Las predicciones de clasificación que se realizan en la segunda columna del análisis de discriminantes están basadas en validaciones cruzadas. Estas garantizan que los resultados estadísticos sean independientes de la partición entre datos de entrenamiento y prueba. Puede observarse que tres poemas que el análisis clúster asociaba a Cornejo (D_p32, D_p36 y D_p38) se atribuyen a León en la validación cruzada. 
8.4.3. Poesía sacra indubitada

\begin{tabular}{|c|c|c|c|c|}
\hline \multicolumn{5}{|c|}{ Poesía indubitada sacra } \\
\hline Primer verso & Localización & $\begin{array}{l}\text { Extensi } \\
\text { ón }\end{array}$ & Métrica & Nombre \\
\hline \multicolumn{5}{|c|}{ Damián Cornejo } \\
\hline $\begin{array}{l}\text { En tu alabanza } \\
\text { mi musa }\end{array}$ & Cornejo (Obras 185) & 164 & Romance & C_si1 \\
\hline $\begin{array}{l}\text { De santa } \\
\text { resurrección }\end{array}$ & Cornejo (Obras 186) & 378 & Romance & C_si2 \\
\hline $\begin{array}{l}\text { En títulos, } \\
\text { Virgen pura }\end{array}$ & Cornejo (Obras 198) & 294 & Quintilla & C_si3 \\
\hline $\begin{array}{l}\text { Dulce Jesús, } \\
\text { Dios mío } \\
\end{array}$ & Cornejo (Obras 190) & 166 & Endecha & C_si4 \\
\hline $\begin{array}{l}\text { Hoy con gusto a } \\
\text { cantar llego }\end{array}$ & Cornejo (Obras 200) & 166 & Quintilla & C_si5 \\
\hline $\begin{array}{l}\text { Oigan, que el } \\
\text { bravo del cielo }\end{array}$ & Cornejo (Obras 191v) & 189 & Romance & C_si6 \\
\hline $\begin{array}{l}\text { Divina Madre } \\
\text { de Gracia, }\end{array}$ & Cornejo (Obras 188v) & 382 & Romance & C_si7 \\
\hline $\begin{array}{l}\text { Haced que la } \\
\text { Gracia } \\
\text { encuentre }\end{array}$ & Cornejo (Obras 196) & 116 & Quintilla & C_si8 \\
\hline $\begin{array}{l}\text { A su esposo, el } \\
\text { alma, escribe }\end{array}$ & Cornejo (Obras 193v) & 191 & Copla & C_si9 \\
\hline \multicolumn{5}{|c|}{ León Marchante } \\
\hline $\begin{array}{l}\text { En la noche más } \\
\text { helada }\end{array}$ & $\begin{array}{l}\text { León (Obras poéticas 1: } \\
17)\end{array}$ & 244 & Romance & L_si1 \\
\hline $\begin{array}{l}\text { Atención, que } \\
\text { hoy de José }\end{array}$ & $\begin{array}{l}\text { León (Obras poéticas 1: } \\
46)\end{array}$ & 372 & Romance & L_si2 \\
\hline $\begin{array}{l}\text { En la noche más } \\
\text { oscura }\end{array}$ & León (Letras n.p.) & 175 & Copla & L_si3 \\
\hline $\begin{array}{l}\text { ¡Oh qué bien } \\
\text { que navega }\end{array}$ & León (Letras n.p.) & 298 & Copla & L_si4 \\
\hline $\begin{array}{l}\text { Hoy un } \\
\text { Francisco hace } \\
\text { fiesta }\end{array}$ & $\begin{array}{l}\text { León (Obras poéticas } 1 \text { : } \\
38 \text { ) }\end{array}$ & 243 & Romance & L_si5 \\
\hline $\begin{array}{l}\text { Pendiente a } \\
\text { morir, de un } \\
\text { leño, }\end{array}$ & $\begin{array}{l}\text { León (Obras poéticas } 1 \text { : } \\
\text { 26) }\end{array}$ & 194 & Romance & L_si6 \\
\hline $\begin{array}{l}\text { La vida quiero } \\
\text { contar }\end{array}$ & $\begin{array}{l}\text { León (Obras poéticas 1: } \\
43 \text { ) }\end{array}$ & 225 & Quintilla & L_si7 \\
\hline $\begin{array}{l}\text { Vaya de jácara y } \\
\text { sea }\end{array}$ & $\begin{array}{l}\text { León (Obras poéticas 1: } \\
\text { 9) }\end{array}$ & 242 & Romance & L_si8 \\
\hline
\end{tabular}




\begin{tabular}{|l|l|r|c|c|}
\hline $\begin{array}{l}\text { Maravillas del } \\
\text { Señor }\end{array}$ & $\begin{array}{l}\text { León (Obras poéticas 1: Juana Inés de la Cruz } \\
\text { 12) }\end{array}$ & 239 & Coplas & L_si9 \\
\hline \multicolumn{5}{|c|}{} \\
\hline $\begin{array}{l}\text { Hoy la maestra } \\
\text { divina }\end{array}$ & Cruz (Obras n.p.) & 249 & Copla & SJ_si1 \\
\hline $\begin{array}{l}\text { La soberana } \\
\text { doctora }\end{array}$ & Cruz (Obras n.p.) & 240 & Romance & SJ_si2 \\
\hline $\begin{array}{l}\text { Hoy es del } \\
\text { divino amor }\end{array}$ & Cruz (Obras n.p.) & 200 & Redondilla & SJ_si3 \\
\hline $\begin{array}{l}\text { Cuán grande, } \\
\text { José, seréis, }\end{array}$ & Cruz (Obras n.p.) & 203 & Redondilla & SJ_si4 \\
\hline $\begin{array}{l}\text { Por celebrar del } \\
\text { Infante }\end{array}$ & Cruz (Villancicos n.p.) & 399 & Copla & SJ_si5 \\
\hline $\begin{array}{l}\text { iAllá va, fuera, } \\
\text { que sale }\end{array}$ & Cruz (Villancicos n.p.) & 301 & Romance & SJ_si6 \\
\hline $\begin{array}{l}\text { Antes que todas } \\
\text { las cosas }\end{array}$ & Cruz (Obras n.p.) & 184 & Copla & SJ_si7 \\
\hline
\end{tabular}

Tabla 42: Corpus de poesía sacra indubitada

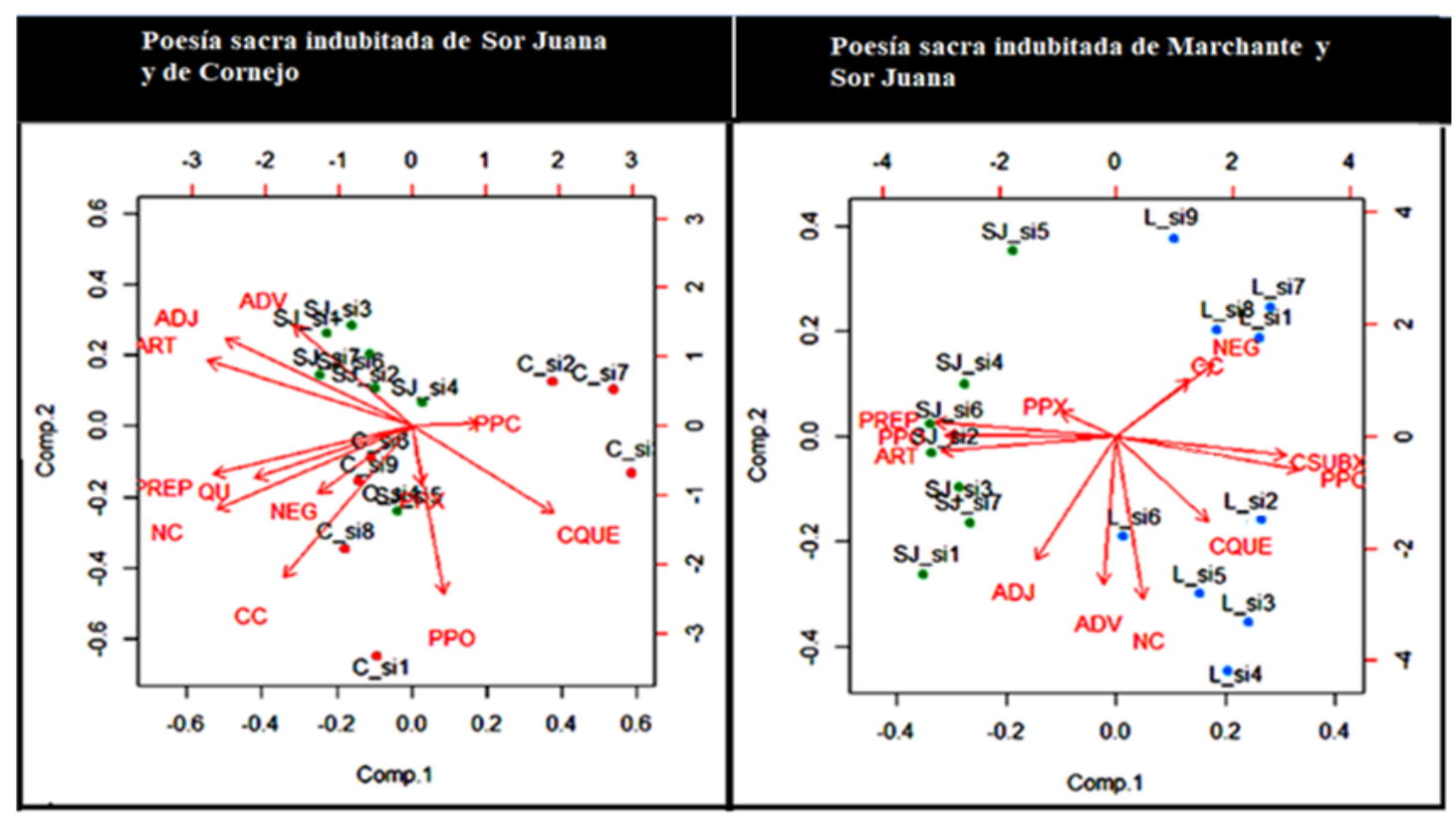

Gráfico 19: Las poesías sacras de Sor Juana, Cornejo y Marchante ${ }^{325}$

${ }^{325}$ Los poemas sacros de Sor Juana manifiestan un uso de la morfosintaxis muy distinto al de las poesías de Cornejo (biplot de la izquierda). Lo mismo sucede al comparar las composiciones de la poeta novohispana con las de Marchante. No obstante, las diferencias estilísticas que posee cada una se acrecientan en el biplot de la derecha. 


\begin{tabular}{|c|c|c|c|c|}
\hline \multicolumn{4}{|c|}{ Poesía dubitada sacra } & \multirow[b]{2}{*}{ Nombre } \\
\hline Primer verso & Localización & Extensión & Métrica & \\
\hline $\begin{array}{l}\text { ¡Ah señor, el de la } \\
\text { hostia! } \\
\text { (Estribillo: ¡Hola! } \\
\text { Qué llega la fiesta, } \\
\text { qué falta la solfa) } \\
\end{array}$ & Cornejo (Obras 183v) & 285 & Copla & D_s2 \\
\hline $\begin{array}{l}\text { Al señor Bautista, el } \\
\text { jaque }\end{array}$ & Cornejo (Obras 169v) & 517 & Romance & D_s3 \\
\hline $\begin{array}{l}\text { De Francisco por } \\
\text { menor }\end{array}$ & Cornejo (Obras 165v) & 271 & Ouintilla & D_s5 \\
\hline $\begin{array}{l}\text { De pie quebrado unas } \\
\text { coplas }\end{array}$ & Cornejo (Obras 164) & 202 & Copla & D_s6 \\
\hline $\begin{array}{l}\text { De tu concepción, } \\
\text { Señora }\end{array}$ & Cornejo (Obras 158) & 214 & Romance & D_s7 \\
\hline $\begin{array}{l}\text { Después que porque } \\
\text { se usa }\end{array}$ & Cornejo (Obras 84v) & 156 & Cuarteta & D_s8 \\
\hline De una niña la pureza & Cornejo (Obras 161) & 291 & Romance & D_s9 \\
\hline $\begin{array}{l}\text { Escriben desde } \\
\text { Toledo }\end{array}$ & Cornejo (Obras 177) & 308 & Romance & D_s10 \\
\hline $\begin{array}{l}\text { Hanme mandado una } \\
\text { cosa }\end{array}$ & Cornejo (Obras 154) & 188 & Quintilla & D_s12 \\
\hline $\begin{array}{l}\text { Hoy mi devoción } \\
\text { aclama }\end{array}$ & Cornejo (Obras 167) & 342 & Quintilla & D_s13 \\
\hline $\begin{array}{l}\text { La Concepción este } \\
\text { día }\end{array}$ & Cornejo (Obras 157) & 188 & Quintilla & D_s14 \\
\hline $\begin{array}{l}\text { Otra vez tengo la } \\
\text { pluma }\end{array}$ & Cornejo (Obras (152) & 349 & Quintilla & D_s16 \\
\hline $\begin{array}{l}\text { Oigan lo que saca en } \\
\text { limpio }\end{array}$ & Cornejo (Obras 195v) & 340 & Romance & D_s17 \\
\hline $\begin{array}{l}\text { Por tomar Judas el } \\
\text { grado }\end{array}$ & Cornejo (Obras 107) & 235 & Quintilla & D_s18 \\
\hline Un devoto singular & Cornejo (Obras 149v) & 192 & Quintilla & D_s22 \\
\hline $\begin{array}{l}\text { Un pecador soy, Dios } \\
\text { mío }\end{array}$ & Cornejo (Obras 172) & 394 & Romance & D_s23 \\
\hline Érase una Virgen pura & Cornejo (Obras 175) & 295 & Pareado & D_s24 \\
\hline $\begin{array}{l}\text { Sabed, señora } \\
\text { doncella }\end{array}$ & Cornejo (Obras 165) & 115 & Romance & D_s25 \\
\hline $\begin{array}{l}\text { La más hidalga } \\
\text { hermosura }\end{array}$ & Cornejo (Obras 155v) & 186 & Quintilla & D_s26 \\
\hline $\begin{array}{l}\text { Hoy a la Concepción } \\
\text { aclamaciones }\end{array}$ & Cornejo (Obras 194v) & 81 & Soneto & D_s27 \\
\hline
\end{tabular}

Tabla 43: Corpus de poesía sacra dubitada 


\begin{tabular}{|c|c|c|}
\hline \multicolumn{3}{|c|}{ Analisis de clasibicaciona } \\
\hline Case flumbet & Cluster & Distance \\
\hline D_s & 2 & 8.850 \\
\hline D_s3 & 2 & 3.097 \\
\hline D_s & 2 & 3,023 \\
\hline D_s & 2 & 7,156 \\
\hline D_s7 & 2 & 3,327 \\
\hline$D_{-}=8$ & 2 & 11,227 \\
\hline$D_{-}=9$ & 2 & 5.556 \\
\hline D_s10 & 2 & 7,868 \\
\hline D_s12 & 2 & 5,332 \\
\hline$D_{-} s 13$ & 2 & 4,197 \\
\hline D_s14 & 2 & 5.929 \\
\hline D_s16 & 2 & 4,579 \\
\hline D_s17 & 2 & 5.040 \\
\hline D_s18 & 2 & 4.810 \\
\hline$D_{-}=22$ & 2 & 6,972 \\
\hline$D_{-}=23$ & 2 & 7,925 \\
\hline D_s24 & 2 & 6.640 \\
\hline D_es & 2 & 9,764 \\
\hline D_s26 & 2 & 7,016 \\
\hline $0 \leq 27$ & 2 & 9.616 \\
\hline$C_{-}=1$ & 2 & 9,839 \\
\hline$c=2$ & 2 & 8.091 \\
\hline$C_{2} 33$ & 2 & 6.065 \\
\hline$c_{-}=4$ & 2 & 5.776 \\
\hline$c_{-} 25$ & 2 & 9.144 \\
\hline c_s6 & 2 & 6.237 \\
\hline$C_{-} s 7$ & 2 & 7.005 \\
\hline$C_{-2}=8$ & 2 & 7,439 \\
\hline$c_{-}=9$ & 2 & 5.770 \\
\hline L_si & 1 & 4,922 \\
\hline$L_{-} s 2$ & 1 & 5.457 \\
\hline$L_{-}=3$ & 1 & 6.318 \\
\hline L_ei4 & 1 & 8,689 \\
\hline L_s5 & 1 & 5,696 \\
\hline L_s6 & 1 & 6,718 \\
\hline L_a7 & 1 & 6,403 \\
\hline L_28 & 1 & 3,385 \\
\hline$L$ s9 & 1 & 11.495 \\
\hline
\end{tabular}

\begin{tabular}{|c|c|c|c|}
\hline \multicolumn{4}{|c|}{ Anślisis discrimianate } \\
\hline & CaseNvumber & Actual Grupo & Predicted Grosep \\
\hline \multirow[t]{38}{*}{ Original } & 0,82 & 2 & 2 \\
\hline & D,s & 2 & 2 \\
\hline & 0,58 & 2 & 2 \\
\hline & D,st & 2 & 2 \\
\hline & D.s7 & 2 & 2 \\
\hline & $D_{-58}$ & 2 & 2 \\
\hline & D,s & 2 & 2 \\
\hline & D,sto & 2 & 2 \\
\hline & 0,512 & 2 & 2 \\
\hline & 0,513 & 2 & 2 \\
\hline & D.s14 & 2 & 2 \\
\hline & D_s16 & 2 & 2 \\
\hline & D.sit & 2 & 2 \\
\hline & D.s18 & 2 & 2 \\
\hline & 0,322 & 2 & 2 \\
\hline & 0.233 & 2 & 2 \\
\hline & 0,324 & 2 & 2 \\
\hline & 0,5 & 2 & 2 \\
\hline & 0,35 & 2 & 2 \\
\hline & 0.527 & 2 & 2 \\
\hline & c_sit & 2 & 2 \\
\hline & c.siz & 2 & 2 \\
\hline & C_sis & 2 & 2 \\
\hline & $c_{-3 i 4}$ & 2 & 2 \\
\hline & c_sis & 2 & 2 \\
\hline & c_sit & 2 & 2 \\
\hline & c.sin & 2 & 2 \\
\hline & Csis & 2 & 2 \\
\hline & c.sig & 2 & 2 \\
\hline & L.sit & 1 & 1 \\
\hline & 452 & 1 & 1 \\
\hline & Lsis & 1 & 1 \\
\hline & Wis & 1 & 1 \\
\hline & wis & 1 & 1 \\
\hline & Lis & 1 & 1 \\
\hline & Lit & 1 & 1 \\
\hline & Lis & $t$ & 1 \\
\hline & LSA & 1 & 1 \\
\hline \multicolumn{4}{|c|}{ Atribución } \\
\hline León & L_si & 1 & \\
\hline Cornejo & $\mathrm{C}_{-} \mathrm{s}$ & 2 & \\
\hline
\end{tabular}

Tabla 44: Análisis clúster y análisis discriminante 326

${ }^{326}$ Todas las pruebas de validación cruzada aplicadas en el análisis de discriminantes coinciden con las atribuciones de autoría aportadas en los clústeres- 


\subsection{ALGUNAS NOTAS SOBRE EL MANUSCRITO “410" DE LA BIBLIOTECA REAL DE LA COLEGIATA DE RONCESVALLES}

Con el propósito de demostrar por qué el manuscrito elegido por Klaus Pörtl para editar la poesía de fray Damián no es el más idóneo, se ha realizado un análisis de sus principales características. El poemario, encuadernado en pergamino, posee la signatura 410 y debe el sobrenombre de "Roncesvalles" al lugar donde fue descubierto. En sus ciento noventa y cinco folios (155 x 215) reúne, aleatoriamente, ciento noventa y siete poemas ${ }^{327}$ bajo el título de "Poesías divinas y humanas, serias y jocosas, que a diferentes asuntos escribió el reverendísimo padre fray Damián Cornejo del Orden de nuestro padre san Francisco".

El manuscrito se compiló en $1737^{328}$. Su conformación en esta fecha parece haber sido propiciada por el auge de las impresiones de las obras de los poetas del Bajo Barroco, ya que pocos años antes se habían reeditado los versos de Antonio de Solís (1732) e impreso la poesía de León Marchante (1733) y la de José Pérez de Montoro (1736). El índice del manuscrito, incompleto y con errores en la foliación, nos desvela que varias páginas (120-121, 133-136 y 192-193) fueron perdidas o sustraídas ${ }^{329}$.

$\mathrm{Su}$ estructura es bastante compleja como consecuencia de que recopila materiales (principalmente de temática profana) de diversas fuentes y entremezcla ocho manos de finales del siglo XVII y del primer tercio del Siglo de las Luces, que dan lugar a once partes $^{330}$. El poemario se abre con poesía humana (1-27), continúa con poemas sacros $(28-84 v)^{331}$ y se cierra con lírica profana $(85-195)^{332}$. En la siguiente tabla, se ofrece una muestra de las diversas caligrafías que integran la obra y se detalla cómo se distribuyen

\footnotetext{
327 El manuscrito contiene un poema "atribuido expresamente a una monja y un mote del conde de Salinas" (Carreira, La obra 41).

328 En 1737, salió a la luz la octava parte de la Crónica Seráfica que, desde el volumen quinto, fue escrita por Eusebio González de Torres

329 Algunos de los textos que faltan en el manuscrito, como "A una monja pidiendo celos de un nombre que tenía como apellido Puerto" (121) o "Habiendo proveído un fraile en un locutorio de monjas y habiéndole escrito al asunto en unas coplas respondió en..." (135), tienen como protagonistas a inmorales miembros del clero. Tal hecho podría haber contribuido a que estos fueran extraídos del manuscrito.

${ }^{330}$ Klaus Pörtl (Cornejo, Das lyrische 31) determinó que en el manuscrito de Roncesvalles existían cinco manos y siete partes. Pero durante esta investigación se han descubierto tres manos más, que dan lugar a once partes: mano cuatro $(84 \mathrm{v})$, mano seis $(145 \mathrm{v}-148 \mathrm{v})$ y mano siete $(171)$.

${ }^{331}$ La mano tres $(28$ - 84v) empleó papel timbrado del año 1706 para transcribir los poemas atribuidos a fray Damián.

332 Cada bloque temático viene precedido por un título: "Poesías humanas que escribió a varios asuntos el reverendísimo padre fray Damián Cornejo", "Poesías sacras que a diferentes asuntos escribió el reverendísimo padre fray Damián Cornejo del Orden de nuestro padre san Francisco" y "Cornejo: poesías humanas".
} 
las distintas manos y partes de esta. También se indica su procedencia y se establece una cronología aproximada:

\section{Caligrafía y estructura}

\section{Mano 1: \\ Primer tercio del XVIII}

Parte 1:

$1-22$

\section{Parte 5:}

-Texto proporcionado por un asistente de los procuradores franciscanos: Gabriel Delgado: $85-123$ -Texto proporcionado por Moreno:

$123 \mathrm{v}-132 \mathrm{v}$

\section{Mano 2: Últimas} décadas del XVII

\section{Parte 2:}

22v-27

Mano 3:
Últimas décadas del XVII
Parte 3:

28-84v Mano 4: Últimas décadas del XVII Parte 4: 84v (fragmento)

\section{Mano 5:} Últimas décadas del XVII

Texto proporcionado (desde el 132v) Mano 6: Primer tercio del XVIII Parte 9: 171 Mano 7:

\section{Últimas décadas del XVII}

\section{Parte 10:}

$145 \mathrm{v}-148 \mathrm{v}$

\section{Mano 8:}

Primer tercio del XVIII

\section{Parte 11:}

$194-195$

por Sebastián "el librero".

\section{Parte 6:}

$138-145 \mathrm{v}$

\section{Parte 7:}

149-170v

\section{Parte 8:}

$171 v-191$

Tabla 45: Análisis de las partes del manuscrito 410 de Roncesvalles

Resulta llamativo observar que el contenido de la mano uno fue proporcionado por fuentes distintas ${ }^{333}$ y que entre ellas se halla un asistente de los procuradores franciscanos. Tal dato podría llevar a pensar que esta es una de las partes más fiables del poemario. No obstante, es en esta mano (sobre todo en la parte cinco) y en la mano cinco, considerada por Pörtl (Cornejo, Das lyrische 31) las más antigua, donde se encuentran

\footnotetext{
${ }^{333}$ Existen varias anotaciones de la mano uno en las que se indica quién proporcionó los materiales: "que me dio Gabriel Delgado, que asiste a los procuradores de san Francisco" (85), "Desde aquí me dio Moreno" (123) y "Desde aquí me dio Sebastián "el librero" (132). Esta mano aporta, además, una nota interesante (90) sobre la recopilación de los poemas y de algunas correcciones que sobre estos se hicieron "también me dio con estas poesía 'El sueño' (que con el que me había dado Moreno se cotejó y se corrigieron algunos defectos) y 'El agosto' (que con uno que yo tenía y otro que vino en las poesías que me dio Benito, de los tres, hice el grande, que tengo comprado aparte)".
} 
varios apócrifos: “dos de Bocángel, uno de Esquilache, otro de Pérez de Montalbán, dos de Calderón y dos más de José de Saravia y Francisco Sáenz de Viteri, aparte uno impreso 32 años antes de nacer Cornejo", que no son señalados en la edición del investigador alemán (Carreira, La obra 41) ${ }^{334}$. En estas manos, especialmente en la primera, aparecen la mayor parte de las composiciones que también se atribuyen a León Marchante ${ }^{335}$.

El manuscrito 410 de Roncesvalles, el más extenso entre los integri de Cornejo, es el que posee más poemas dubitados con el dramaturgo manchego (ochenta y dos) y también uno de los que incluye más textos indubitados: cincuenta y seis. Tanto el porcentaje de los primeros ( $41 \%$ ) como el de los segundos (28\%) es bajo si se compara con el resto de los testimonios integri analizados "Anexo 8.3.3.3.". Esto se debe, principalmente, a que alberga once poesías repetidas (tres de ellas triplicadas) ${ }^{336}$ y catorce que solo aparecen atribuidos a fray Damián en este poemario (Cornejo, Das lyrische 212226). Además, los textos que contiene presentan numerosos errores de copia. Todos estos motivos parecen contradecir la afirmación que hizo su descubridor de que se trataba de "la más fidedigna y completa colección de poesías" del escritor palentino (Pörtl 585).

\subsection{ALGUNAS NOTAS SOBRE LA DIFUSIÓN DE LA POESÍA JOCOSA EN ESPAÑA EN TIEMPOS DE FELIPE IV Y DE CARLOS II}

En el primer tercio del siglo XVII, se produce en España un creciente interés hacia la difusión y la producción de los versos jocosos y eróticos, como consecuencia del progresivo desgaste de la tradición petrarquista, de la influencia de la lírica burlesca

\footnotetext{
334 En esta investigación se han añadido a los apócrifos señalados por Antonio Carreira (La obra 45) los siguientes: "Ufano, altivo, alegre, enamorado" de José de Saravia (123v) y "Aprended, flores, en mí" de Juan Pérez de Montalbán (158).

335 En la primera mano del manuscrito de Roncesvalles, aparecen cuarenta y seis poesías de autoría dubitada con el maestro León; cinco se hallan en la parte una y cuarenta y una en la parte cinco: de estas, treinta y nueve se incluyen en los folios proporcionados por un asistente de los procuradores franciscanos y dos pertenecen a los materiales aportados por Moreno. La segunda mano del poemario alberga una composición de autoría disputada, la tercera mano contiene veinte y la quinta mano posee cuatro.

336 Los poemas que aparecen repetidos o triplicados son: "En Málaga vi a Rufina” (114 y 166), "La más hidalga hermosura" (29v y 194), "Suelto el cabello por el aire ufano" (21v y 117v), "Quiero pues es ocasión" (95v y 132), "Señor jurador he sido" (123v y 152), "Genil, galán de los ríos" (116v y 156), "Solo el silencio testigo" (103v y 112), "Por tomar Judas el grado" (26v y 48), "María, viéndote hermosa" (3v y 188v), "Oye, Catuja, dulce hechizo mío" (8, 22 y 139), "Marica, que a decir mal" (38, 138 y 189v" y "Malo me siento, Marica" $(107,144 \mathrm{v}$ y $190 \mathrm{v})$.
} 
italiana $^{337}$ y de la reivindicación de las obras amatorias de Ovidio ${ }^{338}$. La consolidación del cultivo de estos quedará reflejada en la publicación de poemarios como Donaires del Parnaso (1624-1625), Cosquillas del gusto (1629), El buen humor de las musas (1630), Bureo de las Musas del Turia (1631) y Rimas de Tomé de Burguillos (1634) ${ }^{339}$. A través de estas recopilaciones festivas, el público barroco podía canalizar su gusto por la lírica conceptista y su deseo de evadirse de la decadente realidad social y política que atravesaba el Imperio español (Cacho, El ingenio 19). La consagración oficial de la poesía jocosa se produjo en 1637 con la celebración de la Academia burlesca ${ }^{340}$, un certamen realizado en el Buen Retiro con el objetivo de homenajear a Felipe IV. Las estructuras métricas más demandas en este evento para mofarse de criadas, viejas, beatas, feas, necios mentirosos o doctores fueron el soneto, las redondillas y, sobre todo, el romance ${ }^{341}$.

Uno de los testimonios que mejor evidencia el auge de las composiciones festivas en arte menor a mediados del Siglo de Oro es la antología Poesías varias de grandes ingenios $(1654)^{342}$. José Alfay deseaba ofrecer en esta una obra novedosa y atractiva para

\footnotetext{
${ }^{337}$ Los poetas hispanos de la segunda mitad del quinientos, como Fernando de Herrera, Diego Hurtado de Mendoza o Góngora, tomaron como modelo para cultivar la lírica jocosa los cómicos e ingeniosos versos del dramaturgo y sacerdote italiano Francesco Berni (1497-1535). Estos combinaban la tradición nacional (Dante, Petrarca y Burchiello) y la clásica (Horacio, Virgilio y Catulo) para retratar un mundo mediocre o bajo, poblado de figuras repelentes, inmorales y ridículas y lleno de dobles sentidos o equívocos relacionados con la sexualidad (Cacho, El ingenio 14).

${ }^{338}$ La recuperación que se hizo en la península ibérica a finales del siglo XVI de la poesía menos ortodoxa del autor de las Metamorfosis, gracias a las diversas traducciones y adaptaciones del Remedia amoris y del Ars amandis, jugó un papel relevante en el desarrollo de la lírica erótica hispánica del Siglo de Oro. Javier Blasco (Arte de Amor) en su reedición de este último indaga tales cuestiones.

${ }^{339}$ La distancia entre el rostro vital del poeta (Lope) y su máscara en la escritura (Burguillos) es el resultado del definitivo abandono de las bases del petrarquismo, que intentaban plasmar de forma unitaria las experiencias amorosas del autor. Frente a estas, los escritores del XVII buscan la diversidad en sus poemarios: "El poeta, libre de un amor absorbente y transformador... puede pasear la mirada por el mundo exterior, pero también por nuevos espacios de su interioridad que no son exclusivamente eróticos, y puede, por consiguiente, desarrollar distintos registros expresivos o estilísticos para cuenta de ello o construir una nueva realidad" (Ruiz, La rúbrica 262).

${ }^{340}$ Los poetas galardonados en este certamen fueron Antonio de Solís, Antonio de Covarrubias, Jerónimo de Cáncer, Luis Quiñones, Francisco de Aparicio, Martín de Figueredo, Pedro Rosete, Pedro Méndez de Loyola, Juan Navarro de Espinosa, Marchante, Ramón de Montero, Pedro García, Luis de Belmonte, Juan Mejía, Gaspar de Ávila, Antonio de Huerta, Antonio Coello, Juan Antonio de la Peña, Antonio Martínez, Jerónimo de Esquivel y Francisco Alfaro (Cañas 5-26).

${ }^{341}$ En el siglo XVI, los sonetos y los tercetos (herederos de los capitoli italianos) son los metros preferidos para la lírica festiva, mientras que en la centuria siguiente se mantiene el uso del soneto y se extiende el empleo del romance: "el romancero supuso un punto de partida fundamental para los poetas festivos del siglo XVII, lo cual se aprecia en las abundantes citas y parodias románcenles en sus versos y también en la métrica (...) permite una escritura distendida y cercana a la prosa" (Cacho, El ingenio 20).

${ }^{342}$ El poemario editado por Alfay reúne a los poetas más conocidos de la primera mitad del siglo XVII, distanciándose así de la antología que le precedía: Flores de poetas ilustres (1605). Esta recopila lo más valioso de la poesía del pequeño círculo amigos de Pedro de Espinosa: "encontramos a Barahona de Soto, Herrera y Fray Luis junto con Góngora, Lope y Quevedo, que inician por aquellos años la desviación hacia lo ingenioso. En cambio, en la de nuestro librero zaragozano los nombres responden al gusto de la generación de 1650, que admiraba las obras de Cáncer, Antonio Hurtado de Mendoza y los romances jocosos y burlones de Góngora o Salas Barbadillo" (Blecua, Poesías 11).
} 
todo tipo de públicos. Por ello, como señala José Manuel Blecua (11), el editor zaragozano combinó poemas llenos de gracia y delicadeza con otros burlescos o extravagantes. El resultado fue un corpus, principalmente cómico, en el que se daba cabida a poetas de gran fama (Quevedo, Góngora, Calderón, Salas Barbadillo, Jerónimo de Cáncer, Pérez de Montalbán, Anastasio Pantaleón o Gabriel de Bocángel) y a otros menos conocidos como Juan Centeno o Alberto Díez. La cohesión y continuidad de las ciento treinta y dos composiciones que lo conforman se consiguen a través de la eficiente distribución de los cincuenta y cinco romances que alberga el poemario (Ruiz, Para una 390).

Ante el significativo incremento en la primera mitad del siglo XVII de las composiciones poéticas morbosas o inmorales, la censura literaria en España (tanto la preventiva como la represiva) se incrementó, aunque esta únicamente se aplicaba en caso de herejía o de poner en riesgo la fe: “el Consejo recogerá el libro por escandaloso y lleno de sátiras y vicios, y el Santo Oficio porque mezcla con desvergüenza lo sagrado con lo profano como no se ha visto jamás... el libro irá con el de Pantaleón ${ }^{343}$, por el mismo intento, en peores cifras" (Quevedo, Obras inéditas 38). Hasta la publicación en 1640 del índice de libros prohibidos de la Inquisición no entró en vigor la regla séptima del Concilio de Trento (1545-1563), que establecía la prohibición de textos lascivos, propensos a los deleites carnales o perjudiciales para las buenas costumbres de la iglesia cristiana $^{344}$.

No obstante, la extensa duración de los procesos de censura (más de dos años) y las calificaciones imprevisibles y subjetivas de los censores permitieron, tras la aprobación de la nueva norma, la impresión de versos con contenido ilícito (Muñoz 157207). Para intentar eludir las sanciones de la Inquisición, editores y autores encubrían sus obras mediante títulos poco específicos "poesías varias", las entremezclaban con creaciones moralmente aceptables o las camuflaban con figuras retóricas, eufemismos o

\footnotetext{
${ }^{343}$ Las Obras de Anastasio Pantaleón fueron censuradas por la Inquisición, en 1631, debido a que contenían algunos poemas que combinaban elementos sacros y eróticos. Tras un proceso de expurgación, estas se reeditaron tres años más tarde.

${ }^{344}$ En la regla séptima del índice del Concilio de Trento se prohíben los libros que "expresamente tratan, cuentan o enseñan cosas lascivas u obscenas, porque no solamente se deben ocupar de los problemas de fe, sino también de las costumbres, las cuales se corrompen fácilmente por la lectura de estos libros; todos los que posean esta clase de escritos serán severamente castigados por los obispos. Se permiten, sin embargo, los escritos de los antiguos autores paganos a causa de la elegancia y de las cualidades literarias, pero no debe permitirse su lectura a los adolescentes" (Muñoz 175).
} 
tópicos recurrentes, que podían ser desentrañados por los lectores agudos ${ }^{345}$. Algunos poemarios destacados que emplearon estas estrategias, a mediados del seiscientos, fueron Parnaso español ${ }^{346}$, de Francisco de Quevedo, y Obras varias de Jerónimo Cáncer. Pero la publicación no era el principal cauce para la difusión de la poesía barroca ${ }^{347}$. En una sociedad con altos índices de analfabetismo, la divulgación oral de la lírica sigo siendo la vía más practicada ${ }^{348}$.

La lectura en voz alta ${ }^{349}$ (ante un amplio público) se incrementó a lo largo del siglo XVII gracias al creciente interés cultural que despertaban las academias literarias ${ }^{350}$ y las justas ${ }^{351}$. Estos eventos populares se convirtieron en testimonios de las tendencias poéticas del momento y pusieron de manifiesto el progresivo auge de las composiciones burlescas en las últimas décadas del reinado de Felipe IV (Osuna, Las justas 337). El gusto por la ostentación y por los festejos ${ }^{352}$ del "Rey Planeta" hizo que cualquier acontecimiento político o religioso fuese motivo de celebración ${ }^{353}$. En ellos se cantaban

\footnotetext{
${ }^{345} \mathrm{El}$ empleo de eufemismos en los títulos de cancioneros festivos y la aglomeración de diversos materiales en ellos, como señala Ignacio Díez Fernández (Compilar 302-320), son algunas de las estrategias que también emplearon los editores del siglo XIX. Gracias a estas, Antonio Peratoner y Eduardo Lustonó pudieron publicar antologías poéticas tan relevantes y exitosas como: Museo epigramático o colección de los más festivos epigramas (1864), Flores varias del Parnaso (1876), Juguetes y travesuras de ingenio (1876), Venus picaresca (1881) y Venus retozona (1892).

${ }^{346}$ Parnaso español (1648) logró un éxito comercial tan solo equiparable al obtenido por las Rimas de Lope de Vega. Pero mientras que la prolífica producción impresa del Fénix cayó considerablemente tras la década de 1620, las múltiples reediciones del poemario de Quevedo alcanzaron altas cuotas de mercado hasta mediados del siglo XVIII (Martín y Ruiz, El nombre 31).

${ }^{347}$ La imprenta tuvo una relevancia destacada para la difusión de la poesía en la primera parte del seiscientos. En este periodo, se realizaron unas 278 ediciones de libros de poesía (1.000 a 1.500 ejemplares por tirada), que suman entre 278.000 y 417.000 obras impresas. Esta cifra peca de corta, pues "no incluye los pliegos sueltos poéticos, que se imprimieron por miles y que, para muchos, eran el vehículo principal mediante el cual llegaban a conocer la poesía barroca, ni todos los cancioneros y romanceros que recogió Rodríguez-Moñino, ni todas las ediciones salidas de las imprentas españolas" (Ruiz, Para la historia 21). ${ }^{348}$ La transmisión manuscrita fue el segundo medio más empleado para la difusión de la lírica barroca (especialmente para la de temática festiva) por permitir una comunicación menos coartada, aunque no libre de autorrepresión (Díez Fernández, La poesía 46).

${ }^{349}$ Los escritores del Siglo de Oro concebían sus obras para ser leídas ante un auditorio: "Hasta el discurso académico escrito nace para ser recitado y compartido, ya se trate del Arte nuevo de Lope de Vega, del Discurso poético de Soto de Rojas o de la cedulilla chusca sobre las canillas de un corcovado en la Academia de Fonseca (1662)" (Egido 73).

${ }^{350}$ Alain Bègue elabora un monográfico sobre los catálogos de las academias literarias que se celebraron en España en la segunda mitad del XVII. En él se indaga tanto en su contenido como en la relevancia que estos poseen para conocer la evolución de los discursos poéticos entre las estéticas barroca y neoclásica.

${ }^{351}$ El creciente interés cultural que despiertan las justas poéticas en el siglo XVII hace que estas rebasen los muros de las escuelas o parroquias y que se conviertan en destacados acontecimientos sociales, los cuales reunirán a poetas de la talla de Cervantes, Lope de Vega o los hermanos Argensola. El ambiente festivo de tales eventos y el avance de la poesía jocosa, a mediados del seiscientos, permitieron que los versos cómicos, sin llegar a ser mayoritarios, aumentaran en número e incrementaran su complejidad formal (Osuna, Las justas 337).

${ }^{352}$ Las costosas y frecuentes fiestas que se llevaban a término en España durante el reinado de Felipe IV han sido investigadas por José Deleito y Piñuela en El pueblo también se divierte y en El rey se divierte.

${ }^{353}$ Se celebraban "todos los santos y cumpleaños de las personas reales, los días de toros, los días en que se celebraban Autos de Fe, los días en que se corrían toros, las festividades de los patronos de los distintos
} 
y se representaban en público, acompañadas de música y de elementos teatrales ${ }^{354}$, poesías para festejar o elogiar sucesos protagonizados por destacados miembros de la nobleza o relacionados con el clero (López Guil 69).

Los poetas que participaban en las justas, certámenes o academias literarias de la segunda mitad del siglo XVII tenían que poseer un gran dominio de la retórica ${ }^{355}$ si deseaban hacerse un hueco en el nuevo y prestigioso Parnaso ${ }^{356}$. Este debía incluir a los autores del pasado y abrirse hacia los escritores del presente ${ }^{357}$. La antología Delicias de Apolo: Recreaciones del Parnaso (1670) muestra cómo se van añadiendo a los escritores consagrados (Lope, Góngora y Quevedo) ${ }^{358}$ otros contemporáneos (Juan de Matos Fragoso, Agustín Moreto, Vicente Sánchez o José Tafalla y Negrete). Su editor, José Alfay, deseaba con ello "establecer un horizonte en el que se funden los dos segmentos canónicos, el de la tradición heredada y asumida y el de la creación contemporánea" (Ruiz, Entre dos parnasos 207).

La referencia explícita a "Parnaso" en los títulos de poemarios del Bajo Barroco es un intento de los autores de vincular sus obras con el canon, como ya habían hecho Cervantes, Lope o Quevedo. Las tres musas últimas castellanas: segunda cumbre del Parnaso español (1668), Cima del monte Parnaso español (1672) o Varias, hermosas flores del Parnaso (1680) son algunos ejemplos destacados de esta recurrente práctica

gremios, la Semana Santa, el Corpus Christi, los días de las bodas reales, los nacimientos de los integrantes de la Real Familia, los Carnavales..." (López Guil 35).

${ }^{354}$ La teatralización de las justas no solo afectaba a aspectos relacionados con la escenografía, también tenía repercusiones en la estructura verbal de las obras: "cada vez más orientada hacia los terrenos parateatrales, como ocurría también en los de la oratoria sagrada. La voz en las justas no era letra manuscrita sino para dicha y cantada y escenificada como en el drama, y su impresión, si la hay, es posterior y accidental" (Egido $84)$.

${ }^{355}$ A mediados del siglo XVII se difuminan las fronteras entre poetas y oradores, pues ambos deben aprender y desarrollar un buen uso de la elocuencia. No ha de extrañar, por tanto, que muchos de los participantes de las academias literarias tuvieran cargos relacionados con el ámbito administrativo o jurídico: abogados, financieros o miembros del clero (Bègue, Aproximación 155).

${ }^{356}$ La poesía en la segunda mitad del seiscientos se concibe como una marca de prestigio y performance social del buen gusto. Los nobles que deseaban añadir a su linaje la fama que el cultivo de la lírica otorgaba publicaron sus poemarios: "entre los años 1650 y 1670 (...) vieron la luz de la imprenta alrededor de una veintena de volúmenes poéticos (contando, eso sí, reimpresiones y ediciones ampliadas) de nobles titulados amateurs. Tres nombres copan la casi totalidad de esos títulos: Juan de Moncayo y Gurrea, marqués de San Felices, con sus Rimas (1652) y su Poema trágico de Atalana y Hipómenes (1656); Francisco de Borja y Aragón, príncipe de Esquilache, con su Nápoles recuperada (1651; reimpresa luego en 1658), sus Obras en verso (impresas por primera vez en 1648 y reimpresas y ampliadas en 1654 y 1663); y, sobre todo, Bernardino de Rebolledo" (Jiménez 83).

${ }^{357}$ La evolución y la progresiva apertura del canon poético hacia las nuevas generaciones que se produce en el Bajo Barro han sido estudiadas por Pedro Ruiz (Subversión y La poesía).

${ }^{358}$ Los versos impresos de Quevedo se convirtieron en los más frecuentes en las bibliotecas españolas de la segunda mitad del Siglo XVII y de la primera década del XVIII. A continuación, se hallaban las poesías de Góngora y de Lope de Vega seguidas, con mucha diferencia, de las de Villamediana, de los hermanos Argensola, Esquilache, Ercilla, Bocángel, Ulloa y Pereira, Sor Juana y López de Zárate (Ruiz, Para la historia 31). 
(Martín y Ruiz, El nombre 25-48). Otra estrategia muy empleada para captar la atención de los lectores era ofrecer recopilaciones de versos "variadas". Estas podían reunirse bajo el título de "poesías" o mediante otras nomenclaturas que mostraran la diversidad de su contenido, como es el caso de Entretenimiento de las Musas en esta baraja nueva de versos, dividida en cuatro manjares de asuntos (1654) de Francisco de la Torre y Sevil. El heterogéneo y emergente ${ }^{359}$ mercado editorial que se desarrolló durante el reinado de Carlos II en España propició la profesionalización de los poetas y consolidó la revalorización de las ediciones realizadas en vida del autor ${ }^{360}$. En este periodo, la lírica burlesca ocupó un lugar destacado en los poemarios impresos y en los populares pliegos de $\operatorname{cordel}^{361}$. No obstante, fueron las obras sacras las que más se editaron ${ }^{362}$, debido a la creciente demanda de nuevos poemas para los múltiples festejos religiosos que se celebraban ${ }^{363}$ y al prestigio literario que estas poseían ${ }^{364}$.

León Marchante y José Pérez de Montoro son los escritores que publicaron más versos de temática divina en la segunda mitad del siglo XVII ${ }^{365}$. Estos se impregnaron (en algunos casos) de un tono jocoso. Sus obras continuaron siendo muy demandas en la centuria siguiente, pues en ella se imprimieron los versos sacros y profanos del dramaturgo manchego (1722 y 1733) y del poeta valenciano (1736). Además, se editaron los poemas de algunos de contemporáneos, como el caso de Tafalla y Negrete (1706) y de Antonio de Solís (1716 y 1732), y se realizaron múltiples copias manuscritas de las

\footnotetext{
${ }^{359}$ Si se comparan los catálogos de poesía impresa de la primera parte del siglo XVII (García Arellano 355365) con los de la segunda mitad (Bègue, Relación 399-477), puede observarse un claro incremento de las publicaciones de versos conforme avanza la centuria.

${ }^{360}$ Pedro Ruiz (La poesía y La rúbrica) analiza cómo se produjo la revalorización de la figura del poeta a mediados del Renacimiento y cómo, a partir de este periodo, la publicación de las obras en vida del autor empezó a dejar de ser considerada algo negativo.

${ }^{361}$ La popularidad del libro pequeño y de los pliegos sueltos en el Bajo Barroco dio lugar a la emergencia de nuevos centros de impresión (como Badajoz o Ciudad Real) y condicionó el contenido de las obras poéticas, que debía adaptarse a las características de consumo y de espacio de dicho formato (Álvarez Amo 20).

${ }^{362}$ A partir del inventario de libros de poesía que se imprimieron en el Bajo Barroco (Bègue, Relación 399477), se puede comprobar el elevado número de ediciones de lírica sacra que vieron luz en este periodo.

363 Alain Bègue reúne varios testimonios históricos que ponen de manifiesto la alta demanda de composiciones sacras que se requerían, a mediados del seiscientos, para ser recitadas o cantadas en festejos religiosos: "Vmd. me honre con tres o cuatro villancicos de las mejores letras, y nuevas, que la solfa será muy buena, y entre ellos venga alguno gracioso o de chanza" (Tres 99).

${ }^{364}$ La lírica religiosa en los Siglos de Oro disfrutaba de un estatuto superior cuantitativa y cualitativamente: a la de temática profana: "Así se entienden los reiterados intentos por parte de los poetas de cultivar este campo como puerta de acceso al mecenazgo y al Parnaso: si las incursiones más o menos sinceras de Lope de Vega en el género iban acompañadas de una constante defensa de la superior dignidad de la poesía religiosa, Góngora dejó correr alguna vez su pluma por estos lares con la intención de congraciarse con los grandes de la Corte" (Sáez 72).

${ }^{365}$ En la segunda mitad del siglo XVII, se firmaron diecinueve publicaciones de lírica sacra con el nombre de León Marchante y quince con el de José Pérez de Montoro (Bègue, Relación 399-477).
} 
poesías de fray Damián Cornejo. Las obras de todos estos autores, junto con las de Francisco de Quevedo ${ }^{366}$, son las que más "marcan la pauta en el oscuro comienzo del Siglo de las Luces" (Álvarez Amo 14).

\subsection{IMPRESIONES Y LICENCIAS DE IMPRESIÓN DE LAS OBRAS EN PROSA DE FRAY DAMIÁN CORNEJO}

\subsubsection{Impresiones}

Cornejo, Damián. Crónica Seráfica: vida del glorioso patriarca san Francisco y de sus primeros discípulos escrita por el r[everendísimo] p[adre] f[ray] Damián Cornejo examinador sinodal de este arzobispado y cronista general de su Orden. Parte primera. Madrid: Juan García Infanzón, 1682.

Cornejo, Damián. Crónica Seráfica: vida del glorioso patriarca san Francisco y de sus primeros discípulos escrita por el r[everendísimo] p[adre] f[ray] Damián Cornejo examinador sinodal de este Arzobispado y cronista general de su Orden. Parte segunda. Madrid: Juan García Infanzón, 1684.

Cornejo, Damián. Crónica Seráfica: vida del glorioso patriarca san Francisco y de sus primeros discípulos escrita por el r[everendísimo] p[adre] f[ray] Damián Cornejo examinador sinodal de este arzobispado y cronista general de su Orden. Parte tercera. Madrid: Juan García Infanzón, 1686.

Cornejo, Damián. Vida admirable del ínclito mártir de Cristo B. Raimundo Lull. Mallorca: n.p., 1686.

Cornejo, Damián. Vida admirable de San Luis. Obispo de Tolosa, de los reyes de Sicilia y Nápoles y de la religión seráfica. Escrita por d[on] fr[ay] Damián Cornejo del Orden del seráfico padre s[an] Francisco, y obra obispo de Orense. Zaragoza: Manuel Román, 1695.

Cornejo, Damián. Crónica Seráfica: vida del glorioso patriarca san Francisca de sus primeros discípulos escrita por el r[everendísimo] p[adre] f[ray] Damián Cornejo

\footnotetext{
${ }^{366}$ Los versos impresos de Quevedo se convirtieron en los más frecuentes en las bibliotecas españolas de la segunda mitad del Siglo XVII y de la primera década del XVIII. A continuación, se hallaban las poesías de Góngora y de Lope de Vega seguidas, con mucha diferencia, de las de Villamediana, de los hermanos Argensola, Esquilache, Ercilla, Bocángel, Ulloa y Pereira, Sor Juana y López de Zárate (Ruiz, Para la historia 31).
} 
examinador sinodal de este Arzobispado y cronista general de su Orden. Parte cuarta. Madrid: Juan García Infanzón, 1698.

Cornejo, Damián. Vida de la gloriosa y seráfica Madre santa Coleta, religiosa franciscana. Trasladada esta vida de obras de fray Damián Cornejo del Orden de san Francisco. Vitoria: Bartolomé Riesgo, 1722.

Cornejo, Damián. Glorioso ternario delle vite di tre beati servi di Dio descritte dal Cornegio, e da Wozdingo in lingua spagnuola, e latina, e tradotte nella nostra italiana da Antón María Bonucci. Roma: Girolamo Mainardi, 1724.

Cornejo, Damián. Vita della B. Michelina da Pesaro... scritta in lingua spagnuola da monsignor Damiano Cornejo. Tradutta nell' italiana da Antón María Bonucci. Roma: Girolamo Mainardi, 1724.

Cornejo, Damián. Vida admirable de la gloriosa s[anta] Margarita de Cortona, hija de la venerable Orden Tercera de Penitencia de nuestro santo padre san Francisco, canonizada por nuestro s[antísimo] p[adre] Benedicto XIII el día 16 de mayo de 1728. Madrid: n.p., 1728.

Cornejo, Damián. Vida admirable del ínclito mártir de Cristo B. Raimundo Lul. Mallorca: Ignacio Frau, 1755.

Cornejo, Damián. Vida portentosa de santa Rosa de Viterbo, Caller (Santo Domingo): Agustín Murtas, 1743.

Cornejo, Damián. Vida admirable del inclito B. Raymundo Lul. Escrita por Damián Cornejo Impresa en 1686 y ahora dedicada a s[an] Ignacio de Loyola, Mallorca: Ignacio Frau, 1755 .

Cornejo, Damián. Vida portentosa de san Antonio de Padua. Su auto. fr[ay] Damián Cornejo de la Regular Observancia Murcia: Imprenta de la provincia de Cartagena de San Francisco, 1766.

Cornejo, Damián. Vida portentosa de santa Rosa de Viterbo. Madrid: n.p., 1786.

Cornejo, Damián. Vida admirable del glorioso s[an] Roque: confesor de la venerable Orden Tercera de Penitencia de n[uestra] s[anta] Francisca y abogado de la Peste. Diola a la prensa en la tercera parte de su crónica f[ray] Damián Cornejo reimprímese con su adjunto novenario a instancias de la Piedad. Zaragoza: Francisco Magallón, 1801. Impreso.

Cornejo, Damián. Vida del glorioso patriarca san Francisco de Asís escrita por fray Damián Cornejo de la religión franciscana; publicada pon la V Orden Tercera de Penitencia 
de Religiosas Franciscanas de la Puridad y s[an] Jaime de Valencia. Valencia: n.p., 1884 .

Cornejo, Damián. Vida del glorioso patriarca san Francisco de Sales escrita por fray Damián Cornejo. Valencia: Ramón Ortega, 1884.

Cornejo, Damián. Vida de la seráfica madre s[anta] Clara de Asís escrita porf[ray]. Damián Cornejo, obispo de Orense, de Menores Observantes; y adicionada por f[ray] Francisco H. Malo de la santa provincia de Cartagena. Orihuela: n.p., 1887.

Cornejo, Damián. Santa Isabel de Aragón reina de Portugal: espejo de doncellas, casadas y viudas por f[ray] Damián Cornejo. Madrid: n.p., 1896.

\subsubsection{Licencias de impresión}

[Aprobación]. Anual recuerdo de las memorias dulces de la venerable madre de María de la Paz religiosa que fue en el convento de Santa Catalina de Sena, de Alcalá de Henares, que hizo y dijo fray Juan de Gil Godo de la Orden de Predicadores. Sácale a luz la priora y convento de Santa Catalina. Alcalá: Nicolás de Jamares, 1674. Cf. Bègue (Diccionario 710-713).

[Aprobación]. Compendio historial del aparecimiento de nuestra señora de la Salceda. Madrid: Juan García Infanzón, 1687. Cf. Bègue (Diccionario 710-713).

[Aprobación]. Sermón del glorioso patriarca san Bruno, predicado en su día en la Real Cartuja del Paular de Segovia, por f[ray] Juan Francisco Zorrilla de la Regular Observancia del serafín Francisco. Madrid: Juan García Infanzón, 1690 Cf. Bègue (Diccionario 710-713).

[Aprobación]. Sol de Marruecos, el V padre fr[ay] Juan de Prado, primer provincial de la santa provincia de San Diego de Franciscanos Descalzos de la Andalucía, cuya vida, virtudes y martirio, panegiriza el padre fray Francisco de s[an] Buenaventura. Sevilla: Juan Francisco de Blas, 1691. Cf. Bègue (Diccionario 710-713).

[Aprobación]. Idea de perfección y virtudes, vida de la VM Catalina de Jesús, y san Francisco, hija de su Tercera Orden, y fundadora del Colegio de las Doncellas Pobres de s[anta] Clara de la ciudad de Alcalá de Henares, escrita por f[ray]. Juan Bernique de la Regular Observancia de n[uestro] p[adre] san Francisco. Alcalá: Francisco García Fernández, 1693. Bègue (Diccionario 710-713). 
[Aprobación] Privilegio de reimpresión de los seis primeros tomos de la obra compuesta por fray Damián Cornejo y fray Eusebio González de Torres "Crónica Seráfica", y privilegio de impresión del séptimo volumen. Solicitados por fray Alonso Maroto, 1728. Cf: Archivo Histórico Nacional, Consejos, 50627, Ex 71.

[Aprobación] Licencia y privilegio de reimpresión de los ocho tomos de la obra Crónica seráfica: vida del glorioso patriarca san Francisco, y de sus primeros discípulo. Solicitada por Matías de Velasco, 1739. Cf: Archivo Histórico Nacional, Consejos, 50635, Ex 61.

[Aprobación] Licencia de reimpresión de la obra Vida portentosa de san Antonio de Padua. Solicitada por Andrés José Filoso, 1765. Cf: Archivo Histórico Nacional, Consejos, 177711, Ex 63.

\subsection{EJEMPLO DE EDICIÓN CRÍTICA EN LENGUAJE MARCADO (XML- TEI)}

\subsubsection{Introducción a TEI}

El ingente número de textos que en la actualidad tenemos a nuestra disposición propicia la adquisición de nuevas estrategias para su creación, análisis y conservación. Desde la aparición de la Text Encoding Initiative 367 “TEI”, la codificación informática de estos se ha convertido en una herramienta gratuita, libre y universal (existen manuales para estandarizar la marcación digital "Guidelines") que progresa y crece exponencialmente a través del reciclaje de los materiales que elaboran sus usuarios.

TEI se expresa a través del lenguaje web XML (no depende de ningún software y afecta solo al contenido de los datos) y es empleado en múltiples contextos. El más extendido es el de la edición de textos ${ }^{368}$. El sistema permite no solo abarcar todos los diferentes métodos y escuelas de la crítica textual (ediciones diplomáticas, críticas, genéticas...), sino también incorporar a las obras elementos multimedia o materiales de todo tipo para enriquecer su consulta o investigación.

\footnotetext{
${ }^{367}$ La Text Encoding Initiative fue el primer intento científico de codificar digitalmente textos y, hoy día, es el sistema más empleado. Tiene su base en el Consorcio TEI, que está integrado por personas e instituciones que desarrollan y mantienen actualizada la metodología de marcar los textos. La historia y las bases sobre las que se asienta este sistema han sido estudiadas por Burnard (Introduction y The evolutión). ${ }^{368} \mathrm{Si}$ se desea conocer las características de las ediciones en línea que ya han sido codificadas en TEI, se recomienda consultar los siguientes catálogos online: Digital Scholarly Editions y Catalogue of Digital Editions.
} 
Además, TEI es muy utilizado en la creación e implementación de bibliotecas, catálogos, bases de datos, diccionarios, corpus lingüísticos y archivos virtuales. La información codificada que las obras marcados en este código contienen puede abarcar desde aspectos muy generales (corpus, subcorpus, obras, autores, períodos...) a unidades o elementos descriptivos muy concretos. Gracias a todo ello, se pueden extraer concordancias, realizar análisis estilométricos, gráficos de frecuencias, segmentación gramatical y búsquedas inteligentes.

Una de las últimas contribuciones en el ámbito de la poesía hispana que utiliza este sistema es el proyecto "Góngora” del Labex OBVIL. En él se combina una edición crítica y anotada con una edición digital enriquecida (con metadatos, hipervínculos y contenido multimedia) de textos del siglo XVII relacionados con la recepción de la obra de Luis de Góngora (Pezzini y Ruiz 37). Tal iniciativa es un claro ejemplo del puente que, poco a poco, se va estableciendo entre el pasado y el futuro de la crítica textual.

\subsubsection{Edición de algunos poemas de fray Damián Cornejo}

Con el propósito de dar a conocer cómo se puede realizar la codificación en TEI (mediante el programa Oxygen) de una edición crítica de poesía y de seguir demostrando sus ventajas para el estudio y la divulgación de la filología, se ha realizado una pequeña muestra $^{369}$. Esta está constituida por diversos ficheros XML, que contienen la explicación del proyecto y la edición de cuatro poesías de Cornejo (dos profanas y dos sacras) ${ }^{370}$.

En primer lugar, se ha creado un documento ODD $^{371}$ (con la aplicación en línea Roma) con los módulos: Core, Header, Textstructure, Msdescription, Verse y Textcrit ${ }^{372}$. Estos permiten la descripción detallada del proyecto y del corpus editado, de las fuentes primarias “ $<$ msDesc $>$ ”, de la estructura de las poesías “ $<\lg >$ ” y del aparato crítico que las acompaña " $<$ app $>$ ". Además, pueden incorporar datos específicos del etiquetado que se desea realizar. Nosotros hemos añadido las categorías "dub" e "ind", para señalar si los

\footnotetext{
${ }^{369}$ El documento raíz del proyecto y los poemas editados pueden consultarse en el siguiente enlace: https://drive.google.com/drive/folders/1atORTI0CguelCktU4AGyTZTnRul0G84r?usp =sharing

370 Se han seleccionado los siguientes poemas: "Guardar la mujer es ley", "Haced que la gracia encuentre", "Hoy a la Concepción aclamaciones" y "Un dominico enemigo". Cada uno de ellos, al igual que se hecho con las fuentes primarias y los autores, ha sido etiquetado con un código unívoco "xml: idn" para facilitar su identificación.

${ }^{371}$ El documento ODD es un modelo personalizado de marcado de textos que se asocia a un documento TEI. Este resulta especialmente útil en los trabajos en los que interviene más de una persona, pues garantiza una codificación homogénea.

${ }^{372}$ Las características de los módulos empleados y la información de los elementos que los integran pueden consultarse en los correspondientes apartados de las Guidelines.
} 
poemas seleccionados son de autoría segura o no.

En segundo lugar, se ha elaborado un documento "edco.xml", donde se incluye el “<TeiHeader>". En él, aparece toda la información sobre el proyecto que se está realizando, sobre la obra editada “ $<$ fileDesc $>$ ” y sobre la localización y las características de las fuentes primarias " $<$ sourceDesc $>$ ". A cada uno de los manuscritos elegidos $(A, B$, $D, M$ y $S$ ) se le ha asignado una identificación única " $<$ witness xml:id="BNE”, cuya referencia se ha marcado con " $<$ ref target $=$ "\#..." $><\ldots>$ ". La lista creada de referencias se ha incluido en "<litsWit>". Tras esta, aparecen los criterios que se han seguido para hacer la edición crítica "<encodingDesc>". Las siguientes imágenes son ejemplo de la información que se ha incorporado en los bloques comentados:

Ilustración 3: Presentación del proyecto

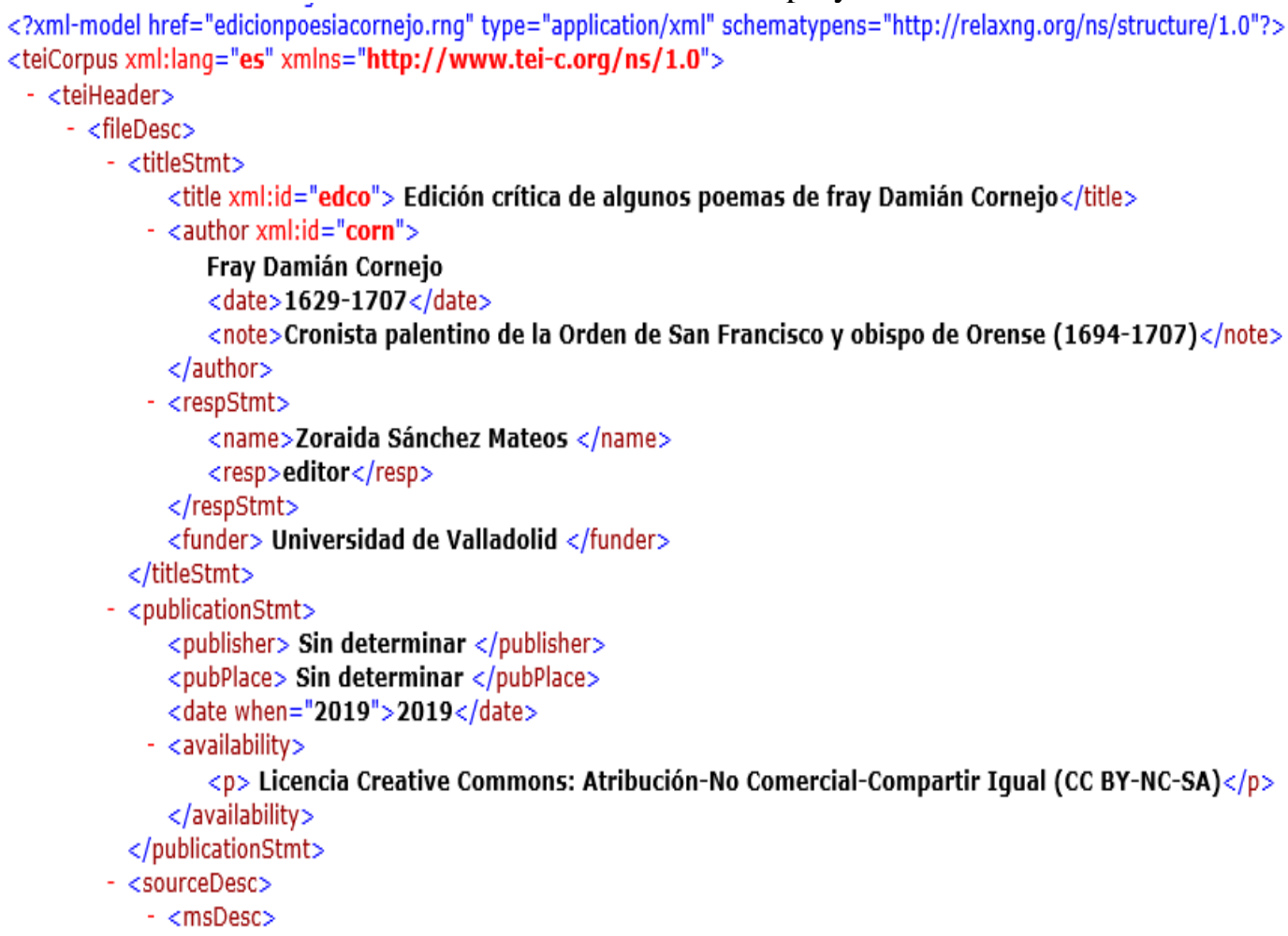


$\langle\mathrm{msDesc}\rangle$

$-<$ msIdentifier>

<institution>Biblioteca Nacional de España</institution>

$\langle$ idno type $=$ "wing" $>$ 2245 $</$ idno $>$

- <altidentifier>

$<$ idno>G. 408</idno>

$</ a$ altidentifier>

$<$ /msidentifier $>$

- <msContents>

- <msitem>

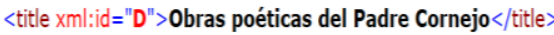

$<$ textLang mainLang="es" $>$ Español $</$ textLang $>$

- <epigraph>

<note>En la segunda hoja de guarda una nota firmada por "Méndez" parece indicar su poseedor original: "Este libro es propiedad de

Don Miguel de Arratiguibel y Gorospe". $</$ note $>$

$</$ epigraph>

- <msitem>

<note>Incluye poemas atribuidos a fray Damián Cornejo (ff. 1-201v)

y a Eugenio Gerardo Lobo (ff. 202-225) </note>

$</$ msitem $>$

- <msitemStruct> $-\langle\mathrm{bib}| \overrightarrow{\rangle}$

A.A.VV. $<$ hi rend= "italic" > Catálogo de manuscritos de la Biblioteca

Nacional con poesía en castellano de los siglos XVI y XVII </hi>

, 1. Madrid: Arco Libros, 1998. 215-256. Impreso.

\langle| ibib $\rangle$

<filiation>Guarda relación con el manuscrito "S 156"de la Biblioteca

Menéndez Pelayo</filiation>

$</$ msitemStruct $>$

$</$ msitem $>$

$</$ msContents $>$

$\langle$ physDesc $>$

< <objectDesc style="encuadernacion_pergarmino" form="codice" >

- 〈supportDesc material="papel">

- <extent>

$<$ foliation $>$ Antigua $</$ foliation $>$

$</$ supportDesc $>$

$\langle/$ objectDesc

$\langle$ handDesc $>$

$\langle p\rangle$ Manuscrito escrito a una sola mano. $\langle/ p\rangle$

$\langle/$ handDesc $>$

$</$ physDesc $>$

$<$ history>

<origin>

<origDate notBefore="1690" notAfter="1715" $>$ Finales del siglo XVII

principiosdel siglo XVIII</origDate>

$<$ /origin $>$

$</$ history $>$

/msDesc $>$

Ilustración 4: Descripción de las fuentes primarias

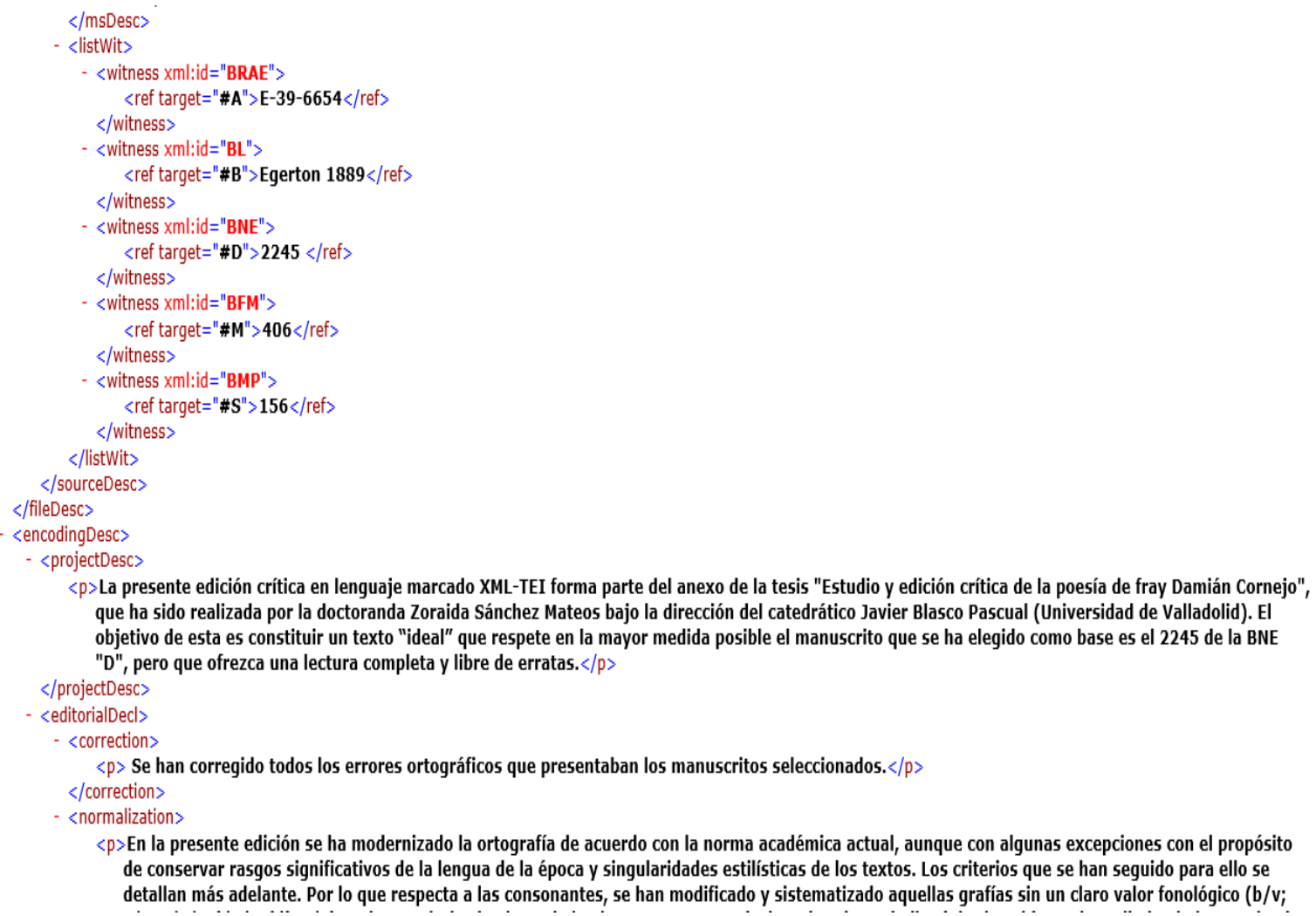

Ilustración 5: Referencias de las fuentes primarias y descripción del proyecto 
En tercer lugar, se ha creado un documento independiente para cada uno de los poemas editados con el propósito de facilitar su edición. No obstante, todos están interconectados con el documento raíz "edco.xml" a través una referencia única construida con las iniciales del primer verso. Ej.: <ref xml:id="hqlg" target="hqlg.xml" $>$ Haced que la gracia encuentre $</$ ref $>$. Estos han sido etiquetados con datos sobre su autoría "<author>"373, su localización "<witness>”, su métrica "<rhyme $>$ 374", las variantes de los manuscritos cotejados " $<\mathrm{rdg}>375$ " y los nombres propios " $<$ persName $>$ " y de lugar " $<$ persPlace $>$ " que contienen para facilitar su consulta individual y la extracción de datos globales.

Por último, se han incorporado las notas filológicas "<note>", las referencias bibliográficas completas de estas "<bibl>” y añadido hipervínculos "<ref >” entre ellos con el objetivo de facilitar la navegación y la consulta de anotaciones similares. La siguiente imagen es una muestra de la codificación de dos de los poemas editados:

\footnotetext{
${ }^{373}$ En todos los textos se ha indicado a los autores a los que se atribuye y el grado de certeza de tales atribuciones mediante las categorías "low", "medium" y "high".

${ }^{374}$ Se han utilizado diversas etiquetas para marcar los diversos elementos relacionados con la métrica: las estructuras de las poesías " $<$ div type "soneto" $>$ ", la de las estrofas " $<$ lg type "cuarteto" $>$ " y la rima de cada verso "<rhyme>".

${ }^{375}$ Las variantes de cada poema se han codificado mediante el elemento " $<\mathrm{rdg}>$ " y la opción seleccionada se ha marcado con la etiqueta "<lem>".
} 


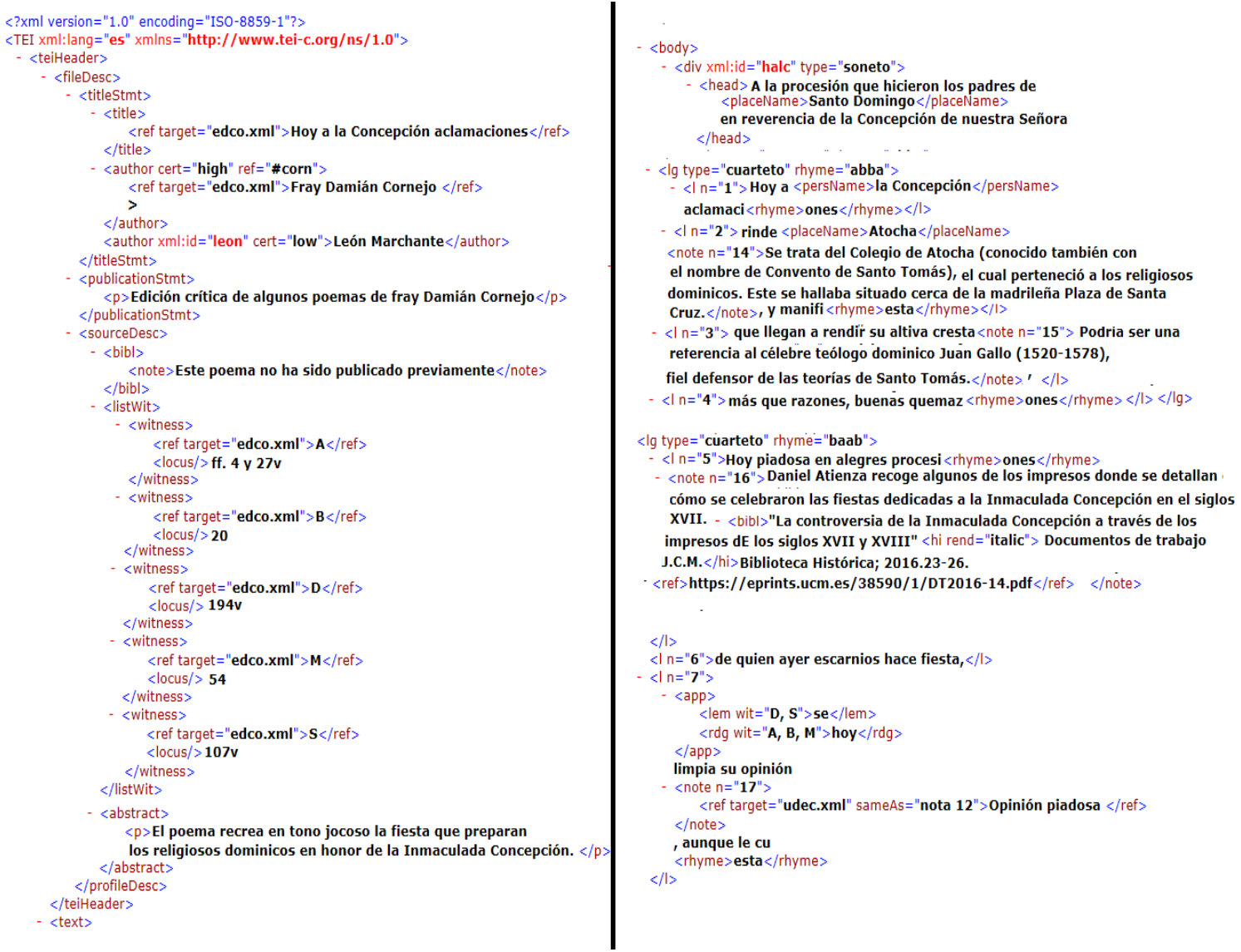

Ilustración 6: Ejemplo de poema 1
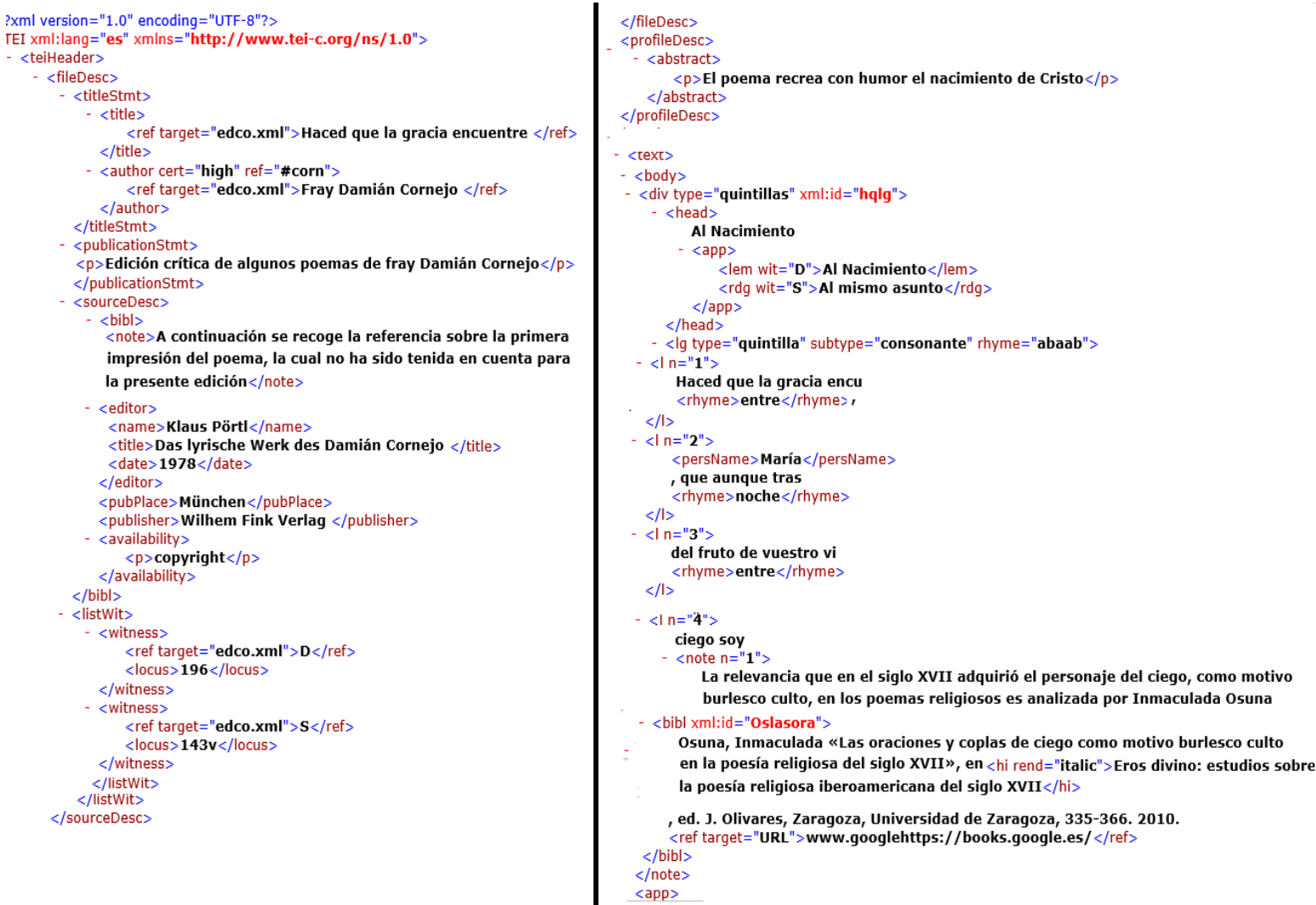

Ilustración 7: Ejemplo de poema 2 
